\title{
Composing the Party Line
}

Music and Politics in Early Cold War Poland and East Germany

\section{David G. Tompkins}

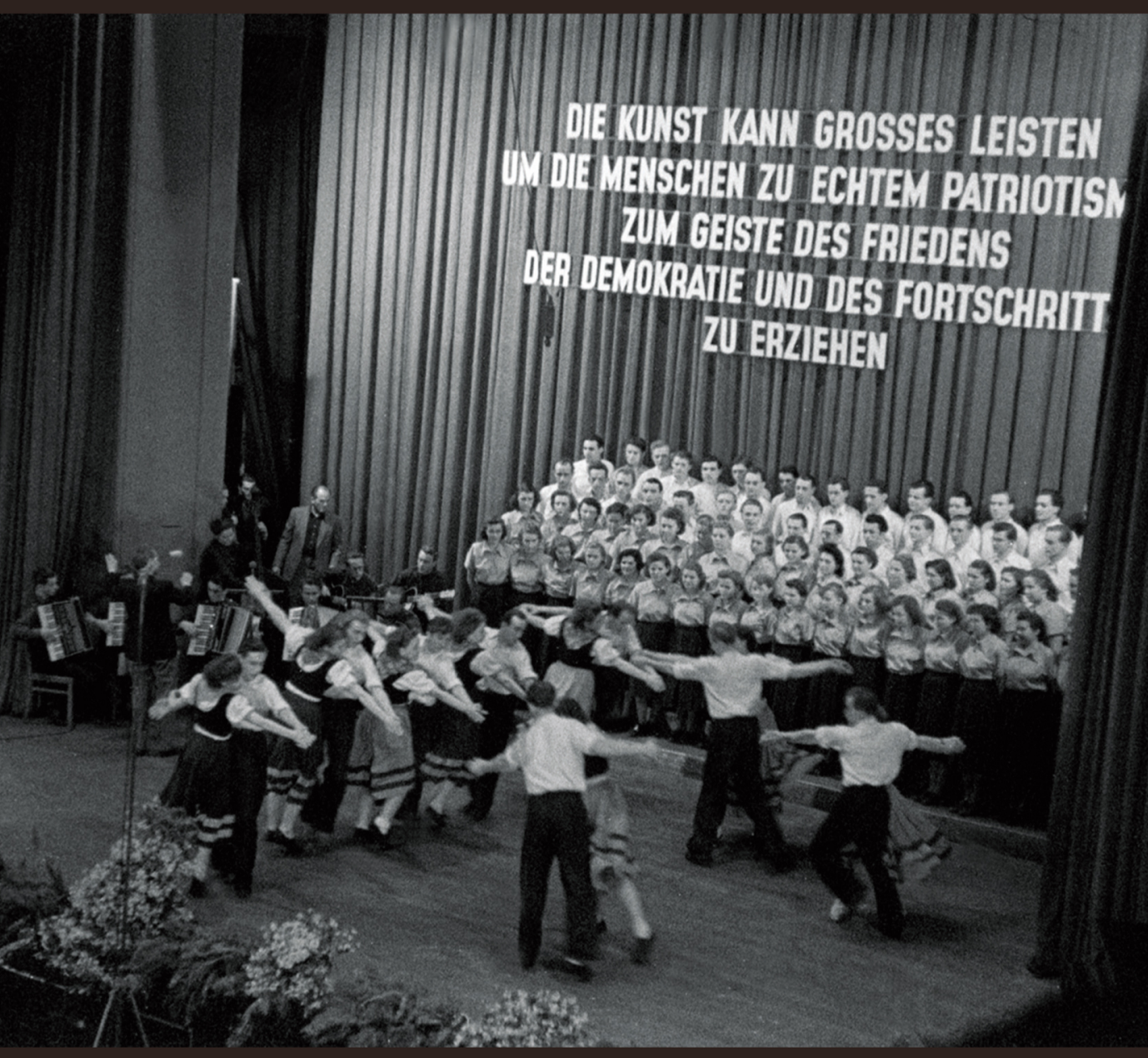




\section{Composing the Party Line}

Music and Politics in Early Cold War Poland and East Germany 


\section{Central European Studies}

Charles W. Ingrao, senior editor

Gary B. Cohen, editor

Franz Szabo, editor

Daniel L. Unowsky, editor 


\section{Composing the Party Line}

Music and Politics in Early Cold War Poland and East Germany

David G. Tompkins

Purdue University Press

West Lafayette, Indiana 
Copyright 2013 by Purdue University. All rights reserved.

Library of Congress Cataloging-in-Publication Data

Tompkins, David G.

Composing the Party Line: Music and Politics in Early Cold War Poland and East Germany / David G. Tompkins.

pages cm. -- (Central European Studies series)

Includes bibliographical references and index.

ISBN 978-1-55753-647-1 (pbk. : alk. paper) -- ISBN 978-1-61249-289-6 (epdf)

-- ISBN 978-1-61249-290-2 (epub) 1. Music--Political aspects--Poland--History--20th century. 2. Music--Political aspects--Germany (East)--History--20th century. 3. Music and state--Poland--History--20th century. 4. Music and state-Germany (East)--History--20th century. I. Title.

ML3916.T67 2013

780.943'109045--dc23

2013013467

Cover image: A student choir and folk music ensemble perform in Leipzig. The slogan reads: "Art can accomplish much in educating people about true patriotism and the spirit of peace, democracy, and progress" (SLUB Dresden / Abt. Deutsche Fotothek, Roger \& Renate Rössing, 25 January 1952).

Thanks to the support of over 200 libraries working through the Knowledge Unlatched program, an electronic version of this book is made available under a Creative Commons (CC-BY-NC) license for global open access. The ISBN of the open access version is 9781557537027 . More information is available at knowledgeunlatched.org 


\section{Contents}

Foreword vii

$\begin{array}{ll}\text { Acknowledgments } & \text { ix }\end{array}$

$\begin{array}{ll}\text { Abbreviations } & \mathrm{xi}\end{array}$

Introduction 1

Chapter One

The Rise and Decline of Socialist Realism in Music 15

Chapter Two

The Composers' Unions between Party Aims and

Professional Autonomy

Chapter Three

The Struggle over Commissions

Chapter Four

The Music Festival as Pedagogical Experience

Chapter Five

The Concert Landscape

$\begin{array}{ll}\text { Conclusion } & 247\end{array}$

$\begin{array}{ll}\text { Bibliography } & 253\end{array}$

$\begin{array}{ll}\text { Index } & 287\end{array}$

Publisher's Note

A list of links to some of the music that is mentioned in this book can be found at http://dx.doi.org/10.5703/1288284315191 



\section{Foreword}

With the passage of nearly a quarter century since the end of communist rule in Central and East-Central Europe, scholars are developing fascinating new perspectives on the realities of governance, economies, societies, and culture in the various stages of communist development. We are learning that, just as the modalities and speed of establishing communist rule after World War II varied significantly from one country to the next, there also was no common blueprint for the implementation of the communist projects for transforming economic production, social relations, and the cultural sphere. Even in the high Stalinist era from 1948/49 through 1953, communist authorities in the various countries used differing tactics, proceeded at differing speeds, and had to negotiate with representatives of many established institutions and interests. Comparative studies of those processes are challenging for researchers, but John Connelly's pioneering study of higher education in East Germany, the Czech lands, and Poland, Captive University: The Sovietization of East German, Czech, and Polish Higher Education, 1945-1956 (Chapel Hill, 2000), demonstrated convincingly their great value for understanding the dynamics of communist transformations.

David Tompkins's research charts in revealing terms how communist authorities in East Germany and Poland attempted during their first decade of rule to reshape the composition and public presentation of new concert music in the name of "socialist realism." The study rests on a great body of research in original documents of party officials, government ministries, and other administrative bodies in the two countries as well as memoirs, periodicals, and much relevant scholarship. Tompkins demonstrates that the relationships between government authorities and composers and performers in the two countries proved to be complex and dynamic. Both governments called for new music to draw on popular national traditions and to communicate to the public in easily accessible ways, and they pointedly criticized "formalism" and abstruse harmonic experimentation. Tompkins shows, however, that in practice cultural authorities in both countries made compromises in their policies. For their part many composers found ways to live with the communist policies and to take advantage of government 
sponsorship, and more proved willing during the high Stalinist period to compose in the genres and styles which the authorities wanted than many would admit later. The stronger position of the ruling Socialist Unity Party (SED) in East German society and among East German artistic and intellectual elites than was the case for the Polish United Workers' Party (PZPR) in Poland resulted in greater and more lasting government influence on East German composers than was the case for their Polish counterparts. Indeed, Tompkins finds that efforts to induce Polish composers to produce socialist realist works largely ceased after 1955/56.

There have been previous studies of individual composers, musical life in general, and general cultural policies under the East German and Polish communist governments, but this is the first archivally based examination of the efforts to develop socialist realism in music in the two countries and the first serious comparative study of the actual impact of communist rule on musical composition in any two Soviet bloc countries during the early Cold War era. With the access to archives in Central and East-Central Europe which scholars now enjoy and models such as David Tompkins's work, one can hope for even more detailed, analytic research in the future on the relationship between government authority and cultural and intellectual life during Central and East-Central Europe's communist era.

Gary B. Cohen Series editor 


\section{Acknowledgments}

Although of course the core responsibility is mine, the commitments in time and energy associated with this book project make it a joint one, helped along by the input and advice of so many kind and insightful people. It is a real pleasure to thank them here.

This project got its start at Columbia University, and was most profoundly influenced by Volker Berghahn, who provided scholarly criticism as well as much encouragement. Brad Abrams gave of his time on occasions too many to count, and Mark von Hagen has been a real friend as well as a crucial critical presence. The suggestions of Boris Gasparov, Walter Frisch, and István Deák were much appreciated.

Over the years, many other colleagues have read various chapter and article drafts or helped in various key ways, and although I can't mention everyone, I'd especially like to thank Eliza Ablovatski, Jan Behrends, John Bohstedt, Beata Bolesławska, Joy Haslam Calico, John Connelly, Winson Chu, Philip Ewell, Anna Fishzon, Eagle Glassheim, Gundula Kreuzer, Molly Wilkinson Johnson, Vejas Liulevicius, Dan Magilow, Ben Martin, Ryan Minor, Denise Phillips, Gilya Schmidt, Christian Schmidt-Rost, Adrian Thomas, Max Vögler, Kimberly Elman Zarecor, and Lisa Zwicker. Celia Applegate's close reading of the manuscript has made it much stronger. More broadly, I thank all my colleagues at the University of Tennessee and Carleton College for the intangible and stimulating atmosphere that strengthens a book like this. And I'd especially like to acknowledge Ari Sammartino, who more than anyone else has been there with helpful criticism and friendly support from the beginning to the end.

In Central Europe, I'd like to thank Christoph Kleßmann and the Zentrum für Zeithistorische Forschung for welcoming me to the Berlin area and offering advice. Barbara Murach at the German Music Archive in Berlin was always a smiling presence while listening to the best that socialist-realist music has to offer. The staffs at the Archiwum Akt Nowych in Warsaw and the Bundesarchiv in Berlin were of course indispensable. Dariusz Jarosz aided me in navigating both Polish archives as well as the early stages of this project. Krystyna Kersten also helped me to crystallize my initial ideas, as did Jan Lencznarowicz. The staff at 
the archive of the Polish Composers' Union, especially Izabela Zymer, unfailingly brought me the correct dusty protocol as well as a warm cup of tea. For essential nonacademic support while abroad, I'd like to thank Krystyna Gott, Rafal Taranowski, the Bielowicz family, and the Simon family.

This project has been made possible by the generous support of a number of organizations, including the American Council of Learned Societies, the Fulbright Foundation, the German Academic Exchange Service, Carleton College, the Germanistic Society of America, the Harriman Institute, the International Research and Exchanges Board, the Kosciuszko Foundation, the National Security Education Program, the Social Science Research Council's Berlin Program for Advanced Studies, and the University of Tennessee. In the early stages of this project, I had the pleasure of taking part in the Woodrow Wilson Center's Junior Scholars Training Seminar as well as the German Historical Institute's Transatlantic Doctoral Seminar, and I offer my thanks to the participants for their comments.

Some passages in this book appeared previously in other venues, and I appreciate the permission of those presses to use revised portions of those publications. Parts of chapter 5 appeared as "Orchestrating Identity: Concerts for the Masses and the Shaping of East Germany Society" in German History 30, no. 3 (2012): 412 28. Some of the material on Andrzej Panunfik appeared as "Composing for and with the Party: Andrzej Panufnik and Stalinist Poland" in The Polish Review 54, no. 3 (2009): 271-88. Parts of chapters 4 and 5 appeared as "Sound and a Socialist Identity: Negotiating the Music Soundscape in the Stalinist GDR" in Germany in the Loud Twentieth Century: An Introduction, edited by Florence Feiereisen and Alexandra Merley Hill, 111-23 (Oxford: Oxford University Press, 2011) and "Instrumentalizing Entertainment and Education: Early Cold War Music Festivals in East Germany and Poland" in Socialist Escapes: Breaking Away from Ideology and Everday Routine in Eastern Europe, 1945-1989, edited by Cathleen M. Giustino, Catherine J. Plum, and Alexander Vari, 27-47 (New York: Berghahn Books, 2013).

I'd also like to thank those at Purdue University Press for helping to shepherd this book along its final stages, in particular Charles Watkinson, Dianna Gilroy, Rebecca Corbin, and Bryan Schaffer. And I very much appreciate the input of series editor Gary Cohen, who heroically read the manuscript not once but twice, which has made this a much stronger book.

Finally, I'd like to thank my family for their support over these many years. My uncle John Cassini and aunt Francine helped to spark my interest in European history as well as music, and always opened their home to me during my stints in Europe. My late stepfather, Thomas Peelen, was an important source of musical inspiration as well as humor. My parents, Jack Tompkins and Suzanne Tompkins, have provided all forms of support in ways too numerous to recount. And this book would not have come together without the love and encouragement of my wife, Avigail Manneberg. I dedicate the book to her. 


\section{Abbreviations}

BASF Badische Anilin- und Soda-Fabrik (Baden Aniline and Soda Factory)

CZOFIM Centralny Zarzą Oper, Filharmonii i Instytucji Muzycznych (Central Administration of Operas, Philharmonic Orchestras and Musical Institutions)

DA Deutschland-Archiv

DKGD Deutsche Konzert- und Gastspieldirektion (German Agency for Concerts and Guest Performances)

DVD Deutsche Veranstaltungsdienst (German Performance Agency)

FDGB Freier Deutscher Gewerkschaftsbund (Free German Trade Union Federation)

FDJ Freie Deutsche Jugend (Free German Youth)

FMP Festiwal Muzyki Polskiej (Festival of Polish Music)

GDR German Democratic Republic (Deutsche Demokratische Republik, or DDR)

GG Geschichte und Gesellschaft

HA Hauptabteilung (Department in MfK)

KK Komisja Kwalifikacyjna (Qualification Committee of the ZKP)

KKO Kreiskulturorchester (District Cultural Orchestra)

KPD Kommunistische Partei Deutschlands (German Communist Party)

LPG Landwirtschaftliche Produktionsgenossenschaft (Agricultural Cooperative) MDM Marszałkowska Dzielnica Mieszkaniowa (Marshall Street Residential District)

MfK Ministerium für Kultur (Ministry of Culture)

MKiS Ministerstwo Kultury i Sztuki (Ministry of Culture and Art)

NEP New Economic Policy

PPIE Przedsiębiorstwa Państwowe Imprez Artystycznych (State Enterprises for Artistic Events)

PPR Polska Partia Robotnicza (Polish Workers' Party)

PPS Polska Partia Socjalistyczna (Polish Socialist Party)

PSL Polskie Stronnictwo Ludowe (Polish Peasant Party)

PWM Polskie Wydawnictwo Muzyczne (Polish Music Publishing House)

PZPR Polska Zjednoczona Partia Robotnicza (Polish United Workers' Party) 
RAPM Russian Association of Proletarian Musicians

SBZ Sowjetische Besatzungszone (Soviet Occupation Zone)

SED Sozialistische Einheitspartei Deutschlands (Socialist Unity Party)

SL Stronnictwo Ludowe (Peasant Party)

SPAM Stowarzyszenie Polskich Artystów Muzyków (Association of Polish Musical Artists)

Stakuko Staatliche Kommission für Kunstangelegenheiten (State Commission for Artistic Affairs)

VDK Verband deutscher Komponisten und Musikwissenschaftler (Union of German Composers and Musicologists)

VEB Volkseigener Betrieb (People's Own Enterprise)

WK Wydział Kultury (Culture Department)

ZG Zarząd Główny (Executive Committee of the ZKP)

ZK Zentralkomitee der SED (Central Committee of the SED)

ZKP Związek Kompozytorów Polskich (Union of Polish Composers)

zł złoty (Polish currency)

ZMP Związek Młodzieży Polskiej (Union of Polish Youth)

ZSL Zjednoczone Stronnictwo Ludowe (United People's Party) 


\section{Introduction}

As part of the program of the week-long East German Composers' Union Congress in October 1954, the assembled composers and musicologists traveled to the Leuna chemical factory "Walter Ulbricht" on the outskirts of Leipzig to attend a concert performed by the State Symphony Orchestra of Gotha. In the palatial "Clubhouse of the Workers," built as the community house for the BASF chemical firm in the late 1920s and restored after the war, and with many of the factory's workers in the audience, all present heard recent, representative instrumental works by five East German composers. The next day during the conference proceedings, metalworker Otto Schnell took the podium in front of the assembled East German musical elites and expressed his disappointment with the concert in unvarnished terms. Schnell called on composers to "introduce the workers to music" and "create music that the broad masses can tolerate." $\mathrm{He}$ encouraged them to write works that would be a moving experience upon first hearing, such as Tchaikovsky's Fifth Symphony. In a sardonic turn of phrase, he stated that, as with a bar offering bad sausage, he and his peers would not return for a repeat of an unpleasant experience. ${ }^{1}$

The following pages seek to understand the deeper forces and broader context behind this scene. Five years after the country's founding, what had become of the project to create a new, socialist music? How did a factory worker find himself addressing the professional composers of his country? How was he familiar with Tchaikovsky, and more generally, what was the role of music in the everyday life of citizens like Schnell during the first postwar decade in East Germany and its Soviet-bloc neighbor, Poland? With respect to the composers Schnell addressed, what did they make of him, and what were they doing at a concert in a chemical factory? What motivated some of the giants of twentieth-century music - Witold Lutosławski, Andrzej Panufnik, Hanns Eisler, and Paul Dessau, to name just a few - to compose music with workers in mind? And since this is a study of art under dictatorships - what was the role of the party and state in all this, and how did political power intersect with music?

In contrast to the overwhelmingly visual world familiar to us, Central Europeans around 1950 inhabited a reality marked by the aural, with the ubiquitous public loudspeaker, high levels of household radio ownership, and a tradition 
of concertgoing; the television did not yet dominate the public sphere and film served only as occasional entertainment. Additionally, music occupies a particularly significant place in the Central European imagination, especially in the German-speaking lands, as it has long been one of the key sites for the expression of national identity there. ${ }^{2}$ In light of its omnipresence and importance, it is not surprising that music would be essential to the political initiatives of the communist regimes of the region. These factors linked up with the core communist belief, refined in the early Soviet Union, that the arts were essential for creating the new socialist society. Unsurprisingly, then, communists in Central Europe placed great emphasis on the musical world and pursued ambitious aims there. Cultural officials interacted extensively with citizens and composers, believing that music offered an exceptional power to shape their populations. Motivated by the conviction that "music is one of the few forces that, on a large scale and with nearly unlimited possibilities, seizes and influences all people," they considered music "a colossal factor in the shaping of man.... it is today a powerful element in the formation of the political and ideological aspects of the nation." ${ }^{3}$ Music thus served a peculiarly important function in the legitimation strategies of these communist regimes in their early phase from 1945 to the late 1950s. The combination of music's historical resonance in the region combined with communism's interest in culture as a tool of influence make music a rich, central site for an examination of the workings of power and everyday life.

This book is a comparative inquiry into the relationship between music and politics in East Germany and Poland from the aftermath of the Second World War, through Stalin's death in 1953, and concluding with the slow process of destalinization thereafter. ${ }^{4}$ This study analyzes the communist parties' claims about and intentions for all kinds of music, both "serious" and light, and examines how composers, performers, and audiences cooperated with and resisted these suggestions and demands. Following anthropologist Katherine Verdery, this study argues that music, as a significant part of cultural production in these countries, played a crucial role in instituting and maintaining the communist regimes of Central Europe. As part of the stalinist project to create and control the new socialist person, the ruling parties in East Germany, the Sozialistische Einheitspartei Deutschlands (Socialist Unity Party of Germany [SED]) and in Poland, the Polska Zjednoczona Partia Robotnicza (Polish United Workers' Party [PZPR]) sought to influence musical production to saturate the public space with politically effective ideas and symbols that furthered the project to construct their version of a socialist society. Music helped the parties establish legitimacy; both extensive state support for musical life and messages in the music itself encouraged musical elites and ordinary citizens in the audience to accept the political elite's dominant position and political mission. The parties invested considerable resources in an attempt to create an authorized musical 
language that would secure and maintain hegemony over the cultural and wider social world. ${ }^{5}$

Despite significant efforts at totalizing domination from above, a striking degree of contestation, creativity, and even innovation existed throughout this period. Rather than describe a situation of absolute control over a stifled, monotonous musical landscape, this study reveals considerable space for intense discussion and indeed negotiation among numerous, differing musical and political pressure groups. Undeniably, and often with a heavy hand, SED and PZPR officials tried to limit the kinds of music produced and heard, especially in the early 1950s. These boundaries, however, were set fairly expansively, and proved to be quite porous in practice. The much-maligned aesthetic paradigm of socialist realism, often incorrectly described as dogmatic prescriptions mandating the production of ponderous ideological works, was surprisingly flexible. Moreover, many composers were intrigued and even felt inspired by its ideas of simplicity and the use of folk motifs, and they produced creative, interesting music that fit within a broad interpretation of its tenets. ${ }^{6}$

More broadly with respect to political and aesthetic issues, the following analysis moves beyond traditional explanations for artist involvement with the party, advanced perhaps most suggestively and famously in Czesław Miłosz's The Captive Mind, with its writers who ingest the mind-altering Murti-Bing pill of dialectical materialism or engage in (self-)deception through Ketman. ${ }^{7}$ Rather, this work treats East German and Polish composers, musicians, and audience members as rational individuals who made a reasoned decision to work with the party in pursuit of their own interests and goals. While other factors behind this musical production are not denied, such as pressure from and fear of a state that demanded a significant measure of compliance, the following pages argue for genuine cooperation as a key motivation, one stemming from overlapping aims, a desire to bring music to new ears, an appreciation for state support of creative work, and an interest in the new musical culture being propagated - as well as less lofty aims like ambition and monetary rewards. This study engages in a careful and contextualized analysis of what individuals said, wrote, composed, and attended at the time, while more problematic subsequent interviews and memoirs will be only infrequently and cautiously evoked where appropriate. ${ }^{8}$

This cooperation never meant the slavish following of orders, though party officials, especially in the years around 1950, did attempt to impose their program in an often heavy-handed manner. Rather, through a complicated, collaborative process, composers pushed for and often achieved their goals of professional autonomy and aesthetic integrity both with and against party directives, even as they - at times eagerly, at times grudgingly - helped negotiate and create the new political and cultural reality. Important and often repressed episodes in the careers of notable East German and Polish composers are examined in detail 
throughout this study. In recent years, the politically inflected works of their Soviet colleagues, most notably Dmitri Shostakovich and Sergei Prokofiev, have experienced a renaissance both in performance halls and scholarly writing. The former's oeuvre has only grown in popularity, even as a synthesis has begun to emerge that strives to make sense of his life and work, especially during the stalinist years. ${ }^{9}$ Prokofiev's socialist-realist works have achieved considerable attention and increasing performances in recent years, with War and Peace included already in two Metropolitan Opera seasons this century and his political cantatas released on CD. ${ }^{10}$ For their peers in Poland and the GDR, such an examination of the equivalent periods is just beginning, and this book forces a reappraisal of key figures and makes a contribution to emerging debates. It illuminates and contextualizes the compositional decisions of Witold Lutosławski, one of the leading composers of the twentieth century, known for his avant-garde and experimental music after 1956, and Andrzej Panufnik, the most prominent composer in Poland during the postwar decade, both of whom wrote socialist-realist music but tried to hide or minimize it later. They, as well as Tadeusz Baird, Grażyna Bacewicz, and other influential figures in the Polish musical world around 1950, all wrote mass songs and larger politically themed works. In the East German context, it examines the struggles of left-leaning luminaries like Hanns Eisler and Paul Dessau to navigate complex political-aesthetic waters, the copious and influential socialistrealist music of Ernst Hermann Meyer and Ottmar Gerster, and the musical milieu of the hundreds of professional composers who chose to live in the GDR.

This book also reveals the diverse responses to this musical production by the East German and Polish populations, and argues that a heterogeneous everyday life existed where party undertakings intersected with audiences and amateur performing ensembles. The parties attempted to collapse the traditional distinction between high and low culture through the formation of a musical world where composers created a new popular music even as philharmonic orchestras performed in factories and workers and peasants entered traditional concert halls. Cultural officials encouraged composers to direct their creative production towards the "working masses" through the composition of mass songs and other accessible works. The parties also helped organize sprawling music festivals and a rich concert life, but in cooperation with musical elites and audiences. Music lovers and ordinary citizens reacted to party initiatives with eagerness or disdain; the parties' aim to mobilize all social groups through music met a motley reality that sometimes included recalcitrant conductors and bored and surly audiences. These consumers of music were not simply acted upon, but interacted in a complex manner with the authorities through open complaints as well as simple nonattendance. Music was of course at the center of the lives of composers and ensemble directors, and was also of great importance to everyday individuals; unsurprisingly, they all asserted their own aims and desires on an ongoing and 
energetic basis. Individuals could stay away from concerts, applaud enthusiastically to music they appreciated, or even express opinions publicly as in the not untypical case of factory worker Schnell. Indeed, we can think of these Central European dictatorships as negotiated ones, with attempts at total political control modified by elites and ordinary citizens participating through a willing if partial embrace of party goals but also by resisting initiatives from above and actively pushing their own in a manner explored more broadly in the historical literature as Eigen-Sinn, generally translated as "a sense of one's own interests." 11 This study describes how the nature of musical life evolved in unexpected ways as officials and composers responded to these responses and demands from below.

These mediated, multiple, and overlapping levels of cooperation and negotiation make the musical world particularly revealing and important for a broader understanding of the workings of power in early socialism. Music provides a fascinating prism through which to view the tension captured in Konrad Jarausch's concept of the "welfare dictatorship," that of emancipatory, egalitarian goals combined with repressive, dictatorial practice. ${ }^{12}$ Although continued research on the party-state apparatus and high politics is necessary and will also be explored in the first chapter, the bulk of this study focuses on how composers and audience members interacted with the political initiatives of the time. Evoking Mary Fulbrook's notion of a "participatory dictatorship," I examine how citizens, through their musical involvement, were "both constrained and affected by, and yet also actively and often voluntarily carried, the ever changing social and political system of the GDR." "13 While recognizing the analytical value of the traditional concepts of "state" and "society," this study seeks to complicate these definitions and show the extensive blurring and overlapping of the two in an effort to gain a more nuanced understanding of the workings of power in these dictatorships. Cultural officials on all levels, from the Ministers of Culture to local bureaucrats, interacted with composers and ensemble leaders. They all found themselves in roles that required the communication of political aims and values to musicians and audiences, but also to take citizens' desires into account. In an excellent recent study focusing on the GDR in the 1960s and 70s, Esther von Richthofen has posited a third agent, that of cultural functionaries, who operated between the traditional categories of state and society. ${ }^{14}$ For the 1950 s in East Germany and Poland, this characterization does not hold; instead, power circulated in a much more complex manner as party leaders, cultural officials at all levels, composers, ensemble leaders, musicians, and audience members all pressed for the realization of their goals. The parties undeniably attempted to establish Gramscian-style hegemony over the musical world, but a more diverse reality took shape as actors at all levels brought in influences from the prewar years, from the west, and from their socialist neighbors. In line with recent research that broadens the field of inquiry to include investigations of social groups and the culture of everyday life in an 
effort to understand lived experience under socialism, the following pages look at the complicated and often chaotic musical realms of both countries to illuminate the construction of the East German and Polish social, political, and cultural landscape in the years around 1950.

The backdrop to this study is the deepening tension between the superpowerled blocs, with a transcultural component that has recently become a focus of intensive research. ${ }^{15}$ Developments in both countries took place against the growing political — and artistic — clash between the United States and the Soviet Union: the cultural Cold War. Each side claimed to be the home of a true, humanist culture that both elevated and satisfied the needs of their respective societies. In the Soviet bloc, communists and sympathizers launched a campaign of extreme vilification against American-inspired cultural production, combined with a thoroughgoing attempt to demonstrate the superiority of socialist culture. Both officials and leading artists promoted socialist realism in music as an alternative to the decadent consumer culture of the West. Belief and interest in the aesthetic tenets of this new socialist art began to wane by the mid-1950s, and East German and especially Polish composers looked increasingly to modernism and also popular musical trends in the West for inspiration. In both countries, however, the encounter between stalinist politics and music made a lasting impression on both the musical and wider social world of elites and ordinary citizens through 1989 and indeed beyond.

Unsurprisingly, then, the arts have increasingly attracted the interest of scholars and a wider public. ${ }^{16}$ Controversies around well-known figures like writer Christa Wolf, reporter Ryszard Kapuściński, poet Zbigniew Herbert, and novelist Andrzej Szczypiorski have mostly given way to more measured examinations of the intersection between art and politics in the context of the cultural Cold War. ${ }^{17}$ Until recently, music has largely been absent except for a few musicological studies that tended to be rather brief and furthermore dismissive of the works created during this time..$^{18}$ Composers and musicians have themselves often contributed to this process of marginalization, retrospectively feeling ashamed of their production during the early Cold War period. Especially in the case of Poland, many scholarly works rely on memoirs or interviews that appeared decades after the stalinist period; these sources often obscure more than they reveal, as the subjects attempted to reinterpret past actions or cast a veil over them. ${ }^{19}$ Recent archival access is only beginning to modify the dominant Cold War interpretation of cowed composers producing worthless works for a supine public, especially with respect to the stalinist era, treated in but a handful of books. The GDR, with two well-known early postwar controversies involving operas-Bertolt Brecht and Paul Dessau's The Judgment of Lukullus and Hanns Eisler's unrealized Faust opera - has had a number of studies of this musical genre. ${ }^{20}$ Several recent books in history have compared musical developments in East and West Germany at 
this time, and a handful of German scholars have recently published significant studies of music in this period, though all tend to focus on musical and political elites. ${ }^{21}$ With respect to Poland, the British musicologist Adrian Thomas has published several pathbreaking thematic articles and addressed the era in a larger study. ${ }^{22}$ Some Polish scholars are also finally beginning to examine the stalinist era more systematically in their biographies of composers, but in general the period is ignored by both Polish musicologists and cultural historians. ${ }^{23}$

This book complements and extends this recent research with respect to music, and also makes a contribution to our understanding of everyday life and the workings of power more generally in the early years of the Cold War. ${ }^{24}$ It continues the move away from totalitarianism theory's focus on binaries like party/artist, or state/society to complicate our understanding of the artistic and quotidian realities of early communism. ${ }^{25}$ Because it investigates the overlapping sites of contact between party, composers, and the wider population, this study belongs to the growing trend that examines "softer" forms of political control in the Soviet bloc as essential tools for the ruling parties to influence society and maintain legitimacy. By studying the sounds and controversies of the musical world, it provides a richer look at an everyday life in stalinist Central Europe that has often been incorrectly viewed as stagnant, repressed, and colorless. The music world in the early Cold War era provides an excellent case study due to its relatively modest but symbolically outsized presence in the wider cultural and political sphere; composers in each country constituted a group in the low hundreds, a size that lends itself to intensive examination, while music as a cultural activity made for a significant site of participation for the wider population.

The comparative approach used here affords a fresh perspective on the communist world in the context of the early Cold War, and engages the transnational phenomenon of how a Soviet-inspired aesthetic ideology interacted with domestic political and musical milieus. Surveys of the historiography on the region unfailingly and repeatedly call for such comparative studies, but to date these have been rare. ${ }^{26}$ As political and cultural entities, East Germany and Poland present two compelling examples of the range of possibility and development among the seven countries of the stalinist Soviet bloc, with roughly equivalent populations in 1949, of 19 and 24 million, respectively. This comparison permits an examination of a similar interaction between politics and the musical and wider world in two neighboring, but historically quite different countries, both of which nonetheless experienced a parallel political, social, and cultural transformation in the postwar period. The two countries looked remarkably similar around 1950, but very different just a few years later, and this study explores why. Notable likenesses reveal much about the "successes" of stalinization, but analogous processes and institutions at times produced dissimilar results that illuminate the aims and limits of the stalinist project. This book thus increases our 
understanding of both the unity and diversity of a Soviet bloc once thought quite homogenous during its first decade. Relatedly, the book grapples with the broader concept of sovietization. The parties in the GDR and Poland adopted and adapted the Soviet Union's relatively developed political system as well as its dominant aesthetic ideology of socialist realism. While the USSR's political and cultural life was hardly static at this time, and indeed developments there continually affected events in the satellite countries, its aesthetic and political system serves as a baseline of comparison and point of reference.

This study examines these transnational dynamics on multiple levels, with this Soviet-inspired ideology and forms of control interacting with Polish and East German contexts. In addition, East Germans and Poles traveled to the neighboring country, introducing their take on socialist realism and socialism, and also playing each other's music, and thereby influencing the other. Despite the official rhetoric of friendship within the bloc, the GDR and Poland had relatively chilly relations at this time - perhaps unsurprising given the experience of the war and the fact that roughly a quarter of the GDR's population was made up of expellees from newly Polish territory. Furthermore, and especially after Stalin's death, the SED looked suspiciously on Polish reforms and curtailed contact. Nonetheless, each country had an organization that promoted exchanges with the other. ${ }^{27}$ Poles were generally more interested in organizing cultural exchanges than their counterparts in the GDR, both because they respected German culture and they wanted to acquaint East Germans with their own..$^{28}$ The circulation of ideas, composers, and ensembles will be explored throughout.

This study touches on the immediate postwar years, but truly picks up the story in 1947-48 with the increased party involvement in the arts, the concurrent push for socialist realism, and the intensification of the Cold War. The core of the book ends in 1956-57, when the PZPR abandoned socialist realism as part of the broader changes related to the Polish October, and as the SED reoriented its cultural policy during Walter Ulbricht's reconsolidation of power. Although the following chapters pursue a top-down narrative, moving from the high-political, theoretical plane through the composers' studio and then on to the festival stage and performance hall, this structure does not mean to suggest that party decisions manifested themselves effortlessly in this manner throughout the musical world. Indeed, considerable contestation marked the debates over both the nature of socialist realism and how to influence and propagate this new music, discussed in an extended first chapter that also provides an overview of the period. The second and third chapters turn to the producers of new music and discuss the Composers' Unions in order to illuminate the processes underpinning the composition and performance of music, and how cultural officials attempted to influence its production, in particular through the tool of commissioning works. The final two chapters examine how this music found its way to the population, and how these 
audiences responded. Chapter 4 looks at a number of key musical festivals to determine their organization and the kinds of music commissioned and performed there. The final chapter examines concert life, both with respect to the professional orchestras as well as to the state-run concert agencies that organized smaller-scale concerts and recitals. Each thematic chapter covers the entire period from the later 1940s to mid-1950s and investigates the workings of power throughout the overlapping strata of officials, musical elites, and ordinary citizens to examine the negotiated musical reality in the two countries. Along the way, the sounds, personalities, and debates of mid-century Central Europe ring out.

\section{Notes}

1 SAPMO-BArch, DY-30, IV 2/9.06/282, 336-39. The concert included Max Dehnert's Merry Prelude for Orchestra (Heiteres Vorspiel für Orchester, 1949), Paul Kurzbach's Divertimento for Small Orchestra (Divertimento für kleines Orchester, 1954), Dieter Nowka's Concerto for Oboe and Orchestra (Konzert für Oboe und Orchester), three arias from Jean Kurt Forest's opera Patriots (Patrioten, 1951), and Max Butting's Sixth Symphony (1945/53). See chapter 4 for more on this episode.

2 Celia Applegate, "What is German Music? Reflections on the Role of Art in the Creation of the Nation," German Studies Review 15 (Winter 1992): 21-32. See also the articles in Celia Applegate and Pamela Potter, eds., Music and German National Identity (Chicago: University of Chicago Press, 2002).

3 Stiftung-Archiv der Parteien und Massenorganisationen der DDR im Bundesarchiv (SAPMO-BArch), DY-30, IV 2/9.06/284, "Über die Entwicklung der Musikkultur der DDR," 76; Włodzimierz Sokorski, in Muzyka 2, no. 1-2 (1951): 5-6.

4 The German Democratic Republic was founded on October 7, 1949, and will be referred to as the GDR or East Germany. Only when specifically discussing pre-October 1949 events will I call it the SBZ or Soviet Zone of Occupation (Sowjetische Besatzungszone). Also, following Padraic Kenney and others, I will refer to stalinism in the lowercase to emphasize the system rather than its founder and, following common convention, define the years from 1947 to 1956 as its era in East Central Europe.

5 Katherine Verdery, National Ideology under Socialism: Identity and Cultural Politics in Ceauşescu's Romania (Berkeley: University of California Press, 1991).

6 Here I follow musicologists Marina Frolova-Walker and Adrian Thomas: "I believe that we should now start recognizing . . . Socialist Realist music as a legitimate, distinct, and even viable part of the twentieth-century repertoire." Marina Frolova-Walker, "The Glib, the Bland, and the Corny: An Aesthetic of Socialist Realism" in Music and Dictatorship in Europe and Latin America, edited by Roberto Illiano and Massimiliano Sala (Turnhout, Belgium: Brepols, 2009), 423. "The socialist-realist perspective in Poland had both ideals and misconceptions; although it is customarily denigrated for its many negative features it should be respected for its loftier intentions and for the fact that it was not by any means monolithic; where it was operational, it was necessarily responsive to changing circumstances. It could not exist ... without its creative realisation by composers and their listeners." Adrian Thomas, "In the Public Eye," in Andrzej Panufnik's Music and Its Reception, edited by Jadwiga Paja-Stach (Kraków: Musica Iagellonica, 2003), 219.

7 Czesław Miłosz, The Captive Mind, 1953, translated by Jane Zielonko (New York: Vintage International, 1990). 
8 With a rare exception or two, I will not use the interviews I conducted with a handful of musical figures in the two countries. In general I found them too contradictory, and furthermore compromised by the many intervening years and caesura of 1989/90.

9 Controversy continues to rage over Shostakovich's relationship to communism and the Soviet state, and what that means for his music. The flashpoint is his purported memoirs, Testimony: The Memoirs of Dmitri Shostakovich, as Told to and Edited by Solomon Volkov 1979 (New York: Limelight, 2004). The definitive biography is Laurel Fay, Shostakovich: A Life (Oxford: Oxford University Press, 1999).

10 See Simon Morrison, The People's Artist: Prokofiev's Soviet Years (Oxford: Oxford University Press, 2008).

11 See especially Thomas Lindenberger, ed., Herrschaft und Eigen-Sinn in der Diktatur. Studien zu Gesellschaftsgeschichte der DDR (Cologne: Böhlau, 1999).

12 Konrad Jarausch, "Care and Coercion: The GDR as Welfare Dictatorship," in Dictatorship as Experience: Towards a Socio-Cultural History of the GDR, edited by Konrad Jarausch (New York: Berghahn Books, 1999), 47-69.

13 Mary Fulbrook, The People's State: East German Society from Hitler to Honecker (New Haven: Yale University Press, 2005), 12.

14 Esther von Richthofen, Bringing Culture to the Masses: Control, Compromise and Participation in the GDR (New York: Berghahn, 2009), see especially 16-17.

15 See especially Annette Vowickel, Marcus M. Payk and Thomas Lindenberger, eds., Cold War Cultures: Perspectives on Eastern and Western European Societies (New York: Berghahn Books, 2012); Peter Romijn, Giles Scott-Smith, and Joes Segal, eds., Divided Dreamworlds? The Cultural Cold War in East and West (Amsterdam: Amsterdam University Press, 2012); Jessica C. E. Gienow-Hecht, "Culture and the Cold War in Europe" in The Cambridge History of the Cold War, Vol I: Origins, edited by Melvyn Leffler and Odd Arne Westad (Cambridge: Cambridge University Press, 2011): 398419; Sari Autio-Sarasmo and Brendan Humphreys, Winter Kept Us Warm: Cold War Interactions Reconsidered (Helsinki: Alesanteri Institute, 2010); Rana Mitter and Patrick Major, eds., Across the Blocs: Cold War Cultural and Social History (London: Frank Cass, 2004); David Caute, The Dancer Defects: The Struggle for Cultural Supremacy during the Cold War (Oxford: Oxford University Press, 2003). For more on developments in the West at this time, see Volker R. Berghahn, America and the Intellectual Cold Wars in Europe: Shepard Stone between Philanthropy, Academy, and Diplomacy (Princeton: Princeton University Press, 2001); Frances Stonor Saunders, The Cultural Cold War: The CIA and the World of Arts and Letters (New York: New Press, 2000); Stephen J. Whitfield, The Culture of the Cold War (Baltimore: Johns Hopkins University Press, 1991).

16 Studies in literature have been particularly early and prominent: Katerina Clark, The Soviet Novel: History as Ritual (Chicago: University of Chicago Press, 1981); Thomas Lahusen, How Life Writes the Book: Real Socialism and Socialist Realism in Stalin's Russia (Ithaca: Cornell University Press, 1997); Evgeny Dobrenko, Political Economy of Socialist Realism (New Haven: Yale University Press, 2007); the start of chapter 1 briefly surveys this literature.

17 Controversies still abound about the nature and meaning of this involvement. For a short introduction in the Polish context, see Gerhard Gnauck, "Die Akte Kapuściński," Die Welt, 23 May 2007, http://www.welt.de/welt_print/article890041/Die_Akte_Kapuscinski.html), and "Blind exorcism in Poland," Sight and Sound, May 30, 2007, http://www.signandsight.com/features/1364.html; the latter is a translation of a Thomas Urban article from the Suddeutsche Zeitung, May 24, 2007. For more on the debates surrounding Zbigniew Herbert, see the 2006 article "Donos Pana Cogito" in Wprost, 
Nr. 33/34 (2006): 32-33, which claimed that Herbert informed for the SB in the late 1960s. Such debates have only intensified with recent allegations that Lech Wałęsa also informed for the secret police.

18 Typical is Jadwiga Paja-Stach, Polish Music from Paderewski to Penderecki (Kraków: Musica Iagellonica, 2010), which skims over socialist-realist composition in a few pages.

19 A recent representative example in English is a recent article by Andrzej Tuchowski, which relies heavily on Irina Nikolska's interviews with Lutosławski (1987-1992) and Panufnik's memoirs (1987) and uses no archival sources, and consequently presents a picture of near-total repression. Andrzej Tuchowski, "The Impact of the Communist Dictatorship and Its Transformations on the Identity of Polish Music in the Years 19451989" in Illiano and Sala, Music and Dictatorship in Europe and Latin America, 33362.

20 Joy Haslam Calico, Brecht at the Opera (Berkeley: University of California Press, 2008); Joachim Lucchesi, Das Verhör in der Oper: Die Debatte um die Aufführung "Das Verhör des Lukullus” von Bertolt Brecht und Paul Dessau (Berlin: BasisDruck, 1993).

21 Elizabeth Janik, Recomposing German Music: Politics and Musical Tradition in Cold War Berlin (Leiden: Brill Academic Publishers, 2005); Toby Thacker, Music after Hitler, 1945-1955 (Aldershot: Ashgate, 2007); Daniel Zur Weihen, Komponieren in der DDR: Institutionen, Organisationen und die erste Komponistengeneration bis 1961 (Köln: Böhlau Verlag, 1999); Peggy Klemke, Taktbeber oder Tabuisierte: Komponisten in der DDR (Marburg: Tectum Verlag, 2007); Maren Köster, Musik-Zeit-Geschehen: Zu den Musikverhältnissen in der SBZ/DDR, 1945 bis 1952 (Saarbrücken: Pfau, 2002); Anne-Kristin Schmidt, Musik als Werkzeug der Indoktrination: Am Beispiel der Festouvertüre 1948 von Ottmar Gerster und dem Mansfelder Oratorium von Ernst Hermann Meyer (Mainz: Are Musik Verlag, 2009); Matthias Tischer, Komponieren für und wider den Staat. Paul Dessau in der DDR (Köln: Böhlau Verlag, 2009). See also the edited volume: Matthias Tischer, ed., Musik in der DDR: Beiträge zu den Musikverhältnissen eines verschwundenen Staates (Berlin: Verlag Ernst Kuhn, 2005).

22 Adrian Thomas, "File 750: Composers, Politics and the Festival of Polish Music (1951)," Polish Music Journal 5, no. 1 (Summer 2002); ibid., "The Hidden Composer: W. Lutosławski and Polish Radio, 1946-1963" in Witold Lutosławski: Człowiek i dzieło w perspektywie kultury muzycznej XX wieku (Poznań: Wydawnictwo Poznańskiego Towarzystwa Przyjaciól Nauk, 1999), 211-220; ibid., "Mobilising our Man: Politics and Music in Poland during the Decade after the Second World War," in Composition-Performance-Reception, edited by Wyndham Thomas (Ashgate: Aldershot, 1998),145-68; ibid., "Your Song is Mine," The Musical Times (August 1995): 403-409; ibid., Polish Music since Szymanowski (Cambridge: Cambridge University Press, 2005). Several older works in English address this period, but lack a broad archival base: Cynthia E. Bylander, The Warsaw Autumn International Festival of Contemporary Music, 195661: Its Goals, Structures, Programs, People (Ph.D. diss, Ohio State University, 1989); Jan Patrick Lee, Musical Life and Sociopolitical Change in Warsaw, Poland, 1944-60 (Ph.D. diss, University of North Carolina, 1979); Lidia Rappoport-Gelfand, Musical Life in Poland: The Postwar Years, 1945-1977 (New York: Gordon and Breach, 1991).

23 A particularly good example is Małgorzata Gąsiorowska, Bacewicz (Kraków: PWM, 1999), which forthrightly addresses the subject's affinities for the stalinist cultural-political program. See also the slim but detailed work by Małgorzata Sułek, Pieśni masowe Witolda Lutosławskiego $w$ kontekście doktryny realizmu socjalistycznego (Kraków: Musica Iagellonica, 2010), which provides useful information on Lutosławski's mass 
songs, but is unfortunately marked by a lack of understanding for the contemporary political and artistic context in which the songs were written.

24 This literature has become quite extensive in recent years, but particularly notable for Poland are Małgorzata Fidelis, Women, Communism, and Industrialization in Postwar Poland (Cambridge: Cambridge University Press, 2010); Dariusz Jarosz, Polacy a Stalinizm (Warsaw: Instytut Historii PAN, 2000); Małgorzata Mazurek, Społeczeństwo kolejki: O doświadczeniach niedoboru 1945-1989 (Warsaw: Trio, 2010), and the many other excellent volumes in the Trio "W krainie PRL" series. With respect to the GDR, see Katherine Pence and Paul Betts, eds., Socialist Modern: East German Everyday Culture and Politics (Ann Arbor, MI: University of Michigan Press, 2008); Konrad Jarausch, ed., Dictatorship as Experience: Towards a Socio-Cultural History of the GDR (New York: Berghahn, 1999); Thomas Lindenberger, ed., Herrschaft und EigenSinn in der Diktatur (Cologne: Böhlau, 1999); Andrew Port, Conflict and Stability in the German Democratic Republic (Cambridge: Cambridge University Press, 2007); Eli Rubin, Synthetic Socialism: Plastics and Dictatorship in the German Democratic Republic (Chapel Hill: University of North Carolina Press, 2008); Esther von Richthofen, Bringing Culture to the Masses: Control Compromise, and Participation in the GDR (New York: Berghahn Books, 2009). More generally, see David Crowley and Susan E. Reid, eds., Pleasures in Socialism: Leisure and Luxury in the Eastern Bloc (Evanston, IL: Northwestern University Press, 2010); and Socialist Spaces: Sites of Everyday Life in the Eastern Bloc (Oxford: Berg, 2002).

25 I find the concept obscures more than it illuminates. For an overview of contemporary debates, see the introduction and relevant articles in Konrad Jarausch, ed., Dictatorship as Experience: Towards a Socio-Cultural History of the GDR (New York: Berghahn Books, 1999); Mary Fulbrook, "Retheorising 'State' and 'Society' in the German Democratic Republic," in The Workers' and Peasants'State: Communism and Society in East Germany under Ulbricht, 1945-1971, edited by Patrick Major and Jonathan Osmond (Manchester: Manchester University Press, 2002), 280-98; and "The State of GDR History" in Francia: Forschungen zu westeuropaischen Geschichte 38, no 1 (2011): 259-70; Elaine Kelly, "Reading the Past in the German Democratic Republic: Thoughts on Writing Histories of Music" in Musikwissenschaft und Kalter Krieg: Das Beispiel DDR, edited by Nina Noeske and Matthias Tischer (Köln: Böhlau, 2010), 117-30; Dolores Augustine, "The Power Question in GDR History," German Studies Review 34, no. 3 (2011): 633-52; Catherine Epstein, "East Germany and Its History since 1989" The Journal of Modern History 75, no. 3 (2003): 634-61; Sandrine Kott, "Everyday Communism: New Social History of the German Democratic Republic," Contemporary European History 13, no. 2 (2004): 233-47; Peter Grieder, "In Defence of Totalitarianism Theory as a Tool of Historical Scholarship," Totalitarian Movements and Political Religions 8, nos. 3-4 (2007): 563-89; Scott Moranda, "Towards a More Holistic History? Historians and East German Everyday Life," Social History 35, no. 3 (2010): 330-39; Andrew Port, "Introduction: The Banalities of East German Historiography," in Becoming East Germans: Socialist Structures and Sensibilities after Hitler, edited by Mary Fulbrook and Andrew I. Port (New York: Berghahn Books, 2013); also see Błażej Brzostek, "Contrasts and Grayness: Looking at the First Decade of Postwar Poland," Journal of Modern European History 2, no. 1 (March 2004): 110-33.

26 A number of edited volumes have appeared in recent years, usually with contributions on individual countries standing in implicit comparison to other articles on another country. Three exemplary monographs that undertake comparison effectively are John Connelly, Captive University: The Sovietization of East German, Czech, and Polish Higher Education, 1945-56 (Chapel Hill: University of North Carolina Press, 2000); 
Jan C. Behrends, Die erfundene Freundschaft. Propaganda für die Sowjetunion in Polen und in der DDR (Cologne: Böhlau, 2006); Małgorzata Mazurek, Socjalistyczny zakład pracy: Porównanie fabrycznej codzienności w PRL i NRD u progu lat sześćdziesiatych (Warsaw: Trio, 2005).

27 Sheldon Anderson, A Cold War in the Soviet Bloc: Polish-East German Relations, 1945 1962 (Boulder, CO: Westview Press, 2001), 62; Hans-Christian Trepte, "Polish Literature and Culture in East Germany: A Window to the West?" The Polish Review 41, no. 1 (1996): 64-65; Christian Lotz, "Zwischen verordneter und ernsthafter Freundschaft. Die Bemühungen der Helmut-von-Gerlach-Gesellschaft um eine deutsch-polnische Annäherung in der DDR und in der Bundesrepublik 1948-1972” in Erinnerungskultur und Versöhnungskitsch, edited by Hans-Henning Hahn, Heidi Hein-Kircher, Anna Kochanowska-Nieborak (Marburg: Verlag Herder Institut, 2008), 201-17.

28 Anderson, A Cold War, 62. 



\section{Chapter One}

\section{The Rise and Decline of Socialist Realism in Music}

In Poland and East Germany in the early Cold War, amateur choirs sang the praises of socialism, professional orchestras played tonal and accessible instrumental music, and catchy mass songs with a political message filled the aural space - in short, socialist realism dominated the musical landscape. The parties in both countries devoted considerable sums as well as political capital and personnel to win over composers and commission ideologically appropriate works and then bring this new music to the general population. Almost without exception, composers responded to these initiatives with interest, and produced an astounding number of socialist-realist works. Musical groups of varying size and skill performed these new compositions, and audiences attended concerts at festivals and in concerts halls in city and countryside.

The story of the origin and rise of socialist realism is strikingly similar in both countries, but with important and compelling differences due to a variety of factors, including the role of the parties, the place of music in each society, the experience of the war, the distinct geopolitical situations, and the attitudes of composers both as individuals and as part of their corporate bodies, the Composers' Unions. In both Poland and East Germany, cultural officials were dependent on musicologists and composers to help them formulate and propagate this new aesthetic ideology, which gave the latter a real measure of power. Together, in shifting and overlapping coalitions, cultural officials and musical elites created socialist-realist music through a complicated process of negotiation, and the latter proved able to modify party goals throughout the period, even before but especially during the thaw after Stalin's death in 1953. Composers did not initially perceive socialist realism as a dogmatic set of rules, but rather helped to develop it as a vibrant artistic theory that motivated and stimulated interesting work. Indeed, throughout much of the postwar decade the theory of socialist realism engaged the interest and imagination of composers in both Poland and the GDR. 
This examination of socialist realism in music will also emphasize the contingent elements of the intersection between art and politics. Although party goals and the high political realities of the Cold War reduced creative options, the debate around socialist realism in music shows that there was considerable room for open discussion, and that no result- beyond an extensive discussion of socialist realism in music — was preordained. The important differences between the East German and Polish cases reinforce this point. A complex interaction between and among artists and cultural officials produced the cultural situation in which composers wrote music and audiences went to the concert hall. Socialist realism as a set of rules was also, however, used as a means to influence and control the composers of Poland and East Germany. While many cultural officials and their allies in the musical world genuinely believed in the correctness of this aesthetic ideology, it also served as a blunt means to attempt to impose and evaluate compliance. These prescriptive and restrictive aspects of socialist realism are the flip side to the utopian and emancipatory idea of a new, positive art with broad appeal, and underlie the power relationships of the period.

Despite the early similarities, by the mid-1950s, the musical worlds of Poland and East Germany looked very different from each other-in Poland, the aesthetic ideology of socialist realism collapsed, while in East Germany, a less restrictive version of this music continued to be composed and performed for decades. In both countries, initial enthusiasm for socialist realism among a broad cross-section of composers gave way to growing disquiet and frustration at the increasing dogmatism and pressure by party officials and their allies in the musical world. Both parties made significant concessions to composer autonomy at the start of destalinization in 1953, but the SED handled this course correction much more successfully through a clever and judicious policy, in contrast to the excessive dogmatism and tactical mistakes committed by its counterpart in Poland. The SED could also count on a larger number of composers, both in absolute and relative terms, who sympathized more fully with its goals.

This chapter will look at the rise and weakening of the concept of socialist realism in the postwar decade in these two countries, but will start with the aesthetic ideology's development in the Soviet Union. This definition provides a baseline for an elaboration of the dominant formulations in East Germany and Poland. A detailed narrative of the period traces the debates on socialist realism from the mid-1940s through the later 1950s in each country, and introduces the major figures involved as well as representative works inspired by its ideas. A final section gives a brief overview of the party and state structures that promoted socialist realism and sought to influence the musical world. 


\section{Genesis in the Soviet Union}

Although the socialist parties in late nineteenth-century Europe had various theories and ideas about art and the working class, it was of course in the Soviet Union where the party had state power to back its aims. Most scholars view the 1920s there as a period of intense experimentation as well as a time of conflict over the role of art in the new Soviet society. A great variety of artistic and political groups jockeyed to preserve or assert their position. The cultural landscape can be broadly simplified into four general groups: old Bolsheviks, such as Lenin and Anatoly Lunacharsky, who believed in basing the new culture on the best art of the past; militant communist cultural organizations such as the Russian Association of Proletarian Musicians (RAPM) that wanted proletarian control over the arts and a new workers' culture; the mainstream intelligentsia, with its tenets of professional autonomy, traditional values, and artistic freedom; and the avantgarde, including figures like Vladimir Mayakovsky and Vsevolod Meyerhold, which desired to institute its radical program of change by excluding all former and competing visions of culture. ${ }^{1}$ During the Cultural Revolution of 1928-1931, the militant groups got the upper hand, but then fell from favor with a turn to more traditional values. ${ }^{2}$ In April 1932 the Soviet leadership dissolved the many different artistic associations, when each artistic discipline eventually became centralized into its own overarching professional union.

Socialist realism was articulated in this context. Stalin and leading cultural figures like Maxim Gorky formulated the term itself in the spring of 1932, and set down its main principles during an October meeting. It was proclaimed the official Soviet art at the First All-Union Congress of Soviet Writers in 1934. ${ }^{3}$ In his speech there, cultural tsar Andrei Zhdanov offered a broad definition of the "method of socialist realism" as a way to "depict reality in its revolutionary development ... combined with the ideological remolding and education of the toiling people in the spirit of socialism." After the hegemony of the militant communist groups during the Cultural Revolution, artists initially viewed the promulgation of socialist realism as a sign of liberalization. ${ }^{5}$ With respect to music, the head of the Moscow Composers' Union assured composers that socialist realism was not dogmatic and would include a number of compositional trends. ${ }^{6}$ In any case, socialist realism appeared a compromise that knitted together the aspirations of a broad spectrum of artists, encompassed both avant-garde demands and traditionminded concerns, and united ideas of high and low culture. ${ }^{7}$

Its nature still notoriously difficult to pin down, socialist realism bedeviled both theorists and artists of the day. They discussed socialist realism incessantly in the 1930s, and then again after the war. Literary scholar Leonid Heller identifies three intertwined, core concepts of socialist realism: an ideological commitment (ideinost), in that the content of the artwork was related to an approved 
idea and was more important than its form, that is, its formal structure should not dominate its content; a national or popular spirit (narodnost), in that art expressed the will of the people and was accessible to them; and most importantly, partymindedness (partiinost), in that the artwork aggressively supported the party and helped construct socialism. ${ }^{8}$ Related to these were the ideas that socialist-realist art was based on and drew from the classics of the past, that artists shared a utopian vision and believed their works helped shape life towards that vision, that artists made contact with the people and joined up with "seething life," and that artistic production expressed a dynamic vision of the world by showing reality not as it was, but in its "revolutionary development." Far easier to identify was socialist realism's antithesis, formalism. ${ }^{10}$ In theory, formalism meant that the formal aspects of a work of art commanded more importance than the subject matter, or content. It became a concept that lumped together most of the modernist movements of the first decades of the twentieth century. The main catchwords in music associated with this vilified term were dissonance, atonal and twelve-tone music, cacophony, and composers like Igor Stravinsky and Arnold Schoenberg.

Soviet artists, critics, and officials debated and refined the nature of socialist realism and formalism over the next two decades, and indeed beyond Stalin's death. How socialist realism actually translated into a novel or painting or, in this case, musical work, proved a difficult and fraught issue for Soviet artists. In the musical realm this was a particularly vexing question. The earliest theoretical and practical discussions of both socialist realism and formalism were worked out predominantly through the medium of literature, and the other arts thus had to struggle to adapt to it. ${ }^{11}$ With respect to music, cultural officials preferred textbased compositions like mass songs and cantatas, with words designed to carry ideological messages desired by the party. Instrumental music had to be easily understandable to the broad masses and preferably melodic, stirring, and uplifting. An important corollary to the official doctrine was the basing of new works on the great masters of the past, including a related emphasis on preserving the national musical tradition - focusing, however, on those aspects of composers or works that fit communist ideology. Musicologist Marina Frolova-Walker points to Nikolai Myaskovsky's Twelfth Symphony, written in 1931, as anticipating the core tenets of socialist realism in its clarity, actual or rumored ideological content (in this case, collectivization), evocation of nineteenth-century Russian composers, and merging of past and contemporary musical styles both high and low. She identifies socialist realism as the product of collaboration in the 1930s between cultural officials and composers and as featuring a stylistic mix of "the classical Western, the classical Russian, the folk Russian, and the popular Soviet," expressed in an immediate and unironic manner. ${ }^{12}$

The first issue of the journal Sovietskaya Muzyka attempted a theoretical explanation, which none other than leading Soviet composer Dmitri Shostakovich 
derided at the time. ${ }^{13}$ Soviet officials, critics, and composers vaguely defined it over the next years as a kind of "heroic classicism," with qualities of tunefulness, folk-music elements, romantic harmony, traditional genre forms, grandeur, and simplicity. ${ }^{14}$ Music played an essential role in the broader debate on several key occasions in the Soviet Union, especially during the first major polemics about formalism. Even after socialist realism had been proclaimed in 1934, modernist styles continued to be quite present in new music. ${ }^{15}$ To counter these trends, an example was needed and found in Shostakovich's opera, Lady Macbeth of Mtsensk. It came under withering criticism in a Pravda editorial, "Muddle instead of Music," for being formalist and appealing to supposedly perverted bourgeois taste through its dissonant and vulgar musical language and subject matter. ${ }^{16}$ Ten days later, Shostakovich's ballet The Limpid Stream was also attacked for formalist deviations due to its alleged artificiality and failure to link up to the people. A huge debate ensued, and Soviet officials clamped down on some of the more extreme manifestations of modernism and suspended performance of some modernist works from the West. Many composers, however, defended Shostakovich, and while most composed in a more melodic style and relied on folk melodies, the following decade was not a period of constricting dogmatism. ${ }^{17}$

Soon after the end of the Second World War, aesthetic debates around socialist realism resumed again, and cultural officials conducted another campaign to influence and, increasingly, control the arts. The worsening Cold War prompted the Soviet leaders, and their equivalents in the people's democracies, to push for ever greater societal transformation and ever more control at an ever greater speed in order to solidify their bloc. Communists expected the arts to take part in the building of socialism throughout East-Central Europe and the Soviet Union, and increasingly pressured artists to work within the tenets of socialist realism.

Constant debates and battles over the nature and application of socialist realism marked the era from 1946 to 1953, associated with party ideologue Andrei Zhdanov, and the definition of styles condemned as formalism expanded. ${ }^{18}$ Three Central Committee decrees in August and September 1946 focused on literature, the theater, and film, and demanded that the arts depict contemporary themes in an optimistic manner and convey an ideological message. ${ }^{19} \mathrm{~A}$ fourth decree, in February 1948, denounced formalism in music and harshly criticized leading Soviet composers such as Shostakovich and Sergei Prokofiev for not being more accessible to a broad public and politically engaged more generally. These moves went even further than the 1930s debates in restricting the permissible, and this narrowing definition of socialist realism provided cultural officials with a more effective means to control artistic production.

The fundamentals of socialist realism were therefore largely set by the late 1940 s, but were by no means completely codified and resistant to interpretation. Indeed, significant debate continued in the late stalinist Soviet Union. The con- 
cept of socialist realism, restrictive yet nonetheless somewhat labile, was then exported throughout the bloc. This fuzzy template was, however, both interpreted and implemented somewhat differently in Poland and East Germany.

\section{Socialist Realism in the GDR and Poland}

With the terms developed in the USSR and translations of key Soviet articles reprinted as guidance and fodder for discussion, officials and composers groped towards a working understanding of socialist realism in the late 1940s. East German composers likely had more context due to debates in Weimar Germany and among left-leaning composers in exile before 1945. Many of their Polish counterparts had in contrast spent time in Paris during the interwar period, with discussions of impressionism and neoclassicism there, although a small minority that included the musicologist Zofia Lissa had some familiarity with socialist realism due to wartime experiences in Soviet-annexed Lwów (today Lviv, Ukraine) and elsewhere in the USSR. In both countries after the war, socialist realism emerged as a framework that allowed for composer input and some individual interpretation.

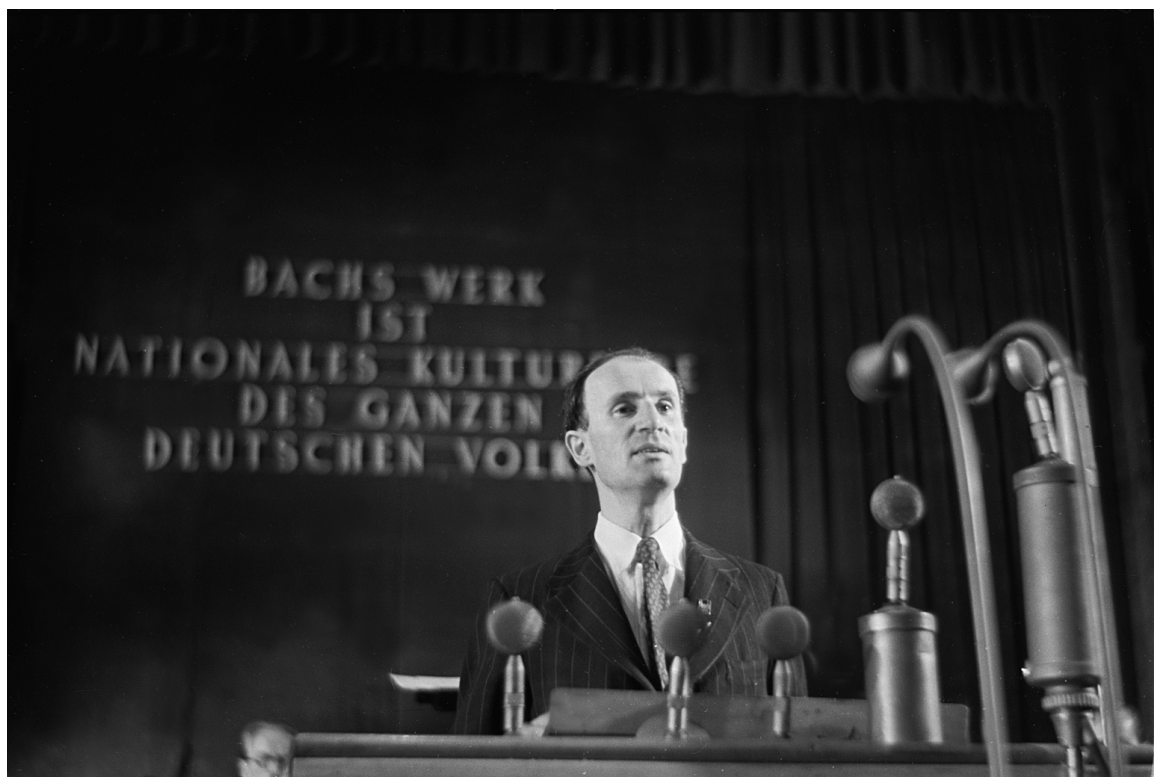

Ernst Hermann Meyer speaks at the 1950 Bach celebrations in Leipzig. The slogan reads:

"Bach's work is the national cultural heritage of the entire German people" (SLUB Dresden / Abt. Deutsche Fotothek, Roger \& Renate Rössing, 28 July 1950).

The most important figure for propagating socialist realism in the GDR was the important musicologist and composer Ernst Hermann Meyer. His book, Musik im Zeitgeschehen (Music in Current Events, 1952), became the bible for 
socialist realism in East Germany. Meyer codified his ideas yet further for the 1954 Composers' Union Congress in order to better shape the debate and educate his composer colleagues, and his fourteen points in summarized and paraphrased form describe socialist-realist music as:

1. formed through personal experience, personality, and individual ideas, thoughts and feelings, and with content that is meant for working people

2. prepared to combat decadent imperialism and fight for the new socialist society and a better, more positive life

3. engaged in creating themes that concretely and actively address working people and their lives, and not vague or abstract

4. willing to fight for peace

5. reflecting reality without simply copying it, that creatively addresses the future

6. not engaged in abstract experimentation, but provides strength for people to solve today's problems

7. reflecting the rich and diverse reality of our people through equally rich and diverse themes, genres, and artistic invention

8. helping to shape the typical conflicts of our time and not focusing on unimportant issues

9. national in form - containing and expressing the national character

10. truly popular and closely linked to folk music without being primitive

11. building on the classics without copying them but rather creatively developing them further

12. perfect in form without making form the absolute priority but rather containing socially relevant content

13. humane, full of life, and life affirming

14. filled with the consciousness that composers have a powerful societal responsibility in this time of world-historical confrontation and social, material and spiritual change. ${ }^{20}$

These tenets, sharpened as they were after several years of discussion, were obviously still quite vague. Meyer's colleagues discussed and contested his ideas extensively, and tried to use them in their own ways, or indeed alter or go beyond them in their compositions.

Meyer's equivalent in Poland was Zofia Lissa, a musicologist somewhat more grounded in Marxist theory than her East German colleague. To paraphrase one scholar's summary of her complex and numerous writings in nine theoretical points and six practical corollaries:

1. Music reflects reality.

2. It is a social phenomenon. 
3. It possesses an ideological character as part of the superstructure; it reflects and supports the aspirations of the social class that is the historical motor of that era.

4. Each era has its own music linked to the forces of progress: "progressive" music.

5. Music linked to the forces of progress is always in accordance with the proper interpretation of reality with respect to its historical dynamic and is called "realistic" music.

6. Music of the bourgeois era, like the music of other eras, proceeds together with the leading class of that era and overcomes reactionary music.

7. The fall of bourgeois music meant the end of technical considerations dominating social and ideological considerations - the end of form dominating content, which is formalism.

8. Realistic music of the socialist era reflects and supports the historical dynamic of its era and thus helps to shape the new social system.

9. This development of socialist realism benefits not only the working class, but all of society, since a classless society is being built.

These highly theoretical, Marxist considerations had six broad implications for the compositional process, in Lissa's view:

1. Vocal and programmatic music was more important than instrumental.

2. Music should have themes appropriate to the era.

3. It should be melodic,

4. Tonal,

5. Linked to folk themes,

6. And tied to the great national and European musical traditions without being a regression to nineteenth-century style. ${ }^{21}$

As in the case of Meyer, Lissa's tenets left considerable room for interpretation. Though Polish composers comported themselves with more reserve and skepticism than their East German counterparts, they also engaged in discussion of socialist realism, and produced an impressive number of musical works that fit into this theory.

In both countries, musicologists played key roles in the formulation and dissemination of socialist realism. In Poland, Lissa's ideas dominated, and her fellow musicologists Józef Chomiński and Stefania Łobaczewska contributed to the articulation of socialist realism. Several composers, like Witold Rudziński and Jan Maklakiewicz, also strongly supported socialist realism, but they did not offer practical guidelines. Cultural officials like Stefan Żółkiewski provided another source of directives, and the main conduit for the musical world was Culture Minister Włodzimierz Sokorski. In the GDR, the main theoreticians of socialist realism were a group of musicologists led by the aforementioned Ernst 
Hermann Meyer, and also included Eberhard Rebling, Harry Goldschmidt, and Georg Knepler. A greater number of composers engaged with the debate there, and even published articles and pamphlets. Several cultural officials here also influenced policy considerably, and included culture minister and poet Johannes R. Becher as well as cultural officials Hans Lauter, Hans Pischner, and Anton Ackermann.

The overwhelming majority of Polish and East German composers responded to the initial political interventions into the music world in the late 1940s either positively or at minimum with cautious curiosity. They found much to agree with in the party's calls to reach out to the people, engage in rebuilding the country, and formulate an antifascist nationalism, and warmly greeted the large sums made available for new compositions. In both countries, this good will began to sour somewhat in the early 1950s, as the party increasingly emphasized dogmatic compliance. Equally important to the aesthetic considerations around socialist realism and formalism were of course the political ones. By the late 1940s, the titanic battles of the Cold War were underway, and through socialist realism as the dominant aesthetic ideology, cultural authorities sought to shape and control both artists and the wider population. Officials constantly exhorted composers to close ranks behind the party program and combat the pernicious influences of the West. Increasingly, however, growing numbers began to resist limits on their compositional freedom, leading to a less hardline socialist-realist paradigm in the GDR and its disappearance altogether in Poland.

\section{Debate and Decline in Poland}

When socialist realism burst onto the Polish musical scene in 1948, few Polish political figures and artists had knowledge of it. The Polish Communist Party garnered only minimal support in Poland during the interwar period, and Stalin's purges took the lives of hundreds of its members, leading to its dissolution in 1938. ${ }^{22}$ A number of cultural figures worked closely with the Soviet authorities in Lviv after its annexation by the USSR in 1939 and became versed in the theories and politics of socialist realism there. ${ }^{23}$ The communist musicologist Zofia Lissa worked at the radio and conservatory in Lviv at this time, and wrote for the official Polish-language daily newspaper. ${ }^{24}$ She spent the war years in the Soviet Union, and was a member of the procommunist Union of Polish Patriots in Moscow. In 1947 she returned to Poland, where she joined her musicologist colleagues Chomiński and Łobaczewska, as well as younger protégés, in elaborating the tenets of socialist realism through positions in the state bureaucracy and Composers' Union. She used Marxist principles to analyze musical works, and her writings were frequent and ubiquitous at the time. In the eyes of most 
composers, she became increasingly disliked and mistrusted for her party-line views and consistent condemnation of competing musical styles.

The dominating figure from the party side was without a doubt Włodzimierz Sokorski, a Polish Communist Party member in the 1930s who also spent the war years in the Soviet Union. A highly influential Deputy Minister of Culture from March 1948, he was appointed Minister in 1952. Sokorski was instrumental both in the implementation of socialist realism in the late 1940s and its attendant political control, and in the process of decentralization and retreat after 1952. In the years from 1954 to 1956, he attempted to compromise with an artistic world increasingly dissatisfied with him and his goals, and his authority among artists gradually eroded. ${ }^{25}$ Sokorski interacted frequently with composers, as he attended most union congresses and many other concerts and meetings. Composers seem not to have feared him, and indeed often spoke well of him. Sokorski was given to the grand gesture and hyperbole; his words carried significant weight, but seem to have been taken with a healthy dose of skepticism. ${ }^{26}$ Party leaders eventually removed him from his post in April 1956 as part of the far-reaching changes that peaked with the Polish October that fall.

More generally, most of the leading musical figures had survived the war, and they brought a diverse musical heritage into the new postwar Polish reality. During the interwar years, many had studied in Paris with the famous pedagogue Nadia Boulanger and soaked up the dominant neoclassical trend whose most influential proponent was Igor Stravinsky, vilified in the stalinist period as the worst of the formalists. A strong interest in composing "national" music similar to that of Béla Bartók coexisted with the neoclassical style among Polish composers. ${ }^{27}$ The most influential legacy here was that of the towering figure of early twentieth-century Polish music, Karol Szymanowski, who took up national and folk themes especially in the final phase of his creative production after the First World War and before his death in 1937; cultural officials were more attracted by these works rather than those from his more modernist and experimental early periods.

Relative freedom in the artistic world marked the first few years after the Second World War. ${ }^{28}$ The Communist authorities concentrated on asserting their dominance over the political realm, while culture remained fairly autonomous, in part because the party initially tread carefully with respect to Polish national culture as it sought to build support. The PZPR nonetheless encouraged artists to create for the broad masses, and most composers found common cause in the suggested turn away from the alleged elitism of the interwar years and toward the people. The atmosphere began to change in late 1947, as the party began to exercise control over the arts, and initiated discussions about socialist realism, and this first phase of growing debate lasted through 1949. 


\section{Initial Engagement}

Although the PZPR had formulated and gradually begun to implement a cultural policy already in 1944, most scholars date the party's concerted turn towards control over the cultural world from November 1947, with President Bolesław Bierut's speech at the opening of a new radio station in Wrocław. His call for increased focus on and organization of the artistic realm initiated a campaign that culminated in a series of conferences in all the arts in 1949, where officials and sympathetic cultural figures pushed socialist realism as the dominant ideology for Poland's artists. They defined it, however, in a general manner, and did not exert much pressure until the following year. At this moment, it was not a foregone conclusion that a narrow, dogmatic version of socialist realism would be promoted. ${ }^{29}$ The myriad contingent factors that led to this outcome included a broad initiative to emulate the Soviet Union, the introduction of the Six-Year Plan in 1950, and the intensification of the Cold War that radicalized politics more generally and produced increasing calls for ideological conformity. ${ }^{30}$ Undeniably, however, the party intended throughout 1948 to influence more significantly the artistic world, and in a manner to its liking. Włodzimierz Sokorski became Deputy Culture Minister that spring, and made known the party's intention to direct the ideological evolution of Polish artists. ${ }^{31}$

In the musical realm, events moved rapidly towards increased politicization and eventually socialist realism. During the Composers' Union's Third Congress in October 1947, already a month before Bierut's Wrocław speech, the very active cultural official and composer Witold Rudziński called upon his colleagues to transform their union into a "forge for ideological issues." 32 Several fellow composers echoed his calls for musical production to become more ideologically engaged. ${ }^{33}$ The ministry also organized a meeting between composers and writers to collaborate on the production of mass songs and postulated the idea of an "engaged music," or one with political content. ${ }^{34}$

Composers in Poland soon experienced the fallout from the early 1948 Zhdanovian polemics in the Soviet Union. In the summer of 1948, in the first of many such visits, a group of Soviet composers, led by young, energetic, and hardline Soviet Composers' Union president Tikhon Khrennikov, came to Warsaw to discuss formalism and realism with their Polish counterparts. ${ }^{35}$ Immediately after, the main music journal Ruch Muzyczny published an article by Khrennikov that praised "realistic" music while attacking formalist music by Stravinsky and Schoenberg. ${ }^{36}$ Opposing position pieces on the formalism debate by Poles appeared on the pages of Ruch Muzyczny soon after. ${ }^{37}$

An international musical meeting at this time in Prague also had some significant influence in Poland. Contrary to the commonly accepted view, however, this Second International Congress of Composers and Music Critics in late May 
1948 did not mark the beginning of the Soviet Union's attempt to impose socialist realism throughout Eastern Europe in the context of the Cold War's onset. ${ }^{38}$ While the numerous Soviet delegates gave strongly political speeches, delegates from all over Europe discussed the less than felicitous state of music at the time in an open manner. A planned "International Union of Progressive Composers and Musicologists," feared by some contemporaries as a potential stalking horse for Soviet control, in fact never came into being. In Poland, the congress proceedings appeared in Ruch Muzyczny, but discussions within the Composers' Union registered dissatisfaction that a broader spectrum of Polish views on contemporary music was not represented in Prague, and composers insisted on more input in any future meetings. ${ }^{39}$

Although not recognized as such by most scholars, the musical world has the particular distinction of being the first site in Poland where cultural officials coherently called on cultural figures to engage with the party's aesthetic program. ${ }^{40}$ At the Fourth Congress of the Composers' Union in late November 1948, Deputy Minister Sokorski gave the keynote speech that touched on formalism and (socialist) realism, though he described both in general terms. ${ }^{41}$ With respect to the latter, Sokorski insisted that it "should not be treated mechanically or as an artistic school" and used vague concepts like "artistic passion" and "unity of form and content" to explicate it. ${ }^{42}$ His overall message was that the party and composers should work together towards a common goal, and he claimed that the era's most prominent composers, Andrzej Panufnik and Witold Lutosławski, had already advanced well along the correct path. His moderate tone served to introduce new terms and ideas for discussion, and composers greeted his speech with "lengthy applause." ${ }^{\circ 3}$ Newly elected union president Zygmunt Mycielski, a widely respected composer who, despite his aristocratic background and leading position among the neoclassically inclined Polish music community in 1930s Paris, affirmed many of Sokorski's themes during his speech, even as he maintained that composers should have the autonomy to choose the form and style of their works. He showed genuine interest in the new ideas and urged his fellow composers to seek to understand the realism-formalism debate. Mycielski portrayed the new aesthetic ideology as embodying the composition of accessible but high-quality works that would appeal to a broad audience. ${ }^{44}$ Mycielski would play a crucial role in the discussions of socialist realism around 1950, and served in key institutional positions that transmitted party aims to composers and composer desires to cultural officials. Dominating the discussion at this point in late 1948 was the concept of popularization (upowszechnianie) - that composers should try to create music for the workers and peasants who made up the overwhelming majority of the population - and all composers approved of this initiative. The congress "Declaration" also focused on this issue, as it called on composers to reject "elitism ... [and] to reach out to the new listener . . . and educate him," while also 
asserting that a turning point had been reached where composers would receive state support and help fulfill its — as yet vaguely defined—goals. ${ }^{45}$ While discussion at the congress focused mostly on practical issues, union members did begin an open, exploratory engagement with the new aesthetic postulates, one that would continue over the succeeding months and years. ${ }^{46}$

After the congress, Ministry of Culture officials noted with satisfaction that this had been the first meeting with such an engaged ideological debate. ${ }^{47}$ In early 1949, Sokorski followed up on his speech by calling on the union leadership to organize a series of discussions on the topics of formalism and realism. ${ }^{48}$ At this point, Sokorski and many of his fellow cultural officials hoped that composers would find the way towards socialist realism on their own, with but a modicum of party-supplied guidance, financial and moral support, and encouragement. ${ }^{49}$ And indeed, the overwhelming majority of composers proved themselves willing to back the party's aims at this time.

Debates on socialist realism continued in the wider cultural milieu throughout the spring of 1949 as officials rhetorically pushed for artists to join in the fight for a new, party-sanctioned art. The PZPR Central Committee held a particularly important meeting in late May that focused on cultural issues. The party triumvir responsible for culture, Jakub Berman, stressed the importance of the arts for shaping worldviews, and insisted that socialist realism was the direction artists must take - though he claimed this offensive did not inhibit artistic freedom, since limited experiments would be permitted. ${ }^{50}$ With respect to music, Berman referenced Zhdanov's theses and attacked composers for creating in a formalist manner. Other party authorities present discussed music and claimed that composers like the country's most noted, Andrzej Panufnik, were responding to the party's efforts and becoming "enemies of formalism." ${ }^{51}$ Soon after, prominent party official Stefan Żółkiewski asserted that artists realized how much they had to change in themselves, and were ready to learn to "think and feel in our way (po naszemu). ${ }^{.52}$

Composers confronted the issues of formalism and (socialist) realism head on at a conference in the small town of Łagów in August 1949. ${ }^{53}$ In much of the relevant literature, Łagów has incorrectly become synonymous with the mailed fist of the totalitarian state imposing socialist realism on helpless composers. ${ }^{54}$ Composers and officials did indeed discuss realism and formalism, and officials clearly favored the former, but did not impose dogmatic definitions or make any threats.

Over four days, Deputy Minister Sokorski, 25 leading composers and musicologists, and a smattering of officials and musicians discussed the nature of formalism and realism, often through the prism of recently composed works performed live at the conference by the Poznan Philharmonic. ${ }^{55}$ The Music Department of the Ministry of Culture organized the conference and specifically chose 
musical works to promote a discussion of formalism and realism in music. ${ }^{56}$ Sokorski opened the proceedings by formulating two aims for the following days: to define the nature of realism and formalism in music and to set the course for composing such works over the next year in preparation for a major festival. ${ }^{57}$ The Deputy Minister led the free-flowing discussion and made frequent interventions into the debate, but never claimed to have superior knowledge - in fact, he often prefaced his opinions with caveats that he was not a musician, but rather simply a "lay person." ${ }^{58}$ Far from asserting a strict dogma, he allowed that realism is "not a defined movement or already crystallized form of musical expression ... [there is not] a magic formula or ready-made prescription." ${ }^{59}$ In a much more political closing speech, he proclaimed both the end of eclecticism and an approaching turning point for all composers towards realism and away from formalism. Surely his references to Lenin and Zhdanov made some composers uneasy, but his generalized guidance for compositions based on folk music and accessible to average citizens held broad appeal at the time. In addition, Sokorski conceded that no one knew what the "realistic, national art of the new, socialist era" looked like, and by exhorting composers to develop such a music, attempted to calm any doubts about limitations on artistic integrity by cautioning them against "oversimplification, one-sidedness, and following the path of least resistance." ${ }^{\prime 60}$

Composers' Union president Zygmunt Mycielski, an accomplished composer in his own right and much esteemed by his colleagues, gave the conference's keynote speech that set the stage for discussion with an overview of Polish music history and an assertion of the need to establish the path that composers should follow. ${ }^{61} \mathrm{He}$ noted that the musical world found itself in an almost unbelievably favorable situation since World War II, with considerable state support for composition, musical ensembles, and music education. With reference to Zhdanov, he laid out the main points of socialist realism in music: content linked to the people, nonelitist, a national style, simplified language, an increased focus on vocal and programmatic works, and a compositional technique subordinate to expression and not a goal in itself. He looked forward to discussing his general tenets with officials and fellow composers, but he did not think it was possible to decide exactly what was a formalist or realist work. ${ }^{62}$

Many composers shared Mycielski's interest in engaging the concepts of realism and formalism, and in charting a new path for Polish music. Roman Palester, who was soon become one of the few Polish composers to choose the life of a permanent émigré, expressed great curiosity in the new aesthetic tenets, though he maintained in a much later interview that his colleagues at Łagów displayed "reserve" and "were not speaking honestly about everything." ${ }^{33}$ Other composers as diverse in background as Kazimierz Sikorski, Jan Ekier, and Piotr Perkowski also engaged in the specific discussion of the terms ${ }^{64}$ Composers sympathetic to the party aims at the time, such as Bolesław Woytowicz, Witold Rudziński, and 
Tadeusz Baird, talked about the relationship of realist music to the new audiences of what they termed their developing socialist society. ${ }^{65}$

A key element of the conference was the performance of works followed by related discussion on their relationship to formalism and realism. In much of the scholarly literature, this is sometimes presented as tantamount to a show trial, complete with the condemnation of individual works; and part of the negative mystique of Łagów is linked to this labeling of works as formalist. A close reading of the conference proceedings shows the truth to be rather different, however. Sokorski often weighed in first, but his opinions seem not to have particularly influenced participants, who had little compunction in expressing opposing viewpoints.

One example pertains to the work of Andrzej Panufnik, arguably Poland's leading composer at the time. In his 1987 autobiography, Panufnik writes that he intentionally declined to come to the Łagów conference, but adds that one of his compositions "had drawn more fire than any other work." ${ }^{66}$ And indeed, his experimental and somewhat abstract Nokturn (1947) for orchestra was one of three contemporary Polish works that Sokorski labeled formalist, but the Deputy Minister delivered the critique even as he called it "a work of great caliber."'67 Furthermore, Sokorski did not reiterate his criticism in his closing comments or in an article published shortly thereafter. ${ }^{68}$ Two composers generally supportive of the party expressed appreciation for the piece despite Sokorski's comments: Bolesław Woytowicz, well respected for running a wartime Warsaw café where much excellent music was performed, found the Nokturn quite good, and his colleague Tadeusz Szeligowski, composer of Poland's first socialist-realist opera and future president of the Composers' Union from 1951 to 1954, also found it comprehensible to potential audiences. ${ }^{69}$

More fraught and complex were the discussions of Zbigniew Turski's threemovement Second Symphony, Olympic, which had achieved a stunning success with the gold medal at the competition linked to the 1948 London Olympic Games. Sokorski found the musical language and content too pessimistic and not appropriate for the new socialist person - perhaps not a surprising criticism, since Turski introduced the piece by explaining that he had tried to evoke the difficult war years and the smoke of the crematorium, and the work is marked by a dark, somber, and dissonant musical language. ${ }^{70}$ The musicologists Zofia Lissa and Józef Chomiński gave nuanced, critical appraisals of the work and a number of composers praised it, while only youthful party member Andrzej Klon attacked it fiercely. ${ }^{71}$ Turski asked Sokorski if the latter's criticism was directed at him or his symphony, and Sokorski acknowledged that he considered only the work formalist. The composer thanked his critics and declared himself ready to undertake new projects - which flowed freely from his pen in the following years, some with a socialist-realist cast, and often funded by the party. ${ }^{72}$ This symphony did 
subsequently disappear from the repertoire for a time because of its alleged pessimism, but this was an anomaly. ${ }^{73}$ The experience seems to have gotten under his skin, however, as Turski was one of the main antagonists of socialist realism's proponents just a few short years later.

The great majority of the participants at Łagów praised most of the performed works, or at minimum judged them to be on the correct path towards realism. The youthful and increasingly prominent Tadeusz Baird premiered his light and accessible Sinfonietta, which received great applause and was even given a repeat performance. Baird joined with his peers Kazimierz Serocki and Jan Krenz, later better known as an accomplished conductor in Poland and abroad, in the Grupa ' 49 , a collective of younger composers initially devoted to fulfilling the aims of socialist realism. Baird and Serocki declared themselves ready to compose "clear and simple music" and rejected the idea of art for art's sake. Serocki even announced that he had recently burned all his previous works upon realizing that his artistic views had changed. ${ }^{74} \mathrm{Krenz}$ composed a number of socialist-realist works at this time while also pursuing a successful career as a conductor. Such enthusiastic attitudes were the most extreme, but did represent the eagerness or, at minimum, openness of the broad majority at this early moment; the evolution of these younger composers away from socialist realism and towards a more complex and experimental musical language by the mid-1950s is also characteristic for most Polish composers. Baird and Serocki were the prime movers behind the Warsaw Autumn Festival, begun in 1956 and featuring music deemed formalist just a few years earlier. ${ }^{75}$

Perhaps most interesting at Lagów was the lack of unity among those who would be most expected to support and propagate the new doctrine. Party member and musicologist Zofia Lissa criticized Sokorski's approach to realism and formalism as overly psychological, and offered an expansive, undogmatic definition of realism - "a trend just becoming postulated"-as "humanistic art." She defined formalism as dehumanized, anti-emotional, abstract, privileging technical experimentation and formal construction over content, not based on folklore, atonal, and pessimistic. ${ }^{76}$ Sokorski in turn belittled her carefully presented ideas on formalism as points of discussion rather than theses; she was also criticized by fellow party member Jan Maklakiewicz. ${ }^{77}$ Composer Witold Rudziński, until recently head of the ministry's Music Department and future president of the Composers' Union, contradicted his former boss Sokorski in praising Turski's symphony. Such dissension hardly represented a supposedly united front in a party-inspired, totalizing project to impose dogmatic norms. Instead, Łagów reveals the exchange of a diverse and overlapping set of political and aesthetic opinions from officials as well as musicologists and composers from inside and outside party ranks. 
The atmosphere at Łagów was rather one of self-criticism and of defining the nature of socialist realism and formalism through open discussion. Sokorski and Zofia Lissa set the general guidelines for what was expected of composers, but with frequent caveats that these were not fixed rules and that socialist realism was not a hardened formula. In an article written just after the conference, Sokorski summarized the contemporary state of affairs with respect to the fight for socialist realism and against formalism. He encouraged composers to turn away from "imperialist," American, cosmopolitan, atonal, and abstract influences and toward socialist realism, a term now with the adjective "socialist" but still vaguely defined as tonal, harmonic, and meaning the unity of form and content. He reiterated that socialist realism was not an "artistic school," but rather a "creative method," and cautioned composers against simplifying their music language to the point that it became primitive. Finally, he maintained his criticism of Turski (but not Panufnik) and rather muddily tried to explicate the formalist elements of the Olympic Symphony, while nonetheless emphasizing that Turski was "a great talent." $"$ At Aagów and in its aftermath, socialist realism was presented as the future of Polish music, but how it would actually look in practice was open to discussion.

\section{Encroaching Dogma}

The space for continued discussion and experimentation began to narrow in late 1949 through 1950, as cultural officials and their musical allies pushed for composers to produce concrete results in their new compositions. Deeply symbolic was the closure of the more independent, Kraków-based journal Ruch Muzyczny and its replacement with Muzyka, published in Warsaw and under the control of the party. Thematically, attention turned to composing works for Stalin's $70^{\text {th }}$ birthday and for the first Festival of Polish Music, the latter meant as a showcase for socialist realism in music. To both, composers responded willingly with politically engaged compositions, though initial rumblings against excessive political interference began. ${ }^{79}$ At another major conference in early 1950, Sokorski urged composers to create works of a realistic character, both to educate fellow composers in the new ideology and to shape the worldview of audiences. He used charged phrases like "the battle" for creating new, expressive, socialist-realist works and overcoming formalism, urged that the small changes already seen should become a huge leap towards socialist realism, and criticized individual compositions. ${ }^{80}$ The participants also discussed several works, including Shostakovich's cantata on Stalin's reforestation campaign, Song of the Forests, which was held up as a prime model for new composition throughout the Soviet bloc and performed frequently due to its positive political message and accessible, melodic musical language. ${ }^{81}$ Shostakovich produced this seven-part work for chorus and soloists 
that celebrated the engagement of young people in the reforestation of Siberia after the Second World War and extolled Stalin as "the great gardener."

Composer Zygmunt Mycielski, who had to this point worked closely for the party's cultural program and would continue to do so, though with growing doubts, captured this turning point in his diary entry in March 1950: "Up to now there has been a cultural NEP. Now the revolution must go farther." Although feeling himself unable to represent this new line and continue as president of the Composers' Union, he did not give up on working towards composing a new music that would be acceptable in the socialist era to come: "I have the sense that I am on the track of certain musical qualities that would produce a simple, useful, clear music — clear thematically, harmonically, rhythmically - sufficiently bright and light. Perhaps they would call this realism?"82 These impulses likely informed the composition of his first, Polish Symphony (Symfonia polska, 1951), in which he attempted to fill the traditional classical form with a national character through a fresh take on folk-based melodies, and his one-act ballet Fun in Lipiny (Zabawa w Lipinach) that thematized tractors, the new countryside, and the tension between traditional rural and contemporary Western culture.

Despite his uncertainties about the new line and his relation to it, Mycielski nonetheless opened the union's June 1950 conference with a thoughtful, stirring speech that described what he believed to be that next historical step, socialist realism, in an effort to convince his fellow composers to engage with this aesthetic ideology. He called on his colleagues to abandon their old ways of thinking and composing, to step out of their "comfortable carriages"-traditional genres of music like the sonata - and into different forms of locomotion. They all lived in a new era of massive changes, which their music must reflect. He advised his peers to break out of their isolation and elitism - by reaching out to the new listener, they could not but create the music of the coming age, a socialist-realist music based on national and folk tradition and for the entire nation, including especially workers and peasants. He interpreted the revolutionary slogans from the Soviet Union as opening a "broad line of artistic possibility" for composing great, creative works that would appeal to and educate the people, works that were simple but not simplified, and that contained deep emotion and ideological content. He praised the progress his colleagues had already made, noted the considerable sums the state provided for composition, and encouraged an embrace of the possibilities of the new era just now coming into being. ${ }^{83}$

Mycielski thereby set the tenor for the first several days of this 1950 conference. Unlike ten months earlier at Łagów, proponents of the party line now assumed that composers had a general grasp of the formalism/realism debate, and therefore they focused here on how to best overcome the former and embrace the latter. Over half of the 40 union members present spoke during the four days of discussions and concerts, and all who did agreed that formalism must be fought. 
Musicologists, cultural officials, and their ideologically inclined colleagues encouraged composers to look within themselves and expunge negative influences held over from earlier formative periods in their lives. No one disagreed that socialist realism should be the goal and that all should reach out to the newly forming society and help shape it through their compositions. Zofia Lissa made a typical contribution, as she praised composers for progress made, but urged them to engage more actively in the pursuit of the socialist-realist program. ${ }^{84}$

A relatively moderate tone gave way to the hardliners later in the conference. Surely chilling was the sharply critical intervention by soon-to-be Composers' Union president Witold Rudziński, who fiercely attacked many composers, including prominent figures like Panufnik and Witold Lutosławski, for not making more progress in overcoming formalist influences. ${ }^{85}$ Antiformalist enragé Jan Maklakiewicz replicated his Łagów performance and fulminated against "the terror of the formalist clique." ${ }^{86}$ Deputy Minister Sokorski expressed deep disappointment that a "new current" of music had not developed in the year since Łagów and lamented the "strange atmosphere of resistance." He claimed composers had muddled the concept of formalism and called upon each of them to produce new realist works, concluding: "the creation of an atmosphere of honest, combative criticism, in which the Polish music of the socialist era will arise - that is our mission!" ${ }^{87}$ He closed the conference with a highly political speech about the need to fight American imperialism and its aesthetic sidekick, formalism. Harshly criticizing leading composers, whom he urged to engage in self-criticism, Sokorski demanded that they renounce formalism in their compositions. ${ }^{88}$ For Sokorski and the hardliners, the time of discussion had ended; for most composers, a difficult period of considerable political pressure began, but one that presented opportunity as well as struggle.

There were thus four broad camps at this 1950 turning point in the debate over socialist realism in music: Deputy Minister Sokorski and a handful of composers and musicologists who demanded that composers embrace a narrow version of socialist realism immediately; a sizeable group of communists and sympathizers who agreed that socialist realism was a desirable goal, but that time was needed for composers to work on themselves and develop a new musical language; perhaps the largest group, composers who were broadly sympathetic to the socialist-realist program, but wanted some compositional freedom and the ability to experiment; and a very small group who renounced socialist realism entirely. Starting in 1951, and then accelerating quickly thereafter, increasing numbers in groups two and three came also to question and ultimately reject socialist realism, as they found it dogmatically interpreted and rigidly imposed.

The election of Witold Rudziński as president of the Composers' Union at this Fifth Congress in June 1950 inaugurated a year-long attempt to realize the party's goal of instituting a hardline version of socialist realism. Born in 1913 and 
active in Vilnius and the surrounding area in his twenties, Rudzińsnki brought an energetic and politically engaged sensibility to his work for the state and the Composers' Union, as well as in his own numerous socialist-realist compositions. At the first meeting of the newly elected Executive Committee in late June 1950, this former Culture Ministry official laid out his vision for a politically engaged union. He called for "the ideological formation of composers - to recognize the basis of socialist ideology, especially Marxist aesthetics, [and for] the fight against the principle of formalism." ${ }^{" 19}$ Rudziński further demanded that composers write for the "mass listener," concentrate on vocal works like the mass song, undertake a yearly two-week stint to interact with workers and peasants, and in general participate actively in the realization of the political goals of the party. ${ }^{90}$

Many of the union leaders present at the June meeting considered Rudziński's plan too ambitious, including party members Lissa, Jan Maklakiewicz, and prodigious writer of mass songs Alfred Gradstein, as well as other composers usually sympathetic to party goals like Tadeusz Szeligowski. Others were less negative, at least at this initial stage; Andrzej Panufnik merely complained that material support for compositions should be emphasized more, and Zygmunt Mycielski in fact called the plan "excellent." ${ }^{\text {"11 }}$ Rudziński's highly ideological agenda soon proved too much for a growing number of composers, however. One of Rudziński's major initiatives was the institution of audition concerts (przestuchania), at which composers performed and discussed new works. He envisioned them as "a direct site in the fight for socialist realism, as an expression of our era, as an instrument for the formation of the masses, [and] as a "factory of joy." "92 Most composers appeared to be less enthusiastic, and many resisted participation, finding them overly ideological.

Similarly, on a broader scale, the initial interest among composers in socialist realism and related willingness to work with the party gave way to misgivings about excessive limitations on artistic freedom. The situation in the Composers' Union deteriorated rapidly, as Rudziński's actions produced a "crisis" there by the end of $1950 .{ }^{93}$ In December 1950, Andrzej Panufnik and Poland's most prominent female composer Grażyna Bacewicz, followed by Jan Maklakiewicz one month later, resigned from the Executive Committee, apparently in protest of Rudziński's actions. ${ }^{94}$ Two composers sympathetic to the party, Mycielski and Szeligowski, were brought onto the Board to replace those who had resigned..$^{95}$ At a key meeting of union leaders with Deputy Minister Sokorski in January, Rudziński acknowledged the criticism, but sought political cover from Sokorski. The latter provided this handsomely, asserting, "The more liberal tone in current discussions on artistic production has been wrongly interpreted as a manifestation of a weakening of the battle against formalism," and called for renewed focus on socialist realism to combat mistaken artistic experiments in naturalist and formalist styles. He pushed composers to continue their self-criticism and 
discussions, but in a conciliatory move, admitted that questions of quality were just as important as questions of ideology. ${ }^{96}$

Growing dissatisfaction with and resistance to Rudziński's policies - and by extension those of the party-caused his resignation in the summer of 1951, the only time in the history of the union that a president did not serve a full term. ${ }^{97}$ Similar expressions of discontent throughout the artistic world at this time led the party to moderate its policies slightly. At a large meeting in the fall, Sokorski relied on the carrot as much as the stick when he praised many composers for the progress they had made in the two years since Łagów and urged them to continue along the "difficult, sometimes painful, and prolonged process" of overcoming formalist tendencies and to do so with more "ideological zeal." 98 Another minor retreat was in evidence during an important Council of State meeting at the end of October 1951, where Jakub Berman continued to call for artists' full engagement behind socialist realism, but pointed to "schematism"- - a problem supposedly manifested in some works of art that followed the rules of socialist realism but were of poor quality. ${ }^{99}$ Again, the emphasis on the aesthetic value of the artwork was indeed a concession, but also surely a straightforward desire for technically accomplished works in the socialist-realist idiom.

Sokorski reinforced this slight change of course at the Sixth Congress of the Composers' Union in December 1951, where he praised many composers for their works performed at the first Festival of Polish Music that year. Although calls to fight against formalism and for ideological engagement continued, the harsh prescriptions about socialist realism from the previous year were toned down considerably. Echoing Berman's October speech, Sokorski condemned "schematism" as a deviation from socialist realism. ${ }^{100}$ The intent was to focus more on the technical quality of the composition, and less on the programmatic or political, and thus was something of a retreat from socialist realism's primary focus on politicized content.

The other main speakers at the December 1951 Congress broadly praised composers for having made ideological progress in the previous two years. Mycielski appealed for more contact with the masses and for smaller and more accessible compositions that would fit comfortably within a socialist-realist mold. ${ }^{101}$ Lissa echoed this call in her speech, which included a largely favorable overview of the compositions played at the Festival. She praised composers' ideological development and overcoming of formalism, and even accepted the use of some compositional techniques from the interwar period that two years earlier would surely have been deemed formalist. ${ }^{102}$ Party members and composers of socialist-realist popular music Edward Olearczyk and Witold Elektorowicz called for more ideological engagement, but dissenting voices were heard as well, as when frequent gadfly Turski attacked party member Alfred Gradstein for his cantata 
A Word on Stalin for not being "national" (i.e., Polish) enough, and for naturalism-two deviations from socialist-realist norms. ${ }^{103}$

Witold Rudziński's exercise in self-flagellation at this congress, five months after his resignation as president, represents a fitting summary of both party and hardliner attitudes in late 1951: he felt composers should have supported his efforts to propagate socialist realism, but admitted that his program was too "maximalist" and that he did not recognize what he called the "gradual and individualized political and ideological maturing process" taking place in his fellow composers. He nonetheless affirmed the larger goal of fighting for socialist realism and committed himself to doing so as an individual union member. ${ }^{104}$ Respected middle-generation composer, pedagogue, and future Composers' Union president Kazimierz Sikorski closed the congress by noting that the era of ideological battle had come to an end, and that a less disruptive era of synthesis should follow. ${ }^{105}$ For the most part, and despite the continuing efforts of party officials and a dwindling number of their composer allies, this new era proved in practice to be a gradual but steady distancing from socialist-realist norms on the part of most composers.

Even with the slowly mounting dissatisfaction in 1951, composers produced a breathtaking number of compositions consonant with the norms of socialist realism during its high point from 1949 to 1953 . Scholars have largely passed over these works, and composers themselves have often disavowed them. Nonetheless, all Polish composers worked within the socialist-realist paradigm at this time. ${ }^{106}$ And there is too much evidence of cooperation, and too little of coercion, to have the latter be a dominant explanatory factor. ${ }^{107}$ Rather, composers agreed with many of the party's goals, especially in bringing music to a wider audience, and found significant common ground in the precepts of socialist realism. After the horrors of the war and Nazi occupation, and the weakness and mistakes of Poland's prewar conservative government, combined with the perceived treason of the Western democracies before and during the war, many composers wanted to help the party rebuild the country and accepted the alliance with the Soviet Union, and proved willing to support the party's vision. Prominent figures like Panufnik and Lutosławski as well as their colleagues of all ages and backgrounds composed political mass songs as well as larger vocal and instrumental works with ideological themes and in a simplified musical language that drew heavily on folk music.

In the decade after the war, Polish composers produced roughly 1500 mass songs, a genre particularly prized for its supposed ability to communicate political messages readily to the population through catchy melodies. ${ }^{108}$ Witold Lutosławski wrote around ten mass songs on political themes in the early 1950s, and many of them proved quite popular among the public, with frequent radio play and multiple printings of the sheet music. ${ }^{109}$ Two marches, Nowa Huta and A Most Beautiful Dream (Najpiękniejszy sen), the latter a rousing celebration of 
young people "forever in love with steel," thematized the showpiece new industrial town outside of Kraków. Comrade (Towarzysz), proclaimed victory under the red flag, while Service to Poland (Stużba Polsce) lauded youth activism in a jaunty krakowiak rhythm. We Go Forward (Naprzód idziemy) described the reconstruction of Poland, and The Victorious Path (Zwyciesska droga) celebrated Polish soldiers' wartime victory that created "a worker and peasant Poland" of "singing tractors" and "red neckties." These songs show real compositional skill and engagement, and Lutosławski took them seriously, as evidenced not least by his anger over the publisher modifying some of the lyrics without his approval. ${ }^{110}$

Panufnik contributed a handful to the genre as well, including perhaps the most infamous, the Song of the United Party (Pieśn Zjednoczonej Partii), composed in 1948 to commemorate the fusion of the communist and socialist parties, an important step in the stalinization of the country. ${ }^{111}$ His simple but stirring piece to a text by poet Leopold Lewin praised the new party as "leader of the masses . . leader of the entire nation." An only slightly less ideological song was his A New Era (Nowy czas), written in 1954 on the occasion of the PZPR's Second Congress and extolling the accomplishments of the past decade in a march-like rhythm. Yet another addition to the genre was Peace on Earth (Pokój nad światem), on a theme used by the party to appeal to a war-weary population, and a political issue with which Panufnik was closely involved throughout this period. ${ }^{112}$

One of the most notable composers of mass songs was Alfred Gradstein, one of the few party-member composers of any stature. His march Salute the Party (Cześć partii) is representative in its far-reaching claims for the party's good works and a refrain ending "Glory, glory, glory to the party. Salute the party!" He is perhaps best known today for the still appreciated On the Right a Bridge, On the Left a Bridge (Na prawo most, na lewo most), which describes the reconstruction of passage across the Vistula river with a catchy waltz-like melody. He also wrote a seemingly limitless number of songs on every conceivable theme, including brotherhood, unity, and stakhanovite workers, and several on the Union of Polish Youth (Zwiqzek Młodzieży Polskiej, ZMP), one of which lauded its members' work in the rural areas (ZMP pomaga wsi, The Union of Polish Youth Helps the Countryside).

An equally accomplished practitioner of the genre was the young Edward Olearczyk, who wrote dozens of songs covering a range from solemn hymn to the lively march. An example of the latter is one of the earliest and most popular mass songs, Millions of Hands (Miliony rak, 1950), on the building of People's Poland with young people "linked by work and song." He tackled such other ideological themes as Song in Praise of Comrade Bierut (Pieśn na cześć towarzysza Bieruta), about Poland's president, with the lines: "Your words are signposts for us, / Simple, powerful, tough as steel, / We will head into the clear future with 
you, / A difficult path of sacrifice and battle." He also celebrated the MDM, Warsaw's socialist-realist architectural core, and Our Party (Nasza partia) in song. Several works put to appealing melody the politically inflected themes of peace and youth organizations. His nearly exclusive focus on such ideological mass songs made him a target of those in the Composers' Union who sought to minimize political influence a few years later, an episode described in chapter 2.

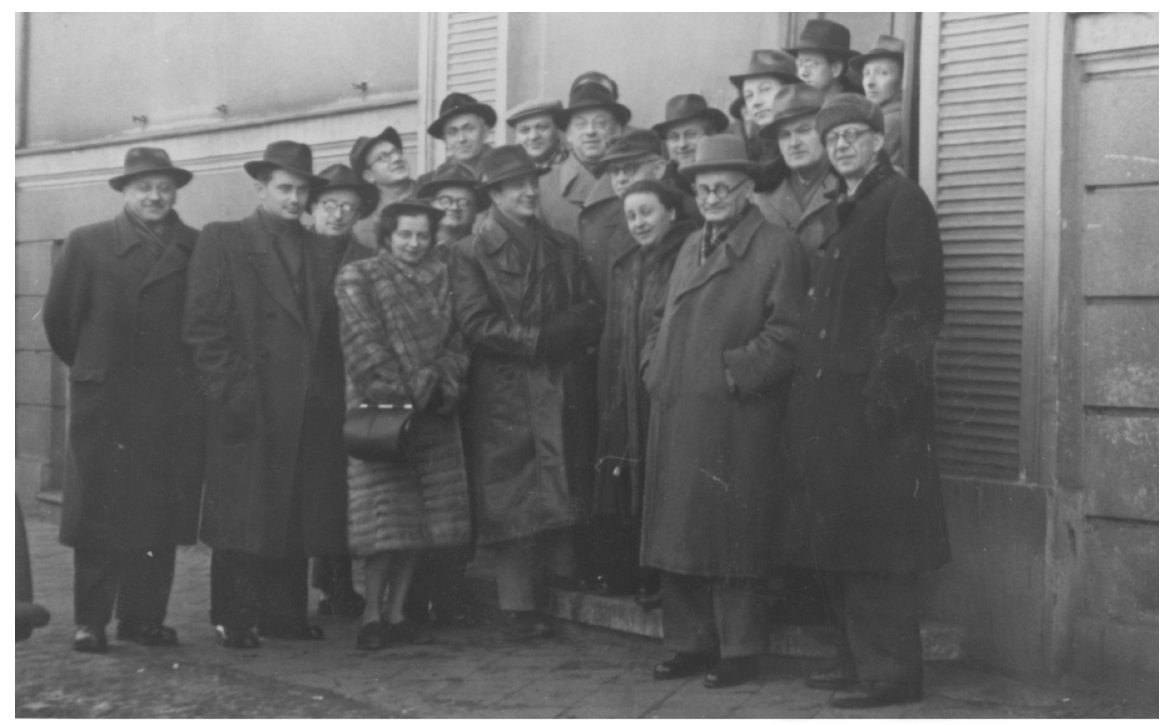

Meeting of the ZKP Plenum in Poznań in December 1952. From left: Stefan Bolesław Poradowski, Tadeusz Baird, Jerzy Jasieński, Andrzej Markowski, Grażyna Bacewicz, Tomasz

Kiesewetter, Jan Ekier, Wawrzyniec Żuławski, unknown, Tadeusz Szeligowski, Hieronim Feicht, Zofia Lissa, Marian Sobieski, Kazimierz Jurdziński, Edward Olearczyk, Bolesław Szabelski, Stanisław Wisłocki, Zygmunt Mycielski, Witold Lutosławski (Photo 0044a, Polish Music Information Center).

A sizeable number of composers added political mass songs to more traditional popular song production during these years. Władysław Szpilman, the protagonist of Roman Polański's 2002 film The Pianist and a prodigious writer of eminently danceable and well-liked songs, wrote a number of works that blurred the border between political mass song and popular song, including The Bricklayer's Waltz (Walczyk murarski), Song about Friendship (Piosenka o przyjaźni) and To Work (Do roboty). Tadeusz Sygietyński, famous as the founding director of the wildly successful folk-dance troupe Mazowsze, composed Song about the Six-Year Plan (Piosenka o 6-letnim planie), which described workers and peasants working together to fulfill their norms. Perhaps his most popular was $B e-$ loved Country (Ukochany kraj) to a text by Konstanty Ildefons Gałczyński that mobilized patriotic feelings to encourage all in the building of a new socialist Poland. Other key works include his March for Peace (Marsz pokoju) and Parade of 
Friendship (Pochód przyjaźni), with its musical portrait of young people united in friendship and led by the Soviet Komsomol. One of the most hagiographic songs of the era was his Song about Bierut (Piosenka o Bierucie), which praised the Polish president with the refrain:

How proudly the sun now rises

And each of our steps is lighter

Because Bierut leads us today,

And he and the people govern the country.

Bierut - the pride of People's Poland,

Bierut-leader of the masses,

To a brighter tomorrow, to a better future,

At the head of the Party he leads us. ${ }^{113}$

Other highly ideological contributions include Witold Rudziński's To the Party (Do partii), which in march rhythm describes the PZPR as inspiration and features the stirring refrain: "You taught us how to work / and give our life for our country / Lead us, our Party, lead / into the era of prosperity!" Party member Jan Maklakiewicz wrote two songs about Stalin, Song about Stalin (Pieśń o Stalinie) and Stalin is with Us (Stalin z nami), the latter written shortly after the Soviet leader's death. Zbigniew Turski, criticized for his Olympic Symphony at Łagów, wrote Song for the First of May (Piosenka pierwszomajowa), which portrays red flags as the hope of millions on the traditional workers' holiday. All in all, nearly every composer, young and old, from the well-known to the obscure, tried their hand at mass song composition. The party consistently encouraged this important aspect of the democratization and politicization of musical culture at the time.

Larger-scale vocal works were particularly prized for their assumed ideological impact, and the showpiece genre of the period was the cantata, designed to educate and appeal to a broad audience. Many composers of the period tried their hand at one, which generally featured some combination of soloists, choir, and significant musical ensemble, and linked up with a tradition of nineteenthcentury secular cantatas that was continued in the Soviet Union. The most famous Polish cantata was perhaps Alfred Gradstein's A Word on Stalin (Stowo o Stalinie, 1951), and future world-renowned conductor Stanisław Skrowaczewski used parts of the same text by poet Władysław Broniewski for his Cantata on Peace (Kantata o pokoju, 1952). ${ }^{114}$ Other notable contributions to the genre of the politicized cantata included Tadeusz Szeligowski's Charter of Hearts (Karta serc, 1952), about the new constitution of People's Poland, and Witold Rudziński's $A$ Peasant's Lot (Chtopska droga, 1952), which traces the fate of the peasant from bondage to freedom in the new socialist reality. Labor was often celebrated in these works, as in particular Bolesław Woytowicz's Cantata in Praise of Work (Kantata na pochwate pracy, 1949), and Jan Maklakiewicz's Silesia Works and 
Sings (Ślask pracuje i śpiewa, 1950). Each of the young composers in the Grupa '49 produced large, programmatic vocal works: Jan Krenz a Conversation of Two Cities (Rozmowa dwóch miast, 1950), between Warsaw and Moscow, Kazimierz Serocki the cantata Warsaw Bricklayer (Warszawski murarz, 1951) and his second symphony, Symphony of Songs (Symfonia pieśni, 1953), inspired by folk music and with texts thematizing peasant life, and Tadeusz Baird the cantatas Song of Revolution (Pieśn rewolucji, 1951) and Ballad of the Soldier's Cup (Ballada o żolnierskim kubku, 1954). All these works employed an accessible if often bombastic musical language that communicated a political message clearly to the listener.

While opera in Poland did not have the same history and contemporary valence as was the case in East Germany, cultural officials did encourage the genre, with little success. ${ }^{115}$ A particular challenge was motivating writers to produce an appropriate libretto, and despite incentives such as a contest, this initiative largely failed. ${ }^{116}$ Tadeusz Szeligowski created the most notable example, The Scholars' Revolt (Bunt żaków, 1951), which dramatized a sixteenth-century rebellion among Kraków students. Witold Rudziński contributed Janko the Musician (Janko Muzykant, 1948-51), based on the Henryk Sienkiewicz novella about a musically inclined peasant who is unable to realize his ambitions in the context of nineteenth-century class society.

As prescribed by socialist realism, instrumental music in general was written in a more understandable style that drew on folk themes and built on national and historical traditions. The works of Poland's best-known female composer, Grażyna Bacewicz (1909-69), are representative of many composers' output during this period. ${ }^{117}$ In her several concertos, three symphonies, and a broad array of chamber music works between the late 1940s and the mid-1950s, she maintained her own take on the neoclassical style she encountered while studying in interwar Paris, but also included significant folk-music elements that fit into the socialistrealist idiom. Her Third Symphony (1952) is fairly representative, with its clear, folklike melodies and trajectory from tension to climax. Also of note is the ballet The Peasant King ( $Z$ chtopa król), which portrays noble and peasant settings, the latter filled with vigorous folk dances while the former come across as grotesque and empty. ${ }^{118}$ The cultural authorities found much to like in her instrumental music and these works won several state prizes in the first half of the 1950s. She was an accomplished violin soloist who turned increasingly to composition, and seems to have thrived in this period, with considerable sympathies for the communist project. ${ }^{119}$

Lutosławski's instrumental works of this period similarly derived from the folk sources encouraged by socialist realism, including his light and lively Little Suite (Mała suita), with original folk melodies from the Rzeszów region. Most noteworthy is his Concerto for Orchestra, begun in 1950 and completed in 1954. 
Also based on folk themes, it was hailed at the time as a major achievement of socialist realism - and is one of his most popular and well-known works today. It is a powerful and expressive piece containing moments of grandeur and a stirring finale, and was greeted with enthusiasm at its premiere, although some were disoriented by the relative novelty of the piece and left the hall in disgust. ${ }^{120}$ Panufnik similarly drew on folk music for a number of works, including his Sinfonia Rustica (1948), which received many performances in 1948 and 1949. It was a technically accomplished and melodic piece that used folk music from the northern area of Poland. Although Panufnik claims in his autobiography that it was banned for not fulfilling the tenets of socialist realism adequately, it was an official submission for the International Peace Prize in the summer of 1950 and in fact performed several times in the following years. ${ }^{121}$ Nearly all composers followed the lead of Panufnik and Lutosławski, and created accessible instrumental works that linked up with Polish folk traditions.

\section{The Thaw in Music}

Throughout 1952 and into 1953, the party continued to push for socialist realism while making minor concessions, even as composers gradually turned away from it due to increasing frustration with its narrowly interpreted tenets. A sharpening of the battle lines took place; the ministry took control over the process of commissioning works, while a growing number of composers, led by Lutosławski, began a process of requalification of union members that marginalized a number of left-leaning composers of lighter popular music. A pattern emerged over these years: calls for ideological purity continued, but in more moderated form as the party made small retreats in the face of artists increasingly demanding more aesthetic freedom. Early in 1952, the Ministry of Culture attempted to generate discussion on the formalism-realism debate by sponsoring articles and initiating contact with composers on the subject, but significant cracks in the paradigm soon began appearing. ${ }^{122}$ In a striking example of a transnational development across the two countries, a December 1952 visit by Bertolt Brecht's theater troupe, the Berliner Ensemble, prompted an influential series of articles in the Polish press that attempted to broaden the definition of socialist realism. ${ }^{123}$ That month, a discussion of Stalin's theses on linguistics at the Council of Culture and Art saw the first organized and coherent attempts by artists to press for a more elastic interpretation of socialist realism. ${ }^{124}$ An article by Zofia Lissa on the same subject soon after also exhibited a slight loosening of her interpretation as well, as she emphasized the autonomous aspects of music. ${ }^{125}$ The developments of 1952 culminated in long discussions at an expanded plenary session of the Composers' Union Executive Committee in December, where a number of composers demanded more compositional freedom, while at the same time Zofia Lissa con- 
tinued to bemoan composers' "lack of passion" in ideological matters, and still called for socialist-realist works that would appeal to the broad masses and that were linked to the issues of the day. ${ }^{126}$

In the first half of 1953, party officials continued their campaign for socialist realism with a policy of gradual concessions to artistic autonomy. Ministry officials pushed for "the further deepening of the battle for socialist-realist art," and called for the next major music festival to "show the further progress of Polish music on the path to socialist realism." 127 Stalin's death on March 5, 1953, resulted in a short period of increased dogmatism during the public commemorations and outpourings of grief; this harder line manifested itself most clearly in a meeting of the Council of Culture and Art in April. ${ }^{128}$ It focused on artistic criticism and produced a resolution calling for "the deepening of the fight for a zealous, Marxist, socialist-realist based . . . literary and artistic criticism, which will be an active force in the formation of contemporary artistic production ... and will sharpen vigilance with respect to the danger of leaving the path of socialist realism." ${ }^{29}$ Ministry official Jan Wilczek gave the keynote speech that acknowledged a weakening of the campaign for socialist realism but exhorted artists to resume the battle to institute it.

The gathering thaw thereafter provided the catalyst for an opening that had been underway publicly since at least late 1952. In the music world, as more broadly, voices of dissent and dissatisfaction had been growing for some time. Jan Ekier's suggestion that political considerations had prevented the performance of works by Zbigniew Turski and others, and a consequent demand for more openness, was greeted with loud applause at an important Composers' Union meeting. ${ }^{130}$ At another forum, Grupa ' 49 member Jan Krenz complained openly about his treatment by Minister Sokorski, who had attacked Krenz's music at previous conferences. ${ }^{131}$ Composers began turning away from the genres of music, like the mass song and cantata, preferred by the proponents of socialist realism. ${ }^{132}$ These developments culminated in a December 1953 meeting of the expanded Executive Committee of the union to discuss the proposed second Festival of Polish Music. The gathering featured an extraordinary speech by Sokorski who admitted "a concept of socialist realism" had not been created. He indeed advocated that composers continue to try to develop such a concept through their works, but allowed that "a broad range of individual styles and possibilities" was permitted. ${ }^{133}$ Mycielski, who had heretofore largely echoed the party line, now spoke openly about how previous prescriptions relating to socialist realism and formalism had been mistaken, and he called for an end to "demagogically formulated and interpreted slogans about realism." He asserted that composers still did not know the true nature of realism in music, and advocated for a diverse selection to be played at the upcoming Festival, including works formerly condemned as formalist like Turski’s Olympic Symphony (1948) and Lutosławski's First Symphony (1947). ${ }^{134}$ 
Sokorski's speech in particular marked a significant blow to the dwindling number of proponents of socialist realism in music, while Mycielski's about-face was highly symbolic of a collapse in composer interest.

In early 1954, continuing discussions and a more permissive atmosphere in the Soviet Union created space for increased experimentation both there and abroad, and at the Second Congress of the PZPR in March and the meeting of the Council of Culture and Art in April, Sokorski advocated giving artists more autonomy - though party officials did not yet widely share this opinion. ${ }^{135}$ At the much-delayed Seventh Congress of the Composers' Union in late April 1954, the concept of socialist realism was further called into question. Zofia Lissa opened the proceedings with a speech that praised the progress made toward socialist realism, and continued her usual calls for composers to help influence society and to be politically engaged. In an surprising and telling move, however, she also conceded a damning number of mistakes. She employed a strategy of affirming the broad goal of realizing socialist realism in music, but now attempted to define the concept more expansively and advocate for its establishment at a more gradual pace, while also criticizing the means employed to foster it over the recent years. She accorded significant blame to Sokorski in an attempt to exculpate herself, thus revealing the continued and growing fractures among PZPR supporters. She lamented black-and-white thinking, especially the false dichotomy of formalism versus socialist realism, and asserted that the "vulgarization" of equating formalism with difficult music, and socialist realism with simple, had been deleterious to the music world. In a significant concession to composers, Lissa affirmed that experimentation with new compositional techniques was desirable, but with the caveat that it must serve the greater goal of contributing to a music linked to the party's goals. ${ }^{136}$

In this manner, Zofia Lissa sought to preserve and indeed reinvigorate socialist realism, while granting that mistakes had been committed and that some autonomy should be allowed, and a spirited, forthright, and at times angry debate ensued. Several composers took her speech as an opportunity to condemn her and the policies she stood for, and they asserted composers' rights to autonomy outside of the strictures of socialist realism. Turski criticized her for imposing the "hegemony" of musicologists, as well as her views and tastes, on composers. ${ }^{137}$ Piotr Perkowski, a more traditional composer who occupied important roles in the Composers' Union and as a pedagogue, echoed this rhetoric as he called her a "dictator" and pleaded for the freedom of experimentation. ${ }^{138}$ Party members and sympathizers such as Mieczysław Drobner, Chomiński, Rudziński, and Szeligowski continued to press for socialist realism and sought to curb composer claims for the right to experiment. ${ }^{139}$ In a reversal of the format of previous years, where he opened these congresses with directives and suggestions, Sokorski gave the closing speech and tried to finesse the state of affairs in a man- 
ner similar to Lissa's. He conceded mistakes but nonetheless pushed for a more general concept of socialist realism in a less dogmatic manner. He cleverly said the difficult previous years had prepared the current phase of reduced ideological control, as long as composers were prepared to follow the party's more expansive cultural-political line. Oddly and improbably, he tried to implicate composers in the ideological excesses of the previous years by asserting they were equally at fault for "jumping out the window" as he was for ordering them to do so. While approving of experimentation, Sokorski echoed party luminary Jakub Berman's recent slogan that freedom of expression must be accompanied by "a socialist compass." 140 Overall, those who had advocated for socialist realism were on the defensive, but still advocated it as a less dogmatic goal and by less restrictive means. The next meeting of the Executive Committee showed which side had the momentum, however, as Kraków composer, Catholic intellectual, and frequent party critic Stefan Kisielewski started a discussion on revising the "aesthetic theories ... used in evaluating works." ${ }^{141}$ A growing number of composers, in words and through their compositions, were moving away from the party at this time of a broader post-Stalin thaw.

These bitter debates typified the contentious atmosphere in the Composers' Union at this time, and even the elections to the Executive Committee were marked by rancor and mistrust. Lissa received the lowest possible number of votes to make it onto the committee, and her position weakened steadily during 1954, despite her efforts to continue directing the artistic output of composers, as did that of the several other communist composers, like Edward Olearczyk, who would soon be demoted in the union. ${ }^{142}$ Of symbolic importance were the preparations for the second Festival of Polish Music, held in the first half of 1955 and controlled by the younger, increasingly independent composers on the Executive Committee; the committee steadily marginalized Lissa, leading to her resignation in the spring of $1955 .{ }^{143}$ Tellingly, the union's most prominent member advocating socialist realism had been forced out of its leadership. Most composers continued to press for more autonomy and freedom, as for example, Kisielewski's call to have more jazz performed. ${ }^{144}$

Party officials began a renewed offensive in the arts in early 1955, and proclaimed the attempt to recover socialist realism from "narrow and vulgar interpretations" an important goal. ${ }^{145}$ Increasing resistance from artists hindered these efforts, as did the aforementioned growing discord among party members themselves. ${ }^{146}$ In music, this friction can be most clearly seen in the mounting divide between nominal allies Lissa and Minister Sokorski. Their differences on the issue of socialist realism became only more evident over the following year. Lissa again blamed the collapse of socialist realism on Sokorski and his composer allies like Rudziński and Maklakiewicz, who had in her view advocated a "vulgarized" version of socialist realism. ${ }^{147}$ Lissa's vision and authority had been nearly 
completely undermined in the eyes of most composers by the Eighth Congress in June 1955. At the congress, composers repeatedly attacked her in moves intended to increase their autonomy from the strictures of socialist realism and political interference in their activities. She did try to defend herself and her advocacy of socialist realism, but revealingly admitted that she and her fellow musicologists may have gone too far in interfering with the creative process. ${ }^{148}$ Nearly all of her allies had turned against her or were silent, save for Bolesław Woytowicz, who broadly supported her program and even at this late date encouraged composers to fulfill Stalin's exhortation to be "engineers of the human soul."149

Building on his speech at the Seventh Congress one year earlier, Sokorski in 1955 engaged in a breathtaking exercise of revisionist spin. He scarcely mentioned socialist realism, and only to claim that he never proclaimed a model of it in music, and further asserted that all composers should be proud to have made it through a period of battle over the issue in the spirit of creative searching. He also maintained that he had never pressured composers, but that each had followed his or her own conscience. Unlike just a few years earlier, he criticized almost no work, but rather meekly suggested that composers should create more accessible music. Overall, instead of pushing composers to engage in a partydirected ideological project, he made vague assertions that recent compositions were somehow part of the party's general plan. ${ }^{150}$ If there had been any doubt over the last year or two that socialist realism in music lay dying, Sokorski gave it the effective coup de grâce in June 1955.

Although a number of party officials and artists, most notably Central Committee cultural official Stefan Żółkiewski, continued to push for socialist realism and ideological control of the arts, the term itself largely disappeared from debate after $1956 .{ }^{151}$ At a key Council of Culture and Art meeting soon after Khrushchev's secret speech, most leading artists condemned socialist realism roundly and proclaimed full freedom of artistic expression. ${ }^{152}$ In music, the breakthrough first Warsaw Autumn festival took place that October, and featured works formerly considered formalist. ${ }^{153}$ By the time of the next Composers' Union Congress in the spring of 1957, Lutosławski declared that composers could at last meet in "an atmosphere of true artistic freedom" where no one would be persecuted for formalism. ${ }^{154}$ In a sign of how radically the frame of reference had changed, one speaker made a plea that all music should be heard and respected, not just the works of "modernists" and "formalists" - a stunning upending of the former situation - while another cautioned that composers should not blindly embrace the new possibilities and reject everything from the previous decade. ${ }^{155}$ Most composers, however, celebrated their expanded freedoms, and some even began the project of interpreting the past decade, and their actions during it, as "a period of political terror" when they were forced to be "instruments of propa- 
ganda." ${ }^{156}$ Such a characterization, widely believed today in popular and some scholarly writing, does not stand up to scrutiny.

In the Polish musical world, the term socialist realism was scarcely heard again. Those composers and musicologists who had represented that line became marginalized or slowly changed their views. The forms of political control associated with socialist realism largely disappeared as well, as the Composers' Union achieved nearly complete autonomy from party interference. Genres linked to it, like the political mass song, dropped almost completely from sight, as did cantatas in praise of Stalin or the party. The proponents of socialist realism, within the party as well as their sympathizers in the wider musical realm, lost the battle they had so enthusiastically engaged in 1949-50. In attempting a complete and accelerated domination for socialist realism, they had alienated the overwhelming majority of Polish composers, nearly all of whom had early been willing to create within the socialist-realist idiom and had indeed produced a considerable number of musical works. Initial interest, combined with an openness to cooperate with the party had, however, turned into growing disquiet and frustration in 1951, and produced a gradually decreasing willingness to work within the party line in the years following. As a result, composers gradually worked to carve out an autonomous space for their creative and professional pursuits. As the party's position weakened yet further after 1953, most composers seized the opportunity to press for even greater compositional and institutional freedom, and turned away from socialist realism and towards its previously vilified antipode, formalism, and the panoply of modernist styles emanating from the West.

\section{Formulation and Modification in the GDR}

By the late 1950s in East Germany, the situation looked very different from that in Poland, as socialist realism continued to be discussed and explored compositionally by the great majority of composers and musicologists. During the previous decade, however, developments in the musical world were strikingly similar. With a slight time lag due to the GDR's geopolitical situation, the encounter with socialist realism unfolded in a manner largely similar to that in Poland. Initial wide-ranging discussion in the late 1940s gave way to an offensive by the SED and its sympathizers in the musical world in the early 1950s, when they promoted a restrictive version of socialist realism. As in Poland, cultural officials made considerable concessions to composer demands for more autonomy with the 1953 thaw and the related liberalization of the "New Course," but continued to propagate a less dogmatic form of socialist realism. This more expansive definition of the ideology's tenets, plus the greater political loyalty of many East German composers, meant that socialist realism continued to be the accepted aesthetic ideology well beyond the late 1950s. In essence, the SED and its musical allies 
reacted more cleverly and flexibly to cases of composer discontent than did the PZPR, and managed to maintain socialist realism as the official ideology, albeit in a weakened form.

To a far greater extent than in Poland, the debates around socialist realism and formalism were fairly well known to many of the leading political and cultural figures in the GDR in the second half of the 1940s. The German participants at the Soviet Writers' Congress in 1934 made up the largest foreign delegation, and in his speech there, poet and future GDR Culture Minister Johannes R. Becher called Zhdanov's propositions a model for a new humanistic German culture. Well-known German communists in both the exile community in Moscow and elsewhere, including the renowned composer Hanns Eisler, debated the relationship between modernist art and politics in the 1930s. ${ }^{157}$ Unsurprisingly, then, officials and composers discussed socialist realism from an early stage in the Soviet Zone, but in a context of considerable artistic freedom through the late 1940s. ${ }^{158}$ Already in February 1946, leading cultural official Anton Ackermann used the common socialist-realist formula of "socialist in content, and realistic in form" to describe the preferred ideal, but claimed the party would not enforce an aesthetic dogma or compromise artistic freedom. ${ }^{159}$ It was clear that the party had a preference, and that at some future point it desired an art that supported its program, but both the timing and the exact nature of that art were very much open questions. Particularly illuminating are the immediate postwar activities of the Kulturbund zur demokratischen Erneuerung Deutschlands (Cultural League for the Democratic Renewal of Germany), a mass organization inspired by the Communists, led by Johannes R. Becher, and supported by the Soviet administration, but that included members of many different political backgrounds from all over Germany. It pushed for a broad-based, antifascist, democratic culture to serve as a foundation for the new Germany; with respect to music, it even organized a number of concerts that included works by composers who would later be condemned as formalist. ${ }^{160}$

\section{Early Discussion}

As in Poland, the year 1948 saw a flurry of cultural-political activity related to socialist realism, but much of it had the character of initiating discussion rather than attempting to impose dogmatic prescriptions. Individual composers and officials in eastern Germany noted and debated key developments originating outside the Soviet Zone, but they had little practical effect. The fallout from Zhdanov's fourth edict in early 1948, which accused leading Soviet composers of formalism and creating in a spirit inimical to the people was, unlike the first three edicts eighteen months earlier, printed and discussed widely in the East German press, although its reception in the cultural world was moderated. ${ }^{161}$ The Second 
International Congress of Composers and Music Critics met in Prague at the end of May, and intense discussion about the future direction of music, as well as socialist realism, took place there and also back in eastern Germany; a major speech by Hanns Eisler occupied a central role. ${ }^{162}$

These international cultural influences came in the context of a broader Cold War atmosphere of growing ideological polarization. At this time, the SED held a "Culture Conference" to express its growing desire to guide artists and their production. Many delegates articulated the postulates of socialist realism in general terms, as in Anton Ackermann's call for the "popular/folk basis in music linked to the continuation of the classical tradition." ${ }^{163}$ In September 1948, Walter Ulbricht announced to fellow party members that the SED would push for a "realistic art." ${ }^{164}$ The SED also devoted greater attention to artists with the announcement of the coming Two-Year Plan in 1948. It sought to engage artists in the implementation of its program, and pushed them to develop a "realistic art," but defined the nature of this art loosely. ${ }^{165}$ This year represents a first if tentative turn towards a harder line in the cultural world. ${ }^{166}$

The Soviet cultural officer Alexander Dymschitz made an important intervention into this gathering debate in late 1948 with two articles in an East German newspaper that linked formalism to imperialist aggression and bourgeois decadence, and called for a democratic and realistic art. ${ }^{167}$ While these articles have often been viewed as a Soviet signal to impose a dogmatic form of socialist realism, it is equally plausible that Dymschitz was translating the Zhdanovian theses in a less rigid way for his East German audience. In general in the years immediately after the war, the first generation of Soviet cultural officers tended to soften the hard line coming from Moscow and were broadly open to modernist trends and cultural experimentation. ${ }^{168}$ The SED planned a nationwide discussion to follow the Dymschitz articles, in an effort to convince artists to join in the campaign to produce and transmit the new socialist musical culture. ${ }^{169}$ The attempt, however, faltered for two years, as many artists proved initially reluctant to engage with the new theories of socialist realism, and the SED was not confident of its strength. The weakness of the party with respect to cultural affairs on the local level presented a further problem. Director Stefan Heymann of the Central Committee's Department of Culture, who had taken an active role in the discussions, criticized the lack of action by provincial party members in the spring of 1949. ${ }^{170}$ The Department acknowledged the "flagging discussion" in the spring of 1950 and planned to reinvigorate the drive to spread socialist realism, in part by mobilizing the "progressive forces" of the arts-related schools. ${ }^{171}$ Heymann listed a number of interventions he had made, including writing articles for newspapers, but concluded that his influence was minimal and that "the position of the formalists remains unshaken." ${ }^{172}$ Further to blame was the fact, seen in later departmental self-criticism, that discussions with artists were "not always 
conducted in a competent manner so that a positive attitude toward realism would develop among bourgeois artists." 173

The first major discussion of socialist realism among leading figures of the musical world took place somewhat belatedly in comparison to literature and painting, at a conference of 31 party composers and musicians on December 15 , 1948. ${ }^{174}$ Culture Department Director Heymann gave the opening remarks and urged his fellow comrades to begin engaging with the new aesthetic program. Musicologist and composer Ernst Hermann Meyer delivered the main address, which pushed for social-realist music, as the eventual term was not yet in common discourse. The theory was generally the same, however. Meyer called for the new, desired music to use a simplified language, link to past masters, be understandable by the people, and fight against the pessimism of the bourgeoisie, prefiguring his 14 points outlined above. As elsewhere in the cultural realm at this time, the debate on the new realism fell largely flat for the next two years. Musical life was decentralized and poorly organized - the GDR itself was not established until October 1949 and the Composers' Union and main music journal Musik und Gesellschaft were not founded until 1951 - and thus the lack of a necessary critical mass also contributed to what in retrospect looks like a lull.

\section{The "Formalism Campaign"}

Renewed efforts to reinvigorate the debate began in earnest after the SED's Third Party Conference in July 1950, which called for a "new progressive German culture" and a "realistic art." 175 Harder and more dogmatic language entered the discourse, and more strident tones manifested themselves over the next year. A key report a few months later reiterated the need for the SED Culture Department to do more to shape the debate and laid out a detailed plan to encourage artists to discuss and follow socialist realism; although somewhat incoherent, it demonstrated the department's desire to control and shape all aspects of artistic production. ${ }^{176}$ And indeed, unlike in the winter of 1948-49, the campaign against formalism, and for (socialist) realism gained traction. ${ }^{177}$ Helped by stronger Soviet influence in the context of the Cold War, and also by party artists increasingly opposed to the toleration of bourgeois, modernist trends, a more determined party with somewhat better trained and disciplined officials worked to propagate the new aesthetic doctrine.

A new debate on formalism in the press began, catalyzed by the publication of two key articles under the authorship of N. Orlow in November 1950 and January 1951. The first attacked Ruslan and Ludmilla and other works performed at the Berlin State Opera for formalist stagings. The author also accused other musical and artistic institutions of being similarly anti-democratic, subversive, and influenced by "American barbarism." The second article criticized formal- 
ism especially in painting and sculpture, and called for artists to follow the path of realism. ${ }^{178}$ Wilhelm Girnus, the editor of the main party daily Neues Deutschland, also published a two-part article at this time that attacked formalism and cosmopolitanism as anti-German. ${ }^{179}$ The Central Committee's Culture Department organized an extension of this discussion in the musical realm, as it planned the publication of eight articles in Neues Deutschland by leading figures like Ernst Hermann Meyer, music critic and historian Karl Laux, and composer Kurt Schwaen on subjects that included formalism, learning from the Soviet Union, and how to develop a progressive musical life. ${ }^{180}$

A high point in the debate came at the meeting of the SED's Central Committee in March 1951, where Culture Secretary Hans Lauter delivered a key speech written in consultation with Soviet authorities as well as SED leaders. ${ }^{181}$ It attacked formalism, and called on artists to develop a "realistic art." 182 This speech launched the so-called "Formalism Campaign," and was continually referenced in the succeeding years. With respect to music, Lauter saw "formalism and decadence ... in the destruction of true emotional value, lack of humane emotional content, feelings of despair as well as world-fleeing mysticism, distorted harmony, and stunted melody," and called upon composers to engage in "constant discussion and criticism on the question of formalism in music." 183 Though Poland lacked a similarly high-profile political, programmatic speech, this party engagement, subsequent discussion in the press, and organization of all artists into nationwide unions in 1951 all bear great similarity to the events of 1949/50 in Poland. And also as in Poland, it commenced a period of intense debate and criticism in the GDR.

Concurrently, controversy around Bertolt Brecht and Paul Dessau's opera The Judgment of Lukullus came to a head. ${ }^{184}$ Although this incident has often been mentioned as an extreme example of party interference in the arts, the story is in fact more complicated. ${ }^{185}$ Concern among party members and some musicologists had been building during rehearsals for this high-profile, antiwar opera about the legendary Roman general's imagined trial and condemnation in hell. Dessau's music did indeed have many of the characteristics of formalism in his modernist and dissonant musical language, and his supporters squared off against his detractors. Though the latter were more numerous, and included key musicologists like Meyer and Georg Knepler, as well as the important music functionary and future Composers' Union head Nathan Notowicz, both groups were represented in high party circles and among party artists during the many discussions. ${ }^{186}$ On March 17, Lauter criticized the work during his party conference speech, and that same day a closed performance of the opera coincidentally took place. Although hardliners like Erich Honecker had instructed the Free German Youth (Freie Deutsche Jugend [FDJ]) and other members of the party faithful to disrupt the performance, many in the audience appreciated the opera. ${ }^{187}$ Soon after, Dessau and Brecht met with President Wilhelm Pieck, Prime Minister 
Otto Grotewohl, and other important cultural officials to discuss the work. They decided that some revisions would be made, and a public premiere was set for the fall. ${ }^{188}$ In fact, the two artists made but minimal changes, and the opera indeed received several performances later that year. ${ }^{189}$ Even the criticism of a delegation of Soviet representatives did not seem to convince Dessau to make significant modifications to his spiky, jarring music. ${ }^{190}$

The debate among SED officials and musical figures was lively and open, and thus this was not simply an example of the party crushing creativity, let alone a polarized conflict that pitted party officials against artists. ${ }^{191}$ Unquestionably, hardliners in the SED and from the Soviet Union along with their sympathizers in the musical world wanted to demonstrate that limits to artistic expression existed, and that the party had the authority to determine these boundaries. It was also certainly not coincidental that Brecht and Dessau - the latter Jewish - had recently returned from emigration at a time of show trials and suspicion throughout the Soviet bloc, and that their left-modernist style did not mesh well with the tenets of socialist realism. ${ }^{192}$

Nonetheless, and despite ongoing criticism, Dessau continued to resist a narrow definition of socialist realism and to compose in his more experimental idiom. Throughout his life, this committed communist and SED member clashed with cultural officials and his more party-line colleagues; an excellent recent study describes him as "honored and harried, praised and reticent, canonized and marginalized." ${ }^{193}$ Like Brecht and his more famous contemporary Hanns Eisler, Dessau continued to believe that modernist techniques could express politically progressive content, and he produced an impressive number of choral works in the first half of the 1950s. Also with Brecht around the time of Lukullus, he wrote the Herrnburger Bericht (Report from Herrnburg, 1951), about the alleged mistreatment of West German youth returning from a rally in East Berlin. His Appell (Call, 1952), against war and militarism, musically evoked Prime Minister Otto Grotewohl's September 1951 appeal for all-German free elections for a national assembly through the use of a broad expressive palette that included a speaker, soloists, mixed choir, children's choir, and orchestra. Another notable and typical collaboration with Brecht is Die Erziehung der Hirse (The Cultivation of Millet, finished 1953, premiered 1954), dedicated to the $35^{\text {th }}$ anniversary of the October Revolution in 1952 and about a Kazakh farmer who developed millet thanks to the technical help of the collective farm. Finally, Lilo Herrmann (1953) thematized the communist resistance fighter executed by the Nazis in 1938. Although Dessau continued to be criticized for his modernist musical language, he occupied an active and leading position in the cultural life of the GDR, and his stature increased in the succeeding years. He stands as an example of how composers could realize their creative and professional goals by working both with and against the party. 
The founding conference of the Composers' Union in April 1951 took place in the context of the "Formalism Campaign" and the SED's attempts to exert more control over the artistic world. ${ }^{194}$ Culture Secretary Hans Lauter played the key role in the planning of this initial congress of the union, and tied it closely to the antiformalist campaign, which he was concurrently organizing. He planned Ernst Hermann Meyer's main speech on the formalism-realism debate, and the SED Politburo edited the conference resolution. ${ }^{195}$ In the centerpiece speech, Meyer attacked formalism, cosmopolitanism, twelve-tone music, Stravinsky, and American kitsch. He urged composers to link their work to the classical tradition and to compose in a realist style; he never used the term "socialist realism," probably because he sought to appeal to a wide range of composers, including those still not completely convinced of the party's goals. ${ }^{196}$ The resolution passed at the end of the conference also avoided the adjective "socialist," as it called on composers to develop an "artistic realism." ${ }^{197}$ Hanns Eisler praised Meyer's speech, but questioned how his formulations could be incorporated into compositional practice - a question that would vex discussions on the issue for years to come. ${ }^{198}$ Also at the conference, the peripatetic head of the Soviet Composers' Union, Tikhon Khrennikov, evoked the authority of the Soviet experience and called for composers to "free themselves from formalistic tendencies." 199 The resolution passed at the end of the conference called on all composers to resist negative American influences, specifically formalism in music, and to compose in a realistic style that was understandable to all and would motivate the populace to realize the SED's goals. ${ }^{200}$ In general, despite the heavy-handed party involvement, openness characterized the debate here, and the participants seemed genuinely concerned with exploring the issues surrounding formalism and realism.

During this period - as in Poland - composers and musicologists from the Soviet Union and to a lesser extent the other People's Democracies played an important role in the discussions on formalism and (socialist) realism, all contributing to a transnational discourse on multiple levels. In addition to Khrennikov, Yuri Shaporin and Boris Yarustovsky gave ideological speeches at the founding conference in 1951, and received loud applause, especially at the mention of Stalin. ${ }^{201}$ Andrei Shtogarenko and composer Anatoli Novikov did the same at the next meeting, the First Union Congress in fall 1952. A stream of articles by composers and musicologists appeared in the main music journal, Musik und Gesellschaft, including most notably a special insert by the Soviet musicologist W. W. Wanslow that explicated Zhdanov's 1948 Central Committee resolution and gave an overview of musical-political developments in the Soviet Union. ${ }^{202}$ Cultural officials constantly exhorted composers to discuss these issues and learn from the Soviet example. In early 1953, eight leading composers gave their positive reaction to Zhdanov's resolutions on music on the occasion of the 
fifth anniversary of their publication. ${ }^{203}$ The Soviet version of socialist realism thus circulated widely in the East German context.

Furthermore, with respect to the GDR and Poland, a member or two from one country's composers' union typically attended the major conferences of the other, contributing some kind of programmatic statement to the discussion and then reporting back to colleagues in the home country. In late 1951, for example, the young composer Günter Kochan and musicologist Karl Laux attended the Polish union's Sixth Congress. ${ }^{204}$ Soon after, Paul Dessau spent a few days with his Polish counterparts in Warsaw and Kraków, and brought back mass songs to share with his colleagues as part of a discussion of this genre. ${ }^{205}$ The following year, Witold Rudziński and Witold Lutosławski attended the First Congress of the VDK and its related festival in Berlin. Lutosławski reported back to the Polish music world through the leading music journal and offered his opinions of the contemporary musical works on offer, thus contributing to the debates in Poland. He criticized, in remarks relevant to concurrent Polish debates, young East German composers for imitating nineteenth-century Romanticism and many of their elders for eclecticism with respect to cantatas. ${ }^{206}$ For his part, Rudziński unsurprisingly expressed genuine-sounding praise of his East German colleagues' progress towards socialist realism. At his own union congress, he referenced his observations made in East Germany to express to his Polish colleagues the idea that "conscientious and constant ideological work among creative artists" can bring impressive results. ${ }^{207}$ From the neighboring country as well as the Soviet Union, ideas and directives were introduced directly at these major meetings and shaped debates and discussions, as Poles and East Germans engaged and influenced each other. ${ }^{208}$

Beyond composers and musicologists interacting among themselves, party and state institutions also played an increasingly active role in the discussions and implementation of socialist realism in music at this time. From the relatively weak and disorganized position prior to 1951 described above, the SED's Culture Department began to engage the artistic world more systematically. ${ }^{209} \mathrm{Cul}$ ture Department officials felt the debate needed to be prosecuted in a "consistent and determined" manner, as artists were reluctant to follow the calls for socialist realism. $^{210}$ The precursor to the Ministry of Culture, the much-reviled Stakuko (Staatliche Kommission für Kunstangelegenheiten, State Commission for Artistic Affairs), came into being in the summer of 1951, and its very raison d'être was imbued with the party's fight to influence the development of socialist realism. This state organ undertook to engage in "persistent struggle against the hostile influences of cosmopolitanism and formalism and for realistic methods in art" through the organization of conferences and festivals and by influencing concert programs and commissions. ${ }^{211}$

The debates resulting from the Formalism Campaign in the spring of 1951 reached a high point at the SED's Second Party Congress in July 1952, where the 
party proclaimed the construction of socialism. Walter Ulbricht demanded that artists free themselves from formalism and embrace socialist realism to help motivate people for the building of socialism. He further called on artists to develop a closer relationship with working people, tie their activity to folk traditions, and learn from the example of the Soviet Union. ${ }^{212}$ Johannes R. Becher, who in his early Kulturbund days had represented a tolerant position of working with bourgeois artists, now summed up the new party line:

The rise of a great German art is only possible with the building of socialism. A great German art will either be socialist-realist, or it will not come into being. Socialist realism is not one creative variant among many, not one creative possibility among others, but rather socialist realism is the only possibility, the only creative method, that can lead to the rise of a great German art. $^{213}$

In its political and ideological implications for the East German musical world, the March 1951 SED Central Committee Plenum was equivalent to the 1949 Łagów conference in Poland, and the Second SED Party Congress in July 1952 and East German Composers' Union Conference close on its heels paralleled the Fifth Polish Composers' Union Congress in June 1950. This modified line represented a narrowing of the possible. With a two-year time lag compared to their counterparts in the PZPR, the SED hardliners were in the ascendant, and attempted to impose a dogmatic interpretation of their preferred aesthetic ideology. The ever intensifying Cold War served as catalyst to tighter political control and a turn to a more rigid definition of socialist realism. In the recollection of one participant in these debates, the musicologist and editor of the key music journal Musik und Gesellschaft Eberhard Rebling: "The daily crackling ill-will, intolerance, and constant threat of a new war came at us from the West, and forced us into exaggerated one-sidedness and an extreme impatience even towards fuzzy but well-meaning opinions from those in our own ranks." ${ }^{14} \mathrm{~A}$ harder line was emerging, and it initially encountered curious interest if also confusion from nearly all East German composers.

With a slightly higher level of vigor than seen in Poland, composers in the GDR engaged with socialist realism during the period of intense debate throughout 1951 and 1952..15 The overwhelming majority embraced the call to build socialism through socialist realism in music. Composers applied themselves to understanding and formulating the concepts that would aid musical composition in a nonformalist and socialist-realist manner. In one example of broad-based interest in socialist realism, a handful of composers from Saxony attempted to develop their own concrete ideas on the subject in early 1952 in the form of an informational pamphlet designed for discussion among all composers. ${ }^{216}$ In the first half, they defined formalism as subjective in form, being extremely individualis- 
tic, cosmopolitan, and constructivist, and marked by naturalism, primitivism, and decadence. To better illustrate its nature, they discussed concrete examples, including works by Stravinsky, Schoenberg, and Webern, but also, controversially, from works by East German colleagues like Hanns Eisler and the young and favored André Asriel. In the second part, they formulated realism as exhibiting the reflection of societal truth, links to the people, a recognition of the role of the national cultural tradition and a further development of that tradition, both ideafilled content and an artistic mastery of form. Positive examples here included the great masters of the German classical tradition, as well as Shostakovich and several contemporary East German composers. Composers' Union Secretary Nathan Notowicz and Eberhard Rebling took the collective to task, however, for unclear analysis and ideological weaknesses. ${ }^{217}$ These two made up part of a core group of Berlin-based musicologists and pedagogues who were bound together by the experience of war years abroad, the choice to move to East Germany, and that all save Rebling had Jewish roots (and Rebling a Jewish wife). This loose cohort also included Meyer, Harry Goldschmidt, and Georg Knepler, and possessed great influence in shaping an ideological line approved by the party. It was perceived as an unjustly powerful group by many composers at the time. Although Notowicz did not possess an advanced degree in music, he occupied the powerful position of Union Secretary for nearly two decades and was a consistent supporter of party aims. Knepler was a well-respected Marxist musicologist born in Austria, and Goldschmidt in Switzerland. Rebling and Notowicz spent the war years in the Netherlands, and Meyer in England. ${ }^{218}$

The primus inter pares and most influential figure in these discussions was the musicologist and composer Ernst Hermann Meyer, who had contributed numerous articles and speeches on the subject over the past several years. He codified his position in the magisterial work Musik im Zeitgeschehen (Music in Current Events, 1952), which became the standard text for socialist realism in music. Meyer also composed works, and in this dual way attempted to guide his colleagues down what he considered the correct, socialist-realist path. His choral output in the early 1950s led the way for the production of many East German composers. The sprawling, seven-part Mansfelder Oratorium (1950), with a traditional tonal structure evoking Handel, gave musical expression to the heroic, centuries-long struggles of Mansfeld workers against feudalism and capitalism, and won a national prize. Meyer traveled with the author of the text, Stephan Hermlin, to this copper mining region to get to know its workers, and produced a large-scale vocal piece that became one of the foundational works of East German socialist-realist music. The first four sections critique capitalism from the middle ages through the nineteenth century, and the final three celebrate the Soviet Union, socialism, and the victory of the working class. Meyer sought to combine the musical styles of past centuries "in the spirit of the time," but it was criticized 
by some of his peers for being overly imitative and unoriginal. ${ }^{219}$ Its premiere in fall 1950 featured both professional and amateur singers, thus incorporating one of the ideals of the new era. ${ }^{220}$ Although it was only performed on a handful of occasions in the early 1950s, it was also praised by many composers and cultural officials, and the latter pushed for it to be played more frequently, resulting in a hundred or so performances in the following decades. ${ }^{221}$

Such cantatas were promoted as much in East Germany as was the case in Poland, from the Dessau cantatas mentioned above, to several by Hanns Eisler, to many more by a wide range of composers. Though not acknowledged by those creating or commissioning them, these monumental vocal works were similar in form if of course rather different in content to many Nazi compositions with titles like the Saar-Kantate, German Hero-Requiem (Deutsches Heldenrequiem) or The Words of the Führer (Führerworte). ${ }^{22}$ Meyer himself composed a number of other large-scale choral works at this time, including the Flight of the Dove (Flug der Taube, 1952), with its praise of the Soviet Union and peaceful construction. A number of colleagues criticized the work as too derivative and even boring, and that and its positive portrayal of Stalin caused it to be rarely performed both before and after 1956.223 Better received but also infrequently played was Des Sieges Gewissheit (The Certainty of Victory, 1952), dedicated to the SED and premiered at its Second Party Conference, and with a text by Johannes R. Becher calling for peace and thanking the Soviet army. ${ }^{224}$ Meyer garnered significant praise and encouragement from political leaders for his efforts, and he considered himself an example for his peers, who followed his lead in composing such largescale choral works with political themes. In addition to Dessau's oeuvre related above, Jean-Kurt Forest contributed Kantate auf Stalin (Cantata about Stalin, 1949), Fred Lohse Arbeit für den Frieden (Work for Peace, 1951), and the young Günter Kochan Die Welt ist jung (The World is Young, 1952).

The President of the Composers' Union, Ottmar Gerster, also contributed a large and influential cantata at this time, Ironworks East (Eisenkombinat-Ost, 1951). Its 13 sections stretch over three-quarters of an hour and feature a full orchestra and mixed choir energetically proclaiming, in straightforward and often stirring fashion, lines that can seem clunky to present-day ears like: "The FiveYear Plan stipulates . . . / Coal and iron, coal and steel, / For construction, / For peaceful construction. / Construction of the needed heavy industry, / For peace, / For peaceful construction." Born in 1893, Gerster worked with worker singing groups in the 1920s, and despite occasional cooperation with the Nazis, had largely kept his head down after 1933. He emerged as one of the more prominent East German composers after the war and served as president of the Composers' Union from its founding through 1968, the year before his death. 


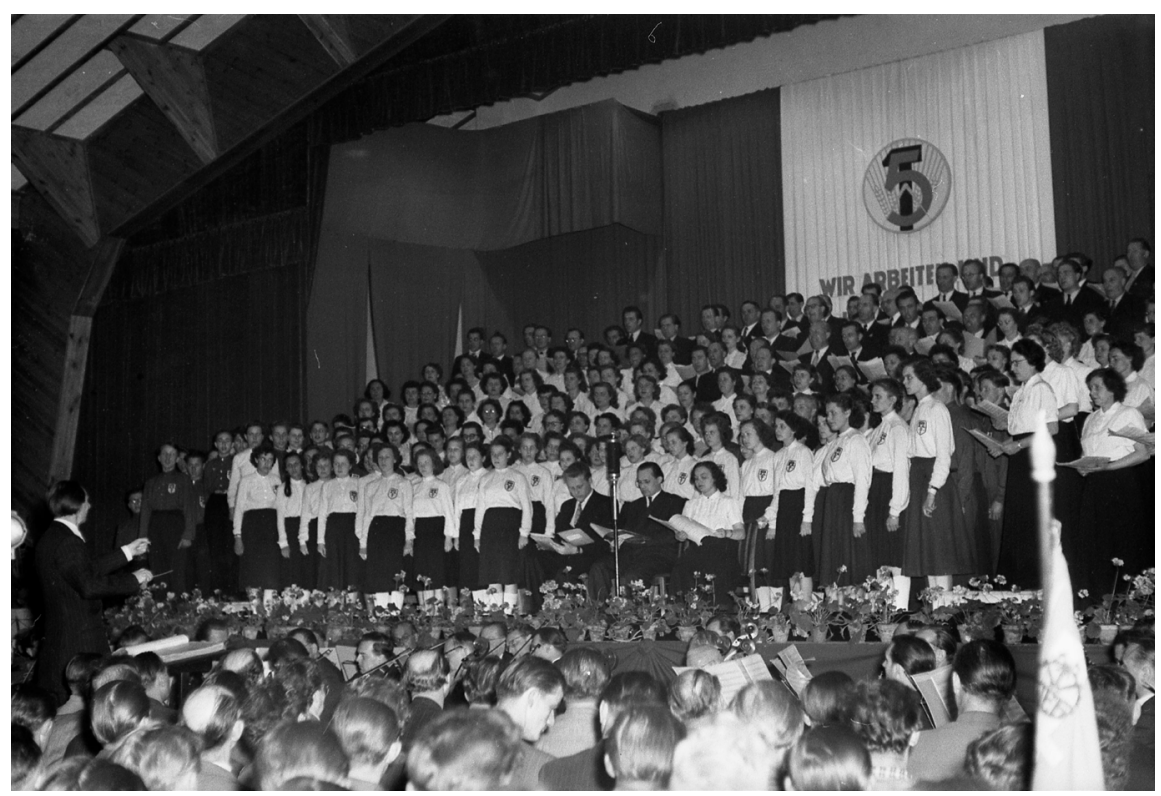

The Berlin Radio Symphony Orchestra and Choir perform Ottmar Gerster's cantata Ironworks East (Eisenkombinat-Ost) in Eisenhüttenstadt on the eve of the 1952 May 1 celebrations; SED General Secretary Walter Ulbricht was in town for the event (Bundesarchiv, Bild 183-145390009 / photographer: Horst Sturm).

Gerster was also one of the leading composers of socialist-realist instrumental music. Indeed, his Festouvertüre of 1948 was one of the first semi-official new and approved works, as it thematized well-known songs like the Internationale, the Marseillaise, and several traditional German and Russian workers' songs in a romantic and easily playable idiom. Gerster composed it for the centennial of the 1848 revolutions, which the SED looked to as a precursor to their own revolution. It was performed frequently and taught in schools through 1989. ${ }^{225}$ His Second Symphony, Thuringian (Thüringische Sinfonie, 1949-52) was another popular and well-received instrumental work with a traditional four-movement arrangement and tonal musical language. In the words of the composer, he sought to capture the essence of Thuringia, both its historical greatness as well as its "struggle for humanity's progress today." ${ }^{226}$ In its form and content, it is an exemplary artifact of socialist realism.

Nearly all composers, of course, created instrumental works of various size and ambition. Johannes Paul Thilman in Dresden and Johann Cilenšek in Weimar represent that generation of composers born just before the First World War; they composed a number of symphonies and concertos for various instruments that fit comfortably into the socialist-realist idiom of the day. Thilman, initially self-taught in Weimar Germany, became increasingly prominent as a composer in East Germany after the war. He wrote a handful of symphonies in this period, as 
well as concertos for tuba, trumpet, violin, and piano, in a melodic style inspired by folk music. ${ }^{227}$ Cilenšek is an interesting case in that he was a former Nazi party member and stormtrooper who suppressed his past to create a successful career in the GDR. ${ }^{228} \mathrm{He}$ composed five symphonies and five concertos in the 1950s in a tonal and conservative style. Of particular note is his three-movement Second Symphony from 1956, which commemorated the tenth anniversary of the liberation of Buchenwald and included a middle movement of "harrowing funeral music" (Trauermusik). ${ }^{229}$ As an official music history of the GDR described it: "In the third movement an attitude of strength and confidence overcomes the idea of bitterness and accusatory suffering. The extraordinary dimensions of the Adagio middle movement - its contradictory sections, the depth of its expression, the instrumental chromaticism, and its dynamic variety—all result not only in a general protest against inhumanity, but also originate from the concrete engagement of the composer for the anti-fascist fighters." ${ }^{230}$ Clearly, Cilenšek had successfully reinvented himself to assimilate to the new political reality.

One of the leading voices on instrumental music and the musical world more generally was Max Butting, who played an influential role in the Composers' Union and Academy of the Arts. He was open about the fact that he had joined the Nazi party and desired to work through and atone for that act. His music reflected this, as for example his Seventh Symphony and a never-performed oratorio The Memorandum (Das Memorandum), both from 1949 and thematizing Nazism and its aftermath. These works received a mixed reception, probably because the emphasis at the time was on positive, future-oriented works rather than working through the difficult past. ${ }^{231}$ A somewhat more successful example was his Eighth Symphony, The Vacation Trip (Urlaubsreise, 1952), a melodic and energetic, four-movement work that captures the relaxed atmosphere of a summer break in Thuringia in three of the movements, while a fourth takes a darker turn with an evocation of Buchenwald. ${ }^{232}$ At its premiere, the audience was appreciative but at least one reviewer lamented the depressing passage. ${ }^{233}$

After roughly a year and a half of intense discussions in the press and music journals, as well as in the regional union organizations, and following an initial phase of socialist-realist musical production, composers and musicologists came together for their union's first postfounding congress in the autumn of 1952, and formalism and socialist realism were a main subject of debate. In his opening speech, union President Gerster called for discussion that would help in "the development of a truly valuable new realistic music," and Stakuko Director Helmut Holtzhauer followed with the demand that "the struggle of the representatives of socialist realism against those of formalism should dominate your congress." ${ }^{234}$ Meyer assumed his natural role as one of the former and delivered a long talk on the nature of socialist realism and what qualities composers needed in order to compose in this style. ${ }^{235}$ Many other musicologists and several leading 
composers, including Thilman, discussed the meaning of socialist realism with respect to music in an open and critical manner, often basing their comments on contemporary works played at the congress. An atmosphere of comradely debate prevailed. ${ }^{236}$

Congress discussions exhibited a tone of people genuinely trying to understand a phenomenon presented positively, while also attempting to shape it in ways that made sense to them. The postulate that music should not be an elitist activity, but rather be shared by every member of society, found complete acceptance. By this time, in late 1952, widespread support for socialist realism existed throughout the East German musical world, as composers made their first real engagements with a doctrine that in theory seemed to include many different approaches and styles; the resolution of the congress stated that "our creative method can only be socialist realism." ${ }^{237}$ Union leaders resolved to conduct the fight against formalism in an even more decided manner in the coming year through "open and sharp criticism against formalism in new works." ${ }^{238}$ Both cultural officials as well as a broad cross-section of composers were involved in this thoroughgoing examination of socialist realism. One significant conflict began to emerge, as the aformentioned group of party-affiliated musicologists led by Meyer claimed the authority to direct composers in the pursuit of a socialistrealist line, an assertion that caused a growing unease among many composers, and even open complaints in the following years. ${ }^{239}$

This phase of intense discussion of socialist realism reached its apogee in the first half of 1953, as did party interventions in the musical world. A typical example is a programmatic article by Eberhard Rebling, published in the spring of 1953. ${ }^{240}$ Here Rebling gave an overview of socialist realism in music based on the writings of Zhdanov, and praised recent examples of works that fit within this ideology. He then discussed the nature of formalism, and mentioned composers who exhibited these negative tendencies, including major figures like Eisler, Rudolf Wagner-Régeny, and Max Butting. Significantly, the editors of the party journal Einheit, as well as members of the Culture Department of the Central Committee, discussed and altered the article so as to communicate the harder line that cultural officials wanted. ${ }^{241}$ As in Poland, the debates over socialist realism involved considerable criticism of fellow colleagues, and no figure, no matter how wellregarded-Eisler, Panufnik, Dessau, or Lutosławski-escaped the critical eye of cultural officials, musicologists, and fellow composers.

Concurrently, Hanns Eisler became involved in polemics surrounding his libretto for a planned opera, Johann Faustus, which he himself wrote on the culturally significant theme of the Faust figure. ${ }^{242}$ Like Dessau, Eisler had recently returned to Central Europe from exile and redbaiting in the United States and already had a long and complicated career of composing politically engaged music, much of it in collaboration with Bertolt Brecht, as well as works inspired by his 
teacher, Arnold Schoenberg. In late 1952 and the first half of 1953, however, cultural officials, musicologists, and fellow composers criticized Eisler for alleged ideological deviations with respect to his critical portrayal of German history and culture, and in particular his revisions of Goethe's version of Faust to represent negative aspects of Germany's fate. As a result, Eisler fell into a deep depression and abandoned the opera. While certainly an example of hardliners interfering in the compositional process, the complicated motivations of the protagonists indicate that this debate over German identity was not a black-and-white example of the party crushing individual creativity. ${ }^{243}$

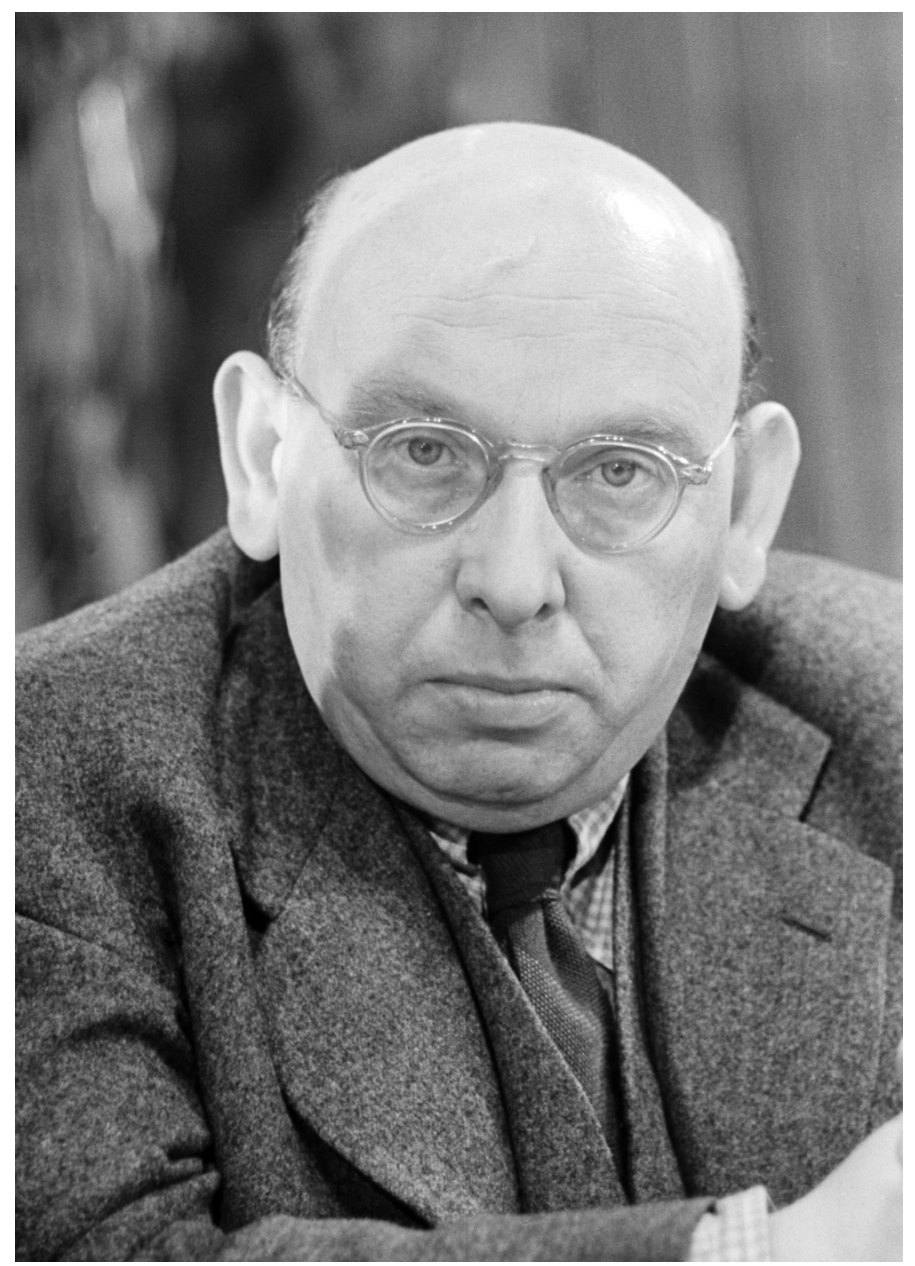

Hanns Eisler in November 1948 (SLUB Dresden / Abt. Deutsche Fotothek, Abraham Pisarek).

More broadly, Eisler struggled to write aesthetically interesting music accessible to the workers and peasants of the GDR in the years around 1950. He 
frequently collaborated with Johannes R. Becher to create mass songs, and contributed some of the most noteworthy examples, including perhaps the best known of the genre - the East German national anthem Risen from the Ruins (Auferstanden aus Ruinen), which interestingly came together in a Polish setting. He and Becher had gone to Warsaw for a Goethe celebration in October of 1949; Becher gave him the poem there, and Eisler worked on the melody on none other than Chopin's piano at Żelazowa Wola. ${ }^{244}$ The two also collaborated on the cycle of the New German Folk Songs (Neue deutsche Volkslieder, 1950-51), including the oft-played We Are Changing the World (Die Welt verändern wir), Lenin, and The Song of the Blue Flag (Lied von der blauen Fahne), about the Free German Youth (FDJ). The two men were enthusiastic about the texts and felt this composition "was a useful and urgently necessary task," a sentiment about mass songs clearly shared by most East German composers. ${ }^{245}$

As in Poland and throughout the communist world, these mass songs were a hallmark of the era in East Germany. Eisler's student André Asriel, like many young composers, wrote a large number of mass songs, for which he was awarded a third-class national prize in 1951 and the considerable sum of 25,000 marks. East German Radio played a significant role in the production and dissemination of these new songs, as many younger composers like Asriel found fruitful employment there. ${ }^{246}$ Perhaps unsurprisingly for someone born in 1922, he composed a number of songs on youthful themes, including Friendship, Unity, Peace (Freundschaft, Einheit, Frieden), about international friendship among young people, and The Young Guard Laughs Bravely (Tapfer lacht die junge Garde), a collaboration with the writer KuBa (Kurt Bartel).

And like Panufnik and Lutosławski in Poland, other heavyweights besides Eisler contributed extensively to the genre. Ernst Hermann Meyer wrote many mass songs, including Song of the New House (Lied vom neuen Haus) and Thanks to the Soviet Army (Dank an die Sowjetarmee), to a text by Johannes R. Becher, a frequent and ideologically proven provider of mass song lyrics. Paul Dessau contributed a number of songs, including Construction Song of the Free German Youth (Aufbaulied der FDJ) and Hello, Brothers from Warsaw (Hallo, Brüder aus Warschau), a fine and melodically interesting song that promotes unity across the troubled border. Its simple but evocative text by writer Armin Müller situates a German worker who sings to his Polish counterparts about fulfilling their respective economic plans, which represent parts of a much larger plan to reshape the world. Many songs focused on postwar reconstruction and the building of a socialist Germany, like Jean Kurt Forest's Lay the Ground for a New Life (Legt den Grund zu einem neuen Leben), which cheerily proclaims "join in! It's a time of change! The liberated land will give us all bread!" as well as Kurt Schwaen's The Song of Construction (Das Lied des Aufbaus). Mass songs frequently celebrated workers and peasants, as in Joachim Werzlau's Morning 
Song of the Tractor Driver (Morgenlied der Traktoristen), which harmonizes the sound of tractors "waking village and field," and Eberhard Schmidt's Railwayman's Song (Eisenbahnerlied), celebrating young conductors moving forward at full steam. Schmidt also contributed the popular Fritz the Tractor Driver (Fritz der Traktorist), which features a folklike melodic line carried by the accordion, and extols Fritz's skills as a student, singer, and on the tractor-qualities that win the affection of Gretel. Works with more explicitly political themes were of course not lacking as well, as in Louis Fürnberg's The Party is Always Right (Die Partei hat immer recht). Such mass songs made up the most prominent feature of the socialist-realist landscape, as they were played frequently on the radio, sung by amateur groups, and appeared in film.

\section{Thaw and Course Correction}

This outpouring of socialist-realist musical production did not satisfy East German cultural officials. Their repeated interventions and criticisms, particularly by the cultural officials in the Stakuko, began to provoke growing dissatisfaction among an increasing number of composers. The resultant turn towards the New Course announced on June 9, 1953, as well as the fallout after the June 17 Uprising thereafter, caused the party and Stakuko to back off the campaign to force the acceptance of socialist realism through bureaucratic methods in favor of persuasion, and to declare that artists had complete creative freedom. ${ }^{247}$ In the aftermath of the Uprising, artists in the Academy of the Arts as well as leading figures in the Composers' Union called on cultural officials to give composers more autonomy. ${ }^{248}$

The Fifteenth Plenum of the SED's Central Committee in late July 1953 acquiesced to many of the demands emanating from the artistic world. Party leaders admitted to a litany of errors, including overcentralized decision making, meddling bureaucratic methods, and unfruitful, suffocating criticism. Officials nonetheless affirmed that socialist realism remained the goal, but one that would be achieved through tolerance and persuasion rather than with bans and impatience. ${ }^{249}$ In the view of the officials in the Stakuko's Music Department, discussions were nonetheless to be intensified, with socialist realism deemed essential. ${ }^{250}$ And indeed most composers broadly agreed with these policies - their dissatisfaction resulted more from the invasive administrative methods employed by some cultural officials. A more expansively defined concept of socialist realism continued to appeal to the great majority.

The SED launched a new cultural offensive in the fall of 1954, but it focused more on getting artists behind the party's broader political goals rather than in enforcing a narrowly-defined aesthetic ideology. Nonetheless, the fight for socialist realism had not disappeared; new Culture Minister Johannes R. Becher encour- 
aged composers on the eve of their Second Congress to engage in theoretical and ideological discussions on socialist realism, "which now as before remains our great goal." ${ }^{251}$ Cultural officials desired that composers should not feel forced into following the postulates of socialist realism, but rather that it should be privileged and encouraged as the best way to compose music. ${ }^{252}$ The head of the ministry's Music Department, Hans Pischner, bemoaned the fact that "socialist realism has often disappeared from view this past year," and asserted that, though it should be the goal of every artist, the party would allow freedom of expression for all those "whose work serves a national German art." 253

The ministry's stance was one of three broad positions taken at the Composers' Union's Second Congress in late October of 1954. Becher's Deputy Minister, Fritz Apelt, echoed Becher's call in asserting that "our goal remains socialist realism." "254 The indefatigable Meyer further refined his ideas about socialist realism into the fourteen points outlined earlier in the chapter, and musicologists Knepler and Goldschmidt also maintained a harder line. ${ }^{255}$ A number of composers and union Secretary Notowicz occupied a middle ground - they all accepted socialist realism as a goal, but redefined it less ideologically and felt that more discussion was needed as to its nature. ${ }^{256} \mathrm{~A}$ third group of several younger composers, however, in effect wanted to expand dramatically the concept of socialist realism. Wilhelm Neef called socialist realism a "distant goal" and demanded more experimentation in the interim, while asserting that socialist realism was becoming a "doctrinaire ossification" leading to a dead end. ${ }^{257}$ Siegfried Köhler, born in 1927 and a leader in the less conformist Leipzig branch of the Composers' Union, called for the right to more experimentation, claiming that the concept merely meant composing for the people in the spirit of socialism, and tried to link the party's demand for socialist content to his desire to use new compositional techniques. ${ }^{258}$ In an apparent compromise, the congress's closing resolution maintained that the "application of the method of socialist realism is necessary," but acknowledged that its realization would take some time and require friendly criticism. $^{259}$

The middle position slowly gave way to relatively polarized extremes throughout 1955. Among the hardliners, cultural officials encouraged socialist realism with "special support" and sought to fight "petty-bourgeois influences."260 In late 1955, the editors of the official music journal Musik und Gesellschaft committed themselves to a "pronounced attitude of a fighting spirit" in the struggle against formalism and "the various manifestations of petty-bourgeois ideology." 261 Typical for the cultural winds of the time was the Fourth German Writers' Conference in January 1956, which passed a binding statement that writers would work for "a strong, socialist literature, a literature of socialist realism."

But a greater spirit of openness also maintained and gathered strength among those calling for more experimentation in 1955, and then especially after Khrush- 
chev's "Secret Speech" early the following year. The Staatsoper presented a staging of Alban Berg's opera Wozzeck in the fall of that year, and other such works by composers formerly considered anathema also appeared in the concert halls of the GDR. The union leadership, normally so hardline, helped organize concerts that included the music of composers previously condemned as formalist, like Anton Webern and Schoenberg. ${ }^{263}$ Those composers who argued for more experimentation and freedom grew more numerous and emboldened during this period. The appearance of three articles in the journal Sonntag by composers Paul Dessau, Kurt Schwaen, and Gerhard Wohlgemuth in early 1956 manifested this change clearly. ${ }^{264}$ All three demanded the right to experiment more, and especially attacked Ernst Hermann Meyer's ideas about socialist realism. The union called a special meeting of its Executive Committee and conducted an open and wideranging discussion about socialist realism and the mistakes made in relation to it. ${ }^{265}$ Hardliners in the socialist realism debate like Meyer and Knepler admitted mistakes, the former for being intolerant at times, the latter for labeling too much music formalist. ${ }^{266}$ Younger union members Köhler and Wohlgemuth talked of a "psychosis" in previous years, in which composers felt like they could not speak their minds or compose as they wished due to the hard line coming from union leaders and the SED; Wohlgemuth directed particularly sharp attacks at the leading musicologists. ${ }^{267}$ Even one of the young exemplars of socialist realism, Günter Kochan, complained that his Violin Concerto had received too much acclaim as a model work, and that he had in fact suffered from the lack of criticism. ${ }^{268}$ Union Secretary Notowicz claimed that "we recognize now that socialist realism is not a style, but rather allows for a large difference in styles." He also admitted errors had been made, but asserted that the basic theses were correct. ${ }^{269}$ Shortly thereafter, the SED echoed Notowicz during the thaw after the Twentieth Party Congress in the Soviet Union, as it officially opened the door to "other creative methods."

The eve of the Third Composers' Union Congress in February 1957 saw a flurry of activity with respect to the still contested issue of socialist realism. In one article, SED member Paul Kurzbach, who was deeply involved in the effort to create a national opera for the GDR, attacked many aspects of Zhdanov's theory of socialist realism as dogmatic, and called for the union to "cultivate different styles and currents." ${ }^{.271}$ In another article, published early that year in Musik und Gesellschaft, Siegfried Köhler praised the "rapid surmounting of the dogmatism in the area of music aesthetics" and claimed that the "recent aesthetic opinions ... with their ossified exaggerations are no longer tenable." ${ }^{\prime 272}$ Despite this attack on the tenets of socialist realism and praise for composers like Schoenberg, Webern, and Berg, he cautioned against going too far in embracing the musical styles of a different, past era. Köhler provides a illuminating example for the situation in the GDR. He reacted strongly to a narrow interpretation of socialist realism, but his own mass songs and cantatas at this time hewed thematically and sonically to 
a fairly traditional definition of socialist realism. Noteworthy in both articles is an affirmation by these composer critics of some of the basic ideological underpinnings of socialist realism as well as a rejection of some Western, "formalist" music - a marked contrast to contemporaneous developments in Poland, where composers turned away from socialist realism entirely. In the GDR, the spectrum of dissent was much narrower than that in Poland, and even the seeming nonconformists were broadly supportive of the party and its aims.

The defenders of socialist realism began marshaling their forces as well. In a meeting just before the 1957 Congress, musicologist Harry Goldschmidt called for further use of the term socialist realism and Thilman stated his desire to preserve the tenets of the ideology. ${ }^{273}$ Meyer acknowledged that the concept had been discredited, but called for its continued usage as it incorporated their goals and stood in opposition to formalism, now defined more weakly as music without appropriate content. He advocated granting more latitude in the choice of musical language as long as the theme proved acceptable. Notowicz again admitted that union leaders had made mistakes, and wanted to move beyond this to give socialist realism a "better, deeper definition." 774

Notowicz's opening speech at the 1957 Congress struck a conciliatory note, and the theoretical discussions at the conference were correspondingly muted. He admitted that both formalism and realism had been used in an "abstract and schematic way," and he moved away from attempting to define formalism, even suggesting that works by Berg and Schoenberg were not necessarily formalist. ${ }^{275} \mathrm{He}$ wanted to abandon the search for exact definitions of socialist realism, and asserted publicly the new idea that it was not a "definite style." Realism, he stated, meant simply that a musical work "communicates an impression of the best thoughts, feelings, and sensations of its time," while the adjective "socialist" merely indicated that the work was created with socialism in mind. Deputy Culture Minister Hans Pischner also admitted past "distortions," called for composers to move beyond "dogmatic restrictions," and broadened the definition of socialist realism in maintaining that it was not "an ossified [method], but rather something in constant development through the inspiration of socialist ideology." He stressed a "socialist standpoint" as necessary for composers, but granted that there were many ways to achieve socialist realism. ${ }^{276}$ Meyer limited his theoretical contribution to calls for melody and appropriate themes in a musical work, and in general praised the diversity of composition in the GDR. ${ }^{277}$ During a discussion of the union's constitution, he was able to convince members to agree to declare socialist realism as of "central" rather than "particular" importance, perhaps because the term had become so expansive. ${ }^{278}$ Paul Kurzbach, a frequent critic of dogmatic definitions, called on composers to work in a socialist spirit, and stressed that the path to socialist realism would be a slow one. ${ }^{279}$ The new constitution for the union stated reasonably that it consisted of "composers and 
musicologists of differing ideological and artistic persuasions, who are taking part together in the socialist construction of the GDR." ${ }^{280}$ Composers like Wolfgang Hohensee praised the new atmosphere of openness and freedom of expression, and the important ministry official Hans-Georg Uszkoreit announced that the Music Department would work in a less bureaucratic manner. ${ }^{281}$ Equilibrium appeared attainable and imminent.

Broader political developments intervened in the musical world, however. Ulbricht and the hardliners began their campaign against their reform-minded opponents late in 1956 , and the $30^{\text {th }}$ and $32^{\text {nd }}$ Plenums of the Central Committee announced the end of tolerating so-called "revisionist" tendencies in the arts, and heralded a consolidation of the party line. ${ }^{282}$ In meetings with ministry officials, Deputy Culture Minister Pischner called the three 1956 articles in Sonntag, "a false discussion," and urged his colleagues in the provinces to encourage public debate on Meyer's socialist-realist tract Musik im Zeitgeschehen ${ }^{283}$ And during a speech at a party school, he called for "a struggle for the carrying through of socialist realism." 284 The SED organized a "Culture Conference" in late October 1957, designed to put an end to the ideological fluctuations of the recent past and affirm socialist realism, albeit in the less dogmatic form of a "creative method" rather than a style. ${ }^{285}$ A certain amount of experimentation and artistic freedom was to be allowed, but the goal of the "ideological battle of opinions" had to be the development of a "socialist art" approved by the SED. Ministry officials were to undertake an "ideological offensive" in order to implement these "socialist cultural policies." ${ }^{286}$ Prominent figures from the musical world such as Eberhard Rebling talked of overcoming the "fluctuations" and "bourgeois tendencies" some composers had been manifesting since the Twentieth Party Congress in the Soviet Union. ${ }^{287}$ By the 1960 Congress, the union further revised its constitution by reaffirming socialist realism as its goal while linking compositional activity explicitly to the party's political goals. ${ }^{288}$

Thus by late 1957, two pillars of the East German music scene had been established. Officials pressed for adherence to socialist realism, but in a considerably less rigid form that allowed for more musical experimentation. Composers had negotiated for greater artistic autonomy and could use different stylistic methods in their compositions, as long as the work was judged somehow socialist and linked to both people and party. The judiciously altered policy of the SED and its musical allies to expand the definition of socialist realism while maintaining the basic integrity of the concept had been a success.

\section{The Party and State Engage the Music World}

As we have seen, cultural officials in both countries played key roles in the development of the musical world in the stalinist decade. Administrators working 
in an impressive array of party and state organizations attempted to shape the socialist-realist music described here, and then sought to propagate the resulting compositions throughout society. They were arguably the most powerful actors in the music world, and an understanding their function is essential. ${ }^{289}$ These individuals showered composers with attention, both wanted and unwanted, and provided musicians and ordinary citizens an extensive number of music-related opportunities. The actions and decisions of cultural officials, and their interactions with musical elites, further demonstrate the negotiated nature of the stalinist musical world. Even at the height of their power in 1950-52, the parties in both countries compromised with composers, and these compromises were only catalyzed by the thaw beginning in 1953 . The SED in particular proved adept at making limited concessions that secured the continued loyalty of musical elites, while initially the Polish party retreated too slowly and clumsily, and then quickly lost any vestiges of support from most composers.

The PZPR and SED believed music had a particular ability to communicate their political goals, and officials therefore invested considerable resources in shaping its production in the framework of socialist realism. The party organs occupied themselves with broader policy issues and worked to influence musical elites, while officials in the state institutions took a much more hands-on approach with respect to composers, musical ensembles, and audiences. Despite the importance accorded music, these party and state bodies could not fulfill the desired goal of total control due to frequent and chaotic bureaucratic reshufflings, staffing problems, broader political turbulence, and not least the resistance and input from the general music world.

\section{Official Belief in the Political Power of Music}

Cultural officials in both countries accorded music an exceptional power to shape people, and this conviction made music of great importance for the parties' political aims. Party members in East Germany were motivated by the belief that "music is an important factor in the formation of man's consciousness. Music can affect man's character in an ennobling, but also brutalizing manner." ${ }^{290} \mathrm{~A}$ provincial functionary attempted to explain how music accomplished this: "Music creates people's character in that it expresses their inner world, depicts their emotional state, and reveals their experiences ... it shows the natural logic of the development of life." ${ }^{291}$ Though the exact workings of music on human consciousness were of course not completely clear to them, cultural officials did frequently assert its great importance in influencing worldviews.

A desire to capture and deploy this allegedly special power permeates SED policy statements during the early 1950s. In the minds of East German officials, music should "strengthen the ideological consciousness of the people" and serve 
as "a means to move the masses and shape consciousness for the building of socialism." ${ }^{292}$ Musical festivals, for instance, were to "develop people's consciousness in a progressive sense" and "affect the consciousness and feelings of millions of people and make a decisive contribution to the re-shaping of our world." ${ }^{\prime 293}$ The music played should help the party "give millions of patriotic Germans optimism and strength released through the emotional effects of music in order to fight for the democratic reunification of Germany and the preservation of peace." 294 The composer, through his musical works, was to "resolve the fight between the people and reaction and death-bringing, people-hating attacks . . . and lead our people to new, bright heights of societal progress and love of life." ${ }^{295}$ With this focus on tapping into people's minds, East German officials quite clearly desired to use music's putative power to help them achieve their political goals.

Polish officials made similarly exalted claims. Deputy Culture Minister Włodzimierz Sokorski and musicologist Zofia Lissa filled their programmatic speeches to composers with exhortations to "shape life," and "educate the new person." ${ }^{296}$ As stated in 1950 in an official communication of the Polish Composers' Union, the main goal for composers was "to make contact with the new listener, to gain insight into his needs, to awaken his musical interests, and to educate him ... if a person is emotionally mobilized at a concert, his artistic experience will become a condition for an ideological experience." ${ }^{297}$ Such fulsome testimonials to the power of music were perhaps a bit less frequent in the Polish context, likely due to a somewhat less important role for music in the Polish cultural firmament.

Animated by these beliefs, the parties in both countries directed considerable energies towards the music world through both party and state administrative bodies. East German and Polish cultural officials shared the same broad aim of building socialism, and while both parties emphasized the importance of fostering a progressive, humanistic national identity, as they of course defined it, the SED also had a significant focus on national reunification. Both parties also accorded great importance to the dissemination or popularization of music to the broader citizenry. The PZPR's vitriol against the West was a bit more diffuse than that in the GDR, likely due to its geopolitical position a bit further away from the front lines of the Cold War. The cultural officials of both countries intended music to help in achieving more general Cold War aims, including the fight for peace and against the perceived military threat from the West, the fostering of a spirit of friendship towards the USSR and other People's Democracies, and especially the creation of a new socialist culture, based on progressive works and artists of the past, which should inculcate a healthy patriotism in the citizens of the GDR and Poland. Officials also expected music to combat the negative influences from the West, both musical and otherwise. These party and state institutions thus charted an ambitious program for the music of the new socialist era. 


\section{The Party Culture Departments and Broad Policy}

The Culture Departments of the Central Committees of the PZPR and SED set the ideological course for culture generally and music specifically, and as a result, helped to direct the whole of musical life in each country. Engaged with policy, these party organs formulated the party's overarching cultural program, such as the ongoing push to bring culture to both workers and the countryside and the propagation of socialist realism in the arts. The departments developed the theoretical and logistical basis of these initiatives, and then largely relied upon the Ministry of Culture and other state bodies, as well as the musical institutions and individual composers and musicians themselves, to do much of the practical work. Artists who were party members became key links in helping officials to influence cultural production and transmit party aims. All these overlapping layers blurred distinctions between state and society. In general, department officials tried to control from the top, with the expectation that goals would trickle down as directives were communicated all over the country. However, these expressed aims met contradictory goals and even resistance as they spread throughout society, and were often diverted and altered.

The central Culture Department of the PZPR, quite small in size, continually pleaded for more personnel so as to better fulfill its mission. ${ }^{298}$ In 1949, the department had but six members in addition to its director. By late 1955, this number had increased to 19 , and the department asked for still more so as to carry out its tasks more effectively. ${ }^{299}$ The Culture Department made one "instructor" responsible for music in the early years, and eventually set up a Music Sector that employed three people at the time of its founding as a separate body in 1954. ${ }^{300}$ Each provincial party organization included several officials responsible for culture, and central officials continually pushed for them to be more active. ${ }^{301}$

The Culture Department employed a three-pronged strategy for influencing and controlling the artistic world. As in Poland more generally, it organized primary party cells in institutions so that party members could propagate political goals coherently. In many musical organizations, party membership was so low that these party cells never formed or only functioned fitfully. The Polish Composers' Union never had one, and when the party began to lose all influence over the union in the mid-1950s, the Culture Department responded by calling a meeting of those few union members who held party cards, and proposed finally to form a cell in the union-but to no avail. ${ }^{302}$ In many other institutions, like the Warsaw Opera and the Mazowsze song-and-dance ensemble, the party had some limited success, especially in 1954-56 when it turned to these party cells in an attempt to exert some measure of control at its time of crisis. ${ }^{303}$

The PZPR Culture Department's most direct strategy was to send its own officials to important meetings so as to influence the proceedings of the artistic 
unions and other musical institutions. Such interventions generally succeeded in the period from 1948 to 1952, with the party at the height of its power and musical elites most receptive to its goals. A backlash developed, however, when officials seemed too dogmatic, dictatorial, and restrictive of artistic freedom, and some organizations, most notably the Composers' Union, gradually and systematically marginalized party influence on them and their members. A final method for influencing the musical world often took the form of organizing meetings or official councils of party members from the various artistic disciplines, with a wide range of invitees. In these contexts, department officials formulated policy with experts from the musical world, and attempted to draw influential nonparty artists into this process. This method can be seen most clearly in the gathering thaw years from 1954 to 1956, when the Culture Department rapidly and catastrophically lost both control over musical developments and the allegiance of most musical figures.

One of the key figures in the Culture Department was its head in the late 1940s and again in the mid-1950s, Stefan Żółkiewski. A party member and literary critic famous for his call for literature to help build socialism at the January 1949 Polish Writers' Congress, he was one of the more energetic and competent officials involved in the nexus between art and politics. His return as leader of the department in the spring of 1955 represented the party's determination to confront and overcome the challenging political situation. He wrote a number of theoretical and practical analyses in 1955 and following years that advocated a renewed offensive, and he attempted to rejuvenate the party's cultural program. ${ }^{304}$ The department subjected itself to a thoroughgoing evaluation at this time, and admitted numerous mistakes, including a too narrow and vulgar definition of socialist realism, the attempt to force acquiescence to party aims through an overcentralized structure, a bureaucratic manner of operating, abuse of trust, as well as a host of other, more general errors like opportunism, thinking too schematically, dogmatism, and "whitewashing." heavy-handed actions taken in the musical world, which he felt were especially damaging to the development of music. ${ }^{306}$ His efforts largely came to naught, however, as artists resisted party interference in the context of the thaw.

As in Poland, the Culture Department in the SED's Central Committee helped to develop the party's political program with respect to culture and then transmit these goals to artists and ordinary citizens. This organ responsible for culture in the SED's Central Committee went by several different names due to the typical transformations and reorganizations that marked the party and state bodies of this period. ${ }^{307}$ A Department for Culture and Education was part of the Central Committee of the KPD, and then the SED after 1946. After fall 1947, the department was renamed the Department of Party Schooling, Culture, and Education; a year and a half later, Party Schooling was taken away and became its own department. 
Further incarnations included the Department for Literature and Art at the end of 1952, and the Department for Art, Literature, and Cultural Mass Work in early 1954. Whatever the name, by 1949, the general outlines of this department for culture were clear. There were four, at times five, Sectors (Sektoren, until 1950 Bereiche), which were also fluid, but generally represented: cadre, art and literature, education, and cultural mass-work. Most issues related to music fell under Art and Literature, but the other sectors, especially cultural mass work, also dealt with music. In the early 1950s, Margarete Knapp handled musical issues, followed by Hermann Lahl. Its heads were Stefan Heymann from 1948 to 1950 and then Egon Rentzsch to 1953. After the latter's ouster, the titular leadership of the department remained empty until 1958; this period was unsurprisingly marked by less coherent and organized work. On a regional level, the department worked with "instructors" responsible for different areas of culture. It similarly worked through state bodies such as the Ministry of Culture as well as music-related institutions like the Composers' Union, but also occupied itself more with the welfare of individual artists. With the assistance of the very numerous East German musical figures who carried party cards, the Culture Department conducted a relatively successful fight for the implementation of socialist realism in music. In its early years, it tried to do too much with too few people, but nonetheless proved able to assert considerable influence through the many committed party members in the music world. By the mid-1950s, in response to pushback from many in the musical realm, it had scaled back some of its goals and reached an equilibrium with most artists through a process of negotiation.

During his time there in the early 1950s, Rentzsch encountered a typical set of problems that plagued the department throughout the period. He wanted to "rejuvenate ideologically" this party organ, but had major problems filling key positions, including that of instructor for music. ${ }^{308}$ Due in large part to the lack of a sufficient number of workers, he found major problems in the department's mode of operation, and had similar troubles with the related organs in the provinces. The officials in the central department made up an odd mix, as older workers educated before the war coexisted uncomfortably with younger workers who completed ideological courses in the late 1940s but had little practical training in cultural affairs. Another important division was between those officials who saw artists as potential enemies to be forced into doing the party's bidding and those who viewed them as partners simply needing some guidance. ${ }^{309}$

Rentzsch struggled to focus the department on the promotion of socialist realism by conducting regular meetings on the subject, and worked "to develop more broadly and strengthen the ideological battle . . . and establish socialist realism against formalism, social democracy, and art-hating imperialist views." 310 Such efforts culminated in the controversies surrounding the commemorations of Karl Marx's $135^{\text {th }}$ birthday in the spring of 1953 . SED officials heavily criticized 
the main concert, which included Jean Kurt Forest's cantata Karl Marx Lived and Taught (Karl Marx hat gelebt und gelehrt) and the premiere of a work by Arno Babajanian, for its significant ideological and aesthetic problems. ${ }^{311}$ The text by favored poet $\mathrm{KuBa}$ allegedly did not capture Marx and his significance, and Forest's music was deemed decadent and formalist. Rentzsch accepted responsibility for "poor leadership and instructions" and was forced out in May of 1953 in an atmosphere of recrimination and back-stabbing. ${ }^{312}$ The fact that he was not replaced for years, combined with the relative thaw starting in 1953, made the department less effective in getting the party's ideological message across. ${ }^{313}$

The department was to transform the party's aims into reality by exerting control over musical life in the GDR, and as in Poland pursued a multitrack approach. An important aspect of this process involved directing the State Commission for Artistic Affairs (Stakuko) and its successor institution, the Ministry for Culture. The department also took an active role in overseeing all cultural institutions throughout the country, and most particularly the Composers' Union. Although the department rarely interacted with individual musical figures, party officials put great emphasis on both gaining the support of and exerting control over artists. The party thereby hoped to influence the ideological messages communicated to the population, supervise the activities of these intellectuals, and earn legitimacy as a patron of the arts. Though later in the 1950s the party encouraged workers to produce their own art, in this period the party, through the Culture Department, focused on existing artists and intellectuals. This aspect of the department's work was stressed much more than in Poland, since the SED had to convince artists to stay in the GDR, and indeed attempted to convince others from the West to come over.

In both Poland and East Germany, the party's Culture Department set overarching goals and relied largely on party members active in the musical world to carry out its program. In the GDR, these party members were more numerous and committed than their counterparts in Poland, and thus helped to institute much of the party's program in the cultural realm. The departments' influence over musical production and performance in the early 1950s was great, due both to their power and to the willingness of many musical figures to accept their goals. The presence of West Germany also forced the SED to make more concessions to keep potentially and actually discontented artists in its zone. A growing disenchantment among artists both inside and outside the party forced officials to operate in a more conciliatory manner and compromise on aims. In Poland, a renewed initiative to regain control after the post-1953 thaw had little concrete effect, and it collapsed as a result of the wider transformations of 1956. In the GDR, the thaw combined with cadre problems weakened the SED's control, but by 1958 the department had reasserted its authority —in contrast to the situation 
in Poland, where composers and much of the music world had achieved nearly complete autonomy from the influence of party officials.

\section{More Direct Involvement through the State Organs}

In both countries, an ambitious state bureaucracy took a more hands-on approach to the general goals of attempting to institute totalizing political control in the music world and encouraging a new socialist-realist music. In Poland, a ministerial body responsible for culture was created soon after the organization of the postwar governing authority in 1944. ${ }^{314}$ This Ministry of Culture and Art included a department for music from its first days, and in the second half of the 1940s even directly employed communist musicologist Zofia Lissa and also the left-leaning composer Witold Rudziński, the controversial president of the Composers' Union in 1950-51.315 During these early years, this Music Department focused on bringing music to workers and peasants by organizing amateur ensembles and concerts for a broad audience. With the attempt to attain greater control of culture in 1948, ministry officials set up another department to influence artistic production, including a section for music, while a separate state body controlled musical institutions. These two functions were then united in 1952 in what marked the high-water point of centralized control in Poland, even as the ministry began a slow process of giving both composers and musical institutions more autonomy as part of the thaw.

Polish Culture Ministry officials had much more direct and practical interaction with artists and artistic institutions than their counterparts in the Culture Department of the PZPR. Composers generally welcomed this support but resented what they considered excessive interference, and a process of negotiation of aims and outcomes marked the period. The ministry fulfilled four broad functions with respect to music: influencing the producers of music and the Composers' Union; managing the opera houses, orchestras, and other musical institutions; overseeing amateur organizations; and disseminating and popularizing music to the masses. The last goal permeated all aspects of the ministry's work, and the first three, while nominally discrete, often overlapped and produced a confusing ministerial structure.

As in Poland, the East German state institutions had much more direct contact with the musical world than the party Culture Department. Soon after the war ended, a German Administration for People's Education was formed under Paul Wandel, and had a department for art and literature with a subdepartment for music. ${ }^{316}$ After the founding of the GDR, this administrative body became the Ministry for People's Education, and the department for art and literature was spun off, soon to become its own institution, the State Commission for Artistic Affairs (Staatliche Kommission für Kunstangelegenheiten, or Stakuko). ${ }^{317}$ 
Modeled on a Soviet institution, the Stakuko officially came into being in the summer of 1951, headed by State Secretary Helmut Holtzhauer and his deputy, Maria Rentmeister. ${ }^{318}$ It lasted only until the end of 1953, when the SED set up a Ministry of Culture as a response to dissatisfaction from the cultural world, in an effort to move away from the period of strict political control of the arts that the Stakuko represented. Other key Stakuko officials included Rudolf Hartig and the young, reasonably competent, and highly committed Hans-Georg Uszkoreit, as well as representatives in the administrative bodies at the regional level. ${ }^{319}$ Uszkoreit, an organist born in 1926, was captured by Soviet troops in 1944 and spent four years in Soviet camps, time that included two "antifascist courses" that led him to socialism and the choice to stay in East Germany ${ }^{320}$ He was a typical example of the rising generation of young party members, and played a crucial role in the musical life of the GDR throughout the 1950s, as he consistently sought to represent and implement the party line..$^{321}$

The Stakuko sought to control the entirety of cultural life, but in theory through the means of exhortation and education and with a minimum of coercion; composers, however, frequently found these actions intrusive and began increasingly to resist its incursions. It worked to enact the larger goals of the SED, and was especially linked to the renewed attempt in the early 1950s to propagate the ideology of socialist realism in the arts. ${ }^{322}$ The Stakuko helped the SED's Culture Department to formulate policy, but bore more responsibility for the actual implementation of these directives. The Stakuko was imbued with the idea that the arts had a concrete effect on people and could educate them in a socialist manner. Officials believed that this could all be logically carried out, and the Music Department of the Stakuko had several-stage plans for mastering the musical realm. Its officials believed that the percentage of a "socialist" musical culture would gradually increase and overcome the vestiges of bourgeois culture and the encroachment of Western cultural influence. These goals were only partially achieved, as the Music Department faced growing dissatisfaction from the music world, as well as the more basic problem of a lack of adequate, qualified personnel.

To most composers and musicians, the Stakuko's efforts seemed heavyhanded, meddlesome, and insensitive to their concerns. Criticism increased throughout 1952, and by the spring of 1953, the Stakuko in response began to pursue a somewhat more conciliatory policy, as for instance allowing orchestras to decide on their own concert programs without approval from Stakuko officials. After the Uprising of June 17, 1953, the Stakuko retreated even further from an "administrative" and "overcentralized" approach to controlling culture in favor of permitting composers and musical institutions more freedom and autonomy; the Stakuko then proposed to influence the musical world through less coercive means, by convincing rather than commanding. ${ }^{323}$ Dissatisfaction among composers, as well as the artistic world more generally, nonetheless continued to 
grow. In response, the SED made a shrewd political move. Unlike in Poland, where the ministerial official most associated with the "errors and deviations" of the earlier era, Włodzimierz Sokorski, stayed in place for years and attempted unsuccessfully to mollify and compromise, in the GDR the Stakuko was disbanded and Secretary Holtzhauer removed. The well-regarded and popular poet Johannes R. Becher became head of a newly formed Ministry of Culture, replacing the Stakuko, an act symbolic of the granting of more autonomy and respect to artists. ${ }^{324}$ Like his Polish counterpart Sokorski, Becher had spent the war years in the Soviet Union, and played a crucial role as the head of the Kulturbund, an influential arts organization, as well as many other politically and culturally important positions in the Soviet Occupation Zone and early GDR.

The ministry came into being in early January 1954, and was to put a new face on efforts to achieve the same goals. The change proved somewhat cosmetic, as nearly identical personnel pursued a very similar political program, though now with different leadership and slightly modified methods. And after a few short years, SED leaders relieved Minister Becher of all but the nominal functions of the ministry, which were taken over by State Secretary Alexander Abusch. ${ }^{325}$ The accomplished harpsichordist and multitalented cultural official Hans Pischner moved from the state radio to become head of the Music Department through 1956, when he then became deputy minister and was replaced by Uszkoreit. ${ }^{326}$ Prior to his promotion to head, former Stakuko hand Uszkoreit led the first of two subdepartments, Contemporary and Classical Music. ${ }^{327}$ The second, Musical Performances, was directed by former Stakuko music head Rudolf Hartig. The new ministry continued the efforts of the Stakuko and sought to influence all areas of musical life in the country. Ministry cultural officials pursued similar goals, but through somewhat modified means: "Bureaucratic, dogmatic, and uncomprehending administration should be replaced by persuasion and selfdetermination. ${ }^{328}$ Composers were to be consulted more frequently, and the authority to give contracts was largely delegated to the Composers' Union, though the Music Department continued to try to influence these decisions.

Throughout this period, state officials in both countries sought to enlist the arts in the realization of the party's vision of a socialist society. In the years around 1950, state institutions grew ever larger and expanded their reach ever deeper into the musical life of the two countries. During these years of its greatest power, they attempted to control every aspect of the musical world, from the composer's studio, through the opera house and concert hall, to the rural house of culture. And for a time, it was indeed quite successful, as composers created politicized music and party-approved music more generally dominated concert repertoires. Growing resentment and resistance by an increasing number of musical figures produced a backlash, however, and state officials were forced to moderate methods and scale back aims. 
Both the PZPR and SED created a significant and ambitious apparatus within both the party and state bureaucracy in an attempt to oversee every note composed and performed. These cultural officials sought to appropriate music for the realization of the party's vision of a socialist society. The party departments responsible for music set broad policy, sought to realize general ideological aims by working closely with musical figures who carried party cards, and directed the practical activities of the Ministries of Culture. The music-related bodies in the ministries carried out this program of influencing the musical world through extensive interaction with composers, oversight with respect to musical ensembles and institutions, and involvement with amateur musical groups. Cultural officials made their presence felt in all areas of musical life, but the extent of this influence was a product of negotiation with composers and the musical world more broadly. In contrast to Poland, where composers achieved nearly complete compositional freedom and musicians near-total autonomy in the mid-1950s, the state bureaucracy in the GDR maintained a significant amount of influence over the musical world. Although the heavy, interventionist hand of the Stakuko was replaced by a Culture Ministry that sought to employ a lighter touch, the underlying goals remained similar, as did much of the personnel employed to implement them. East German officials modified their approach in 1953 due to growing frustration among musical artists, and produced a reasonably successful synthesis of significant influence combined with generalized and widespread acceptance of their somewhat less intrusive oversight.

\section{Conclusion}

A totalizing project of absolute control and ideological conformity was thus never achieved in either country, even at the peak of party power in the early 1950s. Save for the two-year caesura in the late 1940s and consequent time lag, the initial encounter among cultural officials, composers, and socialist realism in the GDR closely resembled that in Poland. In both countries, several years of debate produced a negotiated concept of socialist realism as well as a large number of socialist-realist works by composers who broadly agreed with the party's politicalaesthetic goals. Although a narrow and prescriptive form was propagated around 1950, socialist realism was not simply a rigid straitjacket imposed from above, but rather a framework that guided and also inspired creative work. Soon after, however, East German and Polish cultural officials, aided by sympathetic composers and musicologists, overreached themselves in an increasingly dogmatic advocacy of a more restrictive socialist-realist paradigm, and began to alienate and frustrate some composers. Many in the music world increasingly expressed their discontent with these actions and forced cultural officials to compromise their goals. Indeed, composers and other musical elites had particular power vis- 
à-vis the party, as officials were considerably dependent on them to cooperate in the creation of the new socialist culture. In Poland, Culture Minister Sokorski and other hardliners too slowly granted concessions to demands from composers and society, and a growing assertiveness from below combined with major disarray in party ranks caused a near-catastrophic loss in state and party control vis-à-vis music. A growing number of composers simply resisted the dwindling number of proponents of socialist-realist music. Sokorski's ouster in 1956 symbolized the end of the era of attempted dirigisme from above, and socialist realism lay abandoned.

In the GDR, it was perhaps the shock of June 17, 1953 that truly catalyzed the hardliners to allow greater leeway to musical elites, symbolized most obviously in the replacement of the dogmatic, interfering Stakuko by the Ministry of Culture. The SED made significant concessions more broadly to artistic and musical autonomy at this time, thus appeasing many demands from the music world, but nonetheless maintained a considerable baseline of control on which it could rely in subsequent years. These prudent moves by the SED and its allies in turn secured the loyalty of East German composers already more predisposed to follow official policy than their Polish counterparts. While East German officials never again achieved the intensity of control attained in the early 1950s, they continued successfully to exert far more influence than their counterparts in Poland in the years after 1956-57. In the GDR, socialist realism in weakened and hence more acceptable form lived on well past the late 1950s.

\section{Notes}

1 Sheila Fitzpatrick, The Cultural Front: Power and Culture in Revolutionary Russia. (Ithaca: Cornell University Press, 1991), 1-15; On music in this period, see Neil Edmunds, The Soviet Proletarian Music Movement (Oxford: Peter Lang, 2000), and Amy Nelson, Music for the Revolution: Musicians and Power in Early Soviet Russia (University Park, PA: Penn State University Press, 2004).

2 Nicholas S. Timasheff, The Great Retreat: The Growth and Decline of Communism in Russia. (New York: E. P. Dutton, 1946); Vera Dunham, In Stalin's Time: Middle-Class Values in Soviet Fiction (Durham: Duke Unversity Press, 1990). On debates about the extent of this discontinuity, see the exchange between Michael David-Fox and Sheila Fitzpatrick in Russian Review 58 (April 1999): 181-211.

3 See Matthew Cullerne Bown, Socialist Realist Painting (New Haven: Yale University Press, 1998), 140-41.

4 H. D. Scott, ed., Problems of Soviet Literature: Reports and Speeches at the First Soviet Writer's Congress (New York: International Publishers, 1935), 21.

5 And perhaps intended by the party as such also. See Katerina Clark, "Little Heroes and Big Deeds: Literature Responds to the First Five-Year Plan," in Cultural Revolution in Russia, 1928-1931, edited by Sheila Fitzpatrick (Bloomington: Indiana University Press, 1984), 204.

6 Fitzpatrick, Cultural Front, 184. 
7 Peter Kenez and David Shepherd, "'Revolutionary' Models for High Literature: Resisting Poetics," in Russian Cultural Studies: An Introduction, edited by Catriona Kelly and David Shepherd (Oxford: Oxford University Press, 1998), 47-49.

8 Leonid Heller, "A World of Prettiness: Socialist Realism and Its Aesthetic Categories" in Socialist Realism Without Shores, edited by Thomas Lahusen and Evgeny Dobrenko (Durham: Duke University Press, 1997), 51-75. In the same volume, Evgeny Dobrenko emphasizes the primacy of narodnost with its linkage to partiinost as the foundation of socialist realism. (Evgeny Dobrenko, "The Disaster of Middlebrow Taste, or, Who Invented Socialist Realism?," 157.)

9 Catherine Cooke, "Socialist Realist Architecture: Theory and Practice" in Art of the Soviets: Painting, Sculpture and Architecture in a One-Party State, 1917-1992, edited by Matthew Culllerne Bown and Brandon Taylor (Manchester: Manchester University Press, 1993), 86-105; Bown, Painting, 141-42; Mikhail Iampolski, "Censorship as the Triumph of Life" in Socialist Realism Without Shores, edited by Thomas Lahusen and Evgeny Dobrenko (Durham: Duke University Press, 1997), 135-64.

10 Less vilified but also anathema was naturalism, which generally meant too much attention to superficial detail rather than expressing something meaningful. Sokorski defined it as "a soulless photograph of reality." Muzyka 3, no. 1 (1952).

11 Antoine Baudin, Le realisme socialiste sovietique de la periode jdanovienne (19471953): Les arts plastiques et leurs institutions (Bern: Peter Lang, 1997), 1.

12 Frolova-Walker, "The Glib, The Bland, and The Corny," 417, 403-23.

13 Richard Taruskin, Defining Russia Musically: Historical and Hermeneutical Essays (Princeton: Princeton University Press, 1997), 517.

14 Ibid.; Fitzpatrick, Cultural Front, 213. She notes the ideal was something like Beethoven's Ninth Symphony.

15 Amy Nelson, "The Struggle for Proletarian Music: RAPM and the Cultural Revolution" Slavic Review 59, no. 1 (2000): 129.

16 The editorial was written by either Stalin or Zhdanov, and certainly approved by both. The literature on the 1936 and 1948 campaigns against Shostakovich is immense and the controversy around his relationship to the Soviet system often acrimonious. See especially Kiril Tomoff, Creative Union: The Professional Organization of Soviet Composers, 1939-1953 (Ithaca: Cornell University Press, 2006), 122-51; Fitzpatrick, The Cultural Front, 183-215; Richard Taruskin, Defining Russia Musically, 468-544; Laurel Fay, Shostakovich (Oxford: Oxford University Press, 2000).

17 See Fitzpatrick, Cultural Front, 199-209.

18 Heller, "A World," 57; Vassily Rakitin, "The Avant-Garde and Art of the Stalinist Era" in The Culture of the Stalin Period, edited by Hans Günter (New York: St. Martin's, 1990), 178. For a counterintuitive account of Zhdanov as moderate, see Werner Hahn, Postwar Soviet Politics: The Fall of Zhdanov and the Defeat of Modernization, 19461953 (Ithaca: Cornell University Press, 1982).

19 See Bown, Socialist Realist Painting, 224. For an excellent overview of this period in music, see Tomoff, Creative Union, chapter 5.

20 SAPMO-BArch, DY-30, IV 2/9.06/282, 235-236. The printed version in the journal Musik und Gesellschaft combined points 12 and 13. "Über den sozialistischen Realismus," MuG 5, no. 1 (1955): 9.

21 Władysław Malinowski, "O socjalistycznym realizmie w muzyce," Twórczość, no. 1 (1993): 53-55.

22 Jan de Weydenthal, The Communists of Poland: An Historical Outline (Stanford: Hoover Institution Press, 1978), 32-33. 
23 Jacek Trznadel, Kolaboranci: Tadeusz Boy-Żeleński i grupa komunistycznych pisarzy we Lwowie, 1939-1941 (Warsaw: Wydawnictwo Antyk Marcin Dybowski, 1998). These included important writers in the debates on socialist realism in the late 1940s and early 1950s like Adam Ważyk, Julian Przyboś, Mieczysław Jastrun, and Jerzy Putrament. For an excellent study of Soviet Lviv, see William Jay Risch, The Ukrainian West: Culture and the Fate of Empire in Soviet Lviv (Cambridge: Harvard University Press, 2011).

24 Ibid., 239.

25 Letter from Książek to Ochab, 10 January 1955, AAN [Archiwum Akt Nowych], KC PZPR [Komitet Centralny, Polska Zjednoczona Partia Robotnicza], 237/XVIII-107.

26 Witold Rudziński, "Związek w pierwszym dziesięcioleciu po wojnie," in 50 lat Zwiazku Kompozytorów Polskich, edited by Ludwik Erhardt (Warsaw, 1995), 55-61, and Andrzej Panufnik, Composing Myself (London: Methuen, 1987),196; Beata Bolesławska, Panufnik (Kraków: PWM, 2001), 146.

27 For more on the fate of Bartók's music in communist Hungary, see Danielle FoslerLussier, Musik Divided: Bartók's Legacy in Cold War Culture (Berkeley: University of California Press, 2007).

28 All the general texts follow this periodization for cultural developments; I have relied largely on Barbara Fijałkowka, Polityka i twórcy (Warsaw: PWN, 1985), and Marta Fik, "Kultura polska, 1944-1956," in Polacy wobec przemocy, edited by Barbara Otwinowska and Jan Żaryn (Warsaw: Editions Spotkania, 1996), 220-75. She dates the thaw from 1952, which is a year earlier than most historians, but agrees most closely with the changes in the musical world beginning already in the second half of 1951.

29 This and the following chapter elaborate the debates among party officials and with composers as to the nature of the emerging doctrine. See Fijałkowska, 82-83, 101. Laurie Koloski echoes this doubt on a teleology that hardline plans were already formulated in 1947. Laurie Koloski, Painting Krakow Red: Politics and Culture in Poland, 19451950 (Ph.D. diss, Stanford University, 1998), 318.

30 Jarosiński, Nadwiślański socrealizm (Warsaw: Instytut Badań Literackich, 1999), 16.

31 Włodzimierz Sokorski, "Udział klasy robotniczej w budowaniu kultury narodowej" Nowe Drogi, no. 7 (1948): 79, cited in Fijałkowska, 61.

32 ZKP, 12/3, 7-8. Rudziński was at this time also director of the Ministry's Music Department, and thus an important figure for the transmission of ideological goals to composers.

33 Ibid. See comments by Wilkomirski, 8, and the motion by Gradstein and Ekier, 12.

34 Fik, 112.

35 ZKP, 12/28, Protokół, 4 June 1949; Witold Rudziński, Muzyka naszego stulecia (Warsaw: Wydawnictwo Szkolne i Pedagogiczne, 1998), 153-54.

36 Tikhon Khrennikov, "O nowe drogi twórczości muzycznej," Ruch Muzyczny (RM) 4, no. 18 (1948): 2-6.

37 See especially Józef Chomiński, "Zagadnienia formalizmu i tendencje ideologiczne . ..” RM 4, no. 20 (1948): 2-6, and Stefan Kisielewski, "Czy w muzyce istnieje formalizm?," RM 4, no. 22 (1948): 2-6.

38 Marin Köster, Musik-Zeit-Geschehen: Zu den musikverhältnissen in der SBZ/DDR, 1945 bis 1992 (Saarbrücken: Pfau, 2002): 45-54; Klaus Mehner, "Jahre der Entscheidung. Vom deutschen Nachkriegsklang zur sozialistisch-realistischen Musik," Positionen 27 (1996): 13-18; Mark Carroll, Music and Ideology in Cold War Europe (Cambridge: Cambridge University Press, 2003), 37-49.

39 RM 4, no. 13-14 (1948): 2-27; ZKP, 12/22, Protokół, 20 September 1948. Stefan Kisielewski disagreed with Lissa's viewpoints presented at the Congress, and it was 
decided that discussions would be held among Union members before a common position would be presented at future Congresses.

40 Scholars typically point to literature and the Fourth Congress of the Polish Writers' Union in Szczecin in January 1949, but the Fourth Composers' Union Congress took place two months prior. See for example Jarosz, Polacy a stalinizm, 146; and Marci Shore, Caviar and Ashes: A Warsaw Generation's Life and Death in Marxism, 19181968 (New Haven: Yale, 2006), 278-79.

41 The term "socialist realism" was rarely used before 1950, as references were usually to simply realism, likely as a way to appeal to more composers.

42 See ZKP, 12/4, and printed version as Włodzimierz Sokorski, "Formalizm i realizm w muzyce," $R M$ 4, no. 23-24 (1948): 2-5. He only used "socialist realism" once (3), and otherwise referred to "realism." The adjective "socialist" was not commonly used until 1950.

43 ZKP, 12/4, Protokól, 1.

44 ZKP, 12/4, and printed version in RM 5, no. 1 (1949): 2-6. For example, he asserted that "a mass song should be the same effort as a piano prelude."

45 ZKP, 12/4; printed version in RM 5, no. 1 (1949): 13.

46 ZKP, 12/4. See especially the contributions by Woytowicz, Wilkomirski, Lissa and Perkowski, 22-25 and zał. 1.

47 AAN, MKiS [Ministerstwo Kultury i Sztuki], DTA [Departament Twórczości Artystycznej], 728, Sprawozdanie Wydzialu Muzyki DTA, IV kwartal 1948, 3.

48 ZKP, 12/28, Protokół, 22 February 1949. See chapter 3 for a discussion of ideological schooling.

49 The tone of the discussions at the conferences in 1948 and 1949 bear this out, as do internal party discussions like that in AAN, KC PZPR, 237/XVIII-1, "Protokół z konferencji w sprawach kulturalnych w KC PZPR," 31 May 1949.

50 AAN, KC PZPR, 237/XVIII-1, "Przemówienie tow. Bermana wygłoszone na konferencji w sprawach kulturalnych w KC PZPR," 1-11, esp. 6-7. See also Fijałkowska’s discussion of this meeting on 106-108, 114-15.

51 AAN, KC PZPR, 237/XVIII-1, 8, 38-44, 59-60.

52 AAN, KC PZPR, 237/XVIII-2, "Notatka do oceny sytuacji kulturalnej," July 1949, 51-63

53 "Realism" was used without the adjective "socialist" until Sokorski referred to "socialist realism" at the very end of the conference. $R M 5$, no. 14, (1949): 30 . See the full transcript in $R M$ 5, no. 14 (1949): 12-31.

54 A rare and refreshing exception is Władysław Malinowski, "O socjalistycznym realizmie w muzyce," Twórczość, no. 1 (1993): 50-68. See also Adrian Thomas, Polish Music since Szymanowski (Cambridge: Cambridge University Press, 2005), 43.

55 "Kroniki," $R M$ 5, no. 13 (1949): 35. This was roughly a third of the active members of the Union; save for Panufnik, all of the leading figures were there.

56 AAN, MKiS, DTA, 470, 64, 65, 90, 91, 103. The Composers' Union suggested works, some of which were accepted. It appears the Union could have taken a more active role in the preparations, but chose not to. (ZKP, 12/28, Protokoły, 18 and 28 June 1949.)

$57 R M$ 5, no. 14 (1949): 12. The festival would become the first Festival of Polish Music (1951); see chapter 4.

58 Ibid., 18, 24.

59 Ibid., 13.

60 Ibid., 29-31.

61 The speech was reviewed by the Ministry, a request Mycielski seems to have willingly accepted. See AAN, MKiS, DTA, 470, 103 and ZKP, 12/28, Protokół, 29 June 1949. 
63 "Konferencja Kompozytorów w Łagowie Lubuskim: Protokół," RM 5, no. 14 (1949): 13, 14, 21-22, 25. In a 1986 interview, Palester gave a somewhat confusing account of his decision to leave Poland. He granted that it was perhaps capricious and that he "mistook" a "complex reality," but asserted that it was becoming difficult to tell the difference between truth and lies and good and bad, and thus leaving was necessary to avoid this situation and to preserve artistic honesty. "Rozmowa z Romanem Palestrem" in Jagoda Jędrychowska, Wiedzieć Polskę z oddalenia (Poznań: Kantor Wydawniczy SAWW, 1990), 80-83.

64 "Konferencja Kompozytorów," 13, 14, 21-22, 25.

65 Ibid., 17, 26, 28.

66 Panufnik, Composing Myself, 187. See further discussions of Panufnik in chapter 3 as well as in David Tompkins, "Composing for and with the Party: Andrzej Panufnik and Stalinist Poland," The Polish Review 54, no. 3 (2009): 271-88.

67 "Konferencja Kompozytorów," 24; for more on the Nokturn, see Thomas, Polish Music, 35-37.

68 Włodzimierz Sokorski, "Ku realizmowi socjalistycznemu w muzyce," $R M$ 5, no. 14, (1949): 3-5.

69 Ibid., 24.

70 Ibid., 18-20. For a fuller description see Thomas, Polish Music, 49-51.

71 Ibid., 18-23.

72 Ibid., 27. Just a few months later, he wrote of his willingness to write a work on Stalin in conjunction with his 70th birthday celebrations. (ZKP, 15/37.)

73 Adrian Thomas notes: "It resurfaced on Polish Radio in 1954, was included in the first Warsaw Autumn Festival in 1956, and a quotation from the finale was printed on a Polish stamp for the 1960 Olympics." Adrian Thomas. "Turski, Zbigniew," Grove Music Online. Oxford Music Online, http://www.oxfordmusiconline.com/subscriber/article/ grove/music/28639.

74 “Konferencja Kompozytorów," 28.

75 See chapter 4.

76 Ibid., 13, 16.

77 Ibid., 13, 16, 21.

78 Włodzimierz Sokorski, "Ku realizmowi socjalistycznemu," RM 5, no. 14 (1949): 3-5.

79 ZKP, 12/92, "Protokol z konferencji kompozytorskiej," 4 February 1950; Danuta Gwizdalanka and Krzysztof Meyer, Lutosławski: Droga do dojrzałości (Kraków: PWM, 2003), 224.

80 ZKP, 12/92, "Protokol z konferencji kompozytorskiej," 4 February 1950. About 40 composers and musicologists were present; this was about half of the total membership and a very high percentage of active members.

81 "Sprawozdanie z działalności ZG ZKP za okres kadencji od 11/1948 do 6/1950," Muzyka 1, no. 3-4 (1950): 33.

82 Zygmunt Mycielski, Dziennik, 1950-1959 (Warsaw: Iskry, 1999), 15-16. NEP was the New Economic Policy in the 1920s Soviet Union, a period of relative openness and experimentation in the arts and society.

83 Zygmunt Mycielski, "Przemówienia," Muzyka 1, no. 3-4 (1950): 17-24.

84 AAN, KC PZPR, XVIII-74, 7-23 and ZKP, 12/5, 16-17, 45-46.

85 ZKP, 12/5, 39-40.

86 Ibid., 54.

87 Ibid., 30-34.

88 Ibid., 55-59.

89 Witold Rudziński, "Program pracy ZKP," Muzyka 1, no. 3-4 (1950): 9-13. 
90 Ibid. See also ZKP 12/28, Protokół, 27 June 1950.

91 ZKP, 12/28, Protokół, 27 June 1950.

92 ZKP, 12/28, "Załącznik do protokołu," 9 December 1950. See also Adrian Thomas, "Mobilising our Man: Politics and Music in Poland during the Decade after the Second World War." Composition-Performance-Reception, edited by Wyndham Thomas (Ashgate: Aldershot, 1998), 145-68.

93 AAN, MKiS, DTA, 726, "Plan pracy na rok 1951," 6.

94 ZKP, 12/28, Protokół, 4 December 1950, and ZKP, 12/29, "Protokół z obrad Plenarnego Zebrania ZG ZKP," 15 and 16 January 1951. I have been unable to find any explicit reason given. Less than a year later, Panufnik was again elected vice-president. In his autobiography, Panufnik complained about his Union duties taking up an "alarming amount of [his] time," and he had also recently met his demanding first wife just a few months prior. (Panufnik, Composing Myself, 175.)

95 ZKP, 12/28, "Protokół z obrad Plenarnego Zebrania ZG ZKP," 15 and 16 January 1951. In his diary, Mycielski wrote of his agreement to join the Executive Board, which he had left seven months earlier because he could not accept the dogmatic course of official cultural policy: "Like an idiot, I assented to [join], giving a pathetic (patetyczne) speech in which I said I considered my selection as evidence that they were returning to my point of view with respect to musical affairs and not that I was agreeing to their point of view. I see it that way, but what of it? They got me and that settles it. (Złapali mnie i tyle.)" Zygmunt Mycielski, Dziennik, 1950-59 (Warsaw: Iskry, 1999), 15-16, 38.

96 ZKP, 12/28, "Protokół z obrad Plenarnego Zebrania ZG ZKP," 15 and 16 January 1951.

97 ZKP, 12/29, Protokół, 23 July 1951. In the 1990s, Rudziński published an article that claimed his resignation was a result of a state inspection and Sokorski demanding the dismissal of Stanisław Kołodziejczyk, the director of the ZKP office, on the grounds that he was involved in the intelligence services of the interwar government. Witold Rudziński, "Związek w pierwszym dziesięcioleciu po wojnie," in 50 lat ZKP, edited by Ludwik Erhardt (Warsaw, 1995), 59-61. This explanation seems rather unlikely. While there was an inspection in May 1951, and it did result in the dismissal of Kołodziejczyk, it was apparently requested by the Prezydium. (ZKP, 12/6, Sprawozdanie, 8).

98 AAN, KC PZPR, 237/XVIII-2, Protokół, Narada Krytyki Artystycznej, 17-18 October 1951.

99 Fijałkowska, 158-60.

100 Włodzimierz Sokorski, "Od Łagowa do Festiwalu Muzyki Polskiej" Muzyka 3, no. 1-2 (1952): 3-11. See also "Sprawozdanie z obrad VI Walnego Zgromadzenia ZKP," Muzyka 3, no. 1-2 (1952): 54.

101 Zygmunt Mycielski, "Na marginesie Festiwalu Muzyki Polskiej," Muzyka 3, no. 3-4 (1952): 12-21. He gave fulsome praise, for instance, to Gradstein's "Words on Stalin."

102 Zofia Lissa, "Próba podsumowania Festiwalu i wyników zjazdu," Muzyka 3, no. 3-4 (1952): 21-33.

103 ZKP, 12/6, 10, 36-38. Turski asserted it could have been written by a Spaniard, and that an imitation of a train in the work was an error of naturalism. This could have been a veiled anti-Semitic attack on the Jewish Gradstein.

104 ZKP, 12/6, Załącznik, 1-5.

105 ZKP, 12/6, 48-49. The official summary in Muzyka ("Sprawozdanie z obrad VI Walnego Zgromadzenia ZKP," Muzyka 3, no. 1-2 [1952]: 56.) makes it sound as if he was lamenting the lack of an atmosphere of battle, whereas the official protocol makes clear 
his tone is conciliatory. Throughout the Muzyka summary, the calls for more ideological engagement are played up, surely to reflect the party line.

106 The one exception would perhaps be Stefan Kisielewski, though his pedagogical works did fit the paradigm in a broad sense.

107 And most of the latter is anecdotal and self-exculpatory, and not confirmed by any archival sources.

108 Witold Rudziński, "Pieśń masowa" in Kultura Muzyczna Polski Ludowej, 1944-1955, edited by Zofia Lissa and Józef Chomiński (Kraków: PWM, 1957), 226. See also Sułek, esp. 21-44. For an exploration of the song texts, see Wojciech Tomasik, "Pieśn masowa" in Słownik realizmu socjalisticznego, eds. Zdzisław Łapiński and Wojciech Tomasik (Kraków: Universitas, 2004), 187-93.

109 Sułek, 54-57, 79. She argues they didn't become as popular as some of the major "hits" of the era due to their relatively complex harmonies. See 45-80 for an excellent overview of his mass song production, but one that underestimates its importance both in Lutosławski's musical production as well as its contemporary context.

110 Archive of the Polish Music Publisher (PWM), 06/DN, letter from Lutosławski, 2 November 1950.

111 See the details of the related song contest in chapter 3. For more on this episode and Panufnik more broadly, see David Tompkins, "Composing for and with the Party," 271-85.

112 On Panufnik and the peace movement, see Adrian Thomas, "In the Public Eye: Panufnik and His Music, 1948-1954" in Andrzej Panufnik's Music and Its Reception, edited by Jadwiga Paja-Stach (Kraków: Musica Iagellonica, 2003), 205-20.

113 Zbiorek pieśni rewolucyjnych i masowych do pochodu 1-szo-majowego (Prasa Stalinogród, 1953), text by Sabina Doboszówna.

114 For more on Broniewski, see Shore, Caviar and Ashes.

115 See below and Joy Haslam Calico, "Für eine neue deutsche Nationaloper": Opera in the Discourses of Unification and Legitimation in the German Democratic Republic" in Music and German National Identity, eds. Celia Applegate and Pamela Potter (Chicago: University of Chicago Press, 2002), 190-204.

116 Mieczysław Drobner, "Opera i balet” in Kultura Muzyczna Polski Ludowej 1944-1955 (Kraków: PWM, 1957), 162.

117 Małgorzata Gąsiorowska, Bacewicz (Kraków: PWM, 1999). See also Thomas, Polish Music after Szymanowski, 69-73.

118 Tadeusz Marek, Przewodnik koncertowy (Warsaw, 1955), 21.

119 Gąsiorowska, Bacewicz, 185; see also chapter 3.

120 Gwizdalanka and Meyer, 269-70.

121 Muzyka 1, no. 5 (1950): 70; Muzyka 2, no. 10 (1951): 60; Muzyka 3, no. 5-6 (1952): 104; see also Thomas, "In the Public Eye," 209-10; ibid., "File 750," 3n34; ibid., "The Hidden Composer," 217. For more on this episode, see Tompkins, "Composing for and with the Party," 275-77.

122 AAN, MKiS, DPK, 26, “Sprawozdanie z wykonania planu pracy na I kw 52," 7.

123 Marta Fik, Kultura polska po Jatcie: Kronika lat 1944-1981 (Warsaw: Niezależna Oficyna Wydawnictwa, 1991), 1:207.

124 Fijałkowska, Polityka, 257.

125 Leszek Polony, "Powikłania ideologii estetycznych w powojennym pięćdziesięcioleciu" in Muzyka Polska, 1945-1995 (Kraków: Akademia Muzyczna, 1996), 46-47.

126 ZKP, 12/22, "Stenogram z Zebranie Rozszerzonego Plenum Zarządu Głównego ZKP," 11 December 1952, 7-8. 
127 AAN, MKiS, CZTOiF, 2732, Protokół Kolegium, 17 January 1953, 11; AAN, MKiS, CZTOiF, 2738, "Plan pracy na II kwartal 1953," 11.

128 Fijałkowska, Polityka, 268.

129 AAN, KC PZPR, 237/XVIII-80, "Rezolucja Rady Kultury i Sztuki," 11 April 1953, 56.

130 ZKP, 12/22, "Stenogram z Zebrania Rozszerzonego Plenum Zarządu Głównego ZKP," 11 December 1952, 33-34.

131 ZKP, 12/22, "Protokół surowy narady Zarzadu ZKP," 18 May 1953: 11.

132 ZKP, 12/22, "Stenogram z Zebranie Rozszerzonego Plenum Zarządu Głównego ZKP," 11 December 1952, 7-8. Lissa noted that the number of mass songs fell from 172 in 1951 to 61 in 1952.

133 ZKP, 12/22, "Protokół surowy obrad rozszerzonego Plenum Zarzadu Glownego ZKP," 16-17 December 1953, 20-22.

134 Ibid., 4-5.

135 Fijałkowska, Polityka, 270-74.

136 Speech printed as "Z perspektywy dziesięciolecia," Muzyka 5, no. 7-8 (1954): 3-25.

137 ZKP, 12/7, Protokół, 12-15, 28-29.

138 Ibid., 28-29.

139 Ibid., 25-27, 37-39, Załącznik No. 2.

140 Ibid., 66.

141 ZKP, 12/22, "Protokół zebrania plenarnego ZG ZKP," 3 May 1954.

142 AAN, KC PZPR, 237/XVIII-120:83-89; AAN, KC PZPR, 237/XVIII-143: 181. See chapter 3 .

143 ZKP, 12/8, Protokół: 52; ZKP, 12/23, Protokół, 14 April 1955.

144 ZKP, 12/8, Protokół.

145 AAN, KC PZPR, 237/XVIII-107, letter to Morawski from Książek, 4 February 1955, 42.

146 Fijałkowska, Polityka, 279.

147 AAN, KC PZPR, 237/XVIII-120, 83-89.

148 Ibid., 46-52, 79-81.

149 ZKP, 12/8, 6-25.

150 Ibid., 65-78.

151 See Fijałkowska, Polityka, chapter 5.

152 AAN, KC PZPR, 237/XVIII-150, "Stenogram XIX Sesji Rady Kultury i Sztuki," 24-25 March 1956. Writer Jan Kott asserted that, while the music of Debussy or Stravinsky was bourgeois, it had been wrong to call someone who liked this music an "enemy of the people" (7).

153 See Bylander, The Warsaw Autumn International, and Lisa Jakelski, "The Changing Seasons of the Warsaw Autumn: Contemporary Music in Poland, 1960-1990" (Ph.D. diss., University of California-Berkeley, 2009).

154 ZKP, 12/9, Załącznik, 1-2. Also printed in RM, no. 1 (May 1957): 2-3. In 1991, interestingly, Lutosławski remembered the situation somewhat differently, stating: "The pressures, if there were any, they were 1949-1955" (Emphasis added. Quoted in Gwizdalanka and Meyer, Lutosławski, 300n1).

155 ZKP, 12/9, Piotr Rytel, 16-24 (first morning session); Kamiński, 1-6 (first afternoon session). The latter reminded his fellow composers that they had not all been forced to compose as they did, but rather had chosen to do so.

156 Ibid., Skrowaczewski, 58-62. As mentioned above, he composed a Cantata on Peace to a text on Stalin, and thus in particular likely felt he needed to explain his actions.

157 See Hans-Jürgen Schmidt, Die Expressionismusdebatte: Materialien zu eineim marxistischen Realismuskonzeption (Frankfurt: Suhrkamp, 1973). For more background, see 
David Pike, German Writers in Soviet Exile, 1933-1945 (Chapel Hill: University of North Carolina Press, 1982). Most composers, of course, stayed in Germany and made compromises to varying degrees with the Nazi authorities. (There has been very little research in this area; for an initial foray, see Köster, Musik, 86-102.)

158 Norman Naimark claims that the Soviet officers attempted to impose hardline control in the musical world from a very early stage. Norman Naimark, The Russians in Germany: A History of the Soviet Zone of Occupation (Cambridge: Belknap Press, 1995), 448-52. Köster more convincingly shows that the music world enjoyed almost total freedom through the late 1940s (Köster, Musik, 36-67).

159 "Freiheit der Wissenschaft und Kunst," speech by Anton Ackermann at the First Central Culture Conference of the KPD, 3 February 1946, in Dokumente zur Kunst-, Literatur- und Kulturpolitik der SED, edited by Elimar Schubbe (Stuttgart: Seewald Verlag, 1972), 55. Erbe emphasizes his attacks against "pseudo-artists" and on modernism as representative of the SED's plan to stalinize culture as quickly as possible. Gunter Erbe, Die verfermte Moderne. Die Auseinandersetzung mit dem "Modernismus" in Kulturpolitik, Literaturwissenschaft und Literatur der DDR (Opladen: Westdeutscher Verlag, 1993), 57.

160 See Köster, Musik, 123-34.

161 Pike calls its publication and discussion a significant hardening of the line. Pike, Politics of Culture, 466-72. Köster emphasizes how this hard line was interpreted more liberally by culture officer Barskii. Köster, Musik, 54-67. Heimann asserts that these early discussions of Zhdanov's theses were relatively mild until the early 1950s. Thomas Heimann, DEFA, Künstler und SED-Kulturpolitik: Zum Verhältnis von Kulturpolitik und Filmproduktion in der SBZ/DDR, 1945 bis 1959 (Berlin: VISTAS, 1994), 92-94.

162 Lin Jaldati and Eberhard Rebling. "Sag nie, du gehst den letzten Weg." Lebenserinnerungen 1911 bis 1988. (Marburg: BdWi-Verlag, 1995), 418-21.

163 Anton Ackermann, "Marxistische Kulturpolitik" in Schubbe, Dokumente, 84-90.

164 Quoted in Magdalena Heider, Politik-Kultur-Kulturbund: Zur Gründungs- und Frühgeschichte des Kulturbundes zur demokratischen Erneuerung Deutschlands 1945-1954 in der SBZ/DDR (Cologne: Verlag Wissenschaft und Politik, 1993), 91.

165 "Maßnahmen zur Durchführung der kulturellen Aufgaben der SED," Protokoll der Ersten Parteikonferenz, in Pike, Politics of Culture, 486.

166 Heider, 96; Heimann, 92.

167 Alexander Dymschitz, "Über die formalistische Richtung in der deutschen Malerei," Tägliche Rundschau (19 and 24 November 1948).

168 See Köster, Musik, 79-80, and her portraits of Dymschitz, 29-38 and Sergei Barskii, 54-67.

169 SAPMO-BArch, DY-30, IV 2/9.06/10, “Arbeitsplan des Referats Kunst," 41.

170 SAPMO-BArch, DY-30, IV 2/9.06/32, letter from Heymann to all Landesvorstände, 4 March 1949: 42. See also chapter 2.

171 SAPMO-BArch, DY-30, IV 2/9.06/10, “Arbeitsplan für das Sommersemester 1950," 80.

172 SAPMO-BArch, DY-30, IV 2/9.06/23, Hausmitteilung from Heymann to Abusch, 25 May 1950, 2.

173 SAPMO-BArch, DY-30, IV 2/9.06/109, "Ergänzung zu dem Bericht vom 6.10.50 über die Abwanderung der Künstler nach dem Westen,” 21 October 1950, 153.

174 SAPMO-BArch, DY-30, IV 2/9.06/284, "Bericht über die Konferenz der parteigenössischen Musiker und Komponisten am Mittwoch, dem 15.12.48 im Parteihaus Wallstr. 76-79," 5 January 1949, 3-4.

175 Walter Ulbricht, "Welches sind die Hauptaufgaben auf dem Gebiet der Kultur," 20-24 July 1950, in Schubbe, Dokumente, 149-51. 
176 SAPMO-BArch, DY-30, IV 2/9.06/9, "Bericht über die Auswertung der Beschlüsse des III. Parteitages der SED auf dem Gebiet der Kulturarbeit," 3 February 1951, 50-52.

177 "Realism" was the preferred term, and "socialist realism" only became more commonly used in 1952; this was likely a conscious rhetorical strategy designed to appeal to a broader spectrum of artists.

178 N. Orlow, "Das Reich der Schatten auf der Bühne," Neues Deutschland (19 November 1950); "Wege und Irrwege der modernen Kunst," Tägliche Rundschau, no. 17/1740 (20 January 1951). (The second half was published the next day.) The identity of Orlow is debated and still unclear, but was almost certainly a collective pseudonym for writers from the Tägliche Rundschau. (Köster, 77.)

179 Wilhelm Girnus, "Wo stehen die Feinde der deutschen Kunst?: Bemerkungen zur Frage des Formalismus und des Kosmopolitismus," Neues Deutschland, nos. 36 and 41 (13 and 18 February 1951).

180 SAPMO-BArch, DY-30, IV 2/9.06/130, 17; SAPMO-BArch, DY-30, IV 2/9.06/23, SED-Hausmitteilung from Hans Lauter to Egon Rentzsch, 26 January 1951, 25.

181 The speech was written with the input of one of the Soviet political officers, Vladimir Semjonow, as well as with Ulbricht and the Politburo. In an interview 40 years later, Lauter claimed his speech was meant to start discussion and not to lay down a dogmatic line. (Heimann, DEFA, 94).

182 "Der Kampf gegen den Formalismus in Kunst und Literatur, für eine fortschrittliche deutsche Kultur," Entschließung des ZK der SED, V. Tagung, 15-17 March 1951, in Schubbe, Dokumente, 178-86.

183 Ibid.,181, 185.

184 A somewhat similar precursor was the criticism of Carl Orff's opera Antigonae as formalist after its peformance in Dresden in early 1950. See Köster, 73-75.

185 This incident has received great scholarly attention. See most recently: Köster, Musik, 69-85; Joy Haslam Calico, Brecht at the Opera (Berkeley: University of California Press, 2008), 109-39 and "The Trial, the Condemnation, the Cover-up: Behind the Scenes of Brecht/Dessau's 'Lucullus' Opera(s)" in Cambridge Opera Journal 14, no. 3 (November 2002): 313-42; Joachim Lucchesi, Das Verhör in der Oper: Die Debatte um Brecht/Dessaus "Lukullus" 1951 (Berlin: Basisdruck, 1993); Lars Klingberg, "Die Verurteilung des 'Lukullus' im Jahr 1951,” Beiträge zur Musikwissenschaft (1991): 188-206.

186 See Lucchesi for reproductions of the original documents.

187 Calico, Brecht, 119.

188 Dessau remembered this meeting as a highly positive and constructive one. Dessau, "Bei Wilhelm Pieck zu Gast" in Paul Dessau, Notizen zu Noten (Leipzig: Reclam, 1974), 70.

189 Daniela Reinhold, "Die Verurteilung des Lukullus. Synopse der Fassungen," in Paul Dessau, 1894-1979. Dokumente zu Leben und Werk (Berlin: Henschel, 1994), 109-208. Reinhold demonstrates that in fact more changes were made before the criticism than after. See also Calico, "The Trial," 313-42.

190 See Calico, Brecht, 121-27. Calico emphasizes that criticism coming from the West also pressured the SED to allow performances later that year.

191 See also Köster, Musik, 73.

192 See Gerhard Müller, "Zeitgeschichtliche Aspekte der 'Lukullus-Debatte"” in Paul Dessau: Von Geschichte gezeichnet. Symposium "Paul Dessau” Hamburg 1994, edited by Klaus Angermann (Hofheim: Wolke, 1995), 144-51.

193 "geehrt und bedrängt, gelobt und verschwiegen, kanonisiert und marginalisiert." Matthias Tischer, Komponieren für und wider den Staat. Paul Dessau in der DDR (Cologne: Böhlau Verlag, 2009), 13. 
194 Culture Department officials were making every effort at this time to translate the theoretical discussions into concrete form in artistic works.

195 SAPMO-BArch, DY-30, IV 2/9.06/23, letter to Egon Rentzsch from Hans Lauter, 26 January 1951, 25.

196 Ernst H. Meyer, "Realismus-die Lebensfrage der deutschen Kunst," $M u G$ 1, no. 2 (April 1951): 6-11.

197 “Entschließung," $M u G$ 1, no. 3 (May 1951): 23-25.

198 Hanns Eisler, "Diskussion ist notwendig," $M u G$ 1, no. 2 (April 1951): 12.

199 Tikhon Khrennikov, "Hervorragender Beitrag der deutschen Musik," MuG 1, no. 2 (April 1951): 5.

200 "Entschliessung," $M u G$ 1, no. 3 (1951): 23-25. This resolution was formulated months before the Congress in consultation with leading figures like Meyer, Knepler, Eisler, Laux and Notowicz, and submitted to the Politburo for approval. (SAPMO-BArch, DY30, IV 2/9.06/23, SED-Hausmitteilung from Hans Lauter to Egon Rentzsch, 26 January 1951, 25.)

201 “Die Gründungskonferenz des VDK, 3.-6.4.51" $M u G$ 1, no. 2 (1951).

202 W. W. Wanslow, "Über die Widerspiegelung der Wirklichkeit in der Musik," Sonderdruck zu $M u G$ 1, no. 8 (1951): 1-16.

$203 M u G 3$, no. 2, (1953): 41-44.

204 ZKP 12/6, 15.

205 BArch, DR-1, 41, "Fortsetzung der Diskussion über das Liedschaffen," 3.

206 Witold Lutosławski, "Festiwal Współczesnej Muzyki Niemieckiej w Berlinie,” Muzyka Nr. 1-2 (1953): 38-41. He calls Paul Dessau's Appell a notable exception to the latter.

207 ZKP 12/6, Załącznik, Rudziński.

208 Representatives from other bloc countries for often present as well; attending here were also Zikker from Czechoslovakia ("Protokoll der Ersten Jahreskonferenz des VDK,“ DMA, VDK, 253-60), and Stojanoff from Bulgaria (ibid., 379).

209 SAPMO-BArch, DY-30, IV 2/9.06/284, letter from Rentzsch to Rentmeister, MfV, 1 June 1951, 48.

210 SAPMO-BArch, DY-30, IV 2/9.06/109, letter to Genosse Giejelkow, 4.5.51. Department officials pushed the Kulturbund to engage in the debate more fully and systematically as well. (See Heider, Politik-Kultur-Kulturbund, 139.)

211 BArch, DR-1, 20, “Arbeitsplan der Stakuko für das Jahr 1952," 9 November 1952, 101 102.

212 Walter Ulbricht, "Kampf um ein realistisches Kunstschaffen" in Schubbe, Dokumente, 239-40.

213 "Diskussionsrede Johannes R. Bechers auf der II. Konferenz der SED” in Schubbe, Dokumente, 241.

214 Lin Jaldati and Eberhard Rebling, "Sag nie, du gehst den letzten Weg." Lebenserinnerungen 1911 bis 1988 (Marburg: BdWi-Verlag, 1995), 454.

215 For example, the regional Union bodies in Saxony and Thuringia organized lectures and discussions of specific works. ("Protokoll der Ersten Jahreskonferenz des VDK," DMA, VDK, 321, 339.)

216 F. F. Finke, Werner Hübschmann, Paul Kurzbach, Johannes Thilman, and Fritz Spies, Arbeits- und Studienmaterial zur Frage des Formalismus und Realismus in der Musik" (Dresden: Landesdruckerei Sachsen VEB, 1952). Interestingly, Finke had employed twelve-tone techniques in his Third Orchestral Suite (1949), which further demonstrates the fluidity of the formalist/socialist-realist debate. (See Köster, Musik, 83.)

217 N. Notowicz and E. Rebling, "Zur Frage des Realismus und Formalismus: Kritische Bemerkungen zu einer Broschüre," $M u G$ 2, no. 9 (1952): 7-13. The authors reacted 
especially strongly to the accusations that Eisler and Asriel had formalist tendencies. This episode is an example of the conflict between Berlin-based composers and musicologists and those out in the provinces (discussed in chapter 2).

218 Peggy Klemke, Taktgeber oder Tabuisierte-Komponisten in der DDR. Staatliche Kulturpolitik in den fünfziger Jahren (Marburg: Tectum Verlag, 2007), 38-43. Rebling claims that opposition to this group had an anti-Semitic tone (Jaldati and Rebling, Sag nie, 457).

219 See discussions in SAdK, VDK, 1022; Meyer, Kontraste, 218-25.

220 Anne-Kristin Schmidt, Musik als Werkzeug der Indoktrination: Am Beispiel der Festouvertüre 1948 von Ottmar Gerster und dem Mansfelder Oratorium von Ernst Hermann Meyer (Mainz: Are Musik Verlag, 2009), 117.

221 SAPMO-BArch, DY-30, IV 2/9.06/125, "Entwurf des Arbeitsprogramme des DVD für das Jahr 1952," 127; Klemke, Taktgeber, 106-108.

222 Reinhold Brinkmann, "The Distorted Sublime: Music and National Socialist Ideology-A Sketch" in Music and Nazism: Art under Tyranny, 1933-1945, edited by Michael H. Kater and Albrecht Riethmüller (Laaber: Laaber Verlag, 2003), 43.

223 Klemke, Taktgeber, 109-11.

224 Ibid., 111-13.

225 Schmidt, Musik als Werkzeug, 61-74; Norbert Albrecht, "Musik zum Sprechen bringen: Aspekte der Narration in der frühen DDR-Musik" in Die erzählerische Dimension: eine Gemeinsamkeit der Künste, edited by Eberhard Lämmert (Berlin: Akademie-Verlag 1999), 313-14; Matthias Tischer, Komponieren für und wider den Staat. Paul Dessau in der DDR (Cologne: Böhlau, 2009), 68-70.

226 VEB Deutschle Schallplatten, Franz Konwitschny, Gewandhaus Orchester Leipzig, recorded 1955, Druckgenehmigungs-Nr. Ag 511/118/69. See chapter 4 for an example of its positive reception among audiences.

227 Laux, Musikleben, 239; Vera Grützner, "Thilman, Johannes Paul." Grove Music Online. Oxford Music Online, http://www.oxfordmusiconline.com/subscriber/article/grove/ music/27845.

228 Köster, Musik, 88.

229 Laux, Musikleben, 239.

230 Autorenkollectiv led by Heinz Alfred Brockhaus and Konrad Niemann, Musikgeschichte der Deutsche Demokratischen Republik, 1945-1976 (Berlin: Verlag Neue Musik, 1980), 150.

231 Köster, Musik, 98-103; Max Butting, Musik, die ich miterlebte (Berlin: Henschelverlag, 1955), 228.

232 Dietrich Brennecke, Das Lebenswerk Max Buttings (Leipzig: VEB Deutscher Verlag für Musik, 1973), 202-205.

233 BArch, DR-1, 6128, "Zu den Festtagen zeitgenössichen Musik: Drei neue Werke in Berlin uraufgeführt," Konrad Niemann (no citation).

234 "Protokoll der Ersten Jahreskonferenz des VDK," DMA, VDK, 3, 8. The Stakuko claimed his speech was part of a "breakthrough in the ideological debate in favor of socialist realism." (BArch, DR-1, 20, Arbeitsbericht III/52, 13 October 1952, 202.)

235 "Protokoll der Ersten Jahreskonferenz des VDK, “ DMA, VDK, 39-43.

236 Ibid., see the contributions by Thilman, 69-76; Wohlgemuth, 97-102; Spies, 102-109; Knepler, 126-35; Schönebaum, 221-22; Pischner, 245-50; Rebling, 267-70; Goldschmidt, 281-88; Notowicz, 446-49; Dessau, 413-16, and Eisler, 427-30, who both had come under heavy criticism, defended themselves and warned presciently against "schematism" and superficial critical use of the categories of socialist realism. 
237 (Schaffensmethode) "Entschließung des I. Jahreskongresses des VDK," MuG 2, no. 11 (1952): 358.

238 BArch, DR-1, 42, "Arbeitsplan des VDK für das Jahr 1953”; BArch, DR-1, 41, "Protokoll über die Sitzung des geschäftsführenden Vorstandes," 26 March 1953.

239 See below and Klemke, 45-53.

240 Eberhard Rebling, "Für den sozialistischen Realismus in unserem musikalischen Schaffen," Einheit 8, no. 5 (May 1953): 738-45.

241 See comments by Instrukteur Hermann Lahl in SAPMO-BArch, DY-30, IV 2/9.06/23: 84, and SED Hausmitteilung from Melis, Redaktion "Einheit" to Lauter, 47; for the wider implications of this article, see Zur Weihen, Komponieren, 108-109.

242 This episode has been extensively researched. For recent studies, see Joy Calico, "The Politics of Opera"; Zur Weihen, Komponieren, 164-67; Köster, Musik, 134-58; Werner Mittenzwei, Die Intellektuellen: Literatur und Politik in Ostdeutschland, 1945-2000 (Leipzig: Faber \& Faber, 2001), 104-10.

243 See especially Köster, Musik, 153-58 and Joy Haslam Calico, "The Politics of Opera in the German Democratic Republic, 1945-1961," PhD diss., Duke University, 1999.

244 Jürgen Schebera, Hanns Eisler: Eine Biographie in Texten, Bildern und Dokumenten (Mainz: Schott, 1998), 225.

245 Ibid., 228.

246 See Zur Weihen, Komponieren, 273-75.

247 BArch, DR-1, 5859, Protokoll, 29 June 1953. See also the speeches by Ulbricht and Grotewohl at the 15th Plenum of the Central Committee in July, in Schubbe, Dokumente, 296-97.

248 "Erklärung der Deutschen Akademie der Künste," 30 June 1953 in Schubbe, Dokumente, 289-290; "Vorschläge des VDK zur weiteren Entwicklung unseres Musiklebens," special insert to $M u G 3$, no. 8 (21 July 1953); see also Zur Weihen, Komponieren, 129-36, and Mittenzwei, Die Intellektuellen, 111-22.

249 Ulbricht and Grotewohl's speeches in Schubbe, Dokumente, 296-97.

250 BArch, DR-1, 10, "Skizze der Schlussfolgerungen für unsere Arbeit aus dem 15. Plenum des ZK," Hartig.

251 BArch, DR-1, 45, letter from Becher, MfK an den Kongress des VDK, 18 October 1954.

252 BArch, DR-1, 21, “Arbeitsplan für das Jahr 1955.”

253 SAdK, Hans-Pischner-Archiv, 652, "Referat von Herrn. Professor Pischner anlässlich der Orchesterleitertagung," 18 January 1955, 13.

254 SAPMO-BArch, DY-30, IV 2/9.06/282, "Stenographische Niederschrift des 2. Musikfestes 1954 und Kongresses des VDK," 13.

255 Ibid., 234-40.

256 SAPMO-BArch, DY-30, IV 2/9.06/283, "Protokoll vom 2. Kongress des VDK," 30-32, 369-72.

257 SAPMO-BArch, DY-30, IV 2/9.06/283, "Protokoll vom 2. Kongress des VDK," 267-69.

258 Ibid., 66-70; SAPMO-BArch, DY-30, IV 2/9.06/282, "Stenographische Niederschrift des 2. Musikfestes 1954 und Kongresses des VDK," 256.

259 Ibid., 333. An addition to the Union's Constitution read that Union members "pursue the goal of acquiring the methods of socialist realism to an increasing extent." (294.)

260 BArch, DR-1, 21, “Arbeitsplan für das Jahr 1955; BArch, DR-1, 21, “Arbeitsplan für das Jahr 1956."

261 BArch, DR-1, 381, "Arbeitsplan Musik und Gesellschaft für das Jahr 1956."

262 Quoted in Dieter Schiller, Disziplinierung der Intelligenz: Die Kulturkonferenz der SED vom Oktober 1957 (Berlin: Hefte zur DDR-Geschichte, 1997), 20.

263 SAdK, VDK, 603, Zentralvorstand Protokoll, 25-26 February 1956. 
264 Paul Dessau, "Einiges, worüber wir Musiker nur wenig oder gar nicht sprechen;” Kurt Schwaen, "Fundament ohne Obertöne;" Gerhard Wohlgemuth, "Musikwissenschaft und musikalische Praxis," Sonntag (29 January 1956). Gustav Just (then editor for Sonntag) claims he initiated these pieces after a discussion with Dessau, in which the latter "complained terribly about our 'musical popes' who . . . with their doctrinaire Zhdanov-theses block rather than promote the development of a socialist music." $\mathrm{He}$ says Meyer and Rebling were furious, while Butting, Wagner-Régeny, and Spieß were pleased, but the resultant discussion was "stifled." Gustav Just, Zeuge in eigener Sache: Die fünfziger Jahre (Berlin: Buchverlag Der Morgen, 1990), 28-29.

265 SAdK, VDK, 83, Hildburghausen Zentralvorstandssitzung, 17-18 March 1956. A heavily edited summary appears in $M u G$ 6, nos. 5-7 (1956).

266 Ibid., 14, 42.

267 Ibid., 31, 40-42.

268 Ibid., 39.

269 Ibid., 48-49.

270 "Zu einigen Fragen der Literatur und Kunst," Alexander Abusch, 27 July 1956, in Schubbe, Dokumente, 440-45.

271 Paul Kurzbach, "Über einige ästhetische Ansichten Schdanows," MuG 7, no. 2 (1957): 68-70.

272 Siegfried Köhler, “Ästhetische Normen,” $M u G$ 7, no. 2 (1957): 66-67.

273 SAdK, VDK, 862, Parteiaktiv-Sitzung, 31 January 1957.

274 Ibid.

275 Nathan Notowicz, "Zeitgenössischer Realismus—sozialistische Ideologie," 23 February 1957, in Schubbe, Dokumente, 460-64.

276 "Protokoll der Zentralen Delegiertenkonferenz,“" 23-24 February 1957, DMA, VDK, 107-08.

277 Ibid.,13-20a.

278 Ibid., 163.

279 Ibid., 121-23.

280 BArch, DR-1, 140, "Satzung des VDK," Entwurf.

281 Delegierten-Konferenz, 23-24 February 1957, DMA, VDK, 20ff, 51-60.

282 Walter Ulbricht, "Zum Kampf zwischen dem Marxismus-Leninismus und der Ideologie der Bourgeoisie," 30 January 1957, in Schubbe, Dokumente, 452; Alexander Abusch, "Es gibt nur eine Kulturpolitik," 10-12 July 1957, in Schubbe, Dokumente, 473-78.

283 SAdK, Hans-Pischner-Archiv, 1270, "Bericht von Herrn Prof. Pischner über die Tätigkeit der Arbeitsgruppe zur weiteren Demokratisierung der Arbeit des Staatsapparates des MfK anlässlich der Sitzung mit den Abteilungsleitern der Räte der Bezirke," 22 January 1957. As noted just above, Pischner made a conciliatory speech at the 1957 Composers' Union Congress a mere month later; this seeming contradiction was typical for the official attempt to maintain a hard line while making some concessions.

284 Ibid., 670, "Lektion von Herrn Prof. Pischner in der Zentralen Schule für kulturelle Aufklärung Meissen-Siebeneichen,” 8 February 1957.

285 Alexander Abusch, "Im ideologischen Kampf für eine sozialistische Kultur-Die Entwicklung der sozialistischen Kultur in der Zeit des zweiten Fünfjahrplanes;" "Thesen der Kulturkonferenz der SED," 23-24 October 1957, in Schubbe, Dokumente, 489-507. See also Dieter Schiller, Disziplinierung der Intelligenz, 25-47.

286 BArch, DR-1, 30, "Massnahmeplan des MfK in Auswertung der Kulturkonferenz der SED," 27 November 1957. 
287 BArch, DR-1, 43, "Protokoll ausserordentlicher Zentralvorstandssitzung gemeinsam mit dem Presidium des Tschechoslowakischen Komponistenverbandes," 27 October 1957.

288 Zur Weihen, Komponieren, 323.

289 East German musicologist Günter Mayer calls them the most influential. Günter Mayer, "Reflexionen zur Methodologie der Musikgeschichtsschreibung" in Musikwissenschaft und Kalter Krieg: Das Beispiel DDR, edited by Nina Noeske and Matthias Tischer (Cologne: Böhlau, 2010), 56-57. See von Richthofen, Bringing Culture for a suggestive argument on their importance, especially in the 1960s and 70s.

290 SAPMO-BArch, DY-30, IV 2/9.06/284, "Über die Entwicklung der Musikkultur der DDR,” 76; BArch, DR-1, 6203, "Aufgaben und Arbeitsrichtlinien der Fachkommission Musik," 2 June 1951.

291 BArch, DR-1, 40, "Die Rolle der Musik beim Aufbau des Sozialismus," Referat auf der 1. Jahreskonferenz der Musiker und Musikschaffenden des Bezirks Magdeburg, Gerhard Münnich, Rat des Bezirks Magdeburg, Abt. Kunst u kult. Massenarbeit, Ob. Referent für Musik, 24 February 1953.

292 BArch, DR-1, 8, "Die Schwerpuntkaufgaben der HA Musik," 11 April 1953; BArch, DR-1, 6191, Quartalsplan III/53, 16 May 1953.

293 BArch, DR-1, 82, Schott, "Bericht zur Durchführung der Verordnung vom 10.12.53 auf dem Gebiete der Musik," 6 July 1954; BArch, DR-1, 108, "Warum Woche der Musik in Potsdam?," n.d.

294 SAPMO-BArch, DY-30, IV 2/9.06/281, “Thesen-Entwurf 1954,” 33-34.

295 BArch, DR-1, 21, letter from Pischner to Abusch, 15 October 1954.

296 ZKP 12/5, 45, 24. Lissa sez it 12/6

297 ZKP, 12/5, "Sprawozdanie."

298 Fijałkowska, Polityka, 164-65.

299 AAN, KC PZPR, 237/XVIII-103, “O zakresie i metodach prasy WK KC," 144.

300 Fijałkowska, Polityka, 163; AAN, KC PZPR, 237/XVIII, 104, "Wniosek o uregulowanie stanu etatów dla Wydziału Kultury KC PZPR,” September 1954, 2.

301 At least as of 1953; they were in the Propaganda Department. See Fijałkowska, Polityka, 313 .

302 AAN, KC PZPR, 237/XVIII, 143, "Protokół z narady poświęconej II FMP," 22 November $1954,175-78$. See chapter 2 for information on party membership among composers.

303 AAN, KC PZPR, 237/XVIII, 103. "Notatka o pracy WK KC," June 1954, 3ff; Ibid., Sektor muzyki, 138; AAN, KC PZPR, 237/XVIII-102, "Plan pracy IV kwartal 1955;" AAN, KC PZPR, 237/XVIII, 105, "Projekt nowej koncepcji metod pracy i struktury organizacyjnej WK," 28 June 1956, 25-27.

304 AAN, KC PZPR, 237/XVIII, 111, 85-124.

305 AAN, KC PZPR, 237/XVIII, 107, 4 February 1955, 42; 102, 34-37; AAN, KC PZPR, 237/XVIII, 111, "O aktualnej sytuacji ideologicznej w środowiskach twórczych," 12024.

306 AAN, KC PZPR, 237/XVIII, 111, 93.

307 See Zur Weihen, Komponieren, 99-105; and Beatrice Vierneisel, "Die Kulturabteilung des Zentralkomitees der SED 1946-1964," in Kunstdokumentation SBZ/DDR, 19451990: Aufsätze, Berichte, Materialien, edited by Günter Feist, Eckhart Gillen, and Beatrice Verneisel (Bonn: V.G. Bild-Kunst, 1996), 788-820.

308 SAPMO-BArch, DY-30, IV 2/9.06/9, "Bericht über die Auswertung der Beschlüsse des III. Parteitages der SED auf dem Gebiet der Kulturarbeit," 49-60.

309 Verneisel, "Die Kulturabteilung," 800-805. 
310 SAPMO-BArch, DY-30, IV 2/9.06/11; SAPMO-BArch, DY-30, IV 2/9.06/10, “Arbeitsplan der Abt. Schöne Literatur und Kunst beim ZK," 7 January 1953, 132.

311 Hans Pischner, "Der Chorzyklus Karl Marx hat gelebt und gelehrt von KuBa und Forest" and "Mitteilung des Sekretariats des ZK der SED" in MuG 3 (1953): 244-45. See also BArch, DR-1, 41, "Protokoll der Diskussion über das Werk von Kurt Forest (nach Texten von $\mathrm{KuBa}), " 11$ June 1953.

312 SAPMO-BArch, DY-30, IV 2/9.06/16, "Bericht über die Vorbereitung des Kultur-Programmes der Karl-Marx-Feier,” 125-129. See Feist, Gillen, Verneisel, eds., 802. Gustav Just claims he was designated to take over, but was labeled an "opportunist, appeaser, liberal" by Rentzsch, who had himself claimed to Just to be the victim of intrigues by two other Culture Department members, Willi Adam and Rudolf Herzog. Just, Zeuge, 33-34.

313 Johannes R. Becher also pointed to the state of disarray and ineffectiveness in the Culture Department at this time, calling for a larger and more "viable" institution. Letter to Walter Ulbricht, 13 June 1953, in Der gespaltene Dichter, Johannes R. Becher: Gedichte, Briefe, Dokumente, 1945-1958, edited by Carsten Gansel (Berlin: Aufbau, 1991), 87.

314 For early, general information, see Fijałkowska, Polityka, 23-26.

315 Discussed in chapter 2. The first head of this early music department was Mieczysław Drobner; see his Wspomnienia o poczatkach życia muzycznego w Polsce Ludowej, 1944-1946 (Kraków: PWM, 1985).

316 First called the Deutsche Zentralverwaltung für Volksbildung, it was renamed the Deutsche Verwaltung für Volksbildung sometime in 1946/47. See Angela Reimer, "Organe der Macht 1945-1954: Von der Deutschen Zentralverwaltung für Volksbildung bis zur Gründung des Ministeriums für Kultur" in Kunstdokumentation SBZ/DDR, 1945 1990: Aufsätze, Berichte, Materialien, edited by Günter Feist, Eckhart Gillen, and Beatrice Verneisel (Bonn: V. G. Bild-Kunst, 1996), 821-34.

317 An abbreviation of Staatliche Kunstkommission, and used by officials and artists.

318 For more background details, see Reimer, "Organe der Macht"; Zur Weihen, Komponieren, 124-98; Jochen Staadt, ed., “Die Eroberung der Kultur beginnt!” Die Staatliche Kommission für Kunstangelegenheiten der DDR (1951-1953) und die Kulturpolitik der SED (Frankfurt: Peter Lang, 2011); Toby Thacker, "Anleitung und Kontrolle": Stakuko and the Censorship of Music in the GDR, 1951-53" in Censorship and Cultural Regulation in the Modern Age, edited by Beata Müller (Amsterdam: Rodopi, 2004), 87-110; Dagmar Buchbinder, "'Tage der Provokation und der Ausschweifungen': die Ereignisse um den 17. Juni 1953 im Bereich der Staatlichen Kommission für Kunstangelegenheiten," Zeitschrift des Forschungsverbundes SED-Staat, no. 3 (1997): 3-15; "Kunst- Administration nach sowjetischem Vorbild: Die Staatliche Kommission für Kunstangelegenheiten" in Die DDR-Analysen eines aufgegebenen Staates, edited by Heiner Timmerman (Berlin: Duncker and Humblot, 2001), 389-408.

319 Reimer, "Organe der Macht," 825.

320 "Hans-Georg Uszkoreit über Musik und Politik in der frühen DDR und die Querelen um den Musikverlag 'Lied der Zeit,'" interview with Jochen Voit, July 26, 2008, http:// erinnerungsort.de/hans-georg-uszkoreit- 504.html.

321 See also zur Weihen, "Die Staatliche Kommission," 278-79.

322 For more on the Stakuko, see BArch, DR-1, 8, 10, 20, 24, 6191, 6200, and 6204; also Zur Weihen, Komponieren, 124-98; and Dagmar Buchbinder, "Die Staatliche Kommission für Kunstangelegenheiten (1951-1953) —eine Kulturbehörde 'neuen Typus,"” in “Die Eroberung der Kultur beginnt!' Die Staatliche Kommission für Kunstangelege- 
nheiten der DDR (1951-1953) und die Kulturpolitik der SED, edited by Jochen Staadt (Frankfurt: Peter Lang, 2011), 9-276.

323 BArch, DR-1, 6191, "Protokoll der Sitzung des Kollegiums," 29 June 1953; Quartalarbeitsplan IV/53; BArch, DR-1, 10, "Skizze der Schlussfolgerungen für unsere Arbeit aus dem 15. Plenum des ZK," undated; and BArch, DR-1, 5858 and 5859.

324 He called for a Ministry of Culture himself already at the $15^{\text {th }}$ Central Committee Plenum in July, 1953 (Gansel, Der gespaltene Dichter, 105), and pushed again in a letter to Ulbricht on 9 December 1953 (115).

325 Dieter Schiller, Disziplinierung der Intelligenz. (Berlin: Gesellschaftswissenschaft, 1997), 30.

326 A reorganization took place in 1958, and thus after the period under consideration. For more detail, see Zur Weihen, Komponieren, 200.

327 Renamed "Composition and Musicology" around summer 1956. Summary compiled from documents in BArch, DR-1, 8, 10, 11, 20, 22. See also Zur Weihen, Komponieren, 200-201.

328 "Verordnung über die Bildung eines Ministeriums für Kultur der DDR," in Schubbe, Dokumente, 324. 



\section{Chapter Two}

\section{The Composers' Unions between Party Aims and Professional Autonomy}

From the mediocre to the truly genius, the compositional creativity of Poland and the GDR concentrated itself in the Composers' Unions. All the leading figures joined, and aspiring composers of diverse backgrounds desired to do so. Union membership conferred prestige and status, as well as access to more practical resources like funding, and thus was crucial to the livelihood and self-conception of composers. As advocate and self-regulatory body, the unions represented composers by helping to secure money and performances, and lobbied on their behalf with respect to both state and society. The unions also served as a tool for the political control of musical production by the parties, which sought to use these organizations as a transmission belt for political aims. In an attempt to gain support and cooperation, the state funneled considerable sums through the unions to encourage composition and performance.

The Composers' Union in each country was thus the most important institution for the creators of new music as well as for the cultural officials who desired to influence composers and their musical production. In Poland and the GDR, the unions functioned as complex sites of negotiation among five fluctuating, often overlapping interest groups that bridged the political and musical spheres: cultural officials who sought compliance and support, the union leadership, composers and musicologists who were party members, the broad mass of composers willing to work for the party's aims but who also desired a fair amount of creative and professional autonomy, and a minority of composers who were lukewarm or even opposed to the parties. This chapter describes the structure and function of the unions, and explores the interaction among these various groups in such crucial areas as propagating the new ideology of socialist realism, determining union membership, and organizing performances. Through these issues, the overarching theme of negotiation among composers, their leaders, and cultural officials continues to be explored, as is the nature of the parties' efforts to influence both 
composers and society through political oversight of musical production. Over the course of the stalinist decade, both Polish and East German composers asserted professional control over each union's activities and thereby reduced overt political incursions. In the GDR, as we have seen, this process unfolded with the continued political loyalty of the union leadership intact, and hence SED policy remained largely in force, a major contrast with the situation in Poland.

The equivalent institution in the Soviet Union provided a less than ideal model for the satellite countries since it did not become a fully functioning entity until the late 1940s. After all artistic societies disbanded in a large-scale reorganization in 1932, local and regional composers' unions formed throughout the USSR. ${ }^{1}$ Initially welcomed by a majority of composers as liberation from the dominance of the militant communist musical group RAPM, these unions came to serve as an effective conduit of state power and provided a means to enforce conformity in its early years. ${ }^{2}$ A nation-wide organizational committee first formed in 1939, and its first national congress took place only in 1948 in conjunction with Zhdanov's campaign against formalism. ${ }^{3}$ Important organizational reforms were not undertaken until after the Second World War, and thus the union in the USSR was still coalescing at the time the Polish union formed in 1945, and was also quite new at the time of the GDR union's founding in 1951. The 1948 Congress elected a 51-member directorate, from which a six-person presidium was selected, thus providing the model largely emulated in the GDR, while the Executive Committee in Poland was considerably smaller. ${ }^{4}$

This Union of Soviet Composers directly influenced its sister organizations in Poland and the GDR, as emissaries traveled to both countries and dispensed advice. Of course the concept of socialist realism had been more fully articulated in the USSR in both theory and in practice, and that combined with its role as hegemon meant that the Soviet perspective carried great weight. As referenced above, Soviet representatives often attended the major union meetings, as for example when Polish composers greeted the president of the Soviet Composers' Union Tikhon Khrennikov with thunderous applause at the June 1950 Congress in Warsaw. ${ }^{5}$ Khrennikov also traveled to the Founding Congress of the East German Union in April of 1951, and other Soviet representatives attended the first two regular Congresses in 1952 and 1954; at the former, Ukrainian composer Andrei Shtogarenko gave a strongly ideological speech that also praised Stalin, prompting "the Congress participants to rise from their seats and give lively applause." ${ }^{6}$ In both countries, these Soviet emissaries participated actively at the congresses, gave lectures about the links between music and politics, and even went so far as to approve or disparage individual compositions. Works and articles by Soviet composers and musicologists appeared in the main musical journals for consideration by Polish and East German composers. With minor differences, the 
Composers' Unions in both countries appeared to have undergone sovietization, but the underlying reality would prove rather different.

\section{Związek Kompozytorów Polskich (ZKP): Formation and Structure}

The prewar Association of Polish Composers (Stowarzyszenie Kompozytorów Polskich) had maintained a fragile, ghostlike existence during the war, and dissolved into the Union of Polish Composers (Zwiazek Kompozytorów Polskich, or ZKP) at the latter's first, founding congress, organized largely on composer initiative, in late August 1945. ${ }^{7}$ The prior existence of an analogous organization, plus the initial formation of the new body largely outside of party control, were important factors both in maintaining some independence from political constraints during the most politically charged years around 1950 and in asserting almost complete autonomy thereafter. The ZKP had 50 members in 1945, a number that was to rise steadily to 131 by $1957 .{ }^{8}$ Although a large number of composers sympathized generally with the party's aims, especially in the early years, the Polish union had but a little more than a dozen party members in its ranks. ${ }^{9}$ It also did not have the primary party cell typical of most such institutions; in the Writers' Union, for instance, the cell was crucial in asserting party control and introducing socialist realism. ${ }^{10}$

The high points of union life took place at a General Congress, which met every year or so, and was attended by roughly half of the ZKP's members. ${ }^{11}$ Most of these meetings began with an ideological speech by (Deputy) Culture Minister Włodzimierz Sokorski, followed by another politicized presentation by a union official, often composer Zygmunt Mycielski. At the congresses, the members discussed both the political and organizational issues of the day. They also elected members to the Executive Committee, of nine to twelve members, with a handful making up the Prezydium, consisting of the president, one to three vicepresidents, one or two secretaries, and a treasurer. The Prezydium met regularly, even as much as once a week at some periods, to conduct the pressing business of running the union. Plenary sessions of the entire Executive Committee took place every few months, and sometimes expanded to include other ZKP members, ministry officials, or other invited guests.

Several other committees, each with a handful of members, also attended to union affairs and included the Inspection Committee, the Arbitration Board, and the important Qualification Committee (Komisja Kwalifikacyjna). Until 1952, a Commissions and Purchases Committee was part of the union and made important decisions about which composers would receive money for composing certain works. ${ }^{12}$ The union also helped promote and manage many aspects of composers' professional lives, including sponsoring contests, organizing concerts 
both at home and abroad, publishing works, and assisting in the education of younger composers through its Youth Circle. The union was highly centralized and almost all significant meetings took place in Warsaw. Groups of composers in the other major cities, however, did meet informally and also organized concerts. These groupings became formal entities in 1953 as Regional Circles in Kraków, Łódź, Poznań, and Katowice. ${ }^{13}$

The Polish Composers' Union had a great deal of independence immediately after the war, followed by a period of close cooperation with the party from 1948 to 1951, after which it gradually achieved ever greater autonomy. Through the use of the carrot, in the form of funding and an emphasis on shared aims, the PZPR succeeded in influencing considerably the activities of the union and by extension the works composed by its members. The stick, however, exemplified by dogmatic prescriptions and an intolerance of compositional experimentation, slowly alienated the majority of composers. Beginning in 1951-52, they started a gradual process of emancipating themselves from party control through an assertion of professional autonomy that served to reduce political interference.

\section{Verband deutscher Komponisten und Musikwissenschaftler (VDK): Party-Directed Development}

Composers in Germany had become accustomed to membership in a common organization in the first half of the twentieth century. A Society of German Composers (Genossenschaft deutscher Tonsetzer) was founded in 1903 and concentrated on copyright laws. With the Nazi Gleichschaltung in 1933, a Professional Estate of German Composers (Berufsstand der deutschen Komponisten) was formed and incorporated into the Reich Chamber of Music (Reichsmusikkammer) later that year, and enjoyed significant support from composers for its welcome regulation and support of their professional lives. ${ }^{14}$ With the end of the war came a fragmentation of organizations, and composers in the Soviet Zone of occupied Germany had membership in several different institutions. East German composers only came together in a centralized union at the behest of the party, but in the context of many prior years of such a situation. ${ }^{15}$ After the founding of the GDR in the fall of 1949, the SED took the initiative in grouping artists together in unions so as to more effectively influence their activities - a situation very different from that in Poland, where the composers in effect reconstituted a prewar organization by themselves. The founding conference of the Union of German Composers and Musicologists (Verband deutscher Komponisten und Musikwissenschaftler, or VDK) took place from April 3-6, 1951. Originally part of the broad Kulturbund, the VDK became a fully independent organization one year later. Throughout that year, regional union bodies formed as well, for a total membership of about 250 , a number that had reached 339 by early $1957 .{ }^{16}$ Of these, 86 were SED members, 
many of whom held leading positions in the union. With over a quarter of VDK members in the party, the SED mustered about six times the absolute number and twice the proportional strength of its counterpart in Poland. ${ }^{17}$

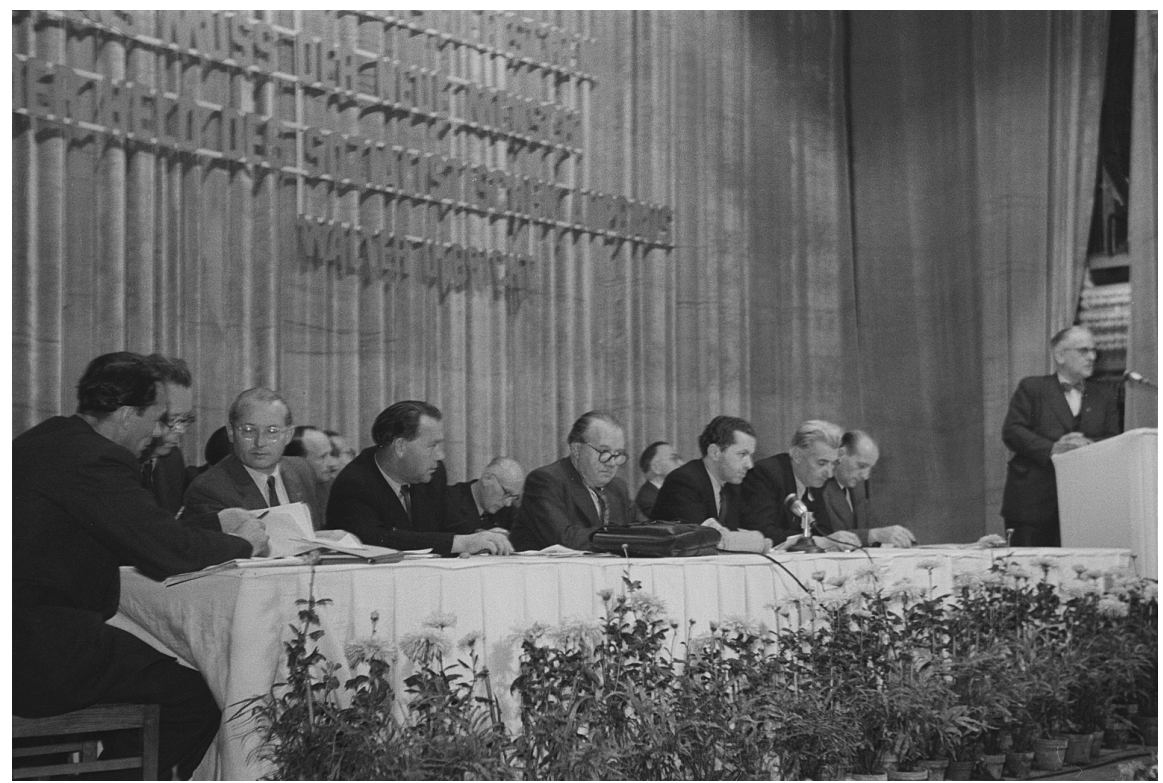

At the First Congress of the German Composers' Union in early October 1952. Union President Ottmar Gerster sits in the center, with black glasses, and to his left is First Secretary Nathan Notowicz. The slogan above is from Walter Ulbricht and reads: "The new person, the hero of the construction of socialism, must be the focus of artistic production" (SLUB Dresden / Abt. Deutsche Fotothek, Abraham Pisarek).

The organizational structure of the VDK resembled that of its Polish (and Soviet) sister institution, except that power was even more centralized, as Berlinbased members closely linked to the party exerted considerable influence- to the frustration of many provincial composers. A central congress of many union members convened roughly every three years starting in 1952. It elected an Executive Committee of 30-40 members, which also included the heads of the regional unions, and met every two to three months. Executive Committee members elected a president, first secretary, five further secretaries, and the heads of genre commissions from its ranks. The president to 1968 was composer Ottmar Gerster and the first secretary to 1961 was the functionary Nathan Notowicz; their long tenures provided continuity and stability at the top, a situation very different from the frequent changes at the head of the Polish union. ${ }^{18} \mathrm{~A}$ further key difference with the Polish ZKP can be seen in the figure of Notowicz, who was not a practicing composer or musicologist, but rather a party-approved cultural official. The secretaries made up the Sekretariat, the effective locus of power in the union that was extremely close to the party; it met weekly in its normal form, 
and monthly in expanded configuration with the heads of the regional unions. ${ }^{19}$ Other important committees were the Admissions Commission and the Contract Commission, both discussed below.

Throughout the period, a constant struggle took place between center and periphery, and pitted composers from the regional union bodies against the VDK leadership and well-known composers in Berlin. While mostly about allocating resources, these disputes also had a political cast as many composers in the capital sympathized strongly with the SED, while some provincial composers pushed for more creative autonomy. At the First Union Congress in 1952, Dresden composer Johannes Paul Thilman used the term "Olympians" to describe the Berlin composers allegedly favored with performances and patronage, a sentiment echoed by Iwan Schönebaum, both of whom channeled this frustration among provincial union members. ${ }^{20}$ Two years later a group of Leipzig composers made similar feelings known, as they pushed for increased decision-making powers for the regional union bodies and away from the centralized Executive Committee in Berlin. ${ }^{21}$ At the Second Union Congress in the fall of 1954, heated discussions took place between union leaders and provincial composers. General Secretary Notowicz defended the center's desire for more power and a harder ideological line against the demands for decentralization and compositional freedom by a number of composers, especially young Siegfried Köhler from Leipzig, and accused them of falsely interpreting the party's New Course. ${ }^{22}$ These struggles continued, and in 1957 union leaders, allied with Hans Pischner from the Ministry's Music Department, tried to pass a resolution that would have allowed the Executive Committee to include prominent figures of their choosing on the committeethus strengthening the party-linked center further with respect to rank-and-file composers - but the VDK membership voted it down despite two attempts. ${ }^{23}$

In the GDR, these conflicts within the union took on the character of regional groups of composers defending their interests against the central leadership. The former, especially composers from Leipzig and Dresden, resented what they perceived as excessive interference from the center, and well as an unfair privileging of the well-known and party-linked composers based in Berlin. In Poland, there was only one other dissenting regional power locus in Kraków, which was simply too small, and the ZKP too centralized in Warsaw, to allow for a serious challenge to the central union authorities around 1950. In Poland, it would take the growing dissatisfaction of a majority of members from across the country to achieve autonomy from the PZPR's influence.

Both the Polish and East German unions had structures similar to their Soviet model, but each manifested significant differences in actual functioning, as Polish composers achieved more creative and professional autonomy. Higher party membership among VDK members, as well as a central leadership consistently supportive of party aims, helped the SED to realize its goals more effectively 
in the music world. In Poland, independent-minded composers occupied major union positions except for the years immediately around 1950. As will be discussed below, the musicologists in both countries were extremely important in carrying out the party's wishes, but the East German musicologists had far more influence on the union's activities than their counterparts in Poland. Through these members, and due to the SED's major role in organizing the VDK, the composers in the GDR came under more political influence, and for a longer time, than their counterparts in Poland.

\section{The Unions Confront Ideology and the Party}

As seen in the previous chapter, by 1950-51 a musical world significantly shaped by party aims confronted composers in both unions. In the organizational life of the unions, the discourse of socialist realism seemed to entrench itself, and the party ideological goals dominated union meetings, musical journals, and educational symposia. More directly, cultural officials took an interventionist hand in the affairs of both the ZKP and VDK. These initiatives show the importance accorded music as well as the parties' reliance on the unions to help realize their program. But composers, in their professional bodies, were always - though sometimes to a greater extent, sometimes to a lesser-able to influence outcomes.

A significant site for contact with party ideas was through so-called ideological courses. In Poland, officials in the PZPR considered such courses particularly important after the 1949 Łagów conference as a means to continue the process of introducing the tenets of socialist realism in particular and Marxism in general. The first took place in 1950 and involved thirty composers; a second was held in August and September of 1951. ${ }^{24}$ The latter involved ten ZKP members as well as seventeen younger composers, and provided an opportunity for participants to learn about Marxist aesthetics as explained by communist musicologist Zofia Lissa, to hear and discuss new works, and to undertake general ideological schooling with assistants of the noted Marxist theoretician, Adam Schaff. ${ }^{25}$ In the spring of 1952, the ZKP conducted a two-part course in the provincial union circles that included lectures on Stalin's theory of superstructure and base, and the transformation of the Polish nation into a socialist one. ${ }^{26}$

Later in 1952, the union organized a three-day course that included lectures on folklore, as well as on Marxism in literature and sculpture. ${ }^{27}$ The workshop included two concerts of Hungarian and Czech music, and attendees listened to and discussed recordings of music by Shostakovich, Aram Khachaturian, and Dmitri Kabalevsky, as well as Béla Bartok, Arthur Honegger, Benjamin Britten, and Paul Hindemith. Real and open engagement with ideological issues took place here. Witold Lutosławski, for example, had an extended exchange with one of the presenters on the subject of Marxist aesthetic theory, the meaning of the 
arts and a class society, and the nature of formalism and socialist realism, and he made a plea for the use of modernist musical techniques: "Despite the reactionary ideology of a work, its purely formal qualities can be useful if they are not closely connected to the reactionary nature of that ideology." His colleague Zygmunt Mycielski grappled with the more general difficulty of applying socialistrealist theory to music, but was certain that a "new creative language must be found, which can embrace most fully the new, young listeners." ${ }^{28}$ Composers spoke openly about their interest in and reservations with the party's aims, and advocated for their own creative approach. Although planning for more courses was announced, it seems that very little if any further schooling was organized, a fact that indicated the growing independence of Polish composers from a weakening party.

The SED put together an even more ambitious program of ideological schooling in the GDR. The regional union organizations coordinated political lectures and discussion of specific works in the early 1950s, and weekend-long symposia on stalinist linguistic theory as well as Marx's writings on culture were planned for $1953 .{ }^{29} \mathrm{~A}$ centrally organized, ten-day course took place in October of that year, featuring ideologically themed lectures by musicologist Georg Knepler and Union First Secretary Notowicz, and including long politicized discussions. Participants attended daily concerts of music by leading contemporary composers from the GDR, the Soviet Union, and the People's Democracies; lengthy analysis and discussion then followed the performance. ${ }^{30}$ Cultural officials planned this colloquium as a model for future courses in each region. ${ }^{31}$ In these contexts, composers and musicologists from both countries frequently encountered the language and ideas supported by the party, and often took part in open debate in an engaged manner.

Another particularly auspicious opportunity to introduce party-approved ideology occurred during union congresses, which a high percentage of composers attended. In Poland, Deputy Minister for Culture Włodzimierz Sokorski gave strongly ideological speeches at each of these congresses, and also played a key role at the 1949 Łagów conference, where composers first discussed the concepts of realism and formalism in depth. The communist musicologist and party member Zofia Lissa similarly presented highly politicized lectures at every congress, and her involvement and influence also extended to the everyday matters taken up by the ZKP leadership. Zygmunt Mycielski also delivered an ideological speech at most congresses. Through these presentations, composers were surrounded by politicized language at their important annual meetings.

In the GDR, high-ranking cultural officials also made significant political pronouncements at the main congresses. SED officials directed the planning of the 1951 Founding Conference in considerable detail, down to the content of speeches and the final published resolution. ${ }^{32}$ There, Kulturbund president and 
later Minister of Culture Johannes R. Becher called for a realistic art and condemned "American cultural barbarism." 33 At the 1952 Congress, Stakuko head Helmut Holtzhauer gave an opening speech that pushed composers to fight for socialist realism and help with the building of socialism. ${ }^{34}$ Two years later, Deputy Minister of Culture Fritz Apelt presented a similarly ideological talk that stressed socialist realism. ${ }^{35}$ At all these congresses, VDK leaders, important composers, and (especially) musicologists gave ideology-filled speeches like those by Lissa and Mycielski of the Polish union. Thus, as in Poland, both cultural officials and party-linked musical producers took an active part in the union's major congresses, and advocated the party goals to be followed.

Less visibly, cultural officials in both countries also attempted to influence union activities more generally. Representatives from the Ministries of Culture intervened directly in union administration in an effort to control composers and their production. In Poland, the Ministry of Culture began increasing pressure on the Composers' Union to follow its ideological program and embrace socialist realism. ${ }^{36}$ For the Fourth Congress in November of 1948, ministry officials prepared ideologically appropriate materials to influence the discussion, and planned politicized content for both the speeches and discussions at the Fifth Congress in June $1950 .{ }^{37}$ The ministry largely coordinated the key conference for promoting socialist realism at Łagów, and in general considered the union its "prime instrument of cultural policy with respect to music" and prepared a six-year plan for it. ${ }^{38}$ Around 1950, at the height of their power, ministry officials also attended meetings of the ZKP's Executive Committee, helped to decide on candidates for the union leadership, and attended concerts where new works were discussed. ${ }^{39}$ Influence over the union was considered the main responsibility of the ministry's Music Department in the early $1950 \mathrm{~s} .{ }^{40}$ Due to cultural officials' ever-increasing dogmatism and hardline policies, however, a growing number of Polish composers began attempting to minimize party and ministry influence in the union's affairs starting in 1951, with incremental success beginning the next year. These composers chafed at the limitations imposed, and sought to carve out more autonomy from cultural officials. The ministry nonetheless continued to attempt to promote cooperation, influence the ZKP with respect to deepening the "ideological level of the composers," and control the choice of the union's executive committee, but found itself increasingly frustrated. ${ }^{41}$ By late 1954, party and ministry officials, as well as composers and musicologists sympathetic to the party, lamented the independence the ZKP had achieved from outside control. ${ }^{42}$ Cultural officials proposed a renewed offensive to establish their influence in the union through a party cell within it, but achieved no concrete success. ${ }^{43}$ Officials from the Music Sector of the Central Committee's Culture Department claimed the ZKP exercised "dictatorial authority in all areas of musical life" and that it had an "apolitical, isolationist attitude" that needed to change. ${ }^{44}$ However, the opposite occurred as the union became increas- 
ingly assertive of its autonomy vis-à-vis the ministry, and by the Ninth Congress in March of 1957, composers openly criticized ministry officials, who had lost all but the most basic of control over the union. ${ }^{45}$

In the GDR, the influence of the party and ministry over the union endured longer. Unlike in Poland, where the ZKP organized itself already in the summer of 1945 on the model of a prewar organization, party officials tightly orchestrated the creation of the East German union in 1951. The SED's Culture Department went so far as to make changes to the Founding Congress program and suggest themes for the speeches, which were strongly oriented towards the fight for socialist realism. ${ }^{46}$ The heavy-handed Stakuko took over the planning of the next congress in 1952 by influencing the discussion in a party-approved ideological direction. ${ }^{47}$ Stakuko officials were closely involved with the VDK's activities in general, as it sent representatives to the union's important meetings and helped coordinate its plans. As noted above, the union leadership was usually only too happy to follow instructions from the Stakuko. Most of the Sekretariat and many of the leading composers in the union were SED members, and they exerted considerable influence over the workings of the union. ${ }^{48}$ To further strengthen the party's position, in 1953 its Culture Department ordered these party members to organize themselves formally in a party organization so as to better influence the VDK and conduct the fight for socialist realism. ${ }^{49}$ In the fall of 1954, the Culture Department urged this organization to increase its efforts to mobilize the union for the goals of the SED. ${ }^{50}$ The party was trying to reassert its influence after a temporary thaw subsequent to the June 17 uprising, but perhaps equally important was the need to exert control in a manner differently than that of the heavy-handed Stakuko. The Ministry of Culture had been founded in early 1954, and although it pursued largely the same goals as its predecessor, it was to do so in a less onerous and interfering manner. The use of such party cells was a way to influence the unions less obviously from the inside. Meetings of these cells took place relatively regularly and coincided with important events; at the seminal Kulturkonferenz in late 1957, Abusch called on them yet again to work harder to influence the VDK. ${ }^{51}$

For much of the period, the language and aims propagated by both the PZPR and especially the SED confronted composers in both unions. Official publications, schooling, and direct intervention by party officials in union affairs served to surround composers with party-approved ideology often supplemented by Soviet materials and visits. In the GDR, this influence was pervasive throughout the period, while in Poland increased independence was attained.

\section{Contesting Membership}

Membership in the union was of crucial importance to composers in both countries. The ZKP and the VDK received large subsidies from their respective gov- 
ernments, and used this money to promote member-composers and their music. Control of union membership thus became a critical point of contention among shifting groups. In both countries, some composers desired and worked for a more exclusive, professionalized union made up of technically competent members who favored serious music. In a telling and crucial difference, however, the push for a smaller Polish union served to limit the party's influence, as the majority of composers desiring autonomy took over the initiative for a more exclusive union to meet their own goals; here, the drive for compositional freedom from political interference overlapped with the desire for a smaller, more professional union. In the GDR, the push for a smaller VDK helped to maintain the dominance of the SED in union life as the politically reliable leadership successfully created and headed an institution both highly professional and ideologically loyal.

\section{ZKP: A Smaller Union Reduces Party Influence}

In Poland in the late 1940s, cultural officials successfully secured union membership for composers who sympathized with their aims, although starting in 1952 a number of composers resisted such attempts. ZKP membership nearly tripled from 1945 to 1957, but a much greater number desired to partake of the benefits and prestige of the union. The struggles over the nature of union membership were one of the major flashpoints of the ZKP's first decade, as ever more composers sought to preserve a union of technically proficient individuals whose primary oeuvre was serious rather than lighter entertainment music. This push for a more professional union dovetailed with a growing desire among many composers to achieve more autonomy from a party attempting for its part to increase its influence over the union.

In 1945, the members of the new ZKP had held membership in the prewar Stowarzyszenie Kompozytorów Polskich, and nine, mostly younger composers joined at the First Congress in $1945 .{ }^{52}$ The new union leadership set up a sixperson Qualification Committee (Komisja Kwalifikacyjna, or KK) at this inaugural ZKP Congress to decide who would subsequently be allowed to join the union. ${ }^{53}$ The procedures for accepting new members were not completely formalized during the first few years of the union's existence. The KK requested materials from prospective candidates and then met, infrequently, to make decisions. ${ }^{54}$ This procedure resulted in a very slow confirmation of new members, and starting in 1949, the committee assembled on a more regular basis, several times a year. If approved, prospective members became regular (zwyczajny) members, or candidate members if those on the commission did not consider the applicant sufficiently qualified. A further category of extraordinary (nadzwyczajny) was also available for those composers not quite qualified or developed enough to join. ${ }^{55}$

Questions surrounding who had the ultimate authority to accept or reject candidates also flared up on numerous occasions. In theory and usually in prac- 
tice, the KK's recommendations were binding on the union leadership. ${ }^{56}$ The KK was, however, often controlled by more independent-minded composers who at times clashed with the more politically engaged Executive Committee in the late 1940s and especially during Rudziński's strongly party-line tenure as ZKP President in 1950-51. Union Secretary and PZPR member Alfred Gradstein asserted in 1949 that the union leadership had ultimate authority, and the Prezydium under Rudziński on at least one occasion changed the decision of the KK. ${ }^{57}$

During the height of party influence from 1949-51, Deputy Minister Sokorski pushed to have a number of left-leaning composers of light entertainment music become members of the union. ${ }^{58}$ The KK's members quickly assented to some, most notably Tadeusz Sygietyński, a prodigious writer of mass songs and the director of the renowned folk-music ensemble Mazowsze, and Władysław Szpilman, both of whom were well respected and considered technically proficient. ${ }^{59}$ The committee accepted PZPR member and composer of light music Witold Elektorowicz shortly thereafter, a decision that would soon prove divisive. ${ }^{60}$ The Prezydium under Rudziński also actively added composers of popular music, as for example the young composer of mass songs Edward Olearczyk (PZPR member, born in 1915), who was made a member outside the usual KK procedures. ${ }^{61}$ In late 1951, a number of party-friendly composers suggested a requalification process for union membership, which sounded like a potential purge of those resisting the party, as the former also proposed looking at the potentially politically suspect wartime activities of all composers. ${ }^{62}$

These moves provoked a minor rebellion among a segment of the more independent composers who desired a professional institution focused more on serious music and who also wanted to limit the party's influence in union activities. As the winds began to shift in early 1952, the new members of the KK, headed by Lutosławski and Kazimierz Sikorski, indeed undertook the requalification process, but managed to turn it against the party in a drive to create a more professionalized union liberated from party influence. ${ }^{63}$ This attempt was similar to the contemporaneous Soviet situation, but there an effort led by Shostakovich and Aram Khachaturian failed when political authorities overturned the union's decisions. ${ }^{64}$ In the Polish case, Lutosławski, secretary of the KK and later its powerful head from 1954 to 1967, pressed a successful drive for a smaller, technically accomplished union focused more on serious music.

Though ostensibly this review of the membership focused on compositional skill, the recently accepted composers of politicized light music bore the brunt of this process, and in particular two party members and composers of political mass songs, Edward Olearczyk and Witold Elektorowicz. Olearczyk studied at the Warsaw Conservatory in the late 1930s and lived in the Soviet Union from 1939-1945. He turned his efforts to composing dozens of popular mass songs and was winner of several state prizes for work that included Our Party (Nasza 
Partia), Millions of Hands (Miliony rak), on the building of People's Poland, and Song in Praise of Comrade Bierut (Pieśń na cześć towarzysza Bieruta). Elektorowicz had received a 1952 Ministry of Culture award for songs composed for young stakhanovite workers. A focus on these two composers celebrated by the political authorities was thus a powerful statement of composer autonomy. Rudziński protested and condemned the requalification as a politically motivated action against those composers sympathetic to the party. ${ }^{65}$ Early in 1952, the KK sent out questionnaires to all members; the fifty-eight most experienced had simply to fill these out, while fifteen other composers had to send in one representative work and a further forty-one of the most questionable cases were asked to submit three. ${ }^{66}$ By the fall, most of the KK's recommendations had been made, with the great majority of composers confirmed in their membership; however, several regular members, including Olearczyk, were to be demoted to candidate membership, and a further six, including Elektorowicz, were to be kicked out of the union altogether due to "insufficient artistic qualifications."

At an expanded meeting of the union's board in December of 1952, composers discussed the KK's recommendations acrimoniously and at length. Zofia Lissa strongly criticized a number of the decisions, including a proposal to allow composers living abroad to remain members, as she claimed that many of them were anticommunist and the union should represent those composers who worked with the party; her proposal went nowhere, as by this time the independent composers were gaining strength. She also argued that Olearczyk should remain a regular member due to his political activity and his many well-known mass songs. ${ }^{68}$ Lutosławski defended the KK's decisions with the assertion that commission members largely considered compositional ability, and that the recommendation to demote Olearczyk to candidate status should prove only temporary, until he had more time to develop his compositional skills. ${ }^{69}$ After seeing more of Olearczyk's work in early 1953, the KK reaffirmed its recommendation of candidate status, and pushed Olearczyk to take a series of lessons on harmony. ${ }^{70}$ The KK remained unsatisfied with his progress in early 1954, and recommended yet more study before they would permit his status as a regular member. ${ }^{71}$

Composers took up these issues again and at length during the Seventh Congress of the ZKP in April 1954, and here the debate largely surrounded the fate of Witold Elektorowicz, recommended for expulsion by the KK. Several union members argued that he should remain in the ZKP, and the union membership passed a motion that allowed him to submit more works to the newly elected $\mathrm{KK}$, now headed by Lutosławski. ${ }^{72}$ At its first subsequent meeting in May, KK members again decided that Electorowicz's works did not meet a high enough standard, and they removed him from the union. The focus on the compositional ability of Olearczyk and Elektorowicz was surely an important factor in the KK's decision, but the circumstantial evidence and comments of Lissa and Rudziński 
indicate that the requalification was also linked to a struggle to diminish the party's influence in the union.

After the requalification upheaval from 1952 to 1954, the KK continued its assigned task of deciding upon applications from aspiring composers, and save for some complaints about it being too restrictive in accepting new members, the era of controversy had come to an end. ${ }^{73}$ The party's idea of an ideologically engaged membership that included more composers of politicized and popular music had been defeated. The Lutosławskian vision of a smaller union comprised of technically qualified members, from both inside the country and abroad, and which did not afford special consideration of political factors such as composing party-approved light music, won out. The party and its supporters in the union enjoyed some important successes in influencing membership around 1950, as a handful of party sympathizers secured a place in the ZKP. Soon after, however, these members were marginalized as part of a general push by a majority of composers for more independence and a more exclusive and professional union membership.

\section{VDK: Restricted Membership Preserves Party Influence}

A similar cleavage between visions for a smaller or larger union existed in the GDR, and in both countries the proponents of a smaller union desired a more professionalized, technically accomplished membership. An interesting reversal of meaning emerged, however, with respect to political influence over the union. Whereas in Poland some composers promoted a more exclusive union so as to keep out party-linked composers, in the GDR union leaders pushed a more restrictive membership policy to preserve party dominance. Opposed to the smallunion policy were the regional East German union bodies, which desired greater membership irrespective both of political loyalty and even of high standards of compositional skill, with the goal of assuring a more vibrant and inclusive regional musical life. As in many other areas, the powerful, party-linked central VDK authorities largely won this struggle.

Leading East German musical figures, as well as the government and party authorities responsible for music, decided upon the invitations for prominent composers to the Founding Conference of the Composers' Union in 1951. Although the members of the new VDK called for the formation of an Admissions Commission at this first conference, such a commission did not constitute itself until the fall of 1952, and was dominated by Berlin-based composers linked to the party. ${ }^{74}$ Instead, during the first year and a half of the union's existence, its Executive Committee, in consultation with the regional unions, made the admissions decisions, thus giving key power to the union leadership. From the Admissions Commission's formation in 1952 until 1957, prospective members were to apply 
to their regional union, whose leaders then evaluated the application and passed their recommendation on to this central Admissions Commission, which made the ultimate decision, if necessary in consultation with the regional union. Prospective members were expected to have technical competence as well as declare themselves willing to work for a "progressive German music," but these general criteria left much room for interpretation. ${ }^{75}$

More often than not, the Admissions Commission turned down the requests for membership, usually on the basis of a lack of technical competence. ${ }^{76}$ These negative decisions produced considerable frustration and anger among those rejected, as well as among provincial union leaders, who particularly disliked the often terse refusal of their recommended candidates. They often knew the applicants personally, and furthermore wanted increased membership so as to have more participation in their regional union's activities. The central Admissions Committee nonetheless generally retained a hard line and insisted upon considerable compositional ability. A typical example was Hans-Werner Haase, whom the Halle Union desired as a member because of his engagement with union activities and the belief that his compositional ability would improve through contact with the union. ${ }^{77}$ Two assessments of Haase's submitted works heavily criticized his compositional ability, and the Admissions Commission also rejected his application. ${ }^{78}$ The genre commission for symphonies was called upon for its opinion and supported his application, but the Admissions Commission nonetheless continued to reject his candidacy. ${ }^{79}$

Political considerations were only infrequently taken into explicit account. One such case, however, was that of Werner Engelhardt, whom the Leipzig Union recommended as a promising composer of dance music. ${ }^{80}$ The Admissions Commission judged his compositions as of a "negative cultural-political kind," seemingly because his style resembled western popular music, and his candidacy was postponed. ${ }^{81}$ In the semipolitical case of Otto-Ludwig Wüstinger in 1955 , the Chamber Music Commission confirmed the Admissions Commission's decision to reject his application, claiming that his music had "no connection to our time" despite the recommendations of the Halle VDK. ${ }^{82}$ In general, however, the commission based the vast majority of rejections on lack of ability, "technical failings," "dilettantism," or other deficiencies in professional competence. ${ }^{83}$

Many composers complained that the guidelines were not clear, and felt particularly frustrated by the Admissions Commission's decisions. Further confusion resulted from the basis for evaluation; sometimes the commission demanded five works in order to decide, but at other times not, and it was also unclear how to evaluate musicologists. ${ }^{84}$ VDK members therefore discussed these issues at length during the 1954 Congress, with sharply different proposals floated by the union leaders and by a group of Leipzig composers. The union's Executive Committee would have done away with the Admissions Commission and given 
itself more power, with the regional unions and genre commissions simply there to make recommendations on prospective members. ${ }^{85}$ The more independent Leipzig composers, typically, wanted to reduce the influence of the Executive Committee in Berlin, and proposed categories and criteria that would automatically guarantee acceptance, but this proposal went nowhere ${ }^{86}$ In the absence of agreement, the Admissions Commission continued its activities largely as before, although it confirmed that five works, including two composed after the war, had to be submitted by composers for consideration. ${ }^{87}$

At this 1954 Congress, as in Poland two years earlier, talk of a requalification of members was in the air. Anticipating a potential politicization of the process, the Leipzig composers wanted to ensure that only "technical" qualifications would be considered ${ }^{88}$ Just after the congress, the Executive Committee put this requalification process into motion, appointing committee members and setting a completion date of March 31, 1955. ${ }^{89}$ But unlike in Poland, it would seem as if political considerations were absent in a narrow sense, and indeed only compositional competence was ultimately considered. ${ }^{90}$ The VDK leadership desired a reduced membership in order to have a union made up of the best qualified composers, with a secondary focus on limiting numbers to thus preserve its - and the party's - dominance. The bulk of rank-and-file composers wanted relaxed standards so as to have more vibrant local union activities. The results of the requalification process were largely inconclusive, as only a small number of composers had their membership revoked.

Frustration among regional composers with the admissions process continued, and thus exact guidelines were still being discussed at the February 1957 Congress. ${ }^{91}$ Many provincial union members attempted again to reduce the influence of the Executive Committee and the Berlin-based union members who made up the Admissions Commission. As a compromise, the Admissions Commission was enlarged to include the heads of the regional union bodies in a concession to the disgruntled composers in the provinces, and the full meetings of members at the congresses were also given a voice in the process..$^{92}$ Despite the compromise, the central union authorities still maintained considerable control over this process through their strong representation on the Admissions Commission.

\section{The Stakes and Meaning of Including Performers}

A further intractable problem and frequent point of contention in both countries was the question of admitting performers to the unions. The Composers' Union in the USSR had faced a similar dilemma, and after significant debate, its leadership narrowly voted against inclusion in the mid-1940s. ${ }^{93}$ In Poland in a situation very similar to the question of accepting more composers, party authorities attempted to secure membership for selected musicians sympathetic to the PZPR, who 
would then presumably exert favorable ideological influence on the ZKP. A more complex situation existed in the GDR, with the terms of the preceding question reversed: there, the central union leaders tried to include prominent performers so as to influence them ideologically and thereby increase the SED's reach more generally. Regional composers often resisted such moves, since they wanted to preserve the VDK as a body of musical producers.

The VDK's Executive Committee in Berlin repeatedly and consistently pushed to allow more performers into the union. In a practical sense, VDK leaders felt that including musicians would help composers get their works performed more frequently; a further benefit seemed to be that the union leadership's ideological program would, through these performer-members, exert more influence in the wider musical world. ${ }^{94}$ Early Executive Committee guidelines set a maximum of 30 percent of total union membership for performers, but this was reduced to 20 percent when discussed at the 1954 Congress. ${ }^{95}$ A long, difficult debate on the matter took place at that congress, as a large number of composers, including the Leipzig Union members, wanted only composers and musicologists in the union. ${ }^{96}$ Some composers desired a limited proposal of allowing performers to be "extraordinary" members without voting rights. ${ }^{97}$ The influential composer and Academy of the Arts member Max Butting also strongly opposed their inclusion, as he wanted the union reserved for creative artists. ${ }^{98}$ Nonetheless, after great effort and pressure, the union leaders, helped by ministry official Hans Pischner, convinced composers to accept performers into the union.

The debate remained somewhat unresolved as late as 1959, as union Secretary Notowicz continued to push the VDK membership to accept yet more performers. ${ }^{99}$ The efforts of the Executive Committee seem largely to have been in vain - in 1960 only 24 performers had joined in a total union membership of 374. ${ }^{100}$ The majority of East German composers seemed to feel that their organization should be a restricted, professional institution of fellow musical producers, and largely succeeded in maintaining this state of affairs. Cultural officials and the union leadership wanted to bring in more performers so as to influence them politically, but achieved negligible results. The central union and ministry authorities proved able to exclude composers they did not approve of, but had a much harder time actively including those performers they desired.

Adding performers to the Polish union was proposed on numerous occasions from at least 1947. ${ }^{101}$ Many in and sympathetic to the PZPR seemed to believe that select musicians could have positive political effects on the union; this situation was a reversal from that in the GDR, where the SED hoped the ideologically sound union would spread its influence. Deputy Minister Sokorski, for example, pushed in 1950 for the inclusion of performers in the ZKP so as to have a joint effort in the fight for socialist realism in music. ${ }^{102}$ Union President Rudziński proposed a Circle of Virtuosos or Performers within the ZKP in late 1950, but 
this never got off the ground due to a lack of interest by the performers as well as fears among composers that it would change the nature of their union. ${ }^{103}$ Officials made further attempts in 1952 and 1953, but these foundered again on a lack of support from the performers themselves, surely combined with the lack of interest by composers as well. ${ }^{104}$

As the ZKP as an institution grew increasingly resistant to party influence after 1952, cultural officials finally abandoned attempts to have performers included in the Composers' Union, and instead mobilized the organization of performers into their own union. ${ }^{105}$ This Association of Polish Musical Artists (Stowarzyszenie Polskich Artystów Muzyków) was to serve as a counterweight to the less politically friendly ZKP in the musical life of Poland, and would help to educate musicians in the ideological program of the party, as well as to bring party-approved music to audiences all over the country. ${ }^{106}$ Throughout 1955, the Culture Department of the Central Committee, as well as a number of partymember musicians, worked on the organization of this association, modeled largely on the ZKP. ${ }^{107}$ The main bone of contention was the association's size, as some of the leading soloists wanted an elite organization to represent their interests, while the party and its musical allies desired a broad-based organization that would have wide influence and the numerical strength to counter the ZKP. ${ }^{108}$ The latter vision prevailed, and while the projected 2000 to 2500 members never became reality, the association did include roughly 1300 members by $1964 .{ }^{109} \mathrm{It}$ was dominated by musicians sympathetic to the party, but ultimately had little effect on composers or their work.

In both countries, a contentious fight for the ideological and professional nature of the Composers' Unions stretched across the stalinist period. In Poland, the PZPR and its allies in the union tried but failed to include performers, but initially did succeed in expanding membership to include more composers who were sympathetic to party goals. After 1952, however, a majority of Polish composers pushed for a smaller union made up of more technically proficient, independentminded composers in order to fulfill the overlapping goals of a more professional institution and diminished party influence. In the GDR, the advocates of a more exclusive membership of accomplished composers were the central union leaders, who also desired a more professional body, but in order to maintain the influence of leading composers linked to the SED. Regional East German composers wanted to increase membership so as to assure an active union life out in the provinces, and found their aims often frustrated. In both countries, interestingly, the unions conducted a requalification, a process very similar to the contemporaneous examination and purges by the PZPR and SED of their respective party memberships. These efforts helped to create a more professional institution with fewer less-accomplished composers. In the GDR, this procedure also cemented the control of the union leadership and hence party influence, while the compos- 
ers in Poland turned the requalification back on the party, in effect manipulating it to purge the union of some sympathetic to the party's aims. The effective use of this process after 1952 demonstrates how the majority of Polish composers had become disillusioned with the party's program, and thus sought to secure their compositional autonomy by asserting their dominance in the union. In the East German union, the SED had broader support, and proved able to maintain its influence on the more narrow and professionalized VDK membership throughout the 1950s. The SED and its allies in the union leadership were only marginally successful in their attempt to use the tool of union membership to spread its influence among performers, however, and only had limited success in the face of opposition from the majority of union members. A professional organization consisting overwhelmingly of composers, with a smaller number of musicologists, pertained in both countries.

\section{The Ambiguous Role of Musicologists}

It is a striking fact that nearly all major musicologists in both countries were closely linked to the parties and played central and indeed indispensable roles in asserting political and ideological influence over composers. Though more influential in the GDR, musicologists in both countries saw themselves as the prophets of the new doctrine of socialist realism, and were greeted by their composer colleagues with initial acceptance followed by growing resentment due to their perceived dogmatism. Zofia Lissa in Poland and Ernst Hermann Meyer in the GDR were only the most prominent of the musicological supporters of both socialist realism and the parties' political program for music. In the USSR, the Composers' Union included both musicologists and composers in an effort to create an atmosphere of "creative stimulation," which proved only partially successful, and musicologists played a less prominent role overall there. ${ }^{110}$

\section{ZKP: Significant Impact Gradually Reduced}

A particularly contentious relationship developed between the musicologists and composers in Poland. An early, somewhat grudging acceptance by composers turned gradually to deepening frustration, and led to the eventual marginalization of party-linked musicologists within the ZKP. The prewar Association of Polish Composers had not included musicologists, and none were in fact at the founding congress of the new Composers' Union in 1945. Zofia Lissa began agitating for their acceptance in 1947 and met with the ZKP's Executive Committee to discuss this proposal, referring to the models of the Soviet Union and Czechoslovakia, both of which combined the two professions in one union. ${ }^{111}$ The Polish Ministry of Culture also advocated including musicologists, convinced that party ideo- 
logical goals would thus be advanced more effectively. ${ }^{112}$ These initiatives met some resistance, as composers feared the nature of their union would be altered by accepting noncomposers. ${ }^{113}$ ZKP leaders nonetheless agreed to introduce a resolution at the November 1948 Congress that would admit the musicologists, in light of the creative nature of both professions and of a need to have more people take part in the administration of the ZKP. ${ }^{114} \mathrm{~A}$ "gentleman's agreement" was struck whereby it was understood that a musicologist would never become union president, but would rather occupy one of the vice-presidential positions. ${ }^{115}$ Both President Piotr Perkowski and Executive Committee member Kazimierz Sikorski spoke on behalf of the proposal, but the anticommunist composer Stefan Kisielewski demanded a secret ballot. Several other composers criticized Kisielewski for his potentially divisive request, but the anonymous vote went forward, with seventeen in favor, and the perhaps surprising number of seven against; this not inconsiderable resistance prefigured battles to come. The musicologists, led by Lissa, consistently found themselves among the most ideologically engaged, and thus the naysayers were surely trying to keep these hardliners out of the union.

Indeed, the musicologists, and especially Zofia Lissa, formed the vanguard of the 1948-49 push for socialist realism and for more ideological engagement. In her speech at the Fifth Congress in June of 1950, she harshly criticized composers for not achieving sufficient ideological progress. In particular, she blamed the musicologists and especially herself for not making sufficiently clear the ideological demands of the new socialist age. ${ }^{116}$ Deputy Minister Sokorski also criticized musicologists for not doing more to expose the "formalist, modernist language and cosmopolitan tendencies that have burdened our musical creations for many years. ${ }^{~} 117 \mathrm{He}$ demanded that the musicologists do more to show composers the correct path. Rudziński took over the presidency of the ZKP at this congress, and an important plank of his ambitious ideological program was that musicologists should provide "great help, especially ideological."118

Lissa led the efforts in the early 1950s to advance the program of socialist realism, and fought fiercely to push composers to take her advice. As noted above, by 1954 she began to soften aspects of her hard line, but this was not nearly enough to satisfy composers like Zbigniew Turski and Piotr Perkowski, who accused her of having instituted the hegemony of musicologists over composers and of being dictatorial and dogmatic. ${ }^{119}$ Perkowski also attacked her musicological colleague Mieczysław Drobner, who had demanded that composers not be allowed to experiment with new compositional techniques, but should rather continue to compose in a socialist-realist style. ${ }^{120}$ Later in 1954 , in a position piece written for the party where she excoriated composers for their reactionary tendencies, Lissa reported a "smear campaign" against herself and claimed that composers were specifically attacking the group of Warsaw musicologists she led. ${ }^{121}$ 
Vitriol directed against the musicologists only increased at the Eighth Congress of June 1955. Kazimierz Serocki, Grupa '49 member and once committed to socialist realism, claimed to speak for many of his colleagues in saying that relations between composers and musicologists had hit a nadir. He accused all musicologists, and especially Stefan Jarociński, of dogmatism, a lack of quality writing, and unclear advice with respect to composers' work. ${ }^{122}$ Both Jarociński and Lissa attempted to defend themselves, but in a conciliatory manner, and Lissa even conceded that their arrogance in prior years must have irritated composers. ${ }^{123}$ Several composers openly supported Serocki's criticism, and even Sikorski, who stated that he had been one of the few advocates of including the musicologists in the ZKP in the first place, condemned Lissa and her colleagues for empty sloganeering and ideological demagoguery. ${ }^{124}$ Lissa's weakened position seems to have had physical effects, as she suffered inflammation of the lungs in the winter of 1956-57, and recuperated in the friendlier atmosphere of the GDR the following summer. ${ }^{125}$

Tension rose up yet again at the Ninth Congress in early 1957. Turski introduced a motion to allow for the potential separation of composers from their musicological colleagues into different unions. ${ }^{126}$ Sikorski opposed the proposal, but on the grounds that now no one felt threatened by the musicologists and thus it was unnecessary. ${ }^{127}$ Serocki echoed this opinion with the view that the days had passed when musicologists formed a court that rendered judgments against which composers could not defend themselves had passed. ${ }^{128}$ In view of the changed political circumstances and vastly increased autonomy of composers, he defended the right of musicologists to remain in the union and freely criticize its members, and the motion was not passed. Thus was the alleged hegemony of the musicologists over. After many years of attempted ideological domination by musicologists, composers felt themselves free to write largely as they wished.

\section{VDK: Crucial and Enduring Influence}

In the GDR, musicologists played a similar and even more influential role in the affairs of the Composers' Union. Already before the VDK was founded in 1951, musicologists occupied a key position in the organization of musical life in the Soviet Zone; at one of the earliest meetings of party members involved in the musical world in late 1948, Ernst Hermann Meyer gave the main speech. Indeed, no discussion took place as to the appropriateness of including musicologists in the East German union; all seemed to feel it natural to have composers and musicologists under one roof, and indeed Meyer, as both musicologist and composer, embodied the close links seen between the two professions. Meyer, Georg Knepler, Harry Goldschmidt, and Eberhard Rebling were only the most active of a group of ideologically engaged musicologists who held important positions within the VDK and took an active role in discussions on music and politics. But 
as in Poland, a significant and growing number of composers opposed the political and aesthetic dominance of the musicologists in the course of the 1950s.

Meyer, especially, saw himself and was seen as the voice of communist musicology in the GDR. His book Musik im Zeitgeschehen (Music in Current Events, 1952) laid the foundations for socialist realism in music, and he gave important lectures at each congress that sought both to formulate the concept and to encourage composers to work in this style. In his perhaps most (in)famous proclamation, at the First Congress in 1952, he claimed the role of "a guide, a lighthouse" in helping composers to find the proper path to create an art that would "develop a new, socialist, and democratic consciousness in [the] people." ${ }^{29}$ Fellow musicologists Knepler, Rebling, and Goldschmidt made lengthy contributions to the congress discussions, and each criticized many of the contemporary works performed at the related concerts. Some leading composers like Hanns Eisler and Paul Dessau reacted negatively to this criticism, but at this point most composers viewed the musicologists as a useful source of information on the new aesthetic paradigm of socialist realism. ${ }^{130}$ Union leaders supported this role for the musicologists, and encouraged them to focus their scholarly activity on contemporary music in order to ideologically influence composers. ${ }^{131}$

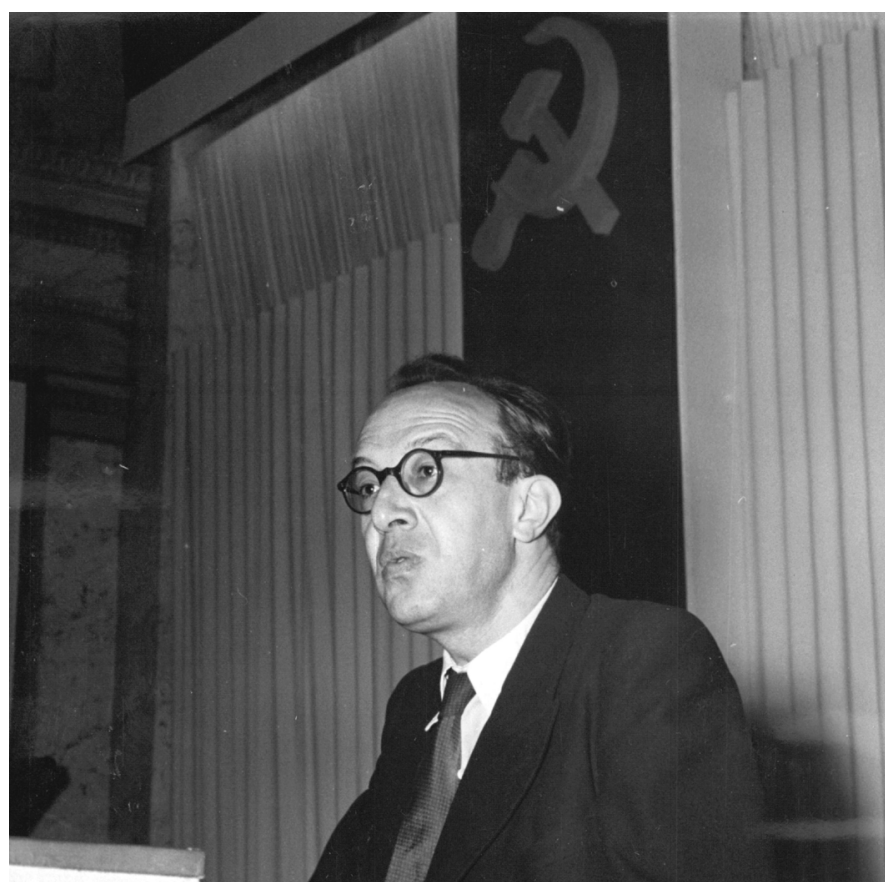

Georg Knepler giving a speech entitled "The example of the Soviet Union with respect to the critical treatment and development of cultural heritage in the realm of music" at the House of Soviet Culture in Berlin on the occasion of the Month of German-Soviet Friendship on November 3, 1951 (BArch 183-12439-0031 / photographer: Hans-Günter Quaschinsky). 
A significant number of composers increasingly opposed such a role for the musicologists, and these differing opinions came into open conflict during the 1954 Congress. Meyer, Knepler, and Goldschmidt dominated the first few days of the meeting, which reached a climax at the end of day three with a long speech about socialist realism given by Goldschmidt, followed by Meyer recapitulating his ideas in fourteen theses on socialist realism. The next day, composer Wilhelm Neef vigorously opposed this dominant role for the musicologists, as he fiercely attacked Goldschmidt's claim that the musicologists had superior knowledge, and also rejected Meyer's idea that the musicologists should guide composers. He received strong applause from a section of the congress participants. ${ }^{132}$ First, Secretary Notowicz tried to finesse the issue by claiming that both composers and musicologists should critique the development of contemporary music. ${ }^{133}$ Max Butting rejected the idea of having musicologists in the VDK at all, as he felt they had not helped composers. ${ }^{134}$ Nonetheless, in 1955 the musicologists planned to continue to develop the aesthetic postulates of socialist realism, and vowed to "support our composer colleagues in every way in creating a new realistic music." 135 Meyer and Goldschmidt continued to press their claim for a leadership role with respect to aesthetic guidance by pushing the socialist-realist line against a growing desire for experimentation, expressed especially in the statements of younger composers like Neef and Siegfried Köhler. ${ }^{136}$

The tension between some composers and these musicologists reached a high point in early 1956, and the musicologists chose to moderate their position. Composers Kurt Schwaen, Paul Dessau, and Gerhard Wohlgemuth criticized musicologists, and especially Meyer, for trying to restrict their compositional freedom. ${ }^{137}$ Meyer apologized for his past intolerance, and fellow musicologist Georg Knepler also claimed that musicologists had never been "against" composers, but had rather attempted to guide them while still allowing autonomy. ${ }^{138}$ Knepler also admitted mistakes, but defended himself by saying he had owned up to them, and that he was being critical in a way that all should have been. Though the leading musicologists planned to take a greater role at the 1957 Congress in an attempt to influence the debate in favor of a harder line, their voices remained generally muted. A tacit compromise seems to have been reached, as henceforth musicologists continued to advise, though now less dogmatically and intrusively.

Though more influential in the GDR, musicologists in both countries played crucial roles as messengers of the parties' goals with respect to the composition of new music. These musicologists saw themselves in the quasi-messianic position of bringing the vision of socialist-realist music to their composer colleagues. They represent another important and compelling stratum in the music world, straddling the worlds of party activists, creators of new culture, and shapers of the new society. Most composers were willing to engage this new ideology in the early postwar years and looked to musicologists for some measure of guidance, 
but soon grew increasingly frustrated by their strident dogmatism, and pushed for a reduction in their influence so as to have more space for compositional freedom.

\section{Audition Concerts}

Another key flashpoint in union life proved to be concerts that premiered new works. From the perspective of their members, perhaps the most important function of the Polish and East German Composers' Unions consisted of helping get new music performed. The parties, and their close allies among the union leaders, naturally also took a great interest in promoting those composers who embraced the parties' program. The professional goal of premiering new compositions at times clashed with the political aim of a party-controlled music. In general, composers simply wanted their works performed as quickly and frequently as possible, while the parties attempted to exert political influence over the production and performance of new music. The union bodies that dealt with this crucial issue provide a fascinating site for an examination of the tension between the union's role as a representative of the collective interests of its members and its function as a transmission belt for party directives. The genre sections and commissions in both countries discussed and promoted new works, and were loosely modeled on the Soviet template. There, for most of the union's existence, composers perceived them as professional bodies essential to the creative process. Some of these Soviet composers, notably Shostakovich, resented this peer review, but others were enthusiastic and most were willing to participate. ${ }^{139}$ In Poland, they became powerful and controversial sites for forging and disseminating the music of the era.

\section{ZKP: Performance Becomes Depoliticized}

In Poland, the ZKP made diverse efforts to have new works performed, most directly by organizing occasional concerts as well as attempting to influence orchestra directors. ${ }^{140}$ Beginning in late 1949 , the ministry pushed the union to coordinate other concerts to present the newer, party-approved works and discuss their socialist-realist and antiformalist merits with composers. ${ }^{141}$ In this spirit, union president Rudziński attempted in 1950 to institute a politicized system for performing and reviewing new works in conjunction with the first Festival of Polish Music, as he set up eleven sections organized by musical genre. ${ }^{142}$ Across the country, section meetings took place to help educate composers in the proper style of socialist realism through discussion of recent music open to the public. ${ }^{143}$ Rudziński saw the resulting audition concerts (przestuchania): "as a direct site for the fight for socialist realism, as an expression of our times, as an instrument for the education of the masses, [and] as a 'factory of joy,' based on a progressive, classical musical tradition." ${ }^{144} \mathrm{He}$ complained, however, that many of the leading 
composers, especially his prominent colleagues on the ZKP Executive Committee, declined to participate. Newspaper articles from the time describe mixed success at best, since many of the audition concerts lacked satisfactory discussion, allegedly due to the absence of workers and other engaged listeners. ${ }^{145}$ Starting in January 1951, only some of these audition concerts remained open to the public, while others were restricted to composers. ${ }^{146}$

After the first festival preparations and Rudziński's ignominious resignation as union president in summer 1951, and combined with the considerable lack of interest among composers, this system of audition concerts became somewhat reduced and less systematized. The union Prezydium attempted to reactivate the sections on several occasions, but to little avail; the relatively small number of roughly 40 works appeared annually in both open and closed audition concerts in 1952 and 1953. ${ }^{147}$ The ZKP organized a large number of concerts in 1954-55 in preparation for the second Festival of Polish Music, especially with respect to light and dance music. ${ }^{148}$ At this time, the new, more independent Prezydium elected in 1954 abandoned the practice of public audition concerts, but did attempt to institute a system whereby all new works would be performed and discussed in closed sessions with other composers in advance of a public performance. ${ }^{149}$ This practice was not always followed, and was rejected completely with respect to symphonic works in June 1955, as the ZKP Executive Committee claimed such "discussion auditions" benefited no one and were "nothing short of a holdover from the time when higher-ups attempted to suggest the direction in which composers should develop their works." ${ }^{150}$ Audition concerts of other kinds of music disappeared by 1956 as well, since composers generally regarded them as tainted by an earlier era of dogmatism. ${ }^{151}$

The ZKP, however, continued to organize regular concerts for the new works of its members, especially with respect to the Warsaw Autumn festival beginning in 1956. There was a crucial difference, however, in that new works immediately premiered for public consumption rather than being subjected first to potentially politicized audition concerts. After early attempts by the party and its allies in the union produced some marginal successes, by the mid-1950s political interference through the medium of audition concerts had ended, largely due to a weakened party and lack of composer participation.

\section{VDK: Hierarchical Structure Promotes Party Control}

The East German union, with its larger membership and more elaborate bureaucratic structure, developed a more complex and thorough system for performing and discussing newly composed works. At the regional level, and similar to the practice nationally in Poland, composers organized themselves into sections devoted to the various genres of music. ${ }^{152}$ Not every genre was represented in each 
region, as a sufficient number of union members simply did not exist throughout the country. ${ }^{153}$ During genre section meetings, members discussed and evaluated new works by fellow section members performed on the piano, played by a local orchestra, or heard on tape. They also talked about related works from the USSR and other people's democracies, and had ideological discussions based on materials sent by the Stakuko.

The preliminary evaluations of new works were then sent from the genre sections on to national genre commissions for consideration. These commissions comprised one member from each region, and met roughly every month to make decisions that had considerable impact on fellow composers. As with the sections, the genre commissions evaluated works by looking at scores, playing excerpts on the piano, listening to recordings, and organizing discussion concerts, sometimes with the participation of workers. ${ }^{154}$ The commissions were to influence the development of music in their particular genre by choosing works for inclusion at festivals as well as those to be recommended for publication and recording and were thus extremely important for determining the nature of the music promoted and performed in the GDR. ${ }^{155}$ The party-linked VDK Executive Committee particularly pushed this aspect of the commissions' work, as it wanted them to be leading bodies in the education of union members through the use of both positive and negative examples. ${ }^{156}$

In practice, these genre commissions became a site of constant controversy and ill feeling among the rank-and-file union members. Composers complained that they operated too slowly and that months would elapse before the relevant genre commission would approve a particular work for publication or performance. ${ }^{157}$ In a rare instance of discord between union leaders and cultural officials, Stakuko representative Uszkoreit pressed the union to do more to improve the functioning of the commissions. He was furious at the cavalier treatment of some composers he thought worthy, and even threatened to take his complaints public to show how poorly he felt the union supported some of its members. ${ }^{158}$

More contentious, however, was the general power of the genre commissions to promote or reject works. In a common criticism, the Leipzig union blasted the commissions for evaluating works in a random, overly subjective, and schematic manner and for judging the overwhelming majority of works negatively. ${ }^{159}$ It asserted that the genre commissions left composers with only two options: either to do exactly what the commissions wanted, which it claimed would lead to musical life becoming stultifyingly uniform, or simply to leave the union. These Leipzig composers advocated giving the regional genre sections more autonomy and authority with respect to the commissions and abandoning the dual system of evaluation, by both sections and commissions, which created an alleged student-teacher relationship. First Secretary Notowicz addressed these criticisms at the Second Congress in 1954 by attempting to beat back the challenge from the 
Leipzig composers. He granted that the commissions should take their work more seriously and include the relevant individual composers during discussions of their compositions but asserted that regional composers enjoyed effective representation since each genre commission had a member from every region. Furthermore, he maintained that the commissions were the most qualified bodies to undertake evaluations, since their membership consisted of specialists in that particular genre from across the country. ${ }^{160}$ Siegfried Köhler, the president of the Leipzig union, reiterated earlier claims that the sections should have more power since they had more time to evaluate individual works, while the commissions met less frequently and gave more superficial judgments. He railed against the idea that the genre commissions were somehow more qualified, and advocated a division of responsibility where the sections would evaluate works while the commissions attempted to get them performed and published. ${ }^{161}$ Despite "lively applause" after Köhler's speech, Notowicz gave little ground and simply asserted that the commissions should be strengthened. ${ }^{162}$

As seen in other areas, many composers felt the union leadership contributed to problems in this process. Max Butting thought the union's central authorities had too much power over the genre commissions, and he advocated that commission leaders should be chosen by each commission's members rather than the VDK's Executive Committee. ${ }^{163}$ A number of composers at the Third Congress in 1957 complained bitterly about how the union leadership ignored decisions made by the commissions in deciding upon a program for the second all-German music festival in 1956, a situation that had happened before. Siegfried Kurz, Wolfgang Hohensee, and Fred Lohse demanded that the genre commissions have more authority with respect to the Sekretariat, but Notowicz adroitly deflected these demands. ${ }^{164}$ And thus typically, despite the pressures of a significant number of composers, the influence of the union leadership - and hence the party-persisted.

Both the ZKP and VDK had bodies that possessed important powers to evaluate and promote the works of their members. And the Polish sections as well as East German commissions tried to propagate the party's vision of acceptably political music. In Poland, the more independent composers asserted ever more control and abolished the use of genre sections as well as the related audition concerts for political purposes. In the GDR, the party-linked Union Executive proved able to maintain its influence over the work of the genre commissions despite often furious complaints from a significant number of union members.

\section{Conclusion}

In their dual role representing composer interests and also transmitting the directives and wishes of cultural officials, the Composers' Unions constitute one of the 
main focal points of this study as sites where the overlapping aims of the ruling party met those of musical elites. Here, the new socialist culture was forged collaboratively. The diverse array of composers and musicologists who made up the unions had considerable autonomy and significant influence in deciding on most aspects of their professional lives. These composers engaged in complex negotiations with each other, their union leadership, and cultural officials in myriad areas relating to the composition and performance of new music.

Important disparities between the countries existed, however, largely due to differing relative strengths of these various shifting, overlapping interest groups. In Poland, cultural officials began trying to influence the ZKP in earnest only in 1948, after the union had been operating largely autonomously for several years. Composers initially welcomed this added attention, accompanied as it was by increased funding for composition and performances, and were also attracted to the PZPR's goal of spreading music throughout the country. Party control peaked in 1950-51 when one of its sympathizers, Witold Rudziński, was elected ZKP president, even while party members like the musicologist Zofia Lissa exerted considerable influence over union life. The initial enthusiasm for the party's program among many composers began to ebb and increasingly turn sour as control became ever more invasive and officials pushed composers to write in a more dogmatic socialist-realist manner that reduced autonomy and creativity. A growing majority of Polish composers then began actively to resist the party's goals, in part through an assertion of professional oversight and norms. The influence of both the hardline musicologists and composers with party membership receded, as did the PZPR's interventions into union affairs. By the mid-1950s, more independent-minded composers had effectively taken over the leadership of the ZKP, and succeeded in marginalizing both party sympathizers and ideological influence more generally. Save for the most basic expressions of fealty, the Composers' Union in Poland had emancipated itself from the political control of the party.

The situation in the GDR differed considerably. The VDK organized itself on the initiative of the party, thus undercutting potential independence, and its leadership strongly supported SED aims while a significant number of its members held party cards. Occasional challenges to the ruling consensus emanated from provincial centers, especially Leipzig, but were effectively staved off with only minor concessions. Most composers broadly agreed with the SED's aims in the political realm, and accepted its influence. The party, through its allies on the VDK Executive Committee, largely retained the ability to shape union policy and to regulate the membership base of the union in its favor. Cultural officials maintained significant political control and ideological influence over composers through and beyond 1957 .

In the first decade after the war, the PZPR and SED invested enormous political and monetary capital in establishing influence over the Composers' Unions. In 
the early years in Poland, and for much of the period in East Germany, composers actively cooperated in propagating the parties' vision of a new socialist society. A complicated negotiating process was always present, and composers in both countries proved able to modify and shape political directives. In Poland, composers eventually achieved nearly full autonomy, while their GDR counterparts obtained a more limited compositional freedom even as they continued to support the party more generally. In both countries, a more professionalized Composers' Union emerged, but the only the SED proved able to deploy these developments effectively to its advantage, while Polish composers used it to emancipate themselves from political influence. A specific area where this dynamic is displayed is in the area of commissioning works, explored in detail in the following chapter.

\section{Notes}

1 See Tomoff, Creative Union, 18-36.

2 Richard Taruskin, Defining Russia Musically: Historical and Hermeneutical Essays (Princeton: Princeton University Press, 1997), 513-14.

3 This ORGKOMITET was in Moscow and coordinated the 28 local chapters. Summary compiled from Boris Schwarz, Music and Musical Life in Soviet Russia, 1917-1970 (New York: Norton, 1972), 112-13, 208-209, 215, 226-28.

4 Schwarz, Music and Musical Life, 215. The presidium included: Asafiev, chairman; Khrennikov, general secretary; Shtogarenko, Koval, Zakharov, Chulaki, secretaries. The Union in the USSR had about 1500 members (224).

5 ZKP, 12/5, 36.

6 "Protokolle I. Jahreskonferenz," DMA, VDK, 14.

7 Ludwik Erhardt, ed., 50 lat Zwiazku Kompozytorów Polskich (Warsaw, 1995). There were 50 members at this time. The Association of Polish Composers was founded in the mid-1920, but had roots in the nineteenth-century Warsaw Musical Association. See http://www.wtm.org.pl/historiaw.htm.

8 ZKP, 12/9, Sprawozdanie, 2. (110 composers and 21 musicologists.)

9 A Central Committee document from early 1955 lists 16 composers and musicologists. (Józef Patkowski is listed as a party member and musicologist in a section marked ZMP; he joined the Union in 1958.) Of these, three were not Composers' Union members: Aleksandr Barchacz, Teodor Ratkowski and Arnold Rezler. The 13 in the Union were Mieczysław Drobner, Eugeniusz Dziewulski, Jerzy Gert, Zygmunt Gross, Faustyn Kulczycki, Zofia Lissa, Stefania Łobaczewska, Stanisław Nawrot, Edward Olearczyk, Stefan Poradowski, Jerzy Sokorski, Augustyn Wiśniewski, and Michał Bristiger from the "youth circle." (AAN, KC PZPR, 237/XVIII-143, 32-36.) Alfred Gradstein was also a party member but died in 1954, as was Witold Elektorowicz before expulsion from the Union in 1954. (See AAN, KC PZPR, 237/XVIII-120, 87.) Witold Rudziński also stated that Jan Maklakiewicz (died 1954) was also a party member. (Witold Rudziński, "Związek w pierwszym dziesięcioleciu po wojnie" in 50 lat ZKP [Warsaw, 1995], 59.) Włodzimierz Kotoński was mentioned as candidate member for the PZPR. (AAN, KC PZPR, 237/XVIII -48, letter from MKiS to Wydział Kultury, KC PZPR.) Andrzej Klon, in the Union only from 1947-1952, referred to himself as a party member at the Łagów conference. (RM 5, no. 14 [1949]: 19.) In the first half of the 1950s, then, roughly 15 members of the Union also held party cards. With a membership of 96 in 1950 and 123 
in 1954, this would make up twelve to 16 percent of overall Union membership - a significant number, but only about half of the roughly one-quarter of East German union members with SED cards (86 out of a membership of 339 in 1957—see below).

10 AAN, KC PZPR, 237/XVIII-139, 7. On the Writers' Union (ZLP), see Fijałkowska, Polityka, 208-10 and Jarosz, Polacy i stalinizm, chapter 4.

11 These Walne Zgromadzenia were supposed to take place every year before July 1 (see 1948 Statute in AAN, MKiS, 289: 40), but met every year and a half or so, except for a long break in the first half of the 1950s: I Congress August/September 1945, II October 1946, III October 1947, IV November 1948, (Lagów conference August 1949), V June 1950, VI December 1951, VII April 1954, VIII June 1955, VIII March 1957.

12 After a reorganization in 1952, called the Komisja Zamówień Kompozytorskich.

13 Although these Kola Terenowe were already mentioned in the 1948 Statute (AAN, MKiS, DTA, 289), they do not seem to have taken concrete form until 1953. (See ZKP, 12/7, Sprawozdanie, 31.) Warsaw had the largest grouping of composers but did not have a separate executive body separate from that of the national ZKP so as not to make more administrative work for already overburdened composers.

14 Alan Steinweis, Art, Ideology, and Economics in Nazi Germany: The Reich Chambers of Music, Theater, and the Visual Arts (Chapel Hill: The University of North Carolina Press, 1993), 11, 36, and throughout.

15 For this institutional prehistory, see Zur Weihen, Komponieren, 296-302, and Köster, Musik, 123-34.

16 Berlin on 26 May 1951 with 40 members, executive committee (Vorstand): Spies, Werzlau, Kochan, Draeger, Naumilkat; Sachsen had three regional Unions with 37 members: Dresden formed on 6 July 1951, Vorstand: Thilman, Griesbach, Wehding, Finke, Kurzbach, Weismann, Petzoldt, Masanetz; Leipzig in July, 1951, Vorstand from 1953: Köhler, Trexler, Lohse, Goetz, Malige, Dehnert; Chemnitz in July 1951, Vorstand: Kurzbach, Hübschmann, Schanze, Schabbel; Thüringen (Weimar) with 53 members on 9 July 1951, Vorstand: Cilenšek, Kath, Kirmße, Fredrich, Kraft; Sachsen-Anhalt (Halle) with 25 members on 14 July 1951, Vorstand: Reuter, Müller, Schneider, SiegmundSchultze, Wenzel, Wohlgemuth; Mecklenburg (Schwerin) on 9 September 1951 with 25 members, Vorstand: Neuhaus, Rabetge, Rücker, Schröder, Havemann, Erdmann. (Chronik des VDK, 1951-1980 [Berlin, 1981], 7-9.) For total numbers, see BArch, DR-1, 42, "Protokoll zur Vorbereitung der Zentralen Delegierten-Konferenz des VDK (1957)."

17 Ibid. See note 9, above. According to Wolfgang Hohensee, as quoted in Zur Weihen, the SED basic party organization had the most power over decision making. (Zur Weihen, Komponieren, 301.)

18 Notowicz's title was General Secretary from 1951-54.

19 SAPMO-BArch, DY-30, IV 2/9.06/281, Satzung (Entwurf) 1954. To 1954 there also existed a geschäftsführender Vorstand (Managing Executive Committee); its functions were taken over by the Sekretariat.

20 "Protokolle I. Jahreskonferenz," 1952, DMA, VDK, 69-76, 221-22.

21 SAPMO-BArch, DY-30, IV 2/9.06/281, “Abschrift VDK," Bezirksleitung Leipzig, 10 September 1954.

22 SAPMO-BArch, DY-30, IV 2/9.06/283.

23 Delegierten-Konferenz, 23-24 February 1957, DMA, VDK, 155-57, 173-80.

24 ZKP, 12/49, Protokól, 15 May 1951. The Ministry criticized them for being too difficult for the composers but praised the concept. AAN, MKiS, 719, Protokół Kolegium Muzycznego Nr. 5, 22 March 1950, 21. The second featured lectures on Marxism- 
Leninism and Marxist aesthetic theory, as well as discussions of contemporary works. Muzyka 2, no. 10 (October 1951), 58.

25 ZKP, 12/93, "Sprawozdanie z kursu ideologicznego-szkoleniowego w Łagowie."

26 ZKP, 12/22, Protokól, 25 February 1952. Lissa gave the lecture on the former, and had sent around a reading list to all Union members. See also ZKP, 12/7, Sprawozdanie, 16.

27 ZKP, 12/29, "Protokół surowy kursu ideologicznego," 16-18 December 1952; 12/116, "Sprawozdanie z koncertów i przesłuchań w okresie szkolenia ideologicznego," 16-18 December 1952; ZKP, 12/7, Sprawozdanie, 16.

28 ZKP, 12/29, "Protokół surowy kursu ideologicznego," 16-18 December 1952, 9-11.

29 "Protokolle I. Jahreskonferenz," DMA, VDK, 321, 339; BArch, DR-1, 42, “Arbeitsplan des VDK für das Jahr 1953."

30 BArch, DR-1, 42, “Arbeitsplan für die Tagung in Kienbaum in der Zeit von 2. bis 10. Oktober 1953."

31 BArch, DR-1, 42, “Arbeitsplan 1954 (Entwurf),” 11 November 1953.

32 SAPMO-BArch, DY-30, IV 2/9.06/23, SED-Hausmitteilung from Hans Lauter to Egon Rentzsch, 26 January 1951, 25.

33 Johannes R. Becher, "Reale Verknüpfung mit dem Leben," MuG 1, no. 2 (1951): 3-4.

34 "Protokolle I. Jahreskonferenz," DMA, VDK, 8.

35 SAPMO-BArch, DY-30, IV 2/9.06/282, "Stenographische Niederschrift des 2. Musikfestes 1954 und Kongresses des VDK," 13.

36 AAN, MKiS, 469, esp. 107.

37 AAN, MKiS, 728, Sprawozdanie IV/1948, 3.; 719, Protokół Kolegium Muzycznego, Nr. 7, 19 April 1950, 28.

38 AAN, MKiS, 470, "Sprawozdanie ogólne za m-c sierpień 1949r.," 103. The Ministry even evaluated Mycielski's speech for the conference before it was given.

39 AAN, MKiS, Sprawozdanie za III kwartal 1950: 116; Sprawozdanie za I kwartal 1950: 108. During the crisis in the ZKP's Executive Committee in late 1950, the Ministry intervened to help settle the issue, and sought to foster the purity of the ZKP's ideological program; 726, "Plan pracy na rok 1951," 6-7. Sprawozdanie, I Kwartal 1950, 107-108.

40 AAN, MKiS, 726, "Szkic planu pracy na r. 1949," 1. The Ministry often put pressure on the ZKP to work harder and more responsibly for the Ministry's goals. ZKP, 12/49, letters from 15 May and 15 October 1951.

41 AAN, MKiS, 2739, "Plan pracy CZTOiF na 1954 roku"; 2733, "Ramowy plan pracy na rok 1954," 7; AAN, KC PZPR, 237/XVIII-148, letter from MKiS to KC PZPR, Wydz. Kult, 23 April 1954.

42 AAN, KC PZPR, 237/XVIII, 148, 181; and AAN, KC PZPR, 237/XVIII, 120, 38.

43 AAN, KC PZPR, 237/XVIII, 143, 180, and AAN, KC PZPR, 237/XVIII, 103, 103.

44 AAN, KC PZPR, 237/XVIII, 120, Notatka, 12 March 1955, 38.

45 ZKP, 12/30, Protokół, 17 June 1953; see the remarks of Dobrowolski and Perkowski in ZKP, 12/9, 26-31.

46 SAPMO-BArch, DY-30, IV 2/9.06/23, letter from Lauter to Rentzsch, 26 January 1951, 25; SAPMO-BArch, DY-30, IV 2/9.06/11, "Beschluß-Protokoll der Abteilungssitzung," 2 March 1951.

47 BArch, DR-1, 20, Arbeitsplan III/52, 170. The greatest supporter of socialist realism in music was Ernst Hermann Meyer, and at the Congress he called upon the Stakuko to "exercise an ideological-artistic control of our work." (Protokolle I. Jahreskonferenz, DMA, VDK, 46.)

48 Zur Weihen, Komponieren, 301.

49 SAPMO-BArch, DY-30, IV 2/9.06/16, "Richtlinien für die Bildung von Grundeinheiten der Partei in den künstlerischen Verbänden," 29 January 1953, 54. 
50 SAPMO-BArch, DY-30, IV 2/9.06/281, from Zentralkomitee der SED, Abt. Kunst, Literatur und kulturelle Massenarbeit an alle Bezirksleitungen der SED, Kulturabteilung, 13 August, 1954.

51 Alexander Abusch "Im ideologischen Kampf für eine sozialistische Kultur," 23 October 1957, in Schubbe, Dokumente, 494.

5250 lat $Z K P, 39-42,50$.

53 Zofia Lissa and Józef Chomiński, eds., Kultura Muzyczna Polski Ludowej, 1944-1955 (Kraków: PWM, 1957), 53. The first head was Bolesław Woytowicz. From 1946-48, Piotr Rytel was head; the other members were: Witold Lutosławski, Roman Palester, Stanisław Wiechowicz, Kazimierz Wiłkomirski, Bolesław Woytowicz. (50 lat ZKP, 21.)

54 In 1947, the KK accepted six and rejected five (ZKP, 12/3 Sprawozdanie KK, 7); in 1948, it accepted 16 and rejected nine (ZKP, 12/56).

55 These extraordinary members had nearly the same rights as regular members, including voting rights at the local level but not during the annual general meetings. See the Union statutes in AAN, MKiS, Dept. Muzyki, 289: 36. It was not completely clear whether "extraordinary" was a stage before regular, or was to be used for members who would likely never attain full status in the Union. ZKP, 12/56, Protokól, 26 May 1949.

56 See the 1948 Statute in AAN, MKiS, 289, 44.

57 ZKP, 12/56, Protokół, 26 May 1949; ZKP, 12/56, Protokół, 18 December 1950, and 12/28, 21 December 1950. The Prezydium decided to accept PZPR member Mieczysław Drobner as a "extraordinary" rather than candidate member; the KK had rejected his candidacy on numerous occasions in the late 1940s (see 12/56). This controversy around Drobner foreshadowed the contentious debates over Olearczyk and Elektorowicz, described in the following pages. Drobner's inclusion demonstrates the strength of the PZPR's allies in 1950, and their failure with Olearczyk and Elektorowicz as yet another example of their weakness a few short years later.

58 AAN, MKiS, 719, Protokół nr. 6 Kolegium Muzycznego, 5 April 1950, 24.

59 ZKP, 12/56, Protokó1, 22 April 1950.

60 ZKP, 12/56, Protokół, 18 December 1950.

61 ZKP, 12/28, Protokół, 2 October 1950. From 27 June 1950 to 15 January 1951, the KK approved 24 applications and rejected 13. ZKP, 12/29, "Sprawozdanie za okres 27 June 1950 to 15 January $1951, " 4$.

62 ZKP, 12/54, "Protokół z posiedzenia Głównej Komsji Rewizyjnej ZKP," 6-10 December 1951.

6350 lat ZKP, 21. Kazimierz Sikorski was elected head and Lutosławski secretary; the other members were Grażyna Bacewicz, Józef Chomiński, Mieczysław Mierzejewski and Stanisław Wiechowicz.

64 Tomoff, Creative Union, 104-106.

65 ZKP, 12/7, Protokól, 53.

66 ZKP, 12/56, Protokół, 31 March 1952.

67 ZKP, 12/56, Protokół, 22 September 1952. The others to be denied re-entry were: Kasztelan, Kowalski, Kozietulski, Kwieciński and Szewczyk; Rzewulski was a candidate member and was rejected.

68 ZKP, 12/22, "Stenogram z Zebranie Rozszerzonego Plenum ZG ZKP," 11 December 1952, 56-66. She took a hardline position, maintaining that "those who are not with us, are against us."

69 Ibid., 68-73. Lutosławski stated further that Olearczyk had "exploited himself" by composing so many mass songs and had neglected his compositional skills.

70 ZKP, 12/57, letter from Szeligowski to Lutosławski, 28 January 1954. 
71 Ibid., Protokół, 1 March 1954.

72 ZKP, 12/7, Protokół, 49-53. Szeligowski and Perkowski pleaded to give Elektorowicz another chance. The new KK was made up of Lutosławski as head (a position he held through 1967), Zygmunt Mycielski as secretary, and Witold Rowicki, Stefania Łobaczewska, Stanisław Wiechowicz, and Czesław Żak.

73 ZKP, 12/57, letter from Dobrowolski and Sikorski of the ZG ZKP to KK, and ZKP, 12/9, Protokó1, 69. From 1955-57, the KK had 41 applications of which 18 were rejected. (ZKP, 12/57, Sprawozdanie, 14 June 1955 to 9 March 1957.)

74 "Die Arbeitsrichtlinien des Verbandes," in $M u G$ 1, no. 3 (1951): 88; SAdK, VDK, 614, Vorstandssitzung, 23 October 1952. The Admissions Commission included: Gerster, Cilenšek, Spies, Marx and Ochs; to evaluate musicologists Knepler, Vetter and Rebling were added. (SAdK, VDK, 473, Vorstandssitzung, 31 October 1952.) Thilman, Butting and Krug were added in 1953. (SAdK, VDK, 293, Protokoll, 3 July 1953.) In 1955, it included: Gerster, Cilenšek, Riethmüller, Spies, Marx, Krug, Ochs, Ortwein. (SAdK, VDK, 293, Protokoll 11 January 1955.)

75 SAPMO-BArch, DY-30, IV 2/9.06/281, Satzung (Entwurf), 82. In late 1952 or early 1953, the members of the Admissions Commission were asked to submit proposals for more specific guidelines, which shows that the criteria were somewhat unclear and subjective. See the "Vorschläge" in SAdK, VDK, 293.

76 SAdK, 293, 294, 4103, and 4104.

77 SAdK, VDK, 4103, two letters from VDK, Halle, 24 January 1955.

78 SAdK, VDK, 4103, Gutachten from Dräger and Schulze. The second even called the works formalist, seemingly due to their extreme "primitivism," presumably poor technique. (Ibid., 293, Protokoll, 1 July 1955.)

79 SAdK, VDK, 4104, under Haase, 1 December 1955; SAdK, VDK, 4104, 293, Protokoll, 10 December 1955.

80 SAdK, VDK, 293, letter from VDK Leipzig, 1 July 1954.

81 SAdK, VDK, 293, Abschrift, AWA, Hauptreferat Abrechnungen, Musikkontrolle, Sonderbericht, Anlage zum Kontrollbericht-Nr. 9, 10 May 1955.

82 SAdK, VDK, 602, Protokoll der Sektion Kammermusik, 24 November 1955; SAdK, VDK, 4104. The Admissions Commission had rejected him on grounds of a lack of skill. (SAdK, VDK, 293, Protokoll, 1 July 1955.)

83 See SAdK, VDK, 293, 294, 4103, 4104.

84 BArch, DR-1, 42, VDK Revisionsbericht 1953/54, 2-3.

85 SAPMO-BArch, DY-30, IV 2/9.06/281, Satzung Entwurf 1954. In this proposal, if a candidate were rejected on either level, he could call for an Appeals Committee made up of a member of the Executive Committee, the head of the relevant genre Commission, and a Union member of his choice. Instead, the Admissions Commission retained final authority.

86 SAPMO-BArch, DY-30, IV 2/9.06/283, 337-349.

87 It appears that the relevant genre Commission was also sometimes called upon in cases where the regional Union disagreed with the Admissions Commission, as in the cases of Haase and Wüstinger mentioned above.

88 SAPMO-BArch, DY-30, IV 2/9.06/281, Abschrift VDK, Bezirksleitung Leipzig, 10 September 1954, 12.

89 BArch, DR-1, 41, "Protokoll über die Zentralvorstandssitzung, Beschluss," 18 November 1954. Committee members were: Gerster, Ortwein, Vetter, Wagner-Régeny.

90 An example was Adolf von Lünen, who was expelled from the VDK because he didn't have "total mastery of technical ability." (BArch, DR-1, 200, letter from 20 April 1955.) 
One of the leaders of the Berlin regional Union, Mucha, thought this and similar expulsions were going too far. (Besprechung, 12 March 1955.)

91 A representative example was the case of Wolfram Zeuner, whom the Leipzig Union recommended for membership in 1955. Leipzig president Köhler was particularly frustrated by the Commission's terse judgment of "musical invention and form not sufficient," and struggled for years to allow this "talented young composer" into the Union. (SAdK, VDK, 4104, letter from Köhler, 12 November 1955.)

92 “Protokoll der Delegierten Konferenz 1957," DMA, VDK, 168-72.

93 Tomoff, Creative Union, 31-33.

94 SAdK, 473, Vorstandssitzung, 31 October 1952, and 478, Vorstandssitzung, 20 November 1953 .

95 SAdK, 473, Vorstandssitzung, 31 October 1952; SAPMO-BArch, DY-30, IV 2/9.06/283, 296-312.

96 SAPMO-BArch, DY-30, IV 2/9.06/281, (no title), Abschrift VDK, Bezirksleitung Leipzig, 10 September 1954.

97 This proposal was in fact passed at the 1954 Congress, 43 to 30, and confirmed during a fraught and complicated second vote, 60 to 44 . Only the repeated interventions of Pischner and Notowicz allowed performers to join as normal members on a third vote, 69 to 36. SAPMO-BArch, DY-30, IV 2/9.06/283, 296-310, 327-31.

98 BArch, DR-1, 45, letter from Butting, 30 November 1954.

99 BArch, DR-1, 47, Protokoll, November 1959.

100 BArch, DR-1, 47, "Protokoll der Zentralen Delegiertenkonferenz," 6.

101 ZKP, 12/22, "Protokół Zebrania Plenum Zarządu Głównego ZKP," 4 July 1947.

102 AAN, MKiS, 719, Protokół nr. 8, Kolegium Muzyczne, 2 May 1950. Polish Music Publishing Director Ochlewski supported such a move as it would help "in the realization of ideological guidelines." Lissa was surprisingly against it since they were not creators; Rudziński was for it.

103 ZKP, 12/28, Protokół 6 November 1950; 12/29, Protokoły 15-16 January 1951 and 19 March 1951; 12/53.

104 ZKP 12/7, Sprawozdanie, 8-9.

105 Initial discussions began in the spring of 1953. See AAN, MKiS, 2738, "Plan pracy na II kwartal 1953,” 28, and ibid., 2733, Kolegium CZOFIM na III kwartal 1953.

106 AAN, KC PZPR, XVIII-143, Protokół, 22 November 1954, 175; AAN, KC PZPR, XVIII, 103, "Informacja o pracy WK KC," November 1954: 15; AAN, KC PZPR, XVIII, 158, 1-17, esp. "SPAM: cele i środki działania," 6-7.

107 The organizational committee included Szpinalski, Kurkiewicz, Wronski, Ekier, Wiłkomirska, Bregy, Rowiński, Latoszewski, Bierdiajew, and Dubiska. (AAN, KC PZPR, XVIII, 107, "Notatka w sprawie utworzenia SPAM," 3 February 1955, 38-40)

108 Stanisław Wisłocki, Zycie jednego muzyka (Warszawa: Oficyna Wydawnicza RYTM, 2000), 89; AAN, KC PZPR, XVIII-143, Protokół, 5 March 1955.

109 AAN, KC PZPR, XVIII, 158, Notatka o SPAM, 29 July 1955, 2; Elżbieta Dziębowska, ed., Polska współczesna kultura muzyczna, 1944-1964 (Kraków: PWM, 1968), 290.

110 Schwarz, Music and Musical Life, 113; Tomoff, Creative Union, 44-45.

111 ZKP, 12/28, Protokół, 12 June 1947.

112 AAN, MKiS, DTA, 469, 13.

113 ZKP, 12/3, Protokół, 15.

114 ZKP, 12/22, Protokół, 20 September 1948.

115 Rudziński, "Związek ...," 54-55. He also notes that this custom was completely forgotten a decade later, as the position of Union president was occupied by musicologists from 1960 to 1985 . 
116 AAN, KC PZPR, XVIII-74, 7-23.

117 ZKP, 12/5, Protokół, 31.

118 ZKP, 12/28, Protokól, 27 June 1950.

119 ZKP, 12/7, Protokół, 12, 29.

120 ZKP, 12/7, Protokół, 25-27, 29.

121 AAN, KC PZPR, XVIII-120, "Sytuacja ideologiczna w środowisku kompozytorów polskich," 87.

122 ZKP, 12/8, Protokół, 25-36.

123 ZKP, 12/8, Protokół,, 81, second day, 14-22.

124 ZKP, 12/8, Protokół, 59-64.

125 SAdK, VDK, 2132, letter from Notowicz, VDK to MfK, 5 June 1957. Notowicz wanted to support her during a time of "great difficulties" in Poland.

126 ZKP, 12/9, Protokół, 22/3.

127 Ibid., 24/1.

128 Ibid., 24/3.

129 "Protokolle I. Jahreskonferenz des VDK," DMA, VDK, 35.

130 "Protokolle I. Jahreskonferenz des VDK," DMA, VDK, 413, 427. Both were also reacting to the criticism from fellow composers.

131 SAdK, 476, Vorstandssitzung, 9 April 1953; BArch, DR-1, 43, “Zum kommenden Kongress des Verbandes," 50.

132 SAPMO-BArch, DY-30, IV 2/9.06/282, 245-50.

133 SAPMO-BArch, DY-30, IV 2/9.06/283, 369.

134 BArch, DR-1, 45, letter from Butting, 30 November 1954.

135 BArch, DR-1, 38, Kommission Musikwissenschaft, Arbeitsplan 1955.

136 SAPMO-BArch, DY-30, IV 2/9.06/282 and /283.

137 Articles in Sonntag, no. 12 (29 January 1956).

138 SAdK, 83, "Sitzung des Zentralvorstandes in Hildburghausen," 17-18 March 1956, 12$15,19-21,42-46$.

139 Tomoff, Creative Union, 37-45; Taruskin, Defining Russia Musically, 514.

140 See also: Adrian Thomas, "Mobilising Our Man: Politics and Music in Poland during the Decade after the Second World War" in Composition, Performance, Reception: Studies in the Creative Process in Music, edited by Wyndham Thomas (Aldershot: Ashgate, 1998), 145-68. Thomas also discusses the way surveys were used to evaluate, in particular, mass songs.

141 AAN, MKiS, 470, "Sprawozdanie ogólne za III kwartal 1949," 91 and 726, "Plan pracy na IV kwartal 1949," 5.

142 ZKP, 12/6, Sprawozdanie, 2. Though organized in conjunction with the first Festival of Polish Music, the sections stayed in effect afterwards. The sections were for the following genres: symphonic music, opera and ballet, chamber music, vocal-stage music, pedagogic music, mass songs, brass, music for children, entertainment and light music, choral and świetlica music, and music criticism.

143 There were 27 sections across the entire country, meeting as often as weekly at this time. (AAN, MKiS, 470, "Sprawozdanie za III kwartal 1950.")

144 ZKP, 12/28, Załącznik do protokołu, 9 December 1950.

$145 \mathrm{ZKP}, 12 / 126$. The best discussions resulted from auditions at which other composers and musicologists were present.

146 ZKP, 12/49, Protokół, 15 March 1951, 9.

147 ZKP, 12/7, Sprawozdanie, 2, 4, 14-15.

148 ZKP, 12/53 and 12/8, Sprawozdanie, 5-6. Between April 1954 and June 1955, the ZKP organized 58 concerts of various kinds that performed over 130 works. 
149 ZKP, 12/8, Sprawozdanie, 5-7.

150 ZKP, 12/9, Sprawozdanie, 7.

151 Only two were reported for 1956. (See ZKP, 12/116, and also Thomas, "Mobilising," 155.)

152 BArch, DR-1, 42, “Arbeitsplan des VDK für das Jahr 1953.” The 10 section areas (same for the genre Commissions) were: Sinfonie, Bühnen- und Chorwerke; Kammermusik; Massenlied und Volksmusik; Blasmusik; Tanzmusik; Unterhaltungsmusik; Musik für Kinder, Filmmusik; Musikwissenschaft; Musikkritik. In the Constitution from 1954, they were: Sinfonische Musik, sinfonische Chor- und Bühnenwerke; Kammermusik; Massenlieder und kleine Kantaten; Volksmusik; Jugend- und Schulmusik; Unterhaltungsmusik; Tanzmusik; Blasmusik; Filmmusik; Musikwissenschaft und Kritik. Zur Weihen, Komponieren, 310. See also the useful schematic drawing on 311.

153 SAdK, 473, Protokoll, 18 December 1952. By late 1952, for example, Weimar had four, Dresden had three, and Leipzig had nine (though not all in Leipzig corresponded to the approved genres noted above, typical for the Leipzig Union's defiant nature).

154 BArch, DR-1, 42, Arbeitsplan 1954 (Entwurf), 11 November 1953.

155 BArch, DR-1, 42, “Arbeitsplan des VDK für das Jahr 1953.” See also Zur Weihen, Komponieren, 309-24.

156 SAPMO-BArch, DY-30, IV 2/9.06/281, Thesen-Entwurf 1954.

157 SAdK, VDK, 614, Vorstandssitzung, 22 October 1953.

158 Barch, DR-1, 190, letter from Uszkoreit, Stakuko to the VDK, betr. Konrad Blumenthal, 30 April 1953.

159 SAPMO-BArch, DY-30, IV 2/9.06/281, Abschrift VDK, Bezirksleitung Leipzig, 10 September 1954, 11-12.

160 SAPMO-BArch, DY-30, IV 2/9.06/283, 40-43.

161 SAPMO-BArch, DY-30, IV 2/9.06/283, 66-73.

162 SAPMO-BArch, DY-30, IV 2/9.06/283, 372.

163 BArch, DR-1, 45, letter from Max Butting, 30 November 1954.

164 Delegierten-Konferenz, 23-24 February 1957, DMA. 


\section{Chapter Three}

\section{The Struggle over Commissions}

During the stalinist era, the creative process met political aims in a drama both public and private. Cultural officials and composers contested and negotiated the crucial artistic decision to undertake a new musical work. The parties in both Poland and the GDR sought to claim this moment for political ends, both to assert control over composers and to influence the music and its messages that then percolated through society. As we have seen, composers often proved willing to create ideological works but also successfully preserved a measure of creative autonomy. The commissioning of works was thus a flashpoint for the relationship between power and creative production.

The money made available by the state for commissions was of great importance for securing composers' material existence. Under a system where the party dominated the concert hall, radio, and music publishing, composers had limited options to support their creative efforts. Although most held steady jobs at conservatories and universities or as directors and conductors of musical ensembles, state-directed funding for their compositions meant a more comfortable existence as well as the related prestige of a commission, and these factors held a considerable attraction for composers. The SED and PZPR provided generous sums for new contemporary works, but tried to commission music that fit their political aims. The majority of composers found enough common ground so that they composed the kind of music the party desired and they also deemed worthy. In both Poland and the GDR, a continual and at times fraught struggle for control of the initial funding decision through the composition process to final approval took place among fluctuating groups within and among ministry and party officials, the union leadership, and individual composers.

Commissions came from a number of different sources during this period, in a strikingly different and more basic system than the USSR's Muzfond, which supplied a vast infrastructure to support Soviet composers' material and professional needs. ${ }^{1}$ In both Poland and the GDR, the committee responsible for 
contracts and commissions was the most prominent coordinating body, and it depended upon funding from various state institutions. This committee consisted of composers and cultural officials, and was a site of contestation and negotiation, as well as the focus of both composer and party dissatisfaction. In Poland for a short period around 1950, another important source of commissions was a generous stipend system that supported compositions for the first Festival of Polish Music. A final major type of commission was that of contests, which the state used as a means to solicit the kinds of works it desired.

All these forms of commissioning reveal a fluid, contested process in both countries throughout the early Cold War years. Composers initially garnered commissions through a decentralized and somewhat random process, from a variety of state sources. A committee responsible for commissions then emerged in both countries to coordinate funding, and thereby standardized this procedure. Although state and party officials attempted to maintain influence over this committee, the Polish and East German Composers' Unions successfully asserted a claim to professional oversight over the commissioning process, which had largely borne fruit by the mid-1950s, when contracting and evaluating works rested largely in the hands of the unions. The practical outcome of these developments proved to be quite different, however. In Poland, as with respect to union affairs more generally, composer control combined with frustration over dogmatic party interference resulted in full autonomy from political influence. In the GDR, a politically loyal union leadership fused a professionalization of the commissioning process with significant political loyalty and thus helped to ensure that contracts with an ideological thrust continued to be granted and fulfilled.

\section{Cooperation, then Composer Autonomy in Poland}

Contrary to the retrospective claims of many composers, nearly all Polish composers eagerly accepted commissions to create socialist-realist works during this period. Especially around 1950, they willingly composed the kinds of music the party desired, as they took part in politicized song contests, proposed ideological works to commemorate Stalin's $70^{\text {th }}$ birthday, accepted stipends for the politically inflected first Festival of Polish Music, and more generally vied for funding of their compositional activity. Increasingly, however, they grew reluctant to follow the PZPR's drive to push through a rigid program of commissioning works that fit a narrowly defined socialist-realist paradigm. By the mid-1950s, a large majority of Polish composers wanted increased compositional freedom and the right to experiment, and succeeded in taking control over the commissioning process by asserting their professional demands and authority against a weakening party.

Especially in the late 1940s, party officials frequently employed the ingenious but unreliable method of contests as a way to solicit large numbers of de- 
sired works from composers. This strategy was particularly favored in the case of mass songs, which the party prized for their supposed ideological effects on the broader population. The ministry helped to organize a first major contest in 1948 and offered sizeable prize money, attracting over 400 entries but producing less than impressive results. ${ }^{2}$ Some contests had a more subtle message, as in the case of one in 1949 to commemorate the $150^{\text {th }}$ anniversary of Alexander Pushkin's birth and thereby promote a positive view of Russians and Russian culture. First place went to Alfred Gradstein with A Winter Evening (Wieczór zimowy) and second to Witold Lutosławski for Avalanche (Lawina). Most contests, however, had more explicitly political themes.

A particularly ideological example involved the commemoration of the December 1948 unification of the Polish Socialist Party and the Polish Workers' Party into the Polish United Workers' Party (PZPR), a key development in the formation of the stalinist political system. Leading composer Andrzej Panufnik won the first prize and the large sum of 70,000 złoty for his Song of the United Party. ${ }^{3}$ In his English-language autobiography written in the late 1980s, Panufnik tries to explain away his involvement, as he does in so many other areas of his artistic and political life during this period. In this case, he relates that musicologist and party member Zofia Lissa blackmailed him into producing the song, and that she made the unlikely threat that the Composers' Union would lose state support without his participation. He writes that he cannily plotted to compose a song to show involvement in an unavoidable situation, but with a submission of such substandard quality that he would surely not win. ${ }^{4}$

In reality, the circumstances were quite different, and show Panufnik's eagerness to involve himself - as did many composers in this and other similar situations - in this competition with highly ideological implications. Culture Ministry officials invited 20 or so composers to take part, but only 15 did so, indicating that participation was not mandatory. ${ }^{5}$ Some composers on the original list of invitees did not submit any songs, while others not on the original list, such as celebrated contemporary Grażyna Bacewicz, did take part—a somewhat surprising event, as it has long been thought that she wrote no explicitly politicized works or mass songs. Her song was not one of the nine finalists, thus indicating that a prestigious name was not a guarantee of success. ${ }^{6}$

Strikingly, Panufnik was one of only six composers to write music for each of the three texts, by well-known poets, that the competition organizers suggested. His winning song was Song of the United Party (Pieśn Zjednoczonej Partii) to a text by Leopold Lewin; the other texts were Song of Unity (Pieśn Jedności) with text by Stanisław Wygodzki, and Onward, Working People (Naprzód ludu roboczy) by Leon Pasternak. ${ }^{7}$ Panufnik's choice to compose three songs hardly represents the efforts of someone trying to lose, and is certainly not consistent with the autobiography's claim that he "composed a song 'on my knee,' literally 
in a few minutes." ${ }^{8}$ His winning entry was indeed simple but not uninteresting, and rather typical for the mass songs of the day. Furthermore, Panufnik modified some of the lyrics to accommodate better his compositional scheme, which further demonstrates that he took the project seriously. Alfred Gradstein won second place in a contest that set a template for others to come.

Unlike the occasional contests, the most reliable stream of commissions came from a number of state-affiliated sources and were subject to some influence from the Composers' Union. Already in 1945 the Ministry of Culture gave 200,000 złoty to the ZKP's short-lived precursor to commission works from composers. ${ }^{9}$ The first centralized dispensing of state money to support and promote compositional activity, however, did not get underway until late 1947, when the Council of State decided to make one million złoty available for the "dissemination and popularization of quality popular music." ${ }^{10}$ Nearly all well-known composers received money to compose one or more songs or short instrumental works. ${ }^{11}$

This initial ad hoc committee then became a more regular Commissions and Purchases Committee made up of composers, musicologists, and ministry officials, and thus represented a mix of interests that made for a deliberative body with a fair amount of autonomy. ${ }^{12}$ It gave out another 420,000 złoty over the next two years for a total of 216 new works from 62 different composers, followed by another 1.07 million złoty for another nearly 300 works before the end of the committee's first incarnation in December $1951 .{ }^{13}$ For the last phase, this works out to a monthly subsidy of at least 1200 złoty per composer, and that would of course be in addition to other state funding, royalty payments, performance fees, or money from the pedagogical or conducting jobs that most composers had. ${ }^{14}$ When the average industrial worker was earning 480 złoty per month and the engineer 810 złoty at this time, composers lived comparatively well indeed. ${ }^{15}$

Although the Commissions Committee was placed under the authority of the ZKP, the ministry maintained great influence on its activities; it was referred to as a "country within a country" to emphasize its relative autonomy with respect to the union. ${ }^{16}$ The committee reserved the right to propose the kind of works composers should produce, and its members from the ministry at times pushed for composers to write works in certain favored genres. ${ }^{17}$ During its first year of activity in 1948, most composers agreed that the committee should have considerable influence over commissioning decisions, in acknowledgment of the fact that the state provided the funds. ${ }^{18}$

Zygmunt Mycielski, who at this time served in leadership positions of the Composers' Union, provided continuity in the commissioning process throughout the entire period. ${ }^{19}$ As one of the main figures on the committee, he played a key role in granting commissions, and worked for many years to help realize the party's goal of a politically inflected contemporary music. But he also tried to 
take his fellow composers' wishes into account, and as disillusionment with the party's aims became increasingly apparent, he helped to assert greater composer autonomy over the commissioning process.

\section{The Stalin $70^{\text {th }}$ Birthday Campaign}

In the aftermath of the August 1949 Łagów conference, which had called on composers to engage creatively with socialist realism and envisioned a largescale festival to feature such works, the Commissions Committee undertook a massive campaign to fulfill the new cultural-political aims. At the curiously late dates of December 11 and 16, 1949, an expanded meeting of the committee decided to solicit musical works in honor of Stalin's $70^{\text {th }}$ birthday, coming but a very short time later on December $22 .{ }^{20}$ Union president and committee member Zygmunt Mycielski sent a letter to all union members, asking them to write large or small vocal works to texts from a book of collected verse, Strofy o Stalinie (Poems on Stalin), about to be published. ${ }^{21}$ Most composers expressed their willingness to participate, and Mycielski put out a press release that 60 composers had indeed done so-including many of the most well-known composers like Lutosławski, who wrote a letter expressing his willingness to write a piece with a text on Stalin. ${ }^{22}$

While typical of composer activity at the time, Lutosławski's personal involvement here is particularly striking given that the composer claimed non-involvement in stalinist politics, maintaining in his later years: "The very thought that many people believed me to have collaborated with the regime is bitterly painful to me . . . I've never been disposed to make a compromise." ${ }^{23}$ Such an assertion is surely untenable given Lutosławski's many political mass songs described in the first chapter. ${ }^{24}$ More compromising still is the short, three-movement work July Garland (Lipcowy wieniec), written earlier in 1949 to commemorate the fifth anniversary of the manifesto of July 22, 1944, when Moscow-backed Polish communists and their allies announced plans for a liberated Poland, and which Poles celebrated during the communist era as the national holiday. ${ }^{25}$ Consonant with these contemporary activities, Lutoskławski wrote in a handwritten letter dated December 14: "In response to the letter of December 12, 1949, I announce my participation in the ZKP's action for the celebration of Joseph Stalin's $70^{\text {th }}$ birthday through the composition of a work based on one of the texts mentioned in the letter." 26

The next Commissions Committee meeting in late March discussed Lutosławski's proposal and granted him 6000 zł for a cantata, a sum significantly above the range suggested in the December meeting. ${ }^{27}$ The fate of this proposed work is unclear, although several possibilities exist. One, of course, is that Lutoskławski simply changed his mind and chose not to write it. Such a 
decision would mesh with an anecdote Lutosławski related in his later years, in which he claims to have refused Deputy Minister Sokorski's wish that he write a political cantata - a rather incongruous refusal given the recent July Garland as well as this letter indicating his willingness. ${ }^{28}$ But perhaps he did indeed compose this cantata, and the work simply disappeared in the intervening decades; a confusing anecdote gives some credence to this hypothesis. During a series of interviews around 1990, Lutosławski related an episode from the early 1980s, when an actress alleged that he had written, some years before, a cantata about Stalin. He explained this away by referring to a series of events decades earlier linked to a supposed mass song "O broni pancernoj (sic)" (About the Armor), for which he claimed a substitute text on Stalin had been submitted. This supposed mass song is likely the third movement of the aforementioned July Garland, but it is also possible that the actress was in fact referring to a piece about Stalin that Lutosławski indeed indicated he was willing to write - though it does seem unlikely that it was in fact composed, since no concrete trace of the work has been found. ${ }^{29} \mathrm{~A}$ final possibility is that this cantata is the same as the recently discovered short cantata Glory to Warsaw! (Warszawie-stawa!). ${ }^{30}$

While officials and the ZKP leadership strongly encouraged composers to take part in the Stalin birthday campaign, such participation was by no means compulsory. ${ }^{31}$ Some composers, like Feliks Wróbel, simply claimed they were too busy, while others received funding at this time for works unrelated to the Stalin campaign, as in the case of Grażyna Bacewicz, who was granted $3900 \mathrm{zt}$ for a cycle of Polish dances. ${ }^{32}$ It would seem that most composers were willing, and many indeed eager, to support the party's drive to create a socialist-realist music in praise of Stalin.

\section{Commissioning a Socialist-Realist Festival Program}

The commissioning for the Stalin birthday campaign merged with an astonishingly complex and generous initiative to fund works related to the sprawling 1951 first Festival of Polish Music. ${ }^{33}$ This and other music festivals will be treated in the next chapter, but a discussion of the commissioning process for this important festival appears here. The Ministry of Culture spearheaded the immense 1950 campaign to commission for the Festival, and kept close control over the process. Deputy Minister Sokorski encouraged the composition of socialist-realist music among musical elites quite open to doing so. Polish composers responded by producing over 300 new works, a staggering number for a union with under a hundred members. ${ }^{34}$

Cultural officials viewed the first Festival of Polish Music as the instantiation of the aesthetic tenets laid down at the 1949 Łagów conference, where socialist realism was strongly encouraged as the preferred form of musical expression. ${ }^{35}$ 
The politically engaged union President Witołd Rudziński called the festival an opportunity "to see how far composers had pushed themselves ahead in their battle for socialist realism." 36 Officials conceptualized the festival as "the next step in the fight for a new music along a socialist-realist line," and calls for socialist-realist works were one of the constant themes during the preparation for and reaction to the festival. ${ }^{37}$ Deputy Minister Sokorski formulated the party's plan for the festival thus:

We desire to create an environment in which composers search and fight for simplicity in their works, for new emotion, and for new means of expression. This atmosphere of battle is essential, and we will not be afraid if this battle intensifies during the festival, for this is exactly what it is all about. If composers have the ambition to move forward, the festival will certainly aid them in breaking with an outdated musical language and in defeating formalist accretions ... it is about making the jump to the new standard of a socialist-realist music. ${ }^{38}$

The party saw the festival as an ideal opportunity to make progress towards the goal of encouraging composers to produce the music it wanted. Officials conceived of the festival as a pedagogical process for composers, a kind of crucible through which they would reinvent themselves as artists in the nascent socialist reality. These aggressive metaphors abounded at the time, but their striking application to the musical world demonstrates both the party's ambitions for the creation of a socialist society as well as the importance of music in its formation. The PZPR desired principally vocal works like cantatas and mass songs with ideological content linked to current issues, such as the struggle for peace, the Six-Year Plan, friendship between the People's Democracies and the Soviet Union, the showpiece industrial town of Nowa Huta, and the "new" countryside. ${ }^{39}$ Almost without exception, composers answered the party's calls for a "new standard" of music to be showcased at the festival. ${ }^{40}$

The festival commissioning process proved to be highly unusual in the nearly absolute control Sokorski exercised, as well as in its use of several-month stipends rather than lump sums for an agreed-upon work. The Deputy Minister discussed this system of stipends and vacation time for festival commissions with the union leaders in early $1950 .{ }^{41}$ Soon after, union president Zygmunt Mycielski sent out a letter to composers querying both the works they planned to compose for the festival and their potential requests for support. ${ }^{42}$ He noted that these stipends were not the only source of funding for festival works, and indeed, the Commissions Committee continued separately to contract for works, including some supposedly already covered by the ministry stipends. ${ }^{43}$ The stipends were in monthly amounts of 600,900 , or $1200 \mathrm{zl}$, and totaled the considerable sum of 206,939 zł. $^{44}$ Deputy Minister Sokorski made sole, unilateral decisions on the 
amount and length of the monthly stipends through handwritten notes on the proposals. ${ }^{45}$ In total, 48 composers - an overwhelming majority that included almost every composer of any significance - received monetary stipends for periods of two months to a year. ${ }^{46}$ Astonishingly, Sokorski turned down not a single composer nor requested an alternate proposal for any reason, political or otherwise. ${ }^{47}$ Save for a small amount of favoritism for several composers who composed highly ideological works, Sokorski's decisions were fair minded and generally linked to the prestige and competence of the composer rather than the theme of the composition-meaning that those composers who chose politicized themes did so on their own, with party encouragement but without coercion.

The situation of Stefan Kisielewski provides further evidence that composers were not forced to align themselves with the ideological program of the party. Kisielewski, a Catholic intellectual from Kraków and one of the PZPR's most outspoken opponents both within and beyond the musical world, was the only notable absence in this stipend system, but even he received a commission for a Symphonic Scherzo from the Commissions Committee at this time. Discussions had taken place about whether he should get the funding, but the committee "[took] the view that it is not necessary to stop the further development of Kisielewski's compositional production through withholding commissions." ${ }^{48}$ Although the party did punish his intransigence by shutting down his influential music journal Ruch Muzyczny at the end of 1949, his colleagues and the union leadership consistently intervened successfully on his behalf to protect his ability to compose.

In his decisions on stipend allocation, Sokorski generally gave the leastknown composers the lowest monthly amount, and the most prominent the highest, of $1200 \mathrm{zl}$ per month. The most numerous group, that consisting of either younger or lesser-known senior composers, received stipends of 600 , or usually 900 zł, per month. For example, Karol Rund Zdenko received 900 zł for several short works, Walerian Gniot 1800 zł over two months for some folk and regional songs and an overture, Jerzy Młodziejowski $1800 \mathrm{zł}$ for a cantata To Work (Do roboty) and Hey, young man! (Hejze młody), and Władysław Walentynowicz 1800 $\mathrm{zl}$ for at least four choral and orchestral works thematically linked to the Gdańsk region. ${ }^{49}$

The surprising presence in this less prestigious grouping of some prominent younger composers, especially the Grupa ' 49 advocates of socialist realism, was later mitigated by subsequent funding. In addition to his original three months at $900 \mathrm{zl}$ per month for a wind quartet and suite of nocturnes, Jan Krenz was given another $2400 \mathrm{zl}$, which likely represented two extra months at the top rate. ${ }^{50}$ He also received the exceedingly generous amount of $9000 \mathrm{zl}$ from the union's Commissions Committee at this time for his monumental cantata for two large choirs representing Warsaw and Moscow, Conversation of Two Cities (Rozmowa 
Dwóch Miast), for a grand total of $14,100 \mathrm{zł}$ for his festival efforts. ${ }^{51}$ Kazimierz Serocki received a long stipend of six months for a piano concerto, a cantata on the Warsaw region, Mazowsze, and Symphonic Images (Obrazy symfoniczne). ${ }^{52}$ Slated also to acquire a union commission for a cantata on peace, Serocki saw this cancelled due the lack of a text from the poet Władysław Broniewski. ${ }^{53}$ That unfulfilled commission may have been replaced with his cantata Warsaw Bricklayer (Murarz warszawski), which won a festival prize. ${ }^{54}$

Perhaps the best known of the Grupa ' 49 composers, Tadeusz Baird, received $10,500 \mathrm{zł}$ total for his festival works. This amount represented an additional 1800 zł on top of his original, three-month grant of $2700 \mathrm{zł}$ for a symphony in C-major, a suite of four dances from the Radom region, and a suite for string orchestra. ${ }^{55}$ As part of the Stalin birthday campaign, he had expressed his willingness to write a large choral work on the suggested texts, and he was granted a further $6000 \mathrm{zl}$ by the union's Commissions Committee for a cantata Song about Stalin (Pieśn o Stalinie) in September 1950, which almost certainly became the cantata Song of Revolution (Pieśń o Rewolucji) and premiered in the summer of $1951 .{ }^{56}$ Despite its promising content, it was heavily criticized at an audition concert in the fall; the communist musicologists Lissa and Łobaczewska considered the music too tragic and dark, and it seems to have been rarely performed thereafter. ${ }^{57}$

Fellow young composer and future world-renowned conductor Stanisław Skrowaczewski received a three-month stipend to work on a string symphony and some songs, as well as a cantata $A$ Word on Stalin (Stowo o Stalinie). ${ }^{58}$ The latter grew out of the Stalin birthday commissions as well, and was to be remunerated with $4500 \mathrm{zl}$, later raised to $6000 \mathrm{zl}$ by the Commissions Committee. ${ }^{59}$ This work almost certainly developed into the Cantata on Peace (Kantata o po$k o j u$ ), based still on the Broniewski poem about Stalin, which premiered after the festival in May 1952, and won a prestigious state prize (third level) in early 1953. The first section portrays the nineteenth-century working class movement, and the second the 1905 revolution, the events of 1917, and the battle of Stalingrad. In the third movement, a solo soprano sings in a folkloric style about the nation affected by war, but now rebuilding, and the cantata concludes with a fugue celebrating peace. ${ }^{60}$ These younger composers answered the party's call for socialist-realist music linked to the Festival and received considerable compensation for their efforts.

Their better-known elders also embraced the festival's ideological aims, and received even richer rewards. As befitting his status as leading composer, combined with his willingness to support the party's program, Andrzej Panufnik was the most generously supported composer by a wide margin — significantly ahead of his closest colleagues and ten to twenty times more than the least fortunate. For the one symphony he produced, he received a total of 13,800 $\mathrm{z}$ from the ministry, ${ }^{61}$ as well as a contract by the union's Commissions Committee for another 
9000 zł. ${ }^{62}$ In March 1950, Panufnik proposed a Symfonia Rewolucyjna - the title probably alludes to the October Revolution in Russia. The ZKP's Commissions Committee accepted the proposal and generously paid out the first two-thirds of the very large 9000 złoty payment at the end of that month, in personally advantageous violation of the usual rules where only half was released initially. ${ }^{63}$ Panufnik restated his intent to write this symphony in an April 21, 1950 letter to union president Zygmunt Mycielski on the occasion of commissioning works for the upcoming Festival of Polish Music. ${ }^{64}$ This original idea of a Symfonia Rewolucyjna, likely originating in the context of the Stalin $70^{\text {th }}$ birthday campaign in the winter of 1949-50, almost certainly became the politically timely Symphony of Peace (Symfonia pokoju) in the summer of $1950 .{ }^{65}$ Although Panufnik later presented the decision to compose this work as the product of political pressure and manipulation, his initial proposal of the even more politicized theme of revolution, as well as subsequent generous and multiple subsidies and his pre-existing, active engagement in the politicized peace movement, make it certain that he willingly composed the Symfonia pokoju. ${ }^{66}$

Cultural officials and Panufnik's colleagues considered it one of the major accomplishments of the stalinist era. Indeed, save for several highly ideological cantatas by other composers, it is perhaps the prime example of socialist-realist music in Poland, with an accessible style and politicized text by Jarosław Iwaszkiewicz, one of the contemporary writers celebrated by the party ${ }^{67}$ Communist officials constantly referenced the theme of peace, and used it to legitimate themselves in the eyes of a population with recent memories of a terrible war. Moreover, Panufnik employed a simplified, tonal, and accessible musical language, and the composer clearly felt he had made no compromises in this area, as he reused much of the music with only minor changes - largely consistent with criticism received from his Polish colleagues-for his Sinfonia Elegiaca, published several years later after he left Poland for England. ${ }^{68}$ The press of the day praised the work, which even received the stamp of approval, albeit characteristically seasoned with some criticism, from communist musicologist Zofia Lissa and other music critics of the time; in particular, many were frustrated with the lack of a convincing climax in the final movement. ${ }^{69}$ Panufnik conducted the premiere in May 1951 with the Warsaw Philharmonic, and it was also included as part of the showpiece final concert of the first Festival of Polish Music later that year. ${ }^{70}$ The other two composers on the program of this festive closing concert were Stanisław Moniuszko and Karol Szymanowski, thus symbolically elevating Panufnik to the pantheon of these Polish musical greats. Cultural officials were very pleased, if not fully_Panufnik garnered "only" the second-highest state prize for the year because of the piece's alleged gothic and religious elements - but this was not out of the ordinary, as the party always pushed for more compliance. 
A handful of other leading composers got generous stipends in the high four figures. Lutosławski received $8400 \mathrm{zł}$ for a planned "folk suite" that surely became the subtly folk-inspired, three-part Silesian Triptych (Tryptyk Slaski) for soprano and orchestra, premiered during the last stage of the festival in December 1951, and recognized with a national prize the following year. ${ }^{71} \mathrm{He}$ had also proposed that his recently composed short cantata July Garland be included in the festival, and cultural officials listed it as linked to the festival preparations. ${ }^{72}$ Party member and ideological stalwart Alfred Gradstein contributed a cantata $A$ Word on Stalin (Stowo o Stalinie) and eight mass songs, for which he received $9000 \mathrm{zł}^{73}$ Grażyna Bacewicz was granted $7200 \mathrm{zł}$ to work on cello concerto and a ballet entitled Polonez na Czorsztynie. ${ }^{74}$ Although he had been heavily criticized at the recent Lagów conference, Zbigniew Turski received a total of $7200 \mathrm{zl}$ for six months to write the ballet Warsaw Legend (Legenda warszawska) as well as a violin concerto and several mass songs. ${ }^{75}$

There are several noteworthy elements in this commissioning process. The ministry made a very large sum of money available, and the overwhelming majority of eligible union members applied for and received a part of it - and, again, not one proposal was denied. Deputy Minister Sokorski generally distributed the money based on prestige and ability, and perhaps most surprisingly, largely irrespective of the ideological nature of the work. Contrary to the previous year or two, Lutosławski's contributions stayed away from overtly ideological themes; other leading composers like Bacewicz and Mycielski also did not compose obviously political works, although the folkloric subject matter and tonal musical language chosen by all three fit comfortably within the bounds of socialist realism. Turski also chose not to write an ideological work, and despite the recent criticism of his second, Olympic Symphony, he received a large sum. One can only conclude that composers were generally free to choose both subject matter and genre, and thus Panufnik's choice of a "Revolutionary"-later "Peace" symphony, as well as the highly ideological works by the younger composers, appear all the more striking.

A considerable degree of compositional freedom did not, however, mean that complying more fully with party desires would go unrewarded. Panufnik's astronomical sums were surely due in part to his choice of subject matter, and perhaps this is indeed at least part of the reason he selected such ideological themes. Jerzy Sokorski contributed numerous political mass songs and ideological cantatas and received the handsome amount of $5100 \mathrm{zk}$; his party membership also surely did not count against him. ${ }^{76}$ The young Stanisław Prószyński (b. 1927) was given 4500 zł for a Peace Symphony, a Kantata o Stalinie, and several other shorter works. ${ }^{77}$ Perhaps the most arresting in this respect is the little-known Stanisław Popiel, who received a sum seemingly disproportionate to his ability and renown. The $5400 \mathrm{zl}$ granted him can probably best be explained by his proposal of a can- 
tata The Deed of Łagów (Czyn Łagowa, relating to the conference where socialist realism was discussed in 1949), and another cantata Day of Liberation (Dzień Wyzwolenia, probably linked to the Red Army's march into Poland in summer 1944), as well as several ideological mass songs. ${ }^{78}$ These were, however, exceptions, as grants were otherwise based on prestige and ability, and irrespective of theme. In the aftermath of the festival, however, composers increasingly pushed for more input in determining how funds were disbursed.

\section{Party Influence Continues}

The stipend gold rush during the first Festival of Polish Music proved to be a one-time event, a result of the intersection of a party at the height of its power with composers still open to its vision. The concurrent, standard funding process through the Commissions Committee also continued to produce a large number of socialist-realist works in the early 1950s. Although the committee was supposed to operate autonomously, the Prezydium of the ZKP did review, confirm, and even alter the committee's decisions and activities through 1951. Additionally, through the composers and musicologists on the committee, regular union members also exerted some influence over the commissioning process. At this point, most composers continued to be broadly willing to work for the party's goals, and composed numerous ideologically tinged works through this standard commissioning procedure. Furthermore, this period coincided with Mycielski's politically reliable tenure as union head, followed by Rudziński's highly politicized year as president, and thus the ZKP as an institution and the committee as an organ both generally respected and propagated the party's aims.

Through the Commissions Committee around 1950, cultural officials and influential figures like musicologist Zofia Lissa pushed for a greater number of accessible works intended for a mass audience, and the ministry continued to demand works that conformed to the emerging doctrine of socialist realism. ${ }^{79}$ The report given at the Fourth Union Congress in June 1950 called for the Commissions Committee to conduct, "in the spirit of the most pressing needs of the moment ... a consistent cultural policy" that would achieve the ideological aims of the party. ${ }^{80}$ In the summer of 1950, new union president Rudziński proposed a reorganization of the committee, so as to have it become a "principled instrument of the fight for the new face of Polish music." ${ }^{\prime 11}$ As president, he claimed ultimate power over the decisions made by the committee, and he took an active role in supervising its activities. ${ }^{82} \mathrm{He}$ centralized the process of commissioning works by insisting the ZKP should control all music requested by the mass organizations, and by reaffirming that the Prezydium had the ultimate right to reject or accept commissioned works upon completion. In the fall of 1950, he repeatedly proposed the formation of a committee to evaluate completed commissioned 
works, but this appears not to have materialized. In response, it seems he arrogated this power to the Prezydium, with the help of reviewers. ${ }^{83}$ His resignation in the summer of 1951 meant that the union leadership's increased control over commissioning would, from the party's perspective, fall into less politically reliable hands.

Surely not coincidentally, in early 1952 the Ministry of Culture instituted major changes in the commissioning process in order to augment its political influence. ${ }^{84}$ Over the objections of the new ZKP Prezydium, it took the committee away from the union and placed it directly under the aegis of the ministry itself. ${ }^{85}$ The ZKP, however, did still have a significant voice on the now seven-person committee, as five members came from the union, joined by a representative from the ministry and another from Polish Radio. ${ }^{86}$ Although part of a larger, country-wide move by the party to take direct control of the disbursement of state funds in the early 1950 s, this change also coincided with a time when some ZKP members seemed to be trying to transition away from the hard ideological line of the Rudziński presidency - and thus this move appeared to be an attempt by the ministry to assert more control over an increasingly oppositional union. Nevertheless, many composers still felt it justified that the ministry have control over the commissioning process. In a letter written just after the transfer of the committee to the ministry, Grażyna Bacewicz praised the commissioning process to her brother, claiming that composers could write generally as they wished, and that colleagues in the West were jealous of this privilege and support. ${ }^{87}$

A growing number, however, felt otherwise. Zbigniew Turski, as so often in similar debates, gave voice to those composers dissatisfied with this move, and he repeatedly agitated to bring the committee back to the ZKP. ${ }^{88}$ These composers complained that the committee's move to the ministry had slowed the entire process considerably, and that it had become in general less felicitous for composers. ${ }^{89}$ The union Prezydium attempted both to speed this process by doing some of the organizational work for the committee, and to influence decision making in a less politicized manner. ${ }^{90}$ This growing assertion of professional authority, despite continuing party attempts to influence the commissioning process, marked the following years.

The newly reorganized 1952 committee entertained proposals for commissions from composers and also coordinated requests from mass organizations. It had an initial budget of the considerable sum of 500,000 zl, of which slightly more than half would be used for remaining payments on prior commissions, and 135,000 zł for new commissions; in 1953 the committee had $431,000 \mathrm{zl}$ at its disposition and in 1954, 600,000, all of which provided for commissions from 75 composers. ${ }^{91}$ In 1952, the committee allocated roughly $100,000 \mathrm{zl}$ for a new "premium" system, whereby both noncommissioned and commissioned works could be given money at the discretion of the committee. 
This innovation was surely designed to encourage composers, on their own initiative, to create works the party desired.$^{92}$ A lively discussion took place at the end of 1952 on the issue of whether the money designated for premiums should be distributed evenly among all composers who successfully fulfilled commissions in the past year, but ministry official Jasieński persevered and preserved the mandated procedure, in which the greatest "achievements" of the last twelve months would be rewarded. ${ }^{93}$ The GDR instituted a similar premium system in 1955, but the ministry and union leaders there used it much more effectively to solicit socialist-realist works.

Early in 1952, the committee continued to commission works from a large number of composers, but gradually shifted its focus to ordering a smaller number of works from more well-known composers, who would produce "vital and valuable" music. ${ }^{94}$ The committee tried to limit commissions in the composerpreferred genres like symphonies and concertos to such works only from leading composers, and to instead order cantatas and other vocal works, a prioritized ranking to which it claimed the composers themselves had agreed at previous congresses. ${ }^{95}$ From its position of increased power and control over the committee, the ministry in 1952 renewed efforts to commission politicized music to its liking, as it pushed for more choral works that had an ideological character, including music that would celebrate the tenth anniversary of the founding of the PRL, and more works about Stalin. ${ }^{96}$ One early commission was Song about Bierut (Pieśn o Bierucie) by Borys Lomani, about the president of Poland, which was initially rejected because the melody was considered too cheerful and light with respect to the text and content. ${ }^{97}$ Composers less friendly to the party had more trouble receiving full compensation at this point, as in the case of Stefan Kisielewski, but his colleagues again intervened on his behalf. ${ }^{98}$ Once again, at the height of stalinism, even those hostile to the state received money from it.

\section{The Union Asserts Professional Control}

In practice, the lines of authority between the ministry and ZKP were not completely clear after the Commission Committee's reorganization in 1952, and the union in fact maintained a significant amount of control over the commissioning process, not least because nearly all of the five or six union members on the committee simultaneously held positions on the ZKP's Executive Committee. Although the actual commissioning was now officially out of its hands, the union Prezydium retained considerable sway over the evaluation of the completed commissioned works, and hence the disbursement of much of the money. The post1952 regulations mandated 25 percent of the total payment upon the signing of the contract, with the next quarter paid when the composer showed progress. The crucial final half was paid out only if the composer had the completed work 
positively evaluated. ${ }^{99}$ The ZKP leadership continued to coordinate an evaluation system developed in 1951 whereby two fellow composers anonymously reviewed submitted works, with a third used in case of conflicting opinions. ${ }^{100}$ In general, older and more experienced composers like Mycielski and Lutosławski conducted the evaluations, though the young Tadeusz Baird perhaps undertook the most. Dozens of composers took part, including even the politically suspect Stefan Kisielewski. The assessments were almost wholly devoid of ideological considerations, save for rare and passing mentions, as for example Zofia Lissa calling the young Kazimierz Serocki's Second Symphony, Symphony of Songs, an "ideological achievement." 101 Rather, composers often harshly criticized a work's technical qualities, and at times gave personal reactions. Even highly ideological works, like Henryk Swolkień's cantata Letter to Stalin (List do Stalina), were simply treated like any other work and judged (harshly, in Swolkień's case) on the compositional merits. ${ }^{102}$ Many composers criticized this procedure as too open to unfair criticism and a potential cause of rancor between composers, and pushed for a more transparent system. ${ }^{103}$ Lutosławski backed a new, more simplified system that supplied a basic form that asked reviewers whether the work fulfilled the commission and was appropriate for public or private performance, and that also gave space for a few comments. ${ }^{104}$

In a further move toward professional autonomy, cultural officials in 1954 formally permitted a "two-track" system, where both the Commissions Committee and the increasingly politically independent union Prezydium had the right to evaluate and approve payment for commissioned works. ${ }^{105}$ The ZKP thus continued to gain control over the activities of the committee and attempted to exercise yet more influence through its members there in 1955. ${ }^{106}$ The Prezydium further tried to extend its authority over both commissions and evaluations by demanding copies of all committee protocols as well as all evaluations. ${ }^{107}$ For its part, the ministry consistently attempted to assert influence over the committee through the mid-1950s, as it tried to convince composers to produce works with a political program or for a broader audience. ${ }^{108}$ Such attempts proved largely useless as the union leaders increasingly took over control of the production of new music, claiming professional authority over any politicized interference from cultural officials.

A last, very limited success for the PZPR occurred in 1953-54 during the preparations for the second Festival of Polish Music. Unlike the complicated commissioning process through stipends linked to the first festival, the second drew upon works already composed or newer pieces ordered through the Commissions Committee. As had happened three years earlier with the first festival, ministry officials tried to solicit politicized works, now linked to the tenth anniversary of People's Poland, but most of the leading composers declined to compose overtly ideological works in this moment of emerging destalinization and 
decreased party credibility. Minister Sokorski softened the line considerably in this context, talking about a need for the festival to show "a wide range of individuality and possibility." ${ }^{109}$ Composers did produce several cantatas, though on less explicitly political themes. ${ }^{110}$ Tadeusz Baird agreed to write the simple and accessible one-movement cantata Ballad of the Soldier's Cup (Ballada o żolnierskim kubku, 1954), about friendship between Polish and Soviet soldiers, for 10,800 zł, and Turski wrote a Cantata about the Vistula River (Kantata o Wiśle) to a Broniewski text for $10,800 .{ }^{111}$ Also, a final attempt to commission mass songs was linked to the decennial of People's Poland, the festival, and the Second Party Congress. A large portion of the money set aside for commissions in 1954 was devoted to soliciting mass songs in praise of the PZPR's Second Congress in the spring of that year. A number of composers responded, including Andrzej Panufnik with A New Era (Nowy czas) celebrating the accomplishments of the last ten years, as well as a handful of others such as Witold Rudziński and Edward Olearczyk with songs in praise of the party. ${ }^{112}$

All composers took part in the second festival, but most composed nonpolitical, often instrumental works of their choosing. Lutosławski was particularly encouraged to compose a cantata, but he first claimed no texts were inspiring, then said he was thinking of doing a short overture on the model of Prokofiev's Russian Overture, before finally agreeing to undertake a number of short instrumental works: two dance preludes for clarinet and piano (for $4000 \mathrm{zl}$ ) and ten pedagogical pieces for violin and piano (5000 zł), and later eight small works for nonprofessionals (2000 zł). While not the large, political works ministry officials wanted, they did fulfill official requests for easier music for amateur groups. ${ }^{113}$ Most other composers also submitted proposals for music that only marginally fulfilled the party's wishes, as for example on folk themes as with Serocki's proposal for a song suite for choir to a folk text, or Bacewicz's Fifth Violin Concerto. ${ }^{114}$ The ability of the party and ministry to attract composer support for political aims and more generally to influence the commissioning process had been significantly reduced, and would wither away in the years following. Composers, too, simply showed far less interest in following the party line, and largely ignored the weakened political offensive.

A somewhat desperate, clumsy attempt by the ministry to circumvent the Commissions Committee entirely and directly commission (PZPR member) Jerzy Sokorski's opera Marynka in late 1956 resulted in the committee's composer-members strenuously protesting and questioning the very raison d'être of the committee - an blunt assertion of professional autonomy unthinkable in its directness a few years earlier. ${ }^{15}$ Although the committee was surely defending its - and the union's - rights and prerogatives against encroachment by the state, it also certainly aimed to defend artistic standards, as the second act of the opera had received a devastating internal evaluation by Kazimierz Sikorski: "this is not 
music." 116 By this time, union control over the commissioning and evaluating process was nearly total.

A continual point of contention was the precise amount of money paid to composers for their work. At the crucial conference at Łagów in 1949, composers discussed the idea of a pension system that would provide enough income for composers to work full-time on their compositions. ${ }^{117}$ Earlier in 1949, ministry officials instituted a Committee of Stipends, Grants, and Subsidies for Literature, Music, and the Arts, and it gave out several-month stipends for leading composers, especially those willing to compose the kinds of works the party desired. ${ }^{118}$ As we have seen, this stipend model reached its apogee during 1950-51, when composers received large sums of money to compose ideologically tinged works for the first Festival of Polish Music in 1951. ${ }^{119}$ Such subsidies seem to have been reduced after this point, and when composers brought up the issue at their Sixth Congress in 1954, Minister Sokorski dismissed the notion that a large number of composers should live from state pensions. ${ }^{120}$ His ministry nonetheless continued to give out a limited number of stipends and grants in the mid-1950s, perhaps surprising at a time when cultural officials complained bitterly about the union's lack of support for their political program. ${ }^{121}$

The money received for typical commissions, therefore, provided an essential part of the income of all ZKP members. The "price list" for the different forms of composition became an issue for composers by at least early 1952. A price list did not yet exist, and most composers felt the amount paid for the various genres of musical works was too modest and poorly calculated. Starting in 1952 , the ZKP began to negotiate with and pressure the ministry to regulate these amounts, and after more than two years of unstinting and often frustrating efforts, the union finally achieved its goal. In August 1954, the composers obtained a regulated price list that insured better and more stable payments. ${ }^{122}$ This seeming success, however, provoked more controversy among composers, as the total budget for commissions remained static and thus these higher payments meant fewer commissions. The committee tried to finesse this by increasing the number of cases where the final 50 percent of the payment was not disbursed due to a work's perceived technical weakness, but this made the affected composers understandably unhappy. ${ }^{123}$

By the mid-1950s, the commissioning process had become standardized, considerably depoliticized, and clearly under the control of composers for their own professional needs. Composers sent in proposals to a Commissions Committee largely controlled by their colleagues, and most were accepted. Although the full payment was not always granted, the reasons depended on compositional competence, and the leading composers almost never encountered a rejection. Politically themed works had nearly vanished, and even light and dance music, previously pushed by the party, was removed from consideration and committee 
funding. ${ }^{124}$ Lutosławski introduced this motion, which favored serious music less subject to politicization. His actions with respect to commissioning new works are representative for the broad majority of composers over the period. Initially, he expressed interest in accepting commissions for socialist-realist music, but gradually pushed for increased composer autonomy. With his many like-minded colleagues, he succeeded in setting professional standards in the face of political interference in the creative process.

Around 1950, however, a majority of the commissioning funds were used to solicit works on Stalin or for other politicized pieces meant for the first Festival of Polish Music. Composers more open to socialist realism found it easier to get a commission, but funding was available to all. The Composers' Union first controlled the Commissions Committee, which proved politically reliable due to its staffing by ministry officials and union members generally sympathetic to the party's program. By placing it under ministry authority in 1952, cultural officials increased their influence over the committee, and hence the kinds of works commissioned. As a concession to composers at this time, it gave five of the seven seats to union members, which proved to be a Trojan horse soon after. These composers, plus an increasingly independent ZKP Prezydium that took over many administrative functions from a gradually weakening ministry, helped give the union de facto control of the commissioning process as part of a broader process of asserting professional autonomy. Throughout the period, although socialist-realist works were favored, composers were able to obtain funding for a range of compositions, and here as well a collaborative approach was evident.

\section{Continued Party Influence in East Germany}

In the GDR, highly ideological works continued to be commissioned through and beyond the postwar decade. The procedure for granting contracts to composers was also not settled there until the mid-1950s, but unlike in Poland, the SED and its allies in the East German Composers' Union (VDK) maintained significant control the entire time. In the early 1950s, however, the process exhibited considerable fluidity and jockeying for influence among cultural officials, the VDK leadership, and various groups of rank-and-file composers. Cultural officials tried to influence the awarding of contracts to promote socialist realism, and were generally helped by the loyal union leaders, while many composers pushed for more creative freedom and regional autonomy in the commissioning process. The central cultural officials usually won out, since they invested considerable political capital in encouraging desired works, and of course largely controlled the purse strings.

The granting of contracts for new music became gradually more systematized and centralized over the stalinist period, though not without producing a 
fair measure of acrimony. Before 1951, composers in the Soviet Zone and then GDR received commissions on an ad-hoc and decentralized basis from state funds and mass organizations. ${ }^{125}$ With the formation of the Composers' Union in the spring of 1951, the regional VDK bodies began to push for and influence the granting of contracts to composers in their areas. ${ }^{126}$ Then in January 1952, the Music Department of the newly formed Stakuko (State Arts Commission), true to its totalizing mandate, stepped in to try to exert full control over the commissioning process. It called a meeting of regional cultural officials, radio employees, and the union leadership to standardize and centralize the system by which composers would receive contracts. All agreed that commissions would only be given for certain genres of music deemed "necessary," including works that fulfilled one of the main aims of socialist realism: "to reflect societal events."127 Mass organizations, factory cultural directors, regional arts officials, and cultural institutions were to make recommendations on what works they desired, and then pass along such requests to the Composers' Union for assignment. Funding could come from the central government, regional governments, or other organizations and institutions. ${ }^{128}$ Somewhat less frequently than in Poland, contests served as a catalyst, as with an early 1952 competition on "Work and Culture" organized by the Free German Trade Union Federation. ${ }^{129}$ East German Radio played a significant role in the production and dissemination of new mass songs and other genres of "lighter" music, as especially younger composers like André Asriel and Günter Kochan found fruitful employment there. ${ }^{130}$ To coordinate this process, a centralized, national Contract Commission with representatives from the Stakuko, the VDK, the Kulturbund, the Academy of the Arts, and relevant mass organizations was proposed, but if formed at this point in 1952, had little effect. ${ }^{131}$

Instead, in 1952 and into 1953, the commissioning of new works proceeded in rather small-scale if highly politicized fashion, dominated by the heavy hand of the Stakuko. At times a Stakuko official negotiated directly with individual composers, while at others the Executive Committee of the union made proposals to the Stakuko. ${ }^{132}$ By the summer of 1952, these cultural officials had given out only about a dozen contracts, almost all of them to well-known, Berlin-based composers like Hanns Eisler and Max Butting, as well as three from West Berlin, presumably in an attempt to garner the sympathy and support of non-GDR composers. Most works had some sort of political association, such as Ernst Hermann Meyer's Call (Aufruf), which would "mobilize the masses and call them to fight for unification and freedom." Union president Ottmar Gerster received a 1000 DM contract for a single-movement symphonic work Departure (Aufbruch) that would mobilize listeners for the patriotic struggle for freedom and also a second proposed 4800 DM contract for a Kantate der Republik, while Johannes Paul Thilman garnered 1800 DM for a War and Peace (Krieg und Frieden) Symphony. Planned themes for works to be contracted later that year included a Cantata of 
Defense, a Symphony of Friendship, and an opera The Patriots (Die Patrioten) with music by Jean Kurt Forest and libretto by KuBa (Kurt Bartel). ${ }^{133}$ As seen in the subject matter of these compositions, as well as in the content of discussions within the Stakuko in late 1952, it is clear that cultural officials had ambitious plans to shape the nature of musical composition through the policy of commissioning works. ${ }^{134}$

Hans-Georg Uszkoreit from the Stakuko emphasized yet further the prerogatives and plans of the Music Department during discussions in the spring of 1953. He stressed that not every composition should receive a contract, but only the best composers should be awarded these "moral" honors, in the sense of receiving funding for working with the party and for its aims. ${ }^{135} \mathrm{He}$ insisted that the Stakuko would not only decide on the musical genres for which contracts would be given, but also reserved the right to determine the themes of the works. ${ }^{136}$ Uszkoreit's ambitious plans would be somewhat tempered by the events of June 1953.

\section{A Standardized and Politicized Process}

Under the influence of the New Course starting in the late spring of 1953, cultural officials granted the Composers' Union more say in the commissioning process. While many composers welcomed this seeming concession, in practical terms the effects were minimal, as the politically reliable union leaders largely exercised this input. Since at least its First Congress in the fall of 1952, the union had made it an official priority to increase its influence in this area through the proposed organization of a limited, music-focused Contract Commission, and had tried to make more connections with the mass organizations so as to get contracts from them. ${ }^{137}$ This Contract Commission, closely linked to the VDK, was finally formed in June 1953, and included union representatives from each region, Fritz Möller from the union Secretariat, and Uszkoreit from the Stakuko. ${ }^{138}$ The party-linked Executive Committee of the union in Berlin had great say as well, as it signed off on the proposals from the Contract Commission, and monitored the process in general. ${ }^{139}$ The union had thus achieved significant oversight with respect to commissioning new works by late 1953, although Uszkoreit and his colleagues exerted considerable control through representation on the commission as well as less formal influence through the sympathetic union leadership. ${ }^{140}$ The Stakuko conceded "mutual agreement on the choice of theme" later in the fall, but Uszkoreit continued to press for politicized subject matter. ${ }^{141}$

Throughout 1953, the first large-scale process of commissioning works got going under the new commissioning guidelines. The regional union organizations sent in recommendations on composers and their works. Unsurprisingly, 
the regional unions proposed too many composers, and not all received contracts due to limited funds. The selection process provoked some confusion and anger from rank-and-file regional composers who felt they deserved commissions. ${ }^{142}$ After receiving these proposals, the Contract Commission then decided upon a list of composers, works, and dates of completion for late 1953 and 1954, and 93 composers received contracts, which represented 26 "centrally contracted works" and 67 "regional contracts." "143 This number grew to 155 by the summer of 1955, with funding coming from the state Kulturfonds, as well as from the culture departments of the local governments. At this point, 65,000 Marks had been disbursed by the Stakuko/ministry and 85,650 by local governments, and an additional 93,000 had been given out by both for operas, operettas, and ballets. ${ }^{144}$

Composers received payment in thirds: the first at signing, the second when the work was delivered, and the last upon approval. ${ }^{145}$ As in Poland, this final installment became a point of contention, since it was sometimes withheld if the work was not deemed acceptable, provoking rancor among the affected composers who felt they should be paid in full for composing the best work possible. ${ }^{146}$ In the early 1950s, union officials organized the assessment of completed contracted works in an ad hoc manner. They called upon outside experts, Academy of the Arts members, or VDK members to conduct evaluations, using a form with various categories. ${ }^{147}$ The process went through further refinement in late 1953, in the spirit of the New Course, in an effort to decentralize this task and as a concession to regional composers who desired more autonomy. Henceforth, the relevant genre section of the regional union bodies assessed works commissioned in each region, after which they would undergo consideration by one of the central genre commissions. Those works centrally commissioned would be directly evaluated by the relevant central genre commission. Overall, then, the central genre commissions exercised greater influence on the evaluation process than the sections, and since the former were generally made up of composers more sympathetic to the SED's aims, they helped to preserve a large measure of centralized, party control. ${ }^{148}$ In both cases, it was the composer-members who judged their peers, but the actual functioning produced many complaints as to the nature of the assessments as well as the time it took. ${ }^{149}$

The majority of these evaluations focused on technical aspects of the composition, but judgments based on politicized and socialist-realist criteria were present to a greater extent than in Poland. The genre commission for mass songs gave Helmut Gerhard Schmidt's Stalin Will Be Our Friend for Eternity (Stalin bleibt uns Freund für Allezeit) a negative assessment due to its text. Despite the promising title, or indeed perhaps because of it - they were encountering the song well into the thaw in late 1954 - the reviewers judged the song politically unacceptable and advised: "to be completely rejected based on its ideology." 150 
The Commission for Light Music similarly refused to recommend Kurt Driesch's orchestral suite A Summer Day (Ein Sommertag), because "it does not do justice to today's reality," code for ideological errors. ${ }^{151}$ These cases were nonetheless more the exception than the rule, as nonideological, technique-based considerations dominated the evaluations, as in the case of Georg Theuer's symphonic poem on the Peasants' Revolt of 1525, judged "conventional and uninteresting" despite its politically appropriate theme, and thus not sufficiently worthy of its final payment. ${ }^{152}$ Similarly, Willi Hera's Cantata for our Thälmann Pioneers (Kantate für unsere Thälmann-Pioniere), on the communist youth organization, although approved by its regional genre section, was evaluated by Kurt Schwaen as primitive, oversimplified, and unworthy of performance. ${ }^{153}$ The overwhelming majority of evaluations noted weaknesses and qualities that could be improved upon, but approved the works, and thus composers received full payment for their commissions. Leading composers Max Butting and Ottmar Gerster urged the union leaders to stop the infrequent practice of withholding the final payment, since they felt full compensation should be granted if the composer had tried his or her best. By late 1954, the denial of the final disbursement would seem to have largely ended. ${ }^{154}$

\section{Direct Union Control and Continued Party Influence}

Many composers felt dissatisfied with what in practice was a highly centralized and top-down evaluation process, as well as with the more general decisionmaking procedure for commissions. In particular, many felt that a small number of favored composers unfairly received a greater number of contracts, and that the contracts given to rank-and-file composers were arbitrarily disbursed. ${ }^{155}$ In response to this growing displeasure, the system of granting contracts underwent further revision throughout 1954 and into 1955. With the replacement of the Stakuko by the Ministry for Culture in early 1954, the responsibility for commissioning passed fully and officially to the Composers' Union, thus continuing the decentralizing thrust of the New Course. ${ }^{156}$ Throughout 1954, regional union and district cultural officials had the ability to give out a number of commissions, although the central Contract Commission and union leaders still had to sign off on these contracts and organize the subsequent evaluation. ${ }^{157}$ The central VDK leadership, in consultation with ministry officials, curbed this nascent regional autonomy after about a year, however. In 1955, then, the central union leadership distributed the bulk of the contracts, and tightened control over the process. ${ }^{158}$ Proposals for contracts still originated on the local level, but now needed approval from the relevant genre commission, with the final confirmation in the hands of the union Secretariat. ${ }^{159}$ The Contract Commission (which had included regional union representatives) was thus deemed unnecessary after only two years in exis- 
tence. Although this looked like a move in the direction of composer autonomy, in reality yet more power accrued to the Berlin-based, party-linked union leaders.

As Ulbricht and SED cultural officials reconsolidated their power throughout 1954-55, the ministry again became more aggressive in its attempts to influence commissioned works despite ceding official control to the union. Cultural officials instituted this latter policy as a concession to composers' wishes, but as has been noted, the political loyalty of the VDK leaders to the party line made any benefits to the average composer slight, and thus the changes largely superficial. The number of contracts given directly by the ministry was set at only two or three per year, and it "based its decision primarily on the recommendations of the union." ${ }^{160}$ For all commissions, however, the ministry continued to try to influence the awarding of contracts indirectly. For example, officials called for fewer instrumental works in favor of text-based compositions understandable to workers. ${ }^{161}$

More specifically, the ministry's Music Department in early 1955 took a more active and explicit role in suggesting what kinds of works should be commissioned. In a letter to the union, Uszkoreit stated that "the decisive factor in granting a contract is the fulfillment of a cultural-political and societal need," and he suggested specific themes for each genre of music. With respect to operettas, Uszkoreit desired materials that would critique Western "Affenkultur" (ape culture) - a crude, racist description of American-inspired popular culture. He also suggested ballets with revolutionary themes from the recent past. Orchestral and chamber music should be more optimistic, with the latter more accessible to less sophisticated audiences. He additionally pushed for "lyrically patriotic and fiercely revolutionary" mass songs on political themes like discouraging the hoarding of food or not meeting economic goals. ${ }^{162}$ A year later, he upgraded the issue of influencing the granting of contracts to one of the main goals of the Music Department. ${ }^{163}$ Thus while the Composers' Union had official control of the process, the ministry continued to exert significant pressure in the following years. In a difference indicative of the post-Stalin divergences between the two countries, this East German dynamic was a nearly exact inversion of the situation in Poland, where the party had official control but the union made the real decision, usually against party interests.

East German cultural officials instituted another important change in 1955, one designed to encourage composers to write works that fulfilled these "culturalpolitical needs" desired by the party. Leaders of the regional unions and heads of the genre commissions were encouraged to suggest such politically-themed works to their fellow composers, who would then receive compensation upon completion as if it were a contract; other works composed without a contract could be given a "premium" if judged particularly successful. ${ }^{164}$ For ministry officials, this change in the commissioning process called for a reduction in the 
practice of giving a large number of contracts, and meant that they would suggest themes and genres, and then give rewards to those composers who complied with the party's program. ${ }^{165}$ The union leaders generally carried out the ministry's wishes in this respect, and the GDR's premium system was far more effective than its equivalent attempted a few years earlier in Poland.

Throughout the period under consideration, the commissioning process in the GDR resulted in remarkably similar outcomes, regardless of who was in fact the granter of the contract. While the union achieved more direct influence over the process through a Contract Commission and coordination of evaluations, this professionalization remained closely tied to the party's goal of socialist-realist music. Cultural officials maintained considerable control-in the early 1950s directly, and through the politically reliable union leaders thereafter-and proved able to direct the production of music towards socialist realism. The loyal union leadership had great and growing influence, and aided cultural officials in realizing the aim of commissioning music that supported the party's aims. Some composers pressed for greater independence from party control, but concessions in this direction were largely superficial. Well-known composers, especially those based in Berlin, had the easiest time receiving a contract. For rank-and-file composers, obtaining a commission was more difficult. An appropriately political theme, or a work in one of the preferred vocal genres like the mass song or cantata, helped increase the composer's chances, as did technical proficiency. Finally, a connection to the union leadership in Berlin, the favor of a regional union head, or the approval of the head of the relevant genre commission also increased the probability of a contract.

\section{Conclusion}

The commissioning process was an arena where political power intersected with individual creative choice, and a fair degree of compromise marked the emergence of the music of the new era. In both countries, the negotiations among cultural officials, the union leadership, and composers over the commissioning process were often intense and fraught, as the stakes over what, whether, and from whom to commission were high. The parties sought to create a new, ideological music to fill the aural space with politically appropriate sound. Both the PZPR and SED succeeded in doing so for a number of years, but only the latter proved able to sustain this success into and through the thaw years. The union leaders in both countries occupied an intermediary role, often representing the party's wishes but also responsive to their memberships. The writers of music were of course essential to this project of dominating symbols and themes in the realm of music, and Polish and East German composers - almost without exception - took part in the creation of a large and fascinating body of socialist-realist music commissioned 
by the state. Individual composers faced a complex decision linked to political conviction, opportunism, creative impulse, and a desire for financial support. And in Poland especially, they proved able to secure commissions for the music they desired to compose, even as what that meant evolved over time.

In both Poland and the GDR, the means of commissioning works followed a similar trajectory and appeared on the surface largely identical. A decentralized process gave way to heightened state control in the early 1950s. Soon after, however, the Composers' Unions in each country took over most responsibility for commissions, thus sharing a trend towards professionalization and also decision making increasingly shielded from direct political interference by cultural officials. In the GDR, however, the loyal union leadership as well as a large number of East German composers continued to support party goals, and thus assured that politicized works were commissioned through and beyond 1956. In Poland, precisely the opposite occurred: union control meant the practical end of overtly ideological musical compositions by mid-decade, as the overwhelming majority of Polish composers and their union leaders had grown disillusioned with party aims and desired more artistic autonomy. Here a growing process of professionalization meant that decisions about music would lead to emancipation from political interference. Polish composers, after several years of ideological commissions, pushed for and achieved greater creative autonomy in the commissioning process, while their East German counterparts accepted considerably less.

\section{Notes}

1 Tomoff, Creative Union, 45-57, 217-27.

2 Thomas, "Mobilising Our Man," 148.

3 The announced first prize was to be the princely sum of 150,000 złoty, but the jury divided it among the top three songs. (AAN, KC PZPR, 237/XVIII-85, 72.)

4 Panufnik, Composing Myself, 182-84. There is no evidence for such a threat. For more on Panufnik in this period, see Tompkins, "Composing for and with the Party."

5 AAN, MKiS, DTA, 728, "Sprawozdanie Wydzialu Muzyki DTA IV Kwartal 1948,” 2.

6 AAN, KC PZPR, 237/XVIII-85, 72, 74.

7 Ibid.

8 Panufnik, Composing Myself, 184.

9 Józef Chomiński and Zofia Lissa, eds., Kultura Muzyczna Polski Ludowej, 1944-1955 (Kraków: PWM, 1957), 53.

10 ZKP, 1228, Protokół, 28 October 1947.

11 ZKP, 12/28, Protokół z Zebrania Komisji: Zamówien na utwory dla upowszechnienia muzyki, 22 November 1947. Załącznik do protokołu zebrania Prezydium, 10 December 1947; ZKP, 12/54, Protokół, 26 February 1948. Over two dozen composers received commissions, including: Bacewicz, Ekier, Gradstein, Kisielewski, Krenz, Lutosławski, Maklakiewicz, Malawski, Mycielski, Palester, Panufnik, Perkowski, Rudziński, Szabelski, Szeligowski, Skrowaczewski, Turski, Wiechowicz, Wisłocki, and Woytowicz. 
12 This Komisja Zamówień i Zakupów was also termed the Komisja Zasitków Twórczych (Commission of Artistic Grants); after the reorganization of 1952, called the Komisja Zamówień Kompozytorskich (Committee of Compositional Commissions).

13 "Sprawozdanie . .." in Muzyka 1, no. 3-4 (1950): 27-28; ZKP, 12/6, Sprawozdanie ZG ZKP from 1 July 1950 to 1 December 1951. A currency reform in October 1950 exchanged prices and wages in old złoty for new at a rate of 100 to 3. For clarity's sake, I will convert all sums henceforth to the post-conversion figures.

14 Although probably at least 62 composers - the number between 1948 and 1950 - received commissions, it is highly likely that ten to twenty received only one, small commission for a mass song or short orchestral work. The $1200 \mathrm{zt} / \mathrm{month}$ figure, then, is based on 50 composers (also roughly the number who received commissions for the first Festival of Polish Music) garnering the great majority of the 1,067,000 $\mathrm{zt}$ for the period of 1 July 1950 to 1 December 1951. (It is unclear whether the Festival stipends, discussed below, are included in this figure, if not, the subsidy per composer would be considerably higher.) In fact, the top two dozen or so composers received the lion's share; the figure would be significantly higher for them. Panufnik, for example, averaged over twice that at this time.

15 Padraic Kenney, Rebuilding Poland: Workers and Communists, 1945-1950 (Ithaca: Cornell University Press, 1996), 291n10.

16 AAN, MKiS, DTA, 728, Sprawozdanie III kwartal 1948, 53; “Sprawozdanie . . ." in Muzyka 1, no. 3-4 (1950): 26.

17 ZKP, 12/54, Protokół, 24 February 1948, and Protokół, 23 June 1951.

18 ZKP, 12/28, Protokół 7-11 April 1949. Gradstein, Wilkomirski, Perkowski, Woytowicz, Sikorski, and Kassern agreed; Turski and Kisielewski wanted composers to control the committee more fully.

19 In 1950-51, the committee was made up of Mycielski, the musicologist Józef Chomiński, Jerzy Jasieński from the Ministry, and Czesław Lewicki from Polish Radio; in the late 1940s, they, as well as Stefan Jarociński, Zofia Lissa, Jerzy Lefeld, and Mieczysław Mierzejewski also were also on the committee at times, as were occasional invited guests. See protocols in 12/54 and "Sprawozdanie ...," Muzyka 1, no. 3-4 (1950): 26.

20 ZKP, 12/54, Protokóły 11 and 16 December, 1949. Initial planning for the Festival of Polish Music began here as well.

21 ZKP, 15/37, letter from ZKP, Zarząd Główny, Mycielski and Gradstein, 12 December 1949. Mycielski explained the lateness of the Union's request as due to the fact that the book was just then being published. General responses from composers in the affirmative follow this first letter, and a second letter (copy not in file) was sent by the Union leadership on January 4, 1950, with the book, and elicited more specific responses from composers as to which texts they planned to use. In a Union Prezydium meeting on December 22, it was decided to inform composers (surely in the letter) that songs would receive 600-1200 zł and cantatas 1500-4500 zł. (ZKP, 12/28, Protokól, 22 December 1949.)

22 The letters as well as Mycielski's press release are in ZKP, 15/37. Composers who expressed willingness to compose related works included Baird, Kiesewetter, Perkowski, Rudziński, Rytel, Skrowaczewski, Turski, and many other lesser-known composers.

23 Irina Nikolska, Conversations with Witold Lutostawski (1987-1992) (Stockholm: Melos, 1994), 39-41.

24 Małgorzata Sułek writes that some western scholars overemphasize Lutosławski's socialist-realist works, which she claims are small in number and marginal. In light of the eight mass songs, several choral works, and instrumental music of a folkloric character and consonant with socialist realism, I would argue that Lutosławski's compositions of 
this nature cannot be dismissed so easily, and reveal much about composers like him during this era. (Sułek, Pieśni masowe, 53-54).

25 See Adrian Thomas' fascinating discussion of this work in "File 750," 9-11.

26 ZKP, 15/37.

27 ZKP, 12/54, Protokół, 25 March 1950. The entry for Lutosławski reads: "The President (Mycielski-DT) will come to an understanding (porozumie się) regarding the commissioning of the cantata to one of the works from the book Strofy o Stalinie, with reference to [Lutosławski's] December 14, 1949 letter." A handwritten marking dated June 12,1950 that appears to be "przypomnie prezesowi" (remind the president) is perhaps meant to remind outgoing president Mycielski to discuss the work with Lutosławski at the Union's Fifth Congress from June 16-19.

28 In this interview many decades later, Lutosławski stated that Sokorski took him into a "store-room" and encouraged him to write a political cantata, to which Lutosławski remembers replying negatively, saying "work of this sort did not interest me." (Nikolska, Conversations, 41.) It is quite possible that Sokorski was encouraging Lutosławski to follow up on his stated willingness to write a work based on a text from Strofy o Stalinie.

29 Thomas, "File 750," 19.

30 See Adrian Thomas, "Mobilising Our Man," 157-59. Another possibility is that Warszawie-stawa! was the result of an autumn 1949 contest organized by the Ministry and linked to the "Month for the Reconstruction of Warsaw" (MKiS, 470, 90, 104). Maciej Gołab dates this cantata to the mid-1950s, a surprisingly late date given that almost all other composers had stopped writing such cantatas at this time. Maciej Gołab, "Wczesna twórczość kompozytorska Witolda Lutosławskiego" in Witold Lutosławski i jego wkład do kultury muzycznej XX wieku, edited by Jadwiga Paja-Stach (Kraków: Musica Iagellonica, 2005), 21-22.

31 ZKP, 12/54, Protokół, 23 March 1950. At this same March 1950 Commissions Committee meeting, other Stalin-related works were approved for funding, for example: R. Bukowski, 4-8 minute choral work, 900 zł; T. Kiesewetter, 2 songs, 2100 zł; P. Rytel, solo and choral piece, 2100 zł; J. Sokorski, 3-4 minute choral song, 750 zł; T. Szeligowski, 20-30 minute cantata, $4500 \mathrm{zl}$.

32 See Wróbel's letter in ZKP, 15/37. On Bacewicz, see ZKP, 12/54, Protokół, 25 March 1950.

33 ZKP, 12/54, Protokół, 25 March 1950. At the March Commissions Committee meeting, it was decided that works commissioned for the Stalin commemoration would be performed during the festival.

34 Zofia Lissa, Music in Poland, 1945-55 (Warsaw: Polonia, 1955), 24.

35 See chapter 1. In the early, planning stages it was referred to as the Festival of Contemporary Music, which shows the importance placed on performing new, socialist-realist music. (AAN, MKiS, DTA, 719, Protokoły, nrs. 3 and 4, February 1950.)

36 Festiwal Muzyki Polskiej: program otwarcia (May 1951).

37 AAN, MKiS, DTA, 470.

38 ZKP, 12/92, "Protokół z konferencji kompozytorskiej," 4 February 1950, 11.

39 AAN, MKiS, 467, "Plan Pracy Wydzialu Muzyki na I kwartal 1951 roku," 23; ZKP, 12/53, "Sprawozdanie z pracy Sekcji Pieśni Masowej," 31 May 1951.

40 For another examination of the Festival commissioning process, see Adrian Thomas, "File 750: Composers, Politics and the Festival of Polish Music (1951)," Polish Music Journal 5, no. 1 (Summer 2002). Thomas does an exhaustive and fascinating analysis of the one eponymous file, but this limited focus results in a loss of the larger context of the Festival's preparation, later stages, and aftermath, and in some cases minor factual mistakes. 
41 ZKP, 12/92, "Protokół z konferencji kompozytorskiej," 4 February 1950, 11.

42 AAN, MKiS, DTA, 750, letter from 27 March 1950, 52.

43 ZKP, 12/54, Protokół, 25 March 1950. The most striking example was Andrzej Panufnik, who apparently received $6000 \mathrm{zl}$ on March 30 (handwritten note on protocol), which almost certainly evolved into the Symfonia pokoju, in addition to his stipend, the most generous relative to any other composer.

44 AAN, NIK (Najwyższa Iżba Kontroli), 159, Dept 5, Wydział 2, 1110, 46-51. To minimize confusion, the figures given here are in the post-October 1950 currency reform equivalents; at the time, the numbers would have been 20,000,30,000, and 40,000 złoty, for a total of $6,897,967 \mathrm{zł}$. A number of composers also received one-time payments and a handful received leaves of absence from their workplaces. For a thorough summary, see Thomas, "File: Appendix." His totals are incorrect, however, for the total stipend money given out since they are based exclusively on one file with documents from 1950. According to a collection of documents in AAN, NIK, 159, Dept 5, Wydział 2, 1110, which are from 1951, the totals are significantly higher, and I will reference them in this section.

45 AAN, NIK, 159, Dept 5, Wydział 2, 1110, letter from Dyrektor Gabinetu Ministra, Edward Drabienko, 27 August, 1951, 27.

46 AAN, NIK, 159, Dept 5, Wydział 2, 1110, 46-51. Some composers received onetime payments and a handful received leaves of absence from work. See Thomas, "File 750-Appendix 1 and 2." His number of 46 composers misses the $1800 \mathrm{zl}$ paid to Włodzimierz Kotonski for a szkice baletowe, 3 tance goralskie, and quartetino na 4 waltornie; and $6000 \mathrm{zł}$ granted to Bolesław Woytowicz for his cantata Prorok.

47 Mycielski's letter had excluded musicologists and composers living abroad. (AAN, MKiS, DTA, 750, letter from 27 March 1950: 32.) Of the 96 Union members by June 1950, 16 were musicologists and more than a handful were abroad. ("Sprawozdanie z działalności ZG ZKP” in Muzyka 1, no. 3-4 (1950): 25.) Thus 48 composers out of an eligible 70 to 75 received grants, or roughly two-thirds. The striking point here, however, is that all the well-known composers of the day took part save for several exceptions: Bolesław Szabelski, Kazimierz Sikorski and Stanisław Wiechowicz. Each appeared in the opening Festival program (Festiwal Muzyki Polskiej: program otwarcia, 90-91), but did not receive funds from the Ministry, although they may have from the Union's Commissions Committee. Szabelski had in any case recently received a Union commission of $9000 \mathrm{zł}$ for his Third Symphony (Thomas, "File 750," 6), and Ministry official Jasieński proposed commissioning cantatas or songs from Sikorski and Wiechowicz in June, 1951. (ZKP, 12/54, Protokół, 23 June 1951.)

48 ZKP, 12/54, Protokół, 25 March 1950.

49 AAN, NIK, 159, Dept 5, Wydział 2, 1110, 17, 46-51.

50 AAN, MKiS, DTA, 750: 38; AAN, NIK, 159, Dept 5, Wydział 2, 1110, 16-17, 46-51.

51 ZKP, 12/54, Protokół, 25 March 1950.

52 AAN, MKiS, DTA, 750: 80; AAN, NIK, 159, Dept 5, Wydział 2, 1110, 16-17, 46-51.

53 ZKP, 12/54, Protokół 10 July 1950.

54 Elżbieta Dziębowska, ed., Polska współczesna kultura muzyczna, 1944-1964 (Kraków: PWM, 1968), 320.

55 AAN, MKiS, DTA, 750, letter from 4 April 1950: 29; AAN, NIK, 159, Dept 5, Wydział 2, 1110, 16-17, 46-51. He received additional funding for Pieśń o Rewolucji from another funding source within the Ministry for at least seven months at 30,000 (900 new) zł/month. (AAN, MKiS, DTA, 464, 77, 121.) 
57 ZKP, 12/116, Protokól, 12 November 1951.

58 AAN, MKiS, DTA, 750, 8; AAN, NIK, 159, Dept 5, Wydział 2, 1110, 16-17, 46-51.

59 ZKP, 12/54, Protokół, 25 March 1950.

60 Tadeusz Marek, Przewodnik koncertowy: Bibliografia twórczości muzycznej 10-lecia (wybór) (Warsaw, 1955), 117-18; Dziębowska, Polska, 321, 325. In an interview on April 25, 2012, Skrowaczewski stated that he was advised to compose this work since he was viewed suspiciously for having spent nearly two years in Paris in the late 1940s; he called its composition a survival tactic, and also said the money was welcome and that Broniewski was a good poet who provided a fine text. Skrowaczewski's recent biography does not include archival research in Poland and thus is often lacking detail and context for this period. See Frederick Edward Harris, Jr., Seeking the Infinite: The Musical Life of Stanisław Skrowaczewski (BookSurge Publishing, 2011).

61 AAN, MKiS, DTA, 750, 80; AAN, NIK, 159, Dept 5, Wydział 2, 1110, 17, 46-51. This figure represents an initial eight-month stipend at $1200 \mathrm{zl}$, plus supplementary payments of 1800 and 2400; he also appeared in both supplemental lists in the latter file.

62 ZKP, 12/54, Protokół, 25 March 1950. The first $6000 \mathrm{zl}$ of that was already paid out on March 30. The total from the Commissions Committee is likely even higher, as he was given another $2000 \mathrm{zl}$ in July 1951 because the Symfonia Pokoju was longer than expected (Ibid., Protokół, 31 July 1951), and also seems to have been additionally supported for the first half of 1951 by a different funding source within the Ministry at 900 zt/month for six months (AAN, MKiS, DTA, 464, 42, 57). During this period, Panufnik also received another contract from the Commissions Committee in the amount of 9000 zł for a "Symfonia liryczna." (ZKP, 12/54, Protokół, 19 December 1950 [handwritten on second copy], and 12/28, Protokó1, 21 December 1950.) It is unknown whether this project was realized.

63 ZKP, 12/54, Protokół, 25 March 1950.

64 AAN, MKiS, DTA, 750, letter from Panunfik, 21 April 1950, 67.

65 See Tompkins, "Composing for and with the Party"; see also Adrian Thomas' excellent reconstruction of the likely genesis of the Symfonia pokoju in Thomas, "File 750," 7-9.

66 Andrzej Panufnik, Composing Myself(London: Methuen 1987), 200-05; Thomas, "File 750," 8-9.

67 See Shore, Caviar and Ashes, esp. 302-304, 319-22.

68 For the contemporary criticisms of the symphony, and Panufnik's reworking of it, see Adrian Thomas, "In the Public Eye," 215-19.

69 Ibid.; Bolesławska, Panufnik, 150-53.

70 Dziębowska, Polska, 318; Festiwal Muzyki Polskiej: finat (Warsaw, 1951), 11.

71 AAN, NIK, 159, Dept 5, Wydział 2, 1110, 17, 46-51. He initally received a five-month stipend at $6000 \mathrm{zł}$, and was later awarded another $2400 \mathrm{zł}$. He also received $6000 \mathrm{zł}$ from the Union's Commissions Committee for the Tryptych Ślaski in November 1951. ZKP, 12/54, Protokół, 15 November 1951.

72 AAN, MKiS, DTA, 750, letter from Lutosławski, 8 April 1950, 56; AAN, NIK, 159, Dept 5, Wydział 2, 1110, 46-51. This stipend was in addition to the likely presumed $6000 \mathrm{zl}$ contract from the Union's Commissions Committee for a cantata linked to the Stalin $70^{\text {th }}$ birthday commemorations, mentioned above. ZKP, 12/54, Protokół, 25 March 1950.

73 AAN, MKiS, DTA, 750, letter from 29 March 1950, 36; AAN, NIK, 159, Dept 5, Wydział 2, 1110, 46-51. He initially received six months at $1200 \mathrm{zl}$, and was later given another $1800 \mathrm{zl}$.

74 AAN, MKiS, DTA, 750, letter from 30 March 1950, 32; AAN, NIK, 159, Dept 5, Wydział $2,1110,16-17,46-51$. The cello concerto was premiered at the time of the Festival: Thomas 
gives September 21 (Thomas, "File 750," 3) while the "Diariusz" in Dziębowska lists it during the final phase of the Festival in December 1951 (Dziębowska, Polska, 319); the ballet likely developed into Z chłopa król (1954) (Dziębowska, Polska, 329).

75 AAN, MKiS, DTA, 750, letter from 2 April 1950, 22; AAN, NIK, 159, Dept 5, Wydział $2,1110,16-17,46-51$. Althought the ballet was listed in his short biography in the festival program (Festiwal Muzyki Polskiej: program otwarcia [1951], 94); he was still working on it in the mid-1950s (Mieczysław Drobner, "Oper i balet" in Kultura Muzyczna Polski Ludowej, 1944-1955 [Kraków: PWM, 1957], 181), but it was apparently never staged (Lissa in Dziębowska, Polska, 49). The second file also listed his violin concerto as composed for the Festival, but it was not premiered until September 1952 (Dziębowska, Polska, 323).

76 AAN, MKiS, DTA, 750, letter from 11 April 1950, 54; AAN, NIK, 159, Dept 5, Wydział $2,1110,16-17,46-51$. He received the highest rate of $1200 \mathrm{zt} /$ month for three months, plus another $1500 \mathrm{zł}$ for a cantata Bzy i róże (Lilacs and Roses) to a text by Louis Aragon and vocal works on Stalin, peace and other political subjects.

77 AAN, MKiS, DTA, 750, letter from 10 April 1950, 61-62; AAN, NIK, 159, Dept 5, Wydział 2, 1110, 16-17, 46-51.

78 See the reference to this phrase as "the idea brought forth at the Lagów conference" in "Sprawozdanie ...," Muzyka 1, no. 3-4 (1950): 34; AAN, MKiS, DTA, 750, letter from 12 April 1950, 87-88; AAN, NIK, 159, Dept 5, Wydział 2, 1110, 16-17, 46-51.

79 ZKP, 12/28, Protokół, 7-11 April 1949; AAN, MKiS, DTA, 469, "Sprawozdanie za IV kwartal 1949," 70.

80 ZKP 12/5, Protokół.

81 ZKP, 12/28, Protokół, 27 June 1950.

82 ZKP, $12 / 28$.

83 ZKP, 12/29, Protokoły, 26 February 1951 and 5 March 1951.

84 Ministry official Jasienski had hinted at this in the previous summer, as he asserted that the Ministry wanted to exert more control over the Committee's activities by commissioning more songs and cantatas, as well as chamber music and piano works. (See ZKP, 12/54, Protokól, 23 June 1951.) A Union "Review Committee" also criticized the commissioning process in late 1951 for not holding composers to their completion dates and for not evaluating completed works sufficiently. (ZKP, 12/54, letter linked to "Protokół z posiedzenia Głównej Komisji Rewizyjnej ZKP," 6-10 December 1951.)

85 ZKP, 12/139, letters from Szeligowski and Żuławski to Sokorski and Cyrankiewicz, 22 January 1952.

86 The Prezydium nominated seven people: Baird, Ekier, Lissa, Lutosławski, Mierzejewski, Mycielski (committee head) and Żuławski; the final five were selected by the Ministry and excluded Baird and Ekier. ZKP, 12/29, Protokó1, 7 January 1952 and ZKP, 12/54, "Protokół Nr. 1 z I-ego posziedzenia Komisji Zamówień Kompozytorskich przy MKiS," 2 February 1952. As of December 1954, the ZKP had six members on the Committee: Mycielski as head, Bacewicz, Baird, Kotoński, Lutosławski, and Mierzejewski. (ZKP, 12/8, Sprawozdanie, 8.)

87 Gąsiorowska, Bacewicz, 185.

88 ZKP, 12/29, Protokół, 21 January 1952, and 12/22, Protokół, 10 March 1952.

89 ZKP, 12/22, Protokół, 10 March 1952.

90 ZKP, 12/8, Sprawozdanie, 10.

91 ZKP, 12/7, 46-48.

92 ZKP, 12/54, "Protokół Nr. 1 z I-ego posziedzenia Komisji Zamówień Kompozytorskich przy MKiS," 2 February 1952 and Protokół Nr. 2, 5 February 1952. An earlier version of this was likely the "zasiłki kompozytorskie" (compositional benefits or support) 
mentioned in ZKP, 12/6, Sprawozdanie from 1 July 1950 to 1 December 1951: 4, where over a million złoty (over 35 million pre-currency reform) was disbursed.

93 ZKP, 12/54, Protokół nr. 10, 27 November 1952.

94 ZKP, 12/7, Protokól, 48. The number of commissioned works accepted for evaluation slipped from high levels around 1950 to 107 for the period April 1954 to June 1955 (ZKP, 12/8, Sprawozdanie, 9) and only 81 in the period from June 1955 to March 1957. (ZKP, 12/9, Sprawozdanie, 7.)

95 ZKP, 12/7, Protokół, 47.

96 AAN, MKiS, CZTOiF, 2732, Protokół, 22 December 1952, 7; ZKP, 12/54, Protokoły, 19 February 1953 and 16 April 1953.

97 ZKP, 12/54, Protokół nr. 4, 27 March 1952 and Protokół nr. 5, 3 May 1952.

98 ZKP, 12/54, Protokóły, 17 May, 10 July, 16 September 1952. His Fantazja na fortepian had received two positive reviews, and thus payment of the remaining 50 percent was approved in May. In July, ministry official Jasieński said the ministry had overruled this decision because the work "aroused very serious reservations." In September, committee member Lutosławski (absent in July) argued against the decision to deny payment of the remaining 50 percent, and maintained that Kisielewski's compositions should not be conflated with his journalistic work, which the party found problematic. Jasieński claimed it was not a political decision and agreed to send out the work for reviews by leading pianists and then reconsider; the thread is then lost. (The reviews by Lutosławski and Ekier are in ZKP, 12/117, numbers 86 and 87.)

99 ZKP, 12/54, Protokół nr. 3, 28 February 1952, and 12/7, Protokół, 48. This procedure was slightly different from its pre-1952 antecedent, where in effect half of the sum was disbursed at the time of signing. (ZKP, 12/28, Protokó1, 10 December 1947.) It was modified again in late 1954, when $1 / 3$ was paid upon signing and the rest upon acceptance. In the case of a negative evaluation, 1/6 was then paid to the composer to make payment at 50 percent of the contracted amount. (ZKP, 12/54, Protokół, 16 November 1954.)

100 See ZKP, 12/117-120. This practice was started in early 1951; before then, commissioned works had their final payment given without any sort of control or evaluation, which led to at least one abuse of the system when Andrzej Klon submitted a slightly reworked, previously written song instead of a commissioned choral work. (AAN, KC PZPR, XVIII-74, 13; ZKP, 12/5, 46); opinions about a small number of works were coordinated by the Music Department of the Ministry. (AAN, MKiS, 470, "Sprawozdanie za styczeń i luty 1949," 93.)

101 ZKP, 12/118, nr. 281.

102 ZKP, 12/117, nr. 126, by Tadeusz Baird. He called it "primitive" and "without musical ambition" but said it fulfilled the commission and could perhaps even be performed.

103 See the negative comments by Wilkomirski and Kazuro (ZKP, 12/8, 33-37, 84) and Rytel (ZKP, 12/9, 18-20). The latter seemed to be apologizing for his extremely negative review of a Bacewicz work six years earlier. (ZKP, 12/117, number 1.)

104 ZKP, 12/54, Protokól, 26 November 1955. By early 1957, many of the reviewers had agreed to have their names revealed on the evaluation. (ZKP, 12/9, Sprawozdanie, 7a.)

105 (The term “dwutworowośćc" is Baird's.) ZKP, 12/54, Protokoły, 12 April 1954 and 1 February 1955. At the first meeting, it was agreed to, and the second decided to add it officially to the committee's regulations; Baird and Lutosławski particularly pushed for this. By 1955, only works that received two negative or otherwise problematic reviews were sent to the committee for a final decision. For positively reviewed works, the Prezydium had the authority to disburse the final payment. In the period from April, 1954 to June 1955, the Prezydium approved 36 works, recommended rejecting 12, and directed 12 to the committee for a final decision. (ZKP, 12/8, Sprawozdanie, 8.) 
106 ZKP, 12/22, "Plan pracy ZKP na 1955," 13 December 1954. More composers, as well as some performers, were added to the committee in early 1955 , for a total of about a dozen members. (ZKP, 12/54.)

107 ZKP, 12/31, Protokół, 25 April 1956.

108 AAN, MKiS, CZIM, 3255, "Protokół Nr. 6/55 z posiedzenia Kolegium CZIM," 29 November $1955,15$.

109 ZKP, 12/22, "Protokol surowy obrad rozszerzonego Plenum Zarzadu Glownego ZKP," 16-17 December 1953, 21.

110 ZKP, 12/54. See the 1953 protocols, especially nr. 2, 19 February 1953.

111 ZKP, 12/54, Protokoły nr. 6 and 5.

112 ZKP, 12/54, Protokoły 3 December 1953, and 21 and 28 January 1954. This action was proposed by Zofia Lissa, who was fiercely attacked for it by Turski at the Fifth Congress. (ZKP, 12/7, 14.)

113 ZKP, 12/54, Protokoły nrs. 2, 3, 9, and Protokół, 12 April 1954.

114 ZKP, 12/54, Protokoł nr. 5.

115 ZKP, 12/54, Protokoły, 18 September 1956 and 6 November 1956.

116 ZKP, 12/119, nr. 394.

117 “Konferencja Kompozytorów w Łagowie Lubuskim: Protokół," Ruch Muzyczny 5, no. 14 (October 1949), especially Maklakiewicz, 28.

118 Komisja Stypendiów, Zasitków i Subwencji literackich, muzycznych i plastycznych, later probably succeeded by the Commission for the Support of Artistic Production (Komisja Popierania Twórczości Artystycznej). See the former's protocols and that of its subcommittee in AAN, MKiS, DTA, 464, 721, 722. Lutosławski was the musical representative on the main committee, and he, Bacewicz, and Gradstein were the main musical representatives on the subcommittee. Money was often given for composers and musicians who were ill, and to help people continue or deepen their musical study. The greatest beneficiaries among composers around 1950 seemed to be Panufnik, Baird, and Mycielski, who got lengthy stipends at $900 \mathrm{zl}$ per month. The Ministry explicitly wanted these grants to be used for the creation of "new" works that passed political muster. (AAN, MKiS, DTA, 467, "Plan pracy na I kwartal 1951," 29.)

119 Another, smaller spike occurred near the end of 1950 for compositions related to the "Month of Polish-Russian Friendship." (AAN, MKiS, DTA, 721, 14.)

120 ZKP, 12/7, Protokół, 33, 65. The money for commissions and royalties, as well as pedagogical or conducting work, made up the bulk of composers' incomes. Other kinds of support, such as housing, money for travel, or creative resorts for composing, were only available for the very few, such as Panufnik.

121 From April 1954 to June 1955, the Commission for the Support of Artistic Production (Komisja Popierania Twórczości Artystycznej) gave ten stipends to regular Union members and six to "Youth Circle" members (ZKP, 12/8, Sprawozdanie, 22); in 1956, 36 composers received these stipends. (ZKP, 12/9, Sprawozdanie, 15.)

122 ZKP, 12/7, Sprawozdanie, 17-18; ZKP, 12/8, Sprawozdanie, 18.

123 ZKP, 12/8, Protokół, 44. To choose a typical example, Anna Maria Klechniowska received two negative evaluations of her cantata based on the "Ode to Youth" by Mickiewicz, and thus the final payment was not disbursed. (ZKP, 12/54, Protokól, 27 November 1954.)

124 ZKP, 12/54, Protokół nr. 5, 26 June 1955.

125 The Kulturfonds were set up in 1949, in part to grant contracts to "progressive artists," and headed by a 32-member Kuratorium, including musical figures Max Butting and Hermann Abendroth, but it would seem that only a small number of works were commissioned. (See Reimer, "Organe der Macht," 829 and Zur Weihen, Komponieren, 
255-56.) Other important sources of financial support were the Anstalt zu Wahrung der Aufführungsrechte, which distributed funding based on the frequency of a work's performance as well as its political importance, and the radio, for which especially younger composers wrote mass songs and other types of "light" music. (Zur Weihen, Komponieren, 256-65, 273-75.)

126 SAdK, 479, Vorstandssitzung 28 September 1951. The regional administrations made funds available for commissions, as in Thuringia and Saxony. In the latter, 50 modest contracts were awarded to 40 composers. ("Protokolle I. Jahreskonferenz," DMA, VDK, 321, 338). Composers in areas without a regional union body, like Potsdam, did not seem to receive any contracts. (BArch, DR-1, 55, letter from Mueller, Ref. Musik in Potsdam to the Stakuko, 10 December 1951.)

127 BArch, DR-1, 55, Stakuko, Musik, Hartig, 28 January 1952. Composers frequently wrote works without a commission; Zur Weihen estimates that less than half of new works were given one. (Zur Weihen, Komponieren, 437.)

128 It was also proposed that already composed works could be given a "premium." This was done regularly starting in 1955 (see below).

$129 M u G 1$ (1952): 31.

130 Zur Weihen, Komponieren, 273-75.

131 This may also have been an embryonic proposal for a Zentrale Auftrags- und Prämienkommission, apparently formed in the summer of 1953. See Reimer, "Organe der Macht," 830-32. It is unclear if or how this commission worked with musical compositions, though plans were made for composers to present proposals along with a recommendation of the VDK (BArch, DR-1, 5858, Entwurf, "Richtlinien für die Arbeitsweise der Staatlichen Auftrags- und Prämienkommission," 169-72).

132 BArch, DR-1, 55, Ref. Musik, Aktenvermerk, 8 April 1952, and Aktenvermerk, 10 April 1952.

133 BArch, DR-1, 50, "Forschungsaufträge," 13 August 1952 and BArch, DR-1, 55, "Betreff: Meldung über Auftragserteilung an Komponisten," 11 August, 1952. Many of these works were not realized or did so in a different form or with a different title.

134 BArch, DR-1, 6191, Niederschrift zur Arbeitsbesprechung, 23 October 1952.

135 SAdK, VDK, 295, "Ergänzungen zum Protokoll vom 26.3.53," 20 April 1953.

136 Ibid. The proposed genres (and number of contracts to be given) included sums as well: 1 Cantata, 1 Oratorio, 2 operas, 1 symphonic poem, 1 concerto, 1 symphony, 1 operetta, one ballet, 10 marches, 10 works for horns, 20 dance music works, 10 light music works, 10 songs, 1 cantata for children.

137 "Protokolle I. Jahreskonferenz," DMA, VDK, 204.

138 SAdK, VDK, 295, "Protokoll über die 1. Sitzung der Auftragskommission," 10 June 1953.

139 SAdK, VDK, 614, Protokoll, 25 June 1953.

140 SAdK, VDK, 303, “Auftragserteilung im Jahre 1954," Uszkoreit, 23 March 1954. This document states that centrally distributed contracts were given by the union. Contracts given on the regional level came under the purview of the local union bodies working with the culture departments of the local governments. For the latter, however, a contemporaneous document did not mention the regional officials, which henceforth lost influence, but rather stressed that the regional Unions worked with the central Contract Commission. (SAdK, VDK, 303, no title, 25 March 1954.)

141 BArch, DR-1, 7, Quartalarbeitsplan IV 1953.

142 SAdK, VDK, 295. See also letter from Malige, Leipzig to Zentralvorstand VDK, Berlin, 22 June 1953. 
143 Ibid. Several drafts of this list are in the file, the last probably from early 1954. Another document states that 94 contracts were given out in 1953/54, in addition to the 12 given in 1952. (BArch, DR-1, 315, "Der Aufschwung der deutschen Kultur," 12; also SAdK, VDK, 303, “Auftragserteilung im Jahre 1954,” Uszkoreit, 23 March 1954.)

144 BArch, DR-1, 55, letter, 19 August 1955.

145 SAdK, VDK, 295, "Protokoll über die 1. Sitzung der Auftragskommission," 10 June 1953.

146 BArch, DR-1, 42, "Revisionsbericht," 7.

147 Most categories on the form focused on technical aspects of the work, though one question asked about the "ideological attitude" of the composer. For more detail see Zur Weihen, Komponieren, 187-189.

148 SAdK, VDK, 478, Vorstandssitzung, 20 November 1953. The ultimate decision seems to have been made for a time by the central Contract Commission. (SAdK, VDK, 303, “Auftragserteilung im Jahr 1954," Uszkoreit, 23 March 1954.) Assessments from wellknown individual composers, especially Academy of the Arts members, continued to be sought as well, as the opinions of Wagner-Régeny, Spies, and Butting were quoted by Möller from the VDK in BArch, DR-1, 54.

149 In Dresden for example, the evaluations done by the sections were done in a slapdash manner and were very subjective, thus creating too much work for the central genre commissions. (SAPMO-BArch, DY-30, IV 2/9.06/281, "Kritik an der Arbeit," 171-73.) For their part, it often took the central genre commissions quite a long time to give their assessment, leading to some frustration among composers. See the representative case of Erwin Dressel in 1954 in BArch, DR-1, 54.

150 SAdK, VDK, 602, Protokoll, Kommission Massenlied, 18 December 1954. Numerous technical problems were also cited.

151 SAdK, VDK, 602, Protokoll, Kommission Unterhaltungsmusik, 30 November 1954. Uszkoreit was dissatisfied with this opinion, as he felt the commission's opinion too hasty and that the work had a place in the repertoire as light music. He asked for a second opinion from Leo Spies, who was brutally critical of Driesch as a "half-educated con-man or psychopath." (SAMPO-BArch, DR-1, 200, letter exchange between Uszkoreit and Spies, 13 and 28 January, 1956.)

152 BArch, DR-1, 55, Rat des Bezirkes Potsdam, Abt. Kultur, Ref Musik, Wysocki, Abt. Leiter and Mielke, Oberrereferent to MfK, HA Musik, Uszkoweit (sic), 18 November 1954. DR-1, 54 and 55 contain numerous evaluations.

153 Ibid., 55, 30 November 1953.

154 SAPMO-BArch, DY-30, IV 2/9.06/283, 132, Schwaen. Although Schwaen states this had not been the case for some time, the example of Theuer, above, would seem to belie this fact. In any case, at some point in the mid-1950s the contract was changed to state that the third installment would be paid upon delivery rather than approval.

155 BArch, DR-1, 33, letter from Kulturbund to MfK about the 2. Programmerklärung, 16 February 1955.

156 SAMPO-BArch, DY-30, IV 2/9.06/284, “Zum Bericht für die Wahlen 1954," 104. The Contract Commission was reorganized slightly in March 1954, and renamed the Central Contract Commission. It did not contain someone from the new Ministry for Culture, but did include a representative from the Kulturfonds, as it provided the funding, though in practice the union simply gave them updates. (SAdK, VDK, 303, letter from Notowicz to the Kulturfonds, 11 March 1954; "Protokoll über die Sitzung der zentralen Auftragskommission," 29 April 1954.)

157 BArch, DR-1, 55, letter from Uszkoreit, MfK to the VDK in Berlin, 23. March 1954.

158 SAdK, VDK, 303, “Zum Auftragswesen innerhalb des Verbandes . ..," 19 April 1955. 
159 The cultural departments of the regional governments could also propose works for commissioning in consultation with the local Union chapter. (BArch, DR-1, 55, letter from Uszkoreit, MfK to Rat des Bezirkes Karl-Marx-Stadt, Abt. Kultur, 7 February 1955.)

160 The document, prepared by the union leadership and dated 19 April 1955, "Zum Auftragswesen innerhalb des Verbandes ..." is in both SAdK, VDK, 303, and attached to BArch, DR-1, 43, Protokoll, 15 April 1955. An earlier draft, "Richtlinien für das Auftragswesen innerhalb des Verbandes (Entwurf)" with handwritten corrections by Uszkoreit, is in BArch, DR-1, 55, 12 March 1955. The final draft both emphasized the role of the ministry and strengthened the Executive Committee of the union.

161 BArch, DR-1, 25, “Innerer Plan für die Jahre 1955 bis 1960," 10 August 1954, 2.

162 SAdK, VDK, 303, letter from Uszkoreit, HA Musik, MfK to VDK, 15 April 1955.

163 BArch, DR-1, 22, letter to Tümmler, Sekretariat des Ministers from Uszkoreit, HA Musik, 1 March 1956.

164 BArch, DR-1, 43, Protokoll, 15 April 1955.

165 BArch, DR-1, 55, letter from Pischner, HA Musik, MfK to Bork, HA Darstellende Kunst, 7 February, 1955. See also BArch, DR-1, 190, letter from Uszkoreit, MfK to Walther Büsch, March 1955. 



\section{Chapter Four}

\section{The Music Festival as Pedagogical Experience}

Music festivals exploded in size and number across Central Europe in the decade after 1945. Many hundreds of thousands of people took part through both professional and amateur choirs and other musical ensembles, while millions more encountered party-approved music by attending concerts. Cultural officials made significant and ongoing attempts to include amateur groups in these festivals and also to bring in audience members from all population groups. Musicians and conductors appreciated the festivals, as they heightened audience interest and attracted attention to ensemble activities. For contemporary composers, the festivals provided very welcome and indeed essential opportunities to have their works performed before audiences. The festivals received significant state support, and the parties of the region invested considerable resources and energy in their preparation and staging. Cultural officials utilized festivals as an incentive for composers to create socialist-realist music, and then worked to introduce the wider population to this music in a fun and festive environment. Both Poland and the GDR featured a wide range of festivals with music as their focus, including high-profile events, those in smaller towns and rural areas, and others devoted to amateur musical groups. Some festivals consisted of a few concerts extending over a long weekend, while others featured hundreds of events and lasted months. Composers and cultural officials heatedly debated and negotiated the content of these festivals, but they generally included a mixture of ideologically acceptable works by past masters as well as socialist-realist works from contemporary composers.

This study has focused on music as an essential element in the parties' use of "softer" forms of control, in opposition to the "harder" forms of coercion and repression often emphasized in the historical literature. In this sense, these music festivals provided key tools in constructing and maintaining a legitimizing political-cultural paradigm that was progressive, national, and socialist—as defined by 
the parties and against the conception emanating from the West. The inclusion in the festivals of carefully screened works by great German or Polish composers of the past served to strengthen the parties' claim to be the true heirs of a positive national tradition, one they would carry into the socialist future. More concretely, both the PZPR and the SED viewed music festivals as a particularly effective means of propagating their ideas and values among the population, with the goal of influencing worldviews and beliefs. Workers and peasants were to attend concerts and even take part in some festivals through involvement in amateur musical groups, and thus to not only come into contact with the ideas and aims of the parties, but in fact participate in their enactment. Individuals chose to attend or stay away and in some cases gave direct feedback, and thus affected the nature of these festivals, as did local festival organizers and ensemble directors, who also gave input or made demands. These music festivals illuminate the interplay between the goals of worker education and cultural-ideological formation on one hand, and the more pragmatic desire to control and dominate the population on the other.

The complex interaction between cultural officials and composers greatly shaped the organization of festivals. The parties considered the festivals an effective way to influence composers through attempts to control programming, and thus officials encouraged and pressured them to compose in a socialist-realist style, and in general to support approved political goals. Composers responded to this pressure in varying ways, and this chapter will also examine their dealings with party authorities, as well as their opportunities for negotiation-which were considerable, given the parties' dependence on their expertise. The participation of these musical producers was a political imperative, as their creative work in the service of the party was key to the project of controlling and changing society by creating the symbols that reinforced party legitimacy and power. The parties in both countries therefore attempted to mobilize, shape, and control their artistic elites as well as the population at large through the medium of music festivals.

Festival culture has of course been a key aspect of human experience for millennia, and the communists unsurprisingly sought to harness it for their aims. Since at least the ancient Greeks, people have come together to celebrate and affirm common values through ritual and art. In the modern era, as for example during the French Revolution, festivals were organized extensively to connect the body politic and help inculcate the values of the new social order. ${ }^{1}$ Richard Wagner pushed this idea further, as he envisioned festivals as a site where artists would merge with the people in a (national) union of shared values. The Salzburg Festival was but one manifestation of the Wagnerian idea, as it came into being in 1920 and played a key role in creating an Austrian identity by forging a link with the past so as to transmit a set of conservative and Catholic values to contemporary audiences. ${ }^{2}$ In Germany especially, there was a rich working-class tradition 
of festivals, as Social Democratic activists in the late Imperial and Weimar periods organized festivals that functioned as political rituals and involved thousands of singers and spectators, and the National Socialists recast and expanded German festival tradition. ${ }^{3}$ And unsurprisingly, the most immediate model for Poland and the GDR was that of the Soviet Union, which used festivals and mass spectacles to project legitimizing myths, especially with respect to the October Revolution. ${ }^{4}$ The Bolsheviks believed that festivals could transform the consciousness of the masses, and organized numerous events to this end. ${ }^{5}$ The SED and PZPR drew inspiration from the experiences of the Soviet Union, but also used aspects of their own national traditions to create festivals that would present the parties as the logical heirs and protectors of a progressive national musical culture, and that would serve to influence their own populations. Composers, ensemble directors, performers, and audiences all confronted festive events that bore a strong political coloring.

\section{The Showpiece Socialist-Realist Festival}

In both Poland and the GDR, musical figures and cultural officials organized a small number of prominent festivals during this period. These major festivals received considerable funding and attention from party and ministry authorities, who took great care in commissioning and promoting relevant music and managing the programs. Composers responded with enthusiasm to these opportunities to have their works performed, but often chafed at the political constraints imposed by officials, and as a result, a complex interaction over programming took place. Audiences also reacted to this new festival music with excitement, boredom, and frustration, and forced the political and cultural elites to modify their aims. In Poland, such major festivals were enormous undertakings, as they featured hundreds of concerts that took place all across the country over a period of months. The PZPR, lacking a longstanding festival tradition, organized a handful of lengthy, country-wide festivals from the center in order to reach as many citizens as possible. The GDR's main festivals were smaller in scale, probably due to a preexisting, well-established culture of festivals organized in cities and towns, but proved equally important in the attention they received from the SED, composers, and audiences.

\section{The Festivals of Polish Music}

In Poland, several elaborate series of events extended across months, with concerts all over Poland in towns and cities of all sizes. The first Festival of Polish Music (Festiwal Muzyki Polskiej) took place in 1951 and the second in 1955; the differences between them exemplify the crisis of party authority in Poland 
after 1953 and its effects in the musical world. The PZPR pursued nearly identical aims as the more powerful SED, but here as elsewhere experienced increasing resistance from composers after Stalin's death and the related thaw. The first festival in 1951 thus shares many broad similarities with all but one of the GDR festivals in its conception, goals, and aims, while the second is interestingly and significantly different as composers acted more autonomously.

Cultural officials initiated a precursor to the two Festivals of Polish Music in 1949. This Festival of Folk Music (Festiwal Muzyki Ludowej), a less polished and less political version of the two later festivals, took place over several weeks in May 1949 and featured 3000 musical ensembles in 500 concerts spread all over Poland. ${ }^{6}$ Although this festival focused more on traditional folk music, 55 composers participated by orchestrating folk songs or creating new folk-based compositions. ${ }^{7}$ The Festival of Folk Music contained the rough outlines of goals the party endeavored to attain in the music world: the PZPR presented itself as a patron of the arts as well as of the Polish nation, and involved composers, amateur performers, and audience members in the expression of these values.

The first Festival of Polish Music in 1951 came the closest to the PZPR's ideal of a thoroughly politicized musical event. It attempted to engage composers and much of the population in a party-sanctioned cultural activity that spread its values and buttressed its legitimacy. ${ }^{8}$ This festival was a sprawling, national event which started in April 1951 and ended eight months later, and featured three distinct phases: the first included a series of concerts by major orchestras which began on April 13 and culminated with the May 1 celebrations; the second was less concentrated, with intermittent concerts by both professional and amateur musical ensembles spanning the months of May to December; the final phase took place in the first half of December, and offered a compact schedule of the highlights of the past year, as well as the final stage of the competition of over 2000 amateur groups, where a total of 360,000 people participated. The entire festival comprised hundreds of concerts, including music from the past as well as the present, with over 300 new works related to the occasion. ${ }^{9}$

A truly stunning range of concerts greeted Poles all over the country. The major orchestras appeared in their usual venues and offered politically themed programs such as concerts in Warsaw and Kraków by the Kraków Philharmonic Orchestra with renowned soloist Halina Czerny-Stefańska that featured Jan Krenz's Conversation of Two Cities (Rozmowa dwóch miast), about Warsaw and Moscow, cheek by jowl with a Chopin piano concerto and Moniuszko opera aria. In Bydgoszcz, the orchestras of the Polish Radio and Pomeranian region combined forces with six local choirs to present a Moniuszko overture, Mieczysław Karłowicz's Violin Concerto (1902), Woytowicz's Kantata in Praise of Work (Kantata na pochwate pracy) and Maklakiwicz's Silesia works and sings (Ślask pracuje i śpiewa), as well as four well-known mass songs. Numerous amateur en- 
sembles entered those same concert halls to sing dozens of the latest mass songs, sometimes in a program that included more traditional vocal works from previous decades and centuries. ${ }^{10}$ Both professional and amateur ensembles performed in smaller towns and villages, in a wide variety of venues, from rural public halls to factory clubrooms.

Party and state institutions took the leading role in the organization of the first festival. The Department of Artistic Production in the Ministry of Culture had the main responsibility of organizing and supervising the preparation for the festival, and its Musical Council was the site of discussions about strategy and planning. Several other departments also contributed to the organization, and a special bureau, firmly under the control of the ministry, was set up to manage the festival. To decide on the programs of the concerts, Polish officials also formed an advisory council made up of representatives close to the party to decide which works, both contemporary and from the past, fit the party's guidelines on socialist realism closely enough to be included in the festival. The Composers' Union also actively took part in the organization of the festival, and did have some influence on its realization - indeed, it continually tried to gain more-but the aforementioned state institutions had the decisive say. ${ }^{11}$ The dominance of the ministry manifested itself most clearly in the selection of the director of the festival bureau. The union had been promised a voice in his selection, but the ministry imposed its own candidate without regard to the union's preference - to the great frustration of many composers. ${ }^{12}$

These various state organizations tailored the goals of the first Festival of Polish Music to the party's wishes. Cultural officials envisioned a "musical army" that would better acquaint the population with party-approved music. ${ }^{13}$ The party's primary aim appeared in internal party documents and the official literature about the festival in this formulation: "The fundamental goal of the festival is to deepen the knowledge of Polish music in society at large, while encouraging further compositional work and linking this to the needs of the broad masses of People's Poland." 14 The dual goals of the festival are here neatly laid out: to bring music to a wider segment of the population, and to encourage composers to create in a style the party deemed suitable for those very people. ${ }^{15}$ During an address to composers at a meeting about the festival, Deputy Minister of Culture Włodzimierz Sokorski set out his conception of the festival as having "didactic significance for both composers as well as the wide mass of listeners ... it will have an ideological-pedagogical character." 16 As seen in the previous chapter, composers received generous funding and responded with hundreds of socialist-realist compositions. For the PZPR, the festival provided an opportunity to propagate a certain kind of music that would school all of society in the ideas and values of the party. 
With respect to the masses, the party's goal for the festival was to mobilize a wide section of the population in support of its broader political aims. The great majority of composers praised this popular aspect of the festival. Lutosławski, for instance, lauded the inclusion of the large number of amateur groups, and Grażyna Bacewicz felt the festival an important aspect of "our cultural politics." ${ }^{17} \mathrm{Com}-$ poser Henryk Swolkien asserted that the festival showed how his colleagues had reached out to the "broad masses of listeners." ${ }^{18}$ Cultural officials frequently noted their view of music's role as a political tool with respect to festivals, seeing them as "a shaping agent for the fundament of life of millions of people" and as "participating in the shaping of man." ${ }^{19}$ In the PZPR's conception of music as essential in propagating its conception of a progressive Polish nationalism combined with socialist ideology, it sought to deploy musical festivals to influence worldviews and win support for its program. The inclusion of thousands of amateur groups in this party-sponsored festival was an important means to this end. ${ }^{20}$

On a more basic level, the party hoped to gain a certain legitimacy both by patronizing the arts and by bringing music to a broader section of society; the PZPR, like the SED, asserted that it strove for a more just social order where every citizen would have access to art previously considered the preserve of elites. In official communications, the party stated repeatedly: "The festival is a powerful means of disseminating Polish music among the broad masses." ${ }^{21}$ In addition to contemporary music, concerts also included works by past composers, and these works were specifically selected to show how composers like Chopin and Szymanowski made up part of a national and realist tradition.

The festival also provided an ideal opportunity to influence professional music groups such as orchestras, as well as their directors and conductors. The party wanted more generally to change the nature of concert programs, which it considered too often conservative and lacking in sufficient and appropriate contemporary works. Deputy Minister Sokorski stated: "The festival should be a turning point in this crisis situation, in which concert programs presently show a banal and mechanical character." ${ }^{22}$ In the festival bureau's official communications, this issue was also frequently emphasized:

A new detail is the inclusion of mass songs in the concert programs, which attests to the breaking with previous conventions and other misguided traditions in the programs of the orchestras ... the festival permits the state operas and orchestras to undertake an overview of their achievements to this date, while at the same time confirming shortcomings and mistakes in their work and will therefore result in the development of a new style of their work. ${ }^{23}$

Similar to their aims vis-à-vis composers, cultural officials viewed the festivals as an opportunity for conductors and music directors to transform themselves and their worldviews so as to conform to the party's aims. 
Cultural officials viewed the first Festival of Polish Music as an opportunity to mobilize composers, musicians, and society in support of party goals. It sought to influence and control both the musical elites and the masses through the preparations and performances of this massive and wide-ranging undertaking. As the president of the Composers' Union, Tadeusz Szeligowski, put it in the program book for the festival's concluding phase, "We will continue to fight for the most expressive content of our musical works, and for a sensibility capable of cooperating in the creation of contemporary man. ${ }^{24}$ The party did obtain enthusiastic participation by composers, musicians, amateur groups, and the population at large, and proclaimed the festival a success. The second attempt at such a festival a few years later, however, was far different and came together in a significantly altered form from the first, reflecting the larger political changes occurring at the time in Poland. Polish composers and other musical elites had gained a considerable amount of autonomy and acted to resist the party's push for a festival that embodied only official ideology and goals. As we have seen, by 1953 the thaw was setting in throughout Polish society, and the party undertook a thoroughgoing review of its policies, even as composers pushed for more professional and aesthetic freedom.

Although not in fact realized until 1955, officials had originally planned the second Festival of Polish Music for 1953, and early organizational efforts in the Ministry of Culture continued to call for the presentation of socialist-realist music. ${ }^{25}$ In December 1953, Minister Sokorski still talked about the next festival as a site for "expressing the battle for a new music," but, much like in the cultural world more generally, a softening of the line seemed to be underway as he mentioned socialist realism far less frequently. ${ }^{26}$ Sokorski and composers agreed that the festival would feature works from the entire postwar period, which created space for music that did not fit a strict definition of socialist realism or of the party's cultural norms. ${ }^{27}$ By the fall of 1954, even the hardliners in the Culture Department of the party's Central Committee acknowledged that a broad range of works could be performed during the festival, including those previously criticized as formalist like Lutosławski's First Symphony or Turski's Olympic Symphony. ${ }^{28}$ During a special council called by the party in late November 1954, communist composers and musicologists complained bitterly about the direction of the preparations for the festival, including the planned performance of many works deemed formalist, but their cautionary words went unheeded. ${ }^{29}$ The majority of composers were determined to press for compositional freedom, and the PZPR was gradually losing control over the cultural realm.

In a significant difference from the overweening party control of the first festival in 1951, the Composers' Union took the responsibility for the planning of the second during the course of 1954. The more independent, younger composers Tadeusz Baird and Kazimierz Serocki pushed through a less ideologically engaged program over the protests of hardliners within the union like the 
communist musicologist Zofia Lissa. ${ }^{30}$ Despite occasional interventions by party and government figures, the state organs and officials that undertook most of the work for the first festival were largely absent from the second; ad hoc committees comprised composers and state representatives, but the former held the "decisive voice." ${ }^{\prime 31}$ Even a proposed organizational committee staffed by functionaries in the ministry never materialized, allowing composers to plan the festival in a more open way, one more consonant with the majority's less rigidly politicized beliefs about music. ${ }^{32}$ Various party pronouncements nonetheless still echoed the goals seen in the first festival of 1951 and showed a continued aspiration to influence composers, but the party was simply too disorganized, and lacked sufficient support in the union, to push through its aims at this time.

The second festival finally began on January 17, 1955 and ran until May 20 of that year, thus spanning a time period less than half as long as that of the first. The festival comprised 250 performances, including 163 symphony orchestra concerts, and had a total attendance of 150,000 . The program featured roughly 450 works by 119 composers, with 320 of those works by 80 living composers. ${ }^{33}$ The number of contemporary works exceeded that of the first festival, probably because composers could present a wider range of works, including those not fully consonant with the socialist-realist canon. In a significant difference from the first festival, concerts focused almost exclusively on these contemporary works, and composers from the past were only lightly programmed. The number of concerts was smaller than that of the first festival, due to the fact that few amateur groups took part. Festival organizers claimed that these groups were preparing at the time for the Fifth World Festival of Youth and Students, which took place in Warsaw in the summer of $1955 .{ }^{34}$ Although certainly true, a not unimportant factor was the desire of most composers to have the festival focus on the more serious works they preferred to compose, works not appropriate for performance by an amateur ensemble.

Composers did not ignore the wider population, however, and discussed the audience at many of the planning meetings for the festival. Indeed, in the mid1950 s, as earlier in the decade, composers kept society in mind during the compositional process. But there was a noticeable shift in focus: whereas during the first festival the party pressed composers to write for the "masses," during the second composers created more as they desired, and in a sense tried to bring the masses to them. In the view of some sympathetic to the party, such efforts proved less than successful, as musicologist Stefan Jarociński charged that composers' isolation from society and lack of political engagement had produced indifference among potential audiences, and another critic accused composers of not reaching out to the population through discussions and meetings. ${ }^{35}$

Nonetheless, many concerts sold out, and festival organizers estimated the overall attendance at 60 to 70 percent of capacity. Baird also noted a fair amount 
of disagreement about the level of attendance, as some composers felt it had been poor. Artur Malawski blamed the weak works selected for some concerts, while Piotr Perkowski felt that more appealing, noncontemporary works should have been included in some of the programs. In a more optimistic assessment, Baird noted that several foreign guests were quite impressed with the audience size. ${ }^{36}$

With respect to the conductors and orchestras, the composers and the union had a great deal of difficulty getting them to perform the desired works. In the fall of 1954, they organized two meetings with conductors and music directors to plan which orchestras would perform which new works. ${ }^{37}$ The composers encountered a fair amount of resistance, usually due to the difficulty of the works and fears that audience attendance would be low at concerts featuring more demanding contemporary music. Ensemble directors and their audiences favored more accessible works to the more difficult pieces preferred by composers. As the concert dates approached, this problem became even more apparent as many conductors unilaterally dropped certain contemporary pieces from the program. ${ }^{38}$ Interestingly, the pressure from the party in 1951 produced more effective results than the lobbying by composers of their conductor colleagues in 1955.

While the second festival shared some of the characteristics with the first, it was much closer to the openness and experimentation of the Warsaw Autumn Festival that began just over a year later in 1956. Annually starting in 1958, this festival still continues today, and symbolized the final break with socialist realism and an engagement with the modern music of the West. Musical ensembles from both West and East performed there, with contemporary music from Polish and Soviet-bloc composers, as well as works by Western composers formerly condemned as anathema, like Schoenberg, Berg, and Stravinsky. ${ }^{39}$ By the mid1950s, then, the PZPR's dreams for a didactic festival culture that would create a socialist polity lay in ruins. The impressive manifestation of its program and vision embodied in the first Festival of Polish Music did not survive. The composers who had embraced the party's aims in 1951 had grown disillusioned. They remade the second iteration of the festival to their own liking, and then launched a more exclusive, international festival catering to more serious and modernist music. Popular audiences turned towards newer festivals coming to prominence that focused on popular song or jazz. ${ }^{40}$

\section{Major Festivals in East Germany}

A handful of significant music festivals also took place across the GDR during the first half of the 1950s, the majority of which were marked by strong party influence. These major festivals included the 1952 Festtage in Berlin and the 1954 Musikfest in Leipzig, both associated with regular congresses of the Union of German Composers and Musicologists (VDK), as well as the Festtage 
neuer Musik (Festival of New Music) in Leipzig in 1955, a festival explicitly organized in opposition to the party's wishes and thus somewhat similar to the second Festival of Polish Music. While these East German festivals were not of the same length and scale as the festivals in Poland, they fulfilled similar functions of highlighting a certain kind of musical work and of bringing that music to a wider audience.

The first major music festival was the Festtage zeitgenössischer Musik (Festival of Contemporary Music) in Berlin, held in conjunction with the First Congress of the VDK, from September 27 to October 6, 1952. As the festival was linked to the newly formed union and thus a showpiece event, both party and government officials, as well as the composers themselves, placed great importance on the selection of the pieces to be performed. A dozen or so concerts included programs featuring many new works by GDR composers. These were organized loosely by genre, and included several of instrumental music and a handful devoted to mass songs or cantatas. ${ }^{41}$ Though not a high priority, attempts were made to include workers in the audience. One concert featuring contemporary mass songs and cantatas by East German luminaries like Hanns Eisler and Paul Dessau and sung by the legendary communist singer Ernst Busch took place at the Bergmann-Borsig factory and was eagerly received by the workers there. ${ }^{42} \mathrm{~A}$ delegation from the factory also came to the union congress itself and expressed enthusiasm for the new, socialist-realist music and called for "a good, lively light music, a useful music that will help working people to relax after fulfilling the plan." ${ }^{\prime 43}$ In general, however, workers did not attend most of the 1952 festival concerts, a fact remedied at the next festival. ${ }^{44}$

Cultural officials took a very active role in trying to shape the kinds of works that made it onto these festival concert programs. Working with the union leadership, they encouraged composers to create acceptably socialist-realist works, and then rewarded those who complied with performances of those works. The push by the party to have the Festtage program dominated by its ideological vision led to conflicts with composers, especially those who were not party members. Most rank-and-file composers sympathized with the party's goals, but only to a point. The Stakuko, however, true to its totalizing mission, wanted every composer to share all its aims, and urged the receptive VDK leaders to involve each union member in the project of performing and discussing ideologically appropriate works at the festival: "the responsibility of the Executive Committee [of the VDK] is to develop the broad, comprehensive and active participation of all composers." ${ }^{.45}$ The SED made great efforts to win artists to its program, and saw this festival as an ideal opportunity to mobilize composers to take part in a party-approved event.

Problems and controversy surrounded the selection of the works for the 1952 Festtage, however. Proposed works were first examined at the regional level in the genre sections, then passed on to the genre commissions, the specialized 
national committees organized by type of music. These commissions, made up of a wide cross-section of composers, analyzed the works and decided which they deemed suitable and worthy of performance at the festival. An overarching Programmkommission, consisting largely of Berlin VDK Executive Committee members closely linked to the party, made the final decisions on the makeup of the concerts. It altered or ignored many of the recommendations of the genre commissions in the interest of creating a more ideological program with a greater number of works by party-linked composers, especially the well-known ones in Berlin. Several months before the Festtage, the director of the Music Department of the Stakuko, Rudolf Hartig, met with the head of this Programmkommission and stressed the party's hard ideological line: "With respect to the acceptance of individual works, one should not proceed by accepting those works that are considered tolerable from a so-called purely musical standpoint, but rather one should accept works that have truly new musical content and reflect the societal reality of our time." ${ }^{\prime 6}$ The message was clear: only socialist-realist works desired by the party should make the cut for the festival program. During the congress linked to the Festtage, union president Ottmar Gerster tried to defuse criticism about the selection process by claiming simply not enough space in the festival existed, and that the rejected works would receive a performance at another time. ${ }^{47}$ Resentment among ordinary members, especially those from the provinces like Johannes Thilman and Iwan Schönebaum from Dresden, erupted during discussions at the congress, but the party's priority to feature socialist-realist works and to pressure composers to create in this style held sway. ${ }^{48}$

Despite this composer dissatisfaction, in the immediate aftermath cultural officials maintained a hard line: "The point of the Festtage was to show the state of contemporary musical production in the GDR, taking into account the socialistrealist point of view," and claimed it was "a success in political, professional, and ideological respects." ${ }^{49}$ Upon reflection a few months later, however, cultural official Uszkoreit qualified this statement: "The Festtage zeitgenössischer Musik exhibited . . . a large number of formalist works." ${ }^{50}$ Despite, or perhaps because of this controversy over the nature of the music selected, the Stakuko reaffirmed its commitment to influence festival programs in its plans immediately after the Festtage, and the stage was set for clashes at the next major festival linked to a Union Congress, in 1954. ${ }^{51}$ Cultural officials had indeed created a precedent during this first festival; they would expend political capital and risk angering some composers in the interests both of promoting the ideal of socialist realism and of trying to encourage and influence their production. Not all accepted this state of affairs without complaint and they pushed back in the future.

That next major festival was the Musikfest des VDK, also connected to a Composer's Union Congress, and took place in Leipzig in late October 1954. The Uprising of June 17 the previous year had taken both artists and party officials by 
surprise, and thus a focus on making contact with the masses was stronger than during the previous festival. Officials in the Culture Section of the SED's Central Committee expressed their goals on the eve of the Musikfest: "The point is not to present our contemporary musical production in the form of interesting concerts that display today's 'sound,' but rather to prove how composers and musicologists are fulfilling their societal mission as 'engineers of the human soul."' 52 Party officials wanted socialist-realist music, and particularly desired the potential effects of this music on the rest of the population. During the discussion at the congress, the links between music and society were frequently mentioned, as when Ernst Hermann Meyer stated in reference to one of the festival concerts: "music has an important function in shaping [peoples'] consciousness," and other composers like Cilenšek and Köhler called on their colleagues to compose for the masses in order win them over to the SED's program, as well as to lift their cultural level in general. ${ }^{53}$

The Musikfest organizers from the union made a great effort to invite workers to the various concerts, and indeed encouraged composers to meet with ordinary audience members after performances, while inviting others to join associated discussions. After the concert on October 26, which included Günter Raphael's Sinfonia breve (1949), Rudolf Wagner-Régeny's Suite from the opera Persische Episode (1951), Helmut Riethmüller's Divertimento for Piano and Horns, and Ottmar Gerster's Second Symphony (Thüringische, 1953), female workers from a Leipzig factory found the first two works, "Dreadful! Horrible!," but were pleased by Gerster's piece, considered one of the model socialist-realist works. ${ }^{54}$ Most audience members also seemed to enjoy the Gerster, but the other works came under heavy criticism. Raphael's piece sounded to one woman like "children pounding on the piano," and other audience members said "it gave me nothing" or "there was no heart and soul in it." ${ }^{\prime 5}$ The writer Jens Gerlach claimed that many audience members at the Musikfest concert in fact enjoyed the work, something he deplored as he found the work a "distorting mirror" and a "mephistophelean no." An official from Erfurt claimed that most audience members disliked the works and regretted buying tickets. ${ }^{57}$ Another congress participant criticized all the works but Gerster's, saying they were technically good, but "not from the heart ... they will never appeal to the workers, never!" Yet another noted that a large portion of the audience left after the first half. ${ }^{58}$ The positive reception of Gerster's clearly socialist-realist work motivated cultural officials both to press composers for similar works and to reach out to a wider audience.

This contact between composers and workers climaxed in the appearance at the related VDK Congress of two workers from the Leuna factory "Walter Ulbricht." As referenced in the introduction, composers had traveled the night before to the outskirts of Leipzig to attend the concert in the factory clubhouse with the workers there. The program consisted of contemporary works by both younger and older 
GDR composers, including Max Dehnert's Merry Prelude for Orchestra (Heiteres Vorspiel für Orchester, 1949), Paul Kurzbach's Divertimento for Small Orchestra (Divertimento für kleines Orchester, 1954), Dieter Nowka's Concerto for Oboe and Orchestra (Konzert für Oboe und Orchester), three arias from Jean Kurt Forest's opera Patriots (Patrioten, 1951), and Max Butting's Sixth Symphony (1945/53). Otto Schnell communicated his disappointment with the concert in strong words and encouraged composers to write music more accessible and enjoyable upon initial exposure, like that of Tchaikovsky. ${ }^{59}$ The evocation of a Russian composera politically savvy reference, to be sure-clearly indicates Schnell's ears were not untutored, and his bluntness impressed those present. Max Dehnert, for example, declared that he accepted the criticism and would give it considered thought. ${ }^{60}$ Composers took these and similar comments seriously, and discussed how best to write for audiences at this and other meetings, and even formed personal relationships with individual factories in order to be in contact with and help musically educate workers. Max Butting, for instance, had revised his Sixth Symphony-begun in 1945, and grappling with the war and the arrival of the Red Army-several times through 1953, and tried more generally at this time to write for a wider audience, as for example music intended for workplace celebrations. ${ }^{61}$

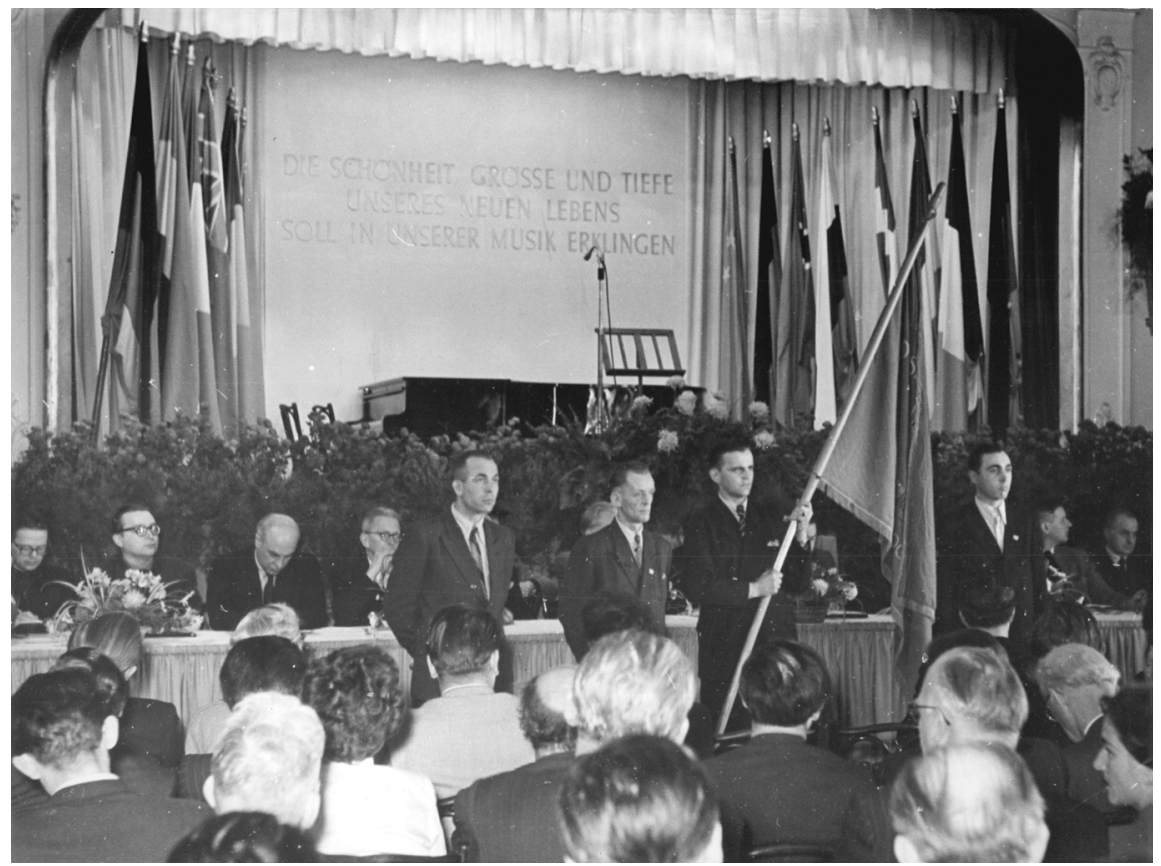

A group of workers greets composers assembled for the second German Composers' Union Congress in Leipzig on October 25, 1954. The slogan in the background reads: "The beauty, greatness, and depth of our new life should ring out in our music" (Bundesarchiv, Bild 183- 
Schnell's colleague Horst Irrgang, choral director at the factory, also spoke, and related the lively and lengthy postconcert discussion he had organized among workers, musicians, and composers. Irrgang talked about the active musical life at the factory, and encouraged composers to write for and make contact with these workers. He further called on composers to help explain their new works at performances, and even suggested including a hundred or so workers in all the aspects of the VDK's Congresses, in order to expose the workers to musical debate, and to have their voices heard during such a discussion. ${ }^{62}$ Audience members embraced the opportunity to give feedback and thereby shape and influence the nature of festival concerts.

While the VDK did not follow Irrgang's suggestion to include workers in union discussions, cultural officials and the VDK leadership emphasized these contacts between composers and workers and made this a main theme of the 1954 festival. Their goals were twofold: to encourage composers to assist the party in influencing and reaching out to ordinary citizens, and to control the composers themselves by insisting that they compose in a certain way. Most composers shared this broad goal, but a significant minority disagreed with the party's nearmonopoly over the organization of festivals.

As had been the case in the 1952 festival, controversy at this 1954 Musikfest also occurred with respect to the selection process of the works to be performed. Party and ministry officials continued their close involvement in the preparation and conception of the program, once again desiring to influence the kind of musical production undertaken by composers by promoting the performance of ideologically appropriate works. Yet again, the Executive Committee in Berlin, made up of prominent composers and musicologists closely linked to the SED, had the main input into a program the party deemed ideologically suitable; and again the VDK leadership made significant changes to what the specialized genre commissions had recommended. Resistance came most specifically from a group of composers in Leipzig, whom central officials accused of opportunistically using the New Course as a pretext to have their perhaps slightly more experimental compositions performed. ${ }^{63}$ After a rather contentious debate at the congress itself, participants decided that only works approved by the relevant genre commissions could be included at such festivals - and thus not pieces added solely at the discretion of the union leadership - but the ultimate decision making remained in the hands of the centralized, party-linked Programmkommission. ${ }^{64}$ Cultural officials and the Union Executive did make a minor concession here, but successfully retained ultimate control over the content of these centralized festivals in theory and largely in practice. ${ }^{65}$ The Leipzig composers remained frustrated, however, and decided to flout party control one year later by organizing their own festival. 
The conflict between state cultural officials and union leaders on the one hand, and rank-and-file composers on the other, reached a peak in the preparations surrounding this next major festival, the Festival of New Music (Festtage neuer Musik), held in Leipzig from October 16-23, 1955. Largely organized by the Leipzig branch of the Composers' Union, with some help from regional state officials, this festival consisted of seven concerts that mostly featured works by local composers, with a few pieces by other GDR composers, Kazimierz Serocki from Poland, and Shostakovich. Reacting to what they perceived as unfair exclusionary treatment at the two congress-linked music festivals, the Leipzig composers packed the festival program with their own works. The complicated, often antagonistic interaction between Hans-Georg Uszkoreit, head of the Music Department in the Ministry of Culture, and composers and officials in Leipzig demonstrates the importance cultural officials placed on having festival programs of which they approved. This controversy also shows how composers successfully maneuvered around this pressure so as to assert their own agenda.

Uszkoreit strongly disapproved of the program of the festival, consisting as it did largely of works by local composers willing to challenge the SED. In an effort to effect changes, he wrote to both the VDK Executive in Berlin, as well as to the local cultural officials in Leipzig. Uszkoreit urged the union leadership to support the festival only after "the program would be fundamentally changed," since he felt it marked by "local patriotism" and "opportunism," and "grants outstanding positions in the program to composers who both in their personal attitudes as well as compositional work cannot be called friends of the GDR." ${ }^{66}$ In a related letter to the local state authorities, Uszkoreit asked for alterations to the festival program, claiming that it "shows no conscious strengthening of new socialist-realist compositions ... [it] does not show suitable respect, nor do notable service, for the development of progressive contemporary musical production in the GDR." ${ }^{67}$ After meeting with the regional union leadership in Leipzig, the local government official in charge of culture perhaps surprisingly sided with the Leipzig composers, and supported the latter's contention that they had been unfairly discriminated against in having their works rejected for performance on other occasions. The local official further claimed that the best way to influence the composers and encourage them to produce more ideologically appropriate works was to adhere to the current festival program and have a lively and politicized discussion about those works. ${ }^{68}$ The only concession to Uszkoreit's demands seems to have been a minimal one - a concert of taped works by Paul Dessau and Ernst Hermann Meyer. Uszkoreit's ultimately unsuccessful efforts show the importance cultural officials placed on influencing musical production and controlling composers and also the ability of composers to negotiate with and indeed defy the central authorities. 
The Leipzig composers sent Uszkoreit a letter both conciliatory and defensive a month after the event. They stressed that it had been important to perform much of this new music for the first time, but also acknowledged they should have chosen the performed works more carefully-though they pointed only to a few smaller pieces by lesser-known composers. The festival organizers did agree with the SED's desire to expose large numbers of people to this music, and shrewdly used this party-sanctioned goal as a justification for their actions. In their self-critical appraisal of the festival, the Leipzig VDK discussed this issue for future festivals: "it is necessary ... to enable a true meeting between the broader working public and our composers, to give the public a glimpse into the work of our composers, while also testing the worth and effects of their work in the resonance of the public." ${ }^{\prime 9}$ Though the Leipzig composers may not have shared all of the political goals of the SED and its cultural officials, they did agree on the view that composers should try to make contact with and influence society. Especially in the atmosphere of the New Course, the Leipzig festival succeeded in realizing composer aims in opposition to the party.

The first two festivals organized in the GDR had many similarities with the 1951 first Festival of Polish Music. Cultural officials in both countries took an active role in organizing events that would promote a political and aesthetic program stamped by party-approved ideology. Both composers and society participated actively in an event that buttressed the parties' legitimacy and helped them to promote a vision of a patriotic and socialist polity. The second Festival of Polish Music, and to a lesser extent the Leipzig festival of 1955, mark an important point in the musical-political histories of the two countries, as composers premiered works that did not explicitly subscribe to the party's socialistrealist ideology. In Poland, the PZPR had lost a significant amount of control over this important group of cultural producers, and thus over the symbols and messages spread by them as well, and was never able to reassert its control. In the GDR, the SED continued to exercise a great deal of influence over similar festivals, though the 1955 Leipzig festival shows that composers were at times able to achieve a measure of their own goals. Furthermore, overlapping and mutable groupings made up of both officials and composers worked together and at cross-purposes, creating a more vibrant festival culture - and musical life more generally.

\section{Local and Amateur Music Festivals}

Both countries featured a number of smaller music festivals, which in the view of East German officials in particular had the potential for significant impact at the regional level. In Poland, these were infrequent and relatively small-scale, as for example the Kraków Days lasting for less than a week every few years. The 
GDR, however, inherited a rich tradition of music festivals organized in smallerand medium-sized cities, and these festivals reached the same strata of citizens as those in Poland who attended the more numerous concerts of the large Polish festivals. The SED exerted its influence here as well to propagate its aims and influence among both musical producers and society.

\section{Local Festivals}

One important and representative mid-size music festival was the Thuringian Festival of Contemporary Music, held in Weimar in 1952, 1954, and on an annual basis thereafter. This festival sought to attract like-minded composers from West Germany to promote the idea that artistic currents in the GDR appealed to composers all across Germany and to try to convince West Germans that a vibrant culture not only existed in the East, but indeed was superior to that in the West. The Ministry of Culture took an active hand in overseeing and organizing the festival, and the local Composers' Union branch followed a line acceptable to the Stakuko's Music Department. Organizers divided concert programs roughly equally between works by composers from the GDR and West Germany. The first festival took place in June 1952 and was called an "all-German" event that attracted many West Germans to concerts that included works by Gerster and Shostakovich. ${ }^{70}$

To decide on an appropriate program for the second iteration two years later, a group of Weimar composers met nineteen times and discussed 77 works, most by fellow local composers, but also including well-known party-approved pieces by the likes of Ottmar Gerster and Max Butting, and even by Soviet composers Aram Khachaturian and Prokofiev. Some of the party's favored genres, like mass songs and cantatas, were underrepresented due to the fact that local composers had not worked much with these forms, but they promised to rectify this lacuna in the future. ${ }^{71}$ Composers' Union president Gerster praised these programs that emerged during "detailed discussions" by the regional VDK members. ${ }^{72}$

The festival organizers made great efforts to bring more of the population to the concert venues. In the festival program booklet, the mayor of Weimar Dr. Hans Wiedemann stated: "Through the introduction of contemporary musical compositions to the broadest circles of the working people, we will make an essential contribution to our political task of including the entire populace in cultural life, so that our new cultural flowering will in reality be carried and supported by all the people." ${ }^{\prime 73}$ The festival organizers engaged a popular local conductor, Kurt Müller, to publicize the festival among the workers of the area, but with minimal success, thus prompting the proposal that the composers them- 
selves would go to the district's factories and workplaces to drum up support for the following year's festival. ${ }^{74}$

These festivals in Weimar were somewhat unusual in their focus on fostering an East-West dialogue, but were otherwise fairly typical for this genre of middletier festival. Ministry officials monitored and assisted the local festival organizers, helped by the union leaders in Berlin. This control from above could be quite onerous, as evidenced in the resignation of the local organizer in Weimar in 1955 because of interference from the VDK leadership. ${ }^{75}$ If, however, the organizers of the Weimar festival, and of other smaller festivals, followed the general guidelines propagated by cultural officials, such interventions were limited. When the festival included ideologically acceptable music and organizers made attempts to attract the local population to the concerts, ministry officials maintained a more distant advisory role.

In the mid-1950s, officials recommended that music festivals be mounted in even smaller towns, since there they cost less and attracted a relatively larger amount of attention. ${ }^{76}$ These smaller music festivals had been taking place throughout eastern Germany for many decades, in places like Schwerin, Markneukirchen, Eisenach, Rheinsberg, and Görlitz. The last two are representative examples of party involvement in festivals on this local scale, and thus of party aims to influence the population musically everywhere.

The town of Rheinsberg in Brandenburg had organized an annual music festival since the late eighteenth century. Local party officials "took control of the festival" and focused it around the concept of cultivating past musical tradition in an attempt to show the party's patronage of a progressive and national culture. ${ }^{77}$ The early festivals presented fairly traditional concerts of nineteenth-century classics, since the core aim was to introduce local workers to this music. ${ }^{78}$ In 1951, the concluding festival concert became yet more ambitious, as amateur groups made up of workers played pieces by Mozart and Schubert for their peers. ${ }^{79}$ Under pressure from cultural officials in Berlin, by 1953 the organizers expanded the festival to add more contemporary and socialist-realist works for concertgoers. While the majority of the twenty or so concerts included traditional classical music, two concerts featured contemporary pieces, as for instance the opening-day performance of Ottmar Gerster's socialist-realist cantata, Eisenhüttenkombinat Ost. Several other concerts included contemporary Soviet or East German composers as part of the program, such as the concert "German Songs from Six Centuries," which also featured music by André Asriel and Siegfried Matthus. ${ }^{80}$

The small but symbolic city of Görlitz also featured a representative music festival. Right on the Oder-Neisse border with Poland, Görlitz boasted of a tradition of festivals dating from the nineteenth century. With its new postwar importance as a border town, the festival programs perhaps unsurprisingly became increasingly political, as in 1951 and 1953, when the emphasis was on develop- 
ing good relations with neighboring Poland. Concerts included productions of nineteenth-century Polish composer Stanisław Moniuszko's nationalist operas, Halka and The Haunted Manor, as well as many works by Chopin and by contemporary Polish composers.

The Görlitz Festival organizers desired to attract a mass audience to all the various concerts and indeed drew 38,000 listeners in 1951, more than half of whom came from local factories. ${ }^{81}$ Mayor Gleißberg stated on the occasion of the 1954 festival: "Our working people should receive new strength and zest for the peaceful reconstruction of our fatherland through the experience of the music of the great masters of the past and present." ${ }^{\prime 82}$ Many of the ten to twenty concerts of these annual Görlitzer Musikwochen were made up of traditional works by nineteenth-century German greats, but also featured a significant number of pieces by well-known composers from the Soviet Union and the other People's Democracies. Starting in 1953, festival organizers added more works by contemporary composers from the GDR, and often in concerts that also featured beloved classics, a mix that helped assure healthy audience numbers. ${ }^{83}$ Not infrequently, the composer himself would show up for a discussion related to the concert. Amateur groups performed many concerts, while others by professional musicians often took place directly in the factories.

Officials regularly organized such music festivals in small- and mediumsized towns across the GDR. They generally realized one of the party's main goals with respect to music: to present the works of approved past masters and the best of contemporary socialist-realist production to a large cross-section of the citizenry. They, along with the rural music festivals discussed below, were perhaps the premier example of the ministry's goals for music festivals: "to introduce the broadest possible circles of the population to music, while at the same time introducing artists to the people." ${ }^{\prime 84}$ Composers, musicians and the population participated together in a party-directed project that provided opportunities for ideological education in an entertaining environment.

\section{Amateur Festivals}

In both countries, cultural officials organized a large number of festivals to involve amateur musical groups in activities under the aegis of the parties. These amateur festivals provided officials an opportunity to increase contact with many people in a more casual setting arranged by the parties. Such festivals were generally linked to competitions among non-professional groups across each country; the best ensembles advanced to a series of concerts in a main city for the final celebration. In Poland, annual festivals encouraged and structured significant amateur musical activity. Some of the more notable examples were the Festival of Amateur Musical Groups of 1953, which featured 
200,000 participants in 900 choirs, 273 brass bands, and 40 song and dance groups. Another festival organized by the Central Council of the Trade Unions in 1954 had 1420 choral groups, 1300 dance groups, 902 instrumental groups, and 42 song and dance groups. ${ }^{85}$ In the competitions to decide who would take part in the Fifth World Festival of Youth and Students, held in Warsaw in 1955, roughly 25,000 ensembles and soloists competed ${ }^{86}$ And as we have seen, both Festivals of Polish Music also incorporated the participation of amateur musical ensembles. This mass involvement reached truly astonishing levels during the stalinist era.

In the GDR, the festivals that perhaps best expressed the party's goal of mobilizing broad swaths of society to partake in party-sanctioned musical events were the German Festivals of Folk Art (Deutsche Festspiele der Volkskunst), held in 1952 and 1954. These festivals sought to have amateur musical groups perform politically acceptable folk music as well as newer socialist-realist works like Eisler's New German Folk Songs (Neue deutsche Volkslieder) or Meyer's Mansfelder Oratorium. Contests in the provinces in which six to seven thousand amateur groups took part then concluded with several days of concerts by the best groups. ${ }^{87}$ The first festival of 1952 took place in Berlin and offered a handful of concerts over a long July weekend. It culminated in a massive concert in the center of town, where "all of Berlin dance[d] on the Marx-Engels-Platz!" 88 Cultural officials viewed the Festspiele in these typical terms: "This bursting forth of the creative power of our people ... is mirrored in the creative work of our professional and amateur artists, and will be, along with the cultivation of our cultural heritage, the content of the German Festival of Folk Art." ${ }^{89}$ The Festspiele provided an ideal opportunity for the party to link the "creative power" of the population, or perhaps the simple desire to have fun, to its goals. Further, the inclusion and popularization of works by great German composers sought to demonstrate that the party was the true custodian of a progressive German culture.

For the second German Festival of Folk Art two years later, officials expanded the competition among the various amateur groups, climaxing in the actual Festspiele in Park Sanssouci in Potsdam. Juries evaluated the ensembles based on socialist-realist principles. In the view of cultural authorities, these competitions "lead to political and professional qualifications ... [and] contribute to the development of our progressive culture, in that they strengthen the artistic work of the people, increase the artistic achievements of the workers . . a at the same time, our artists work more closely with the workers in the amateur groups and create works for them." ${ }^{\circ 0}$ These Festspiele in the GDR, as well as other similar amateur festivals in both countries, embodied the festival ideal to which the parties aspired: professional artists working with ordinary people in a party-directed project to create a new and socialist culture. 


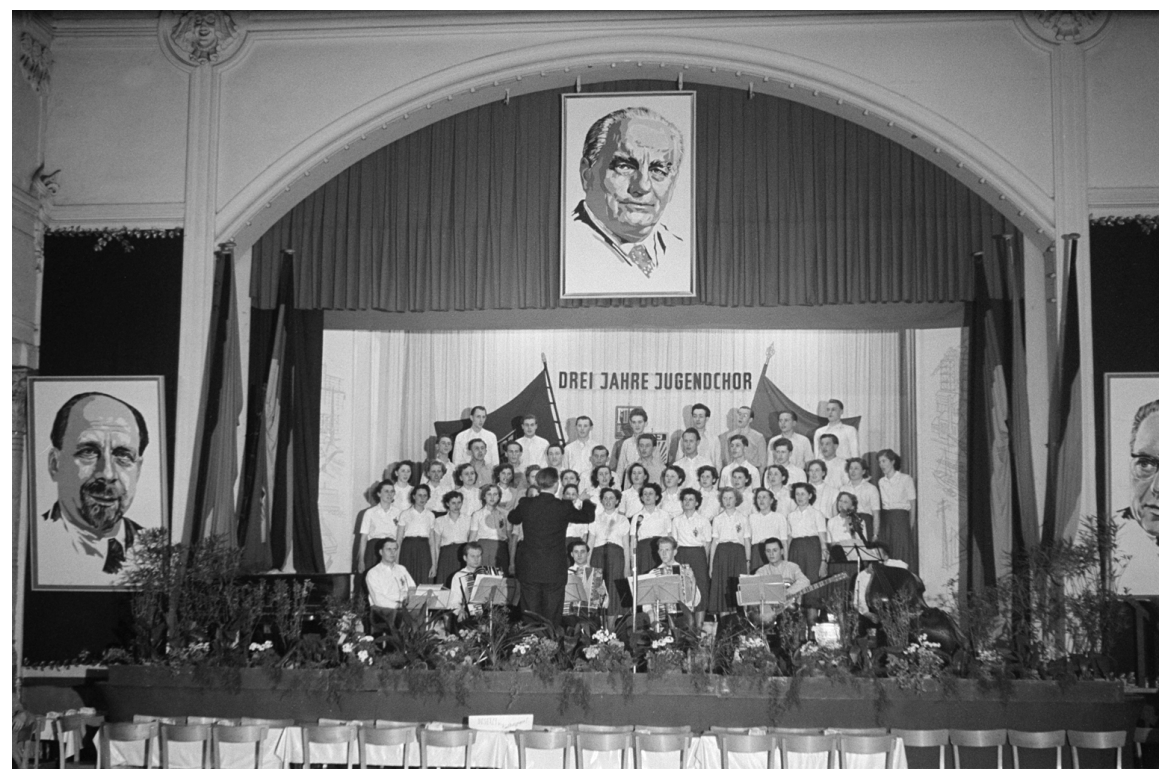

The choir and orchestra of the Leipzig Iron- and Steelworks on stage and surrounded by portraits, clockwise from left, of SED General Secretary Walter Ulbricht, President Wilhelm Pieck, and Prime Minister Otto Grotewohl (SLUB Dresden / Abt. Deutsche Fotothek, Roger \& Renate Rössing, October 1954).

\section{Rural Music Festivals in the GDR}

Both the SED and the PZPR made considerable efforts to bring music out to the countryside in order to extend politicized music to the most remote villages of each country. In Poland, this effort took the form of concerts organized by the state concert agency, Artos, discussed in the following chapter. The GDR's equivalent agency did the same, but East German cultural officials additionally worked to organize a large number of rural music festivals, known as the ländliche Musiktage. Music for the countryside became a focus of greater attention in the aftermath of the Uprising of June 17, 1953, when the party struggled to improve conditions for all sectors of society and convince all citizens of the SED's legitimacy and authority. The rural festivals aimed to serve as "the great culturalpolitical lever that will help us fulfill the demands of the Seventeenth Plenum," with its emphasis on the rural areas. ${ }^{91}$ The SED believed bringing music to the nonurban masses would help spread its message and establish legitimacy in all areas of the country.

The district of Rostock organized the first of what would come to be referred to as ländliche Musiktage from December 6-12, 1953. As the planning for these festivals began in advance of the party's intensified focus on rural areas, the Rostock district's festivals anticipated the leading edge of this adjustment in SED 
cultural policies. The goal of the cultural authorities in Rostock was to mobilize professional and amateur musicians to perform music for a wide and non-traditional audience. During that first iteration, 354 concerts took place in nearly every village in Rostock's seven sub-districts (Kreise) and attracted the impressive number of 40,000 listeners. The organizers in Rostock congratulated themselves for bringing serious music to those who had never heard it before, and made ambitious claims about winning the ears of the rural population for this music. ${ }^{92}$

Officials in the Ministry of Culture seized on the Rostock festival as a model for the proposed rural music festivals to be instituted all across the GDR. As with other areas of musical life, they concluded that the Rostock concerts "created an example of how the consciousness of humans can be developed in a progressive sense through the influence of music . . . this example will then be spread over all regions," and made it ministry policy to encourage at least one rural festival per district per year. ${ }^{93}$ To help jump-start the formation of these festivals, the ministry arranged for special financial support to be made available from the state cultural funds from 1954 to $1956 .{ }^{94}$ The ministry particularly prioritized the bringing of musical culture to the rural areas, since the officials believed that music represented "an effective means of political-educational work with respect to the masses. ${ }^{\circ 5}$ Officials felt these festivals provided a method of creating the model socialist citizen, and also helped to "overcome the cultural backwardness of the village. ${ }^{966}$ Alongside pedagogical aims, enjoyment and entertainment were of course also important goals of the concerts, as seen in the program booklet from the district of Grevesmühlen: "The aims of the festival are to bring joy and gaiety to our people through music, and to acquaint them with the works of our present and past masters." ${ }^{97}$ Professional and amateur musicians from city and countryside came together to perform for rural audiences during these festivals. Cultural officials thereby hoped to promote solidarity among different sectors of the population, and to realize the goals of collapsing the distinction between high and low culture, and between urban and rural citizens. In sum, cultural officials viewed these concerts as an effective way of making contact with and influencing the rural population while presenting the party's program in a positive light.

The rural festivals generally consisted of small-scale concerts, performed by local orchestras, chamber music groups, or soloists. Audiences numbered usually in the dozens, or sometimes hundreds. High-ranking officials in the ministry debated and experimented with the programming for these concerts in the different districts to strike a balance between ideological considerations and audience satisfaction. In the early days of the ländliche Musiktage in 1954, ministry officials pushed for more contemporary socialist-realist music at these festivals, but this strategy made it quite difficult to attract a sufficient audience, as happened at several concerts during Neubrandenburg's festivals in 1955 and $1956 .{ }^{98}$ A concert of serious music in Halle had similar problems, but at this early stage the ministry 
preferred to blame the population's low interest on the local officials' failure to work hard enough to convince people to come. ${ }^{99}$ At the other extreme, one series of concerts in Magdeburg featured Verdi arias, considered ideologically worthless by the central authorities, and the ministry came down hard on officials there for "orienting to the preferred wishes of the orchestra leaders, rather than taking into account the formation and education of the listeners." 100

A happy medium, which attracted respectable audience numbers while satisfying the ministry's push to have a political thrust behind the program, developed slowly. Playing less-demanding works by ideologically appropriate German masters pleased listeners while passing political muster; such concerts contributed to cultivating the classical tradition as defined by the party and also fulfilled the political goal of bringing culture to the masses. Other concerts featured gehobene Unterhaltungsmusik, or more refined light music, often written by contemporary composers and having at least a vaguely ideological cast. ${ }^{101}$ By 1956 , the ministry had made a tactical decision to reduce the number of politicized contemporary works in these concerts in order to educate the ears of rural populations more gradually. ${ }^{102}$ Concertgoers thus succeeded in negotiating for concerts they found more pleasing. If the party pushed programs consisting of strict socialist-realist works too far, the concert halls remained empty. Cultural officials acquiesced to programs that generally contained ideologically acceptable crowd-pleasers, with an occasional lighter contemporary work included as well.

The cultural departments of the governing council of each district bore responsibility for the organization of these rural festivals, and the ministry officials in Berlin encouraged them to coordinate effectively. The party viewed this project in explicitly cultural-political terms, and the ministry came down hard on those districts that did not put on good festivals. ${ }^{103}$ It constantly exhorted local officials to organize more fully and stretch the available funds as far as possible. The opinions of Leipzig district officials that the well-planned 1954 festival in subdistrict Torgau, with its ten concerts and 1000 listeners, simply did not accomplish enough in relation to the resources invested, did not deter the central ministry in Berlin from pushing its aims with renewed vigor in $1955 .{ }^{104}$ It criticized other districts strongly for not doing more; officials in Cottbus, for example, were taken to task for pushing most of the work onto the local branch of the state concert agency and relying too heavily on the local orchestra instead of trying to promote the involvement of amateur groups. ${ }^{105}$ In another case, the ministry reprimanded local officials in Magdeburg for not using festival subsidies properly, for presenting concerts that did not contribute to the ideological formation of the audiences (for instance, the concert of Verdi arias mentioned above), and for in general ignoring its "diverse recommendations." 106 Central Ministry officials constantly found themselves admonishing local officials for using funds to subsidize previ- 
ously planned concerts by local orchestras when that money was to be used for planning new concerts in the spirit of the ländliche Musiktage.

By 1957, these rural festivals had been taking place for several years, with the ministry well pleased at the progress in many regions, especially in the early model district of Rostock. Other districts, like Cottbus and Frankfurt/Oder, were less organized and had few or no festivals, despite continued pressure from the ministry in Berlin, in yet another example of central party authorities struggling to implement their aims. Nonetheless, the party and ministry considered the rural festivals a political and cultural success, as well as a key means of both spreading a message to a broader section of society and involving these citizens in its aims. The rural population generally seemed to attend and appreciate these festivals, especially after it had forced a recalibration to more entertaining and less politicized concerts around 1955 .

\section{Conclusion}

In the stalinist decade, the parties in both countries actively engaged artistic elites and society more broadly in creating a master symbolic narrative that embodied a progressive, humanist nationalism combined with socialism. Through the institution of music festivals of all kinds, cultural officials encouraged composers to assist them in creating this paradigm, which, for music, was embodied in the concept of socialist realism. Indeed, the participation of a sufficient number of composers was essential, as the parties could not attempt their domination of the symbolic world by force alone. The SED was mostly successful in establishing its political-cultural vision through the many festivals in the GDR, despite notable exceptions where composers proved able to negotiate and achieve some of their own, differing objectives. In Poland, the PZPR had great success with the first Festival of Polish Music, though party dominance began to break down after 1953. Thereafter, composers were able to carve out a great deal of autonomy with respect to the second Festival of Polish Music, and then emancipate themselves almost completely with the Warsaw Autumn festival starting in 1956.

Throughout both countries, amateur performers and concertgoers took part in and attended festivals stamped with the vision of the SED and PZPR. By participating in and attending these politically inflected events, they at minimum tacitly acknowledged the legitimacy of socialist rule. They sang and heard partyapproved works from the past, as well as the ideologized production of the present, and the messages expressed in these musical compositions filled the aural space of the concert hall and factory clubhouse. Of course, citizens could stay away from the concerts, and attendance was an abiding concern of the parties and festival organizers; tension always existed between fulfilling political goals through appropriate programming and performing popular, but ideologically 
worthless works that would guarantee a full house. Over time and through a process of give and take, officials arrived at concert programs that entertained and educated. The music festivals described here were one element of a symbolic universe that surrounded the composer, the factory worker, and the peasant, at leisure as well as at work. Though voices of dissent to the parties' aims were heard and negotiation of party goals did take place, for much of the period under consideration, most composers and much of the population willingly participated in the building of the socialist project through the medium of festivals. A similar dynamic motivated the organization of concert life more generally, the subject of the final chapter.

\section{Notes}

1 Mona Ozouf, La fête révolutionnaire, 1789-1799 (Paris: Editions Gallimard, 1976).

2 Michael P. Steinberg, Austria as Theater and Ideology: The Meaning of the Salzburg Festival (Ithaca: Cornell University Press, 1990).

3 Vernon L. Lidtke, The Alternative Culture: Socialist Labor in Imperial Germany (Oxford: Oxford University Press, 1985), 75-101; Frederic Spotts, Hitler and the Power of Aesthetics (Woodstock: Overlook Press, 2003).

4 James von Geldern, Bolshevik Festivals, 1917-1920 (Berkeley: University of California Press, 1993).

5 Katerina Clark, Petersburg: Crucible of Cultural Revolution (Cambridge, MA: Harvard University Press, 1995), 243-50.

6 Jerzy Jasieński, “Znaczenie Festiwalu Ludowej Muzyki Polskiej dla ruchu amatorskiego," $R M$, no. 9 (1949): 4-6.

7 AAN, KC PZPR, 237/XVIII-1, 44.

8 The complicated commissioning process is discussed in the previous chapter.

9 Zofia Lissa, Music in Poland, 1945-1955 (Warsaw: Polonia, 1955), 24.

10 Festiwal Muzyki Polskiej: program otwarcia, April 1951.

11 See especially AAN, MKiS, DIAiO, 41 and 42.

12 ZKP, 12/28, Protokóły, 11 November 1950 and 9 December 1950.

13 AAN, MKiS, DIAiO, 40, "Notatka o Festiwalu Muzyki Polskiej."

14 AAN, MKiS, DTA, 728, "Sprawozdanie Wydziału Muzyki DTA za I kwartal 1950 roku," 68.

15 This message was consistently emphasized in the press articles linked to the Festival; see ZKP, 12/121, esp. Jerzy Jasieński, "Poznajemy polską muzykę," Sztandar Młodych (21 April 1951).

16 ZKP, 12/92, "Protokół z konferencji kompozytorskiej," 4 February 1950, 2.

17 "Express rozmawia z czołowymi laureatami nagród FMP," Express Wieczorny, no. 9 (10 January 1952), in ZKP, 12/121.

18 Henryk Swolkień, "Rok 1951 w muzyce polskiej," Głos pracy, no. 16 (18 January 1952), in ZKP, 12/121.

19 AAN, MKiS, DIAiO, 38, Notatka o Festiwalu Muzyki Polskiej, 22 November 1950, 34-37; Tadeusz Marek, "Społeczny Aspekt Festiwalu Muzyki Muzyki Polskiej” in Festiwal Muzyki Polskiej: Finat (December 1951).

20 AAN, MKiS, DIAiO, 41, "Protokół z posiedzenia Buira FMP," 7 June 1950.

21 AAN, MKiS, DTA, 750, Informacja nr. 3, 140. 
22 AAN, MKiS, DTA, 719, Protokół 11, 16 February 1951, 50.

23 AAN, MKiS, DTA, 750, Informacja nr. 2, 117.

24 Tadeusz Szeligowski, "Wpływ Festiwalu Muzyki Polskiej na twótczość kompozytorów" in Festiwat Muzyki Polskiej: finat (Warsaw, 1951), 38.

25 AAN, MKiS, CZTOiF, 2738, "Plan pracy CZOFiIM na 1953," 1-3.

26 ZKP, 12/22, "Protokół surowy obrad rozszerzonego Plenum Zarządu Głównego ZKP," 16-17 December 1953, 21.

27 Ibid., 36.

28 AAN, KC PZPR, 237/XVIII-120, "Notatka w sprawie przygotowań do FMP," 11 October 1954, 53-57.

29 AAN, KC PZPR, 237/XVIII-143, "Protokół z narady poswieconej II FMP odbytej w Wydziału Kultury," 22 November 1954, 175-80.

30 AAN, KC PZPR, 237/XVIII-120, "Uwagi w sprawie przygotowań do FMP w 1955," 81-82.

31 Tadeusz Baird, "II Festiwal Muzyki Polskiej” Muzyka 6, no. 9-10 (1955): 26. For a specific example of the Union planning the Festival concerts, see ZKP, 12/23, Protokó z zebrania Rozszerzonego Plenum Zarządu Głównego ZKP, 6 March 1955.

32 Tadeusz Baird, "II Festiwal Muzyki Polskiej" Muzyka 6, no. 9-10 (1955): 32. This was a mixed blessing, as all the work fell on the composers, something about which they frequently complained.

33 Ibid.

34 AAN, KC PZPR, 237/XVIII-120, "Notatka w sprawie przygotowań do FMP," 11 October 1954, 53. See Andrzej Krywicki, Poststalinowski karnawat radości: V Światowy Festiwal Młodzieży i Studentów o Pokój i Przyjaźn, Warszawa 1955r. (Warsaw: Trio, 2009); David Tompkins, "Instrumentalizing Entertainment and Education: Early Cold War Music Festivals in East Germany and Poland" in Socialist Escapes: Breaking Away from Ideology and Everyday Routine in Eastern Europe, 1945-1989, edited by Cathleen M. Giustino, Catherine J. Plum, and Alexander Vari (New York: Berghahn Books, 2013), 27-47.

35 ZKP, 12/8, 28; Czesław Głubiński, "Po II Festivalu Muzyki Polskiej,” Głos Robotniczy, no. 140 (14 June 1955), in ZKP, 12/125.

36 Baird, "II FMP," 35-38; Jerzy Hordyński, "Z Krakowskimi Kompozytorami-o muzyce," Życie literackie, no. 26 (26 June 1955), in ZKP, 12/125.

37 ZKP, 12/95, "Stenogram z narady dyrygentów i kompozytorów," 13 September 1954.

38 Baird, "II FMP," 27-29. Baird later claimed that conductors and musicians had "warmly participated" in the process, but at the time of the Festival, he described great difficulty. Tadeusz Baird and Izabella Grzenkowicz, Rozmowy, szkice, refleksje (Kraków: PWM: 1982), 101.

39 For an exhaustive study of the Warsaw Autumn Festival, see Bylander, The Warsaw Autumn International Festival, 87-174, and the more recent study by Lisa Jakelski, The Changing Seasons of the Warsaw Autumn: Contemporary Music in Poland, 1960-1990 (Ph.D. diss., University of California-Berkeley, 2009).

40 The literature on jazz and popular music is immense. See especially Uta Poiger, Jazz, Rock, and Rebels: Cold War Politics and American Culture in a Divided Germany (Berkeley: University of California Press, 2000); Rüdiger Ritter and Gertrud Pickhan, eds., Jazz Behind the Iron Curtain (Frankfurt: Peter Lang, 2010); Christian SchmidtRost, "Heiße Rhythmen im Kalten Krieg: Swing und Jazz hören in der SBZ/DDR und der VR Polen (1945-1970) in Zeithistorischen Forschungen/Studies in Contemporary History, Online-Edition 8 (2011), http://www.zeithistorische-forschungen.de/ site/40209138/default.aspx. 
41 Lutosławski was one of the foreign observers at the conference and was quite critical of the cantatas for featuring boring music; he considered the one exception Paul Dessau's Call, referenced in the first chapter. Witold Lutosławski, "Festiwal współczesnej muzyki niemieckiej w Berlinie," Muzyka 1, no. 2 (1953): 38-41.

42 BArch, DR-1, 6128, "Diese Musik verstehen auch wir!: Ein Rückblick auf die Festtage zeitgenössischer Musik"” (no citation).

43 "Protokolle I. Jahreskonferenz," DMA, VDK, 155.

44 Ibid., 157-59.

45 BArch, DR-1, 7, "Einschätzung."

46 BArch, DR-1, 6128, "Niederschrift, betreffend Kongress und Festtage zeitgenössischer Musik des VDK," 19 July 1952.

47 "Protokoll I. Jahreskongresses des VDK," DMA, VDK, 185.

48 Ibid.; also see Zur Weihen, Komponieren, 315-16.

49 BArch, DR-1, 20, Arbeitsplan III/52 and Arbeitsbericht III/52; BArch, DR-1, 7, "Einschätzung des Kongresses der deutschen Komponisten und Musikwissenschaftler und der Festtage zeitgenössischer Musik," 11 September 1952, 1-4 (this date must be wrong as the report is in the past tense, indicating the Festtage were over).

50 BArch, DR-1, 206, "Protokoll zur Orchesterleitertagung," 5 June 1953, 3.

51 BArch, DR-1, 20, "Arbeitsplan der Staatlichen Kommission für Kunstangelegenheiten für das Jahr 1952," 9 November 1952.

52 SAPMO-BArch, DY-30, IV 2/9.06/281.

53 "bewußtseinsbildende Funktion." SAPMO-BArch, DY-30, IV 2/9.06/282, 28, 95, 241.

54 "Furchtbar! Entsetzlich!" SAPMO-BArch, DY-30, IV 2/9.06/282, 294. See the description of the Gerster symphony in chapter 1.

55 Ibid, 297. Raphael's piece was rhythmically complex, and perhaps difficult for the audience to understand. He also lived in the Federal Republic, and this may also have contributed to some of the negative reaction. The Sinfonia breve was played other times in the GDR as well, and one conference participant reported that in Jena, although most audience members did not appreciate it, a small number of "youth, students, but also workers" gave it "enthusiastic and continuous" applause; one student even wrote a letter to the local paper expressing high praise as he felt it captured the spirit of the times (303-304).

56 Ibid., 306-307.

57 Ibid., 308-10.

58 Ibid., 301-302.

59 Ibid., 336-39.

60 Ibid., 349-51.

61 Dietrich Brennecke, Das Lebenswerk Max Buttings (Leipzig: Deutscher Verlag für Musik, 1973), 124, 137; Butting, Musikgeschichte, 229-30.

62 SAPMO-BArch, DY-30, IV 2/9.06/282.

63 SAPMO-BArch, DY-30, IV 2/9.06/283, 42; also see Zur Weihen, Komponieren, 316-18.

64 SAPMO-BArch, DY-30, IV 2/9.06/281, "Satzung des Verband deutscher Komponisten und Musikwissenschaftler (Entwurf)," 92; see also Zur Weihen, Komponieren, 318. Recriminations continued after the congress; see Fidelio Finke's criticism of Notowicz in the Protokoll über die Zentralvorstandssitzung from 18 November 1954 in BArch, DR-1/40.

65 Controversy continued in the succeeding years on this very same issue; for the AllGerman Music Festival in Coburg in 1956, the Sekretariat overruled the commissions; these actions infuriated many composers and sparked acrimonious discussions at the 
1957 Union Congress ("Protokoll der Zentralen Delegiertenkonferenz," 23-24 February 1957, DMA, VDK; see also Zur Weihen, Komponieren, 318-24.).

66 BArch, DR-1, 42, letter from Uszkoreit, HA Musik, MfK to VDK in Berlin, 4 August 1955.

67 BArch, DR-1, 42, letter from Uszkoreit, HA Musik, MfK to Ref. Musik, Abt. Kultur, Rat des Bezirkes Leipzig, 22 August 1955.

68 BArch, DR-1, 42, letter from Mehmel, Stellv. Abt-Leiter, Rat des Bezirkes Leipzig, Abt. Kultur, Ref. Musik to Uszkoreit, MfK, 16 September 1955.

69 BArch, DR-1, 42, letter from VDK Leipzig to HA Musik, MfK, 25 November 1955. Uszkoreit was deeply disturbed by these proceedings, especially by the role of Köhler, who he faulted for his "pushiness" and "ideological immaturity." (BArch, DR-1, 42, 192, Letter from Uszkoreit to Notowicz, 15 September 1955.)

70 See articles in DR-1, 6128.

71 SAPMO-BArch, DY-30, IV 2/9.06/288, "Notizen über die II. Thüringische Festtage zeitgenössischer Musik in Weimar vom 4. bis 7. Juni 1954," 52-55.

72 "Protokoll I. Jahreskonferenz," DMA, VDK, 1.

73 BArch, DR-1, 108, Programm, II. Thüringische Festtage zeitgenössischer Musik.

74 SAPMO-BArch, DY-30, IV 2/9.06/288, Notizen, 61.

75 BArch, DR-1, 45, "Bericht über die Vorbereitung und Durchführung der Festtage zeitgenössischer Musik in Weimar," May 1955.

76 SAPMO-BArch, DY-30, IV 2/9.06/283, 134-35.

77 SAPMO-BArch, DY-30, IV 2/9.06/288, 39, letter from Stadtleitung, Stadtparteiorganisation Rheinsberg, SED, to ZK der SED, Abteilung Agitation/Kultur, 25 April 1952.

78 SAPMO-BArch, DY-30, IV 2/9.06/288, Program for the Rheinsberger Musiktage 1950, 22-27 August, 3-12.

79 SAPMO-BArch, DY-30, IV 2/9.06/288, Program for the Rheinsberger Musiktage 1951, 12-17 May 1951.

80 SAPMO-BArch, DY-30, IV 2/9.06/288, Program for the Rheinsberger Musiktage 1953, 47.

81 SAPMO-BArch, DY-30, IV 2/9.06/288, 15-18. Letter from Oberbürgermeister of Görlitz to Ottmar Gerster, VDK, 10/8/51. The mayor was attempting to convince the VDK to hold its 1952 Festival in Görlitz.

82 SAPMO-BArch, DY-30, IV 2/9.06/288, Program for the Görlitzer Musikwochen 1954, 30.

83 See programs in BArch, DR-1, 104 and 108, also SAPMO-BArch, DY-30/IV 2/9.06/288.

84 SAdK, Hans-Pischner-Archiv, 655.

85 Elżbieta Dziębowska, "Ruch amatorski," in Kultura Muzyczna Polski Ludowej, 19441955, edited by Józef Chomiński and Zofia Lissa (Kraków: PWM, 1957), 30.

86 AAN, KC PZPR, 237/VIII-425, 44-50.

87 BArch, DR-1, 315, "Der Aufschwung der deutschen Kultur," 60.

88 SAPMO-BArch, DY-30, IV 2/9.06/287, Programm, Deutsche Festspiele der Volkskunst.

89 BArch, DR-1, 108, Potsdamer Musiktage pamphlet, article by Lanke, Leiter der Abteilung für Kunstangelegenheiten, 1952.

90 SAPMO-BArch, DY-30, IV 2/9.06/16, "Betr. Wettbewerbe und Festspiele der Volkskunst 1954/54,” Büro des Sekretariats, Schöne Literatur und Kunst, 21 January 1953, 44.

91 BArch, DR-1, 9, Protokoll, 4 April 1955.

92 SAPMO-BArch, DY-30, IV 2/9.06/284, 94-96.

93 BArch, DR-1, 82, "Bericht zur Durchführung der Verordnung vom 10. Dezember 1953 auf dem Gebiete der Musik," 6 July 1954; BArch, DR-1, 8, "Vorschläge zur Verordnung vom 10.12.53," 12 April 1954. 
94 BArch, DR-1, 27, letter from Schott an alle Räte der Bezirke, Abt. Kultur, 25 October 1955.

95 BArch, DR-1, 107, letter from Schott, HA Musik, MfK, 3 April 1956.

96 BArch, DR-1, 138, "Erfahrungen aus den ländlichen Musiktagen“, HA Musik, Schott, 1 December 1954.

97 BArch, DR-1, 103, Program for the ländliche Musiktage, Kreis Grevemühlen, 4-11 December 1955.

98 BArch, DR-1, 138, “Erfahrungen;” BArch, DR-1/107, "Bericht über ländliche Musiktage," 13.1.57. Concerts with more traditional music gained interested audiences. (DR1/103, "Bericht: Auswertung in der Zeit vom 20.10. bis 20.11.56.")

99 BArch, DR-1, 138, Letter from Schott, HA Musik, MfK, Betr. Ländliche Musiktage in Halle, 1954, 14 January 1955.

100 BArch, DR-1, 103, letter from Fischer, HA Musik, MfK to Rat des Bezirkes, Magdeburg, 22 December 1955.

101 For example, the festival in Dresden in 1955. BArch, DR-1, 9, "Bericht über die Vorbereitung und Durchführung der ländlichen Musiktage in den einzelnen Bezirken, “ 8 December 1955.

102 BArch, DR-1, 103, “Auswertungsbericht Neubrandenburg, 25.9-2.10.55," and letter 30.6.52.

103 BArch, DR-1, 138.

104 BArch, DR-1, 138, letter from Scheidewind, Ref. Musik, Abt. Kultur, Leipzig, 1 December 1954.

105 The latter was a common problem; the ministry continually railed against use of their funds to pay for usual concerts by existing local orchestras. BArch, DR-1, 107, letter from Schott, HA Musik, MfK to Rat des Bezirkes Cottbus, 1 February 1956.

106 BArch, DR-1, 103, letters from Fischer, 22 December 1955, and from Schott to Rat des Bezirkes Magdeburg, Abt. Kultur, 10 April 1956. 



\section{Chapter Five}

\section{The Concert Landscape}

All over East Germany and Poland, from the hallowed chambers of the Berlin Staatsoper to the most basic public hall in the Polish countryside, music supported by state funds blanketed the landscape. Workers, peasants, and the traditional urban concertgoer encountered Bach and Chopin, but also cantatas about Stalin and mass songs praising the party, in performance spaces from traditional concert halls to factory clubhouses and rural venues. The entirety of this music, however, was not always what party officials, music ensemble directors, or audiences desired. Each group played a significant role in determining what music appeared in public venues, as struggles and negotiation marked the emergence of concert life in the proclaimed new socialist era.

In addition to music festivals, concerts more generally were an effective means to bring music to large numbers of East Germans and Poles. The parties aspired to influence both the programs and ensembles involved in the countless concerts, large and small, organized across the two countries. The PZPR and SED attempted to monopolize the organization of smaller-scale concerts through a monopolistic, national concert agency, and pushed to clear the field of private impresarios. Cultural officials also strove to influence the activities of the orchestral ensembles of the two countries, provoking varied responses from music directors and musicians. The parties engineered an explosion in the number of orchestras, with mixed results, and also struggled to maintain control over the programming of these ensembles. In all areas of concert life, aspirations to total domination were hindered by organizational and staffing challenges, stubborn and ambitious ensemble leaders, underqualified and unwilling performers, and concertgoers reluctant to accept programs stamped with the party's vision. Tension between disgruntled audiences and ambitious plans for a thoroughly ideological musical landscape forced officials to compromise, leading to the gradual emergence of the musical stage revue as well as other concert programs that both entertained and educated. 


\section{The State Concert Agencies}

The SED and the PZPR created extraordinary institutions that attempted to control most of the smaller-scale concerts organized in the two countries. ${ }^{1}$ The parties charged a state concert agency with the utopian goal of bringing music to workers and peasants in order to shape them into cultivated individuals. Both parties supplied the definition of cultivation and, through these institutions animated by a belief in the transformative power of music, organized performances appropriate to the "new socialist person." At the same time, cultural officials believed that they could secure the allegiance and loyalty of the population by bringing the best of past and contemporary music to untrained and presumably appreciative ears. To create a monopoly for approved music and thereby achieve control over the concert world, the parties struggled to eliminate any private concert agencies in a prolonged and fierce battle. These two sprawling and influential concert-organizing institutions-Artos and its successor the CZIE in Poland and the DVD and its replacement the DKGD in the GDR - faced challenges in mobilizing performers and casting an appealing yet ideological musical web over audiences.

In Poland, the formation of the state concert agency followed a pattern similar to the other institutions examined here: a basic template evolved and grew over the first years after the Second World War, achieved a certain stability by 1950 , peaked in influence in the early part of the next decade, and declined rapidly after 1953. In the immediate postwar period, the party created a Central Concert Bureau linked to the Polish Musicians' Trade Union to organize musical events. The party folded this institution into the State Organization for Artistic Events, Artos, in July of 1948, and then nationalized it as an official state organization on January $1,1950 .^{2}$ Artos continued to operate until late 1954, when the Ministry of Art and Culture dissolved and subsumed it as part of the general drive to reform during destalinization. This successor institution within the ministry, the Central Administration for Artistic Events (Centralny Zarzad Imprez Estradowych, or CZIE) then took over most Artos functions. ${ }^{3}$ The ministry had granted Artos monopoly rights to organize concerts in October 1951, though in reality neither it nor the CZIE ever enjoyed such absolute control. ${ }^{4}$ And although Artos officially operated independently from the state and PZPR apparatus until its reorganization into the CZIE in 1954, in practice it functioned like a department in the Ministry of Culture during the entire period, and indeed came under frequent and close scrutiny by state and party authorities. The central office in Warsaw had 110 workers in 1953; throughout the country, Artos employed 386 people in 1950, a number that rose to 869 by $1953 .{ }^{5}$ Both Artos and its successor the CZIE played an active role outside the capital with offices scattered across the country. ${ }^{6}$ This apparatus, both in Warsaw and the provinces, sought to direct the bulk of non-orchestral concerts throughout the country. 
The equivalent institution in the GDR took shape more slowly given the uncertainties surrounding the political fate of Eastern Germany. After the chaos of World War II, a plethora of public and private bodies took part in restarting concert life in the Soviet Zone. The former were regionally organized at first and grew in importance over the next several years, especially after many private concert organizers collapsed with the currency reform of 1948. In the next year in the freshly-minted GDR, the newly formed, nationwide German Performance Agency (Deutsche Veranstaltungsdienst, or DVD) absorbed these regional agencies. $^{7}$ The Stakuko, the Ministry of Culture's predecessor, took over the DVD in June 1951 in order to supervise more closely the organization of concerts and to help expand its role in creating ideologically appropriate programs. Then, on January 1, 1953, this organization became a state-owned enterprise, and was renamed the German Agency for Concerts and Guest Performances (Deutsche Konzert- und Gastspieldirektion, or DKGD). ${ }^{8}$ This organization, as well as state support for orchestras and musical performance more generally, made for a major expansion on the Nazi funding of thousands of concerts per year and subsidies for existing and several newly founded orchestras. ${ }^{9}$

By 1951, the East German agency had three main departments, including an Art Department that was the most important, in light of official emphasis on creating politically appropriate programs. ${ }^{10}$ Connected to the Art Department was a program committee that made recommendations regarding ideological and artistic facets of potential programs, an inspection commission (AbnahmeKommission) that consisted of representatives from relevant mass organizations and decided on the programs that would indeed be used, and an eight-person Autorenkollektiv that helped write new programs. As part of the New Course, officials added a further consultative body in 1954, a music council made up of composers, musicologists, and professors that met roughly bimonthly to advise the DKGD on its various projects. The GDR's concert agency employed 321 workers in 1952, including 117 in the main office in Berlin and 204 out in the six regional offices. ${ }^{11}$ Despite discussion of reducing the total number of workers, it in fact had risen to 416 by late 1954, as the number of regional offices ballooned to 15 , and 564 by $1957 .{ }^{12}$ The hundreds of employees in each country's agency testified to the importance the SED and PZPR placed on their work and mission.

\section{Personnel Challenges}

Both organizations desired to engage both highly qualified performers as well as administrative personnel in the project of educating, influencing, and entertaining their respective populations - with decidedly mixed results on all counts. Artos made use of a qualifying committee designed to evaluate whether musicians and singers possessed the necessary skills, a process largely limited to artistic, 
and not ideological, considerations. ${ }^{13}$ In practice, however, many performers in Artos-sponsored events had not been vetted by this committee, a situation Artos repeatedly vowed to rectify, with mixed results. ${ }^{14}$ Those who had in fact undergone committee scrutiny nonetheless often left much to be desired, as complaints about performers with dubious "moral" and artistic qualifications were rife. ${ }^{15}$ And even those individuals who had received the highest qualification did not always seem so talented in practice, thus prompting the leaders of the Music Department of Artos to demand requalification for questionable cases. ${ }^{16}$ Generally, the majority of performers in Artos productions received positive or acceptable evaluations, but negative assessments were all too frequent. One inspector rated an Olsztyn ensemble's performance on "a catastrophic level . . with gaffes of a political nature ... from the entire group not a single member is worthy of continued collaboration." ${ }^{\prime 17}$

Artos blamed part of this problem on its rapid expansion, which made it necessary for regional offices to use underqualified, inexperienced, and even amateur performers in its concerts. In the view of central Artos officials, this state of affairs was not only a disservice to audiences, but also to the artists themselves, as they often became ill while working under difficult conditions in the countryside, and in the longer term had their artistic development arrested. ${ }^{18}$ In general, Artos leaders wanted its administrators in the provinces to take more care in developing and employing performers. ${ }^{19}$ To this end, Artos organized ideological and vocational schooling for numerous artists, though officials often cancelled these courses due to lack of funds. In this inconsistent manner the party, through Artos, tried to shape these individuals as part of their goal of influencing all of society. Artos planned to drop the worst of the performers from its programs, even as it tried to expand its collaboration with quality artists. ${ }^{20}$ Tales of songs chaotically sung and instruments poorly played filled inspectors' reports, although positive reviews of some Artos productions also exist. ${ }^{21}$

The DVD/DKGD experienced similar criticism relating to its artists, and offered an identical explanation: that the organization's explosive growth and increased responsibilities forced it to use performers of varying and unproven quality. Unlike Artos, which tried to supply some artistic schooling for its performers, the East German agency blamed the Artists' Union for not providing proper training. ${ }^{22}$ Since it counted on this and other educational institutions to provide adequate artistic preparation, from an early stage the DVD/DKGD focused on "systematically attracting and systematically controlling" the best professional artists as well as young aspiring performers. ${ }^{23}$ This goal remained constant-in 1956 the organization's Music Council proposed to select and foster the best artists by giving them the most prestigious concerts. ${ }^{24}$

The porous border with the West added another consideration lacking in Poland, as DVD/DKGD officials could hire West German soloists and ensembles, 
which often attracted larger audiences, due probably to simple interest in the less familiar. The high-profile "Hour of Music," for example, engaged artists from the Federal Republic in roughly one out of every five concerts during the 195455 season and every seventh event in 1955-56. ${ }^{25}$ Ministry officials opposed this high percentage, as it claimed that 30 percent of the 2000 freelance musicians in the GDR were un- or underemployed. The latter individuals often complained bitterly about this and other perceived slights perpetrated by the DVD/DKGD. ${ }^{26}$ The tensions involved in attracting audiences while satisfying both party and musicians proved to be considerable.

The leaders of both the Polish and East German agencies also strove to have competent and politically aware administrators working for them at all levels of the organization. The cadre question proved a constantly vexing one in many cases, however, especially with respect to coordination between the central office and the provinces. From its initial years onwards, Artos in Poland constantly suffered from a "paucity" of good workers that made its work much more difficult. ${ }^{27}$ Both internal and external reviews revealed numerous problems with Artos employees. An internal report charged that "administrators skimp on their obligations ... even technical issues are fulfilled negligently and without a sense of responsibility." ${ }^{28}$ Artos attempted to justify these cadre problems by asserting that many of the workers they hired had already been rejected by other artsrelated institutions due to professional and political shortcomings, and that this small, problematic pool provided Artos its only job candidates. A related report claimed that many workers had formerly worked for private impresarios, and were thus "politically doubtful." ${ }^{29}$ In order to motivate its regional concert organizers to work more intensively and responsibly, Artos replaced fixed salaries with an incentive-based system, which it claimed it used fairly in contrast to the abusive practices of former impresarios. As with its performers, Artos placed hope in professional and political schooling for its workers, but here too intention and reality diverged. While Artos did sponsor a two-week course in 1954, another planned training session in 1956 was not carried out. ${ }^{30}$ The PZPR, through its primary party cells in Artos, also tried to effect changes among Artos personnel, especially with respect to "hooliganism, drunkenness, and immoral conduct." It was able to claim little success due to the alleged deaf ears of Artos leadership, as well as continued lax hiring of new workers of uncertain moral and political standing. ${ }^{31}$

With respect to programming, Artos's greatest problem seemed to be asserting control over its offices in the provinces. As a 1953 report put it, the leaders of the Warsaw, Łódź, and Szczecin offices worked well, but many others had not mastered their regions' problems or become an important factor in the cultural life of their areas. ${ }^{32}$ In a typical example, a party review of Artos's Gdańsk office faulted its director Aleksander Kostrzewa for not pushing his employees harder 
and exercising the necessary vigilance with respect to their political mistakes. The report also criticized other leading Artos administrators in Gdańsk for sloppy work and a lack of political preparation. ${ }^{33}$ Lublin's director Tadeusz Chyla also garnered the disapprobation of the party; in disregard of the regulations, he had been locally appointed without the Ministry of Culture's approval. The ministry also considered him overly ambitious and too sympathetic to musical groups "with clerical and sentimental overtones." ${ }^{34}$ Despite this criticism, he was not removed, and almost two years later regional government officials were still calling for his ouster due to his alleged dictatorial methods, his antipathy to party and state, and his refusal to hire party members. ${ }^{35}$ The Polish party's weakness throughout the country is quite evident here, as Artos, an organization it created, proved to be resistant to party influence on many levels.

The DVD/DKGD shared many of the same problems as its counterpart in Poland, especially with respect to finding qualified personnel. In its early days, it also hired former employees of private concert organizers, and agency Director Kurt Grösch complained they inappropriately asserted their expertise over more politically reliable workers in the DVD/DKGD. ${ }^{36}$ Another particular problem pertained to workers who possessed the requisite practical skills, but knew little about music, a state of affairs the Stakuko wanted to change. ${ }^{37}$ By 1953, DKGD leaders could praise themselves for having assembled "a cadre made up largely of socially aware employees," though they acknowledged that the agency did need to make some improvement. ${ }^{38}$ The Stakuko, however, was less confident in the DKGD employees, and proposed an extensive ideological and practical schooling program that involved a yearly two-week course for some workers, a training day twice a month for others, and two lesson-hours a week for employees in the regional offices. ${ }^{39}$ In the opinion of an inspection report, a further problem was simply over-hiring; the Berlin office, for example, employed 56 people instead of the approved $40.4^{40}$ These problems of underqualification and overstaffing, if anything, seemed to be even more intractable at the regional offices.

A confidential report by the Ministry for Culture in late 1954 demonstrated that many of these cadre problems had only gotten worse. Most of the DKGD's 57 central office employees at the time were not SED members - nine had in fact been in the "fascist" Wehrmacht - and only four had any professional training in the arts. The report reserved special criticism for Director Grösch. The inspectors accused him of a litany of errors, from drinking alcohol on the job to suppressing open discussion..$^{41}$ The Grösch era, which had begun in early 1952 with the advent of the Stakuko's centralized dirigisme, ended ignominiously in early 1957 with the appointment of Helmut Damerius as director. ${ }^{42}$

A lack of qualified personnel hindered the fulfillment of both agencies' broad aims. This cadre weakness was further compounded by frequent problems between the central and regional offices, especially in the case of Poland. Further- 
more, the regional officials often made concessions to audience taste, a theme explored below, which infuriated a central leadership striving for ideological purity. And both the Polish and East German agencies also encountered obstacles in finding performers who were both talented and disciplined, thus making it more difficult to carry out their project of bringing appropriate music to the workers and peasants of their respective countries. These manifold staffing problems hampered the two agencies' aims to permeate concert life with the desired political message.

\section{Ideological Mission}

Complications notwithstanding, infusing socialist ideals into an expanded musical world was the driving imperative behind the Polish and East German concert agencies. For its part, and despite its several incarnations, the basic goals of Artos remained generally constant over this period, and coalesced into two overarching aims: to organize party-sanctioned concerts for all members of Polish society, and to produce the content for these events by creating new repertoire and approving selected works from the past. As part of its plan to reach all citizens and "fight for the new listener," Artos pursued a three-pronged strategy of organizing smaller concerts in schools, in workplaces and factories, and in the countryside and small towns. ${ }^{43}$ Artos officials considered school concerts the most important, but factory and rural concerts took on increasing importance as Artos struggled to fulfill the PZPR's goal of bringing music to the working class and peasantry. Artos viewed its concerts as "essential for attracting the masses to music and for gradually forming them." 44

During its first years in the late 1940s, Artos attempted to establish itself by licensing performances and organizing concerts both in the countryside and factories, but also quickly turned to making its programs more ideological. ${ }^{45}$ Increasingly, Artos became involved in producing the content of the actual concerts, instead of merely approving or rejecting proposed performances. ${ }^{46}$ Preceding many concerts, vetted speeches placed the performance in an approved ideological context and praised the party's achievements in the cultural and wider political realm. Speakers proclaimed that the party had liberated music from the stranglehold of the bourgeoisie and that culture now rested in the hands of the workers. These didactic, introductory speeches also provided a new, socialist (and unsurprisingly predictable) interpretation of music history: Mozart was a progressive for his time, Chopin expressed the hopes and desires of progressive humanity, and Karol Szymanowski exhibited an awareness of the sufferings of the people through his music. ${ }^{47}$

While on the surface the East German agency's scope seemed more circumscribed than that of its Polish counterpart, in practice the DVD/DKGD did also 
develop ideologically appropriate programs and work with authors and composers, though this emphasis waxed and waned given the political situation. As with Artos, DVD/DKGD officials viewed themselves as bringing culture to the masses, and concentrated on factories and the countryside; school concerts were less of a priority than in Poland. ${ }^{48}$ As the official impresario of the state, the DVD/DKGD managed a wide variety of events, from concerts given by major orchestras like the Dresden Philharmonic or Leipzig's Gewandhaus orchestra, to small dance productions or recitals, and with an audience size from a few dozen to many thousands. These concerts sometimes took place in formal concert halls, but more frequently in factory clubhouses or modest venues out in rural areas. There was an early and constant push to work with the FDGB and other unions in order to reach new ears in factories and workplaces; a focus on attaining even the smallest village in the farthest-flung area of the countryside later complemented such aims. ${ }^{49}$

Both the East German and Polish agencies put great faith in the transformative power of music in the pursuit of explicitly ideological goals, and thus the concert agencies were key in reaching ears. Artos saw itself engaged in a "battle for the new listener," so as to "form the new citizen and rebuild his psyche." The DVD/DKGD's aims were quite similar, though they seemed to resonate with a particularly German sense of Bildung (cultivation). The agency's overarching goal was

to organize events with educative and consciousness-forming (bewusstseinsbildenden) character and to raise the cultural level of the population. The value of the DKGD's work ... is taking culturally and educationally valuable artworks in an understandable form to the broadest reaches of the population in both cities and the countryside, and filling people with enthusiasm for great works of art. ${ }^{51}$

Similar calls to "further develop and change the social consciousness of the workers" imbued the organization's ethos, and were connected to aspirations to "lift the cultural level of the workers." ${ }_{52}$ The DVD/DKGD sought to realize the Enlightenment project of bringing culture to the uncultivated in order to help form them into progressive human beings. A desire to transmit the best of German and world culture to the population was clearly on display here. It is also quite evident, however, that these activities intended to mold the population into model GDR citizens. Indeed, the DKGD's principal objective for 1954 was "to win the workers for the 'New Course' of the party through the means of art" and to foster patriotism and loyalty to the state. ${ }^{53}$

In the view of party leaders, however, the DKGD did not live up to its mission, and it came under heavy criticism in 1957, a time when the hardliners around Ulbricht reasserted stricter control. Alexander Abusch excoriated the 
agency's leaders at the Kulturkonferenz for "opportunistically" organizing popular programs without concentrating enough on ideological considerations. ${ }^{54}$ As mentioned, party leaders removed Director Kurt Grösch, and they pressed the new leadership to exercise more ideological and centralized control. ${ }^{55}$ The DKGD explicitly reiterated its aims at this time by asserting that the introduction of the best of both past and contemporary music from Germany and the Soviet bloc countries should influence the population to be more patriotic, motivated, and socialist. ${ }^{56}$

Although well over half of Artos's concerts took place in schools rather than in workplaces or the countryside, the numbers of concerts and attendees in Poland lagged behind equivalent statistics for the GDR, a state of affairs that suggests that the East Germans were more successful than the Poles in reaching their peasants and workers. For Poland, the figures are: ${ }^{57}$

$\begin{array}{lll}1950 & 6,162 \text { events } & 2,117,592 \text { spectators } \\ 1951 & 8,642 & 3,804,099 \\ 1952 & 11,335 & 4,848,272 \\ 1953 \text { (planned) } & 14,807 & 5,011,370\end{array}$

While for the GDR: ${ }^{58}$

1952

1953

1954

1955
20,214 events

29,821

(unavailable) $^{59}$

34,389
$6,350,000$ spectators

$10,700,000$

$12,000,000$

Though these figures are undoubtedly somewhat exaggerated, since officials pressured the agencies to demonstrate success, such inflation was probably slight due to internal control, especially in the case of the GDR. Both countries showed spectacular increases in both the numbers of events and attendees. The significantly higher figures for the GDR indicate a more modernized society, a more highly developed musical infrastructure, and a more involved party. The East German numbers are even more impressive since they do not include most school concerts, a fact that demonstrates a much higher penetration of factories and the countryside than in Poland.

A small but not insignificant ideological goal was that of increasing the unity of and understanding within the socialist bloc, and thus each country's agency had a hand in organizing guest performances of artists from the other country. Despite the relatively cool high-level relations between Poland and the GDR, officials worked both to promote a positive image of their country's music to citizens of the other, and also to present the other's music in a positive light. One notable example was a visit to Poland from Dresden's Kreuzchor, a boys' choir, which performed Bach, Wagner, and even PZPR member Jan Maklakiewicz's song The Traktor Driver and the Girl (Traktorzysta i dziewczyna). ${ }^{60}$ This performance was 
part of a larger "Week of Progressive German Culture" in the fall of 1954. At home, the East Germans similarly organized weeks of friendship that featured Polish ensembles performing both contemporary music and that of past masters ${ }^{61}$

Both agencies had lofty ideological goals in their mission to bring musical culture to a broad cross-section of their respective societies, and they did achieve considerable success. They thereby carried out one of the parties' stated aims - to democratize culture and attempt to elevate every citizen. These efforts, the SED and PZPR hoped, would earn them legitimacy in the eyes of their respective peoples. Through the experience of attending party-organized concerts and hearing party-approved music, the state concert agencies hoped that workers and peasants would be shaped in the way the parties desired.

\section{Concert Programs and Audience Response}

Party and concert agency officials in both countries considered influence over the ideological context of these events more important than the sheer number of concerts, however. The authorities screened older works from each country's classical heritage before they granted performance approval, as they wanted to present a particular image of important national composers and shape the message communicated by this music. The agencies also paid considerable attention to works by composers from other countries, as well as more serious programs of folk music. The main push, however, was for new, ideologically tinged works that would aid in the creation of the new socialist person, and this effort often took the form of the musical stage revue (Estradenkonzert or impreza estradowa) in response to audience taste. In general, officials linked both serious and light programs to current political events and filled them with explicitly ideological themes. Sometimes concerts coincided with an artistic commemoration, which also generally contained some political overtones.

Unsurprisingly, the works of Poland's primary musical legend Frédéric (Fryderyk) Chopin featured in many of the concerts organized by Artos. A massive cultural mobilization took place in 1949 for the $100^{\text {th }}$ anniversary of Chopin's death, and Artos participated by organizing a large number of events. For example, in Szczecin the local branch planned no less than 43 concerts in factories and other workplaces. ${ }^{62}$ Artos also programmed Chopin's music frequently in concerts linked to various political events, as the party strove to establish legitimacy by linking itself to this powerful and respected symbol of the Polish nation. The specific works chosen and the manner of their presentation were of concern to Artos, since its officials had been criticized for Chopin programs that were "chaotic and random." ${ }^{63}$ 


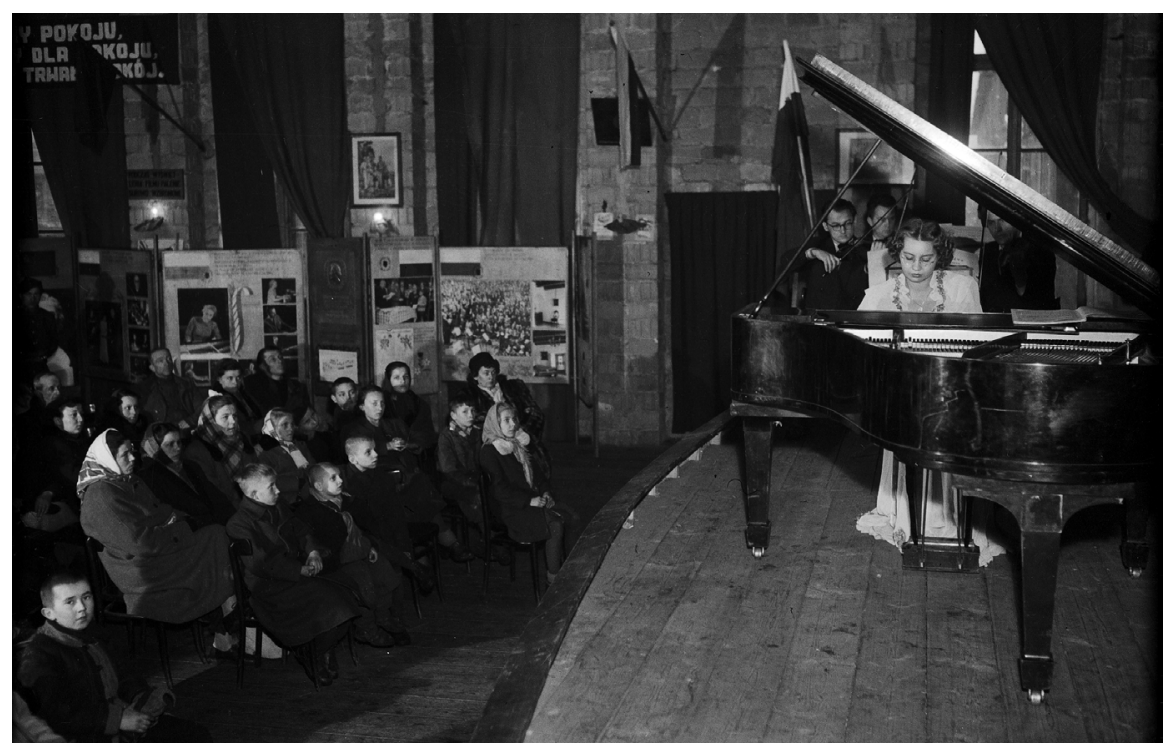

A February 1951 concert by pianist Barbara Hesse-Bukowska for workers and their families at a factory in the Warsaw neighborhood of Żerań on the occasion of the $141^{\text {st }}$ anniversary of Chopin's birthday. Note the slogan about "peace" in the upper left and the warm clothes worn by the audience members in the likely unheated hall (PAP 11647/4, CAF Kondracki).

Other notable Polish composers from the past also received attention on anniversary occasions, as Artos endeavored to fulfill the party's desire to be seen as both the rightful heir of a progressive Polish cultural tradition and the entity that brought this culture to all sections of society. Concerts frequently featured the esteemed nineteenth-century opera and song composer, Stanisław Moniuszko, especially around the time of the $80^{\text {th }}$ anniversary of his death in 1952 . The influential Karol Szymanowski posed more problems because cultural officials considered many of his works formalist, but the party nonetheless claimed him as well due to his patriotism and worldwide fame. On the occasion of the fifteenth anniversary of his death in 1952, Artos organized concerts all over the country. ${ }^{64}$ For these events, authorities often selected Szymanowski's folk-based late works and largely avoided his earlier, more modernist compositions. ${ }^{65}$

In didactic concerts with names like "Polish Music in Its Historical Development" and "Travels along the Musical Score," the party introduced new listeners to the great works of the Polish canon. A small but significant number of concerts featured compositions by contemporary Polish composers. ${ }^{66}$ Also frequently played were the traditional German classical composers, now defined as representatives of a progressive German political-cultural tradition. Typical concerts included one featuring Beethoven in a cycle entitled "Composer Profiles," or series of concerts related to a composer anniversary. Other common programs 
included "An Evening of ..." structured around a certain genre of music like the waltz, aria, or sonata. ${ }^{67}$ Other composers that received special attention in the typical year of 1954 were Ludomir Różycki, Henryk Wieniawski, Mussorgsky, Tchaikovsky, Bach, Schubert, Mozart, and Rossini. ${ }^{68}$ The presence of the Russians perhaps stands out, but this eclectic list would seem to indicate a desire to bring the best of the national and international musical tradition to the Polish population. Polish audiences, however, did not necessarily appreciate all of these composers. A 1952 internal analysis of the popularity of Artos's programs found that the best-attended were those that included opera arias, especially those by Moniuszko, Verdi, Bizet, and Puccini. Recitals by well-known performers came a close second. Moderately popular were programs of light and dance music, and least popular were chamber music concerts. ${ }^{69}$ The key factor overall seemed to be melody, as audiences strongly favored music of a lyrical nature, from light music to that of Soviet composers. ${ }^{70}$

Like the Polish authorities, East German officials also sought to bring the workers and peasants the best of the classical musical tradition, as well as contemporary works by both Germans and composers from the other socialist countries. ${ }^{71}$ Also as in Poland, the DVD/DKGD, where possible, linked its concerts to composer anniversaries or important political holidays. ${ }^{72}$ Particularly noteworthy here are the $200^{\text {th }}$ anniversary of Bach's death in 1950 and the $125^{\text {th }}$ anniversary of Beethoven's in 1952, with both cast as progressive for their time, and resulting in a spirited jousting with the Federal Republic to define their legacies. ${ }^{73}$ In general, programs contained "a positive approach to life and were optimistic and formative" and were also to "relate to societal problems." ful programs and those entertaining on an elevated level are desired . . . joy in life should be encouraged and the productive energies of the workers should be further developed." 75 But these concerts were not just about entertainment: "The main aim of the programming of the DKGD must be to influence the developmental process of the masses." ${ }^{\text {76 }}$ The party clearly attempted to determine how this development would take place, even as they worked on making it fun, too.

Indeed, the cultural authorities and the DVD/DKGD formulated specific goals for the content of the programs. Each regional office should feature "quality" music in 60 percent of its events, with theater and cabaret 30 percent and other genres 10 percent. ${ }^{77}$ Reaching this goal of 60 percent for musical programs proved challenging for the regional representatives of the concert agency. As frustrated local officials noted in 1953, this aim was "in no way reached ... and we ask for a change, if necessary through the prevention of pure entertainment and cabaret programs." ${ }^{78}$ Cultural officials wanted more concerts of serious music, and had to contend with popular pressure for lighter fare.

Despite protests from concertgoers, German authorities also included a high percentage of contemporary music in their programs. Agency guidelines man- 
dated that, of the musical events, half featured Volksmusik and half serious music, with the latter broken into 50 percent of past masters, 25 percent of music from the USSR and Soviet bloc countries, and a final quarter of contemporary music from all over the world, but mostly the GDR. ${ }^{79}$ The amount of contemporary music differentiated the GDR's agency from its counterpart in Poland; the DVD/DKGD made a sustained push to reach this 25 percent, and indeed to exceed it. ${ }^{80}$ By 1957, of the 114 programs played by DKGD-engaged soloists, 71 percent contained at least one work by a contemporary composer. ${ }^{81}$ This push for more serious and contemporary works met with varying reactions from audiences. Lighter programs, like the Volkslieder and contemporary songs played by the Dresdner Heimat-Quintett, garnered frequent and positive feedback from concertgoers. ${ }^{82}$ More serious programs often received negative reactions from audiences, but the DKGD central authorities tried to maintain a firm line. Regional cultural officials complained that people were less interested in contemporary works because they favored lighter music and disliked concerts on too high of a level or too "high quality." ${ }^{83}$ Nonetheless, in 1957 the DKGD leadership still pursued the same policy: "Despite protests from the audience, we will not lower the current number of contemporary works." ${ }^{84}$ All this produced an unsurprising reaction from audiences - they often avoided such events. One official from Neubrandenburg related that people stayed away from concerts advertised as chamber or orchestral music, and a 1956 Berlin newspaper article described the all-too-common situation of a chamber concert with an audience of ten. ${ }^{85}$ The central DVD/DGKD administrators confronted the thorny dilemma of balancing politicized and demanding programs with the desires of the population, and strongly favored the former.

However, the programming policy developed in the DVD/DKGD main offices at times differed from concert reality out in the East German provinces. Local officials often did not follow the tough official line and defied central control by organizing less ideological, but more entertaining concerts so as to attract audiences - an attempt to fulfill the directive to reach more people and use resources effectively, while also satisfying the local population. In response, a key official report on the Berlin region condemned the practice of organizing more light concerts in place of serious ones in order to make more money and meet budgetary goals. ${ }^{86}$ The DVD/DKGD had at best only limited success, as a Ministry of Culture official complained in 1957: "The leadership of the DKGD did not endeavor to develop a socialist culture and only supported the creation of progressive programs in a small way. In contrast, it wasted large sums of developmental money on a large number of petty bourgeois programs that had no cultural-political or material effect." ${ }^{87}$ During the thaw years after 1953, some in the concert agency's ranks attempted to compromise between the demands of the party and the desires of the concertgoers, and in the end displeased both. 
The jewel in the DKGD's crown, and a moderate achievement in this context, was a concert series with soloists, chamber groups and small ensembles, developed in 1953 and entitled the "Hour of Music." The prospectus for the series clearly describes the intent:

The "Hour of Music" should offer our people the experience of great art in exemplary renditions. We are attempting to realize this goal through diverse programs, in which both the classical cultural heritage as well as contemporary works of all nations are focused upon, and through the participation of our greatest artistic talents.

Music is a living force that strengthens, forms, and educates us for the great tasks of our time.

Let the "Hour of Music" help our working people in cities and the country to make their lives richer and more beautiful..$^{88}$

The alleged power of music to shape and motivate the country's citizens inspired this initiative, and indeed the "Hour" aimed to focus largely on workers in factories and the countryside. The goal of the second season in 1954-55 was to present roughly half of the concerts in factories. ${ }^{89}$ Audiences were small in the first several years, with an average of 205 to $225 .{ }^{90}$ Roughly three-quarters of the performers came from the GDR, but 13 to 18 percent were West German, and a few musicians came from the Soviet Union and other bloc countries. The DKGD demanded that contemporary works be included in the concert programs, and eventually instituted a policy where each concert would have at least one contemporary work from the country of the soloist or ensemble. ${ }^{91}$ In the 1345 concerts of the 1954-55 season, 103 out of 220 performed composers were contemporary, including 33 from the GDR. ${ }^{92}$ These high numbers continued during the 1955-56 season, as nearly half of the works performed were by contemporary composers. ${ }^{93}$ The "Hour" fulfilled a niche mapped out by the DKGD: to bring serious music by past and present masters to the people of the GDR. Despite numerous organizational problems, the "Hour" did prove to be a modest success with concertgoers. ${ }^{94}$ To generate more enthusiasm for party-approved musical initiatives, East German authorities also developed the concept of a less-serious "Hour of Music" that would also offer quality fare by competent musicians, but of a lighter nature and with explanatory lectures given by noted composers and musicologists. ${ }^{95}$

In Poland, Artos did not have the same success with its lighter fare as it did organizing more serious programs. One step down from concerts featuring Chopin and the like included frequent and popular concerts of opera and operetta arias, especially those of Verdi and Puccini. ${ }^{96}$ Another popular program focused exclusively on nineteenth-century French composers like Massenet, Halevy, and Meyerbeer. ${ }^{97}$ Most, however, were mixtures of the usual Italian and German clas- 
sics, with perhaps a greater number of Russian and Czech pieces than might be expected. Artos administrators pushed for more Polish, Russian, and Soviet selections in these programs, but appear to have had only limited success. The audiences desired more traditional music, and local authorities in large measure acquiesced, in a significant difference from their counterparts in East Germany, who attempted to program less Verdi and more socialist realism. ${ }^{98}$ Artos used two traveling operatic troupes in the early 1950s: "Janek" played to sold-out venues on a regular basis (here again, central administrators constantly desired to make the programs more ideologically appropriate), and "Pajacy" got underway by $1954 .{ }^{99}$

Operettas were more problematic for Artos officials, who disapproved of their often frivolous and "bourgeois" subject matter, while the public enjoyed them greatly. Operetta had a particularly contradictory history in the Soviet Union, as this art form was originally considered bourgeois and unsuited to a revolutionary program, and operetta theaters were frequently closed down in the first years after the revolution. Thereafter, however, both traditional Viennese operettas as well as indigenous folk musicals were standard offerings. ${ }^{100}$ In Poland, Artos attempted to control the productions of these popular Viennese operettas as well as to encourage the production of new, ideologically appropriate ones. ${ }^{101}$ In one typical example, Artos granted a license for a company to produce Franz Lehár's The Land of Smiles in 1953, but found the production to be "ill-prepared and on a low artistic level." That it nonetheless achieved great success and unusually full performance halls prompted Artos to focus on better and more appropriate operetta programs. ${ }^{102}$ Artos's success at changing operetta programming was at best limited, as The Land of Smiles continued to be poorly produced in 1955. ${ }^{103}$ Reviewers also targeted other operettas from Artos' successor institution; in October 1955, three inspectors attended a performance of Paul Abraham's 1930 operetta Victoria and her Hussar. They deplored the libretto for being "naïve and banal," but interestingly did not comment on the negative portrayal of the Russians or the heroic American protagonist. While criticizing the orchestra, ballet, and choir, they remarked that the director saved the production from being "trash" and noted that the audience was highly appreciative and asked for encores. ${ }^{104}$ Here as elsewhere, the desires of the population trumped the political demands of the party, as politically inappropriate operettas played to full houses around Poland.

In its early years especially, the DVD/DKGD also organized a large number of concerts with selections from operas and operettas. Its leaders, however, recommended that operetta music never feature as the main content of a program, but rather be used for lighter moments in concerts devoted to other music. ${ }^{105}$ East German cultural officials also pushed for ideologically suitable new operettas, but without much success save for Eberhard Schmidt's Bolero (1952), set in the 
Spain of Cervantes and portraying the poet's links to the fight of the peasantry against its oppressors. ${ }^{106}$ In both countries, opera and operetta were particular crowd pleasers, and the two agencies struggled to reconcile this popularity with the nature and amount of this music played.

Both in Poland and the GDR, authorities frequently linked concerts to various political celebrations, anniversaries, and holidays in order to associate partyapproved music with leisure and relaxation. For example, Artos organized a large-scale series of concerts all over Poland tied to the "Month of Polish-Russian Friendship" of 1948, which started on October 7 and culminated with commemorations of the Russian Revolution on November 7. These concerts unsurprisingly featured a good deal of Russian, Soviet, and Polish music. ${ }^{107}$ In one area of Silesia during the following year's celebrations, Artos organized 96 events consisting mostly of Polish and Russian songs, and attracted some 50,000 people. According to the local party authorities, the programs had an "appropriate ideological and artistic level," and audiences attended with "great respect and enthusiasm" and responded with "lively applause." 108 The governmental authorities in Silesia complained, however, that the concerts were a success almost in spite of themselves, as Artos exhibited "weak control" as well as "incompetence and a lack of initiative." 109 Lublin's cultural administrators took a negative view of Artos' performance, complaining that the featured works often had little to do with the occasion, and that poor organization resulted in flawed events. ${ }^{110}$ In the Kraków region, Artos seemed to do a better job, where the local officials praised Artos for organizing 248 concerts, largely in factories and workplaces. Over 100,000 spectators in the area heard Soviet songs and other music, and excepting one case of an "undisciplined audience," officials reported enthusiastic responses and a "political-propaganda" success. ${ }^{111}$ In Szczecin, almost 15,000 agricultural workers responded "quite warmly" to concerts of Soviet music, but the local government administrators were somewhat critical of the performances of the same overplayed Soviet repertoire. ${ }^{12}$ Artos's involvement also included numerous school concerts, which hewed closely to the appropriate political line. The ministry's Musical Department Director Paweł Kruk, who explained in reference to these celebrations: "music is propaganda," would have been quite pleased. ${ }^{113}$ Because all of these reports come from party officials, it is hard to determine if the events were as successful as these comments suggest, but the copious negative criticism also in these sources lends them credibility. In the end, Artos did organize concerts of Soviet music attended and at least moderately enjoyed by hundreds of thousands of Polish workers, peasants, and students.

Artos also provided musical entertainment for the wave of celebrations linked to the unification of the two workers' parties in December 1948. For over 100,000 concertgoers, it organized 164 concerts that included violin pieces by Dvořák, Mussorgsky, and Henryk Wieniawski, vocal works by Polish and Rus- 
sian composers, and recitations of poetry. Officials claimed "the arts were reaching the shop floors and the hearts of workers." And indeed, a factory committee in Żyrardów related that its audience reacted "with great satisfaction and thunderous applause," and the leaders of the State Alcohol Monopoly factory in Warsaw asked for more such events, because "they entertain, and educate." ${ }^{114}$ While these comments came from party members within the various factories, they do seem to indicate engagement with the music.

Artos further enhanced other important holidays with musical performances. The birthdays of important political leaders like Stalin and president Bolesław Bierut, May 1 and the July 22 liberation day, various elections, and the ratification of the new constitution in 1952 all provided symbolic occasions to shape the new socialist person with music. Officials chose music from traditional Polish, Russian, or Soviet composers in addition to the usual festive works by the great nineteenth-century German composers, and mixed in a few contemporary mass songs. ${ }^{115}$ For the GDR, a similar list of commemorative events provided the DVD/ DKGD with opportunities to organize entertaining and didactic programs. ${ }^{116} \mathrm{Au}-$ thorities linked the gravity and prestige of music to events considered important by the parties as a means to legitimize and celebrate their rule.

Both agencies thus placed considerable emphasis on programs of contemporary and classical European music. In theory, this music communicated an ideological message to millions in both countries. Indeed, especially in East Germany, authorities could count some successes, especially those concerts relating to the transmission of a particular take on each country's musical heritage. In practice, however, the kind of musical "education" authorities had in mind did not reach the hoped-for larger numbers. Despite the best efforts of the agencies, many concerts were poorly planned or simply contained music without the desired ideological focus. The GDR's agency did a much better job of maintaining a consistent message, but in both countries regional officials sometimes bowed to audience demand for lighter programs with less explicit political content.

\section{The Musical Stage Revue as Compromise}

Audiences in both countries pushed back against concerts that skewed too political without also entertaining, and a tacitly negotiated solution emerged. In response to the difficulties in creating ideologically appropriate programs that also diverted, cultural authorities in both countries worked to develop new genres of musical performance in the early 1950s. This imperative crystallized around the concept of the impreza estradowa or Estradenkonzert, a lightly politicized stage revue that combined song, instrumental music, and spoken word in a musical variety show. A konferansjer or Conferencier (narrator or emcee) linked the songs and sketches and played a crucial role in communicating a political message. The 
goal was to produce a cabaret-like performance that would combine light entertainment with an ideological message in an attempt to entertain and influence urban and rural audiences. Both countries had, of course, long traditions of staged musical-theatrical events, from carnivals up through the more recent cabaret. The most contemporary template, however, was an import from the Soviet Union that used the term estrada to refer to a wide variety of staged performances. After many variations and buffeting in the political winds of the 1920s and 1930s there, it developed into a generalized appellation for staged light entertainment. ${ }^{117}$ The state concert agencies in Poland and East Germany explicitly modeled themselves on the Soviet experience. ${ }^{118}$

Throughout the first half of the 1950s, Artos officials struggled to square the circle of the ideologically appropriate, entertaining event, and focused on the challenge of creating and producing quality imprezy estradowe. ${ }^{119}$ Officials proved able to identify what was not acceptable, but had a very difficult time developing appropriate programs themselves. In 1950, an Artos inspector heavily criticized two widely seen performances in this new genre, "Summer Humor" and "Laughs above the Norm," for being "typical examples of a petty-bourgeois review and of a very low standard," code for banal entertainment that did not politically edify. The Artos administrator responsible for this programming acknowledged its weaknesses and claimed new, more appropriate productions were in the works - but the aforementioned two would continue to be performed for yet another month due to the lack of any other options. ${ }^{120}$ A fairly typical estradowa program included a Paderewski minuet, a Russian song, several contemporary Polish mass songs, and a handful of political sketches. Throughout the performance, the emcee was supposed to provide lively comments and jokes with a political edge. ${ }^{121}$ Common ideological themes included friendship with the Soviet Union, the building of communism, reconstruction of the country, and peace. ${ }^{122}$ Artos also translated songs from the Soviet Union and the other people's democracies to provide appropriate material for these programs. ${ }^{123}$

Program development remained a considerable problem for Artos, which received massive criticism from within and without for its activities in this area. A spate of evaluations in 1953 heavily criticized these performances for "thoughtless and conception-less medleys" and advised Artos to "withdraw programs devoid of ideals, which are harmful due to their low standard and lack of appropriate content." ${ }^{24}$ Another inspector excoriated Artos's imprezy estradowe for their poor organization and muddled ideological content. He described a typical Artos program as including an introductory song followed by the reading of a newspaper article on politics and a few stale jokes, then two Russian or Soviet songs, a political sketch, two contemporary songs (often prewar songs with new words), a political poem and feuilleton, then a final song by the entire ensemble. 
This inspector asserted that such unoriginal and pointless programs neither aided the party's goals nor entertained the audience. ${ }^{125}$

A few of these reports did credit Artos with some progress since its early days, but the praise was faint and only positive in its relative context. By 1954, party cultural officials noted that improvements had been made on programs formerly rife with "serious political blunders, vulgar and insipid jokes . . . cheap sentimentalism, and artistic and literary mediocrity." ${ }^{126}$ One inspector described Artos's early programs as "insipid . . . including prewar trash . . . boring." He called for programs that were "cheerful, with an optimistic look at the world, funny, and including scathing satire" to attract audiences unreceptive as a result of Artos's previous programs. ${ }^{127}$

On the local and regional level, Artos officials often could not live up to central planners' goals. For example, a group of party officials initially praised a planned Gdańsk performance of "Meeting at Ania's" (Spotkanie u Ani) for focusing on a contemporary political theme, in this case, the life of a young female tractor driver. ${ }^{128}$ In its actual production, however, some of these same officials found much to criticize. The director of the ensemble had added new material to a script sent out by the central offices in Warsaw, but had allegedly not thought through the political implications of these changes. The inspectors found that the mix of new and original text created an "ideologically flawed" picture of Ania, and that in general the production did not hold together well. ${ }^{129}$

A more typical medley of songs and texts for the countryside, "Give Us a Happy Face" (Prosimy o przyjemny wyraz twarzy), also met with significant criticism by central inspectors due its lack of political punch. One reviewer felt the mix of Polish and Russian songs leaned too far towards the latter, thus potentially boring the audience, and the texts did not adequately engage the political problems of the day. The inspectors characterized the texts to songs like "The Wasters of Raw Materials" (Brakoroby), "Beatnik" (Bikiniarz), and "The Drunk and the Swine" (Pijak i świnia) as dealing with political issues unimportant to a rural audience. A song asking citizens to subordinate love to work was recommended for deletion, as they considered such exhortations simply too far from reality. Other aspects of the program supposedly gave the impression of "prewar trash" and inspectors blamed in large part the Artistic Director in Gdańsk, who had written many of the supplementary texts. ${ }^{130}$

A 1953 inspection of the regional office in Lublin produced criticism of "A Common Story" (Zwykta historia), a stage revue made up of fourteen songs and sketches. The central office in Warsaw sent the material, but the inspector found it inappropriate for the rural audiences in this eastern region. He labeled one song, "On Bureaucracy," of poor quality, and implausible and irrelevant to the countryside. Another about the advance of women as well as "The Apartment Speculator" were also criticized for being far from the concerns of this rural region's 
audiences, and the latter was even called "yesterday's problem." In general, he deemed the program politically inappropriate. ${ }^{131}$

Such negative examples were legion. While Artos inspectors did sometimes praise programs and performers, the majority of their evaluations were critical, and often extremely so. All too frequently, inspectors found the music "shrill and chaotic," the performers "lacking taste," the program "haphazard" or "hopelessly stupid," and the overall impression of the performance "devoid of artistic experience and has not the slightest reason to exist" or even a "total mistake." 132 Often the audience was small and bored; an extreme but generally not untypical example included "ninety percent hooligans . . . who smoked cigarettes, conversed, laughed, and made loud and rude comments to the performers." ${ }^{133}$ One performance for workers moved the inspector to write: "My impression of the entirety was unbelievably unpleasant and sad ... the [song] texts in most cases were nonsensical, pornographic, and had a destructive effect on the taste of this new audience. The performance was ideologically and artistically harmful." ${ }^{134}$ By 1954, six years after the founding of Artos, it continued to be criticized for using stale or inappropriate material, having low artistic standards, and employing nonideological, poorly conceived programs that focused on irrelevant love stories or human foibles. ${ }^{135}$

Audiences did at times also react positively to Artos's revue programs. One performance in a small town outside Kraków was applauded with cries of "long live Kraków's Artos!" ${ }^{136}$ In another, the audience reacted in a lively manner and sang along, and further asked that the ensemble return more frequently. ${ }^{137}$ Perhaps the most positive reaction took place in Silesia, where an orchestra was rewarded with "a hurricane of applause" from spectators who especially appreciated a Czech foxtrot, a Brahms waltz, and, interestingly, Hanns Eisler's antiAmerican mass song Ami Go Home, which had to be repeated several times due to audience enthusiasm. ${ }^{138}$ Such responses proved nonetheless relatively infrequent. Jazz began to be included in programs in the mid-1950s - a clear sign of the political and cultural sea change underway - and these events proved to be popular and successful with audiences. ${ }^{139}$

Artos faced a host of other problems related to these imprezy. The most common complaint of central administrators and inspectors was that the traveling ensembles went to familiar and easily accessible locales, and failed to seek out new audiences in more remote parts of the country. ${ }^{140}$ Some groups played the same concerts too frequently for the same audiences, while others performed programs designed for the countryside in cities. ${ }^{141}$ Yet another common problem was that regional Artos employees failed to send in proposed new programs to the central office in a timely fashion, and thus unapproved performances often took place before suggestions and changes could be made by Artos leaders. ${ }^{142}$ The obstacles to providing quality and ideologically appropriate concerts for the 
masses were formidable, and while it achieved some successes, Artos was clearly not up to the task.

In the GDR, officials also viewed the Estradenkonzert as a way to attract and influence new listeners. Here too, the term was a general one used to indicate events that combined songs and theater, and that would introduce the "merriment" that audiences so desired without sacrificing the pedagogical and political goals of the party. ${ }^{143}$ East German officials did not consider these concerts an end in themselves, but rather a way to introduce new ears gradually to serious music, and especially contemporary music. ${ }^{144}$ Ministry of Culture official Uszkoreit put it succinctly: "Estradenkonzerte should be an intermediary step for those who are not yet ready for more serious concerts." 145 The aim was to "win new listeners for good music," and thus the concerts should be well thought out and have artistic integrity. ${ }^{146}$ Ideologically useful programs were to be free of the usual "entertainment tax," and included concerts with music from the "progressive cultural patrimony," both national and foreign, progressive contemporary composition from the GDR, USSR, and People's Democracies, and dance and light programs, including cabaret, that had been approved by officials from the DKGD. The tax itself was viewed as a means to "limit and overcome" musical performances that the party wanted to stamp out. ${ }^{147}$ Ministry officials were not adequately satisfied, however, as they continued to push for more and better Estradenkonzerte in $1956 .{ }^{148}$

Audiences reacted to these programs with ambivalence. There are many reports of successful events, as for instance one in Drewitz that produced a lively discussion with the workers in the audience as well as calls for more such programs. ${ }^{149}$ On the other hand, an early, Estraden-like concert entitled "A Trip around the World in Song" came in for heavy criticism by one reviewer. She called the program poorly organized, with an operetta aria stuck in the middle of a number of songs related to liberation struggles. The performers were, in her view, wretched, and the ideological message of the evening muddled at best. ${ }^{150}$ Organizers for clubhouses out in the countryside also criticized "Love, Laughter and Music" (a two-hour program with two emcees, an accordion duo, and a comic) for being poorly put together, inappropriate for their audiences, and lacking good content. $^{151}$

Yet another problematic aspect of these stated reviews in both countries was the role played by the emcee. This position was considered of great importance in the Soviet Union, as this person shaped the political tone of the evening. ${ }^{152}$ In Poland, the emcee played a crucial part in keeping the audience interested and simultaneously assisted in the communicating of a political message. Yet criticism by Artos officials and ministry and party inspectors was frequent and vociferous. Emcees were generally supposed to follow an approved script, but they often ad-libbed, and in doing so frequently committed serious political blunders. Their 
jokes at times verged on the vulgar, or recalled the politically questionable humor of the prewar period. ${ }^{153}$ One inspector criticized such "weak, old, shabby jokes, for example about the talkativeness of women." 154 Artos officials also wanted the emcee not to coquette with audience members, not to ask for applause, and to avoid appealing to the worst instincts of the audience. Artos also demanded that the emcee refuse requests for encores, as it felt this was another way in which uncontrolled content could tarnish the desired ideological sheen of the program. ${ }^{155}$

The DVD/DKGD also recognized the importance of the role of the emcee in its Estradenkonzerte. Though many fulfilled this position well, there were frequently others like the one at the Drewitz program described above; despite an otherwise successful program, the reviewer found him unclear and longwinded, and the source of worthless ideological guidance. ${ }^{156}$ The DVD/DKGD and the party desired to do more to educate the emcees both ideologically and artistically. ${ }^{157}$ At a minimum, the party demanded that they affirm the socialist transformation taking place in society-a very basic expectation that demonstrates the scope of the problem. ${ }^{158}$

In infrequently achieved ideal form, these stage revues were an effective response to popular demand for fun, as they provided light entertainment while transmitting party-approved messages. Audience reaction was, however, decidedly mixed. In both countries, serious problems in basic materials and in the actual production prevented the successful achievement of the concerts' aims. A politicized program emanating from the center encountered a complicated reality of provincial mismanagement and underqualified performers. The DVD/DKGD realized some of its goals more effectively than its Polish counterpart, but both proved unable to consistently organize ideologically appropriate concerts that both pleased and educated the population.

\section{Unauthorized Concerts}

In addition to the challenge of balancing engaging performances with an ideological message, the agencies also contended with a bevy of private concert organizers. The latter were also active during this period and appealed to audience desires for entertaining, unpolitical programs outside of the totalizing gaze of the parties. They therefore became targets of the authorities' wrath. Because of the parties' desire to control all aspects of cultural life and to communicate a unified message, officials attacked unlicensed groups playing potentially subversive music as well as those who might organize their events.

In Poland in the late 1940s, the force of the state gradually came down upon these illegal performances, known as dzikie imprezy - "wild" or unlicensed concerts. In Szczecin for instance, the authorities began an aggressive program to "exterminate the dzikie imprezy of private concert organizers." 159 In 1948, the 
Music Department in the Ministry of Culture ordered all amateur musical groups to register with the government in the hopes that they could control the "wild" performing groups. By October of 1951, officials granted Artos a monopoly over the organization of all concerts in Poland; in practice, this order meant that all events needed to be registered with Artos, but that other persons or institutions could still organize concerts. ${ }^{160}$ Around this time, Deputy Minister of Culture Sokorski ordered local government officials to work together more effectively in order to step up attempts to "liquidate the plague of unlicensed events." He particularly called attention to "scheming, profit-seeking organizers" who illegally organized concerts on the fringes of official campaigns like the "Committee for the Defense of Peace," "Help for Korea," or "Rebuilding Warsaw." Such concerts allegedly "appealed to bourgeois tastes" and were harmful to the development of progressive cultural policies. ${ }^{161}$

By 1953, Artos officials could claim considerable, though not uniform success in eliminating such unlicensed events. One report, for example, asserted a need for continued vigilance as some groups "impersonated Artos-approved groups and offered pernicious programs of poor quality." 162 Another report described impresarios who continued to organize concerts under the cover of major political campaigns like the popular theme of "Rebuilding Warsaw." One case, relating to a certain W. Kozlowski, even resulted in a court verdict. ${ }^{163}$ These examples of the party cracking down occurred in 1953, near the apex of stalinist control in Poland, when cultural officials could most powerfully exercise their influence with respect to unapproved performances.

These seeming successes proved chimerical at best. As the PZPR was weakening by 1955, reports once again noted a "plague of wild performances that base their programs on unrefined entertainment without any artistic standard."164 Another report talked of "anarchy" with respect to concert organizing, as well as a spreading of "trash and pseudo-artistic superficiality." Perhaps equally important for cultural officials, all this activity resulted in money going to "schemers" rather than to the state. ${ }^{165}$ The problems continued, however, as in Wrocław, where cultural authorities reported a huge deficit that they blamed on the proliferating number of unauthorized groups organizing competing events. ${ }^{166}$ And in early 1957, the Composers' Union discussed the large number of unlicensed bands, now playing jazz and rock ' $n$ ' roll, which were "ruining the need for the consumption of decent music."167 In Poland, the party's pretensions to total control had been definitively shattered.

The GDR produced a larger number of dramatic cases in its dealings with the private concert organizers. In contrast to Poland, where the unauthorized performances seemed to be undertaken by small-scale operators, East Germany had a number of longstanding and important impresarios in its major cities. The road to DVD/DKGD dominance was tortuous and fraught. 
Many private Konzertagenturen had gone out of business in the late 1940s due to the currency reform and increased involvement by the party and state in the organization of musical life. Some notable concert agencies nonetheless still operated, and the heavy hand of the Stakuko, working with the somewhat more conciliatory DVD/DKGD, made itself felt starting in 1952. Recently appointed Director Grösch, in consultation with Stakuko head Holtzhauer, proposed asserting control over the private concert organizers through three methods: allowing some to work as free agents, but requiring that they give a percentage of their profits to the DVD; co-opting others to work directly for the agency; and ignoring others in hopes that they would simply disappear. ${ }^{168}$ Indeed, throughout 1952, the DVD took an accommodating approach to many of the independent concert organizers and desired to work closely with them to make use of their expertise. ${ }^{169}$ True to its monopolistic desires to control all cultural life on its terms, however, the Stakuko pushed for options two and three, and declared that the newly forming DKGD would directly control all concert organizing. According to the Stakuko, there no longer existed a "societal need" for private impresarios, and thus all licenses would be revoked as of December 31, 1952. ${ }^{170}$ With the advent of the New Course and the Uprising of June 17, 1953, the party and the Stakuko took a more conciliatory line and reinstated the licenses. Inexorably, however, officials pressured the private agencies and instituted an even more massive crackdown.

In the early 1950s, some impresarios attempted to work under the aegis of the agency, as in the case of Friedhelm Rabofsky. At first he attempted to play off the DVD against the Stakuko to preserve his autonomy and business. By the fall of 1952, he had yielded and begun to work with the DVD/DKGD in a sort of freelance capacity, especially in the area of engaging foreign soloists, but this had ended by April 1953 in mutual recriminations. Rabofsky then tried to preserve some employment for himself by proposing that he would serve as manager for a handful of artists, but was temporarily saved by the changing of the political winds in the late spring of 1953, when he resumed his activities as an impresario-for a short time. ${ }^{171}$

Other concert organizers tried to fight the new regulations and continue their business activity. Hermann Lorz pleaded his case to the local governmental authorities in Dresden and eventually wrote a long letter to the Central Committee of the SED that argued both his legal right to continue working as well as the continued need for his services in his hometown. ${ }^{172} \mathrm{He}$ eventually came to an accommodation with the DKGD, and he managed to survive as head of a heavily monitored private firm. ${ }^{173}$ His Dresden colleague, Erich Knoblauch, staged an even more spirited defense of his activities as a private concert organizer. Knoblauch had worked as an impresario since 1920 and had even handled a visit by the noted communist sympathizer Paul Robeson in 1930. In 1952, he marshaled the 
support of the local government, who praised his good work to the Stakuko. ${ }^{174}$ In a long letter to officials in early 1953, he defended his right to continue his activities through sophisticated legal argumentation, his wish to work for the good of the GDR, and the purported evident need for his skills. ${ }^{175}$

With the advent of the New Course, the recently revoked licenses were reinstated in the summer of 1953. Emboldened by this success and the thaw in general, Knoblauch imprudently continued his offensive by pressing for the right to expand his activities from Saxony to all of the GDR and by demanding damages for the months in 1953 when his license was revoked and his business and health consequently suffered. Both claims provoked a lengthy legal battle in the form of an exchange of letters in which ministry and local officials resorted to obfuscation and stalling to stymie the assertions of Knoblauch's lawyers. ${ }^{176}$

This general state of affairs took a dramatic turn in the spring of 1955, when authorities arrested Rabofsky and the head of Konzertagentur Hothan in Halle, Siegfried Walter. ${ }^{177}$ Despite an outpouring of supportive letters from cultural figures, a trial of Walter, Rabofsky, and also Knoblauch began in early 1956. In July, the first two were sentenced to two and three years of imprisonment respectively, while Knoblauch received five. The authorities alleged that these three violated article 6 of the constitution, which prohibited antistate agitation (Boykotthetze). The judgment asserted that they had worked closely with West German concert agencies and made negative comments about the GDR and the DKGD there. It also maintained that they had misused their licenses as cover for other, unlicensed organizers.

In the GDR, and less so in Poland, the parties and the state concert organizers acted aggressively to eliminate any competitors. The authorities' actions seem a perfect instance of Jan Gross's concept of the "spoiler state," where weak structures assert and maintain their control by removing other potential sites of power. ${ }^{178}$ Both Artos and the DVD/DKGD were relatively frail organizations that had difficulty carrying out their assigned tasks. With the help of their respective parties and governments, they acted to achieve dominance only partly through quality work and interesting programs but also by clearing the playing field through the full force of the stalinist apparatus. In the GDR, the party was able to realize and maintain a significant number of its totalizing aims, while in Poland this proved far less the case.

\section{The Orchestral Landscape}

Cultural officials in both countries also undertook ambitious initiatives in the more traditional world of symphony orchestras, as they dramatically expanded the number of ensembles and worked to assert influence over both musicians and concert programming. This orchestral bubble popped spectacularly in the 
GDR, but the significant and enduring increase demonstrates the desire of the Polish and East German parties to have a greater number of professional ensembles play more approved music for ever larger audiences. All three goals were achieved, but less successfully than the SED and PZPR had hoped, in part due to the conflicting desires of conductors, musicians, and concertgoers. These orchestras represented a prestigious and important source of musical performances, and thus received considerable largesse and attention from cultural officials. Conductors and musicians seized these opportunities to advance their own personal and professional agendas, at times counter to that of the party. Unsurprisingly, the parties wanted these professional ensembles to play music that supported their political aims, and as a result control over both the nature of these ensembles and the actual concert programs proved to be a significant point of contention. The PZPR and SED pressed orchestras to travel to factories and the countryside and give performances for non-traditional audiences, as well as to become more closely involved with the amateur groups based there. Cultural officials also attempted to influence conductors, music directors, and musicians directly to carry out party aims through the means of ideological schooling for these orchestra members. Thanks to tradition as well as contemporary efforts, East Germany had more orchestras per inhabitant than any other country in the world and especially offered many opportunities to create a politically effective socialist network of orchestras. ${ }^{179}$

In Poland, events in the realm of the professional musical ensembles followed the familiar pattern. A massive expansion in the late 1940s was linked closely to heightened party control, which gradually gave way to much more autonomy by the mid-1950s. In interwar Poland, there had been but a handful of orchestras, and only one or two significant opera houses. The three opera companies giving performances in 1948 increased to five by 1956, and were joined by two operetta ensembles. ${ }^{180}$ By 1947, six large philharmonic orchestras and four smaller symphony orchestras had already been revived or created, figures that jumped to seven and six by 1949, and then to nine and nine by 1956 , with the number of concerts given annually rising from under 600 to nearly $6000 .{ }^{181}$ In the late 1940s, Polish authorities nationalized nearly all the ensembles and put them directly under the control of the Ministry of Culture. This growth was intended to be as much bottom-up as top-down; cultural officials envisioned the most successful amateur groups maturing into professional organizations that would then be taken under the wing of the state. ${ }^{182}$

The smaller, lower-tier professional ensembles were of varying quality and political reliability. Some manifested a lack of discipline and gave sub-par concerts, like the orchestra in Kielce, which had poor attendance at the ideological courses organized for its members and rarely gave concerts in the countryside. ${ }^{183}$ Another small ensemble in Bielsko-Biała received a devastating evaluation 
from a Culture Ministry inspector in 1950, and also given that their best players had recently gone to the Polish National Radio Symphony Orchestra, was disbanded - despite the broader push to expand the number of ensembles. ${ }^{184}$ Much more successful was the "Traveling Symphony Orchestra of the Workers' Philharmonic Society," which gave a wide variety of concerts including works from Beethoven to mass songs, many of which were well received by these new audiences. From its base in Poznań, it gave these concerts out in the countryside, in schools, and in workplaces, and also took active part in political campaigns. ${ }^{185}$

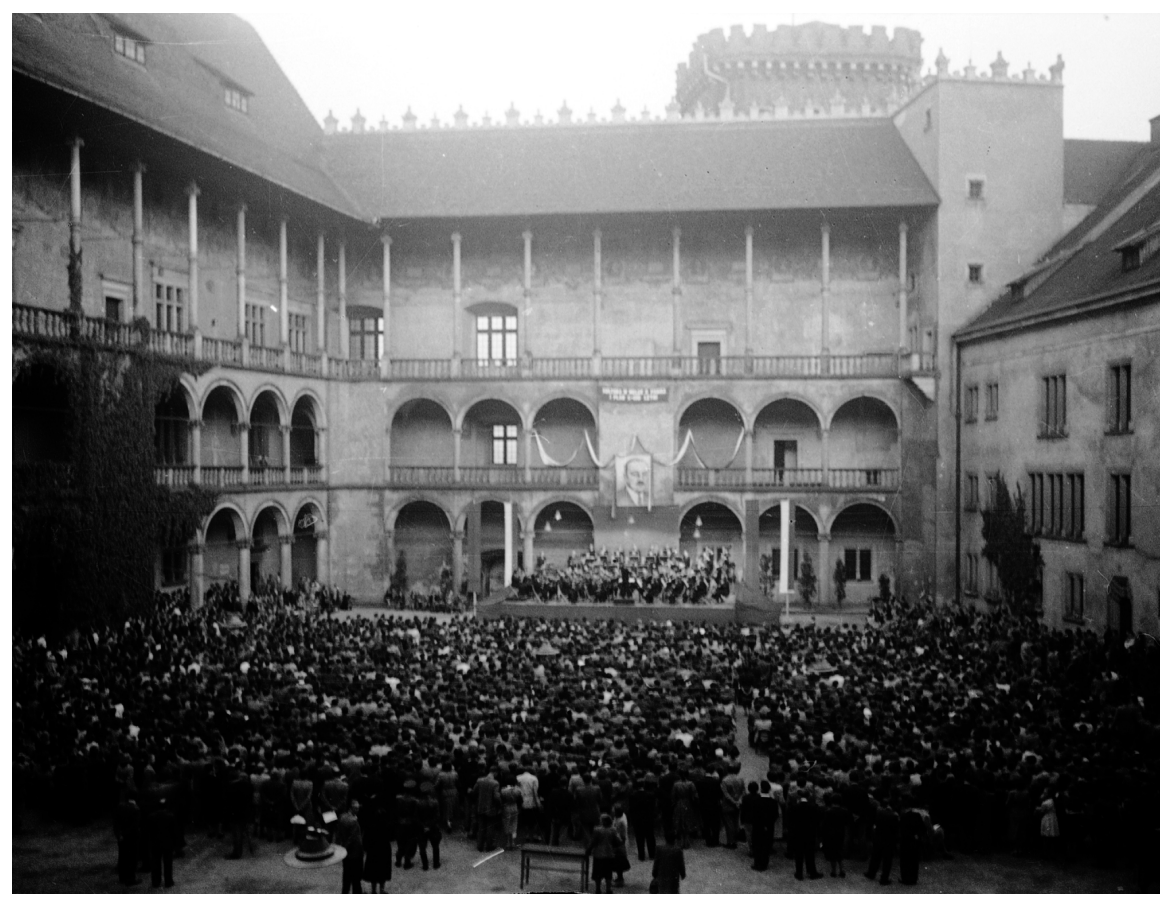

A 1952 concert given by the Polish Radio Orchestra under conductor Jerzy Gert at the Wawel Castle in Kraków. Note the image of Bolesław Bierut, President of Poland and PZPR General Secretary, as well as the slogan above it referring to the Six-Year Plan (PAP

\section{1/10, CAF Węglowski).}

The rapid expansion of ensembles caused severe problems, since an adequate number of trained musicians simply did not exist, leading to poaching of both conductors and performers among the leading orchestras. The most active here would seem to have been the philharmonic orchestra in Warsaw; its leaders used its central location, symbolism, political contacts, and higher salaries to try to lure the best musicians from other ensembles in an effort to create the premier orchestra in Poland. Around 1950 the Polish National Radio Symphony Orchestra, perhaps the leading ensemble of the time, was raided, and a few years 
later the Poznań Philharmonic strove to defend itself. ${ }^{186}$ In 1955 the Polish Radio Orchestra of Bydgoszcz paid the ultimate price in losing its best members to Warsaw; it was dissolved despite energetic appeals by its members to the party on the basis of its political and artistic successes, which included numerous concerts in workplaces and a concert cycle "On Saturday after Work." 187

The experience of the Warsaw Philharmonic crystallized a series of conflicting issues related to the nexus of music and politics in the orchestral setting, and demonstrates how conductors and musicians could use their standing, combined with the party's reliance on them to create a respected ensemble, to secure their own goals. After a difficult start postwar with five conductors in five years, it seemed to achieve some stability under Witold Rowicki around 1950. He initially seemed ideal from the party's perspective, as he was talented and respected, programmed a high percentage of contemporary Polish music, and drew large audiences. ${ }^{188}$ And while officials recognized these strong points and generally considered him politically loyal, they also faulted his egotism and lack of ideological engagement and complained that he prevented the party from effectively controlling the ensemble. ${ }^{189}$ Rowicki was well aware of his prestige and standing, and acted with relative impunity with respect to the party; a crisis situation developed as PZPR officials and party members in the orchestra clashed with him repeatedly. In early 1955, with the symbolic importance of the ensemble raised further with its showpiece new home and renaming as the "National Philharmonic," the PZPR finally moved to assert control over the orchestra and removed him as conductor and artistic director, provoking significant dissatisfaction and even violence from his supporters. In order not to make a martyr of him, he was given prominent positions with other leading ensembles for the next few years, and in a sign of party weakness, was back at the helm in Warsaw in $1958 .{ }^{190}$ Bohdan Wodiczko was appointed the new leader in the interim against the wishes of some in the orchestra and in a very chaotic situation both administratively and politically. ${ }^{191}$ Cultural officials sought to support him and attract better musicians through housing and financial incentives in order to create an ensemble that would represent People's Poland well at the Chopin Piano Competition in 1955 and the Warsaw Autumn Festival the following year. ${ }^{192}$ Despite Rowicki's dramatic but temporary removal, these events demonstrate the power of musical elites to negotiate a significant amount of autonomy, even in the face of committed and concentrated efforts by party officials.

The state provided orchestras with generous subsidies, and also subjected their concert programs to review to ensure they passed political muster. ${ }^{193}$ In practice, however, cultural officials acted with a relatively moderate hand when it came to repertoire, as they called for lighter music more accessible to workers, a link between concert programs and political commemorations, and increased 
attention to contemporary music; by mid-decade, postwar Polish music made up a quarter of concert programs. ${ }^{194}$ Starting already in late 1953, ministry officials gave orchestras more autonomy, but were reluctant to give up total control over concert programs, and even held up the concurrent East German decision (explored below) to relinquish this prerogative as a negative model. ${ }^{195}$ As they had feared, with the increased freedom music directors began programming works of many Western composers previously deemed formalist. ${ }^{196}$ Relatedly, and as part of its broader drive to decentralize, by 1956 the ministry had placed oversight responsibility for the smaller symphony orchestras with regional authorities but maintained control over the larger philharmonic orchestras. ${ }^{197}$ The Composers' Union and performers from their own union protested against the former measure, arguing that regional cultural officials lacked the necessary expertise, and asked for more autonomy to be given directly to the directors of these musical ensembles. ${ }^{198}$ In a weakened state at the end of the stalinist decade, party and ministry officials flailed about for a way to maintain influence over programming, but proved unable to do much formally or informally to reassert control over concert repertoire.

The ministry sought to influence orchestras and their members in other ways as well, such as founding primary party cells in most musical ensembles, though their efficacy was questionable, especially as the party began to lose legitimacy after $1953 .{ }^{199}$ In the early 1950 s, the PZPR organized numerous ideological courses for conductors and musical directors, as well as musicians. ${ }^{200}$ Officials also constantly exhorted the professional ensembles to reach out to their amateur counterparts and set up programs where the former would serve as patron and advisor to the latter. ${ }^{201} \mathrm{Few}$ of the professionals showed much interest in this unpaid work, and the amateur ensemble directors were often unenthusiastic as well, as the advice and criticism of the experts often undermined their authority with their musicians. ${ }^{202}$ In all these ways, the party attempted to include orchestra members in its vision and further sought to draw them into the project to make contact with and influence the wider population.

In the GDR, the party's interaction with orchestras shared the same broad outlines as the situation in Poland but was much more intensive and ambitious in all aspects, with the notable exception of a concession on control over concert programming. While the sizeable number of 48 ensembles existed in the territory of the GDR before 1945, and there was a long history of state support for musical ensembles in German-speaking Central Europe, only eight years later cultural officials could claim to oversee roughly 200 large and small orchestras. ${ }^{203}$ As in Poland, the party supervised concert programs, provided ideological training, and linked professional and amateur musicians as means to control the political content of the music being performed. 
The goals for East Germany's orchestras were identical to those in Poland: to perform party-approved music from the past and present in front of ever-larger sectors of the population. Cultural officials expected that these musical ensembles would:

bring the national cultural heritage and contemporary musical production to the working people. The decisive factor is that, through the manner in which it is conveyed, music, like the other arts, can function as a rousing (begeisternde) force for the construction of society; but this can only happen when every [musician] is filled with the awareness of music's societal meaning and is willing to collaborate with the workers on the building of socialism..$^{204}$

The party demanded that orchestra members and conductors embrace its program fully and help communicate its goals to society. Ensemble directors were charged with the goal of "winning the working masses" through "progressive programs" and bluntly told that "programming is a political question." ${ }^{205} \mathrm{Cul}-$ tural officials constantly pushed these musical ensembles to give 60 to 80 percent of their concerts in factories and out in the countryside, especially with the focus of the 1953 New Course on satisfying the needs of workers and peasants. ${ }^{206}$ Concerts were to be accompanied by effective brochures or preceded by lectures, and when offered by an ensemble that "combines technical skills with ideological knowledge" would create a "receptive listener attuned to the educational influence of the musical art." ${ }^{" 207}$ These efforts produced a mixed success, as some orchestras claimed enthusiastic audiences, while others reported low attendance. ${ }^{208}$

Although the specific categories changed several times during this period, the general outlines remained the same (and were broadly similar to the categories introduced under National Socialism in 1938). There were seven "nationally important" (republikwichtig) philharmonic orchestras in the top level, followed by a handful of regional symphony orchestras (Landessinfonieorchester, later Staatliche Sinfonie-Orchester) ${ }^{209}$ Underneath the elite orchestras were "district cultural orchestras" (Kreiskulturorchester) divided into five levels of competence, a group of orchestras associated with theaters, and finally a large group of "community orchestras" (Gemeinschaftsorchester) ${ }^{210}$ During the first half of the 1950s, a veritable explosion took place, as a dozen or so district orchestras grew to around 40, and a few dozen "community orchestras" mushroomed to over 135. ${ }^{211}$ Justification for this expansion was founded on music's "immediate means to raise consciousness, especially in our current fight for peace ... conveying our classical cultural legacy and good light music must both take place ... also our dance music must be refined and newly formulated, and private interests must be removed." ${ }^{212}$ This new orchestral landscape thus bore heavy responsibility, and initially received significant support from the state for these tasks. 
This proliferation of ensembles naturally required the people to staff them, and there were simply not enough to go around. Some of the shortage was due to musicians relocating to the West, and officials speculated that they were dissatisfied with their treatment by state authorities or pursued higher salaries there, of roughly 30 percent. $^{213}$ A related failure to attract West German musicians to the East also pertained, but a chronic problem was an undersupply of East German performers more generally - in early 1955, 300 positions were unfilled throughout the country. Far more dramatically than in Poland, a process of cannibalization took place on all levels: the many theater orchestras lost members to the district orchestras, while the latter in turn saw musicians leave for the police orchestras (Volkspolizeiorchester). ${ }^{214}$ Even in light of the fact that many lessqualified freelance performers of popular light entertainment music had joined district orchestras, the gap remained, and indeed an intensified negative effect occurred as then both a lesser amount of quality popular music was performed and the weaker skills of these musicians dragged down the overall proficiency of the district orchestras. ${ }^{215}$ This all came at a time when officials were increasingly concerned with providing "worthwhile" popular music to "drive out . . the influence of the capitalist music industry-kitsch." 216 The SED simply could not hope to realize its far-reaching cultural-political aims with the existing financial and human resources.

This Darwinian state of affairs also extended to the structure of the biosphere, as it were. Ensembles jockeyed to be moved up a level and sought to justify their advancement and related funding through both artistic prowess but also social and political engagement. The early 1950s must have seemed like golden years to directors and musicians, especially after late Weimar privation and the difficult economic situation in the early years of Nazism. ${ }^{217}$ But then the high point of this frenzied creation and movement of ensembles was reached in 1954 and a die-off began, due to lack of funding and insufficient audience numbers. Officials increasingly viewed the initiative as a flawed one due to a perceived excess of light music on offer and not enough serious, a failure to more systematically attract and educate potential audiences, and in general the blunt truth that they "had not been able to win over workers, peasants, and the youth as a regular audience." ${ }^{218}$ As a consequence, a major reorganization reduced the number of ensembles in East Germany by merging many of the smaller orchestras. Ministry officials in particular criticized some of the district orchestras for playing too much light entertainment music, and not enough of the more serious music for which these 42-person "cultural orchestras" had been developed. Perhaps more important was the staggering cost to the state; the district orchestras recouped less than 15 percent of their expenses from ticket sales, and required a collective subsidy of over eight million marks. As a solution, the ministry merged some district orchestras with the theater orchestra of the same city, and in other cases 
combined two nearby district orchestras to produce a stronger ensemble as well as a smaller orchestra to play lighter music. ${ }^{219}$ The remaining orchestras were to increase their number of concerts so as to "satisfy the diverse needs of workers in city and country as much as possible" and also to strive to be more profitable. ${ }^{220}$ The "community orchestras" on the lowest rung suffered the most from the reduction in ministry largesse; after seventy of these orchestras had received subsidies in 1953, the Stakuko withdrew most funding, and many simply collapsed. ${ }^{221}$ This drive to amalgamate and reduce the number of orchestras, while increasing their concerts and focusing on providing quality light music, remained priorities through 1957 and beyond. ${ }^{222}$ Nonetheless, a large number of ensembles continued to perform for millions of audience members each year. ${ }^{223}$

As in Poland, East German cultural officials considered control over concert programs a high priority, but in a significant concession tactically abandoned this aim as part of the New Course. Initially, in the interests of promoting "progressive musical development," starting in the fall of 1951 the Stakuko required that the "nationally important" orchestras have their repertoire approved by the central authorities, while smaller orchestras should submit their programs to regional Stakuko officials. ${ }^{224}$ All were to follow the same guidelines for the year's musical programming: 25 percent contemporary East German, half from the European "classical cultural heritage," and a final quarter from the Soviet Union, the other People's Democracies, or "progressive composers" from other countries. ${ }^{225}$ The goal was to have a mix of classic and new that would entertain and educate a broad audience. ${ }^{226}$ In the spring of 1953, the Stakuko sent orchestras one list of recommended contemporary works as well as a second with approved works from the past, both compiled to "promote patriotic education."227

During this phase of heavy interference in the early 1950s, Stakuko officials made regular interventions into the programming of ensembles large and small. The latter, lacking institutional prestige and a well-respected conductor, were particularly susceptible; indeed their funding and very existence depended on official approval of the kind of music they performed and the contexts in which they performed it. ${ }^{228}$ Often these official actions took the form of generalized directives like reminders about the percentages above, as well as of encouraging the inclusion of Estradenkonzerte. ${ }^{229}$ Tables and reports were generated to keep track of the amount and kinds of programming, and ensembles received a reprimand if they strayed too far from the recommended proportions. ${ }^{230}$ For the 1952-1953 season, for instance, the Rostock theater orchestra was taken to task for having only one East German work, and an insufficient number from the Soviet Union and the people's democracies. The Greifswald theater orchestra was condemned even more harshly for its complete lack of East German and Soviet bloc composers and but one Soviet work. These two orchestras were admonished to improve their programs for the next year, while the theater orchestra in Stralsund-with 
only two contemporary works, and both from West Germany-was forced to modify its programming after the start of the season to correct its apparently grave mistakes. ${ }^{231}$ Uszkoreit went so far as to make suggestions about individual concerts within a season. In the first half of 1953, he pressed the music director of the Plauen theater orchestra to abandon plans for a concert of all contemporary music in the interest of sprinkling such works in a variety of programs so as to better maintain audience interest. ${ }^{232}$ With respect to the culture orchestra in Riesa, he pushed for specific East German works to be included, and suggested Günter Kochan's celebrated socialist-realist Violin Concerto in the seventh concert of the season. ${ }^{233}$ The culture orchestras of Hildburghausen and Sonneberg were both instructed to replace Prokofiev's Suite from The Love for Three Oranges with "a more successful, realistic work" by that iconic composer. ${ }^{234}$ At the height of the Stakuko's power, such interventions were legion. ${ }^{235}$

The programs of the more prominent ensembles were also subject to official scrutiny, but their musical directors were better able to assert a measure of autonomy, although officials did reject some works deemed too formalist. During the 1952-53 concert season, for example, the Dresden Staatskapelle under Rudolf Kempe was ordered to remove a 12-tone symphony by Swiss composer Rolf Liebermann and criticized for an inadequate number of Soviet compositions, even as it received praise for its programming of new works from the GDR and other people's democracies. ${ }^{236}$ Franz Konwitschny took over from Kempe in 1953 and was similarly taken to task for neglecting Soviet and Soviet-bloc composers and for underprogramming East German works. ${ }^{237}$ In his other position as conductor of the Gewandhausorchester in Leipzig, he even dared in the early 1950s to include the personification of formalism, Stravinsky, with his Firebird Suite. ${ }^{238}$ Curiously and spectacularly, he was forced to remove it from the program on such short notice that some audience members reacted with loud and unpleasant surprise to the substitution of Tchaikovsky's Sixth Symphony. (Interestingly, Konwitschny chose not to capitalize on this audience dissatisfaction but instead responded by turning from the podium and shouting "rascals" into the hall. ${ }^{239} \mathrm{He}$ also received a mild rebuke for a dearth of Soviet compositions and for overprogramming Bruckner with six major works from a composer officials deemed too mystical and not so appropriate for the building of socialism. ${ }^{240}$

Those ensemble directors like Konwitschny with a reputation and tied to an elite institution, could and did push back at times. A particularly high-profile and revealing example of the dynamic between cultural officials and ensemble leaders can been seen in the interaction between cultural official Hans-Georg Uszkoreit and Heinz Bongartz, artistic director of the Dresden Philharmonic and a member of the SED. The latter's programming for the 1952-53 season had come under fire for its lack of sufficient contemporary works from the Soviet Union and other bloc countries. ${ }^{241}$ And Uszkoreit alleged serious problems in 
the upcoming 1953-54 season, in particular criticizing a ten-concert series entitled "Masterworks of the Twentieth Century." In Uszkoreit's view, works by Werner Egk, Hans Pfitzner, Gustav Mahler, and Paul Hindemith - the first two seen as aesthetically linked to Nazism and the last to Western modernism-did not "do justice to our cultural-political mission." He requested that their works be replaced, and he also asked that some music by East German composers be included. Bongartz rejected Uszkoreit's demands on the grounds that there were no East German masterpieces yet - and he referenced a recent Composers' Union statement to back up his claim. And besides, he noted, other concerts that season featured works by GDR composers like Günter Kochan, Fidelio Finke, and Ottmar Gerster. He defended all the programmed works as appropriate and challenged Uszkoreit to demonstrate why they were problematic. Bongartz conducted two discussions of the issue with the ensemble's musicians and claimed they also fully supported the programming. With respect to audiences, he asserted that their working-class attendees did indeed have the sophistication to appreciate the concerts, as evidenced by purchased subscriptions and sold-out concerts. Uszkoreit attempted to garner support for his position from the Composers' Union and from leading musicologist Eberhard Rebling, but in the end the series remained as originally programmed. ${ }^{242}$ Through skillful aesthetic and political argumentation, Bongartz mediated the demands of the state and maintained the musical autonomy of his ensemble. His SED membership surely strengthened an already powerful position as a respected musical figure, and furthermore the exchange took place in May and early June of 1953, so perhaps Bongartz also sensed the impending relaxation of control as part of the New Course and in the aftermath of the June 17 Uprising. Nonetheless, this episode shows that the party was hardly monolithic, even near its peak of power.

A few years later, Bongartz was still complaining about contemporary East German works, and demanded that composers create for ensembles and audiences "from the heart, with gravity, and with a greater sense of responsibility."243 As a seeming consequence of his frustration with the oeuvre of his contemporary composers, he consistently gave less attention to their works, which made up, for example, only ten percent of the Dresden Philharmonic's 1955-56 season. ${ }^{244} \mathrm{He}$ also continued to program problematic composers like Hans Pfitzner, eliciting an impassioned plea from Culture Ministry official Pischner related to one concert's program booklet that overly praised the fascist-leaning composer: "Certainly we want to cultivate and value everything beautiful and great in our German cultural tradition. But I believe that we cannot abdicate our ideological vigilance for one moment. So for this reason I write with the request that you influence more effectively these concert overviews, which can lead our audiences astray." ${ }^{245}$ Cultural officials considered the stakes high, but with prominent musical figures could not simply impose their will. 
In a major concession to ensembles and their leaders, cultural officials ended direct control over concert programs in July 1953 as part of the cultural thaw in the New Course and post-June 17 era, although guidelines remained. ${ }^{246}$ As in other areas, the authorities were henceforth supposed to rely on persuasion rather than direct intervention, and these limited but significant concessions combined with less intrusive means helped the party to maintain control far better than its counterpart could in Poland. ${ }^{247}$ The new regulation went into effect on July 16, 1953, but as recently as June 15, the Stakuko had reaffirmed the requirement that orchestras obtain approval of their concert programs, and Uszkoreit continued to make significant suggestions to regional orchestra leaders as late as early July. ${ }^{248}$ Nonetheless, the course correction was swift and helped to satisfy the demand for more autonomy in the musical world. Orchestra directors were still required to submit programs, and cultural officials continued to try to influence repertoire, albeit through "patient convincing" and criticism in the press. ${ }^{249}$

In practical terms, this new approach produced contradictory effects. Starting in the summer of 1953, Stakuko officials undertook a major inspection of all the district orchestras, including a critical examination of their repertoire, but refrained from directly forcing changes in concert programs. ${ }^{250}$ Uszkoreit noted two negative outcomes to the revised cultural policy: some music directors performed only safe classics, for fear of presenting a work deemed formalist and then getting criticized after the concert, while others seized the new opportunities to program "formalist" compositions. Konwitschny immediately put the Firebird Suite back into a concert. During a discussion of this situation, Soviet musicologist Georgij Chubov agreed with the revised guidelines, preferring discussion with the aim of convincing instead of the prohibition of works. ${ }^{251}$ Many orchestras had difficulty fulfilling the guidelines that 25 percent of the music be contemporary, and even when the ministry provisionally reduced this figure to 15 percent in 1955, many ensembles still found this figure difficult to achieve. ${ }^{252}$

Both before and after the policy change on programming, many of the leading conductors were consistently faulted, but made only minor concessions, and seem to have suffered no sanction for their alleged failings. They were constantly reminded to fulfill the recommended percentages, as in 1956 when the ensembles in Halle and Schwerin were taken to task for programming contemporary East German music for only 12 and 13 percent of their programs, while that in Gotha and the Gewandhausorchester both received praise for coming close to the 25 percent mark. ${ }^{253}$ Officials faced ensembles that had cultural prestige and institutional authority, and could not simply dictate policy. Futhermore, the international standing of the ensembles and their directors also gave conductors leverage with respect to programming. 
Through the 1950s, East German cultural officials continued a broader offensive to influence the activities of musical ensembles. They mandated political schooling and encouraged contact with workers and peasants. The Stakuko introduced a wide-ranging program of ideological training that far exceeded the one implemented by its counterpart in Poland. Each orchestra was to conduct a seminar every two weeks dealing with topics on the relationship between music and socialism, including socialist realism and music in the Soviet Union. Twice a year, musical directors and conductors were to take part in centrally-directed seminars on similar themes. ${ }^{254}$ Officials frequently proved unable to realize their aims here, as for instance in 1955, when only a third of district cultural orchestras responded to the first invitation, and some who did so did not even attend in the end. ${ }^{255}$ On at least one other occasion, the music directors and conductors who attended found it a waste of time. ${ }^{256}$ In a related initiative, to facilitate contact between musicians and workers, and in hopes of more enthusiastically enlisting performers in the party's program, officials encouraged orchestras to make "friendship contracts" to improve cultural life in factories and thereby to influence broad swaths of society. ${ }^{257}$ This contact proved successful in many cases, as for instance a Saalfeld ensemble that maintained close links with the local iron ore mine in Kamsdorf and the porcelain factory in Könitz, including discussions of "problems of production...contemporary political issues ... the programming of our concerts." 258 On the other hand, cultural officials constantly found themselves fighting the "arrogance" of many of the larger orchestras, which were reluctant to travel outside of the concert halls of their own cities, let alone to outlying factories or to the countryside. ${ }^{259}$ In both areas, officials struggled to motivate orchestra directors and musicians, who often refused to carry out party directives despite pressure from above.

Attendance figures for both countries are hard to come by and of uncertain reliability, but do show a genuine increase. Musical directors had an incentive to inflate audience numbers so as to justify the ensemble's existence or to claim that its success argued for a higher position in the hierarchy. Furthermore, some of the tickets were sold in block subscription form to workplaces and mass organizations, which could result in empty seats. Officials made such subscriptions for workers a priority as part of their general aim to expand the audience base, with mixed success. ${ }^{260}$ The Gewandhausorchester, for example, in its 1954-55 season sold 2074 subscriptions, of which 1741 came from workplaces, and it began to hold its open rehearsal on Wednesday evenings in an effort to attract more workers to its performances. ${ }^{261}$ Overall, in Poland reported attendance rose from 560,000 in 1949 to over 1.5 million in 1954, while the 1955/56 concert year in the GDR attracted almost 2.2 million concertgoers. ${ }^{262}$ The Philharmonic in Warsaw, for instance, regularly reported exceeding planned attendance figures, with houses of over 1000 for most concerts. ${ }^{263}$ Cultural officials in East Germany noted 
that concert halls were sometimes half full or less and blamed this on music directors who were not making sufficient efforts to reach out to new audiences. ${ }^{264}$ In general, audience numbers in both countries were considered relatively healthy, although efforts were unsurprisingly made to increase them.

In both countries, the parties directed a massive expansion in the number of musical ensembles and lavished subsidies on a breathtaking number of orchestras of varying size and quality. Concert life in East Germany was more developed, and the SED devoted more resources and attention to it. This state of affairs was surely due to the longer and more developed tradition of symphonic music in Germany, as well as the desire of the SED to prove its legitimacy by demonstrating that music was cultivated more assiduously in the GDR than in the Federal Republic. The less dramatic but nonetheless sizeable increase in orchestral activity in Poland produced a more stable situation than the overly ambitious goals set in East Germany. Cultural officials in both attempted to control much of the orchestras' activities - most obviously concert programs, but also the choice of concert venue, as well as the ideological formation of both musicians and audiences. The Stakuko appeared most interventionist in controlling repertoire in the early 1950s, but made the key decision to abandon this direct oversight in the context of the New Course, and thereafter officials maintained less formal but still significant influence. Cultural officials in Poland tried to maintain their control over concert programs throughout the period, but were forced to largely abandon this effort by the mid-1950s as orchestras, as well as the musical world more generally, achieved considerable autonomy from the state.

\section{Conclusion}

The SED and PZPR attempted to control the music heard in all venues, from the grandest concert hall to the smallest factory clubroom. With the belief that music was a powerful means of communicating a political message to large numbers of people, the parties created these state concert agencies and expanded the number of orchestras. On the surface, it did seem that the utopian goal of bringing the best of past and present music to formerly neglected workers and peasants, while also shaping them ideologically, had been fulfilled. Using these resources, officials then worked to create and promote specific programming in order to appeal to and influence new ears in factories and the countryside. In these ways, the parties' overarching goal of dominating the musical world, as well as worldviews more generally, was advanced, if only partially. By enlisting large numbers of performers and musical directors in this project, they gained cooperation in helping to build socialism. The parties hoped that by showing themselves committed both to fostering culture and to cultivating their respective national traditions, they would 
establish their legitimacy in the eyes of their populations. And indeed, many millions attended performances organized by these institutions and ensembles, and thus experienced pre-screened music in selected contexts.

But there were simply too many obstacles to the complete, effective implementation of the parties' totalizing program. The two state concert agencies encountered significant problems in the creation of appropriate, appealing programs with capable artists and managed by competent administrators. In the case of orchestras, the parties directed an impressive expansion in the number of ensembles and concerts offered, but struggled to maintain influence over the musicians as well as control over programming. While East German officials abandoned formal rights to the latter, they were nonetheless able to direct orchestral life towards promoting party goals more effectively than in Poland. Ordinary citizens did have real say as well, seen when the concert agencies responded to audience tastes and offered programs that entertained as well as educated. The stage revue emerged as a compromise between party aims of politically educative concerts and audience demands for an entertaining musical experience. Although the parties, through musical institutions both large and small, aspired to total control of performance halls and the symbolic messages communicated there, such a state of affairs was never achieved since officials regularly made concessions to the demands and desires of both musical elites and ordinary citizens.

The concert agency and cultural officials in the GDR on balance fulfilled the SED's aims more successfully than their counterparts in Poland. East Germany had a more highly developed musical tradition and many more musical ensembles, and thus its officials organized concerts for a more receptive audience. They did, however, have to eliminate significant competition from private agencies so as to clear the field for their desired programs; Artos initially had an easier time in this respect. Germany also had a stronger tradition of cultural activities for workers, and thus the DVD/DKGD followed paths already trodden by the pre-1933 socialist and communist parties, and also inherited the legacy of an extensive Nazi musical infrastructure. Further, the SED was simply more powerful than the PZPR, and could count on a greater number of party members in cultural institutions, local administrations, and factories to help carry through its plans. When the thaw came in 1953, the authorities were forced to concede more concertrelated freedom in Poland, while in the GDR the brief relaxation was followed by renewed control with a somewhat lighter touch shortly thereafter. 


\section{Notes}

1 The following discussion does not touch on dance music, generally considered a separate genre and also subject to considerable party involvement and hand wringing. See Poiger, Jazz, Rock, and Rebels; Thacker, Music after Hitler, ch. 7; Mark Fenemore, Sex, Thugs and Rock ' $n$ ' Roll: Teenage Rebels in Cold War East Germany (New York: Berghahn Books, 2007).

2 Stowarzyszenie Społeczne Organizacji Imprez Artystycznych "Artos" and then Państwowa Organizacja Imprez Artystycznych "Artos."

3 AAN, MKiS, CZIM, 3257, 1-11, and 3321. The Central Administration for Musical Institutions (Centralny Zarzad Instytucji Muzycznych) took over those Artos functions that dealt with more serious music. A Central Administration for Theatres was also formed at this time. For more, see chapter 2.

4 AAN, Artos, 40, 101.

5 AAN, KC PZPR, 237/XVIII-26: 16; AAN, Artos, 40, 31. The Chief Director oversaw half of the organization, and the Deputy Director the other half. These two officials managed ten departments: accounting, light stage performance (estradowy), music, cadre, organization, employment and wages, commerce and expenses, planning, finances, administration and economics, and legal counsel. The second and third of these are of the greatest interest. The estradowy, or light stage performances, department is discussed below. Department Three, the music department, was divided into four sections: school concerts, programs, concert organization, and the secretariat of the qualification commission. Director Paweł Kruk oversaw nine workers in the goal of bringing music to all sectors of Polish society (AAN, KC PZPR, 237/XVIII-26, 12-17).

6 Larger cities had a dozen or more workers in regional offices, while smaller towns had only a worker or two. The former were called Oddziaty Terenowe or Okregowe Przedsiębiorstwa Estrady; after 1954, the State Enterprises for Artistic Events [Przedsiębiorstwa Państwowe Imprez Artystycznych, or PPIE]; after 1957 they were placed under more regional control. (AAN, MKiS, CZIE, 35.) The latter were known as Delegatury Wojewódzkie, later Terenowe Stanowiska Pracy.

7 SAPMO-BArch, DY-30, IV 2/9.06/125, letter from Preuß, DVD, Landesstelle Thüringen to SED, Zentralsekretariat, 10 March 1951, 28-30.

8 To refer to these two agencies over the entire period under consideration, I will use the infelicitous but necessary acronym DVD/DKGD.

9 Steinweis, Art, Ideology and Economics, 76.

10 Obersspielleitung, Sachgebiet Musik, Sachgebiet Artistik, Unterabteilung Dramaturgie. SAPMO-BArch, DY-30, IV 2/9.06/125, “Arbeitsrichtlinien des DVD,” 3-5. It contained four subdepartments: music, theater, texts, and nonmusical events like political cabaret.

11 SAPMO-BArch, DY-30, IV 2/9.06/125, letter from Grösch, DVD, Zentral to Holtzhauer, Stakuko, 1 February 1952, 95-96.

12 BArch, DR-1, 33, "Bericht: Betr. Tätigkeit der DKGD," 4. (The higher number was surely due to the reforms of the regional administration in 1952.) BArch, DR-1, 361, "Entwurf für einen Stellenplan der DKGD," 21 May 1957.

13 AAN, Artos, 99, "Wykaz Artystów współpracających z Działem Muzycznym Artosu," 260.

14 AAN, Artos, 41, letter from Kosacz, Dept. Kontroli, MKiS, to Dyrektor Artosu, 3 September 1952; and response from Artos, 31 January 1953.

15 AAN, Artos, 40, 9.

16 AAN, Artos, 14, 39.

17 AAN, Artos, 56, 6. 
18 Stories of unheated venues and inadequate transportation abound. See AAN, Artos, 41 and 57.

19 AAN, Artos, 40, 9.

20 AAN, KC PZPR, 237/XVIII-26, 3-5.

21 AAN, MKiS, CZIE, 18.

22 BArch, DR-1, 33, "Bericht: Betr. Tätigkeit der DKGD," 24 November 1954, 2.

23 BArch, DR-1, 40, "Protokoll zur Musikreferenten-Konferenz," 13 October 1952.

24 BArch, DR-1, 282, "VII. Sitzung des Musikbeirates der DKGD," 26 March 1956.

25 BArch, DR-1, 33, "Protokoll über die Fachbeiratssitzung der DKGD," 18 December 1955.

26 BArch, DR-1, 33, “Bericht: Betr. Tätigkeit der DKGD,” 24 November 1954, 2-3.

27 AAN, MKiS, DTA, 719, Protokół nr. 9, 13 September 1950.

28 AAN, Artos, 38, letter from Inspektorat Kontroli Wewnętrznej Artosu to Dyrektor Naczelny Artosu, 20 April 1952, 10.

29 AAN, Artos, 40, "Materiał Działu Kadr do notatki dla MKiS," 15 September 1953, 83, 97.

30 AAN, Artos, "Plan pracy na rok 1954," 10; AAN, MKiS, CZIE, 15, "Sprawozdanie na IV kwartal 1956."

31 AAN, KC PZPR 237/XVIII-26, "Notatka: na polecenie KC PZPR,” 21 October 1953, 16-18.

32 AAN, Artos, 40, "Tematyka inspekcyjna dla Artosu," no date, 9.

33 AAN, KC PZPR, 237/XVIII-26, 28 September 1953, 23-31.

34 AAN, KC PZPR, 237/XVIII-85, 26 February 1949, 27.

35 AAN, KC PZPR, 237/XVIII-26, 2 November 1950, 77.

36 SAPMO-BArch, DY-30, IV 2/9.06/125, letter from Grösch to Holtzhauer, 1 February 1952, 92.

37 BArch, DR-1, 10, “Zur Verbesserung der Arbeit der DKGD,” Hartig, 20 July 1953.

38 BArch, DR-1, 278, "Entwurf des Arbeitsplanes der DKGD für das Jahr 1954," 9.

39 BArch, DR-1, 10, "Zur Verbesserung."

40 BArch, DR-1, 33, "Revisionsprotokoll," 4 February 1955, 11.

41 BArch, DR-1, 33, "Bericht, Betr. Tätigkeit der DKGD," 22 November 1954, 6-9.

42 SAPMO-BArch, DY-30, IV 2/9.06/125, "Entwurf für den Bericht an den V Parteitag: Veranstaltungswesen, Entwicklung seit der 3. Parteikonferenz, März 1956 bis heute," 3 May 1951, 21.

43 “Zamierzenia Artos-u na rok 1951,” Muzyka 2, no. 1 (1951): 12-13.

44 AAN, Artos, 57, 33.

45 See Director Stanisław Siekierko's “Z działalności ‘Artos,”” RM 5, no. 16 (1949): 41-43.

46 AAN, Artos, 106, "Protokół narady produkcyjnej," 3 March 1951.

47 See numerous examples in AAN, Artos, 102.

48 In 1952, the goal was to have 75 percent of the DVD's concerts out in the countryside (BArch, DR-1, 6200, "Protokoll über die Orchesterleitertagung," 26 November 1952); similarly in 1953, 80 percent of the DKGD's concerts with small orchestras were to take place in factories or rural areas (BArch, DR-1, 6191, Plan, 28 March 1953). For more on factories and culture more generally there, see Annette Schuhmann, Kulturarbeit im sozialistischen Betrieb. Gewerkschaftliche Erziehungspraxis in der SBZ/DDR 1946 bis 1970 (Cologne: Böhlau Verlag, 2006).

49 SAPMO-BArch, DY-30, IV 2/9.06/125, 131; SAPMO-BArch, DY-30, IV 2/9.06/125, 8 November 1952, 136.

50 “Zamierzenia ARTOSu na rok 1951," Muzyka 2, no. 1 (1951): 12; AAN, Artos, 40, “Materiał Dzialu Kadr do notatki dla MKiS,"15 September 1953, 82. 
51 BArch, DR-1, 278, “Zur Verbesserung der Arbeit der DKGD,” 20 July 1953, 1.

52 SAPMO-BArch, DY-30, IV 2/9.06/125, 126.

53 BArch, DR-1, 278, "Entwurf des Arbeitsplanes der DKGD für das Jahr 1954."

54 Alexander Abusch, "Im ideologischen Kampf für eine sozialistische Kultur-Die Entwicklung der sozialistischen Kultur in der Zeit des zweiten Fünfjahrplanes," 23 October 1957, in Schubbe, 493.

55 BArch, DR-1, 30, Maßnahmeplan des MfK in Auswertung der Kulturkonferenz der SED, 27 November 1957.

56 BArch, DR-1, 282, "Perspektivplan der DKGD," 12 June 1957. See also SAdK, HansPischner-Archiv, 889, 11.

57 AAN, Artos, 40, 31.

58 BArch, DR-1, 8, "Erfolge in der Musik."

59 In the first trimester, 29,821 events with 6.5 million spectators. BArch, DR-1, 25, "Zum Bericht für die Wahlen 1954 (Musik)."

60 AAN, MKIS, CZTOiF, 2787, 1.

61 SAPMO-BArch, DY-30, IV 2/20/86, /155, /172.

62 AAN, MKiS, DTA, 477, 33.

63 AAN, MKiS, DIAiO, 42, 16.

64 ZKP, 12/7, "Sprawozdanie z Działalności Zarządu Głównego," 26.

65 AAN, Artos, 99, 118.

66 AAN, Artos 99.

67 AAN, Artos 105.

68 AAN, Artos 15, 1.

69 AAN, Artos 57, 33.

70 AAN, Artos 57, 36.

71 SAPMO-BArch, DY-30, IV 2/9.06/125, 49.

72 BArch, DR-1, 278, “Zur Verbesserung der Arbeit der DKGD," 20 July 1953, 3.

73 For the former, see Janik, Recomposing, 221-28; Thacker, Music after Hitler, ch. 5.

74 SAPMO-BArch, DY-30, IV 2/9.06/125, 127.

75 BArch, DR-1, 278, "Entwurf des Arbeitsplanes der DKGD für das Jahr 1954."

76 BArch, DR-1, 281, "Plattform der SED-Betriebparteiorganisation zur Konferenz der DKGD mit den Künstlern und Kulturschaffenden," May 1956.

77 BArch, DR-1, 40, "Protokoll zur Musikreferenten-Besprechung," 28 August 1952.

78 BArch, DR-1, 279, letter from Abt. Kunst und kulturelle Massenarbeit, Rat des Bezirkes Suhl, 14 February 1953.

79 BArch, DR-1, 40, "Protokoll zur Musikreferenten-Konferenz," 13 October 1952, 6.

80 BArch, DR-1, 278, "Zur Verbesserung der Arbeit der DKGD," 20 July 1953, 3.

81 BArch, DR-1, 273, "DKGD Zentrale," 12 October 1957. Of the 76 programs by musicians from the GDR, 63 percent had programs that contained at least one work by a GDR composer.

82 SAPMO-BArch, DY-30, IV 2/9.06/125, 269-73.

83 BArch, DR-1, 279, letter from Rat des Bezirkes, Leipzig, 31 January 1953.

84 BArch, DR-1, 272, letter from Fox, DKGD to MfK, 30 April 1957.

85 BArch, DR-1, 40, "Protokoll zur Musikreferenten-Konferenz," 13 October 1952, 9; Eberhard Schmidt, "Künstler auf Reisen," Berliner Zeitung, no. 29 (3 February 1956), in BArch, DR-1, 279.

86 BArch, DR-1, 33, "Revisionsprotokoll," MfK, HV-Film, Revisionsgruppe, 4 February 1955.

87 BArch, DR-1, 282, letter from HA Leiter Hoffmann, HA Kulturelle Massenarbeit to Stellvertreter des Ministers Pischner, 8 March 1957. 
88 BArch, DR-1, 279, "Geleitwort für den Prospekt der Stunde der Musik," 2 July 1953.

89 SAPMO-BArch, DY-30, IV 2/9.06/91, ”Durchführung der Verordnung vom 10.12.53 auf den verschiedenen Gebieten der Kunst und kulturellen Massenarbeit auf der Grundlage des Arbeitsplanes des MfK," 15 September 1954.

90 BArch, DR-1, 33, "Protokoll über die Fachbeiratssitzung der DKGD," 16 December 1955.

91 Laux, Musikleben, 75.

92 BArch, DR-1, 271, "Stunde der Musik 1954/55 (Programmabteilung)."

93 BArch, DR-1, 281, "Gedanken zur Konferenz der DKGD mit Künstlern und Kulturschaffenden."

94 Kurt Grösch, "Die 'Stunde der Musik,"” MuG 4, no. 2 (1954): 22-23.

95 BArch, DR-1, 9, "Vorschläge der HA Musik für die Beschlüsse der IV. LPG-Konferenz auf dem Gebiet der Kultur," 18 January 1956.

96 AAN, Artos, 40, 97.

97 AAN, Artos, 99, 1.

98 AAN, KC PZPR, 237/XVIII-26, 12-17. See the section on "Rural Music Festivals," above.

99 Ibid.; AAN, Artos, 15, 6, 13.

100 Richard Stites, Russian Popular Culture: Entertainment and Society since 1900 (Cambridge: Cambridge University Press, 1992), 53, 81.

101 AAN, Artos, 79, 16 April 1954.

102 AAN, Artos, 40, 97.

103 AAN, MKiS, CZIM, 3255, "Posiedzenie Kolegium Centralnego Zarządu Instytucji Muzycznych," 15 April 1955, 5.

104 AAN, MKiS, CZIE 18, 19 October 1955.

105 BArch, DR-1, 40, "Protokoll zur Musikreferenten-Konferenz," 13 October 1952, 3.

106 SAAdK, 303, letter from Uszkoreit, MfK to VDK, 15 April 1955; SAPMO-BArch, DY-30, IV 2/9.06, Abschrift, Abteilung Kultur der Bezirksleitung der SED Schwerin, 330-331.

107 See reports in AAN, MKiS, DTA, 475 and 476.

108 AAN, KC PZPR, 237/XVIII-26, 57.

109 Ibid.

110 Ibid., 65.

111 Ibid., 61.

112 Ibid., 69.

113 AAN, Artos, 79, 25 June 1954.

114 AAN, KC PZPR, 237/XVIII-85, Sprawozdanie z akcji koncertów masowych, 144-48.

115 AAN, Artos, 99, pp. 61, 108, 159.

116 SAPMO-BArch, DY-30, IV 2/9.06/125, 20, Letter from SED-Betriebsgruppe der VAB to DVD Berlin, 29 November 1950.

117 Stites, Russian Popular Culture, 16-22, 49-53, 78-81. See also Matthias Stadelmann.““O, wie gut ist es, im sowjetischen Land zu leben'-Unterhaltungskultur als gesellschaftliches Integrationsmoment im stalinistischen Regime," GuG 30 (2004): 74-93.

118 “Zamierzenia Artos-u na rok 1951," Muzyka 2, no. 1 (1951): 13; DMA, VDK, "Protokolle I. Jahreskonferenz, 159, 229.

119 The second department of Artos was devoted to estradowy, or light stage performances, and operated under a director who oversaw 18 workers; an artistic council made up of five Artos administrators, two representatives of the Writers' Union, and one from the Composers' Union, provided advice and direction. This department also contained two sections: programmatic artistic supervision, and administration. The former occu- 
pied itself with evaluating and ordering these mixed musical and theater compositions. (AAN, KC PZPR, 237/XVIII-26, 12-17).

120 AAN, Artos, 26, letter do Kierownika Inspekcji, 29 November 1950.

121 AAN, Artos, 48, 18.

122 AAN, Artos, 56, 21.

123 AAN, Artos, 59, 1, 3, 4, 10.

124 AAN, KC PZPR, 237/XVIII-26, 2.

125 AAN, KC PZPR, 237/XVIII-110, 126-35.

126 AAN, KC PZPR, 237/XVIII-110, "Notatka w sprawie repertuaru Artosu," 118.

127 AAN, Artos, 40, 92.

128 AAN, KC PZPR, 237/XVIII-26, 2.

129 AAN, KC PZPR, 237/XVIII-26, 24-27.

130 Ibid.

131 Ibid., 35-57.

132 AAN, MKiS, CZIE, 18, 181, 205, 108, 190. See similar comments throughout file.

133 AAN, MKiS, CZIE, 18, 125.

134 AAN, Artos, 56, 1.

135 AAN, KC PZPR, 237/XVIII-110, 122.

136 Ibid., 21.

137 AAN, Artos 75, 9.

138 AAN, Artos 75, 39.

139 AAN, MKiS, CZIE, 18, see throughout file.

140 AAN, Artos, 38, letter from Inspektorat Wewnętrznej Artosu to Dyrektor Naczelny, 20 April 1952, 10.

141 AAN, Artos, 41, Odpis from Dept. Kontroli, MKiS to Obywatel Dyrektor Artos, 3 September 1952; AAN, Artos, 40, “Analiza lustracji Oddziałów Terenowych," 23 July 1953, 27.

142 AAN, Artos, 40, 9.

143 SAdK, VDK, 1023, "Arbeitskonferenz des Zentralhauses für Laienkunst am 3. und 4.3.54," 125.; BArch, DR-1, 355, "Bericht über den Instrukteureinsatz am 27.1.53 beim Rat des Bezirkes Cottbus, Abteilung Kunst."

144 BArch, DR-1, 8, Protokoll, 26 February 1953.

145 BArch, DR-1, 201, "Bericht über das Referat des Kollegen Uszkoreit am 20.5.54."

146 Ibid., "Bericht zum Referat des Kollegen Uszkoreit am 16.9.54."

147 BArch, DR-1, 6178, Abschrift von Abschrift, Uszkoreit, HA Musik to DKGD, 21 November 1953. Also here are many letters where tax-free status is requested and often denied when officials felt that "the cultural level of the working people [was not being] lifted." (letter 17 February 1954.)

148 BArch, DR-1, 355, letter from Uszkoreit to Hoffman, HA Kulturelle Massenarbeit, "Betr. Kurzbericht über die Erfüllung der beiden Programmerklärungen auf dem Gebiete der Musik," 8 March 1956.

149 BArch, DR-1, 6201, "Bericht über die Instrukteureinsatz am 27.1.53 beim Rat des Bezirkes Cottbus, Abteilung Kunst."

150 Ilse Schütt, "Das war nicht aus der Schatzruhe," Tribüne, no. 11 (9 February 1951), in SAPMO-BArch, DY-30, IV 2/9.06/125, 163.

151 BArch, DR-1, 33, "Bericht: Betr. Tätigkeit der DKGD,” 24 November 1954, 3.

152 von Geldern, Bolshevik Festivals.

153 AAN, KC PZPR, 237/XVIII-110, 118; AAN, KC PZPR, 237/XVIII-26, 26. 
154 AAN, KC PZPR, 237/XVIII-110, 127. One example of a lame, politically problematic joke was a play on the saying: "Those who wake early, are rewarded by God." The konferansjer tweaked this into: "Those who wake early, yawn."

155 AAN, KC PZPR, 237/XVIII-26, 2-4.

156 Ilse Schütt, "Das war nicht aus der Schatztruhe," Tribüne, Nr. 11 (9 September 1951), in SAPMO-BArch, DY-30, IV 2/9.06/125, 163.

157 BArch, DR-1, 33, "Bericht, Betr. Tätigkeit der DKGD," 22 November 1954.

158 BArch, DR-1, 278, "Vorlage DKGD," 10 September 1953, 5.

159 AAN, MKiS, DTA, 477, 20.

160 AAN, Artos, 40, 100.

161 AAN, CZTOiF, 2740, 23-24.

162 AAN, KC PZPR, 237/XVIII-26, "Wnioski z narady aktywu partyjnego," 12 October 1953.

163 AAN, Artos, 40, 101. Indeed, one report here, from 25 July 1953 (23), claims they were 100 percent eliminated.

164 AAN, KC PZPR, 237/XVIII-120, “Sektor Muzyki,” 9 April 1955, 39.

165 AAN, KC PZPR, 237/XVIII-149, letter from Jerzy Merson, MKiS to KC PZPR, 24 February 1955.

166 AAN, MKiS, CZIE, 25, "Protokół z posiedzenia CZIE,” 25 August 1956, 57.

167 ZKP 12/9, IX Walny Zjazd, 10 March 1957.

168 SAPMO-BArch, DY-30, IV 2/9.06/125, letter from Grösch to Holtzhauer, 9 February $1952,101$.

169 BArch, DR-1, 40, "Protokoll zur Musikreferenten-Konferenz," 13 October 1952, 8.

170 Some extensions were granted until March 31, 1953. SAPMO-BArch, DY-30, IV 2/9.06/246, letter from Abt. Kunst u. Kulturelle Massenarbeit, Rat des Bezirkes Dresden to Konzertdirektion Erich Knoblauch, 22 January 1953, 279.

171 BArch, DR-1, 269, exchanged letters, 1952-55.

172 SAPMO-BArch, DY-30, IV 2/9.06/246, letter from Lorz to Referat Schöne Literatur und Kunst, ZK der SED, 14 April 1953, 276-78.

173 BArch, DR-1, 238, "Stenographisches Protokoll der Beratung der Leitung des MfK mit den Abteilungsleitern für Kultur der Räte der Bezirke," 10 December 1957. He is mentioned here as the last private concert organizer in Dresden.

174 BArch, DR-1, 269, letter from Verwaltung für Kunstangelegenheiten, Rat des Bezirkes Dresden, Landesregierung Sachsen to HA Darstellende Kunst und Musik, Stakuko, 3 September 1952.

175 SAPMO-BArch, DY-30, IV 2/9.06/246, 27 January 1953, 280-82.

176 BArch, DR-1, 33.

177 On 6 April 1955. Letter from his wife, Gerda Rabofsky, BArch, DR-1, 269, 29 April 1955; BArch, DR-1, 269, letter from Folkmann to Generalstaatsanwaltschaft, 5 May 1955.

178 Jan Gross, Revolution from Abroad: The Soviet Conquest of Poland's Western Ukraine and Western Belorussia (Princeton: Princeton University Press, 1988).

179 As of 1990, the orchestras in the GDR numbered 76, which was less than half of those existing in the mid-1950s. Nonetheless, this came to one orchestra for every 220,000 inhabitants; for West Germany, it was one per 690,000; in the USA, one per 1.6 million; in Great Britain, one per 6.1 million. Jutta Allmendinger, "Staatskultur und Marktkultur, Ostdeutsche Orchester im Vergleich" in Kultur und Kulturträger in der DDR, eds. Anna-Sabine Ernst et al. (Berlin: Akademie Verlag, 1993), 230.

180 Dziębowska, Kultura muzyczna, 21.

181 Ibid., 17. 
182 AAN, MKiS, CZTOiF, 2732, Protokół Kolegium CZTOiF, 17 January 1953, 10.

183 AAN, MKiS, CZTOiF, 2768. Composers frequently complained about the poor level of the country's musical ensembles (see esp. ZKP, 12/8, Part I: 53, 56, and Part II: 11, 104.).

184 AAN, MKiS, CZTOiF, 2768.

185 AAN, MKiS, CZTOiF, 2773, reports throughout file.

186 AAN, KC PZPR, 237/XVIII-85, 44-47; AAN, KC PZPR, 237/XVIII-120, 30-31, 62; Stanisław Wisłocki, Życie jednego muzyka (Warszawa: Oficyna Wydawnicza RYTM, 2000), 86-87.

187 AAN, KC PZPR, 237/XVIII-120, 30. A number of its members also went to the Filharmonia Pomorska (Pomeranian Philharmonic), which had been elevated in important two years prior, thus helping to render the Radio Orchestra of Bydgoszcz somewhat superfluous. "Orkiestra Symfoniczna Polskiego Radia w Bydgoszczy," http://pl.wikipedia. org/wiki/Orkiestra_Symfoniczna_Polskiego_Radia_w_Bydgoszczy.

188 AAN, MKiS, CZTOiF, 2765 and 2766.

189 AAN, KC PZPR, 237/XVIII-24, "Sprawozdanie" (no date, but probably summer-fall 1953), 109-16; AAN, MKiS, CZTOiF, 2795, 41.

190 AAN, KC PZPR, 237/XVIII-107, "Notatka o sytuacji na terenie Filharmonii Narodowej," 120-23.

191 Ibid., 122; Stanisław Wisłocki, Stanisław Wisłocki: Życie jednego muzyka (Warsaw: Oficyna Wydawnicza RYTM, 2000), 87; AAN, KC PZPR, 237/XVIII-120, Sektor Muzyki, 18 June 1955, 21.

192 AAN, KC PZPR, 237/XVIII-107, letters, 4 November 1955 and 1 December 1955, 233, 253.

193 AAN, MKiS, DTA, 469, Sprawozdanie DTA za I kwartal 1949, 92-93; AAN, MKiS, DTA, 470, Sprawozdanie, October 1949, 109; ZKP, 12/5, 56.

194 AAN, MKiS, CZTOiF, 2738, "Plan pracy CZOFIM na 1953," 1; AAN, MKiS, CZTOiF, 2738, "Plan pracy na II kwartal 1953," 11; AAN, MKiS, CZTOiF, GDTOiF, 2378; Dziębowska, Kultura muzyczna, 18.

195 (See below on the GDR.) AAN, MKiS, CZTOiF, 2732, "Protokół Nr. 10 posiedzenia rozszerzonego Kolegium CZTOiF," 24 December 1954, 85; AAN, MKiS, CZIM, 3255, Protokół Nr. 6, 29 November 1955.

196 AAN, MKiS, CZTOiF, 2732, Protokół Nr. 10, 87; AAN, MKiS, CZIM, 3321, "Plan pracy na rok 1957," 8; Fijałkowska, Polityka, 406, 513.

197 Compare the lists in AAN, MKiS, CZIM, 3257, 44-45 and 61-62. The Ministry maintained control in Gdańsk, Stalinogród (Katowice), Kraków, Lublin, Łódź, Poznań, Warsaw, Bydgoszcz, and Szczecin.

198 ZKP, 12/9, letter from ZKP and SPAM to Józef Cyrankiewicz, 1 March 1957.

199 AAN, KC PZPR, 237/XVIII 24, "Notatka z posiedzenia egzekutywy KW w Gdansku," 11 December 1953, 143; AAN, KC PZPR, 237/XVIII 124, Sprawozdanie, 109; AAN, KC PZPR, 237/XVIII 103, 138-41.

200 AAN, MKiS, GDTOiF, 2367 and 2368; AAN, MKiS, CZTOiF, 2733, "Ramowy plan pracy CZTOiF na rok 1954," 7.

201 AAN, MKiS, CZTOiF, 2738, 1; AAN, KC PZPR, 237/XVIII-148, "Plan pracy MKiS na rok 1954," 14, and "Odpis: Projekt instrukcji w sprawie współpracy zwiazkowego ruchu amatorskiego z zawodowymi placowkami artystycznymi," 62.

202 AAN, MKiS, CZIM, 3255, Protokół Nr. 7, 24 December 1955, 19.

203 Janik, Recomposing, 11-17, 31-32, 61; Allmendinger, "Staatskultur," 225.

204 BArch, DR-1, 10, "Über die Entwicklung der Musikkultur in der DDR," no date (likely May 1953). 
205 SAPMO-BArch, DY-30, IV 2/9.06/279, "Referat zur Orchesterleiter-Tagung," 26 November 1952, 2, 8.

206 BArch, DR-1, 8, "Vorschläge zur Verordnung vom 10.12.53," 12 April 1954; BArch, DR-1, 8, Bericht, 14 April 1953.

207 SAPMO-BArch, DY-30, IV 2/9.06/279, "Bericht von der Orchesterleitertagung," 26 November 1952, 3.

208 See especially BArch, DR-1, 82, reports from spring 1954.

209 See the organizational descriptions in BArch, DR-1, 6136, "Liste der Orchester der DDR nach ihrer Leistungshöhe" (no date, probably late 1951); BArch, DR-1, 10, "Orchesterordnung der DDR," 4. Entwurf, 21 April 1954. For information on orchestras during National Socialism, see Steinweis, Art, Ideology and Economics, 83-84.

210 In the early 1950s, there were also "community training orchestras" (Gemeinschaftsschulungsorchester) that were to comprise local musicians on a volunteer basis to provide technical and political training. The goal was to have these develop into "community orchestras" or district orchestras, and it would appear that this indeed happened rapidly. (BArch, DR-1, 6203, "Planaufgaben zum Fünfjahrplan," Hartig, 8 December 1951.)

211 The growth was so rapid that even cultural officials had trouble keeping count. See BArch, DR-1, 6136, "Liste der Orchester der DDR nach ihrer Leistungshöhe," (no date, probably late 1951); BArch, DR-1, 10, "Theater- und Kulturorchester der DDR," 13 March 1953; BArch, DR-1, 6196, “Analyse zur Planabrechnung I/54,” Schott, 22 July 1954; SAPMO-BArch, DY-30, IV 2/9.06/284, “Zum Bericht für die Wahlen 1954,” 11 June 1954, 103.

212 BArch, DR-1, 6136, letter from Dr. Siegmund-Schultze to the Landesregierung Sachsen-Anhalt, 26 November 1951.

213 In early 1957, the Ministry reported the following losses: five from the Dresden Staatskapelle, six from the Leipzig Gewandhaus Orchestra, six from Karl-Marx-Stadt, seven from Dessau, and three from Schwerin. (BArch, DR-1, 138, "Zur Situation auf dem Gebiet des Orchesterwesens," 5 March 1957, 4.) The Ministry had been concerned about this for some time. See ibid., letter from Pischner to Bork, 10 November 1954; BArch, DR-1, 6169, “Analyse zur Planabrechnung I/54," 22 July 1954. For more on the battle over personnel, see Michael Lemke, "Der 'Sängerkrieg ' in Berlin" in Schaufenster der Systemkonkurrenz: Die Region Berlin-Brandenburg im Kalten Krieg, edited by Michael Lemke (Cologne: Böhlau Verlag, 2006), 269-296, and Janik, Recomposing, 219-20.

214 BArch, DR-1, 10, "Vorlage über eine Reorganisation des Orchesterwesens in der DDR mit dem Ziel der Verbesserung der Qualität der Musikaufführungen bei größtmöglicher Befriedigung der vielfältigen kulturellen Ansprüche der Werktätigen unter dem Gesichtspunkt des sparsamsten materiellen Aufwandes," 13 April 1955. See also BArch, DR1, 138, "Plan zur Verbesserung der Musikkultur in der DDR," 11 March 1955; BArch, DR-1, 140, letter from Zentraler Bühnennachweis, Abt. Oper/Operette to MfK, 4 April 1955 .

215 BArch, DR-1, 10, "Vorlage über eine Reorganisation ...," 2.

216 BArch, DR-1, 9, "Vorschläge der HA Musik für die Beschlüsse der IV. LPG-Konferenz auf dem Gebiet der Kultur," Pischner, 18 January 1956.

217 Steinweis, Art, Ideology, and Economics, 81-82. In an exact mirror of the situation in the GDR, in order to survive a punishing economic environment, ensembles in the later 1930s asked to be classified beneath their true artistic level so that they would be able to pay their members on a lower pay scale. See also Michael Kater, The Twisted Muse: 
Musicians and Their Music in the Third Reich (Oxford: Oxford University Press, 1997), 7-10.

218 BArch, DR-1, 136, "Bericht von dem Rat des Bezirkes," no date.

219 BArch, DR-1, 10, "Vorlage über eine Reorganisation ...,", 1-4.

220 BArch, DR-1, 355, "Entwicklung der Musik im 2. Fünfjahrplan,” 31 January 1956. See also BArch, DR-1, 355, "Grundlagen für das Jahrbuch 1956 der DDR zum Gebiet der Musik"; BArch, DR-1, 138, "Zur Situation auf dem Gebiet des Orchesterwesens," 5 March 1957.

221 SAPMO-BArch, DY-30, IV 2/9.06/284, “Zum Bericht für die Wahlen 1954,” 11 June 1954, 103; SAPMO-BArch, DY-30, IV 2/9.06/91, "Die Hauptaufgaben der HA Musik in 1955," (no date), 28. A small number of subsidies were given out in subsequent years. See also BArch, DR-1, 82, "Bericht zur Durchführung der Verordnung vom 10.12.53," HA Musik, 3 August 1954.

222 "Protokoll der Delegierten-Konferenz des VDK," 23-24 February 1957, DMA, VDK, 52-55; BArch, DR-1, 30, “Zur kulturellen Entwicklung im 2. Fünfjahrplan,” Lahl, 14 November 1957.

223 Laux, Das Musikleben, 58.

224 BArch, DR-1, 27, "Konzert-Planung der Orchester in öffentlicher Hand, anerkannter Kultur-Orchester und konzertierender Theater-Orchester," Holtzhauer. In practice, officials in Berlin also exercised considerable influence over the concert programs of the provincial orchestras, both directly and through close oversight of regional officials.

225 BArch, DR-1, 55, Ref. Musik, Hartig, 28 January 1952.

226 BArch, DR-1, 6161, letter from Uszkoreit to GMD Walter Stoschek, Stadttheater Plauen, 21 April 1953.

227 BArch, DR-1, 8, Bericht, 11 April 1953. The Stakuko asked the Composers' Union for help in developing the first list. (SAdK, 295, letter from Möller, 13 May 1953, and. "Vorschläge für Aufführungen zeitgenössischer Musik.")

228 SAPMO-BArch, DY-30, IV 2/9.06/286.

229 See throughout, BArch, DR-1, 6161.

230 See throughout, DR-1, 138.

231 SAPMO-BArch, DY-30, IV 2/9.06/279, "Referat zur Orchesterleiter-Tagung," 26 November 1952, 6 .

232 BArch, DR-1, 6161, exchange of letters in spring 1953.

233 Ibid., letter from Uszkoreit to Rat des Bezirkes Dresden, 6 July 1953.

234 Ibid., Uszkoreit to Rat des Bezirkes Suhl, 6 July 1953.

235 See throughout, BArch, DR-1, 6161.

236 SAPMO-BArch, DY-30, IV 2/9.06/279, "Referat zur Orchesterleiter-Tagung," 26 November 1952, 3 .

237 SAPMO-BArch, DY-30, IV 2/9.06/284, 225. By the end of the decade, this had been at least partially addressed (Laux, Musikleben, 93).

238 BArch, DR-1, 10, "Protokoll der Besprechung mit dem sowjetischen Musikwissenschaftler Prof. Chubow" (no date, likely late 1953 or early 1954).

239 See the interview excerpts with Paul-Heinz Dittrich in Zur Weihen, Komponieren, 402.

240 SAPMO-BArch, DY-30, IV 2/9.06/279, "Referat zur Orchesterleiter-Tagung," 26 November 1952, 3; Konwitschny did promote leading contemporary GDR composers like Dessau, Eisler, and Gerster in his roles as conductor of the Gewandhaus orchestra and as musical director of the Dresden Staatsoper. (Wolfram Schwinger, "Konwitschny, Franz." Grove Music Online. Oxford Music Online, accessed July 26, 2012, http://www. oxfordmusiconline.com/subscriber/article/grove/music/15350). 
241 SAPMO-BArch, DY-30, IV 2/9.06/279, "Referat zur Orchesterleiter-Tagung," 26 November 1952, 3.

242 See the exchange of letters in BArch, DR-1, 6161.

243 BArch, DR-1, 207, "Stenografische Niederschrift der Orchesterleitertagung des MfK am 13. und 14. Februar 1956 in der DAdK."

244 BArch, DR-1, 138, "Kurze Analyse der bis zum 10.9.55 vorliegenden Konzertprogramme 1955-56."

245 BArch, DR-1, 138, Letter from Pischner to Professor Bongartz, 12 October 54.

246 BArch, DR-1, 5858, "Vorlage zur Konzertplanung und -kontrolle," Uszkoreit, 151.

247 BArch, DR-1, 5858, "Protokoll der Sitzungen des Kollegiums," 15 June 1953.

248 SAPMO-BArch, 6161, letters from Uszkoreit on 6 July 1953

249 BArch, DR-1, 5858, "Vorlage zur Konzertplanung und -kontrolle," Uszkoreit, 151. This had also been discussed at a Stakuko meeting with Akademie der Künste members in early July. BArch, DR-1, 6191, "Protokoll der Sitzung der Kunstkommission," 7 July 1953.

250 BArch, DR-1, 20, Merkblatt 1, "Die Entwicklung der Musikkultur in der DDR, Betr. Überprüfung der KKO," no date (likely spring 1953), 260-265; ibid., 6191, "Bericht über die Erfüllung der Schwerpunktaufgaben im Juli 1953," 1 August 1953 and Schwerpunktbericht, September 1953, 1 October 1953.

251 BArch, DR-1, 10, "Protokoll der Besprechung mit dem sowjetischen Musikwissenschaftler Prof. Chubow" (no date, likely late 1953 or early 1954).

252 BArch, DR-1, 138, "Kurze Analyse der bis zum 10.9.55 vorliegenden Konzertprogramme 1955-56." For more concrete percentages that show better compliance, see also SAdK, Hans-Pischner-Archiv, 657, "Referat für die Orchesterleitertagung," 13-14 February 1956, 27.

253 SAdK, Hans-Pischner-Archiv, 657, 27-28.

254 BArch, DR-1, 10, "Zur Reorganisation der Orchesterchöre und Quartette," April 1953. See reports on these trainings in: BArch, DR-1, 6200, "Protokoll über die Orchesterleitertagung," 26 November 1952; BArch, DR-1, 138, "Vertraulich: 1. Dirigentenlehrgang in Halle vom 23.8-10.9.1954," and "Bericht über die 3. Lehrgänge für Orchestermusiker vom 20.7.55-22.8.55;" BArch, DR-1, 8, Bericht, 11 April 1953; for typical speeches at these courses, see SAdK, Hans-Pischner-Archiv, 652, "Die gesellschaftliche Rolle der Musik beim Aufbau einer Volkskultur in der DDR," Orchesterleitertagung, 18 January 1955, and SAdK, Hans-Pischner-Archiv, 657, "Referat für die Orchesterleitertagung am 13.-14. Februar 1956."

255 BArch, DR-1, 203, "Betr. 3. und 4. Lehrgang für Orchestermusiker" and "Bericht über die 3 Lehrgänge für Orchestermusiker vom 20.7-22.8.1955.“

256 DR-1, 6200, Protokoll über die Orchesterleitertagung vom 26 November 1952.

257 BArch, DR-1, 10, “Zur Reorganisation der Orchesterchöre und Quartette," April 1953; BArch, DR-1, 82, "Bericht zur Durchführung der Verordnung von 10.12.53," 3 August 1954.

258 BArch, DR-1, 82, Sinfonie-Orchester Saalfeld, 6 April 1954.

259 BArch, DR-1, 355, "Instrukteureinsatz nach Gotha, Arnstadt, Erfurt," 2 February 1953; BArch, DR-1, 8, Bericht, 14 April 1953.

260 For example with respect to Riesa's culture orchestra, see BArch, DR-1, 139, Rat des Bezirkes Dresden to Stakuko, 2 June 1953. A report from Dresden from mid-decade noted progress, but that more needed to be done to attract workers (SAPMO-BArch, DY-30, IV 2/9.06/284, 225-27).

261 Laux, Musikleben, 83. 
262 In Poland, nearly three million attended in 1955, and this increase was due to the 1955 Chopin Piano Competition concerts. Dziębowska, "Ruch koncertowy i operowy" in Kultura Muzyczna Polski Ludowej, eds. Józef Chomiński and Zofia Lissa (Kraków: PWM, 1957), 18; Laux, Musikleben, 58. In the same period, the GDR had almost nine million attendees at operas and operettas (59), while for the same genres in Poland in 1955, there were just over two million (Dziębowska, "Ruch koncertowy," 21).

263 AAN, MKiS, CZTOiF, 2732, "Sprawozdanie artystyczne za rok 1952," 3.

264 BArch, DR-1, 6200, "Protokoll über die Orchesterleitertagung," 26 November 1952. 



\section{Conclusion}

In the early Cold War years in Poland and the GDR, the ruling parties and their formidable state bureaucracies possessed considerable power to remake their societies. PZPR and SED officials, along with their allies more broadly, attempted total transformation and control at the apex of their strength around 1950. Inspired by the idea of music's outsized role in influencing worldviews, the parties sought to utilize this art form's distinctive properties to help reconstruct the social world in line with party goals. In the late 1940s and early 1950s, the two parties achieved notable successes in working with composers to create a new music, and then in disseminating these works to the broader population. In their thrust to dominate both the real and symbolic terrain of the musical world, as well as to shape and control the "new socialist person" more generally, the PZPR and SED devoted considerable monetary and political capital to this important sector of both cultural production and everyday life. The parties created an extensive music-related apparatus within their own party organizations as well as the state bureaucracy, though they constantly battled with underqualified and insufficient personnel. Officials then strove to extend their influence to musical institutions they helped promote, such as the Composers' Unions, festivals, concert agencies, and performing ensembles. This impressive musical infrastructure demonstrated the parties' claim to be serious and enthusiastic wards of tradition, as well as their commitment to making that cultural patrimony available to every worker and peasant - in addition to, of course, a blunt desire for control by tapping the potential of music. As part of the project to create a contemporary and politicized new music and make it widely accessible, the parties distributed lavish support among composers and made inexpensive entertainment available to audiences, thereby earning appreciation as well as a basis of legitimacy.

The SED and PZPR ultimately proved unable to master the musical realm completely. Although often amenable to following party directives, composers, musicians, and audiences expressed and achieved their own, sometimes opposing goals, or at times worked with officials to modify them in a form they preferred. While the parties had great influence, developments in the musical world were the product of negotiation between cultural officials and musical figures. The Composers' Unions in particular were key sites for this interaction between mu- 
sic and politics, since officials and their musical allies used them as a transmission belt for party directives. But more importantly, the unions provided a milieu for composers to regulate their professional lives and discuss their aesthetic ambitions, and changing factions in their membership debated and worked out the pressing issues of the day. An increasing majority of Polish composers pushed a gradual process of professionalization, which helped to emancipate themselves from party control, while the SED succeeded in maintaining its influence through the loyal union leadership despite similar developments in East Germany.

Instead of a still-common conception of artists forced into compliance by an omnipotent party, this study describes a situation where nearly all composers willingly cooperated in creating a new, socialist-realist music for the emerging stalinist reality. Furthermore, the parties never presented themselves as a unified front to the music world. Especially in Poland, party members in the bureaucracy and among composers vied to realize their own visions for this music, even as nonparty musical figures adopted or abandoned positions from the hardline to the lukewarm. Composers in both countries found significant common ground with a party that sought to educate the population about both past and present music, and also cooperated for other reasons such as financial incentives, a desire for recognition, and political pressure, though this last was much less powerful than is often asserted in the literature. In the early 1950s, this room for maneuver was at its narrowest, but composers always had more options than submission, silence, or writing for the desk drawer.

Relatedly, the encounter between the musical world and socialist realism was by no means as bleak as often asserted. Initially, Polish and East German composers approached the new aesthetic ideas with interest and responded in an astonishingly productive manner, creating countless mass songs, cantatas, and orchestral works that aspired to high artistic standards and contributed to a vibrant musical life. Frustration only came when the parties pushed to narrow the boundaries of the acceptable around 1950. A growing resistance to these strictures from some composers already in 1951, and then an initial and tentative willingness by the party to relax them beginning in late 1952 in Poland and a bit later in the GDR, fed into the broader thaw after Stalin's death in March 1953. In Poland, composers achieved nearly complete autonomy by 1956, while their colleagues in the GDR continued to work within the- -henceforth expanded - tenets of socialist realism.

The music of the stalinist era, then, emerged in a complex context of many actors pursuing diverse agendas. These overlapping groupings complicate an understanding of these countries as separated into a clear division between state and society. Though the parties attempted to oversee an assertion of control from the top-down and were partially successful, multiple and mediating layers filtered power in all directions, with cultural officials, composers, ensemble directors, 
concert organizers, musicians, and audience members of many backgounds helping to shape the creation of music and the manner and spaces in which it was performed.

The populations of Poland and the GDR could experience extensive musical offerings at festivals, in the formal concert hall, or in the factory or rural clubroom. During this period, society engaged with a music strongly, albeit not exclusively, influenced by the parties. Concerts of all kinds and sizes were largely devoid of the music of "formalist" composers until the mid-1950s, and often included party-approved, contemporary works that fit the socialist-realist paradigm and also included mass songs, some of which achieved significant and enduring popularity. Musical icons like Bach and Beethoven in the GDR and Chopin in Poland were cast as progressives of their time, and press articles and concert booklets formulated this interpretation for wider consumption. Opportunities to negotiate existed here too, as festival organizers, musical directors, and individual ensemble members interacted directly with the state over policy or indirectly by moving to a different ensemble — or even to a different country. Audiences shaped events as well by staying away from some concerts, thus prompting the development of lighter music programs with less overt ideological content. These citizens did make themselves heard, and often criticized both the party and composers for not supplying them with sufficient and acceptable music that entertained. Increasingly, people turned to the popular music of the West instead of domestic production.

Equally important is the Cold War context of fierce competition between the two opposing systems. For much of the period, the parties were able to mobilize a large section of the music world against what it demonized as soulless experimentation or popular kitsch coming from the West. By the mid-1950s, however, Western culture, both high and low, proved too seductive to both composers and audiences, and the weakened, destalinizing regimes were no longer able to keep it out. Works by formerly condemned composers came to concert halls, and jazz and Western popular music gained an increasing audience. In Poland, officials largely gave up the fight, even as their East German counterparts continued a policy of granting some concessions while energetically promoting musical works more aligned with official ideology.

This story has been both a comparative and also a transnational one, with ideas, people, and music crossing the Oder-Neisse border. More significant, however, was that fact each country derived the templates for many aspects of musical life from the Soviet Union. Articles from the Soviet musical press appeared in both countries, and Soviet composers and musicologists made regular visits to Poland and East Germany in order to consult and advise, while leading Polish and East German musical figures traveled to the Soviet Union in return. Socialist realism, the party and state cultural apparatus, the organization of festivals and 
concert life - all were largely based on the Soviet model. But the outward, seemingly uniform appearance of these Soviet-like structures in both countries should not deceive. These two representative members of the communist bloc exhibited significant differences in their own particular, national encounter with stalinism, thus demonstrating intra-bloc diversity during the postwar decade.

Indeed, despite the many similarities between the two countries, especially in the years around 1950, the SED was undeniably more successful in influencing the musical world in East Germany than its counterpart to the east. Although many in Poland were willing to tolerate communist rule, and a minority actively supported it, the SED enjoyed a higher level of cooperation in both the musical world and in society more generally. In relative terms, East German composers carried party cards at twice the level of their Polish counterparts. More significantly, many of the influential, major composers and musicologists in the GDR were communists or strong sympathizers, while most of the leading composers in Poland held the PZPR and its goals at a greater distance. Furthermore, the existence of West Germany played a dual role as both an escape valve to those dissatisfied in the GDR, as well as a useful "other" against which to consolidate the SED's own vision of a progressive, anti-fascist polity. Both aesthetically and politically, a larger number of East German composers had a broader affinity for the communist project than their counterparts in Poland. Germany had a stronger working-class musical tradition, including significant Social Democratic and communist parties that had an active presence in the musical realm before 1933 . Additionally, in the 1920s and 1930s, many of the leading East German figures in the cultural and musical world had engaged in Soviet aesthetic debates, or had even spent time in Moscow. In contrast, during the same period many Poles traveled to Paris to study the music of the neoclassical school, with artistic ideas quite different from those of socialist realism.

The key institutions of the Composers' Unions, while similar in structure, also played differing roles in the two countries. Polish composers had banded together to weather the Nazi occupation, and thereby possessed a sense of solidarity and autonomy that East German composers, who had been in exile or made compromises with Nazism, had not. The Polish Composers' Union was a continuation of an interwar institution, and its founding in 1945 pre-dated significant party involvement in the arts. Save for a brief time in around 1950, the union leadership in Poland consisted largely of members who were not strong supporters of the PZPR's goals. In contrast, the East German union was led throughout the period by an SED member, Nathan Notowicz, and party allies dominated its Presidium. Party officials also closely supervised the very creation of the East German union in 1951, and it never enjoyed the relative freedoms of its counterpart in Poland.

In addition to these advantages, the SED operated more cleverly and effectively than the PZPR. In 1953, a year of gathering crisis in both countries, 
the East German party made a series of concessions to the musical world. The much-hated Stakuko was replaced at the start of 1954 by a Ministry of Culture that acted less dogmatically; officials also gave composers more autonomy over the commissioning process, and granted orchestras the formal right to determine their own programs. These limited but meaningful compromises proved to be sufficient to satisfy most musical figures, and thus East German cultural officials maintained a reduced but significant amount of influence. In Poland, the party backed off its hard line in a reluctant, halting, and clumsy manner, which further alienated composers already chafing at party restrictions. A majority of Polish composers pressed for increased professional autonomy and achieved near-total independence by 1956 .

After 1957, the differences between the two countries only increased. In Poland, socialist realism was scarcely mentioned again, and the party and state cultural institutions rarely interfered in the music world. A vibrant jazz scene emerged and popular music exhibited strong Western influences, while an impressive number of annual festivals featured this music and popularized it throughout society. Composers created largely as they wished, and concert programs often offered music formerly discouraged, both domestic and from abroad. The Warsaw Autumn festival, begun in 1956 and then occurring annually starting in 1958, was representative for Poland's openness to Western and modernist music. The "Polish School" of music took form in the late 1950s, and composers like Lutosławski as well as younger composers such as Krzysztof Penderecki and Henryk Mikołaj Górecki achieved international acclaim for their modernist works. ${ }^{1}$ Though the stalinist decade is largely forgotten in light of these impressive developments, this study suggests that the extensive institutional and monetary support provided to composers and musical ensembles during the early Cold War years established a crucial foundation for these later achievements.

In the GDR, the increased freedoms of the thaw were somewhat restricted once again in the late 1950s, and the SED maintained considerable influence over the musical world. In the realm of popular music, cultural authorities shifted between greater and lesser acceptance of Western trends over the succeeding decades. The "Bitterfeld Way" was proclaimed in 1959 and called for a partnership between creative artists and workers, intensifying trends seen earlier in the decade such as composers reaching out to workers and musical ensembles performing in factories. East German composers continued to produce music in a socialistrealist idiom, though the style was expanded considerably and opened to Western influences and experimentation. ${ }^{2}$ Musical elites worked more than less willingly for the party's goals beyond the 1950s, and accommodated themselves or took pride in their country's achievements, as can be seen in numerous memoirs from the Honecker era. ${ }^{3}$ Such an interpretation has largely continued in Germany after 1989, as many East Germans affirm their culture, including that from the 1950s. 
In Poland in recent years, while there is some nostalgia for the culture of the stalinist era-as evidenced in the profusion of CD collections of stalinist mass songs - the postwar decade is viewed quite negatively and with a decided lack of context. Composers have often attempted to bury their socialist-realist compositions, and generally disavow any association with the political developments of the time. The claims later in life of Poland's two leading composers of the day, Andrzej Panufnik and Witold Lutosławski, prove instructive. Both cooperated with the party in the early 1950 s, but had achieved autonomy by the mid-1950s in very different ways. Panufnik, to a greater extent than most of his colleagues, worked closely with the party and benefited handsomely through the writing of numerous socialist-realist works. He then chose the path of emigration, to Great Britain, at the curiously late date of July 1954, when the political winds had begun to shift clearly in the direction of more openness and composers had achieved ever-increasing autonomy. Near the end of his life, he published a highly problematic memoir that tried to explain away and justify his involvement with the party and his musical production of the time. ${ }^{4}$ His celebrated contemporary who stayed, Witold Lutosławski, went even further, claiming: "I've never been disposed to make a compromise." ${ }^{5}$ This statement is surely untenable given that he composed a number of political mass songs, a highly ideological cantata, and several folk-based instrumental works that fit comfortably within the concept of socialist realism. The contemporary resonance of and motivations behind this music are more comprehensible in light of this study_like nearly all composers in both countries, he found much common ground with a party determined to create, fund, and propagate a new, socialist-realist music for the hoped-for new socialist society.

\section{Notes}

1 See Jakielski, "Changing Seasons" and Thomas, Polish Music.

2 Laura Silverberg, The East German Sonderweg to Modern Music, 1956-1971 (Ph.D. diss., University of Pennsylvania, 2007).

3 See especially Hans Pischner, Premieren eines Lebens: Autobiographie (Berlin: Verlag der Nation, 1986), and Dietrich Brennecke and Mathias Hansen, eds., Ernst Hermann Meyer. Kontraste, Konflikte: Erinnerungen, Gespräche, Kommentare (Berlin: Verlag Neue Musik, 1979). See also Günter Mayer, "Reflexionen zur Methodologie der Musikgeschichtsschreibung" in Musikwissenschaft und Kalter Krieg: Das Beispiel DDR, edited by Nina Noeske and Matthias Tischer (Cologne: Böhlau, 2010), 21-67.

4 Panufnik, Composing Myself. For a detailed discussion of Panufnik's career before emigration, see Tompkins, "Composing for and with the Party."

5 Nikolska, Conversations, 39. 


\section{Bibliography}

\section{Archives}

\section{Poland}

Archiwum Akt Nowych (AAN), Warsaw—Archive of Modern Records

Ministerstwo Kultury i Sztuki (MKiS)—Ministry of Culture and Art

- Biuro Amatorskiego Ruchu Artystycznego (BARA)—Bureau of the Amateur Artistic Movement

- Biuro Obchodów Artystycznych (BOA)—Bureau of Artistic Festivals

- Centralny Zarząd Imprez Estradowych (CZIE)—Central Administration of Light Performances

- Centralny Zarząd Instytucji Muzycznych (CZIM)—Central Administration of Musical Institutions

- Centralny Zarząd Teatrów, Orkiestr i Filharmonii (CZTOiF)—Central Administration of Theaters, Orchestras and Philharmonic Orchestras

- Departament Imprez Artystycznych i Obchodów (DIAiO)—Dept. of Artistic Performances and Festivals

- Departament Muzyki-Music Department

- Departament Polityki Kulturalnej (DPK)—Dept. of Cultural Politics

- Departament Twórczości Artystycznej (DTA)—Dept. of Artistic Production)

- Generalna Dyrekcja Teatrów, Oper i Filharmonii (GDTOiF)—General Direction of Theaters, Operas and Philharmonic Orchestras

Komitet Centralny, Polska Zjednoczona Partia Robotnicza (KC PZPR)—Central Committee of the Polish United Workers' Party

- Wydział Kultury (WK)—Culture Department

- Wydział Oświaty (WO)_Education Department

- Wydział Propagandy (WP)_Propaganda Department 
Państwowa Organizacja Imprez Artystycznych "Artos”-State Organization for Artistic Activities.

Najwyższa Izba Kontroli (NIK)_Supreme Oversight Office

Archiwum Polskiego Wydawnictwa Muzycznego (PWM)-Archive of the Polish Musical Publishing House, Kraków.

Archiwum Związku Kompozytorów Polskich (ZKP)—Archive of the Polish Composers' Union, Warsaw.

\section{Germany}

Bundesarchiv, Berlin (BArch)_German Federal Archive

DR-1: Ministerium für Kultur (MfK)

- Music Department

- Staatliche Kommission für Kunstangelegenheiten (Stakuko)

Stiftung-Archiv der Parteien und Massenorganisationen der DDR im Bundesarchiv (SAPMO-BArch), Berlin-Archival Foundation for the Parties and Mass Organisations in the German Federal Archive

DY-30: Zentralkomitee der SED

- IV 2/2.026 Büro Professor Alfred Kurella

- IV 2/9.06 Bereich Kultur

Stiftung-Archiv der Akademie der Künste (SAdK), Berlin-Archival Foundation for the Academy of the Arts

- Hans Pischner-Archiv

- Rudolf Wagner-Régeny-Archiv

- Verband deutscher Komponisten und Musikwissenschaftler (VDK)

Deutsche Musikbibliothek, Deutsches Musik-Archiv (DMA), Berlin.

\section{Journals and Newspapers}

Einheit

Kuźnica

Musik und Gesellschaft (MuG)

Muzyka

Neues Deutschland

Nowa Kultura

Odrodzenie 
Ruch Muzyczny (RM)

Sonntag

Tägliche Rundschau

\section{Printed and Secondary Sources}

10 Lat Opery Warszawskiej, 1945-55. Warsaw: Państwowa Opera w Warszawie, 1955.

Abrams, Bradley Francis. The Struggle for the Soul of the Nation: Czech Culture and the Rise of Communism. Lanham, MD: Rowman \& Littlefield, 2005.

Abusch, Alexander. Der Junge Künstler in unserer Zeit. Berlin: Verlag Junge Welt, 1956.

Albrecht, Norbert. "Musik zum Sprechen bringen: Aspekte der Narration in der frühen DDR-Musik." In Die erzählerische Dimension: eine Gemeinsamkeit der Künste, ed. Eberhard Lämmert, 305-30. Berlin: Akademie-Verlag, 1999.

Allinson, Mark. Politics and Popular Opinion in East Germany, 1945-1968. Manchester: Manchester University Press, 2000.

Allmendinger, Jutta. "Staatskultur und Marktkultur, Ostdeutsche Orchester im Vergleich." In Kultur und Kulturträger in der DDR, ed. Stiftung Mitteldeutscher Kulturrat, 225-75. Berlin: Akademie Verlag, 1993.

Amos, Heike. Auferstanden aus Ruinen: Die Nationalhymne der DDR, 19491990. Berlin: Dietz Verlag, 1997.

-. Politik und Organisation der SED-Zentrale 1949-1963. Struktur und Arbeitsweise von Politbüro, Sekretariat, Zentralkomitee und ZK-Apparat. Münster: LIT, 2003.

Anderson, Sheldon. A Cold War in the Soviet Bloc: Polish-East German Relations, 1945-1962. Boulder, CO: Westview Press, 2001.

Angermann, Klaus, ed. Paul Dessau: von Geschichte gezeichnet. Hofheim: Wolke, 1995.

Applegate, Celia. "What is German Music? Reflections on the Role of Art in the Creation of the Nation." German Studies Review 15 (Winter 1992): 21-32. http://dx.doi.org/10.2307/1430638.

Arnold, Klaus. Kalter Krieg im Äther. Der Deutschlandsender und die Westpropaganda der DDR. Münster: LIT, 2002.

Augustine, Dolores. "The Power Question in GDR History." German Studies Review 34, no. 3 (2011): 633-52.

Autio-Sarasmo, Sari, and Brendan Humphreys, eds. Winter Kept Us Warm: Cold War Interactions Reconsidered. Helsinki: Alesanteri Institute, 2010. 
Badstübner-Peters, Evemarie. "'Lassen wir sie tanzen . . . 'Nachkriegsjugend und moderne Freizeitskultur in SBZ und früher DDR." In Aber nicht im Gleichschritt. Zur Entstehung der Freien Deutschen Jugend, ed. Helga Gotschlich, Katharina Lange, and Edeltraud Schulze, 66-78. Berlin: Metropol, 1997.

Baculewski, Krzysztof. Historia Muzyki Polskiej. vol. VII. Współczesność, Part 1: 1939-1974. Warsaw: Sutkowski Edition, 1996.

—. Polska twórczość kompozytorska, 1945-1984. Kraków: PWM, 1987.

Baird, Tadeusz, and Izabella Grzenkowicz. Rozmowy, szkice, refleksje. Kraków: PWM, 1982.

Bálint, András Varga. Lutosławski Profile. London: Chester Music, 1976.

Barck, Simone. "Das Dekadenz-Verdikt. Zur Konjunktur eines kulturpolitischen 'Kampfkonzepts' Ende der 1950er bis Mitte der 1960er Jahre.” In Historische DDR-Forschung: Aufsätze und Studien, ed. Jürgen Kocka, 327-44. Berlin: Akademie Verlag, 1993.

_. "Die fremde Freunde. Historische Wahrnehmungsweisen deutsch-sowjetischer Kulturbeziehungen in der SBZ in den Jahren 1948 und 1949." In Amerikanisierung und Sowjetisierung in Deutschland, 1945-1970, ed. Konrad Jarausch and Hannes Siegrist, 335-59. Frankfurt: Campus, 1997.

Barck, Simone, Martina Langermann, and Siegfried Lokatis. "Jedes Buch ein Abenteuer": Zensur-System und literarische Öffentlichkeiten in der DDR bis Ende der sechziger Jahre. Berlin: Akademie Verlag, 1997.

Barth, Bernd-Rainer, Christoph Links, Helmut Müller Enbergs, and Jan Wielgohs, eds. Wer war wer in der DDR. Ein biographisches Handbuch. Frankfurt-am-Main. Fischer Verlag, 1995.

Baudin, Antoine. Le realisme socialiste sovietique de la periode jdanovienne (1947-1953): Les arts plastiques et leurs institutions. Bern: Peter Lang, 1997. . "'Why is Soviet Painting Hidden from Us?' Zhdanov Art and Its International Relations and Fallout, 1947-1953." In Socialist Realism Without Shores, ed. Thomas Lahusen and Evgeny Dobrenko, 227-56. Durham: Duke University Press, 1997.

Bathrick, David. The Powers of Speech: The Politics of Culture in the GDR. Lincoln: University of Nebraska Press, 1995.

Beckles-Willson, Rachel. Ligeti, Kurtág, and Hungarian Music during the Cold War. Cambridge: Cambridge University Press, 2007.

. "Memory, Dictatorship, and Trauma: Ligeti at the Hungarian Musicians' Union 1949-1953." In Music and Dictatorship in Europe and Latin America, ed. Roberto Illiano and Massimiliano Sala, 471-83. Turnhout, Belgium: Brepols, 2009.

Behrends, Jan C. Die erfundene Freundschaft. Propaganda für die Sowjetunion in Polen und in der DDR. Köln: Böhlau, 2006. 
Behrens, Alexander. Johannes R. Becher. Eine politische Biographie. Köln: Böhlau Verlag, 2003.

Bentzien, Hans. Was geschah am 17. Juni? Vorgeschichte-Verlauf-Hintergründe. Berlin: edition ost, 2003.

Berger, Manfred, et al. Kultur und Kulturträger in der DDR. Analysen. Berlin: Stiftung Mitteldeutscher Kulturrat, 1993.

Berghahn, Volker R. America and the Intellectual Cold Wars in Europe: Shepard Stone between Philanthropy, Academy, and Diplomacy. Princeton: Princeton University Press, 2001.

Betts, Paul. Within Walls: Private Life in the German Democratic Republic. New York: Oxford University Press, 2010.

Blake, David, ed. Hanns Eisler: A Miscellany. Luxembourg: Harwood Academic Publishers, 1995.

Blessing, Benita. The Antifascist Classroom: Denazification in Soviet-occupied Germany, 1945-1949. New York: Palgrave Macmillan, 2006.

Börner, Sylvia. Die Kunstdebatten 1945 bis 1955 in Ostdeutschland als Faktoren aesthetischer Theoriebildungsprozesse. Frankfurt: Peter Lang, 1993.

Bolesławska, Beata. "Andrzej Panufnik and the Pressures of Stalinism in PostWar Poland." Tempo 3, no. 220 (April 2002): 14-19. http://dx.doi.org/10.1017/ S0040298200009013.

_. Panufnik. Warsaw: PWM, 2001.

Bown, Matthew Cullerne. Socialist Realist Painting. New Haven: Yale University Press, 1998.

Boysen, Jacqueline. "Der Neue Kurs"-Tauewetter oder die Ruhe vor dem Sturm?: Konflikt zwischen Literatur und Partei in der DDR 1953-1961. Hamburg: Universität Hamburg, 1992.

Braun, Matthias. Die Literaturzeitschrift "Sinn und Form": ein ungeliebtes Aushängeschild der SED-Kulturpolitik. Bremen: Ed. Temmen, 2003.

Brennecke, Dietrich. Das Lebenswerk Max Buttings. Leipzig: VEB Deutscher Verlag für Musik, 1973.

Brennecke, Dietrich, Hannelore Gerlach, and Mathias Hansen, eds. Musiker in unserer Zeit: Mitglieder der Sektion Musik der Akademie der Künste der DDR. Leipzig: VEB Deutscher Verlag fuer Musik, 1979.

Brennecke, Dietrich, and Mathias Hansen, eds. Ernst Hermann Meyer. Kontraste, Konflikte: Errinerungen, Gespräche, Kommentare. Berlin: Verlag Neue Musik, 1979.

Brie, Michael. "Staatssozialistische Länder Europas im Vergleich: Alternative Herrschaftsstrategien und divergente Typen." In Einheit als Privileg: vergleichende Perspektiven auf die Transformation Ostdeutschlands, ed. Helmut Wiesenthal, 39-104. Frankfurt: Campus, 1996. 
Brinkmann, Reinhold. "The Distorted Sublime: Music and National Socialist Ideology_A Sketch." In Music and Nazism: Art under Tyranny, 1933-1945, ed. Michael H. Kater and Albrecht Riethmüller, 43-63. Laaber: Laaber Verlag, 2003.

Brockhaus, Alfred, and Konrad Niemann. Musikgeschichte der DDR, 1945-1976. Berlin: Verlag Neue Musik, 1979.

Brodala, Marta, Anna Lisiecka, and Tadeusz Ruzikowski. Przebudować człowieka. Komunistyczne wysiłki zmiany mentalności. Warsaw: Wydawnictwo Trio, 2001.

Brooke, Caroline. "'May You Live in Interesting Times': Recent Literature on the Stalin Era." Contemporary European History 12, no. 1 (2003): 119-27. http:// dx.doi.org/10.1017/S0960777303001073.

Brooks, Jeffrey. "Socialist Realism in Pravda: Read All about It!" Slavic Review 53, no. 4 (1994): 973-91. http://dx.doi.org/10.2307/2500842.

- Thank You, Comrade Stalin! Soviet Public Culture from Revolution to Cold War. Princeton: Princeton University Press, 2000.

Brzostek, Błażej. "Contrasts and Grayness: Looking at the First Decade of Postwar Poland." Journal of Modern European History 2, no. 1 (2004): 110-33.

_. "Dźwięki i ikonosfera stalinowskiej Warszawy anno domini 1953." In Polska 1944/45-1989. Życie codzienne w Polsce 1945-1955. Studia i materiaty 5, ed. Krystyna Kersten, 11-27. Warsaw: Instytut Historii PAN, 2001.

"Prasa lat stalinowskich jako źródło do badania codzienności mieszkanców Warszawy." In Polska 1944/45-1989. Warsztat badawczy. Studia i materiały 6, 23-47. Warsaw: Instytut Historii PAN, 2004.

. Za progiem. Codzienność w przestrzeni publiczniej Warszawy w lat 1955-70. Warsaw: Trio, 2007.

Buchbinder, Dagmar. "Erträumtes und Erreichtes-Goethes sozialistische Erben." Zeitschrift des Forschungsverbandes SED-Staat 15 (2004): 162-74.

- "Kunst-Administration nach sowjetischem Vorbild: Die Staatliche Kommission für Kunstangelegenheiten." In Die DDR-Analysen eines aufgegebenen Staates, ed. Heiner Timmerman, 389-408. Berlin: Duncker and Humblot, 2001.

"Die Staatliche Kommission für Kunstangelegenheiten (1951-1953)— eine Kulturbehörde 'neuen Typus."” In "Die Eroberung der Kultur beginnt!" Die Staatliche Kommission für Kunstangelegenheiten der DDR (1951-1953) und die Kulturpolitik der SED, ed. Jochen Staadt, 9-276. Frankfurt: Peter Lang, 2011.

—_ "Tage der Provokation und der Ausschweifungen." Zeitschrift des Forschungsverbundes SED-Staat 3 (1997).

Bunge, Hans. Die Debatte um Hanns Eislers “Johann Faustus”: Eine Dokumentation. Berlin: BasisDruck, 1991. 
Butting, Max. Musikgeschichte, die ich miterlebte. Berlin: Henschelverlag, 1955. Bylander, Cynthia E. The Warsaw Autumn International Festival of Contemporary Music, 1956-61: Its Goals, Structures, Programs, People. PhD diss., Ohio State University, 1989.

Caldwell, Peter. Dictatorship, State Planning, and Social Theory in the German Democratic Republic. Cambridge, England: Cambridge University Press, 2003.

Calico, Joy Haslam. Brecht at the Opera. Berkeley: University of California Press, 2008. http://dx.doi.org/10.1525/california/9780520254824.001.0001.

_. "“Für eine neue deutsche Nationaloper": Opera in the Discourses of Unification and Legitimation in the German Democratic Republic." In Music and German National Identity, ed. Celia Applegate and Pamela Potter, 190-204. Chicago: University of Chicago Press, 2002.

. "The Politics of Opera in the German Democratic Republic, 1945-1961." PhD diss., Duke University, 1999.

Carroll, Mark. Music and Ideology in Cold War Europe. Cambridge: Cambridge University Press, 2003.

Caute, David. The Dancer Defects: The Struggle for Cultural Supremacy during the Cold War. Oxford: Oxford University Press, 2003.

Chomiński, Józef. Muzyka Polski Ludowej. Warsaw: Państwowe Wydawnictwo Naukowe, 1968. , and Zofia Lissa, eds. Kultura Muzyczna Polski Ludowej, 1944-1955. Kraków: PWM, 1957.

Chronik des VDK, 1951-1980. Berlin, 1981

Ciesla, Burghard. "Zwischen den Krisen. Sozialer Wandel, ökonomische Rahmenbedingungen und Lebenslage in der DDR, 1953-1956." In Entstalinierungskrise in Ostmitteleuropa, 1953-1956. vom 17. Juni bis zum ungarischen Volksaufstand, ed. Jan Foitzik, 271-91. Paderborn: Ferdinand Schöningh, 2001.

Clark, Katerina. "Little Heroes and Big Deeds: Literature Responds to the First Five-Year Plan." In Cultural Revolution in Russia, 1928-1931, ed. Sheila Fitzpatrick, 189-206. Bloomington: Indiana University Press, 1984.

- Petersburg, Crucible of Cultural Revolution. Cambridge: Harvard University Press, 1995.

—. "Socialist Realism and the Sacralizing of Space." In The Landscape of Stalinism: The Art and Ideology of Soviet Space, ed. Evgeny Dobrenko and Eric Naiman, 3-18. Seattle: University of Washington Press, 2003.

- The Soviet Novel: History as Ritual. Chicago: University of Chicago Press, 1981. 
Connelly, John. Captive University: The Sovietization of East German, Czech, and Polish Higher Education, 1945-56. Chapel Hill: University of North Carolina Press, 2000.

Cooke, Catherine. "Socialist Realist Architecture: Theory and Practice." In Art of the Soviets: Painting, Sculpture and Architecture in a One-Party State, 19171992, ed. Matthew Culllerne Bown and Brandon Taylor, 86-105. Manchester: Manchester University Press, 1993.

Crowley, David, and Susan E. Reid, eds. Pleasures in Socialism: Leisure and Luxury in the Eastern Bloc. Evanston, IL: Northwestern University Press, 2010.

Socialist Spaces: Sites of Everyday Life in the Eastern Bloc. Oxford: Berg, 2002.

Dąbrowska, Danuta, and Piotr Michałowski, eds. Presja i ekspresja: zjazd szczeciński i socrealizm. Szczecin: Wydawnictwo Naukowe Uniwersytetu Szczecińskiego, 2002.

Davies, Peter. "Hanns Eisler's Faustus-Libretto and the Problem of East German National Identity." Music \& Letters 81, no. 4 (2000): 585-98. http://dx.doi. org $/ 10.1093 / \mathrm{ml} / 81.4 .585$.

Davies, Sarah. Popular Opinion in Stalin's Russia: Terror, Propaganda and Dissent, 1934-1941. Cambridge: Cambridge University Press, 1997. http://dx.doi. org/10.1017/CBO9780511612053.

Dennis, Mike. The Rise and Fall of the German Democratic Republic, 19451990. Essex: Pearson, 2000.

Dessau, Paul. Notizen zu Noten. Leipzig: Reclam, 1974.

. Paul Dessau: Aus Gesprächen. Leipzig: VEB Deutscher Verlag für Musik, 1974.

Deutschländer, Horst. "DDR-Soziokultur und -leben—Einige ausgewählte Gesichtspunkte." In Die DDR war anders. Kritische Würdigung ihrer wichtigen sozialkulturellen Einrichtungen, ed. Stefan Bollinger and Fritz Vilmar, 35-57. Berlin: Forschungsgruppe Kritische Analyse des Vereinigungsprozesse, 2002.

De Weydenthal, Jan. The Communists of Poland: An Historical Outline. Stanford: Hoover Institution Press, 1978.

Dibelius, Ulrich, and Frank Schneider, eds. Neue Musik im geteilten Deutschland: Dokumente aus den fünfziger Jahren. Berlin: Henschel, 1993.

Dietrich, Gerd. Politik und Kultur in der sowjetischen Besatzungszone Deutschlands (SBZ) 1945-1949. Berlin: Peter Lang, 1993. . "“. . . wie eine kleine Oktoberrevolution . . '? Kulturpolitik der SMAD 1945-1949." In Kulturpolitik im besetzten Deutschland 1945-1949, ed. Gabriele Clemens, 219-36. Stuttgart: Franz Steiner Verlag, 1994. 
Dietzel, Ulrich, and Gudrun Geißler, eds. Zwischen Diskussion und Disziplin. Dokumente zur Geschichte der Akademie der Künste (Ost) 1945/50-1993. Berlin, 1997.

Dobrenko, Evgeny. "The Disaster of Middlebrow Taste, or, Who 'Invented' Socialist Realism?" In Socialist Realism Without Shores, ed. Thomas Lahusen and Evgeny Dobrenko, 135-84. Durham: Duke University Press, 1997.

. Political Economy of Socialist Realism. New Haven: Yale University Press, 2007.

Droba, Krzysztof, Teresa Malecka, and Krzystztof Szwajgier, eds. Muzyka Polska, 1945-1995: Materialy sesji naukowej 6-10 grudnia 1995 w 20-lecie zakladu analizy i interpretacji muzyki. Kraków: Akademia Muzyczna, 1996.

Drobner, Mieczysław. Wspomnienia o poczqtkach życia muzycznego w Polsce Ludowej, 1944-1946. Kraków: PWM, 1985.

Dunham, Vera. In Stalin's Time: Middle-Class Values in Soviet Fiction. Durham: Duke Unversity Press, 1990.

Dwars, Jens-Fietje. Abgrund des Widerspruchs: das Leben des Johannes R. Becher. Berlin: Aufbau, 1998.

Dziębowska, Elżbieta, ed., Polska współczesna kultura muzyczna, 1944-1964. Kraków: PWM, 1968.

—. "Ruch koncertowy i operowy." In Kultura Muzyczna Polski Ludowej, ed. Józef Chomiński and Zofia Lissa, 17-24. Kraków: PWM, 1957.

—. Muzykologia Krakowska, 1911-1986. Kraków: PWN, 1987.

Edmunds, Neil. "Music and Politics: The Case of the Russian Association of Proletarian Musicians." Slavonic and East European Review 78, no. 1 (2000): 66-89.

- The Soviet Proletarian Music Movement. Oxford: Peter Lang, 2000.

Eisler, Jerzy. “Życie codzienne w Warszawie w okresie Planu Sześcioletniego.” In Polska 1944/45-1989. Życie codzienne w Polsce 1945-1955. Studia i materiały 5, ed. Krystyna Kersten, 28-45. Warsaw: Instytut Historii PAN, 2001.

Elsner, Jürgen, and Givi Ordzonikidze, eds. Sozialistische Musikkultur: Traditionen, Probleme, Perspektiven. vol. II. Berlin: Verlag Neue Musik, 1983.

Emmerich, Wolfgang. ““'Deutsche Intellektuelle: was nun? Zum Funktionswandel der (ostdeutschen) literarischen Intelligenz zwischen 1945 and 1998." In After the GDR: New Perspectives on the Old GDR and the Young." In Länder, ed. Laurence McFalls and Lothar Probst. Atlanta, Amsterdam: Rodopi, 2001.

Eppelmann, Rainer, Bernd Faulenbach, and Ulrich Mählert, eds. Bilanz und Perspektiven der DDR-Forschung. Paderborn: Ferdinand Schöningh, 2003.

Eppelmann, Rainer, Horst Möller, Günter Nooke, and Dorothee Wilms, eds. Lexikon des DDR-Sozialismus. Das Staats- und Gesellschaftssystem der Deutschen Demokratischen Republik. Paderborn: Ferdinand Schöningh, 1996. 
Epstein, Catherine. "East Germany and Its History since 1989." Journal of Modern History 75, no. 3 (2003): 634-61. http://dx.doi.org/10.1086/380240.

. The Last Revolutionaries: German Communists and Their Century. Cambridge, MA: Harvard University Press, 2003.

Erbe, Günter. Die verfemte Moderne. Die Auseinandersetzung mit dem "Modernismus" in Kulturpolitik, Literaturwissenschaft und Literatur der DDR. Opladen: Westdeutscher, 1993.

Erhardt, Ludwik. 50 Lat Zwiazku Kompozytorów Polskich. Warsaw, 1995.

Fay, Laurel. Shostakovich: A Life. Oxford: Oxford University Press, 2000.

Feinstein, Margarete Myers. State Symbols: The Quest for Legitimacy in the Federal Republic of Germany and the German Democratic Republic, 1949-1959. Boston: Brill Academic, 2001.

Feist, Günter, Eckhart Gillen, and Beatrice Vierneisel, eds. Kunstdokumentation SBZ/DDR, 1945-1990: Aufsätze, Berichte, Materialien. Bonn: V. G. BildKunst, 1996.

Fenemore, Mark. Sex, Thugs and Rock 'n'Roll: Teenage Rebels in Cold War East Germany. New York: Berghahn Books, 2009.

Fidelis, Małgorzata. Women, Communism, and Industrialization in Postwar Poland. Cambridge: Cambridge University Press, 2010.

Fijałkowska, Barbara. Polityka i twórcy (1948-1959). Warsaw: PWN, 1985.

Fik, Marta. Autorytecie wroc?: Szkice o postawach polskich intelektualistów po pażdzierniku 1956. Warsaw: Oficyna Wydawnicza Errata, 1997.

. "Cenzor jako współautor.” In Literatura i władza, 131-46. Warsaw: Instytut Badań Literackich, 1996.

—. "Kultura polska 1944-1956." In Polacy wobec przemocy, 1944-1956, ed. Barbara Otwinowska and Jan Żaryn, 220-75. Warsaw: Editions Spotkania, 1996.

—. Kultura polska po Jałcie: kronika lat 1944-1981. Warsaw: Niezależna Oficyna Wydawnicza, 1991.

Finke, F. F. Werner Hübschmann, Paul Kurzbach, Johannes Paul Thilman, and Fritz Spies. Arbeits- und Studienmaterial zur Frage des Formalismus und Realismus in der Musik. Dresden: Landesdruckerei Sachsen VEB, 1952.

Fitzpatrick, Sheila. The Cultural Front: Power and Culture in Revolutionary Russia. Ithaca: Cornell University Press, 1992.

Everyday Stalinism: Ordinary LIfe in Extraordinary Times: Soviet Russia in the 1930s. New York: Oxford University Press, 1999.

Flack, Monika, ed. Auf der Suche nach dem verlorenen Staat: Die Kunst der Parteien und Massenorganisationen der DDR. Berlin: Deutsches Historisches Museum, 1994.

Foitzik, Jan. "Ostmitteleuropa zwischen 1953 und 1956. Sozialer Hintergrund und politischer Kontext der Entstalinierungskrise." In Entstalinierungskrise 
in Ostmitteleuropa, 1953-1956. vom 17. Juni bis zum ungarischen Volksaufstand, ed. Jan Foitzik, 21-54. Paderborn: Ferdinand Schöningh, 2001.

—. "Sowjetische Hegemonie und Ostintegration der DDR." In Vor dem Mauerbau. Politik und Gesellschaft in der DDR der fünfziger Jahren, ed. Dierk Hoffmann, Michael Schwartz, and Hermann Wentker, 39-58. München: R. Oldenbourg Verlag, 2003.

Fosler-Lussier, Daniele. "Béla Bartók and the Transition to Communism in Hungary, 1945-1955.” Ph.D. Diss., University of California-Berkeley, 1999.

—. Musik Divided: Bartók's Legacy in Cold War Culture. Berkeley: University of California Press, 2007.

Frank, Mario. Walter Ulbricht: Eine deutsche Biographie. Berlin: Siedler, 2001. Fröde, Bernd. "Musikentwicklung in der DDR in den fünfziger Jahren und ihre Auswirkungen auf die Schulmusikerziehung." In 10 Jahre danach-Sichten auf die schulische Musikpädagogik in der DDR. Probleme-Impulse-Initiativen, ed. Bernd Fröde and Birgit Jank, 109-42. Essen: Verlag Die Blaue Eule, 2002.

Frolova-Walker, Marina. "The Glib, the Bland, and the Corny: An Aesthetic of Socialist Realism." In Music and Dictatorship in Europe and Latin America, ed. Roberto Illiano and Massimiliano Sala, 403-23. Turnhout, Belgium: Brepols, 2009.

—. "National in Form, Socialist in Content': Musical Nation-Building in the Soviet Republics." Journal of the American Musicological Society 51, no. 2 (1998): 331-71. http://dx.doi.org/10.2307/831980.

Fulbrook, Mary. Anatomy of a Dictatorship: Inside the GDR, 1949-1989. Oxford: Oxford University Press, 1995.

. Interpretations of the Two Germanies. New York: St. Martin's, 2000.

- The People's State: East German Society from Htiler to Honecker. New Haven: Yale University Press, 2005.

—. "Politik, Wissenschaft und Moral. Zur neueren Geschichte der DDR." Geschichte und Gesellschaft (Vandenhoeck \& Ruprecht) 22, no. 3 (1996): 458-71.

_. "Retheorising 'State' and 'Society' in the German Democratic Republic." In The Workers' and Peasants' State: Communism and Society in East Germany under Ulbricht, 1945-1971, ed. Patrick Major and Jonathan Osmond, 280-98. Manchester: Manchester University Press, 2002.

Gansel, Carsten, ed. Der gespaltene Dichter, Johannes R. Becher: Gedichte, Briefe, Dokumente, 1945-1958. Berlin: Aufbau-Verlag, 1991.

- Parlament des Geistes: Literatur zwischen Hoffnung und Repression, 1945-1961. Berlin: BasisDruck, 1996.

Gąsiorowska, Małgorzata. Bacewicz. Kraków: PWM, 1999. 
“Muzyka polska lat 1945-1955 wobec socrealizmu." In Muzyka, słowo, sens, ed. Anna Oberc. Kraków: AM, 1994.

—. O Grazynie Bacewicz: materialy z konferencji muzykologicznej. Poznań: Wydawnictwo Muzyczne Brevis, 1998.

Gasparov, Boris. "The Symphony as Mode of Production: Shostakovich's Fourth Symphony and the End of the Romantic Narrative." In Language and Revolution: Making Modern Political Identities, ed. Igal Halfin. London: Frank Cass Publishers, 2002.

Gerlach, Caroline. Untersuchungen zur Tanzmusik in der DDR. Leipzig: VEB Deutscher Verlag für Musik, 1981.

Gibas, Monika. "'Lieder für den Jahrestag': Anmerkungen zur Festmusik I." In Wiedergeburten. Zur Geschichte der runden Jahrestage der DDR, ed. Monika Gibas, Rainer Gries, Barbara Jakoby, and Doris Müller, 70-80. Leipzig: Leipziger Universitätsverlag, 1999.

Gienow-Hecht, Jessica C. E. "Culture and the Cold War in Europe." In The Cambridge History of the Cold War, vol I, Origins, ed. Melvyn Leffler and Odd Arne Westad, 398-419. Cambridge: Cambridge University Press, 2011. http:// dx.doi.org/10.1017/CHOL9780521837194.020.

Gillen, Eckhart. Das Kunstkombinat DDR: Zäsuren einer gescheiterten Kunstpolitik. Bonn: VG Bild-Kunst, 2005.

Gillen, Eckhart, and Rainer Haarmann. Kunst in der DDR. Köln: Kiepenheuer \& Witsch, 1990.

Glaesner, Gert-Joachim. "Selbstinszenierung von Partei und Staat." In Parteiauftrag: Ein neues Deutschland. Bilder, Rituale und Symbole der frühen DDR, ed. Dieter Vorsteher, 20-39. Berlin: Koehler \& Amelang, 1997.

Glaser, Hermann. Deutsche Kultur. Ein historischer Überblick von 1945 bis zur Gegenwart. Bonn: bpb, 2003.

Głowiński, Michał. Rytuat i demogogia: 13 szkiców o sztuce zdegradowanej. Warsaw: Oficyna Polska Encyklopedia Niezależna, 1992.

—. "Władza ludowa przemawia do pisarzy." In Literatura i władza, 115-28. Warsaw: Instytut Badań Literackich, 1996.

Goeschen, Ulrike. Vom sozialistischen Realismus zur Kunst im Realismus: Die Rezeption der Moderne in Kunst und Kunstwissenschaft der DDR. Berlin: Duncker \& Humblot, 2001.

Gołab, Maciej. "Wczesna twórczość kompozytorska Witolda Lutosławskiego." In Witold Lutosławski i jego wkład do kultury muzycznej XX wieku, ed. Jadwiga Paja-Stach, 13-26. Kraków: Musica Iagellonica, 2005.

Gołębiowski, Marian. Filharmonia w Warszawie, 1901-1976. Kraków: PWM, 1976.

Grieder, Peter. The East German Leadership, 1946-1973. Manchester: Manchester University Press, 1999. 
- "In Defence of Totalitarianism Theory as a Tool of Historical Scholarship." Totalitarian Movements and Political Religions 8, no. 3-4 (2007): 563-89.

Gries, Rainer. "Propagandageschichte als Kulturgeschichte: Methodische Erwartungen und Erfahrungen." Deutschland Archiv 4 (2000): 559-70.

Gross, Jan. Revolution from Abroad: The Soviet Conquest of Poland's Western Ukraine and Western Belorussia. Princeton: Princeton University Press, 1988.

Groys, Boris. The Total Art of Stalinism: Avant-Garde, Aesthetic Dictatorship, and Beyond. Princeton: Princeton University Press, 1992.

Günther, Hans. "'Broad Is My Motherland': The Mother Archetype and Space in the Soviet Mass Song." In The Landscape of Stalinism: The Art and Ideology of Soviet Space, ed. Evgeny Dobrenko and Eric Naiman, 77-95. Seattle: University of Washington Press, 2003.

- The Culture of the Stalin Period. New York: St. Martin's, 1990.

Gwizdalanka, Danuta, and Krzysztof Meyer. Lutosławski: Droga do dojrzałości. Kraków: PWM, 2003.

Hahlweg-Elchlepp, Ursula. "Ein Gesetz, das nicht in Kraft trat. Der Entwurf eines Theatergesetzes der DDR 1950/51." In Die DDR-Analysen eines aufgegebenen Staates, ed. Heiner Timmerman, 509-31. Berlin: Duncker and Humblot, 2001.

Hahn, Werner. Postwar Soviet Politics: The Fall of Zhdanov and the Defeat of Modernization, 1946-1953. Ithaca: Cornell University Press, 1982.

Hain, Simone. "Die Salons der Sozialisten. Geschichte und Gestalt der Kulturhäuser in der DDR." In Die Salons der Sozialisten: Kulturhaeuser in der $D D R$, ed. Simone Hain and Stephan Stroux, 89-149. Berlin: Ch. Links Verlag, 1996.

Hanke, Irma. "Deutsche Traditionen. Notizen zur Kulturpolitik der DDR." In Rückblicke auf die DDR, ed. Gisela Helwig, 75-84. Köln: Deutschland Archiv, 1995.

Hanuszewska, Mieczysława, and Bogusław Schäffer, eds. Almanach polskich kompozytorów współczesnych. Kraków: PWM, 1966.

Harris, Jr. Frederick Edward. Seeking the Infinite: The Musical Life of Stanistaw Skrowaczewski. BookSurge Publishing, 2011.

Harrison, Hope Millard. Driving the Soviets up the Wall: Soviet-East German Relations, 1953-1961. Princeton: Princeton University Press, 2003.

Hartmann, Anne, and Wolfram Eggeling. Sowjetische Präsenz im kulturellen Leben der SBZ und frühen DDR 1945-1953. Berlin: Akademie Verlag, 1998. http://dx.doi.org/10.1524/9783050047478.

Hartung, Ulrich. Arbeiter- und Bauerntempel: DDR-Kulturhäuser der fünfziger Jahre--ein architekturhistorisches Kompendium. Berlin: Schelzky \& Jeep, 1997. 
Heider, Magdalena. Politik, Kultur, Kulturbund: zur Gründungs- und Frühgeschichte des Kulturbundes zur Demokratischen Erneuerung Deutschlands 1945-1954 in der SBZ/DDR. Köln: Verlag Wissenschaft und Politik, 1993.

— KulturbundProtokolle. Köln: Edition Deutschland Archiv, 1990.

Heimann, Thomas. DEFA, Künstler und SED-Kulturpolitik: Zum Verhältnis von Kulturpolitik und Filmproduktion in der SBZ/DDR, 1945 bis 1959. Berlin: VISTAS, 1994.

-"Vom Lebensweg des Jazz. Notizen zu einem umstrittenen Dokumentarfilm der DEFA." In apropos: Film 2000. Das Jahrbuch der DEFA-Stiftung, ed. Ralf Schenk and Erika Richter, 229-40. Berlin: Das Neue Berlin, 2000.

Hell, Julia. Post-Fascist Fantasies: Psychoanalysis, History, and the Literature of East Germany. Durham: Duke University Press, 1997.

Heller, Leonid. "A World of Prettiness: Socialist Realism and Its Aesthetic Categories." In Socialist Realism Without Shores, ed. Thomas Lahusen and Evgeny Dobrenko, 51-75. Durham: Duke University Press, 1997.

Helman, Zofia. Neoklasycyzm w muzyce polskiej XX wieku. Kraków: PWM, 1985. . Roman Palester: twórca i dzieło. Kraków: Musica Iagellonica, 1999.

—. "Zofia Lissa, 1908-1980." Polish Musicological Studies 2 (1986): 7-24. Hennenberg, Fritz. Hanns Eisler. Leipzig: VEB Bibliographisches Institut, 1986. Herbert, Ulrich. "Drei deutsche Vergangenheiten. Über den Umgang mit der deutschen Zeitgeschichte." In Doppelte Zeitgeschichte. Deutsch-deutsche Beziehungen 1945-1990, ed. Arnd Bauerkämper, Martin Sabrow, and Bernd Stöver, 376-90. Bonn: Dietz, 1998.

Herbst, Andreas, Gerd-Rüdiger Stephan, and Jürgen Winkler, eds. Die SED: Geschichte, Organisation, Politik. Ein Handbuch. Berlin: Dietz Verlag, 1997.

Herf, Jeffrey. Divided Memory: The Nazi Past in the Two Germanys. Cambridge: Harvard University Press, 1997.

Hierowski, Zdzisław. Opera Ślaska,1945-1955. Stalinogród: Wydawnictwo "Śląsk," 1956.

Hillman, Eva. Das Massenlied: Begriff, Geschichte, Analysen: Dargestellt am Liedgut, 1945-1970. Leipzig, 1972.

_. Das Massenlied: Studien zu seiner Entwicklung und Bedeutung in der $D D R$. Leipzig: Institut für Volkskunstforschung des Zentralhauses für Kulturarbeit, 1967.

Hirszowicz, Maria. Pułapki zaangażowania: intelektualiści w stużbie komunizmu. Warsaw: Wydawnictwo Naukowe Scholar, 2001.

Hoffmann, Dierk. Die DDR unter Ulbricht: gewaltsame Neuordnung und gescheiterte Modernisierung. Zürich: Pendo Verlag, 2003. 
—-, Karl-Heinz Schmidt, and Peter Skyba, eds. Die DDR vor dem Mauerbau. Dokumente zur Geschichte des anderen deutschen Staates, 1949-1961. München: Piper, 1993.

Hofmann, Hans-Georg. “'Die Tanzmusik muss neue Wege gehen.' Bemerkungen zur kulturtheoretischen Diskussion der Tanz-und Unterhaltungsmusik in der DDR in den 1950er und 60er Jahren und zu ihrem Einfluss auf die Musikpraxis." In Geschichte und Medien der "gehobenen Unterhaltungsmusik," ed. Mathias Spohr. Zürich: Chronos Verlag, 1999.

Hofmann, Michael. "'Mit uns zieht die neue Zeit': Zur Programmatik sozialistischer Massenfeste." In Wiedergeburten. Zur Geschichte der runden Jahrestage der DDR, ed. Monika Gibas, Rainer Gries, Barbara Jakoby, and Doris Müller, 41-51. Leipzig: Leipziger Universitätsverlag, 1999.

Holmes, Amy. "Deutsche Demokratische Rockmusik. Amerikanische kulturelle Hegemonie oder Errungenschaft von unten?" In Die DDR war anders. Kritische Würdigung ihrer wichtigen sozialkulturellen Einrichtungen, ed. Stefan Bollinger and Fritz Vilmar, 83-103. Berlin: Forschungsgruppe Kritische Analyse des Vereinigungsprozesse, 2002.

Holtstrater, Knut. "Kurzschlüsse und Abbrüche in der musikaesthetischen Argumentation in der DDR." In Die unerträgliche Leichtigkeit der Kunst: Aesthetisches und politisches Handeln in der DDR, ed. Michael Berg, Knut Holtsträter, and Albrecht von Massow von Böhlau, 193-205. Cologne: Böhlau Verlag, 2007.

Holzweißig, Günter. Zensur ohne Zensor: Die SED-Informationsdiktatur. Bonn: Bouvier Verlag, 1997.

Homma, Martina. Witold Lutosławski: Zwölfton-Harmonik-Formbildung aleatorischer Kontrapunkt: Studien zum Gesamtwerk unter Einbeziehung der Skizzen. Köln: Bela Verlag, 1995.

Iampolski, Mikhail. "Censorship as the Triumph of Life." In Socialist Realism Without Shores, ed. Thomas Lahusen and Evgeny Dobrenko, 165-77. Durham: Duke University Press, 1997.

Ihme-Tuchel, Beate. Die DDR. Darmstadt: Wissenschaftliche Buchgesellschaft, 2002.

. "Die frühe Schriftstellerpolitik der SED und das 'Desaster der interpretierenden Klasse." In Die DDR in Deutschland. Ein Rückblick auf 50 Jahre, ed. Heiner Timmermann, 711-30. Berlin: Duncker and Humblot, 2001.

Jabłoński, Maciej, and Janina Tatarska, eds. Muzyka i totalitaryzm. Poznań: Ars Nova, 1996.

Jäger, Manfred. Kultur und Politik in der DDR, 1945-1990. Köln, 1995.

Jaldati, Lin and Eberhard Rebling. "Sag nie, du gehst den letzten Weg." Lebenserinnerungen 1911 bis 1988. Marburg: BdWi-Verlag, 1995. 
Jakelski, Lisa. "The Changing Seasons of the Warsaw Autumn: Contemporary Music in Poland, 1960-1990." Ph.D. diss. University of California-Berkeley, 2009.

Janik, Elizabeth Koch. “The Golden Hunger Years': Music and Superpower Rivalry in Occupied Berlin." German History 22, no. 1 (2004): 76-100. http:// dx.doi.org/10.1191/0266355404gh300oa.

- "Music in Cold War Berlin: German Tradition and Allied Occupation, 1945-1951.” Ph.D. diss., Georgetown University, 2001.

- Recomposing German Music: Politics and Musical Tradition in Cold War Berlin. Boston: Brill, 2005.

Jankowski, B. M., and M. Misiorny. Muzyka i życie muzyczne na Ziemiach Zachodnich i Pótnocnych, 1945-1965. Poznań: Wydawnictwo Poznańskie, 1968.

Jarausch, Konrad. "Care and Coercion: The GDR as Welfare Dictatorship." In Dictatorship as Experience: Toward a Social-Cultural History of the GDR, ed. Konrad Jarausch, 47-71. New York: Berghahn Books, 1999.

— Princeton: Princeton University Press, 2003.

Jarmułowicz, Małgorzata. Sezony błędów $i$ wypaczeń: socrealizm $w$ dramacie $i$ teatrze polskim. Gdańsk: Wydawnictwo Uniwersytetu Gdańskiego, 2003.

Jarosiński, Zbigniew. "Literatura jako władza (z ideologii socrealizmu)." In Literatura $i$ władza, 149-66. Warsaw: Instytut Badań Literackich, 1996.

—. Nadwiślański socrealizm. Warsaw: Instytut Badań Literackich, 1999.

Jarosz, Dariusz. "Co Nowa Huta zawdzięcza Adamowi Ważykowi?" In Realizm socjalistyczny w Polsce z perspektywy 50 lat, ed. Stefan Zabierowskiego, 283-96. Katowice: Wydawnictwo Uniwersytetu Śląskiego, 2001.

. 'Masy pracujace przede wszystkim.' Organizacja wypoczynku w Polsce, 1945-1956. Warsaw: Instytut Historii PAN, 2003.

- Polacy a stalinizm, 1948-1956. Warsaw: Instytut Historii PAN, 2000.

- Polityka władz komunistycznych w Polsce w latach 1948-1956 a chtopi. Warsaw: DiG, 1998.

Jędrychowska, Jagoda. “Rozmowa z Romanem Palestrem” In Wiedzieć Polskę z oddalenia, 74-95. Poznań: Kantor Wydawniczy SAWW, 1990.

Jessen, Ralph. "Die Gesellschaft im Staatssozialismus. Probleme einer Sozialgeschichte der DDR." GG 21, no. 2 (1995): 96-110.

Johnson, James H. Listening in Paris: A Cultural History. Berkeley: University of California Press, 1995.

Just, Gustav. Zeuge in eigener Sache: Die fünfziger Jahre. Berlin: Buchverlag Der Morgen, 1990.

Kaczyński, Tadeusz. Andrzej Panufnik i jego muzyka. Warsaw: Wydawnictwo Naukowe PWN, 1994.

Lutosławski: Zycie i muzyka. Warsaw: Sutkowski Edition, 1995. 
Rozmowy z Witoldem Lutosławskim. Kraków: PWM, 1972.

Kaelble, Hartmut, Jürgen Kocka, and Hartmut Zwahr, eds. Sozialgeschichte der DDR. Stuttgart: Klett Cotta, 1994.

Kampf gegen den Formalismus in der Kunst und Literatur, für eine fortschrittliche deutsche Kultur. Dresden: Kulturbund zur demokratische Erneuerung Deutschlands, 1951.

Karbusicky, Vladimir. Ideologie im Lied, Lied in der Ideologie. Köln: Musikverlage Hans Gerig, 1973.

Kater, Michael. The Twisted Muse: Musicians and Their Music in the Third Reich. New York: Oxford University Press, 1997. http://dx.doi.org/10.1093/ acprof:oso/9780195096200.001.0001.

Kelly, Elaine. "Reading the Past in the German Democratic Republic: Thoughts on Writing Histories of Music.” In Musikwissenschaft und Kalter Krieg: Das Beispiel DDR, ed. Nina Noeske and Matthias Tischer, 117-30. Cologne: Böhlau Verlag, 2010.

Kenez, Peter, and David Shepherd. "'Revolutionary' Models for High Literature: Resisting Poetics.” In Russian Cultural Studies: An Introduction, ed. Catriona Kelly and David Shepherd. Oxford: Oxford University Press, 1998.

Kenney, Padraic. Rebuilding Poland: Workers and Communists, 1945-1950. Ithaca: Cornell University Press, 1997.

Kertzer, David I. Ritual, Politics, and Power. New Haven: Yale, 1988.

Kieslich, Lothar. Kommunisten gegen Kommunisten. Die Intellektuellenpolitik der SED im Umfeld des XX. Parteitages der KPdSU und des Ungarn-Aufstands. Gießen: Kletsmeier, 1998.

Kirchenwitz, Lutz. Folk, Chanson und Liedermacher in der DDR. Chronisten, Kritiker, Kaisergeburtstagssänger. Berlin: Dietz Verlag, 1993.

Kisielewski, Stefan. Z muzyka przez lata. Kraków: Wydawnictwo Literackie, 1957.

Klein, Thomas. "Für die Einheit und Reinheit der Partei." Die innerparteilichen Kontrollorgane der SED in der Ära Ulbricht. Köln: Böhlau Verlag, 2002.

Klemke, Peggy. "Die Rolle von DDR-Musikwissenschaftlern bei der Durchsetzung der Kulturpolitik in den fünfziger Jahren." In Das war die DDR. DDRForschung im Fadenkreuz von Herrschaft, Aussenbeziehungen, Kultur und Souveränität, ed. Heiner Timmermann, 552-72. Muenster: Lit Verlag, 2004.

- Taktgeber oder Tabuisierte-Komponisten in der DDR. Staatliche Kulturpolitik in den fünfziger Jahren. Marburg: Tectum Verlag, 2007.

Kleßmann, Christoph. Die doppelte Staatsgründung: Deutsche Geschichte, 1945-1955. Göttingen: Vandenhoek and Ruprecht, 1991.

. Das gespaltene Land: Leben in Deutschland, 1945-1990: Texte und Dokumente zur Sozialgeschichte. München: C. H. Beck, 1993. 
. Zwei Staaten, eine Nation: Deutsche Geschichte 1955-1970. Bonn: bpb, 1997.

Klingberg, Lars. Anmerkungen zu Musik und Politik in der SBZ und frühen DDR. Beiträge zur Wirtschafts- und Sozialgeschichte, 1998.

_. Politisch fest in unseren Handen: musikalische und musikwissenschaftliche Gesellschaften in der DDR. Kassel: Barenreiter, 1997.

—. Die Verurteilung des 'Lukullus' im Jahr 1951, 188-206. Beiträge zur Musikwissenschaft, 1991.

Kłoskowska, Antonina. Kultura masowa. Krytyka i obrona. Warsaw: PWN, 1964.

Knepler, Georg. Geschichte als Weg zum Musikverständnis. Leipzig: Reclam, 1977.

Kocka, Jürgen, and Martin Sabrow. Die DDR als Geschichte: Fragen-Hypothesen-Perspektiven. Berlin: Akademie Verlag, 1994.

- "Eine durchherrschte Gesellschaft." In Sozialgeschichte der DDR, ed. Hartmut Kaelble, Jürgen Kocka, and Hartmut Zwahr, 547-53. Stuttgart: Klett Cotta, 1994.

- Historische DDR-Forschung. Aufsätze und Studien. Berlin: Akademie Verlag, 1993.

Kofin, Ewa. "Losy kultury muzycznej." In Nim będzie zapomniana. Szkice o kulturze PRL-u, ed. Stefan Bednarek, 180-98. Wrocław: Wydawnictwo Uniwersytetu Wrocławskiego, 1997.

Koller, Jürgen. Zur Kulturpolitik in der DDR: Entwickung und Tendenzen. Bonn: Friedrich-Ebert-Stiftung, 1989.

Koloski, Laurie S. "Painting Kraków Red: Politics and Culture in Poland, 19451950.” Ph.D. diss., Stanford University, 1998.

Komponisten und Musikwissenschaftler der Deutschen Demokratischen Republik: Kurzbiographien und Werkverzeichnisse. Berlin: Verlag Neue Musik, 1959.

Kopstein, Jeffrey. The Politics of Economic Decline in East Germany, 19451989. Chapel Hill: University of North Carolina Press, 1997.

Köster, Maren. "Kulturhunger: Zu den Kulturbund-Konzerten vom 1946 bis 1949." Positionen 27 (May 1996): 19-22.

- Musik-Zeit-Geschehen: Zu den Musikverhältnissen in der SBZ/DDR, 1945 bis 1952. Saarbrücken: Pfau, 2002.

_. "Tui und Teufel. Zu Eislers 'Johann Faustus."” In Hanns Eisler: 's müßt dem Himmel Höllenangst werden, ed. Maren Köster, 36-53. Hofheim: Wolke Verlag, 1998.

Kotkin, Stephen. Magnetic Mountain: Stalinism as a Civilization. Berkeley: University of California Press, 1995. 
Kott, Sandrine. "A la recherche d'une culture socialiste, le cas des enterprises de RDA (1949-1989)." Vingtième siècle. Revue d'histoire 63, no. 63 (JulySeptember 1999): 87-106. http://dx.doi.org/10.2307/3770703.

- Le communisme au quotidien: les entreprises d'État dans la société estallemande. Paris: Belin, 2001.

_ . "Everyday Communism: New Social History of the German Democratic Republic.” Contemporary European History 13, no. 2 (1999): 233-47. http:// dx.doi.org/10.1017/S0960777304001699.

Kowalczuk, Ilko-Sascha. Das bewegte Jahrzehnt. Geschichte der DDR von 1949 bis 1961. Bonn: bpb, 2003.

Krüger, Antje. "Verschwundenes Land-verschwundene Lieder? Die Singbewegung der DDR." In Die DDR war anders. Kritische Würdigung ihrer wichtigen sozialkulturellen Einrichtungen, ed. Stefan Bollinger and Fritz Vilmar, 58-82. Berlin: Forschungsgruppe Kritische Analyse des Vereinigungsprozesse, 2002. Krywicki, Andrzej. Poststalinowski karnawat radości: V Światowy Festiwal Młodzieży i Studentów o Pokój i Przyjaźń, Warszawa 1955r. Warsaw: Trio, 2009.

Kubik, Jan. The Power of Symbols against the Symbols of Power: The Rise of Solidarity and the Fall of State Socialism in Poland. University Park, PA: Pennsylvania State University Press, 1994.

Kulturpolitisches Wörterbuch. Berlin: Dietz Verlag, 1970.

Kynass, Hans-Joachim, ed. Erinnerungen, Gedanken: Gründungsmitglieder zum dreißigjährigen Bestehen des VKM der DDR. Berlin, 1981.

Lahusen, Thomas. How Life Writes the Book: Real Socialism and Socialist Realism in Stalin's Russia. Ithaca: Cornell University Press, 1997.

—. "Socialist Realism in Search of Its Shores: Some Historical Remarks on the "Historically Open Aesthetic System of the Truthful Representation of Life." In Socialist Realism Without Shores, ed. Thomas Lahusen and Evgeny Dobrenko, 5-26. Durham: Duke University Press, 1997.

Larkey, Edward. Rotes Rockradio. Populäre Musik und die Kommerzialisierung des DDR-Rundfunks. Berlin: Lit Verlag, 2007.

Lauter, Hans. Der Kampf gegen den Formalismus in Kunst und Literatur, für eine fortschrittliche deutsche Kultur: Referat von Hans Lauter, Diskussion und Entschliessung von der 5. Tagung des Zentralkomitees der Sozialistischen Einheitspartei Deutschlands vom 15.-17. März 1951. Berlin: Dietz Verlag, 1951.

Laux, Karl. Das Musikleben in der Deutschen Demokratischen Republik (19451959). Leipzig: VEB Deutscher Verlag für Musik, 1963.

Lebow, Katherine Anne. Nowa Huta, 1949-1957: Stalinism and Everyday Life in Poland's "First Socialist City." Ph.D. diss., Columbia University, 2002. 
Lee, Jan Patrick. Musical Life and Sociopolitical Change in Warsaw, Poland, 1944-60. Ph.D. diss., University of North Carolina, 1979.

Lemke, Michael. "Die fünfziger Jahre-Aufbau und Krisen in der DDR." In Bilanz und Perspektiven der DDR-Forschung, ed. Rainer Eppelmann, Bernd Faulenbach, and Ulrich Mählert, 53-59. Paderborn: Ferdinand Schöningh, 2003.

. "Der 'Sängerkrieg' in Berlin." In Schaufenster der Systemkonkurrenz: Die Region Berlin-Brandenburg im Kalten Krieg, ed. Michael Lemke, 26995. Cologne: Böhlau, 2006.

Lidkte, Vernon L. The Alternative Culture: Socialist Labor in Imperial Germany. Oxford: Oxford University Press, 1985.

Lindenberger, Thomas. "Geteilte Welt, geteilter Himmel? Der kalte Krieg und die Massenmedien in gesellschaftsgeschichtlicher Perspektive." In Zwischen Pop und Propaganda: Radio in der DDR, ed. Klaus Arnold and Christoph Classen. Berlin: Ch. Links Verlag, 2004.

- Herrschaft und Eigen-Sinn in der Diktatur: Studien zur Gesellschaftsgeschichte der DDR. Köln: Böhlau Verlag, 1999.

—. "SED-Herrschaft als soziale Praxis, Herrschaft und 'Eigen-Sinn': Problemstellung und Begriffe." In Staatssicherheit und Gesellschaft: Studien zum Herrschaftsalltag in der DDR, ed. Jens Gieseke, 23-47. Göttingen: Vandenhoeck \& Ruprecht, 2007.

Lissa, Zofia. Music in Poland, 1945-1955. Warsaw: Polonia, 1955.

, and Józef Chomiński, eds. Kultura muzyczna Polski Ludowej, 19441955. Kraków: PWM, 1957.

Losiak, Robert. "Pejzaż muzyczny Peerelu.” In Nim będzie zapomniana. Szkice o kulturze PRL-u, ed. Stefan Bednarek, 199-204. Wrocław: Wydawnictwo Uniwersytetu Wrocławskiego, 1997.

Loth, Wilfried. Stalins ungeliebtes Kind. Reinbek: Rowohlt, 1994.

Lotz, Christian. "Zwischen verordneter und ernsthafter Freundschaft. Die Bemühungen der Helmut-von-Gerlach-Gesellschaft um eine deutsch-polnische Annäherung in der DDR und in der Bundesrepublik 1948-1972." In Erinnerungskultur und Versöhnungskitsch, ed. Hans-Henning Hahn, Heidi HeinKircher, Anna Kochanowska-Nieborak, 201-17. Marburg: Verlag Herder Institut, 2008.

Lucchesi, J. Das Verhör in der Oper. Die Debatte um die Aufführung "Das Verhör des Lukullus" von Bertold Brecht und Paul Dessau. Berlin: BasisDruck, 1993.

Lüdtke, Alf. "Organizational Order or Eigensinn?: Workers' Privacy and Workers' Politics in Imperial Germany." In Rites of Power: Symbolism, Ritual, and Politics since the Middle Ages, ed. Sean Wilentz, 303-33. Philadelphia: University of Pennsylvania Press, 1985. 
, and Peter Becker, eds. Akten. Eingaben. Schaufenster. Die DDR und ihre Texte: Erkundungen zu Herrschaft und Alltag. Berlin: Akademie Verlag, 1997. Machcewicz, Paweł. "Der Umbruch 1956 in Polen. Gesellschaftliches Bewußtsein, Massenbewegung, politische Krise." In Entstalinierungskrise in Ostmitteleuropa, 1953-1956. vom 17. Juni bis zum ungarischen Volksaufstand, ed. Jan Foitzik, 139-64. Paderborn: Ferdinand Schöningh, 2001.

."Zmiana czy kontynuacja? Polska przed i po październiku '56." In $P R L$ : trwanie i zmiana, ed. Dariusz Stola and Marcin Zaremba, 99-158. Warsaw: Wydawnictwo Wyższej Szkoły Przedsiębiorczości i Zarządzania, 2003.

Machlitt, Manfred, ed. Eberhard Schmidt: Ein Lied — ein Atemzug, Erinnerungen und Dokumente. Berlin: Verlag Neue Musik, 1987.

Maier, Charles S. Dissolution: The Crisis of Communism and the End of East Germany. Princeton: Princeton University Press, 1997.

Major, Patrick, and Rana Mitter. "East is East and West is West? Towards a Comparative Socio-Cultural History of the Cold War." In Across the Blocs: Cold War Cultural and Social History, ed. Patrick Major and Rana Mitter, 1-22. London: Frank Cass, 2004.

Major, Patrick, and Jonathan Osmond. The Workers' and Peasants' State: Communism and Society in East Germany under Ulbricht 1945-71. Manchester: Manchester University Press, 2002.

Malinowski, Władysław. “O socjalistycznym realizmie w muzyce.” Twórczość 1 (1993): 50-68.

Mally, Lynn. Culture of the Future: the Proletkult Movement in Revolutionary Russia. Berkeley: University of California Press, 1990.

Malycha, Andreas. Die SED: Geschichte ihrer Stalinisierung, 1946-1953. Paderborn: Ferdinand Schöningh, 2000.

Marek, Tadeusz. Przewodnik koncertowy: Bibliografia twórczości muzycznej 10-lecia (wybór). Warsaw, 1955.

—. Wspótczesna muzyka polska (1945-1956): próba charakterystyki. Kraków: PWM, 1956.

Markiewicz, Leon. Grzegorz Fitelberg, 1879-1953: życie i dzieło. Katowice: Fibak Marquard, 1996.

Markowska, Elzbieta. Jana Krenza pięćdziesiat lat z batutq: rozmowy o muzyce polskiej. Kraków: PWM, 1996.

Marschall-Reiser, Johanna. ““. . . die Kunst eine machtvolle Waffe, . . ’: Die Staatliche Kommission fuer Kunstangelegenheiten und die Erschliessung ihrer Aktenüberlieferung im Bestand Ministerium für Kultur der DDR (DR1)." Mitteilungen aus dem Bundearchiv. (January 1999): 41-51.

Mayer, Günter. "Hanns Eisler und der 17. Juni 1953." Positionen 10, no. 31 (February 2003): 9-12. 
-. "Hanns Eisler und der 17. Juni 1953 (Teil 2)." Positionen 10, no. 32 (June 2003): 20-21.

_. "Hanns Eisler nach der Faustus-Debatte." Positionen 10, no. 33 (October 2003): 6-9.

- "Hat Hanns Eisler nach der 'Faustus'-Debatte resigniert?" In Beitrage 2000. Hanns-Eisler Symposium zum 100. Geburtstag von Hanns Eisler, ed. Harald Goertz and Teresa Hrdlicka. Kassel: Bärenreiter, 2000.

. "Reflexionen zur Methodologie der Musikgeschichtsschreibung." In Musikwissenschaft und Kalter Krieg: Das Beispiel DDR, ed. Nina Noeske and Matthias Tischer, 77-95. Köln: Böhlau, 2010.

Mazurek, Małgorzata. Socjalistyczny zakład pracy: Porównanie fabrycznej codzienności w PRL i NRD u progu lat sześćdziesiatych. Warsaw: Trio, 2005.

McElvoy, Anne. The Saddled Cow: East Germany's Life and Legacy. London: Faber and Faber, 1992.

McFalls, Lawrence. Communism's Collapse, Democracy's Demise?: The Cultural Context and Consequences of the East German Revolution. New York: New York University Press, 1995.

Mehner, Klaus. "Jahre der Entscheidung. Vom deutschen Nachkriegsklang zur sozialistisch-realistischen Musik." Positionen 27 (May 1996): 13-18.

Meuschel, Sigrid. Legimitation und Parteiherrschaft: Zum Paradox von Stabilität und Revolution in der DDR, 1945-1989. Frankfurt: Suhrkamp, 1992.

—. "Machtmonopol und homogenisierte Gesellschaft. Anmerkungen zu Detlef Pollack." GG 26, no. 1 (2000): 171-83.

Meyer, Ernst Hermann. Musik im Zeitgeschehen. Berlin: Verlag Bruno Henschel und Sohn, 1952.

Michałowski, Kornel, ed. Bibliografia Polskich Czasopism Muzycznych: Ruch Muzyczny, 1945-1949, 1957-59. Tom XIV, część 1. Warsaw, 1970.

Miłosz, Czesław. The Captive Mind. 1953. Jane Zielonko, trans. New York: Vintage International, 1990.

Mittenzwei, Werner. Die Intellektuellen: Literatur und Politik in Ostdeutschland, 1945-2000. Leipzig: Faber \& Faber, 2001.

_ . "On the 'Faustus' Debate. On the risk involved in writing a new 'Faust' for the German public, as undertaken in 1953 by the composer and author Hanns Eisler, and the consequences thereof." In Hanns Eisler: A Miscellany, ed. David Blake, 363-92. Luxembourg: Harwood Academic Publishers, 1995.

Mitter, Armin, and Stefan Wolle. Untergang auf Raten: Unbekannte Kapitel der DDR-Geschichte. München: Bertelsmann, 1993.

Moranda, Scott. "Towards a More Holistic History? Historians and East German Everyday Life." Social History 35, no. 3 (2010): 330-38. http://dx.doi.org/10 $.1080 / 03071022.2010 .492133$. 
Morrison, Simon. The People's Artist: Prokofiev's Soviet Years. Oxford: Oxford University Press, 2008. http://dx.doi.org/10.1093/acprof: oso/9780195181678.001.0001.

Mosse, George. The Nationalization of the Masses: Political Symbolism and Mass Movements in Germany from the Napoleonic Wars through the Third Reich. Ithaca: Cornell University Press, 1975.

Mozejko, Edward. Der sozialistische Realismus: Theorie, Entwicklung und Versagen. Bonn: Bouvier, 1977.

- "Teoretyczne koncepje i przyjęcie realizmu socjalistycznego jako metody twórczej w krytyce marksistowskiej Zachodu." In Realizm socjalistyczny w Polsce z perspektywy 50 lat, ed. Stefan Zabierowski, 70-100. Katowice: Wydawnictwo Uniwersytetu Śląskiego, 2001.

Mrygoniowie, Adam and Ewa. Bibliografia Polskiego Pismiennictwa Muzykologicznego (1945-1970). Warsaw: PWN, 1972.

Mühl-Benninghaus, Wolfgang. "'Der Mensch ist nicht Ewiges...' Zu Problemen von Unterhaltungssendungen des Rundfunks der Sowjetischen Besatzungszone." In Zwischen Pop und Propaganda: Radio in der DDR, ed. Klaus Arnold and Christoph Classen, 67-82. Berlin: Ch. Links Verlag, 2004.

Müller, Gerhard. "Ein deutsches Trauerspiel. Die Debatte über Eislers Johann Faustus." Eisler-Mitteilung 9, no. 30 (October 2002): 8-12.

_. "Eisler und die Faustus-Debatte." In Hanns Eisler der Zeitgenosse: Positionen-Perspektiven. Materialien zu den Eisler-Festen 1994/95, ed. Günter Mayer, 60-66. Leipzig: Deutscher Verlag für Musik, 1997.

Murzański, Stanisław. Między kompromisem a zdradq: intelektualiści wobec przemocy, 1945-1956. Kraków: Wydawnictwo Arcana, 2002.

Mycielski, Zygmunt. Dziennik, 1950-1959. Warsaw: Iskry, 1999.

Nabokov, Nicolas. Bagázh: Memoirs of a Russian Cosmopolitan. New York: Athaneum, 1975.

- Old Friends and New Music. Boston: Atlantic, 1951.

Nagel, Hans-Jürgen. "Musik und Politik: Paul Dessau und Hanns Eisler." In Zwischen Politik und Kultur: Juden in der DDR, ed. Moshe Zuckermann, 227-38. Göttingen: Wallstein Verlag, 2002.

Naimark, Norman. The Russians in Germany: A History of the Soviet Zone of Occupation, 1945-1949. Cambridge: Belknap Press, 1995.

Natanson, Jacek. Tygodnik “Odrodzenie," 1944-50. Warsaw: PWN, 1987.

Nelson, Amy. Music for the Revolution: Musicians and Power in Early Soviet Russia. Pennsylvania State University, 2004.

Nelson, Amy. "The Struggle for Proletarian Music: RAPM and the Cultural Revolution." Slavic Review 59, no. 1 (2000): 101-32. http://dx.doi. org/10.2307/2696906. 
Niethammer, Lutz. "Erfahrungen und Strukturen. Prolegomena zu einer Geschichte der Gesellschaft der DDR." In Sozialgeschichte der DDR, ed. Hartmut Kaelble, Jürgen Kocka, and Hartmut Zwahr, 95-115. Stuttgart: Klett Cotta, 1994.

Nikolska, Irina. Conversations with Witold Lutostawski (1987-1992). Stockholm: Melos, 1994.

Nobis, Adam. "Między upowszechnianiem a oświecaniem." In Nim będzie zapomniana. Szkice o kulturze PRL-u, ed. Stefan Bednarek, 84-96. Wrocław: Wydawnictwo Uniwersytetu Wrocławskiego, 1997.

Nothnagle, Alan. Building the East German Myth: Historical Mythology and Youth Propaganda in the German Democratic Republic, 1945-1989. Ann Arbor: University of Michigan Press, 1999.

Offner, Hannelore. "Überwachung, Kontrolle, Manipulation. Das MfS und eine Verflechtung mit Kunst- und Kulturinstitutionen." In Die DDR-Analysen eines aufgegebenen Staates, ed. Heiner Timmerman, 495-507. Berlin: Duncker and Humblot, 2001.

Olkhovsky, Andrey. Music under the Soviets: The Agony of an Art. New York: Praeger, 1955.

Ozouf, Mona. La fête révolutionnaire, 1789-1799. Paris: Editions Gallimard, 1976.

Paczkowski, Andrzej. Pół wieku dziejów Polski, 1939-1989. Warsaw: PWN, 1998.

- Od sfatszowanego zwycięstwa do prawdziwej klęski: szkice do portretu PRL. Kraków: Wydawnictwo Literackie, 1999.

Painter, Karen. "Musical Aesthetics and National Socialism." In Music and Dictatorship in Europe and Latin America, ed. Roberto Illiano and Massimiliano Sala, 121-40. Turnhout: Brepols, 2009.

- Symphonic Aspirations: German Music and Politics, 1933-1945. Cambridge: Harvard University Press, 2008.

Paja-Stach, Jadwiga. Polish Music from Paderewski to Penderecki. Kraków: Musica Iagellonica, 2010.

—. Witold Lutosławski i jego styl muzyczny. Kraków: Musica Iagellonica, 1997.

Palmowski, Jan. "Workshop Report: Between Conformity and Eigen-Sinn: New Approaches to GDR History." German History 20, no. 4 (2002): 494-502. http://dx.doi.org/10.1191/0266355402gh268oa.

Panek, Wacław. Upowszechnianie kultury muzycznej. Warsaw: Instytut Wydawniczy CRZZ, 1980.

Panufnik, Andrzej. Composing Myself. London: Methuen, 1987.

Pence, Katherine, and Paul Betts, eds. Socialist Modern: East German Everyday Culture and Politics. Ann Arbor: University of Michigan Press, 2008. 
Perris, Arnold. Music as Propaganda: Art to Persuade, Art to Control. Westport, CT: Greenwood Press, 1985.

Peterson, Edward N. Russian Commands and German Resistance: the Soviet Occupation, 1945-1949. New York: Peter Lang, 1999.

Pike, David. German Writers in Soviet Exile, 1933-1945. Chapel Hill: University of North Carolina Press, 1982.

- The Politics of Culture in Soviet-Occupied Germany. Stanford: Stanford University Press, 1992.

Pischner, Hans. Premieren eines Lebens: Autobiographie. Berlin: Verlag der Nation, 1986.

Poiger, Uta G. "American Jazz in the German Cold War." In Music and German National Identity, ed. Celia Applegate and Pamela Potter, 218-33. Chicago: University of Chicago Press, 2002.

—. Jazz, Rock, and Rebels: Cold War Politics and American Culture in a Divided Germany. Berkeley: University of California Press, 2000.

Pollack, Detlef. "Die konstitutionelle Widersprüchlichkeit der DDR. Oder: War die DDR-Gesellschaft homogen?" GG 24, no. 1 (1998): 110-32.

—. "Die offene Gesellschaft und ihre Freunde." GG 26, no. 1 (2000): 18496.

Polony, Leszek. "Powikłania ideologii estetycznych w powojennym pięćdziesięcioleciu.” In Muzyka Polska, 1945-1995, ed. Krzysztof Droba, Teresa Malecka, and Krzysztof Szwajgier. Kraków: Akademia Muzyczna, 1996.

Poręba, Stanisław. "Problemy genezy realizmu socjalistycznego." In Realizm socjalistyczny w Polsce z perspektywy 50 lat, ed. Stefan Zabierowski, 50-60. Katowice: Wydawnictwo Uniwersytetu Śląskiego, 2001.

Port, Andrew I. Conflict and Stability in the German Democratic Republic. Cambridge: Cambridge University Press, 2007.

- "Introduction: The Banalites of East German Historiography." In $B e-$ coming East Germans: Socialist Structures and Sensibilities after Hitler, ed. Mary Fulbrook and Andrew I. Port. New York: Berghahn Books, 2013.

Prieberg, Fred K. Musik im anderen Deutschland. Köln: Wissenschaft und Politik, 1968.

Pritchard, Gareth. The Making of the GDR: from Antifascism to Stalinism. New York: Manchester University Press, 2000.

Prokop, Jan. Pisarze w sluzbie przemocy. Kraków: Virdis, 1995.

Prokop, Siegfried. Intellektuelle im Krisenjahr 1953. Enquete über die Lage der Intelligenz der DDR. Analyse und Dokumentation. Schkeuditz: Schkeuditzer Buchverlag, 2003.

Prokopowicz, Maria, ed. Przewodnik po bibliotekach i zbiorach muzycznych $w$ Polsce. Warsaw: Stowarzyszenie Bibliotekarzy Polskich, 1982. 
Pszczółkowski, Tomasz. "Ausgewählte Probleme eines Kulturvergleiches zwischen der DDR und Polen." In Das War die DDR. DDR-Forschung im Fadenkreuz von Herrschaft, Aussenbeziehungen, Kultur und Souveränität, ed. Heiner Timmermann, 677-702. Münster: Lit Verlag, 2004.

Rae, Charles Bodman. The Music of Lutostawski. London: Faber and Faber, 1994. Rakitin, Vassily. "The Avant-Garde and Art of the Stalinist Era." In The Culture of the Stalin Period, ed. Hans Günter. New York: St. Martin's, 1990.

Rappoport-Gelfand, Lidia. Musical Life in Poland: The Postwar Years, 19451977. New York: Gordon and Breach, 1991.

Rauhut, Michael. Beat in der Grauzone: DDR-Rock 1964 bis 1972: Politik und Alltag. Berlin: BasisDruck, 1993.

—. Rock in der DDR 1964 bis 1989. Bonn: bpb, 2002.

Reimer, Angelika. "Organe der Macht 1945-1954: Von der Deutschen Zentralverwaltung für Volksbildung bis zur Gründung des Ministeriums für Kultur." In Kunstdokumentation SBZ/DDR, 1945-1990: Aufsätze, Berichte, Materialien, ed. Günter Feist, Eckhart Gillen, and Beatrice Verneisel, 821-34. Bonn: V.G. Bild-Kunst, 1996.

Reinhold, Daniela, ed. Paul Dessau, 1894-1979. Dokumente zu Leben und Werk. Berlin: Henschel, 1994.

Risch, William Jay. The Ukrainian West: Culture and the Fate of Empire in Soviet Lviv. Cambridge: Harvard University Press, 2011. http://dx.doi.org/10.4159/ harvard.9780674061262.

Ritter, Rüdiger, and Gertrud Pickhan, eds. Jazz Behind the Iron Curtain. Frankfurt: Peter Lang, 2010.

Robin, Régine. Socialist Realism: An Impossible Aesthetic. Stanford: Stanford University Press, 1992.

Rolf, Malte. Das sowjetische Massenfest. Hamburg: Hamburger Edition, 2006.

Rokicki, Konrad. "Literaci a partia, 1945-1968." In PRL: trwanie i zmiana, ed. Dariusz Stola and Marcin Zaremba, 373-95. Warsaw: Wydawnictwo Wyższej Szkoły Przedsiębiorczości i Zarządzania, 2003.

Romijn, Peter, Giles Scott-Smith, and Joes Segal, eds. Divided Dreamworlds?: The Cultural Cold War in East and West. Amsterdam: Amsterdam University Press, 2012.

Ross, Corey. Constructing Socialism at the Grass-Roots: The Transformation of East Germany, 1945-65. New York: St. Martin's, 2000. http://dx.doi. org/10.1057/9781403919724.

- The East German Dictatorship: Problems and Perspectives in the Interpretation of the GDR. London: Arnold, 2002.

Roszkowski, Wojciech. Historia Polski, 1914-1996. Warsaw: PWM, 1997.

Rubin, Eli. Synthetic Socialism: Plastics and Dictatorship in the German Democratic Republic. Chapel Hill: The University of North Carolina Press, 2008. 
Rudziński, Witold. Muzyka naszego stulecia. Warsaw: Wydawnictwa Szkolne i Pedagogiczne, 1995.

- "Związek w pierwszym dziesięcioleciu po wojnie." In 50 lat Zwiqzku Kompozytorów Polskich, ed. Ludwik Erhardt, 49-61. Warsaw: Związek Kompozytorów Polskich, 1995.

Rüther, Günther. "Überzeugungen und Verführungen. Schriftsteller in der Diktatur." DA 37, no. 4 (2004): 602-10.

Ryback, Timothy. Rock around the Bloc: A History of Rock Music in Eastern Europe and the Soviet Union. Oxford: Oxford University Press, 1990.

Satjukow, Silka, and Rainer Gries. "Sozialistische Helden. Figuren der Propaganda und Personen des Vertrauens." DA 35, no. 5 (2002): 782-92.

Sauer, Birgit. "Volksfeste in der DDR: Zum Verhältnis von Volkskultur und Arbeiterkultur." In Politische Kultur in der DDR, ed. Hans-Georg Wehling, 194207. Stuttgart: Verlag W. Kohlhammer, 1989.

Saunders, Frances Stonor. The Cultural Cold War: The CIA and the World of Arts and Letters. New York: New Press, 2000.

Schaarschmidt, Thomas. "Der Kulturbund als Heimatverein? Anmerkungen zu Anspruch und Realität des Kulturbundes in den vierziger und fünfziger Jahren aus regionalhistorischer Sicht." In Die DDR-Analysen eines aufgegebenen Staates, ed. Heiner Timmerman, 357-88. Berlin: Duncker and Humblot, 2001.

Schaeffer, Boguslaw. Almanach polskich kompozytorów współczesnych. Kraków: PWM, 1966.

—. Leksykon kompozytorów XX wieku. Kraków: PWM, 1963.

- Maty informator muzyki XX w. Kraków: PWM, 1958.

Schebera, Jürgen. Hanns Eisler: eine Biografie in Texten, Bildern und Dokumenten. Mainz: Schott, 1998.

Schiller, Dieter. Disziplinierung der Intelligenz. Berlin: Gesellschaftswissenschaft, 1997.

- "Selbstbesinnung, Selbstzensur, Selbstzerstörung: Zum politischen Dilemma Johannes R. Bechers in seinen letzten Lebensjahren." Zeitschrift fur Geschichtswissenschaft 41, no. 12 (1993): 1071-77.

—. Der verweigerte Dialog. Zum Verhältnis von Parteiführung der SED und Schriftstellern im Krisenjahr 1956. Berlin: Karl Dietz Verlag, 2003.

Schivelbusch, Wolfgang. Vor dem Vorhang: Das geistige Berlin, 1945-1948. Frankfurt: Fischer, 1997.

Schmidt, Anne-Kristin. Musik als Werkzeug der Indoktrination: Am Beispiel der Festouvertüre 1948 von Ottmar Gerster und dem Mansfelder Oratorium von Ernst Hermann Meyer. Mainz: Are Musik Verlag, 2009.

Schmidt-Rost, Christian. "Freedom within Limitations - Getting Access to Jazz in the GDR and PRP between 1945 and 1961." In Jazz Behind the Iron Curtain, ed. Rüdiger Ritter and Gertrud Pickhan, 223-38. Frankfurt: Peter Lang, 2010. 
. "Heiße Rhythmen im Kalten Krieg: Swing und Jazz hören in der SBZ/ DDR und der VR Polen (1945-1970). In Zeithistorischen Forschungen/Studies in Contemporary History, Online-Edition 8 (2011). http://www.zeithistorische-forschungen.de/site/40209138/default.aspx.

Schmitt, Hans-Jürgen. Die Expressionismusdebatte: Materialien zu einer marxistischen Realismuskonzeption. Frankfurt: Suhrkamp, 1973.

Schneider, Frank. "Aufbruch mit Widersprüchen: Neue Musik im Zeichen der Nachkriegspolitik." In Deutsche Leitkultur Musik? Zur Musikgeschichte nach dem Holocaust, ed. Albrecht Riethmueller, 163-72. Stuttgart: Franz Steiner Verlag, 2006.

- Momentaufnahme: Notate zu Musik und Musikern in der DDR. Leipzig: Verlag Philipp Reclam, 1979.

- " "Referat anläßlich der Medientage München 1992: Symposium 'Musik in den Medien." In Mit uns zieht die neue Zeit . . . : 40 Jahre DDR-Medien, ed. Heide Riedel, 218-22. Berlin: Vistas, 1994.

. Das Streichquartettschaffen in der DDR bis 1970. Leipzig: VEB Deutscher Verlag für Musik, 1980.

Schroeder, Klaus. Der SED-Staat. Partei, Staat und Gesellschaft, 1949-1990. München: Carl Hanser Verlag, 1998.

Schubbe, Elimar, ed. Dokumente zur Kunst-, Literatur- und Kulturpolitik der SED. Stuttgart: Seewald Verlag, 1972.

Schuhmann, Annette. Kulturarbeit im sozialistischen Betrieb. Gewerkschaftliche Erziehungspraxis in der SBZ/DDR 1946 bis 1970. Köln: Böhlau Verlag, 2006.

Schultz, Uwe. Das Fest: Eine Kulturgeschichte von der Antike bis zur Gegenwart. München: Verlag C. H. Beck, 1988.

Schurdel, Harry D. "Die Hoheitssymbole der Deutschen Demokratischen Republik." In Parteiauftrag: Ein neues Deutschland. Bilder, Rituale und Symbole der frühen $D D R$, ed. Dieter Vorsteher, 44-62. Berlin: Koehler \& Amelang, 1997.

Schütrumpf, Jörn. "Die Klassik-Mittel zur Alleinherrschaft.” In Parteiauftrag: Ein neues Deutschland. Bilder, Rituale und Symbole der frühen DDR, ed. Dieter Vorsteher, 196-203. Berlin: Koehler \& Amelang, 1997.

Schwarz, Boris. Music and Musical Life in Soviet Russia, 1917-1970. New York: Norton, 1972.

Scott, H. D., ed. Problems of Soviet Literature: Reports and Speeches at the First Soviet Writer's Congress. New York: International Publishers, 1935.

Scott-Smith, Giles, and Hans Krabbendam, eds. The Cultural Cold War in Western Europe, 1945-1960. London: Frank Cass, 2003.

Shore, Marci. Caviar and Ashes: A Warsaw Generation's Life and Death in Marxism, 1918-1968. New Haven: Yale, 2006. 
Shostakovich, Dmitri D., and Solomon Volkov. Testimony: The Memoirs of Dmitri Shostakovich. New York: Harper \& Row, 1979.

Silverberg, Laura. "Between Dissonance and Dissidence: Socialist Modernism in the German Democratic Republic.” Journal of Musicology 26, no. 1 (2009): 44-84. http://dx.doi.org/10.1525/jm.2009.26.1.44.

—. The East German Sonderweg to Modern Music, 1956-1971. Ph.D. diss. University of Pennsylvania, 2007.

Śledziński, Stefan, ed. 150 lat Państwowej Wyższej Szkoły Muzycznej w Warszawie. Kraków: PWM, 1960.

Sokorski, Włodzimierz. "Rozmowa Sztuki: Włodzimierz Sokorski." Sztuka 13, no. 2 (1988): 24-32.

—. Sztuka w walce o socjalizmu. Kraków: PIW, 1950.

, and Stanisław Zawiśliński. Wyznania zdrajcy: fakty i plotki. Chicago: Andy Grafik, 1991.

Solga, Heike. Auf dem Weg in eine klassenlose Gesellschaft?: Klassenlagen und Mobilität zwischen Generationen in der DDR. Berlin: Akademie Verlag, 1995. Sowa, Andrzej Leon. Wielka Historia Polska: Od drugiej do trzeciej Rzeczypospolitej (1945-2001). Vol. 5. Part II. Kraków: Fogra Oficyna Wydawnicza, 2003.

Sowiński, Paweł. Komunistyczne święto: obchody 1 maja w latach 1948-1954. Warsaw: Trio, 2000.

Spahn, Peter. Gesellschaft, Komponisten, Medien. Aspekte sozialistischer Musikkultur in der DDR. Berlin: Verlag Neue Musik, 1987.

Spotts, Frederic. Hitler and the Power of Aesthetics. Woodstock: Overlook Press, 2003.

Stadelmann, Matthias. "“O, wie gut ist es, im sowjetischen Land zu leben'-Unterhaltungskultur als gesellschaftliches Integrationsmoment im stalinistischen Regime." GG 30 (2004): 74-93.

Stather, Martin, ed. Einer frohen Zukunst entgegen!: Kunst in der DDR der 50er Jahre. Mannheim: Mannheimer Kunstverein, 1999.

Steinberg, Michael P. Austria as Theater and Ideology: The Meaning of the Salzburg Festival. Ithaca: Cornell University Press, 1990.

Steinweis, Alan. Art, Ideology \& Economics in Nazi Germany: The Reich Chambers of Music, Theater, and the Visual Arts. Chapel Hill: University of North Carolina Press, 1993.

Stephan, Gerd-Rüdiger, Andreas Herbst, Christine Krauss, Daniel Küchenmeister, and Detlef Nakath, eds. Die Parteien und Organisation der DDR: Ein Handbuch. Berlin: Karl-Dietz Verlag, 2002.

Stites, Richard. Russian Popular Culture: Entertainment and Society since 1900. Cambridge: Cambridge University Press, 1992. 
Stowarzyszenie Polskich Artystów Muzyków. Kronika wroclawskiego oddzialu SPAM, lata 1957-78. Wrocław, 1979.

Stucky, Steven. Lutosławski and His Music. Cambridge: Cambridge University Press, 1981.

Sułek, Małgorzata. Pieśni masowe Witolda Lutosławskiego w kontekście doktryny realizmu socjalistycznego. Kraków: Musica Iagellonica, 2010.

Świda-Ziemba, Hanna. Człowiek wewnętrznie zniewolony. Problemy psychosocjologiczne minionej formacji. Warsaw: ISNS UW, 1998.

Tarnawska-Kaczorowska, Krystyna. "Totalitaryzm i muzyka." Przeglad Powszechny 4 (1992): 107-13.

Taruskin, Richard. Defining Russia Musically: Historical and Hermeneutical Essays. Princeton: Princeton University Press, 1997.

Taubman, William. Khrushchev: The Man and His Era. New York: Norton, 2003.

Thacker, Toby. "'Anleitung und Kontrolle': Stakuko and the Censorship of Music in the GDR, 1951-1953." In Censorship and Cultural Regulation in the Modern Age, ed. Beate Müller, 87-110. Amsterdam: Rodopi, 2004.

- "The Fifth Column: Dance Music in the Early GDR." In The Workers" and Peasants'State: Communism and Society in East Germany, 1945-71, ed. Jonathan Osmond and Patrick Major, 227-43. Manchester: Manchester University Press, 2002.

- Music after Hitler, 1945-1955. Aldershot: Ashgate, 2007.

Thomas, Adrian. "File 750: Composers, Politics and the Festival of Polish Music (1951)." Polish Music Journal 5, no. 1 (2002).

. "The Hidden Composer: W. Lutosławski and Polish Radio, 1946-1963." In Witold Lutosławski: Człowiek i dzieło w perspektywie kultury muzycznej XX wiek, ed. Jan Astriab, Maciej Jabłoński, and Jan Stęszewski, 211-20. Poznań: Wydawnictwo Poznańskiego Towarzystwa Przyjaciól Nauk, 1999.

—. "In the Public Eye." In Andrzej Panufnik's Music and Its Reception, ed. Jadwiga Paja-Stach, 205-20. Kraków: Musica Iagellonica, 2003.

"Mobilising our Man: Politics and Music in Poland during the Decade after the Second World War." In Composition-Performance-Reception, ed. Wyndham Thomas, 145-68. Aldershot: Ashgate, 1998.

- Polish Music since Szymanowski. Cambridge: Cambridge University Press, 2005.

—. "Your Song is Mine." The Musical Times (August 1995): 403-09.

Thomas, Rüdiger. "Kultur und Kulturpolitik in der DDR." In Bilanz und Perspektiven der DDR-Forschung, ed. Rainer Eppelmann, Bernd Faulenbach, and Ulrich Mählert, 260-71. Paderborn: Ferdinand Schöningh, 2003.

—. "Lebensspuren. Zur Mentalitätsgeschichte der Deutschen in der DDR." In Rückblicke auf die DDR, ed. Gisela Helwig, 183-96. Köln: Deutschland Archiv, 1995. 
Tighe, Carl. The Politics of Literature: Poland 1945-1989. Cardiff: University of Wales Press, 1999.

Timasheff, Nicholas S. The Great Retreat: The Growth and Decline of Communism in Russia. New York: E. P. Dutton, 1946.

Tischer, Matthias. Komponieren für und wider den Staat. Paul Dessau in der DDR. Köln: Böhlau Verlag, 2009.

—. Musik in der DDR. Berlin: Verlag Ernst Kuhn, 2005.

Tomasik, Wojciech. Inżyniera dusz: literatura realizmu socjalistycznego w planie 'propagandy monumentalnej'. Wrocław: Wydawnictwo Leopoldinum, 1999.

—_. "Pieśń masowa." In Słownik realizmu socjalisticznego, ed. Zdzisław Łapiński and Wojciech Tomasik, 187-93. Kraków: Universitas, 2004.

Tomoff, Kiril. Creative Union: The Professional Organization of Soviet Composers, 1939-1953. Ithaca: Cornell University Press, 2006.

Tompkins, David. "Composing for and with the Party: Andrzej Panufnik and Stalinist Poland." Polish Review 54, no. 3 (2009): 271-88.

" Instrumentalizing Entertainment and Education: Early Cold War Music Festivals in East Germany and Poland.” In Socialist Escapes: Breaking Away from Ideology and Everyday Routine in Eastern Europe, 1945-1989, ed. Cathleen M. Giustino, Catherine J. Plum, and Alexander Vari, 27-47. New York: Berghahn Books, 2013.

- "Orchestrating Identity: Concerts for the Masses and the Shaping of East German Society." German History 30, no. 3 (2012): 412-28. http://dx.doi. org/10.1093/gerhis/ghs042.

Torańska, Teresa. "Them": Stalin's Polish Puppets. Trans. Agnieszka Kolakowska. New York: Harper \& Row, 1987.

Trepte, Hans-Christian. "Polish Literature and Culture in East Germany: A Window to the West?" Polish Review 41, no. 1 (1996): 64-65.

Tschernig, Erika, Monika Kollega, and Gundrun Müller, eds. Unsere Kultur: DDR-Zeittafel, 1945-87. Berlin: Dietz Verlag, 1989.

Trznadel, Jacek. Hanba domowa: rozmowy z pisarzami. Lublin: Wydawnictwo "Test," 1990.

- Kolaboranci: Tadeusz Boy-Żelenski i grupa komunistycznych pisarzy we Lwowie, 1939-1941. Warsaw: Wydawnictwo Antyk Marcin Dybowski, 1998.

Tubielewicz-Mattsson, Dorota. "Socrealistyczne mity a progresywizm. Czy tęsknimy za socrealizmem? Postawienie problemu." In Realizm socjalistyczny $w$ Polsce z perspektywy 50 lat, ed. Stefan Zabierowski, 101-10. Katowice: Wydawnictwo Uniwersytetu Śląskiego, 2001.

Tuchowski, Andrzej. "The Impact of the Communist Dictatorship and Its Transformations on the Identity of Polish Music in the Years 1945-1989." In Music and Dictatorship in Europe and Latin America, ed. Roberto Illiano and Massimiliano Sala, 333-62. Turnhout, Belgium: Brepols, 2009. 
. . . und an der Stalinallee: Eine Sammlung neuer Lieder- und Textmaterialien zum Nationalen Aufbauprogramm Berlin 1952. Berlin: Tribüne Verlag und Druckereien des FDGB, 1952.

Verdery, Katherine. National Ideology under Socialism: Identity and Cultural Politics in Ceauşescu's Romania. Berkeley: University of California Press, 1991. http://dx.doi.org/10.1525/california/9780520072169.001.0001.

Vierneisel, Beatrice. "Die Kulturabteilung des Zentralkomitee der SED 19461964.” In Kunstdokumentation SBZ/DDR, 1945-1990: Aufsätze, Berichte, Materialien, ed. Günter Feist, Eckhart Gillen, and Beatrice Verneisel, 788820. Bonn: V.G. Bild-Kunst, 1996.

Vogt-Schneider, Sabine. "Staatsoper Unter den Linden" oder "Deutsche Staatsoper"?: Auseinandersetzungen um Kulturpolitik und Spielbetrieb in den Jahren zwischen 1945 und 1955. Berlin: Verlag Ernst Kuhn, 1998.

von Eschen, Penny M. Satchmo Blows Up the World: Jazz Ambassadors Play the Cold War. Cambridge: Harvard University Press, 2004.

von Geldern, James. Bolshevik Festivals, 1917-1920. Berkeley: University of California Press, 1993.

von Richthofen, Esther. Bringing Culture to the Masses: Control, Compromise and Participation in the GDR. New York: Berghahn Books, 2009.

von Saldern, Adalheid. "Entertainment, Gender Image, and Cultivating an Audience: Radio in the GDR in the 1950s." In The Challenge of Modernity: German Social and Cultural Studies, 1890-1960, ed. Adalheid von Saldern and Bruce Little, 348-78. Ann Arbor: University of Michigan Press, 2002.

— Lenkung und Ablenkung. Tübingen: Diskord, 1998.

Vowickel, Annette, Marcus M. Payk, and Thomas Lindenberger, eds. Cold War Cultures: Perspectives on Eastern and Western European Societies. New York: Berghahn Books, 2012.

Waldorff, Jerzy. Wybór pism: ciernie i korona. Warsaw: Wiedza Powszechna, 1993.

Walicki, Andrzej. "Totalitaryzm i postttotalitaryzm. Próba definicji." In Polskie zmagania z wolnościq. Wydziane z boku, ed. Andrzej Walicki, 97-112. Kraków: TAiWPN Universitas, 2000.

Wallis, Aleksander. Atlas kultury Polski 1946-1980. Międzychód: Wydawnictwo Echo, 1994.

Walther, Joachim. Sicherungsbereich Literatur: Schriftsteller und Staatssicherheit in der Deutschen Demokratischen Republik. Berlin: Links, 1996.

Weber, Hermann. Die DDR, 1945-1990. München: R. Oldenbourg Verlag, 1993. . Geschichte der DDR. München: Deutscher Taschenbuch Verlag, 1999.

Wehler, Hans-Ulrich. "Diktaturenvergleich, Totalitarismustheorie und DDR-Geschichte." In Doppelte Zeitgeschichte. Deutsch-deutsche Beziehungen 1945- 
1990, ed. Arnd Bauerkämper, Martin Sabrow, and Bernd Stöver, 346-52. Bonn: Dietz, 1998.

Weitz, Eric D. Creating German Communism, 1890-1990: From Popular Protests to Socialist State. Princeton: Princeton University Press, 1997.

Werblan, Andrzej. Stalinizm w Polsce. Warsaw: Wydawnictwo "Fakt," 1991.

Werkentin, Falco. "Die Politik der SED nach der 2. Parteikonferenz im Juli 1952." In Der Aufbau der "Grundlagen der Sozialismus" in der DDR 1952/53, ed. Falco Werkentin, 53-70. Berlin: Berliner Landesbeauftragten für die Unterlagen des Staatssicherheitsdienstes der ehemaligen DDR, 2002.

White, Anne. De-Stalinization and the House of Culture: Declining State Control over Leisure in the USSR, Poland, and Hungary, 1953-89. London: Routledge, 1990.

Whitfield, Stephen J. The Culture of the Cold War. Baltimore: The Johns Hopkins University Press, 1991.

Wieczorkiewicz, Paweł. "O sowieckim socrealizmie i jego genezie-uwagi historyka." In Realizm socjalistyczny w Polsce z perspektywy 50 lat, ed. Stefan Zabierowski, 7-25. Katowice: Wydawnictwo Uniwersytetu Śląskiego, 2001.

Wierling, Dorothee. "The Hilter Youth Generation in the GDR: Insecurities, Ambitions and Dilemmas." In Dictatorship as Experience: Towards a Socio-Cultural History of the GDR, ed. Konrad Jarausch, 307-24. New York: Berghahn Books, 1999.

Wisłocki, Stanisław. Stanisław Wisłocki: Życie jednego muzyka. Warsaw: Oficyna Wydawnicza RYTM, 2000.

Wiszniowka, Monika. "Stefan Kisielewski i socrealizm." In Realizm socjalistyczny w Polsce z perspektywy 50 lat, ed. Stefan Zabierowski, 297-312. Katowice: Wydawnictwo Uniwersytetu Śląskiego, 2001.

Włodarczyk, Wojciech. Socrealizm: sztuka polska w latach 1950-54. Paris: Libella, 1986.

Wolle, Stefan. "Die DDR zwischen Tauwetter und Kaltem Krieg. 'Mutmassungen' über das Jahr 1956." In Entstalinierungskrise in Ostmitteleuropa, 1953-1956. vom 17. Juni bis zum ungarischen Volksaufstand, ed. Jan Foitzik, 293-330. Paderborn: Ferdinand Schöningh, 2001.

Wybraniec, Eugenia. Kultura Muzyczna w województwie katowickim/Music Culture in the Katowice Province. Katowice: Biblioteka Glówna PWSM, 1979.

Zaremba, Marcin. Komunizm, legitymizacja, nacjonalizm: nacjonalistyczna legitymizacja władzy komunistycznej w Polsce. Warsaw: Trio, 2001.

Zawodniak, Mariusz. "Zjazdy, narady, konferencje. Wyprowadzenie do tematu." In Presja i ekspresja: zjazd szczeciński i socrealizm, ed. Danuta Dombrovska and Piotr Michalowski. Szczecin: Wydawnictwo Naukowe Uniwersytetu Szczecińskiego, 2002. 
Zbiorek pieśni rewolucyjnych i masowych do pochodu 1-szo-majowego. Prasa Stalinogród, 1953.

Zhdanov, Andrei. Essays on Literature, Philosophy, and Music. New York: International Publishers, 1950.

Zur Weihen, Daniel. "Anleitung und Kontrolle: Arbeitsbedingungen für junge Komponisten in der DDR der 50er Jahre und deren Folgen." In Zwischen Macht und Freiheit: Neue Musik in der DDR, ed. Michael Berg, Albrecht von Massow und Nina Noeske 23-37. Cologne: Böhlau Verlag, 2004.

_. "Biographie und Situation-Komponieren in der DDR bis 1961. Untersuchungen zum Verhältnis künstlerischer Entwicklung und gesellschafter Rahmenbedingungen am Beispiel der ersten Kompositionsgeneration der DDR." In Die DDR-Analysen eines aufgegebenen Staates, ed. Heiner Timmermann, 465-93. Berlin: Duncker and Humblot, 2001.

- Komponieren in der DDR. Institutionen, Organisationen und die Erste Komponistengeneration bis 1961: Analysen. Köln: Stiftung Mitteldeutscher Kulturrat, 1999.

"Die Staatliche Kommission für Kunstangelegenheiten und die Komposition zeitgenössischer Musik.” In "Die Eroberung der Kultur beginnt!” Die Staatliche Kommission für Kunstangelegenheiten der DDR (1951-1953) und die Kulturpolitik der SED, ed. Jochen Staadt, 277-350. Frankfurt: Peter Lang, 2011.

Zwierzchowski, Piotr. Zapomniani bohaterowie. O bohaterach filmowych polskiego socrealizmu. Warsaw: Wydawnictwo Trio, 2000. 


\section{Index}

Abraham, Paul

Victoria and her Hussar, 211

Abusch, Alexander, 74, 204-205

Ackermann, Anton, 23, 47, 48

Admissions Commission (VDK), 108-110, $127 \mathrm{n} 74$

All-German Music Festival, 193-194n65

amateur music festivals, 185-186

Ami Go Home, 216

antifascism, 23, 47, 58, 74, 202, 230, 250

anti-Semitism, 82n103, 88n218

"Apartment Speculator, The," 215-216

Apelt, Fritz, 63, 103

Artos (Poland), 198, 200, 201-202

concert programs and audience response, 210-213

ideological mission, 203-206

musical stage revues, 214-217

unauthorized concerts and, 219

Asriel, André, 55, 61, 149

Friendship, Unity, Peace (Freundschaft, Einheit, Frieden), 61

music festivals and, 184

Young Guard Laughs Bravely, The

(Tapfer lacht die junge Garde), 61

Association of Polish Composers (Stowar-

zyszenie Kompozytorów Polskich), 97, 105

Association of Polish Musical Artists

(Stowarzyszenie Polskich Artystów Muzyków), 112

audiences, concert, 206-213, 231-232

audition concerts (przestuchania), 34, 118-121

Avalanche (Lawina), 133

Bacewicz, Grażyna, 4, 34, 38, 133, 136, $162 \mathrm{n} 118$

on the commission process, 143
Festival of Polish Music and, 172

The Peasant King ( $Z$ chtopa król), 40

Polonez na Czorsztynie, 141

Third Symphony, 40

Baird, Tadeusz, 4, 30, 38

Ballad of the Soldier's Cup (Ballada o żolnierskim kubku), 40, 146

evaluations of works, 145

Festival of Polish Music and, 146, 173, 174-175

Sinfonietta, 29

Song about Stalin (Pieśń o Stalinie), 39, 139

Song of Revolution (Pieśń rewolucji), 40, 139

Ballad of the Soldier's Cup (Ballada o żolnierskim kubku), 40, 146

Bartel, Kurt (KuBa)

Cantata of Defense, 149-150

Patriots, The (Die Patrioten), 150

Symphony of Friendship, 150

Young Guard Laughs Bravely, The

(Tapfer lacht die junge Garde), 61

Bartók, Béla, 24, 101

Becher, Johannes R., 23, 47, 54, 56, 61, 62-63

condemnation of America by, 103

as head of Ministry of Culture, 75

Lenin, 61

New German Folk Songs (Neue deutsche Volkslieder), 61

Risen from the Ruins (Auferstanden aus Ruinen), 61

Song of the Blue Flag, The (Lied von der blauen Fahne), 61

We Are Changing the World (Die Welt verändern wir), 61

Beloved Country (Ukochany kraj), 38

Berg, Alban, 64, 65

Festival of Polish Music and, 175 
Berliner Ensemble, 41

Berlin Radio Symphony Orchestra and Choir, 57

Berlin State Opera, 49

Berman, Jakub, 27, 44

Bielsko-Biała orchestra, 222-223

Bierut, Bolesław, 25, 37, 39, 107, 144, 213, 223

Bildung (cultivation), 204

Bitterfeld Way, 251

Bolero, 211-212

Bongartz, Heinz, 229-230

Boulanger, Nadia, 24

Brecht, Bertolt, 6, 41, 50-51

The Cultivation of Millet (Die Erziehung der Hirse), 51

Judgment of Lukullus, The (Die Verurteilung des Lukullus), 6, 50-51

Report from Herrnburg (Herrnburger Bericht), 51

Bricklayer's Waltz, The (Walczyk murarski), 38

Britten, Benjamin, 101

Broniewski, Władysław, 39, 139

Busch, Ernst, 176

Butting, Max, 59, 111, 117, 152

on central authority and power, 121

commissions process and, 149

Eighth Symphony, The Vacation Trip

(Urlaubsreise), 58

Memorandum, The (Das Memorandum), 58

music festivals and, 183

Sixth Symphony, 179

Call (Aufruf), 149

Cantata about Peace (Kantata o pokoju), 139

Cantata about Stalin (Kantate auf Stalin), 56

Cantata about the Vistula River (Kantata o Wiśle), 146

Cantata for our Thälmann Pioneers (Kantate für unsere Thälmann-Pioniere), 152

Cantata in Praise of Work (Kantata na pochwate pracy), 39, 170

Cantata of Defense, 149-150

Cantata on Peace (Kantata o pokoju), 39

cantatas, 39-40, 55-56, 135-136, 138-139

Captive Mind, The, 3
Central Concert Bureau (Poland), 198

Central Administration for Artistic Events (Poland), 198

Central Council of Trade Unions, 186

Central Europe importance of music in, 1-2 music festivals growth in, 167-169 thaw years, 15, 41-46, 209-210, 221, $231,234,248,251$

Certainty of Victory, The (Des Sieges Gewissheit), 56

Chamber Music Commission (VDK), 109

Charter of Hearts (Karta serc), 39

Chomiński, Józef, 22, 23, 29, 44

Chopin concert programs, 170, 185, 206, 207, 210

Chopin, Frédéric (Fryderyk) 61, 172, 197, 203, 206

Chubov, Georgij, 231

Cilenšek, Johann, 57-58, 178

Circle of Virtuosos (ZKP), 111-112

Commission for Light Music (East Germany), 152

commissioning process, 131-132, 154-155

in East Germany, 148-154

payments, 158n44, 159n62

in Poland, 132-148, 156n14

"Common Story, A," 215

community training orchestras

(Gemeinschaftsschulungsorchester), 242n210

Comrade (Towarzysz), 37

Concerto for Oboe and Orchestra (Konzert für Oboe und Orchester), 179

Concerto for Orchestra, 40

concerts

ideological mission of, 203-206

musical stage revue, 213-218

orchestral landscape and, 221-233, 240n179, 242n210

parties' purpose in developing, 197, 233-234

programs and audience response, 206-213

state concert agencies and, 198-203, $234,235 \mathrm{n} 5$

unauthorized, 218-221

Conferencier, 213

Construction Song of the Free German Youth (Aufbaulied der FDJ), 61 
Contract Commission (SED), 152-153, $164 \mathrm{n} 156$

Conversation of Two Cities (Rozmowa dwóch miast), 40, 138-139, 170

cosmopolitanism, 50, 52, 54

Cultivation of Millet, The (Die Erziehung der Hirse), 51

cultural Cold War, 6, 48, 247

Cultural League for the Democratic Renewal of Germany (Kulturbund zur demokratischen Erneuerung Deutschlands), 47, 75, 98, 102-103, 149

Culture Department (PZPR), 69-70, 103, 112,173

Culture Department (SED), 49-50, 53, 59, 70-73, 74, 104

Czerny-Stefańska, Halina, 170

dance music, $235 \mathrm{n} 1$

Day of Liberation (Dzień Wyzwolenia), 142

Deed of Lagów, The (Czyn Lagowa), 142

Dehnert, Max, 179

Merry Prelude for Orchestra (Heiteres

Vorspiel für kleines Orchester), 179

Department for Art, Literature, and Cultural Mass Work (SED), 71

Department of Literature and Art (SED), 71

Department of Party Schooling, Culture, and Education (SED), 70

Departure (Aufbruch), 149

Dessau, Paul, 1, 4, 50-51, 64, 90n264, 116 Construction Song of the Free German

Youth (Aufbaulied der FDJ), 61

criticism of musicologists, 117

Cultivation of Millet, The (Die Erziehung der Hirse), 51

Hello, Brothers from Warsaw (Hallo,

Brüder aus Warschau), 61

Judgment of Lukullus, The (Die Verurteilung des Lukullus), 6, 50, 51

Lilo Herrmann, 51

music festivals and, 176, 181

Report from Herrnburg (Herrnburger

Bericht), 51

visit to Poland, 53

Divertimento, 178

Divertimento for Small Orchestra (Divertimento für kleines Orchester), 179

Dresden Philharmonic, 204, 205, 230
Driesch, Kurt

Summer Day, A (Ein Sommertag), 152

Drobner, Mieczysław, 44, 114, 126n57

Dymschitz, Alexander, 48

East Germany. See also Sozialistische

Einheitspartei Deutschlands (Socialist

Unity Party of Germany [SED]); Union

of German Composers and Musicolo-

gists (Verband deutscher Komponisten

und Musikwissenschaftler [VDK])

cantatas, 56

commemorations of Karl Marx's 135th

birthday in, 71-72

commissions process in, 148-154

course correction on socialist realism, 62-66

debate over formalism in, 54-56

defenders of socialist realism in, 64-66

early discussion of socialist realism in, 47-49

formalism in, 49-62, 65

formulation and modification of socialist realism in, 46-66

Free German Youth (Freie Deutsche Jugend [FDJ]), 50, 61

genre commissions, 176-177

heterogeneous everyday life in, 4-6

importance of music in, 2

Kulturbund zur demokratischen Erneuerung Deutschlands, 47, 75, 98, 102-103, 149

leading composers, 56-58

local and amateur music festivals, 182-186

mass songs, 61-62, 151

music festivals, 175-182

New Course, 62-63, 150, 152, 180, 182, 199, 204, 220, 226, 230-231

party influence on composers' union in, 148-154

power of the party in music of, 66-76

relations with West Germany, 183-184

rural music festivals in, 187-190, $236 n 48$

socialist realism in, 20-23

Soviet ideology in, 6-9

Soviet Occupation Zone, 75 
Stakuko (Staatliche Kommission für Kunstangelegenheiten), 53, 58, 62, 72-75, 103-104, 120, 149-154, 177, $183,220,228-229,232,251$

state concert agencies, 198-203, 234

Two-Year Plan, 48

Uprising of June 17, 1953, 74, 77

Week of Progressive German Culture, 206

East German Composers' Union. See Union of German Composers and Musicologists (Verband deutscher Komponisten und Musikwissenschaftler [VDK])

Egk, Werner, 230

Eigen-Sinn, 5

Eisler, Hanns, 1, 4, 47, 51, 52, 55, 56, 116 amateur festivals and, 186

Ami Go Home, 216

commissions process and, 149

criticisms of, 60

Johann Faustus, 6, 59-60

Lenin, 61

music festivals and, 176

New German Folk Songs (Neue deutsche Volkslieder), 61, 186

Risen from the Ruins (Auferstanden aus Ruinen), 61

Song of the Blue Flag, The (Lied von der blauen Fahne), 61

We Are Changing the World (Die Welt verändern wir), 61

Ekier, Jan, 28, 38, 42

Elektorowicz, Witold, 35, 106, 107, 126n57

Engelhardt, Werner, 109

Estradenkonzert, 206, 213-218, 228

factory workers and music festivals, 178-180

Federal Republic of Germany. See West Germany

Feicht, Hieronim, 38

Festival of Amateur Music Groups, 185-186

Festival of Contemporary Music (Festtage zeitgenössischer Musik), 176, 177

Festival of Folk Music, 170

Festival of New Music (Festtage neuer Musik), 175-176, 181-182

Festivals of Polish Music (Festiwaty Muzyki Polskiej), 31, 35, 42, 44, 147,
$148,169-175,182,190$

origins of, 169-170

purpose of, 173

works commissioned for, 118-119,

136-142, 145-146

Festouvertüre, 57

Finke, Fidelio, 230

First All-Union Congress of Soviet Writers (1934), 17

Flight of the Dove (Flug der Taube), 56

folk music, 19, 21, 28, 37, 40-41, 58, 106

concert programs, 206, 211

festival, 170, 186

Forest, Jean-Kurt

Cantata about Stalin (Kantate auf Stalin), 56

Cantata of Defense, 149-150

Karl Marx Lived and Taught (Karl Marx hat gelebt und gelehrt), 72

Lay the Ground for a New Life (Legt den Grund zu einem neuen Leben), 61

Patriots, The (Die Patrioten), 150, 179

Symphony of Friendship, 150

formalism

in East Germany, 49-62, 63, 65

in Poland, 18, 19, 26-29, 32, 45

linked to imperialist aggression and bourgeois decadence, 48-49, 66

Sokorski on, 27-28, 33

Free German Youth (Freie Deutsche Jugend [FDJ]), 50, 61

Friendship, Unity, Peace (Freundschaft, Einheit, Frieden), 61

Fritz the Tractor Driver (Fritz der Traktorist), 62

Frolova-Walker, Marina, 9n6, 18

Fulbrook, Mary, 5

Fun in Lipiny (Zabawa w Lipinach), 32

Fürnberg, Louis

Party Is Always Right, The (Die Partei hat immer recht), 62

Gałczyński, Konstanty Ildefons, 38

Gehobene Unterhaltungsmusik, 189

Gemeinschaftsorchester (community orchestra), 226, 228

Gemeinschaftsschulungsorchester (community training orchestras), 242n210

genre commissions (East Germany), 176-177 
Gerlach, Jens, 178

German Agency for Concerts and Guest Performances (Deutsche Konzert- und Gastspieldirektion [DKGD]), 199, 200-203

concert programs and audience responses, 206-211

ideological mission, 203-206

musical stage revues, $217-218$

unauthorized concerts and, 219-221

German Democratic Republic (GDR). See East Germany.

German Festivals of Folk Art (Deutsche Festspiele der Volkskunst), 186

German Performance Agency (Deutsche Veranstaltungsdienst [DVD]), 199, 200-203

concert programs and audience responses, 206-211

ideological mission, 203-206

musical stage revues, 217-218

unauthorized concerts and, 219-221

German Hero-Requiem (Deutsches Heldenrequiem), 56

German Writers' Conference, 63

Gerster, Ottmar, 4, 56-57, 99, 152, 230

commissions process and, 149

Departure (Aufbruch), 149

Festouvertüre, 57

Ironworks East (Eisenkombinat-Ost), 56,57

music festivals and, 177, 183

Second Symphony (Thuringian/Thüringische), 57, 178

Gewandhausorchester, 204, 231-232

Girnus, Wilhelm, 50

"Give Us a Happy Face," 215

Gleichschaltung, 98

Glory to Warsaw! (Warszawie-slawa!), 136

Gniot, Walerian, 138

Goldschmidt, Harry, 23, 55, 65, 115-117

Gorky, Maxim, 17

Görlitz Festival, 184-185

Gradstein, Alfred, 35-36, 106, 162n118

commissions process and, 133, 134

On the Right a Bridge, on the Left a

Bridge (Na prawo most, na lewo most), 37

Salute the Party (Cześć partii), 37
Winter Evening, A (Wieczór zimowy), 133

Word on Stalin, A (Stowo o Stalinie), 36, $39,139,141$

Greifswald Theater Orchestra, 228

Grösch, Kurt, 205

Gross, Jan, 221

Grotewohl, Otto, 51

Grupa '49, 30, 40, 138-139

Haase, Hans-Werner, 109

Halka, 185

Hartig, Rudolf, 74, 75, 177

Haunted Manor, The, 185

Heller, Leonid, 17

Hello, Brothers from Warsaw (Hallo,

Brüder aus Warshau), 61

Hera, Willi

Cantata for our Thälmann Pioneers

(Kantate für unsere Thälmann-Pioniere), 152

Herbert, Zbigniew, 6

Hermlin, Stephan, 55

Hesse-Bukowska, Barbara, 207

Hey, young man! (Hejze młody), 138

Heymann, Stefan, 48, 49, 71

Hindemith, Paul, 101, 230

Hohensee, Wolfgang, 66, 121

Holtzhauer, Helmut, 58, 74, 75, 103, 220

Honecker, Erich, 50

Honegger, Arthur, 101

"Hour of Music" concert series, 201, 210

Impreza estradowa, 206, 213-216

Ironworks East (Eisenkombinat-Ost), 56, 57

Irrgang, Horst, 180

Iwaszkiewicz, Jarosław, 140

Janko the Musician (Janko Muzykant), 40

Jarausch, Konrad, 5

Jarociński, Stefan, 174

Jasieński, Jerzy, 38, 144

jazz music, 216, 219, 249

Johann Faustus, 6, 59-60

Judgment of Lukullus, The (Die Verur-

teilung des Lukullus), 6, 50, 51

July Garland (Lipcowy wieniec), 135, 136

Jurdziński, Kazimierz, 38

Just, Gustav, 90n264 
Kabalevsky, Dmitri, 101

Kantate der Republik, 149

Kapuściński, Ryszard, 6

Karl Marx Lived and Taught (Karl Marx hat gelebt und gelehrt), 72

Karłowicz, Mieczysław, 170

Kempe, Rudolf, 229

Khachaturian, Aram, 101, 106, 183

Khrennikov, Tikhon, 25, 52, 96

Khrushchev, Nikita, 63-64 secret speech, 45

Kiesewetter, Tomasz, 38

Kisielewski, Stefan, 44, 114, 138, 144 evaluations of works, 145 Symphonic Scherzo, 138

Klon, Andrzej, 29

Knapp, Margarete, 71

Knepler, Georg, 23, 50, 55, 64, 102, 115-117

Knoblauch, Erich, 220-221

Kochan, Günter, 53, 64, 149, 229, 230 Die Welt ist jung (The World is Young), 56

Violin Concerto, 64, 229

Köhler, Siegfried, 63, 100, 117, 121

Komisja Kwalifikacyjna (ZKP) (Qualification Committee), 105-108, 127n72

Konferansjer, 214, 217-218

Konwitschny, Franz, 229, 231, 243n240

Kraków Days festival, 183

Kraków Philharmonic Orchestra, 170

Kreiskulturorchester (district cultural orchestra) 226-227

Krenz, Jan, 29, 42 commissions process and, 138-139

Conversation of Two Cities (Rozmowa dwóch miast), 40, 138-139, 170

Kreuzchor choir, 205

Kruk, Pawel, 212

KuBa. See Bartel, Kurt

Kulturbund zur demokratischen Erneuerung Deutschlands, (Cultural League for the Democratic Renewal of Germany), 47, 75, 98, 102-103, 149

Kulturfonds, 151, 162-163n125

Kurz, Siegfried, 121

Kurzbach, Paul, 64, 65

Divertimento for Small Orchestra

(Divertimento für kleines Orchester), 179
Lady Macbeth of Mtsensk, 19

Łagów conference, 27-31, 35, 102, 135, 147

Lahl, Hermann, 71

Landessinfonieorchester, 226

Ländliche Musiktage (rural music festivals), 187-188, 190, 236n48

Land of Smiles, The, 211

Lauter, Hans, 23, 50, 52

Laux, Karl, 50, 53

Lay the Ground for a New Life (Legt den Grund zu einem neuen Leben), 61

Lehár, Franz Land of Smiles, The, 211

Lenin, 61

Letter to Stalin (List do Stalina), 145

Leuna chemical factory, 1, 178-179

Lewin, Leopold, 37, 133

Liebermann, Rolf, 229

Lilo Herrmann, 51

Limpid Stream, The, 19

Lissa, Zofia, 20, 21-22, 23, 29, 34, 38, 41, 101, 107, 122

commissions process and and, 133

Culture Department and, 68, 73

Festival of Polish Music and, 139, 140, 174

on musicologists, 113-114

praise for socialist realism, 43-45

on Serocki, 145

speeches given by, 102, 103

on works for mass audiences, 142

Little Suite (Mała suita), 40

Łobaczewska, Stefania, 22, 23

Festival of Polish Music and, 139

local music festivals, 182-185

Lohse, Fred, 121

Work for Peace (Arbeit für den Frieden), 56

Lomani, Borys

Song about Bierut (Pieśń o Bierucie), 144

London Olympic Games (1948), 29

Lorz, Hermann, 220

Love for Three Oranges, The, 229

Lunacharsky, Anatoly, 17

Lutosławski, Witold, 1, 4, 33, 36, 38,

$40-41,53,251,252$

cantatas, 135-136 
commissions process and, 133, 135, 141,148

Comrade (Towarzysz), 37

Concerto for Orchestra, 40

evaluations of works, 145

Festival of Polish Music and, 172

First Symphony, 42, 173

on formalism and artistic freedom, 45

Glory to Warsaw! (Warszawie-sława!), 136

July Garland (Lipcowy wieniec), 135, 136

Lawina (Avalanche), 133

Little Suite (Mała suita), 40

on Marxist aesthetic theory, 101-102

Most Beautiful Dream, A (Najpiękniejszy sen), 36-37

Nowa Huta, 36-37

Qualification Committee (Komisja Kwalifikacyjna) headed by, 106-108 Service to Poland (Stużba Polsce), 37

Victorious Path, The (Zwycięska droga), 37

We Go Forward (Naprzód idziemy), 37

Lwów/Lviv, Ukraine, 20

Mahler, Gustav, 230

Maklakiewicz, Jan, 22, 29, 34

on formalism, 33

Silesia Works and Sings (Ślask pracuje $i$ śpiewa), 39-40, 170

Song about Stalin (Pieśń o Stalinie), 39

Stalin is with Us (Stalin z nami), 39

Traktor Driver and the Girl, The (Traktorzysta i dziewczyna), 205

Mansfelder Oratorium, 55, 186

March for Peace (Marsz pokoju), 38

Markowski, Andrzej, 38

Marx, Karl, 71-72

Marxism, 21-22, 42, 55, 101

Marynka, 146

mass songs

East German, 61-62, 151

Polish, 36-39

Matthus, Siegfried, 184

Mayakovsky, Vladimir, 17

Mazowsze, 139

Mazowsze song-and-dance ensemble, 38, 69, 106

"Meeting at Ania's," 215 membership, union, 104-108

Memorandum, The (Das Memorandum), 58

Merry Prelude for Orchestra (Heiteres

Vorspiel für kleines Orchester), 179

Meyer, Ernst Hermann, 4, 20, 22-23, 49,

$50,52,55,59,64,66$

Call (Aufruf), 149

Certainty of Victory, The (Des Sieges

Gewissheit), 56

Flight of the Dove (Flug der Taube), 56

Kantate der Republik, 149

Mansfelder Oratorium, 55, 186

mass songs by, 61

music festivals and, 178, 181

musicology and, 115-117

Musik im Zeitgeschehen (Music in Current Events), 20-21, 55, 66, 116

Meyerhold, Vsevolod, 17

Mikołaj, Henryk, 251

Millions of Hands (Miliony rqk), 37, 107

Milosz, Czeslaw

Captive Mind, The, 3

Ministry for People's Education (GDR), 73

Ministry of Culture (East Germany), 53, 63, 69, 72, 75-76, 100, 104, 151, 152-154, 181, 183, 188-189, 199, 209, 202, 209, 221,251

Ministry of Culture (Poland), 30, 41, 69, 73, 76, 103, 113, 134, 136, 143, 171, $173,198,202,212,219,222-223,225$

Młodziejowski, Jerzy

Hey, young man! (Hejze młody), 138

To Work (Do roboty), 138

modernism, 18-19, 45-51, 102, 114, 251

Möller, Fritz, 150

Moniuszko, Stanislaw, 140, 207

Halka, 185

Haunted Manor, The, 185

"Month of Polish-Russian Friendship," 212

Morning Song of the Tractor Driver (Morgenlied der Traktoristen), 61-62

Most Beautiful Dream, A (Najpiękniejszy sen), 36-37

"Muddle instead of Music" Pravda editorial, 19

Müller, Armin, 61

Müller, Kurt, 183

musical stage revues, 213-218. See also impreza estradowa and Estradenkonzerte 
music festivals. See also Festivals of Polish Music

in East Germany, 175-182

factory workers and, 178-180

growth of, 167-169

local, 182-185

in Poland, 169-175

rural, 187-190, 236n48

as showcase for socialist-realism, 169-182, 190-191, 249

musicologists, 113-121, 123-124n9

Musikfest des VDK, 177-178, 180

Musik im Zeitgeschehen (Music in Current Events), 20-21, 55, 66, 116

Musik und Gesellschaft, 49, 52, 54, 63, 64

Muzyka, 31

Myaskovsky, Nikolai

Twelfth Symphony, 18

Mycielski, Zygmunt, 26, 28, 31, 34, 38,

$82 \mathrm{n} 95$

on application of socialist realism to music, 102

commissions process and, 134-135, $156 \mathrm{n} 19,156 \mathrm{n} 21$

dissent expressed by, 42-43

evaluations of works, 145

Festival of Polish Music and, 137, 140

Fun in Lipiny (Zabawa w Lipinach), 32

Polish Symphony (Symfonia polska), 32

as president of the composers' union, 142

speeches given by, 102, 103

Union of Polish Composers and, 97

naturalism, 78n10, 82n103

Neef, Wilhelm, 63, 117

neoclassical school of music, 24, 250

Neues Deutschland, 50

New Course (East Germany), 62-63, 150, $152,180,182,199,204,220,226$, 230-231

New Economic Policy (NEP), 32, 81

New Era, A (Nowy czas), 37, 146

New German Folk Songs (Neue deutsche Volkslieder), 61, 186

Nokturn, 29

Notowicz, Nathan, 50, 55, 63-65, 99, $120-121,250$

Novikov, Anatoli, 52

Nowa Huta, 36-37, 137
Nowka, Dieter

Concerto for Oboe and Orchestra

(Konzert für Oboe und Orchester), 179

October Revolution (1917), 51, 140, 141

Olearczyk, Edward, 35, 37, 38, 40, 106-107, 126n57, 146

demotion of, 44

Millions of Hands (Miliony rqk), 37, 107

Our Party (Nasza partia), 38, 106-107

Song in Praise of Comrade Bierut

(Pieśn na cześć towarzysza Bieruta),

37-38, 107

Olympic Symphony, 29, 31, 39, 42, 141, 173

On the Right a Bridge, on the Left a Bridge

(Na prawo most, na lewo most), 37

Onward, Working People (Naprzód ludu roboczy), 133

operettas, 211

orchestral landscape and concerts, 221-233, 240n179, 242n210

Orlow, N., 49

Our Party (Nasza partia), 38, 106-107

Palester, Roman, 28

Panufnik, Andrzej, 1, 27, 33, 36, 252

commissions process and, 133-134

Festival of Polish Music and, 139-140

New Era, A (Nowy czas), 37, 146

Nokturn, 29

Onward, Working People (Naprzód ludu roboczy), 133

Peace on Earth (Pokój nad swiatem), 37

Sinfonia Elegiaca, 140

Sinfonia Rustica, 41

Song of the United Party (Pieśn Zjednoczonej Partii), 37, 133

Song of Unity (Pieśń Jednosci), 133

Symfonia Rewolucyjna, 140

Symphony of Peace (Symfonia pokoju), 140

Parade of Friendship (Pochód przyjaźni), 38-39

Paris, France, 20, 24, 26, 40, 250

Party Is Always Right, The (Die Partei hat immer recht), 62

Pasternak, Leon, 133 
Patriots, The (Die Patrioten), 150, 179

Peace on Earth (Pokój nad światem), 37

Peasant King, The (Z chłopa król), 40

Peasant's Lot, A (Chtopska droga), 39

Peasants' Revolt of 1525,152

Penderecki, Krzysztof, 251

pensions of composers, 147

performers in the composers' unions, 110-113

Perkowski, Piotr, 28, 44, 114

Persische Episode, 178

Pfitzner, Hans, 230

Pianist, The, 38

Pieck, Wilhelm, 50

Pischner, Hans, 23, 63, 66, 90n283, 100, 111, 230

Poems on Stalin (Strofy o Stalinie), 135

Poland. See also Polska Zjednoczona Partia Robotnicza (Polish United Workers' Party [PZPR]); Union of Polish Composers (Zwiazek Kompozytorów Polskich [ZKP]) cantatas, 39-40 commissions process in, $132-148$ debate over and decline of socialist realism in, 23-46, 251

encroaching dogma of socialist realism in, 31-41

Festivals of Polish Music, 31, 35, 42,

$44,118-119,169-175$

gradual concessions over socialist realism in, 41-46

heterogeneous everyday life in, 4-6

importance of music in, 2

initial engagement of cultural policy in, 25-31

Łagów conference, 27-31, 35

local and amateur music festivals, 182-186

mass songs produced in, 36-39

Polish October (1956), 8, 24

power of the party in music of, 66-76

rise of socialist realism in, 20-23

Six-Year Plan, 25, 39, 103, 137, 223

socialist-realist festival program com-

missioned in, 136-142

Soviet ideology in, 6-9

state concert agencies, 198-203, 234

unauthorized concerts in, 218-219 voices of dissent and dissatisfaction in, $42-43$

Warsaw Autumn Festival (1956), 29, 175

World Festival of Youth and Students, 174, 186

Polański, Roman, 38

Polish Communist Party, 23, 135

Polish Composers' Union. See Union of

Polish Composers (Zwiqzek Kompozytorów Polskich [ZKP])

Polish Musicians' Trade Union, 198

Polish National Radio Symphony, 223

Polish October (1956), 8, 24

Polish Radio Orchestra of Bydgoszcz, 224

Polish Symphony (Symfonia polska), 32

Polish Writers' Congress, 70, 97

Polonez na Czorsztynie, 141

Polska Zjednoczona Partia Robotnicza (Polish United Workers' Party [PZPR]), 2, 27, 37, 39, 43, 247-250.

commissions process and, 132-148

Culture Department, 69-70, 103, 112, 173

direct involvement in music through state organs, 73-76

influence on the composers' union, 142-144

music festivals and, 168, 169-175, 190

official belief in the political power of music, 67-68, 247-248

orchestral landscape and, 221-225

Second Party Congress (1954), 146

unions confronting ideology and, 101-104

popularization (upowszechnianie), 26

Poradowski, Stefan Bolesław, 38

Poznań Philharmonic, 27

Pravda, 19

Prezydium (ZKP), 97, 106, 119, 126n57, $142,143,144-145,148$

Professional Estate of German Composers (Berufsstand der deutschen Komponisten), 98

Prokofiev, Sergei, 4, 19, 183

Love for Three Oranges, The, 229

Russian Overture, 146

Prószyński, Stanisław

Day of Liberation (Dzień Wyzwolenia), 142 
Deed of Łagów, The (Czyn Łagowa), 142

Kantata o Stalinie, 141

Peace Symphony, 141

przestuchania (audition concerts), 34,

118-121

Pushkin, Alexander, 133

Qualification Committee (Komisja Kwalifikacyjna), 97, 105-108, 127n72

Rabofsky, Friedhelm, 220, 221

Railwayman's Song (Eisenbahnerlied), 62

Raphael, Günter

Sinfonia breve, 178

realism. See socialist realism.

Rebling, Eberhard, 23, 54, 55, 59, 66, 115, 230

Reich Chamber of Music (Reichsmusikkammer), 98

Rentmeister, Maria, 74

Rentzsch, Egon, 71-72

Report from Herrnburg (Herrnburger Bericht), 51

republikwichtig, 226

Riethmüller, Helmut

\section{Divertimento, 178}

Risen from the Ruins (Auferstanden aus Ruinen), 61

Robeson, Paul, 220

rock 'n' roll music, 219, 235n1

Rostock festival, 188

Rostock Theater Orchestra, 228-229

Rowicki, Witold, 224

Ruch Muzyczny, 25, 26, 31, 138

Rudziński, Witold, 22, 25, 28, 29, 44, 82n97, 107, 146

Culture Department and, 73

Festival of Polish Music and, 137

on formalism, 33

Janko the Musician (Janko Muzykant), 40

To the Party (Do partii), 39

A Peasant's Lot (Chtopska droga), 39 praise for East German composers, 53 as president of the composers' union, 33-34, 36, 106, 122, 142, 143

rural music festivals (Ländliche Musiktage), 187-190, 236n48
Ruslan and Ludmilla, 49

Russian Association of Proletarian Musicians (RAPM), 17

Russian Overture, 146

Saar-Kantate, 56

Salute the Party (Cześć partii), 37

Salzburg Festival, 168

Schaff, Adam, 101

Schmidt, Eberhard

Bolero, 211-212

Fritz the Tractor Driver (Fritz der Traktorist), 62

Railwayman's Song (Eisenbahnerlied), 62

Schmidt, Helmut Gerhard

Stalin Will Be Our Friend for Eternity (Stalin bleibt uns Freund für Allezeit), 151

Schnell, Otto, 1, 179, 180

Schoenberg, Arnold, 18, 25, 55, 60, 64, 65

Festival of Polish Music and, 175

Scholars' Revolt, The (Bunt żaków), 40

Schwaen, Kurt, 50, 64, 152

criticism of muscologists, 117

Song of Construction, The (Das Lied des Aufbaus), 61

Second International Congress of Composers and Music Critics (1948), 25-26, 47-48

SED. See Sozialistische Einheitspartei

Deutschlands (Socialist Unity Party of Germany [SED])

Serocki, Kazimierz, 29

East German music festivals and, 181

Festival of Polish Music and, 173-174

Lissa on, 145

Mazowsze, 139

Symphonic Images (Obrazy symfoniczne), 139

Symphony of Songs (Symfonia pieśni), 40, 145

Warsaw Bricklayer (Warszawski murarz), 40

Service to Poland (Stużba Polsce), 37

Shaporin, Yuri, 52

Shostakovich, Dmitri, 4, 18-19, 55, 101

Lady Macbeth of Mtsensk, 19

The Limpid Stream, 19

music festivals and, 181 
Song of the Forests, 31-32

Shtogarenko, Andrei, 52, 96

Sienkiewicz, Henryk, 40

Sinfonia breve, 178

Sikorski, Kazimierz, 28, 36, 106, 114

evaluations of works, 146-147

Silesia Works and Sings (Ślask pracuje $i$ śpiewa), 39-40, 170

Sinfonia Elegiaca, 140

Sinfonia Rustica, 41

Sinfonietta, 29

Six-Year Plan (Poland), 25, 39, 103, 137, 223

Skrowaczewski, Stanisław

Cantata on Peace (Kantata o pokoju), 39, 139

Word on Stalin, A (Stowo o Stalinie),

39, 139

Sobieski, Marian, 38

socialist realism, 4, 15-16, 251

composers support of, 22-23, 56-58

core concepts, 17-18

debate and decline in Poland, 23-46, 251

debate in East Germany, 54-56

debates over nature and application of, 19

early growth in the GDR and Poland, 20-23, 47-49, 76-77

East German course correction on, 62-66

encroaching dogma of, 31-41

festival program commission in Poland, 136-142, 173

formalism and, 18, 19, 26-29, 32, 45, 48-49

genesis in the Soviet Union, 17-20

gradual concessions over, 41-46

music festivals as showcase for,

169-182, 190-191, 249

Society of German Composers (Genossenschaft deutscher Tonsetzer), 98

Sokorski, Jerzy

Marynka, 146

unauthorized concerts and, 219

Sokorski, Włodzimierz, 22, 24-27, 29, 42, 43,68

advice to composers, 31

attempts at mollifying and compromise with artists, 75 commissions process and, 136, 141

definition of naturalism, $78 \mathrm{n} 10$

demands for embrace of socialist realism, 33

Festival of Polish Music and, 136-138, $146,171,172$

on formalism, 27-28, 33

Łagów conference and, 102

on musicologists, 114

revisionist spin by, 45

Song about Bierut (Piosenka o Bierucie), 39

Song about Bierut (Pieśń o Bierucie), 144

Song about Friendship (Piosenka o przyjaźni), 38

Song about Stalin (Pieśń o Stalinie), 39, 139

Song about the Six-Year Plan (Piosenka o 6-letnim planie), 38

Song for the First of May (Piosenka pierwszomajowa), 39

Song in Praise of Comrade Bierut (Pieśn na cześć towarzysza Bieruta), 37-38, 107

Song of Construction, The (Das Lied des Aufbaus), 61

Song of Revolution (Pieśń rewolucji), 40, 139

Song of the Blue Flag, The (Lied von der blauen Fahne), 61

Song of the Forests (Shostakovich), 31-32

Song of the United Party (Pieśn Zjednoczonej Partii), 37, 133

Song of Unity (Pieśń Jedności), 133

Sonntag journal, 64, 66

sovietization, 8,97

Soviet Occupation Zone (East Germany), 47, 75, 98, 115, 149, 199

Sovietskaya Muzyka, 18-19

Soviet Union, the, 36, 74, 137, 214, 249-250. See also Union of Soviet Composers genesis of socialist realism in, 17-20 Muzfond, 131

New Economic Policy (NEP), 32, 81 revolutionary slogans, 32

Sozialistische Einheitspartei Deutschlands (Socialist Unity Party of Germany [SED]), 2, 48, 247-252. See also East Germany

Central Committee Plenum, 54 
composers' union confronting ideology and, 101-104

continued influence on the composers' union, 148-154

Contract Commission, 152-153

Culture Conference (1957), 66

Culture Department, 49-50, 53, 59, $70-73,74,104$

direct involvement in music through state organs, 73-76

Fifteenth Plenum (1953), 62

formalism campaign, 49-62

music festivals and, 175-182, 190

official belief in the political power of music, 67-68, 247-248

orchestral landscape and, 225-233

party culture departments and broad policy, 69-73

rural music festivals and, 187-188

Second Party Congress (1952), 53-54

view on music festivals, 168

Staatliche Sinfonie-Orchester, 226

Staatsoper, 64

Stakuko (Staatliche Kommission für Kunstangelegenheiten), 53, 58, 62, 72-75, 103-104, 120, 251. See also Ministry of Culture.

commissioning process, 149-154

music festivals and, 177, 183

orchestras and, 228, 232

unauthorized concerts and, 220

Stalin, Joseph, 2, 8, 56, 96, 213

death of, $15,42,248$

formulation of socialist realism, 17

70th birthday campaign commissions, 135-136, 139

Stalin is with Us (Stalin z nami), 39

Stalinization, 7

Stalin Will Be Our Friend for Eternity (Stalin bleibt uns Freund für Allezeit), 151

State Commission for Artistic Affairs (SED). See Stakuko (Staatliche Kommission für Kunstangelegenheiten)

State concert agencies, 198-203, 234, $235 \mathrm{n} 5$

State Organization for Artistic Events (Poland). See Artos

State Symphony Orchestra of Gotha, 1

Stravinsky, Igor, 18, 24, 25, 52, 55

Festival of Polish Music and, 175
Strofy o Stalinie, 157n27

Sułek, Małgorzata, 156-157n24

Summer Day, A (Ein Sommertag), 152

Swolkień, Henryk

Festival of Polish Music and, 172

Letter to Stalin (List do Stalina), 145

Sygietyński, Tadeusz

Beloved Country (Ukochany kraj), 38

March for Peace (Marsz pokoju), 38

Parade of Friendship (Pochód przyjaźni), 38-39

Song about Bierut (Piosenka o Bierucie), 39

Song about the Six-Year Plan (Piosenka o 6-letnim planie), 38

Symfonia Rewolucyjna, 140

Symphonic Images (Obrazy symfoniczne),

139

Symphonic Scherzo, 138

Symphony of Friendship, 150

Symphony of Peace (Symfonia pokoju), 140

Symphony of Songs (Symfonia pieśni), 40, 145

Szabelski, Bolesław, 38

Szczypiorski, Andrzej, 6

Szeligowski, Tadeusz, 29, 38, 44

Charter of Hearts (Karta serc), 39

Festival of Polish Music and, 173

The Scholars' Revolt (Bunt żaków), 40

Szpilman, Władysław

Bricklayer's Waltz, The (Walczyk murarski), 38

Song about Friendship (Piosenka o przyjaźni), 38

To Work (Do roboty), 38

Szymanowski, Karol, 24, 140, 172, 203, 207

Tchaikovsky, Pyotr Ilyich

Fifth Symphony, 1, 179, 229

thaw years, 15, 41-46, 209-210, 221, 231,

234, 248, 251

Theuer, Georg, 152

Thilman, Johannes Paul, 57, 65, 100

War and Peace (Krieg und Frieden) symphony, 149

Thomas, Adrian, 9n6

Thuringian, Second Symphony (Thüringische Sinfonie), 57, 178 
Thuringian Festival of Contemporary

Music, 183

totalitarianism theory, 7

To the Party (Do partii), 39

To Work (Do roboty), 38, 138

Traktor Driver and the Girl, The (Traktorzysta i dziewczyna), 205

"Traveling Symphony Orchestra of the Workers' Philharmonic Society," 223

"Trip around the World in Song, A," 217

Tuchowski, Andrzej, 11n19

Turski, Zbigniew, 42, 114

Cantata about the Vistula River (Kantata o Wiśle), 146

Festival of Polish Music, 146

on party control over the union, 143

Second Symphony (Olympic), 29, 31, $39,42,141,173$

Song for the First of May (Piosenka pierwszomajowa), 39

Warsaw Legend (Legenda warszawska), 141

Twentieth Party Congress of the Soviet

Communist Party (1956), 64

Two-Year Plan (East Germany), 48

Ulbricht, Walter, 8, 48, 54, 99, 153

unauthorized concerts, 218-221

Union of German Composers and Musicologists (Verband deutscher Komponisten und Musikwissenschaftler [VDK]), 8-9, 95-130

Admissions Commission, 108-110 ambiguous role of musicologists in, 115-118, 123-124n9

audition concerts, 119-121

confronting ideology and the party, 101-104

continued party influence on, 148-154

Culture Department and, 72, 73, 74

direct control over commissions, 152-154

First Congress (1952), 52, 54, 58-59, 100,150

Founding Congress (1951), 49, 52, 96, 108

genre commissions, $176-177$

importance of, 95-96, 122-123

inclusion of performers, 110-113
Leipzig Regional Union, 100, 109-110,

$111,120-121,122,180-182$

major festivals, $175-176$

membership, 104-105, 108-110

orchestras and, 230

party-directed development of, 98-101

Second Congress (1954), 1, 21, 63, 100, 177

structure, 100-101

support for socialist realism, 59

Third Congress (1957), 64-66

Union of Polish Composers (Zwiazek Kompozytorów Polskich [ZKP]), 23, 28, 29, 68, 250. See also Poland

ambiguous role of musicologists in, 113-115

assertion of professional control by,

144-148

audition concerts, 118-119

autonomy achieved by, 46

Circle of Virtuosos or Performers,

$111-112$

commissions process, 132-148, 156n14

compositional freedom demanded by

members of, $41-42$

confronting ideology and the party,

101-104

contentious atmosphere within, 44

Culture Department and, 69-70, 73

Eighth Congress (1955), 115

Fifth Congress (1950), 33-34, 54, 96, 114

formation and structure, 97-98

Fourth Congress (1948), 26, 142

importance of, 95-96, 122-123

inclusion of performers, 110-113

influence on Festival of Polish Music,

136-142, 171, 173-174

membership, 104-108

Mycielski on, 31

party influence on, 142-144

Prezydium, 97, 106, 119, 126n57, 142, $143,144-145,148$

Qualification Committee (Komisja

Kwalifikacyjna), 97, 105-108,

$127 \mathrm{n} 72$

resignations over artistic freedom, 34-35

Sixth Congress (1951), 35-36, 53

Seventh Congress (1954), 43, 45, 107 
structure, 100-101

Third Congress (1947), 25

Union of Polish Patriots, 23

Union of Polish Youth (Zwiqzek Młodzieży Polskiej, ZMP), 37

Union of Soviet Composers, 25, 96-97. See also Soviet Union, the

upowszechnianie, 26

Uprising of June 17, 1953, 74, 77

Uszkoreit, Hans-Georg, 66, 74, 150, 153

music festivals and, 181

orchestras and, 229, 230, 231

VDK. See East German Composers' Union (Verband deutscher Komponisten und Musikwissenschaftler [VDK])

Verdery, Katherine, 2

Victoria and her Hussar, 211

Victorious Path, The (Zwycięska droga), 37

Volkspolizeiorchester, 227

Von Richthofen, Esther, 5

Wagner, Richard, 168

Wagner-Régeny, Rudolf, 59

Suite from Persische Episode, 178

Walentynowicz, Władysław, 138

Walter, Siegfried, 221

Wanslow, W. W., 52

Warsaw Autumn Festival (1956), 29, 175

Warsaw Bricklayer (Warszawski murarz), 40

Warsaw Legend (Legenda warszawska), 141

Warsaw Opera, 69

Warsaw Philharmonic, 140, 224

We Are Changing the World (Die Welt verändern wir), 61

Webern, Anton, 55, 64

We Go Forward (Naprzód idziemy), 37

Welfare dictatorship, 5

Werzlau, Joachim Morning Song of the Tractor Driver

(Morgenlied der Traktoristen), 61-62

West Germany, 72, 183-184, 201, 208, 233, 250

Wiedemann, Hans, 183

Wilczek, Jan, 42

Winter Evening, A (Wieczór zimowy), 133

Wisłocki, Stanisław, 38
Wohlgemuth, Gerhard, 64 criticism of muscologists, 117

Wolf, Christa, 6

Word on Stalin, A (Slowo o Stalinie), 36, 39, 139, 141

Words of the Führer, The (Führerworte), 56

Work for Peace (Arbeit für den Frieden), 56

World Festival of Youth and Students, 174, 186

World is Young, The (Die Welt ist jung), 56

Woytowicz, Bolesław, 28, 45

Cantata in Praise of Work (Kantata na pochwate pracy), 39, 170

Wozzeck, 64

Wróbel, Feliks, 136

Wüstinger, Otto-Ludwig, 109

Wygodzki, Stanisław, 133

Yarustovsky, Boris, 52

Young Guard Laughs Bravely, The (Tapfer lacht die junge Garde), 61

Zdenko, Karol Rund, 138

Zhdanov, Andrei, 17, 19, 27, 47, 64, 96

ZKP. See Union of Polish Composers

(Zwiazek Kompozytorów Polskich

[ZKP])

ZMP pomaga wsi (The Union of Polish

Youth Helps the Countryside), 37

Żółkiewski, Stefan, 22, 27, 45, 70

Żuławski, Wawrzyniec, 38 


\section{Central European Studies}

This book examines the exercise of power in the stalinist music world as well as the ways in which composers and ordinary people responded to it. It presents a comparative inquiry into the relationship between music and politics in the German Democratic Republic and Poland from the aftermath of World War II through Stalin's death in 1953, concluding with the slow process of de-stalinization in the mid- to late-1950s. The author explores how the Communist parties in both countries expressed their attitudes to music of all kinds, and how composers, performers, and audiences cooperated with, resisted, and negotiated these suggestions and demands.

Based on a deep analysis of the archival and contemporary published sources on state, party, and professional organizations concerned with musical life, Tompkins argues that music, as a significant part of cultural production in these countries, played a key role in instituting and maintaining the regimes of East Central Europe. As part of the stalinist project to create and control a new socialist identity at the personal as well as collective level, the ruling parties in East Germany and Poland sought to saturate public space through the production of music. Politically effective ideas and symbols were introduced that furthered attempts to, in the parlance of the day, "engineer the human soul."

Music also helped the Communist parties establish legitimacy. Extensive state support for musical life encouraged musical elites and audiences to accept the dominant position and political missions of these regimes. Party leaders invested considerable resources in the attempt to create an authorized musical language that would secure and maintain hegemony over the cultural and wider social worlds. The responses of composers and audiences ran the gamut from enthusiasm to suspicion, but indifference was not an option.

\section{David G. Tompkins teaches the history of modern Europe at Carleton College in Northfield, Minnesota. In addition to research interests in music and Communism, he writes on the cultural history of Central Europe more broadly and is currently working on a project that looks at images of friends and enemies in the Communist world. He lives in Minneapolis with his wife and daughter.}

\section{PURDUE UNIVERSITY PRESS}

West Lafayette, Indiana www.press.purdue.edu

ISBN: 978-1-55753-647-1

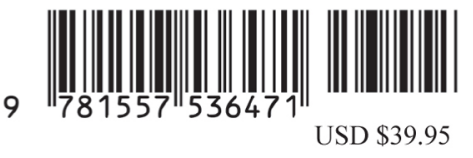

